\title{
c.nommonyly
}

\section{Catalog of Significant Historical Earthquakes in the Central United States}

By W. H. Bakun ${ }^{1}$ and M. G. Hopper ${ }^{2}$

Open-File Report 2004-1086

2004

Any use of trade, firm, or product names is for descriptive purposes only and does not imply endorsement by the U.S. Government.

U.S. DEPARTMENT OF THE INTERIOR

U.S. GEOLOGICAL SURVEY

${ }^{1}$ Menlo Park, Calif.

${ }^{2}$ Golden, Colo. 


\begin{abstract}
We use Modified Mercalli intensity assignments to estimate source locations and moment magnitude $\mathbf{M}$ for eighteen $19^{\text {th }}$-century and twenty early- $20^{\text {th }}$-century earthquakes in the central United States (CUS) for which estimates of $\mathbf{M}$ are otherwise not available. We use these estimates, and locations and $\mathbf{M}$ estimated elsewhere, to compile a catelog of significant historical earthquakes in the CUS. The 1811-1812 New Madrid earthquakes apparently dominated CUS seismicity in the first two decades of the 19th century. M5-6 earthquakes occurred in the New Madrid Seismic Zone in 1843 and 1878, but none have occurred since 1878. There has been persistent seismic activity in the Illinois Basin in southern Illinois and Indiana, with $\mathbf{M}>5.0$ earthquakes in 1895, 1909, 1917, 1968, and 1987. Four other $\mathbf{M}>5.0$ CUS historical earthquakes have occurred: in Kansas in 1867, in Nebraska in 1877, in Oklahoma in 1882, and in Kentucky in 1980.
\end{abstract}

Introduction

\title{
Contents
}

Explanation of Intensity Data and Isoseismal Maps $\quad 6$

$\begin{array}{ll}\text { Explanation of Estimates of } \mathbf{M} \text { and Location } & 7\end{array}$

Intensity Centers, Preferred Locations, and Associations with Faults $\quad 8$

$\begin{array}{lr}\text { Acknowledgements } & 9\end{array}$

$\begin{array}{ll}\text { References } & 10\end{array}$

Figure 1. Map of Locations of Central US Earthquakes Analyzed 15

Table 1. Summary List of Central US Earthquakes Analyzed 16

Central US Earthquakes Analyzed (Details)

\begin{tabular}{|c|c|c|}
\hline \#1 1827 July 5 11:30 UTC & (Indiana) & 17 \\
\hline \#2 1827 August 7 04:30 UTC & (Indiana) & 18 \\
\hline \#3 1838 June 9 14:45 UTC & (Illinois) & 19 \\
\hline \#4 1843 February 17 05:00 UTC & (Arkansas) & 20 \\
\hline \#5 1850 April 5 02:05 UTC & (Indiana) & 21 \\
\hline \#6 1857 October 8 10:00 UTC & (Illinois) & 22 \\
\hline \#7 1865 August 17 15:00 UTC & (Arkansas) & 23 \\
\hline \#8 1867 April 24 20:22 UTC & (Kansas) & 24 \\
\hline \#9 1876 September 26 06:15 UTC & (Illinois) & 25 \\
\hline \#10 1877 November 15 17:45 UTC & (Nebraska) & 26 \\
\hline \#11 1878 November 19 05:52 UTC & (Arkansas) & 27 \\
\hline \#12 1882 October 22 22:15 UTC & (Oklahoma) & 28 \\
\hline \#13 1883 January 11 07:12 UTC & (Missouri) & 29 \\
\hline
\end{tabular}




$\begin{array}{lll}\text { \#14 1883 December 5 15:20 UTC } & \text { (Arkansas) } & 30 \\ \text { \#15 1884 September 19 19:14 UTC } & \text { (Ohio) } & 31 \\ \text { \#16 1887 August 2 18:36 UTC } & \text { (Illinois) } & 32 \\ \text { \#17 1891 September 27 04:55 UTC } & \text { (Illinois) } & 33 \\ \text { \#18 1899 April 30 02:05 UTC } & \text { (Indiana) } & 34 \\ \text { \#19 1903 February 9 00:21 UTC } & \text { (Illinois) } & 35 \\ \text { \#20 1903 November 4 19:14 UTC } & \text { (Missouri) } & 36 \\ \text { \#21 1905 August 22 05:08 UTC } & \text { (Missouri) } & 37 \\ \text { \#22 1906 January 8 00:15 UTC } & \text { (Kansas) } & 38 \\ \text { \#23 1909 May 26 14:42 UTC } & \text { (Illinois) } & 39 \\ \text { \#24 1909 July 19 04:34 UTC } & \text { (Illinois) } & 40 \\ \text { \#25 1909 September 27 09:45 UTC } & \text { (Illinois) } & 41 \\ \text { \#26 1911 March 31 16:57 UTC } & \text { (Arkansas) } & 43 \\ \text { \#27 1917 April 9 20:52 UTC } & \text { (Illinois) } & 44 \\ \text { \#28 1922 March 22 22:29 UTC } & \text { (Illinois) } & 46 \\ \text { \#29 1922 November 27 03:31 UTC } & \text { (Illinois) } & 47 \\ \text { \#30 1923 October 28 17:10 UTC } & \text { (Arkansas) } & 48 \\ \text { \#31 1925 April 27 04:05 UTC } & \text { (Indiana) } & 49 \\ \text { \#32 1927 May 7 08:28 UTC } & \text { (Arkansas) } & 50 \\ \text { \#33 1931 December 17 03:36 UTC } & \text { (Mississippi) } & 51 \\ \text { \#34 1934 August 20 00:47 UTC } & \text { (Missouri) } & 52 \\ \text { \#35 1937 March 2 14:47 UTC } & \text { (Ohio) } & 53 \\ \text { \#36 1937 March 9 05:44 UTC } & \text { (Ohio) } & 54 \\ \text { \#37 1938 September 17 03:34 UTC } & \text { (Arkansas) } & \text { (Oklahoma) } \\ \text { \#38 1952 April 9 16:29 UTC } & & \end{array}$

Table 2. Summary List of Significant Historical Central US Earthquakes 55

Figure 2. Map of Locations of Significant Historical CUS Earthquakes 57

Appendix 1. Damage Reports and Intensity Assignments

$\begin{array}{lll}\text { \#1 1827 July 5 11:30 UTC } & \text { (Indiana) } & 58 \\ \text { \#2 1827 August 7 04:30 UTC } & \text { (Indiana) } & 59 \\ \text { \#3 1838 June 9 14:45 UTC } & \text { (Illinois) } & 60 \\ \text { \#4 1843 February 17 05:00 UTC } & \text { (Arkansas) } & 61 \\ \text { \#5 1850 April 5 02:05 UTC } & \text { (Indiana) } & 63 \\ \text { \#6 1857 October 8 10:00 UTC } & \text { (Illinois) } & 66 \\ \text { \#7 1865 August 17 15:00 UTC } & \text { (Arkansas) } & 71 \\ \text { \#8 1867 April 24 20:22 UTC } & \text { (Kansas) } & 72 \\ \text { \#9 1876 September 26 06:15 UTC } & \text { (Illinois) } & 76 \\ \text { \#10 1877 November 15 17:45 UTC } & \text { (Nebraska) } & 79 \\ \text { \#11 1878 November 19 05:52 UTC } & \text { (Arkansas) } & 80 \\ \text { \#12 1882 October 22 22:15 UTC } & \text { (Oklahoma) } & 81 \\ \text { \#13 1883 January 11 07:12 UTC } & \text { (Missouri) } & \text { (Arkansas) } \\ \text { \#14 1883 December 5 15:20 UTC } & \text { (Ohio) } & \end{array}$




$\begin{array}{llll}\text { \#16 } 1887 \text { August } 2 \text { 18:36 UTC } & \text { (Illinois) } & 89 \\ \text { \#17 1891 September 27 04:55 UTC } & \text { (Illinois) } & 91 \\ \text { \#18 1899 April 30 02:05 UTC } & \text { (Indiana) } & 95 \\ \text { \#19 1903 February 9 00:21 UTC } & \text { (Illinois) } & 96 \\ \text { \#20 1903 November 4 19:14 UTC } & \text { (Missouri) } & 98 \\ \text { \#21 1905 August 22 05:08 UTC } & \text { (Missouri) } & 100 \\ \text { \#22 1906 January 8 00:15 UTC } & \text { (Kansas) } & 104 \\ \text { \#23 1909 May 26 14:42 UTC } & \text { (Illinois) } & 106 \\ \text { \#24 1909 July 19 04:34 UTC } & \text { (Illinois) } & 112 \\ \text { \#25 1909 September 27 09:45 UTC } & \text { (Illinois) } & 116 \\ \text { \#26 1911 March 31 16:57 UTC } & \text { (Arkansas) } & 118 \\ \text { \#27 1917 April 9 20:52 UTC } & \text { (Illinois) } & 120 \\ \text { \#28 1922 March 22 22:29 UTC } & \text { (Illinois) } & 121 \\ \text { \#29 1922 November 27 03:31 UTC } & \text { (Illinois) } & 122 \\ \text { \#30 1923 October 28 17:10 UTC } & \text { (Arkansas) } & 124 \\ \text { \#31 1925 April 27 04:05 UTC } & \text { (Indiana) } & 126 \\ \text { \#32 1927 May 7 08:28 UTC } & \text { (Arkansas) } & 128 \\ \text { \#33 1931 December 17 03:36 UTC } & \text { (Mississippi) } & 130 \\ \text { \#34 1934 August 20 00:47 UTC } & \text { (Missouri) } & 132 \\ \text { \#35 1937 March 2 14:47 UTC } & \text { (Ohio) } & 134 \\ \text { \#36 1937 March 9 05:44 UTC } & \text { (Ohio) } & 137 \\ \text { \#37 1938 September 17 03:34 UTC } & \text { (Arkansas) } & 138 \\ \text { \#38 1952 April 9 16:29 UTC } & \text { (Oklahoma) }\end{array}$




\section{Introduction}

A full evaluation of historical seismic activity in the central United States $(C U S)$ is important in estimating the seismic hazard in the region. Estimates of the moment magnitude M (Hanks and Kanamori, 1979) of the three largest 1811-1812 New Madrid (NM) earthquakes range from 7.2 to 8.0 (Johnston, 1996b; Hough et al., 2000; Bakun and Hopper, 2004). The expected recurrence of the 1811-1812 NM sequence every 500 years (Tuttle et al., 2002) dominates the U.S. Geological Survey (USGS) estimates of seismic hazard over much of the CUS (Harmsen et al., 1999; Frankel et al., 2000, 2002). Earthquakes in the New Madrid Seismic Zone, however, do not constitute all of the CUS seismic hazard. Several 5.0 M 6.0 historical earthquakes have occurred elsewhere, and have caused significant damage. Moreover, paleoseismic studies (e.g., Munson et al., 1997) have shown that large Holocene earthquakes have occurred in Illinois and Indiana where 5.0 M 6.0 historical earthquakes have occurred.

The purpose of this study is to estimate $\mathbf{M}$ and the locations for CUS earthquakes with $\mathbf{M}$ potentially greater than 5.0 and for which estimates of $\mathbf{M}$ are otherwise not available. We used the compilations of Stover and Coffman (1993) to identify 38 earthquakes in Arkansas, Illinois, Indiana, Iowa, Kentucky, Louisiana, Michigan, Minnesota, Mississippi, Missouri, Nebraska, Ohio, Oklahoma, Tennessee, and Wisconsin for analysis (Figure 1 and Table 1). The intensity magnitude $\mathbf{M}_{\mathrm{I}}$, our best estimate of $\mathbf{M}$, is 5.0 or larger for 6 of the 38 events studied.

We use estimates in Table 1, and the $\mathbf{M}$ and locations for CUS earthquakes estimated elsewhere, to compile a catalog of significant historical CUS earthquakes (Table 2 and Figure 2). Table 2 includes all felt CUS events for which $\mathbf{M}$ have been estimated. No claims are made for completeness. 


\section{Explanation of Intensity Data and Isoseismal Maps}

The isoseismal maps show site intensities (Arabic numbers) and contours (Roman numerals) in the Modified Mercalli intensity (MMI) scale (Wood and Neumann, 1931; Richter, 1958; Stover and Coffman, 1993, p. 3-4). No consistent set of questions useful for assigning intensity is covered by newspaper stories and other types of information available for historical earthquakes. Newspaper articles tend to spend much more space discussing the response by people (poor indicators of MMI level) than they do the details of what happened to objects or structures (excellent indicators of MMI level). Intensities assigned on the basis of such often sketchy or ambiguous information rely heavily on the interpretation by the analyst of a set of occurrences that together comprise a shaking level. Such interpretation varies from analyst to analyst and may even vary for a single analyst over time. For uniformity in this study, all intensities have been reevaluated (by MGH), and intensities assigned by previous researchers are used only when no accounts are available for reevaluation. The historical accounts used and our intensity assignments for the 38 earthquakes analyzed are listed in Appendix 1.

Additional notations were sometimes used in place of traditional MMI values:

$0 \quad$ Not felt, explicitly stated (e.g., "The earthquake was not felt at A.")

$\mathrm{N} \quad$ Not mentioned in a place from which a report would be expected if the shock were felt (e.g., a newspaper covering the earthquake effects elsewhere but not mentioning any effects in the newspaper's own town)

F Felt, but without sufficient information for MMI assignment (e.g., "The earthquake was also felt at $\mathrm{A}, \mathrm{B}, \ldots .$. )

G Ground or water effects (which are not used for MMI assignment because they may occur throughout the scale). "G" is assigned only if an MMI cannot be assigned to the site based on other effects.

1 Not felt, but effects observed (e.g., swinging or swaying things, dizziness, sudden ground water changes, etc. for no immediately apparent reason)

Isoseismals are drawn to enclose areas of a predominant intensity. The number of isoseismals drawn is determined by what the data will support, and combined isoseismals, beyond the usual "I-III," are used when the data are insufficient for separating areas. Site intensities on the maps show where isoseismal areas are well defined, and where sections of a contour have necessarily been connected across a nearly blank patch of map. Two examples (\#2, August 1827 and \#4, February 1843) have so few intensity assignments that they perhaps should have been shown without contours; instead, a dashed line is used to represent the approximate location and size of the felt area. "Not Felt" reports, which usually delimit the outer felt area for canvassed earthquakes, are seldom available for old earthquakes. Thus, the outer isoseismal (felt area) may sometimes be too large because it encompasses most of the MMIs on the periphery, some of which may actually be isolated felt sites beyond the limit of the general felt area.

The epicenter listed in Stover and Coffman (1993) is shown on each isoseismal map by an upward-pointing star. Our preferred location is shown by a downward pointing star. 


\section{Explanation of Estimates of $M$ and Location}

Following Bakun and Wentworth (1997), we have excluded "felt" and "not felt" intensity reports. The numbers of MMI assignments are summarized in Table 1. We analyze the MMI assignments using the technique of Bakun and Wentworth (1997) as applied in Bakun and Hopper's (2004) analysis of historical CUS events. We calculate $M_{I}$ and $r m s\left(M_{I}\right)$ over a grid of trial epicenter locations.

$$
\mathrm{M}_{\mathrm{I}}=\text { mean }\left(\mathrm{M}_{\mathrm{i}}\right),
$$

where

$$
\mathrm{M}_{\mathrm{i}}=\left\{\left(\mathrm{MMI}_{\mathrm{i}}-\delta \mathrm{MMI}_{\mathrm{i}}\right)-2.89+0.00277 * \Delta_{\mathrm{i}}+2.10 * \log \left(\Delta_{\mathrm{i}}\right)\right\} / 1.36,
$$

and $\mathrm{MMI}_{\mathrm{i}}$ is the $\mathrm{MMI}$ value at site $\mathrm{i}, \delta \mathrm{MMI}_{\mathrm{i}}$ is the empirical site correction for site $\mathrm{i}$ if available (otherwise $=0$ ), and $\Delta_{\mathrm{i}}$ is the epicentral distance $(\mathrm{km})$. Following Bakun et al. (2003), we use MMI > III in calculating $\mathrm{M}_{\mathrm{I}}$. The empirical site corrections are listed in Bakun and Hopper (2003).

$$
\operatorname{rms}\left[M_{I}\right]=\left[r m s\left(M_{I}-M_{i}\right)-r m s_{0}\left(M_{I}-M_{i}\right)\right] \text {, }
$$

where rms $\left(\mathrm{M}_{\mathrm{I}}-\mathrm{M}_{\mathrm{i}}\right)=\left\{\sum_{\mathrm{i}}\left[\mathrm{W}_{\mathrm{i}} *\left(\mathrm{M}_{\mathrm{I}}-\mathrm{M}_{\mathrm{i}}\right)\right]^{2} / \sum_{\mathrm{i}} \mathrm{W}_{\mathrm{i}}{ }^{2}\right\}^{1 / 2}, \mathrm{rms}_{0}\left(\mathrm{M}_{\mathrm{I}}-\mathrm{M}_{\mathrm{i}}\right)$ is the minimum rms $\left(\mathrm{M}_{\mathrm{I}}-\mathrm{M}_{\mathrm{i}}\right)$ over the grid of trial epicenters, and $\mathrm{W}_{\mathrm{i}}$ is Bakun and Wentworth's (1997) distance weighting function

$$
\mathrm{W}_{\mathrm{i}}= \begin{cases}0.1+\cos \left[\left(\Delta_{\mathrm{i}} / 150\right)^{*} \pi / 2\right] & \text { for } \Delta_{\mathrm{i}}<150 \mathrm{~km} \\ 0.1 & \text { for } \Delta_{\mathrm{i}} \geq 150 \mathrm{~km} .\end{cases}
$$

The rms $\left[\mathrm{M}_{\mathrm{I}}\right]$ contours bound the epicentral region with levels of confidence in the sense that there is a 0.95 probability that the epicenter lies in the region within the $95 \%$ confidence contour, there is a 0.67 probability that the epicenter lies in the region within the $67 \%$ confidence contour, and so on. Values for the contours for different levels of confidence and numbers of MMI assignments are tabulated in the corrected table 5b of Bakun and Wentworth (1999). Bakun et al. (2003) showed that Bakun and Wentworth's (1999) contour values are appropriate for ENA earthquakes. The intensity center, IC on the maps of epicentral regions for individual earthquakes, is the trial epicenter location for which $\mathrm{rms}\left[\mathrm{M}_{\mathrm{I}}\right]$ is minimum (Bakun, 1999).

$\mathrm{M}_{\mathrm{I}}$ values at feasible trial locations within the appropriate confidence-level contours provide the best estimates of $\mathbf{M}$ for these source locations. The uncertainties in $\mathbf{M}$ for California events are tabulated in the corrected Table 5a of Bakun and Wentworth (1999), but Bakun et al. (2003) showed that the $95 \%$ uncertainties for earthquakes in ENA are $\pm 0.1 \mathbf{M}$ units larger than for earthquakes in California. 


\section{Intensity Centers, Preferred Locations, and Associations with Faults}

Detailed studies show that earthquakes in the CUS generally can be associated with mapped faults. For example, microearthquakes in the New Madrid Seismic Zone define a clear pattern of intersecting planar faults (Atkinson et al., 2000), and earthquakes from 1974 to 1990 within the Illinois Basin are associated with known basement faults (Taylor, 1991). We assume in this report that historical earthquakes in the CUS, like the recent events, can be explained by reactivation of basement faults. We use epicenters (if available), intensity centers, the confidence contours for location, and mapped basement faults to infer a preferred location for each historical earthquake and, where possible, a tentative association with a causative fault. We emphasize the tentative nature of our associations of earthquakes with specific faults or structural features, particularly in the Illinois Basin where structural features with associated bedrock faulting are ubiquitous (Nelson, 1995).

The intensity center is often the only objective estimate of a point-source location for an historical earthquake. The intensity center is our preferred location for 20 of the 38 events listed in Table 1. Intensity centers for 12 of the 20 events $(\# 3,6,9,16,17,19,20,21,24,28$, 30, and 34) are located on mapped faults in the NMSZ or Illinois Basin. Our preferred location for the other 8 events $(\# 8,10,12,15,22,23,27$, and 33) is the intensity center because an instrumental epicenter is not available, and there are no mapped faults in the NMSZ or Illinois Basin within the confidence contours for location.

Our preferred location is an arbitrary location on a mapped fault within the confidence contours for location for 6 events $(\# 1,2,5,18,25$, and 31) in the Illinois Basin and for 5 events $(\# 4,7,11$, 13, and 31) in the NMSZ. Not only are these locations on the selected fault arbitrary, but sometimes a location on a neighboring fault would also satisfy the intensity data. While our specific fault associations are often tentative, we are more confident of our associations of events with the Illinois Basin or the NMSZ.

The intensity center is the grid search point where $\operatorname{rms}\left[\mathrm{M}_{\mathrm{I}}\right]$ is minimum. If intensity assignments at nearby sites differ significantly, the distance-weighting algorithm, equation (4), effectively pushes the minimum $\mathrm{rms}\left[\mathrm{M}_{\mathrm{I}}\right]$ away from the discordant intensity assignments. In such cases, the intensity center is often located off the edge of the field of intensity assignments, and is a bad estimate of the source location. Clearly this is the case for events \#14, 26, and 29, and out preferred location for these events is an arbitrary location near the maximum intensity assignments.

Instrumental epicenter locations are available for more recent events in our study, and we adopt these epicenters as our preferred locations for 3 events (\#35, 36, and 38). The instrumental epicenter for event \#37 is only 18 kilometers southeast of the south end of the Blytheville Arch segment of the NMSZ, and our preferred location is the nearest point on that segment for this event. 


\section{Acknowledgements}

We thank John Nelson of the Illinois Geological Survey, John McBride of Brigham Young University, and Susan Hough and Rus Wheeler of the USGS for their helpful comments and suggestions. Tom Hildenbrand provided files of digitized fault traces in the Illinois basin. The Generic Mapping Tools software package by Wessel and Smith (1991) was used to generate many of the figures in this report. This work was funded by the USGS Earthquake Hazards Reduction Program and by the U S Nuclear Regulatory Commission (USGS Agreement Y6166/RES-00-001 FY-03). 


\section{References}

Atkinson, G., and 24 others (2000). Reassessing the New Madrid Seismic Zone, Eos, Amer. Geophys. Un. Trans. 81, no. 35, 397,402-403.

Bakun, W. H. (1999). Seismic activity of the San Francisco Bay region, Bull. Seism. Soc. Am. 89, 764-784.

Bakun, W. H., A. C. Johnston, and M. G. Hopper (2003). Estimating locations and magnitudes of earthquakes in eastern North America from Modified Mercalli intensities, Bull. Seism. Soc. Am. 93, 190-202.

Bakun, W. H., and M. G. Hopper (2003). Empirical MMI site corrections for towns in ENA, U.S. Geol. Surv. Open-file Rept.03-377, 34pp. (geopubs.wr.usgs.gov/open-file/of03-377/) (last accessed August 2003)

Bakun, W. H., and M. G. Hopper (2004). Magnitudes and locations of the 1811-1812 New Madrid, Missouri, and 1886 Charleston, South Carolina, earthquakes, Bull. Seism. Soc. Am. 94, 64-75.

Bakun, W. H. and C. M. Wentworth (1997). Estimating earthquake location and magnitude from seismic intensity data, Bull. Seism. Soc. Am. 87, 1502-1521.

Bakun, W. H. and C. M. Wentworth (1999). Erratum to Estimating earthquake location and magnitude from seismic intensity data, Bull. Seism. Soc. Am. 89, 557.

Bear, G. W., J. A. Rupp, and A. J. Rudman (1997). Seismic interpretation of the deep structure of the Wabash Valley fault system, Seismol. Res. Lett. 68, 624-640.

Burchett, R.R. (1979). Earthquakes in Nebraska, Conservation and Survey Division, Institute of Agriculture and Natural Resources, The University of Nebraska - Lincoln, Educational Circular No. 4 (supported by Contract NRC-04-76-315, U.S. Nuclear Regulatory commission), 20pp.

Carlson, S. M. (1984). Investigations of recent and historical seismicity in east Texas, The University of Texas at Austin, Master of Arts Thesis, 197 pp.

Coffman, J. L., and C. A. von Hake (1973). Earthquake History of the United States, U.S. Dept. of Commerce, National Oceanic and Atmospheric Administration, Publication 41-1, Revised Edition (Through 1970), 208pp.

Dewey, J. W., and D. W. Gordon (1984). Map showing recomputed hypocenters of earthquakes in the Eastern and Central United States and adjacent Canada, 1925--1980, U. S. Geol. Surv. Misc Field Studies Map MF-1699, pamphlet, 39pp. 
DuBois, S.M., and F. W. Wilson (1978). A revised and augmented list of earthquake intensities for Kansas, 1867-1977, Kansas Geological Survey, Lawrence, KS, The University of Kansas, Environmental Geology Series 2, 56pp.

Frankel, A. D., C. S. Mueller, T. P. Barnhard, E. V. Leyendecker, R. L. Wesson, S. C. Harmsen, F. W. Klein, D. M. Perkins, N. C. Dickman, and M. G. Hopper (2000). USGS national seismic hazard maps, Earthquake Spectra 16, 1-19.

Frankel, A. D., M. D. Petersen, C. S. Mueller, K. M. Haller, R. L. Wheeler, E. V. Leyendecker, R. L. Wesson, S. C. Harmsen, C. H. Cramer, D. M. Perkins, and K. S. Rukstales (2002). Documentation for the 2002 update of national seismic hazard maps, U.S. Geol. Surv. Open-file Rept.02-420, 33pp.

Hamburger, M. W., and J. A. Rupp (1988). The June 1987 southeastern Illinois earthquake: possible tectonism associated with the La Salle Anticlinal Belt, Seismol. Res. Lett. 59, 151-159.

Hanks, T. C., and H. Kanamori (1979). A moment magnitude scale, J. Geophys. Res. 84, 23482350 .

Harmsen, S., D. Perkins, and A. Frankel (1999). Deaggregation of probabilistic ground motions in the central and eastern United States, Bull. Seism. Soc. Am. 89, 1-13.

Heinrich, R.R. (1941). A contribution to the seismic history of Missouri, Bull. Seism. Soc. Am. 31, 187-224.

Herrmann, R. B. (1979). Surface wave focal mechanisms for Eastern North American earthquakes with tectonic implications, J. Geophys. Res. 84, 3543-3552.

Herrmann, R. B., C. A. Langston, and J. E. Zollweg (1982). The Sharpsburg, Kentucky, earthquake of 27 July 1980, Bull. Seism. Soc. Am. 72, 1219-1239.

Herrmann, R. B., and C. J. Ammon (1997). Faulting parameters of earthquakes in the New Madrid, Missouri, region, Engineering Geology 46, 299-311.

Hildenbrand, T. G., J. H. McBride and D. Ravat (2002). The Commerce Geophysical Lineamentand its possible relation to mesoproterozoic igneous complexes and large earthquakes in the central Illinois Basin, Seismol. Res. Lett. 73, 640-659.

Hildenbrand, T. G., and D. Ravat (2002). Geophysical setting of the Wabash Valley Fault System, Seismol. Res. Lett. 68, 567-585.

Hough, S. E. (2001). Triggered earthquakes and the 1811-1812 New Madrid, Central United States, earthquake sequence, Bull. Seism. Soc. Am. 91, 1574-1581.

Hough, S. E., J. G. Armbruster, L. Seeber, and J. F. Hough (2000). On the Modified Mercalli intensities and magnitudes of the 1811-1812 New Madrid earthquakes, J. Geophys. Res. 105, 23,839-23,864. 
Hough, S. E., and S. Martin (2002). Magnitude estimates of two large aftershocks of the 16 December 1811 New Madrid earthquake, Bull. Seism. Soc. Am. 92, 3259-3268.

Johnston, A. C. (1996a). Seismic moment assessment of earthquakes in stable continental regions-I. Instrumental seismicity, Geophys. J. Int. 124, 381-414.

Johnston, A. C. (1996b). Seismic moment assessment of earthquakes in stable continental regions-III. New Madrid 1811-1812, Charleston 1886 and Lisbon 1755, Geophys. J. Int. 126, 314-344.

Johnston, A. C., and E. S. Schweig (1996). The enigma of the New Madrid earthquakes of 18111812, Ann. Rev. Earth Planet. Sci. 24, 339-384.

Kim, W.-Y. (2003). The 18 June 2002 Caborn, Indiana, earthquake: reactivation of ancient rift in the Wabash Valley seismic zone?, Bull. Seism. Soc. Am. 93, 2201-2211.

Lykins, W.H.R.(1867). Earthquake in Kansas, American Journal of Science, 1867, 2nd series,. 44, 132.

McBride, J. H. (1998). Understanding basement tectonics of an interior cratonic basin: southern Illinois Basin, USA, Tectonophysics 293, 1-20.

McBride, J. H., A. J. M. Pugin, W. J. Nelson, T. H. Larson, S. L. Sargent, J. A. Devera, F. B. Denny, and E. W. Woolery (1993). Variable post-Paleozoic deformation detected by seismic profiling across the northwestern "prong" of new Madrid seismic zone, Tectonophysics 368, 171191.

Merriam, D.F. (1956). History of earthquakes in Kansas, Bull. Seism. Soc. Am. 46, 87-96.

Moneymaker, B.C. (1954). Some early earthquakes in Tennessee and adjacent states (1699 to 1850), Journal of the Tennessee Academy of Science 29, no. 3, 224-233

Moneymaker, B.C. (1958). Earthquakes in Tennessee and nearby sections of neighboring States 1926 to 1950, Journal of the Tennessee Academy of Science 33, no. 3, p. 224-239.

Monthly Weather Review (1884). Earthquakes [earthquake of September 19, 1884 in Ohio], Monthly Weather Review, Sept., 1984, 235-238.

Munson, P. J., S. F. Obermeier, C. A. Munson, and E. R. Hajic (1997). Liquefaction evidence for Holocene and latest Pleistocene seismicity in the southern halves of Indiana and Illinois: a preliminary overview, Seism. Res. Lett. 68, 521-536.

Murphy, L.M., and W. K. Cloud (1954). United States earthquakes 1952, U.S. Coast and Geodetic Survey, Serial 773, 112pp.

National Earthquake Information Center. Earthquake Data Base System, A multi-catalog database of historical earthquakes that could be searched via NEIC's main computer prior to development of NEIC's earthquake web search (http://neic.usgs.gov/neis/epic/). 
Nelson, J. W. (1995). Structural features in Illinois, Ill. State Geol. Surv. Bull. 100, 144pp.

Neumann, F. (1936). United States earthquakes 1934, U.S. Coast and Geodetic Survey, Serial 593, 99pp.

Neumann, F. (1940). United States Earthquakes 1937, U.S. Coast and Geodetic Survey, Washington, D. C., 55 pp.

Neumann, F., and R. R. Bodle (1932). United States earthquakes 1931, U.S. Coast and Geodetic Survey, Serial 553, 26p.

Nguyen, B. V., and R. B. Herrmann (1992). Determination of source parameters for central and eastern North American earthquakes (1982-1986), Seism. Res. Lett. 63, 567-586.

Parker, J. D. (1868). Earthquake in Kansas, American Journal of Science, 2nd Series 45, 129131.

Parker, J. D. (1912). Earthquake in Kansas, Kansas State Historical Society, Kansas Hist. Colln., 12, 121-131.

Reis, J. (2002). Quakes also felt in 1937, The Cincinnati Post (Web), March 11, 2002.

Richter, C.F. (1958). Elementary seismology:, San Francisco, W.H. Freeman and Company, $768 p p$.

Rockwood (1883). Notes on American earthquakes, No. 12, American Journal of Science 25 , 359.

Schwartz, S. Y., and D. H. Christensen (1988). The 12 July 1986 St. Mary's, Ohio, earthquake and recent seismicity in the Anna, Ohio, seismogenic zone, Seism. Res. Lett. 59, 57-62.

Stover, C. W. and J. L. Coffman (1993). Seismicity of the United States, 1568-1989 (Revised), U. S. Geological Survey Prof. Pap. 1527, 418pp.

Street, R.L., and R. F. Green (1984). The historical seismicity of Central United States, 18111928: University of Kentucky Research Foundation, Lexington, Ky., 550pp.

Taylor, K. B. (1991). Seismotectonics of the Illinois Basin and the northern half of the Ozark Uplift, Ph. D thesis, Saint Louis Univ., St. Louis, Mo, 242pp.

Taylor, K. B., R. B. Herrmann, M. W. Hamburger, G. L. Pavlis, A. C. Johnston, C. Langer, and C. Lam (1989). The southeastern Illinois earthquake of 10 June 1987, Seism. Res. Lett. 60, 101110.

Tuttle, M. P., E. S. Schweig, J. D. Sims, R. H. Lafferty, L. W. Wolf, and M. L. Haynes (2002). The earthquake potential of the New Madrid Seismic zone, Bull. Seism. Soc. Am. 92, 2080-2089. 
Walter, E. J. (1939). The Arkansas earthquake of September 17, 1938, Bull. Seism. Soc. Am. 29, 497-503.

Wessel, P. and W. H. F. Smith (1991). Free software helps map and display data, EOS 72, 441, 445-446.

Westland, A.J., and R. R. Henrich (1940). A macroseismic study of the Ohio earthquakes of March 1937, Bull. Seism. Soc. Am. 30, 251-260.

Williams, W.. G.(1867). Earthquake in Kansas, American Journal of Science, 1867, 2nd series 44, 132.

Wheeler, R. I. (1997). Boundary separating the seismically active Reelfoot rift from the sparsely seismic Rough Creek graben, Kentucky and Illinois, Seismol. Res. Lett. 73, 776-791.

Wood, H. O., and F. Neumann (1931). Modified Mercalli Intensity Scale of 1931, Bull. Seismol. Soc. Am. 21, 277-283. 


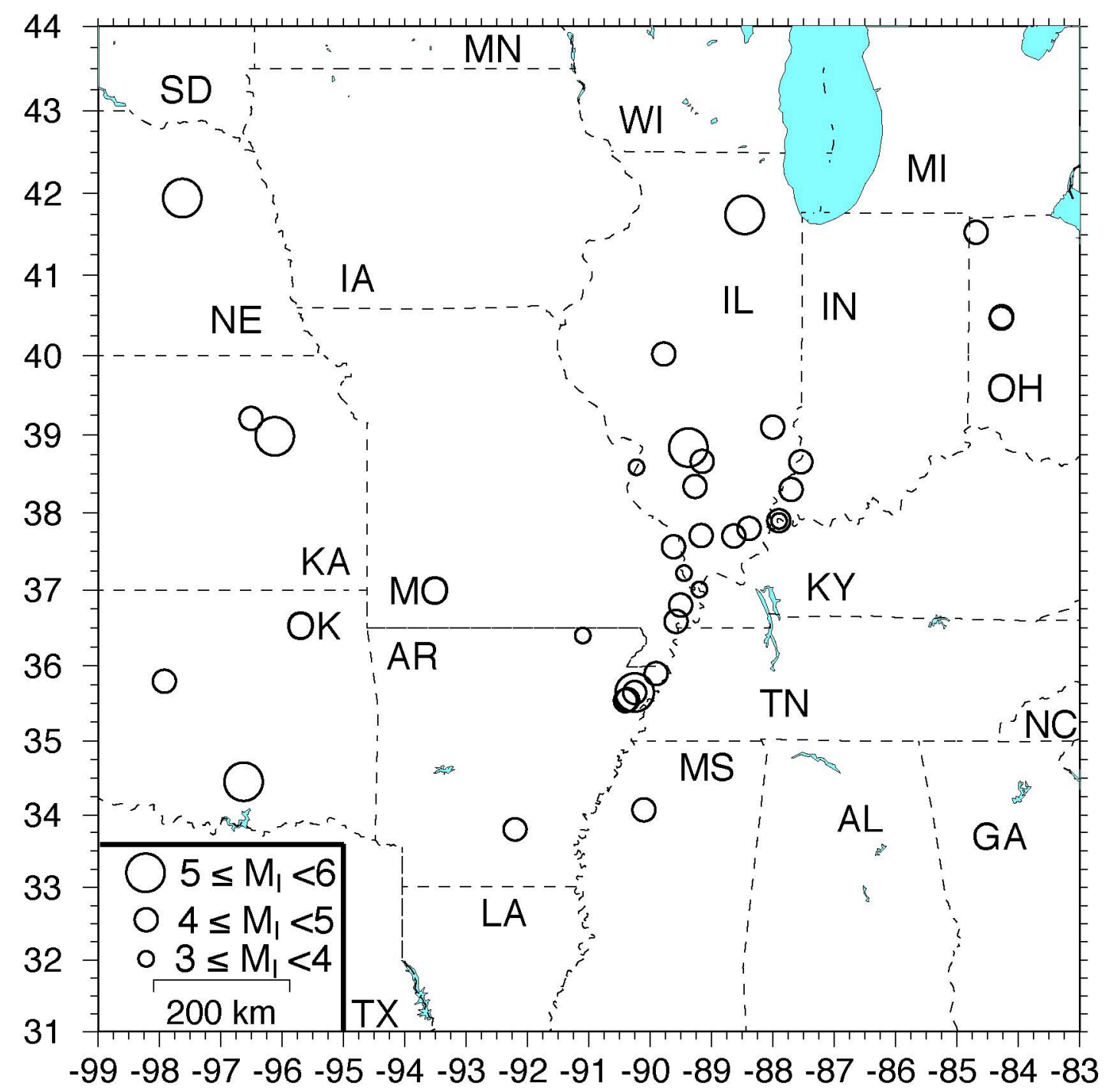

Figure 1. Locations (circles) of 38 historical earthquakes in the central United States for which epicenters and $\mathbf{M}$ were estimated. Symbol size is proportional to $M_{1}$ (see key), our best estimate of $\mathbf{M}$. 
Table 1. Some Historical Earthquakes in the Central United States

\begin{tabular}{|c|c|c|c|c|c|c|c|c|}
\hline \multirow[b]{2}{*}{ \# } & \multirow[b]{2}{*}{ (yr-mo-day) } & \multirow[b]{2}{*}{ State } & \multirow[b]{2}{*}{ \# $\mathbf{M M I}^{+}$} & \multicolumn{2}{|c|}{ Location } & \multirow[b]{2}{*}{ Associated Structural Feature ${ }^{\S}$} & \multicolumn{2}{|c|}{ Magnitude } \\
\hline & & & & $\begin{array}{l}\text { Lat } \\
\left({ }^{\circ} \mathbf{N}\right)\end{array}$ & $\begin{array}{l}\text { Long } \\
\left({ }^{\circ} \mathbf{W}\right)\end{array}$ & & $M_{I}$ & $M( \pm 2 \sigma)$ \\
\hline 1 & $1827-07-05$ & Indiana & 9,7 & 37.90 & 87.90 & III. Basin ( (Wabash Valley fault system) & 4.7 & $4.1-5.2$ \\
\hline 2 & $1827-08-07$ & Indiana & 3,2 & 37.90 & 87.90 & III. Basin (Wabash Valley fault system?) & 3.5 & $2.7-4.2$ \\
\hline 3 & $1838-06-09$ & Illinois & 8,5 & 38.59 & 90.22 & Ill. Basin (Waterloo-Dupo Anticline) & 3.9 & $3.2-4.5$ \\
\hline 4 & $1843-02-17$ & Arkansas & 2,0 & 35.90 & 89.90 & NMSZ (Blytheville Arch segment) & 4.2 & $3.1-5.0$ \\
\hline 5 & $1850-04-05$ & Indiana & 7,1 & 38.30 & 87.70 & IIl. Basin (Wabash Valley fault system?) & 4.6 & $3.3-5.6$ \\
\hline 6 & $1857-10-08$ & Illinois & 24,17 & 38.66 & 89.16 & Ill. Basin (Du Quoin Monocline) & 4.5 & $4.0-4.9$ \\
\hline 7 & $1865-08-17$ & Arkansas & 5,2 & 35.54 & 90.40 & NMSZ (Blytheville Arch segment) & 4.7 & $4.1-5.2$ \\
\hline 8 & $1867-04-24$ & Kansas & 35,31 & 38.98 & 96.12 & None & 5.2 & $4.8-5.6$ \\
\hline 9 & $1876-09-25$ & Illinois & 10,9 & 38.66 & 87.55 & $\begin{array}{l}\text { Ill. Basin (Charleston Monocline or New } \\
\text { Harmony fault zone) }\end{array}$ & 4.3 & $3.7-4.8$ \\
\hline 10 & $1877-11-15$ & Nebraska & 18,14 & 41.95 & 97.63 & None & 5.6 & $5.1-6.0$ \\
\hline 11 & $1878-11-19$ & Arkansas & 22,16 & 35.65 & 90.25 & NMSZ (Blytheville Arch segment) & 5.0 & $4.5-5.4$ \\
\hline 12 & $1882-10-22$ & Oklahoma & 10,5 & 34.45 & 96.63 & None & 5.7 & $5.0-6.3$ \\
\hline 13 & $1883-01-11$ & Missouri & 19,14 & 36.80 & 89.50 & NMSZ (New Madrid North segment) & 4.2 & $3.7-4.6$ \\
\hline 14 & $1883-12-05$ & Arkansas & 5,2 & 36.40 & 91.10 & None & 3.8 & $3.1-4.4$ \\
\hline 15 & 1884-09-19 & Ohio & 117,86 & 41.53 & 84.69 & None & 4.9 & $4.5-5.2$ \\
\hline 16 & $1887-08-02$ & Illinois & 56,49 & 37.70 & 88.64 & III. Basin (Cottage Grove fault system) & 4.6 & $4.2-4.9$ \\
\hline 17 & $1891-09-27$ & Illinois & 126,110 & 38.34 & 89.27 & Ill. Basin (Du Quoin Monocline) & 4.9 & $4.6-5.2$ \\
\hline 18 & $1899-04-30$ & Indiana & 15,11 & 38.30 & 87.70 & III. Basin (Wabash Valley fault system) & 4.9 & $4.4-5.3$ \\
\hline 19 & 1903-02-09 & Illinois & 37,28 & 37.71 & 89.17 & $\begin{array}{l}\text { Ill. Basin (Cottage Grove fault system or } \\
\text { Ste. Genevieve fault zone) }\end{array}$ & 4.4 & $4.0-4.7$ \\
\hline 20 & $1903-11-04$ & Missouri & 38,25 & 36.59 & 89.58 & NMSZ (Reelfoot blind thrust) & 4.7 & $4.3-5.0$ \\
\hline 21 & $1905-08-22$ & Missouri & 106,74 & 37.56 & 89.62 & III. Basin (Ste. Genevieve fault zone) & 4.6 & $4.2-4.9$ \\
\hline 22 & $1906-01-08$ & Kansas & 24,16 & 39.21 & 96.51 & None & 4.1 & $3.7-4.4$ \\
\hline 23 & $1909-05-26$ & Illinois & 98,78 & 41.74 & 88.46 & Sandwich fault zone & 5.0 & $4.6-5.3$ \\
\hline 24 & 1909-07-19 & Illinois & 24,15 & 40.02 & 89.78 & Ill. Basin (None) & 4.5 & $4.0-4.9$ \\
\hline 25 & $1909-09-27$ & Indiana & 114.83 & 39.10 & 88.00 & Ill. Basin (La Salle Anticlinorium?) & 4.8 & $4.4-5.1$ \\
\hline 26 & $1911-03-31$ & Arkansas & 23,17 & 33.80 & 92.20 & None & 4.3 & $3.8-4.7$ \\
\hline 27 & 1917-04-09 & Illinois & 54,46 & 38.84 & 89.38 & IIl. Basin (None) & 5.2 & $4.8-5.5$ \\
\hline 28 & $1922-03-22$ & Illinois & 24,20 & 37.22 & 89.45 & IIl. Basin (Ste. Genevieve fault zone) & 3.7 & $3.2-4.1$ \\
\hline 29 & $1922-11-27$ & Illinois & 18,9 & 37.80 & 88.40 & III. Basin (Cottage Grove fault system?) & 4.4 & $3.8-4.9$ \\
\hline 30 & $1923-10-28$ & Arkansas & 25,13 & 35.54 & 90.40 & NMSZ (Blytheville Arch segment) & 4.1 & $3.6-4.5$ \\
\hline 31 & $1925-04-27$ & Indiana & 45,33 & 38.30 & 87.70 & III. Basin (Wabash Valley fault system) & 4.7 & $4.3-5.0$ \\
\hline 32 & $1927-05-07$ & Arkansas & 23,22 & 35.65 & 90.25 & NMSZ (Blytheville Arch segment) & 4.5 & $4.0-4.9$ \\
\hline 33 & $1931-12-17$ & Mississippi & 103,59 & 34.07 & 90.10 & None & 4.2 & $3.8-4.5$ \\
\hline 34 & $1934-08-20$ & Missouri & 87,53 & 37.01 & 89.20 & Ill. Basin (Olmstead fault) & 3.7 & $3.3-4.0$ \\
\hline 35 & 1937-03-02 & Ohio & 7,7 & 40.49 & 84.27 & None & 4.5 & $4.1-4.8$ \\
\hline 36 & 1937-03-09 & Ohio & 17,14 & 40.47 & 84.28 & None & 4.6 & $4.1-5.0$ \\
\hline 37 & $1938-09-17$ & Arkansas & 15,9 & 35.55 & 90.37 & NMSZ (Blytheville Arch segment) & 4.4 & $3.9-4.8$ \\
\hline 38 & 1952-04-09 & Oklahoma & 235,136 & 35.53 & 97.85 & Nemaha fault & 4.9 & $4.5-5.2$ \\
\hline & $\begin{array}{l}X, Y \text { where } X \text { is } \\
\text { and } Y \text { is the }\end{array}$ & he total $n$ & 111 dSSI & 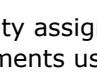 & a in es & $\begin{array}{l}\text { used in the location estimation } \\
\text { timating } \mathrm{M}_{\mathrm{I}} \text {. }\end{array}$ & & \\
\hline & $\begin{array}{l}\text { Nelson's (199 } \\
\text { and near th } \\
\text { historical ea } \\
\text { Basin. Whil } \\
\text { regional ass }\end{array}$ & 5) and Johns & and Sch & 's (19s & nom & $\begin{array}{l}\text { nclature adopted for events in the Illinois } \\
\text { ively. It is rarely possible to unambiguousl }\end{array}$ & IIl. B & \\
\hline
\end{tabular}




\section{\#1) 1827 July 5 11:30 UTC (Indiana)}

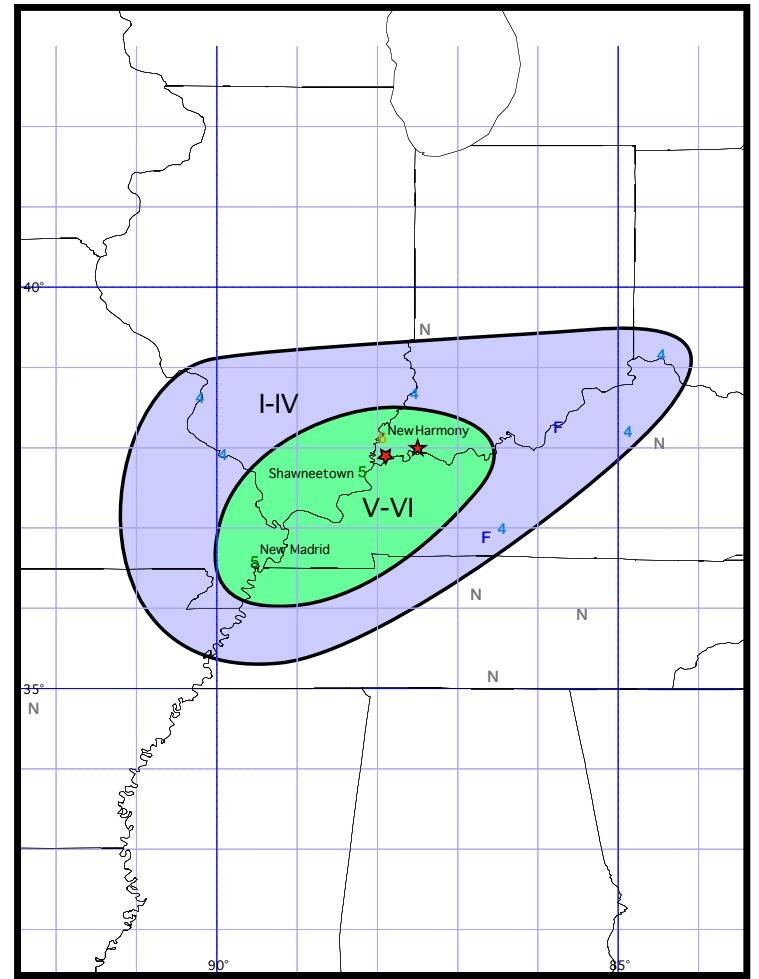

Isoseismal map. Numbers are $\mathrm{MMI}$ assignments; $\mathrm{F}$ denotes that the event was felt, but that the information is not sufficient to assign an $\mathrm{MMl} ; 0$ denotes that the event was reported as not felt; and $\mathrm{N}$ denotes that the event was not mentioned and is presumed "not felt". Click here to view damage reports and intensity assignments listed in Appendix 1, Part 01. The thick black isoseismal lines enclose isoseismal areas (V: green; IV: blue; etc.). The upward-pointing red star is Stover and Coffman's (1993) epicenter location; the downward-pointing star is our preferred location (see Table 1).

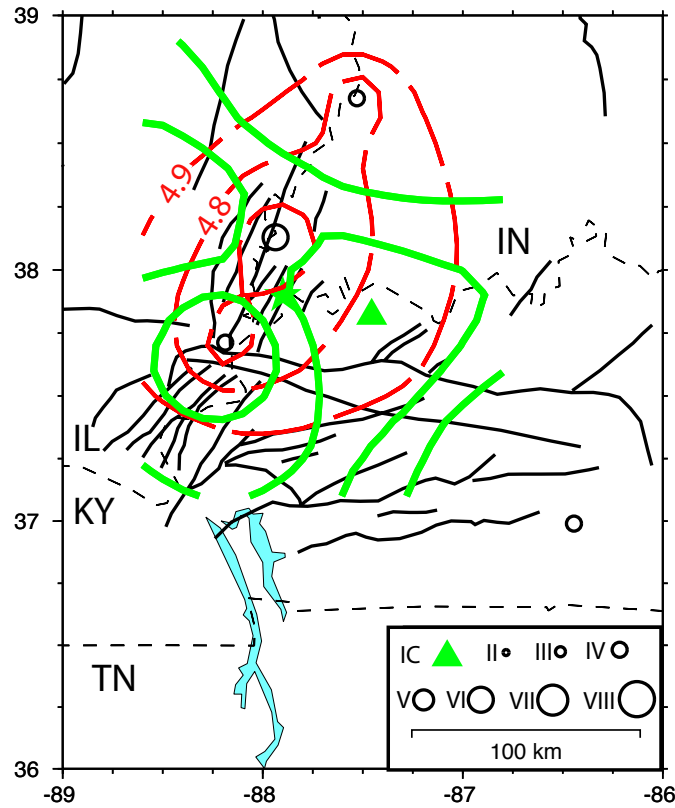

The epicentral region. Our preferred location is shown as a green star. IC is the intensity center. Faults are shown as black lines. Black circles are sites with MMI assignments; 7.0 (MMl-site corrections) $<8.0$ are plotted as MMI VII, and so on. The contours of $\mathrm{M}_{\mathrm{I}}$ (dashed red lines) are the best estimates of $\mathbf{M}$ from the $\mathrm{MMI}$ assignments for assumed epicenters on that contour. The rms $\left[M_{l}\right]$ contours corresponding to the $67 \%$ (innermost contour) and 95\% confidence levels (outermost contour) for location from Bakun and Wentworth (1999) are shown as solid green lines; there is an 0.67 probability that the epicenter lies within the $67 \%$ contour and an 0.95 probability that the epicenter lies within the $95 \%$ contour.

Comments. The intensity center is 40 kilometers east of our preferred epicenter on the Wabash Valley fault system. $M_{1}$ is 4.7 and $\mathbf{M}$ is 4.1 to 5.2 at the $95 \%$ confidence range. 


\section{\#2) 1827 August 7 04:30 UTC (Indiana)}

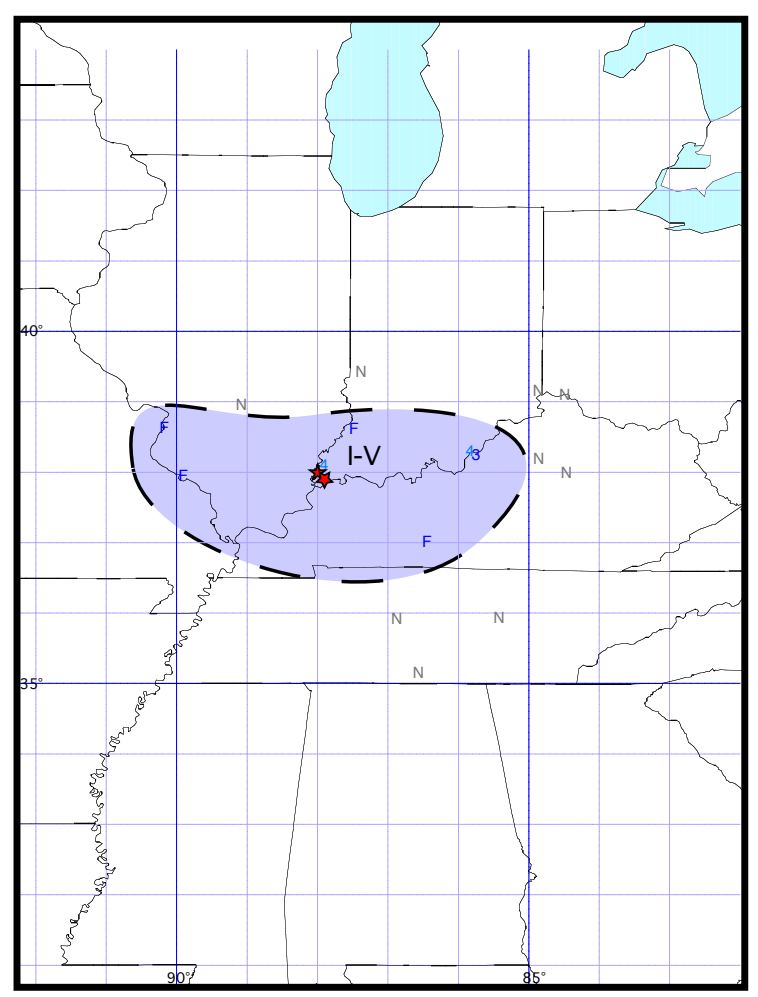

The epicentral region. There are only three $\mathrm{MMI}$ assignments so that a map of the epicentral region is not shown.

Isoseismal map. Numbers are MMI assignments; $\mathrm{F}$ denotes that the event was felt, but that the information is not sufficient to assign an $\mathrm{MMl} ; 0$ denotes that the event was reported as not felt; and $\mathrm{N}$ denotes that the event was not mentioned and is presumed "not felt". Click here to view damage reports and intensity assignments listed in Appendix 1, Part 02. The thick black isoseismal lines enclose isoseismal areas (V: green; IV: blue; etc.). The upward-pointing red star is Stover and Coffman's (1993) epicenter location; the downward-pointing star is our preferred location (see Table 1).

Comments. There are only three intensity assignments so that the source location is only constrained to the Illinois Basin, and $M_{1}$ is less than 4.5 for sources in southern Illinois and southern Indiana. For an arbitrary location on the Wabash Valley fault system at the preferred location for the 5 July 1827 event, $M_{1}$ is 3.5 and $\mathbf{M}$ is 2.7 to 4.2 at the $95 \%$ confidence range. 


\section{\#3) 1838 June 9 14:45 UTC (Illinois)}

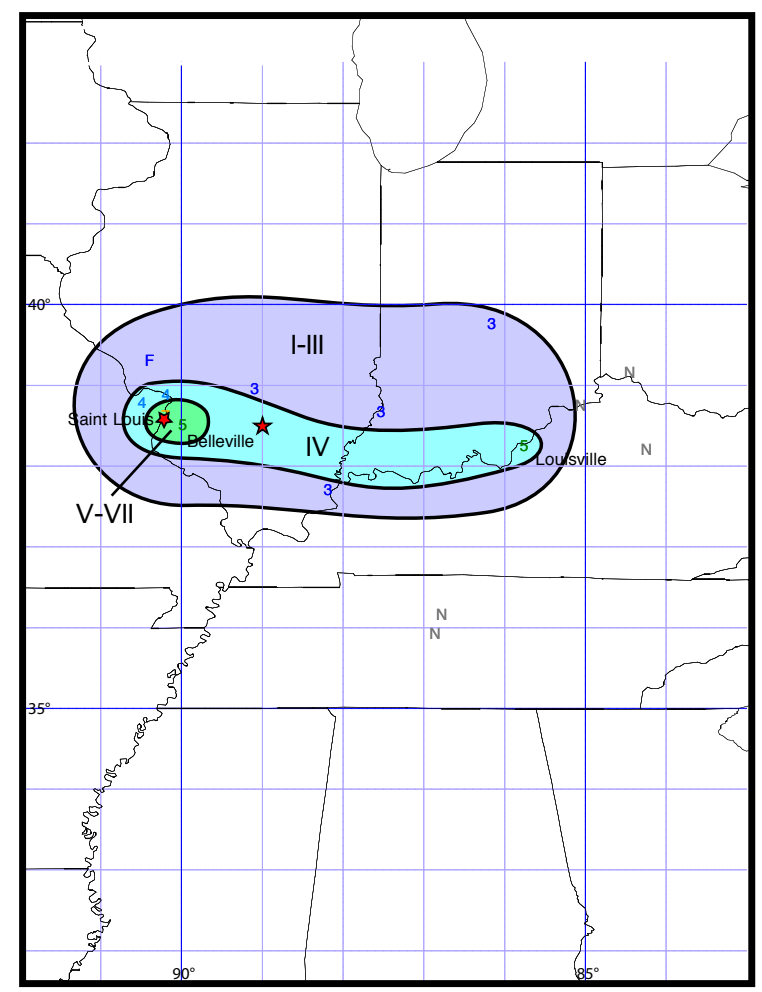

Isoseismal map. Numbers are MMI assignments; F denotes that the event was felt, but that the information is not sufficient to assign an $\mathrm{MMl} ; 0$ denotes that the event was reported as not felt; and $\mathrm{N}$ denotes that the event was not mentioned and is presumed "not felt". Click here to view damage reports and intensity assignments listed in Appendix 1, Part 03. The thick black isoseismal lines enclose isoseismal areas (V: green; IV: blue; etc.). The upwardpointing red star is Stover and Coffman's (1993) epicenter location; the downward-pointing star is our preferred location (see Table 1).

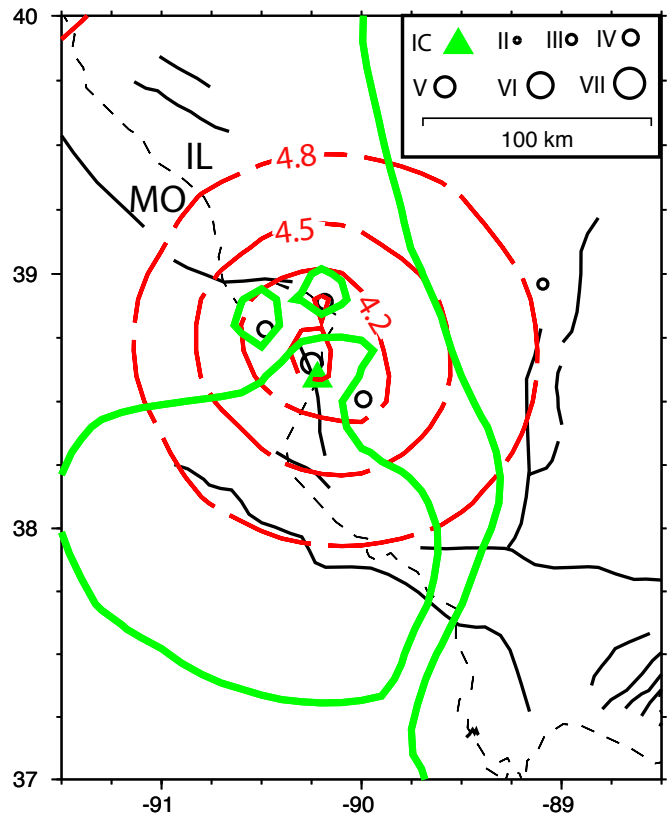

The epicentral region. Faults are shown as black lines. IC is the intensity center. Black circles are sites with MMl assignments; 7.0 (MMI-site corrections) $<8.0$ are plotted as MMI VII, and so on. The contours of $M_{I}$ (dashed red lines) are the best estimates of $\mathbf{M}$ from the $\mathbf{M M l}$ assignments for assumed epicenters on that contour. The rms $\left[\mathrm{M}_{\mathrm{l}}\right]$ contours corresponding to the $67 \%$ (innermost contour) and $95 \%$ confidence levels (outermost contour) for location from Bakun and Wentworth (1999) are shown as solid green lines; there is an 0.67 probability that the epicenter lies within the $67 \%$ contour and an 0.95 probability that the epicenter lies within the $95 \%$ contour.

Comments. The intensity center is located on the Waterloo-Dupo Anticline. Drape-folding of sedimentary layers across a basement fault is strongly suggested (Nelson, 1995), but reflection data that might confirm the presence of bedrock root faulting is not available (John McBride, personal communication, 2003). $\mathrm{M}_{1}$ is 3.9 for a source location beneath the anticline. $\mathbf{M}$ is 3.2 to 4.5 at the $95 \%$ confidence range. 


\section{\#4) 1843 February 17 05:00 UTC Arkansas)}

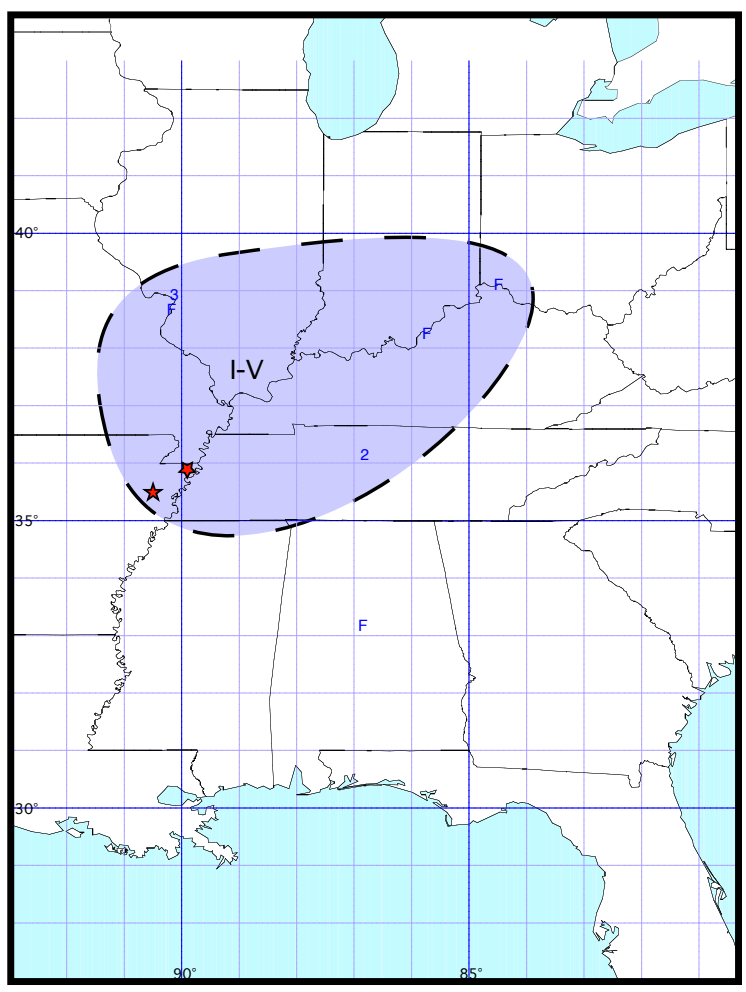

The epicentral region. There are only two MMI assignments so that a map of the epicentral region is not shown. We assume a location on the NMSZ.

Isoseismal map. Numbers are MMI assignments; $\mathrm{F}$ denotes that the event was felt, but that the information is not sufficient to assign an $\mathrm{MMl} ; 0$ denotes that the event was reported as not felt; and $\mathrm{N}$ denotes that the event was not mentioned and is presumed "not felt". Click here to view damage reports and intensity assignments listed in Appendix 1, Part 04. The thick black isoseismal lines enclose isoseismal areas (V: green; IV: blue; etc.). The upward-pointing red star is Stover and Coffman's (1993) epicenter location; the downward-pointing star is our preferred location (see Table 1).

Comments. There is not sufficient data to constrain the location, but we can estimate the magnitude if we assume that this is an aftershock of the M6.2 event that occurred on 5 January 1843 on the Blytheville Arch segment of the NMSZ (Bakun et al., 2003). Assuming Bakun et al.'s (2003) location for the 5 January 1843 event $\left(35.90^{\circ} \mathrm{N}, 89.90^{\circ} \mathrm{W}\right), \mathrm{M}_{\mathrm{l}}$ is 4.6 for the MMI III at Alton, $\mathrm{IL}$, and 3.9 for the MMI II at Nashville, TN. $\mathrm{M}_{1}$ is 4.2 and $\mathbf{M}$ is 3.1 to 5.0 at the $95 \%$ confidence range. 


\section{\#5) 1850 April 5 02:05 UTC (Indiana)}

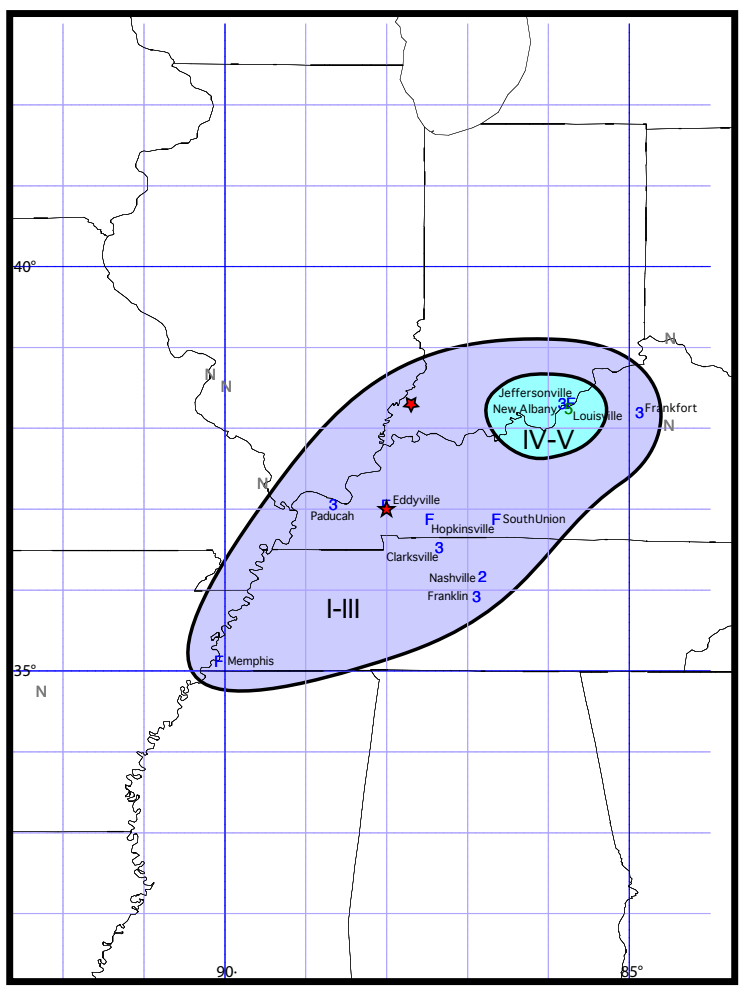

Isoseismal map. Numbers are MMI assignments; F denotes that the event was felt, but that the information is not sufficient to assign an $\mathrm{MMl} ; 0$ denotes that the event was reported as not felt; and $\mathrm{N}$ denotes that the event was not mentioned and is presumed "not felt". Click here to view damage reports and intensity assignments listed in Appendix 1, Part 05. The thick black isoseismal lines enclose isoseismal areas (V: green; IV: blue; etc.). The upwardpointing red star is Stover and Coffman's (1993) epicenter location; the downward-pointing star is our preferred location (see Table 1).

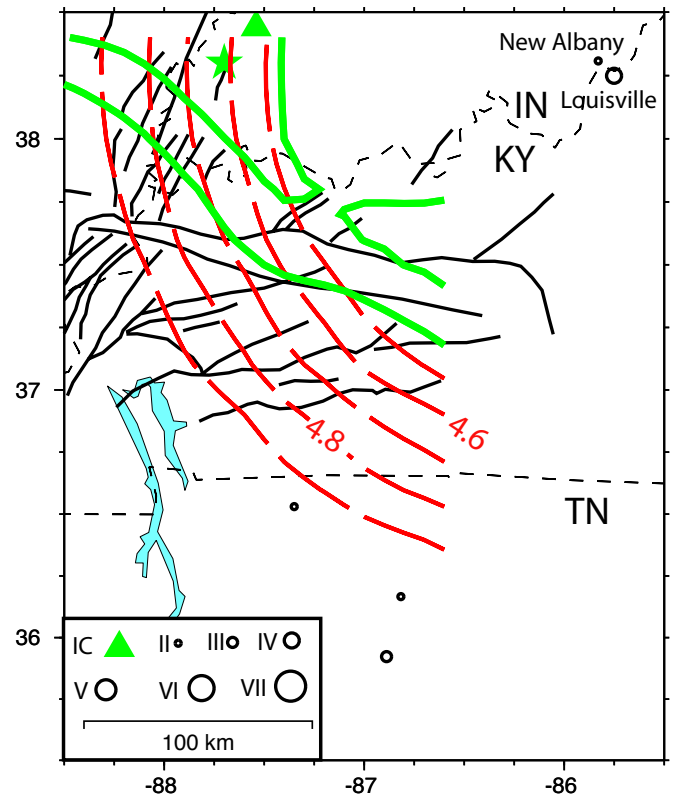

The epicentral region. Faults are shown as black lines. Our preferred location is shown as a green star. IC is the intensity center. Black circles are sites with MMl assignments; 7.0 (MMI-site corrections) $<8.0$ are plotted as MMI VII, and so on. The contours of $M_{I}$ (dashed red lines) are the best estimates of $\mathbf{M}$ from the MMl assignments for assumed epicenters on that contour. The rms $\left[\mathrm{M}_{\mathrm{l}}\right]$ contours corresponding to the $67 \%$ (innermost contour) and $95 \%$ confidence levels (outermost contour) for location from Bakun and Wentworth (1999) are shown as solid green lines; there is an 0.67 probability that the epicenter lies within the $67 \%$ contour and an 0.95 probability that the epicenter lies within the $95 \%$ contour.

Comments. There are only seven MMI assignments, and they are not self consistent. In particular, the MMIV at Louisville, Kentucky, (no site correction available) is across the Ohio River from the MMI III at New Albany, Indiana (site correction = 0.98). For consistency, we have applied the New Albany site correction to the Louisville MMI assignment for this analysis. Stover and Coffman's (1993) epicenter is in northwest Kentucky, but the intensity center is in Indiana near the Wabash Valley fault system. For our preferred location on the Wabash Valley fault system, $M_{1}$ is 4.6 and $\mathbf{M}$ is 3.3 to 5.6 at the $95 \%$ confidence range. 


\section{\#6) 1857 October 8 10:00UTC (Illinois)}

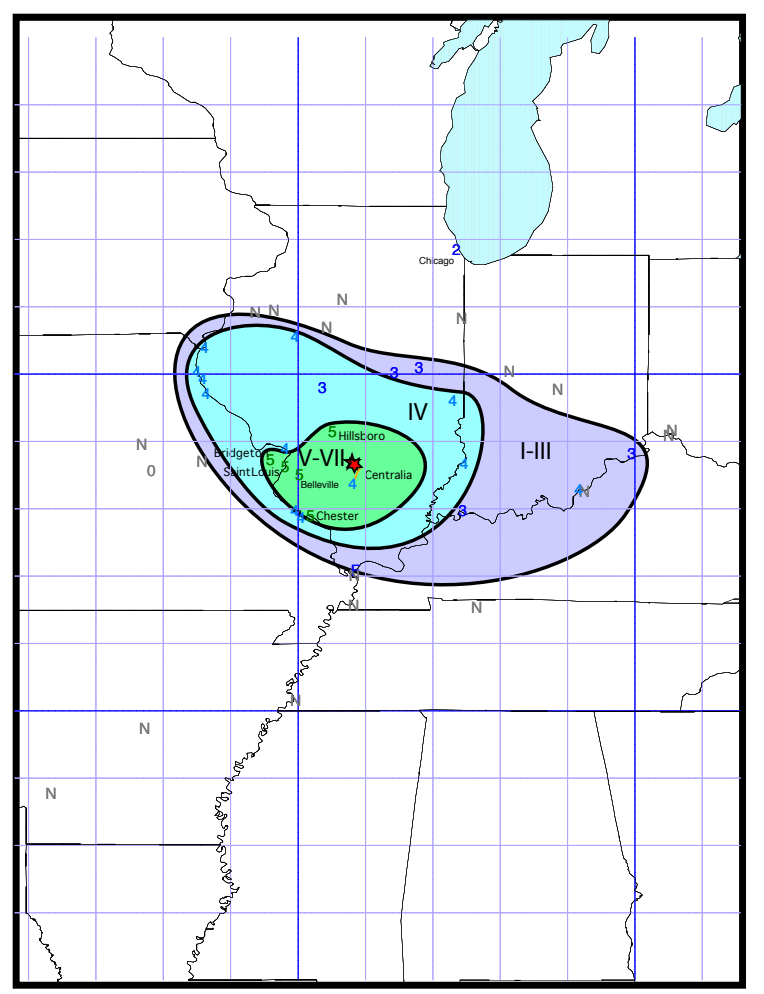

Isoseismal map. Numbers are MMI assignments; F denotes that the event was felt, but that the information is not sufficient to assign an $\mathrm{MMl} ; 0$ denotes that the event was reported as not felt; and $\mathrm{N}$ denotes that the event was not mentioned and is presumed "not felt". Click here to view damage reports and intensity assignments listed in Appendix 1, Part 06. The thick black isoseismal lines enclose isoseismal areas (V: green; IV: blue; etc.). The upward-pointing red star is Stover and Coffman's (1993) epicenter location; the downward-pointing star is our preferred location (see Table 1).

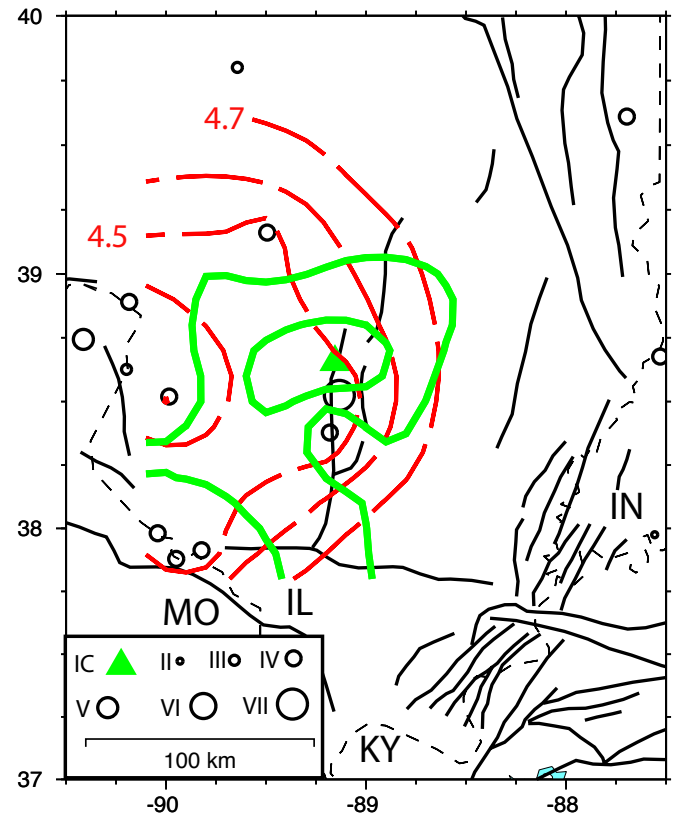

The epicentral region. Faults are shown as black lines. IC is the intensity center. Black circles are sites with $\mathrm{MMI}$ assignments; 7.0 (MMI-site corrections) $<8.0$ are plotted as MMI VII, and so on. The contours of $M_{I}$ (dashed red lines) are the best estimates of $\mathbf{M}$ from the MMl assignments for assumed epicenters on that contour. The rms $\left[\mathrm{M}_{\mathrm{l}}\right]$ contours corresponding to the $67 \%$ (innermost contour) and $95 \%$ confidence levels (outermost contour) for location from Bakun and Wentworth (1999) are shown as solid green lines; there is an 0.67 probability that the epicenter lies within the $67 \%$ contour and an 0.95 probability that the epicenter lies within the $95 \%$ contour.

Comments. The intensity center is located on the north end of the Du Quoin Monocline. Seismic reflection data over the southern Du Quoin Monocline show asymmetric folding overlying a west-dipping reverse fault (McBride, 1998). At Centralia, 15 kilometers south of the intensity center, the first of three reported shocks threw down chimneys (Stover and Coffman, 1993), consistent with a source located beneath the Du Quoin Monocline near Centralia. $\mathbf{M}_{1}$ is 4.5 and $\mathbf{M}$ is 4.0 to 4.9 at the $95 \%$ confidence range. 


\section{\#7) 1865 August 17 15:00 UTC (Arkansas)}

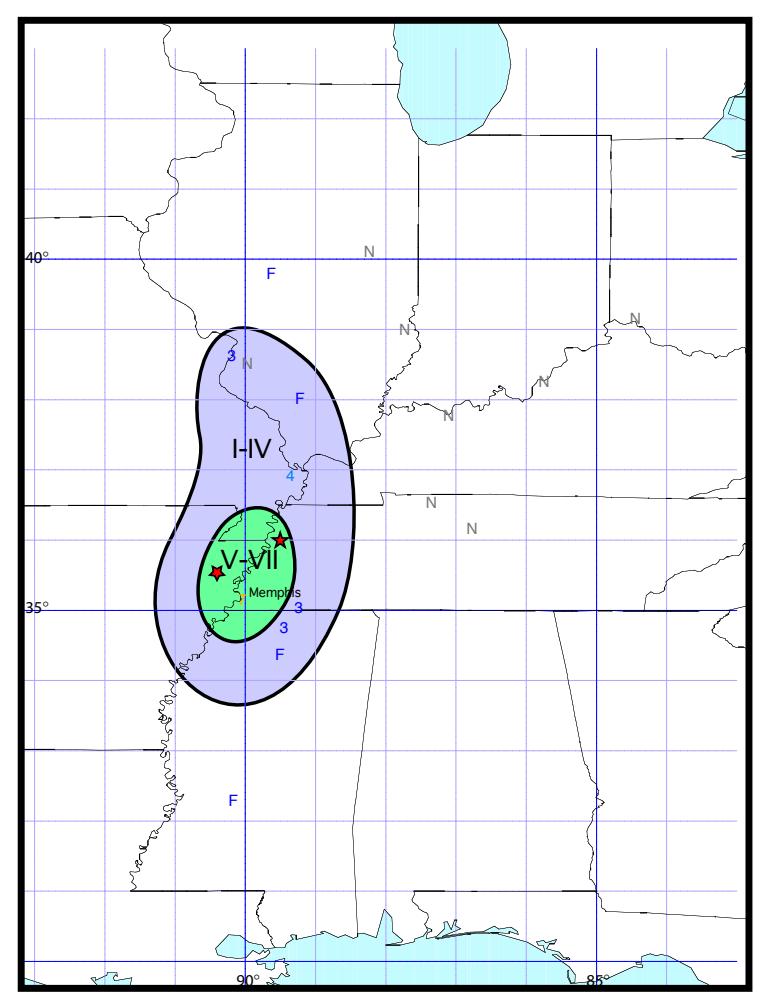

Isoseismal map. Numbers are MMI assignments; $F$ denotes that the event was felt, but that the information is not sufficient to assign an $\mathrm{MMI} ; 0$ denotes that the event was reported as not felt; and $\mathrm{N}$ denotes that the event was not mentioned and is presumed "not felt". Click here to view damage reports and intensity assignments listed in Appendix 1, Part 07. The thick black isoseismal lines enclose isoseismal areas (V: green; IV: blue; etc.). The upward-pointing red star is Stover and Coffman's (1993) epicenter location; the downward-pointing star is our preferred location (see Table 1).

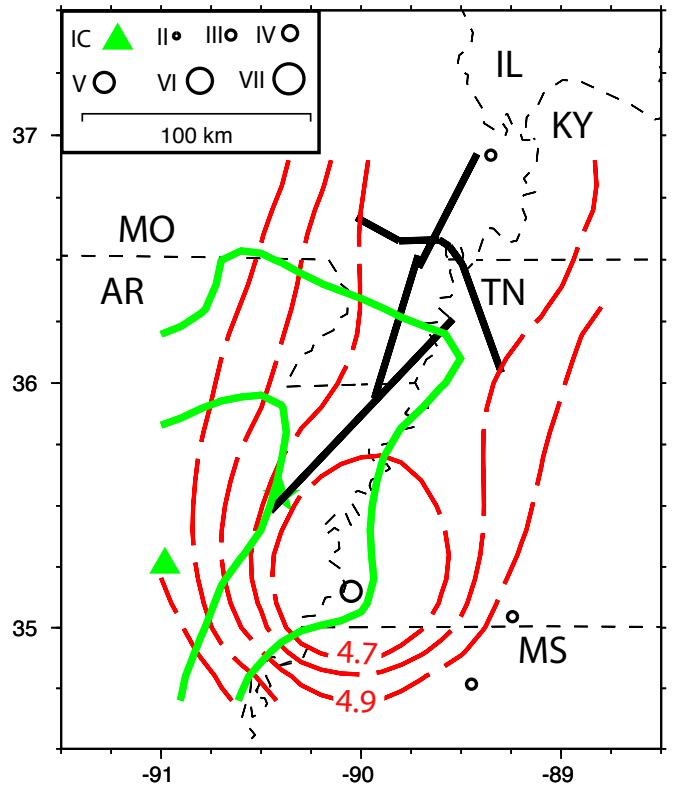

The epicentral region. IC is the intensity center. Our preferred location is shown as a green star. The thick black lines represent Johnston and Schweig's (1996) NMSZ segments. Black circles are sites with MMI assignments; $7.0 \leq$ (MMl -site corrections) $<8.0$ are plotted as MMI VII, and so on. The contours of $M_{\mathrm{I}}$ (dashed red lines) are the best estimates of $\mathbf{M}$ from the $\mathrm{MMI}$ assignments for assumed epicenters on that contour. The rms $\left[\mathrm{M}_{\mathrm{l}}\right]$ contours corresponding to the $67 \%$ (innermost contour) and 95\% confidence levels (outermost contour) for location from Bakun and Wentworth (1999) are shown as solid green lines; there is an 0.67 probability that the epicenter lies within the $67 \%$ contour and an 0.95 probability that the epicenter lies within the $95 \%$ contour.

Comments. The location is poorly constrained, but the reports of chimneys thrown down in Memphis (MMI VII) suggest a nearby source. $M_{1}$ is 4.7 for a location on the Blytheville Arch segment of the NMSZ. $\mathbf{M}$ is 4.1 to 5.2 at the $95 \%$ confidence range. 


\section{\#8) 1867 April 24 20:22 UTC (Kansas)}

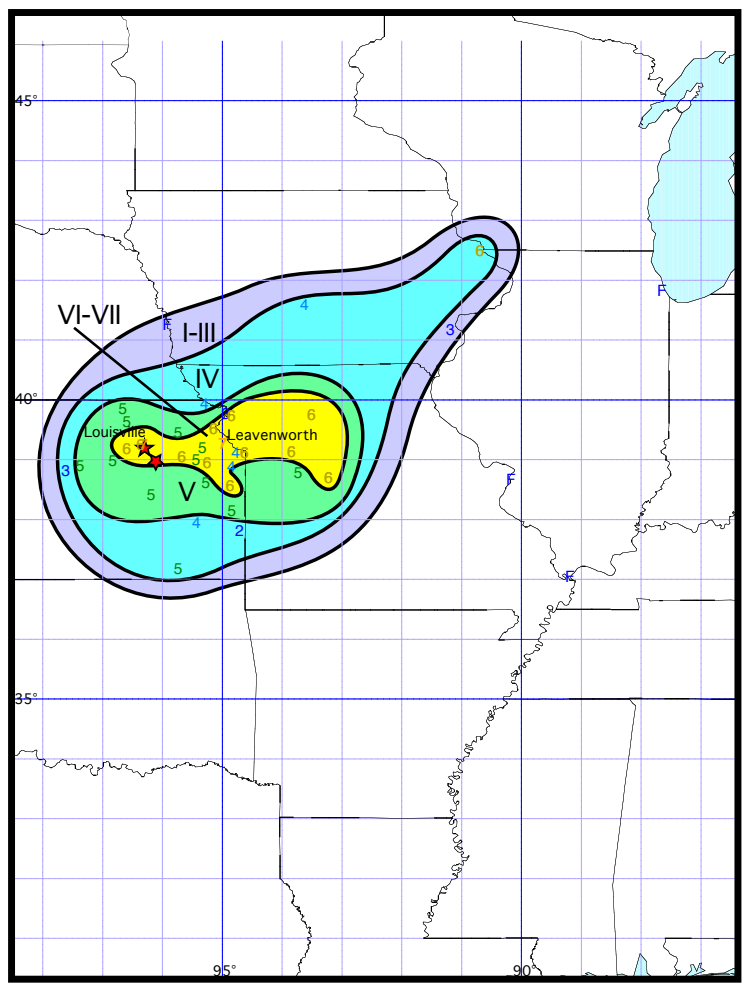

Isoseismal map. Numbers are MMI assignments; $\mathrm{F}$ denotes that the event was felt, but that the information is not sufficient to assign an $\mathrm{MMl} ; 0$ denotes that the event was reported as not felt; and $\mathrm{N}$ denotes that the event was not mentioned and is presumed "not felt". Click here to view damage reports and intensity assignments listed in Appendix 1, Part 08. The thick black isoseismal lines enclose isoseismal areas (V: green; IV: blue; etc.). The upward-pointing red star is Stover and Coffman's (1993) epicenter location; the downward-pointing star is our preferred location (see Table 1).

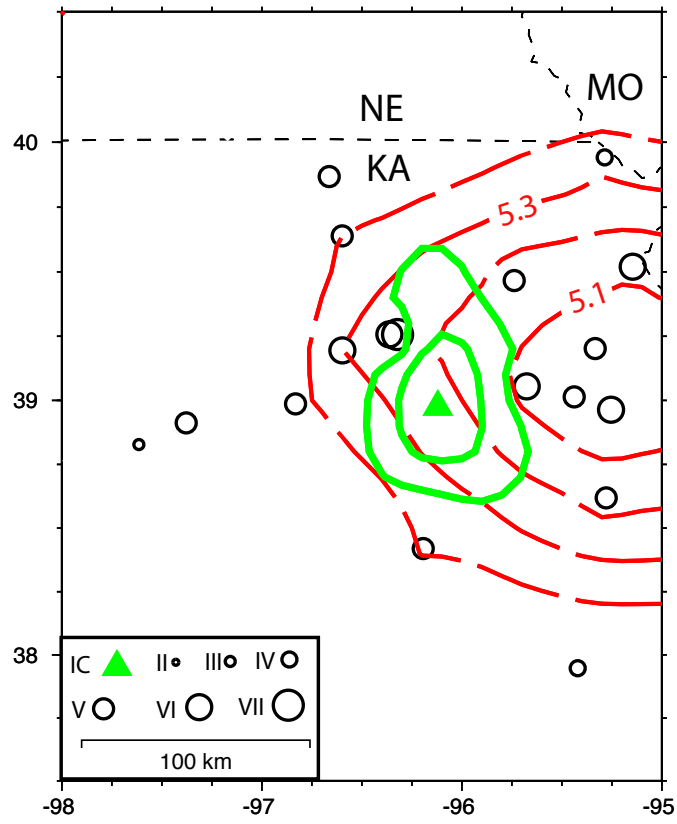

The epicentral region. IC is the intensity center. Black circles are sites with MMl assignments; 7.0 (MMI-site corrections) $<8.0$ are plotted as MMI VII, and so on. The contours of $M_{1}$ (dashed red lines) are the best estimates of $\mathbf{M}$ from the MMI assignments for assumed epicenters on that contour. The rms $\left[\mathrm{M}_{\mathrm{l}}\right]$ contours corresponding to the $67 \%$ (innermost contour) and $95 \%$ confidence levels (outermost contour) for location from Bakun and Wentworth (1999) are shown as solid green lines; there is an 0.67 probability that the epicenter lies within the $67 \%$ contour and an 0.95 probability that the epicenter lies within the $95 \%$ contour.

Comments. This significant earthquake occurred near the town of Manhattan in northeast Kansas. A $0.6 \mathrm{~m}$ wave was observed moving south to north on the Kansas River at Manhattan (Stover and Coffman, 1993). $\mathbf{M}_{1}$ is 5.2 and $\mathbf{M}$ is 4.8 to 5.6 at the $95 \%$ confidence range. 


\section{\#9) 1876 September 25 06:15 UTC (Illinois)}

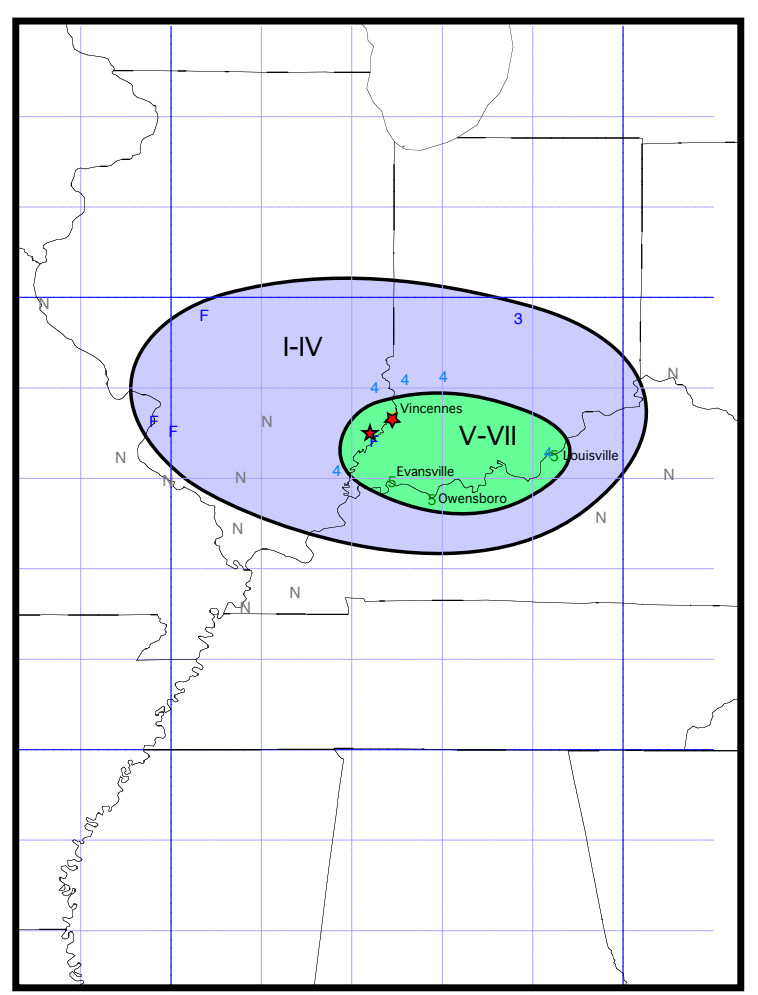

Isoseismal map. Numbers are MMI assignments; F denotes that the event was felt, but that the information is not sufficient to assign an $\mathrm{MMl} ; 0$ denotes that the event was reported as not felt; and $\mathrm{N}$ denotes that the event was not mentioned and is presumed "not felt". Click here to view damage reports and intensity assignments listed in Appendix 1, Part 09. The thick black isoseismal lines enclose isoseismal areas (V: green; IV: blue; etc.). The upward-pointing red star is Stover and Coffman's (1993) epicenter location; the downward-pointing star is our preferred location (see Table 1).

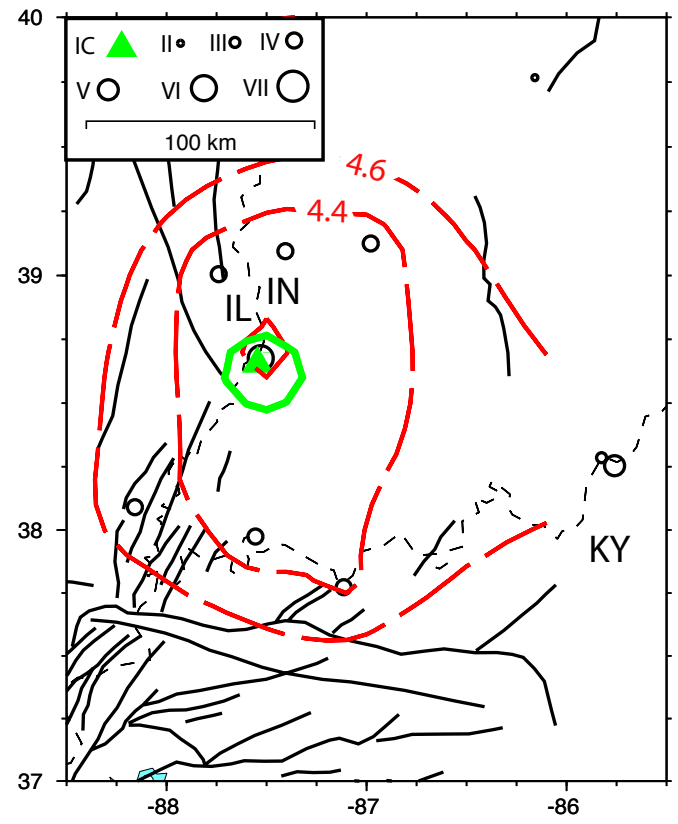

The epicentral region. Faults are shown as black lines. IC is the intensity center. Black circles are sites with MMl assignments; 7.0 (MMI-site corrections) $<8.0$ are plotted as MMI VII, and so on. The contours of $M_{I}$ (dashed red lines) are the best estimates of $\mathbf{M}$ from the MMl assignments for assumed epicenters on that contour. The rms $\left[\mathrm{M}_{\mathrm{l}}\right]$ contours corresponding to the $67 \%$ (innermost contour) and $95 \%$ confidence levels (outermost contour) for location from Bakun and Wentworth (1999) are shown as solid green lines; there is an 0.67 probability that the epicenter lies within the $67 \%$ contour and an 0.95 probability that the epicenter lies within the $95 \%$ contour.

Comments. The location of the second and larger of two earthquakes about 15 minutes apart is constrained to near the intersection of the south end of the Charleston Monocline and the north end of the New Harmony fault zone of parallel overlapping normal faults. The Charleston Monocline is the southeast member of the NW-SE striking La Salle Anticlinorium and the New Harmony fault zone comprises the eastern flank of the NE-SW striking Wabash Valley fault system. Faulting in the basement cores of both structures is evident in seismic reflection data (John McBride, pers. comm., 2003). The 10 June 1987 M5.0 earthquake, located 36 kilometers to the west of the 1876 intensity center, was associated by Hamburger and Rupp (1988) with basement deformation within a complex structural transition zone connecting the two tectonic regimes; a similar interpretation is appropriate for the 1876 event. Note that the intensity center lies within the Commerce Geophysical Lineament, a major rheological boundary related to both surface and deep structures (Hildenbrand et al., 2002) and near the locations of three $M>6.0$ prehistoric earthquakes (Hildenbrand and Ravat, 1997). $\mathbf{M}_{1}$ is 4.3 and $\mathbf{M}$ is 3.7 to 4.8 at the $95 \%$ confidence range. 


\section{\#10) 1877 November 15 17:45 UTC (Nebraska)}

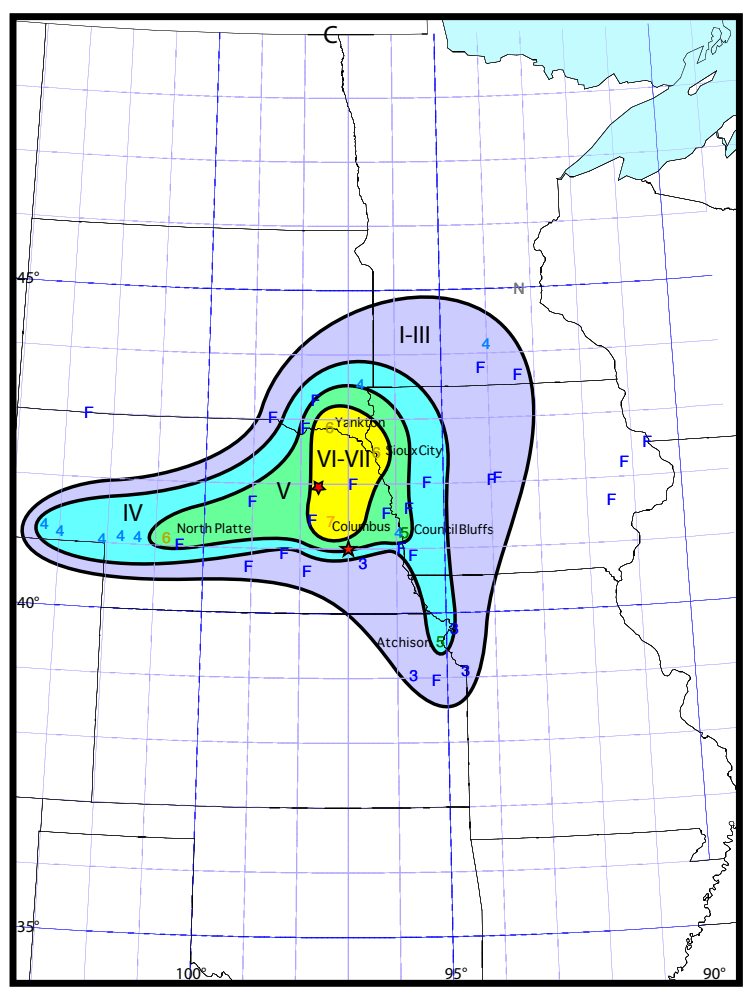

Isoseismal map. Numbers are $\mathrm{MMI}$ assignments; $\mathrm{F}$ denotes that the event was felt, but that the information is not sufficient to assign an $\mathrm{MMl} ; 0$ denotes that the event was reported as not felt; and $\mathrm{N}$ denotes that the event was not mentioned and is presumed "not felt". Click here to view damage reports and intensity assignments listed in Appendix 1, Part 10. The thick black isoseismal lines enclose isoseismal areas (V: green; IV: blue; etc.). The upward-pointing red star is Stover and Coffman's (1993) epicenter location; the downward-pointing star is our preferred location (see Table 1).

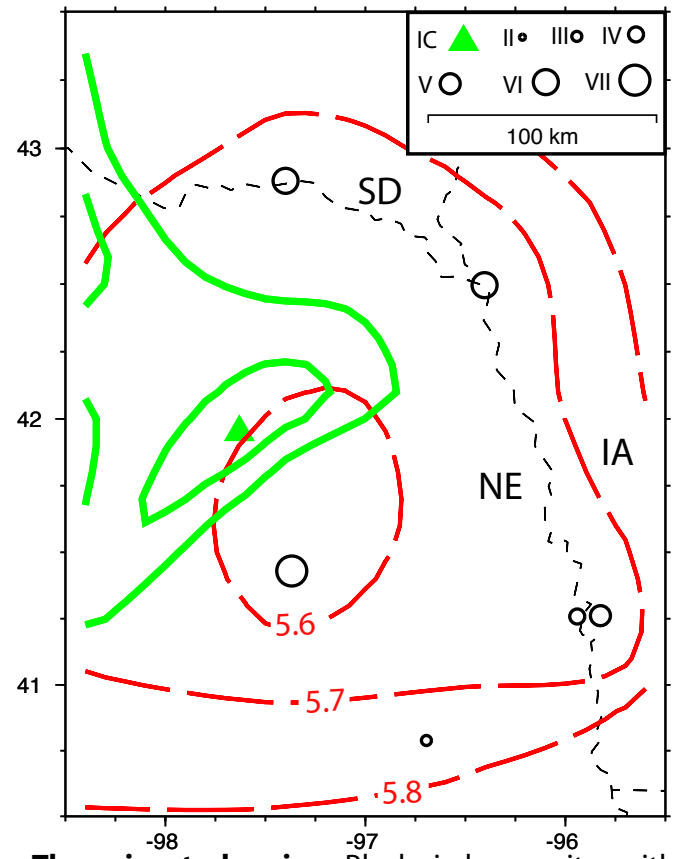

The epicentral region. Black circles are sites with $\mathrm{MMI}$ assignments; 7.0 (MMI -site corrections) $<8.0$ are plotted as MMI VII, and so on. IC is the intensity center. The contours of $M_{1}$ (dashed red lines) are the best estimates of $\mathbf{M}$ from the $\mathrm{MMI}$ assignments for assumed epicenters on that contour. The rms $\left[M_{l}\right]$ contours corresponding to the $67 \%$ (innermost contour) and $95 \%$ confidence levels (outermost contour) for location from Bakun and Wentworth (1999) are shown as solid green lines; there is an 0.67 probability that the epicenter lies within the $67 \%$ contour and an 0.95 probability that the epicenter lies within the $95 \%$ contour.

Comments. This eastern Nebaska event was felt over all or parts of lowa, Kansas, Minnesota, Missouri, Nebraska, South Dakota, and Minnesota (Stover and Coffman, 1993). $\mathbf{M}_{\mathbf{l}}$ is 5.6 and $\mathbf{M}$ is 5.1 to 6.0 at the $95 \%$ confidence range. 


\section{\#11) 1878 November 19 05:52 UTC (Arkansas)}

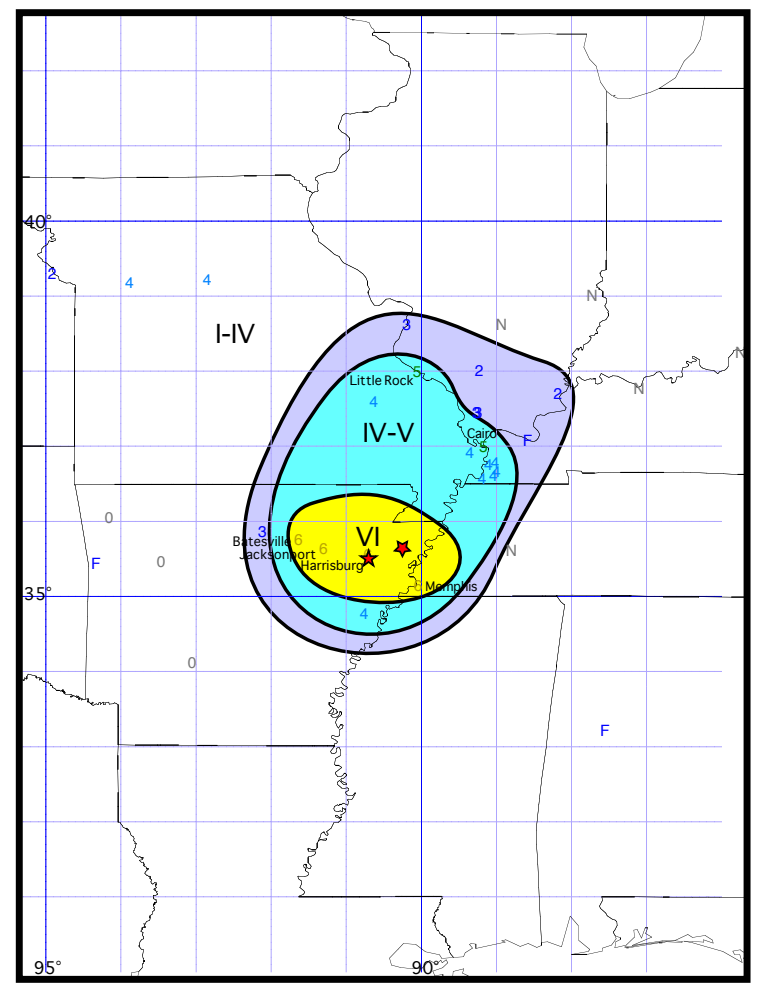

Isoseismal map. Numbers are $\mathrm{MMI}$ assignments; $\mathrm{F}$ denotes that the event was felt, but that the information is not sufficient to assign an $\mathrm{MMl} ; 0$ denotes that the event was reported as not felt; and $\mathrm{N}$ denotes that the event was not mentioned and is presumed "not felt". Click here to view damage reports and intensity assignments listed in Appendix 1, Part 11. The thick black isoseismal lines enclose isoseismal areas (V: green; IV: blue; etc.). The upward-pointing red star is Stover and Coffman's (1993) epicenter location; the downward-pointing star is our preferred location (see Table 1).

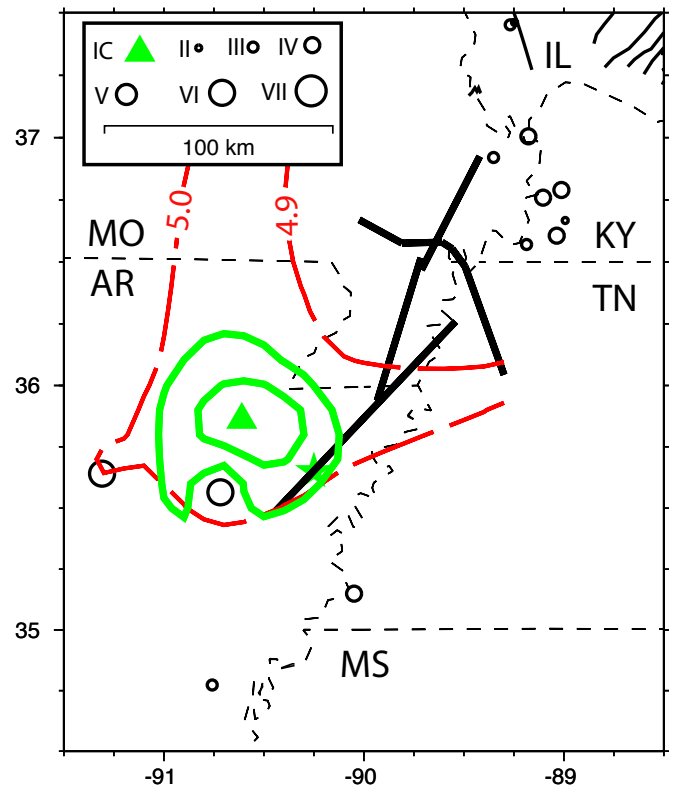

The epicentral region. IC is the intensity center. Our preferred location is shown as a green star. Faults are shown as black lines. The thick black lines represent Johnston and Schweig's (1996) NMSZ segments. Black circles are sites with MMI assignments; 7.0 (MMI -site corrections) $<8.0$ are plotted as MMI VII, and so on. The contours of $M_{l}$ (dashed red lines) are the best estimates of $\mathbf{M}$ from the $\mathrm{MMI}$ assignments for assumed epicenters on that contour. The rms $\left[\mathrm{M}_{\mathrm{l}}\right]$ contours corresponding to the $67 \%$ (innermost contour) and $95 \%$ confidence levels (outermost contour) for location from Bakun and Wentworth (1999) are shown as solid green lines; there is an 0.67 probability that the epicenter lies within the $67 \%$ contour and an 0.95 probability that the epicenter lies within the $95 \%$ contour.

Comments. The intensity data are consistent with a location on the Blytheville Arch segment of the NMSZ. $M_{1}$ is 5.0 and $\mathbf{M}$ is 4.5 to 5.4 at the $95 \%$ confidence range. 


\section{\#12)1882 October 22 22:15 UTC (Oklahoma)}

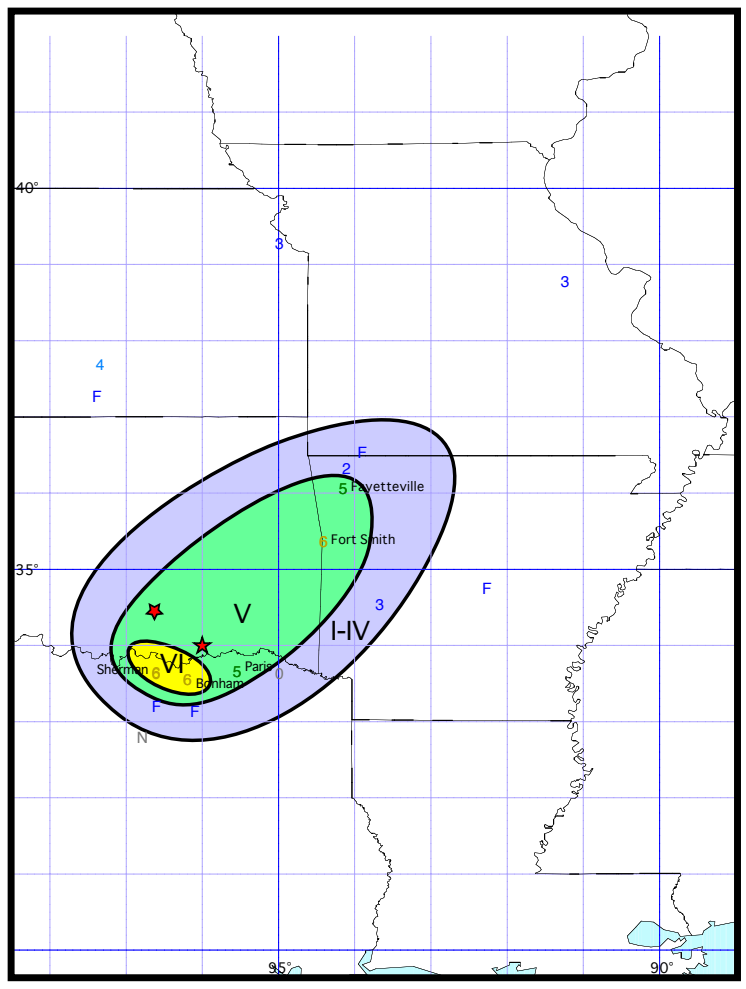

Isoseismal map. Numbers are $\mathrm{MMI}$ assignments; $\mathrm{F}$ denotes that the event was felt, but that the information is not sufficient to assign an $\mathrm{MMl} ; 0$ denotes that the event was reported as not felt; and $\mathrm{N}$ denotes that the event was not mentioned and is presumed "not felt". Click here to view damage reports and intensity assignments listed in Appendix 1, Part 12. The thick black isoseismal lines enclose isoseismal areas (V: green; IV: blue; etc.). The upward-pointing red star is Stover and Coffman's (1993) epicenter location; the downward-pointing star is our preferred location (see Table 1).

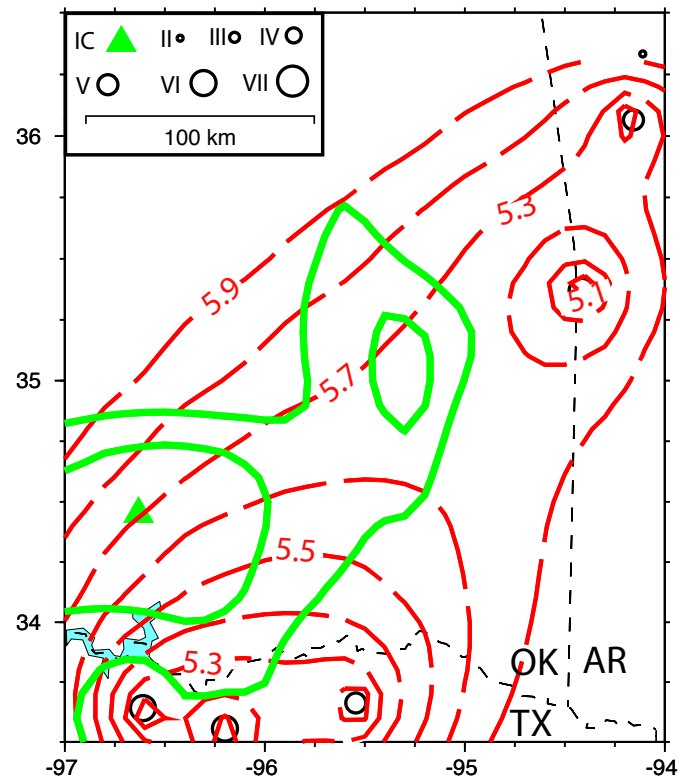

The epicentral region. Black circles are sites with $\mathrm{MMI}$ assignments; 7.0 (MMl-site corrections) $<8.0$ are plotted as MMI VII, and so on. IC is the intensity center. The contours of $M_{1}$ (dashed red lines) are the best estimates of $\mathbf{M}$ from the $\mathrm{MMI}$ assignments for assumed epicenters on that contour. The rms $\left[M_{l}\right]$ contours corresponding to the $67 \%$ (innermost contour) and $95 \%$ confidence levels (outermost contour) for location from Bakun and Wentworth (1999) are shown as solid green lines; there is an 0.67 probability that the epicenter lies within the $67 \%$ contour and an 0.95 probability that the epicenter lies within the $95 \%$ contour.

Comments. This earthquake was felt over a wide region, including Arkansas, Kansas, Missouri, Oklahoma, and Texas (Stover and Coffman, 1993). The descriptions of damage, and the intensity assignments, are uncertain for several of the sites, so that the location and magnitude are uncertain, but the significant shaking at widespread sites is consistent with an M51/2 - 6 source. Although few felt reports are available for sites in the Oklahoma Territory, the intensity center is located in southeast Oklahoma, consistent with the conclusions of Carlson (1984) that the event occurred in southeast Oklahoma rather than in northeast Texas. $M_{1}$ is 5.7 and $\mathbf{M}$ is 5.0 to 6.3 at the $95 \%$ confidence range. 


\section{\#13) 1883 January 11 07:12 UTC (Missouri)}

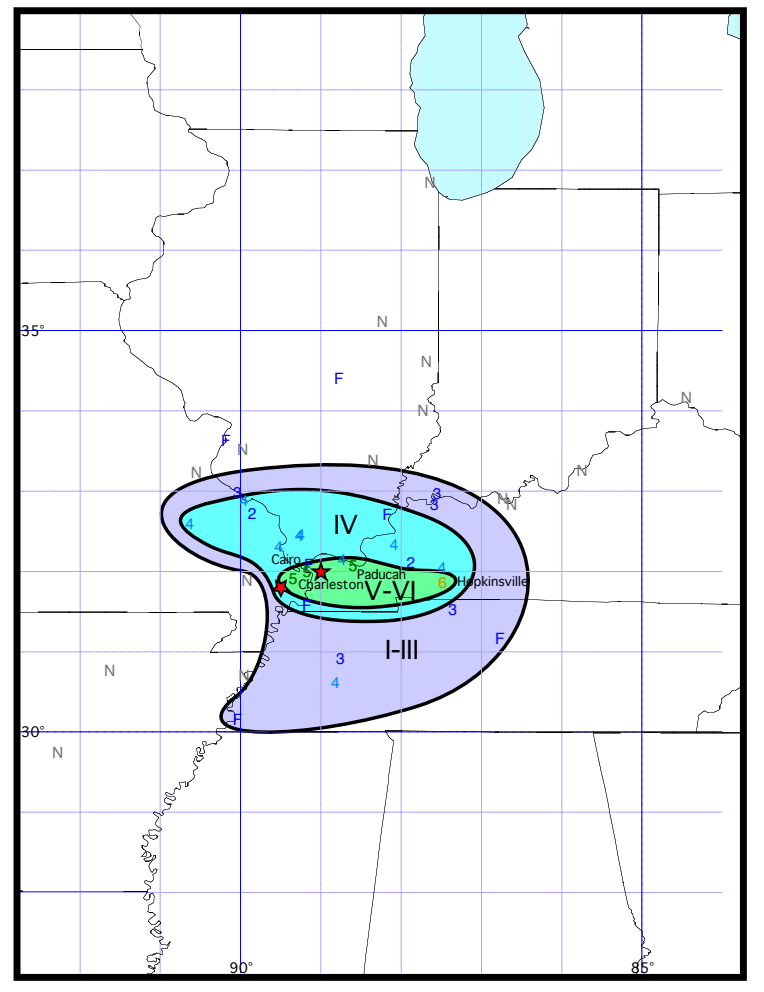

Isoseismal map. Numbers are MMI assignments; $\mathrm{F}$ denotes that the event was felt, but that the information is not sufficient to assign an $\mathrm{MMl} ; 0$ denotes that the event was reported as not felt; and $\mathrm{N}$ denotes that the event was not mentioned and is presumed "not felt". Click here to view damage reports and intensity assignments listed in Appendix 1, Part13. The thick black isoseismal lines enclose isoseismal areas (V: green; IV: blue; etc.). The upwardpointing red star is Stover and Coffman's (1993) epicenter location; the downward-pointing star is our preferred location (see Table 1).

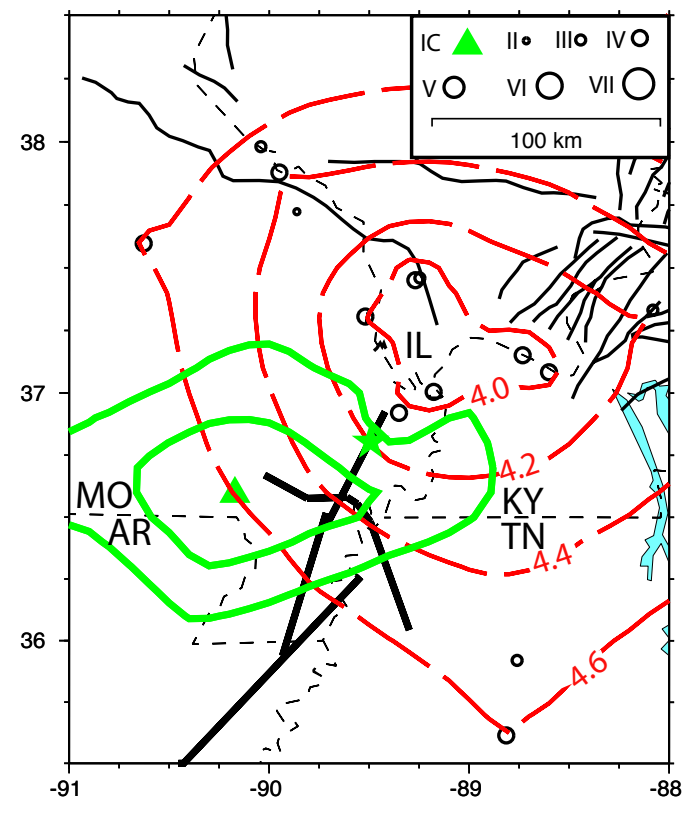

The epicentral region. IC is the intensity center. Our preferred location is shown as a green star. The thick black lines represent Johnston and Schweig's (1996) NMSZ segments. Black circles are sites with MMI assignments; 7.0 (MMI -site corrections) $<8.0$ are plotted as MMI VII, and so on. The contours of $\mathrm{M}_{\mathrm{I}}$ (dashed red lines) are the best estimates of $\mathbf{M}$ from the MMI assignments for assumed epicenters on that contour. The rms $\left[\mathrm{M}_{\mathrm{l}}\right]$ contours corresponding to the $67 \%$ (innermost contour) and 95\% confidence levels (outermost contour) for location from Bakun and Wentworth (1999) are shown as solid green lines; there is an 0.67 probability that the epicenter lies within the $67 \%$ contour and an 0.95 probability that the epicenter lies within the $95 \%$ contour.

Comments. The intensity center is located west of the NMSZ in a region with no intensity assignments. A more plausible source location is near the Missouri-Illinois-Kentucky border region, perhaps near the location of the 20 August 1934 event. Our preferred location is on the New Madrid North segment of the NMSZ. $\mathbf{M}_{1}$ is 4.2 and $\mathbf{M}$ is 3.7 to 4.6 at the $95 \%$ confidence range. 


\section{\#14) 1883 December 5 15:20 UTC (Arkansas)}

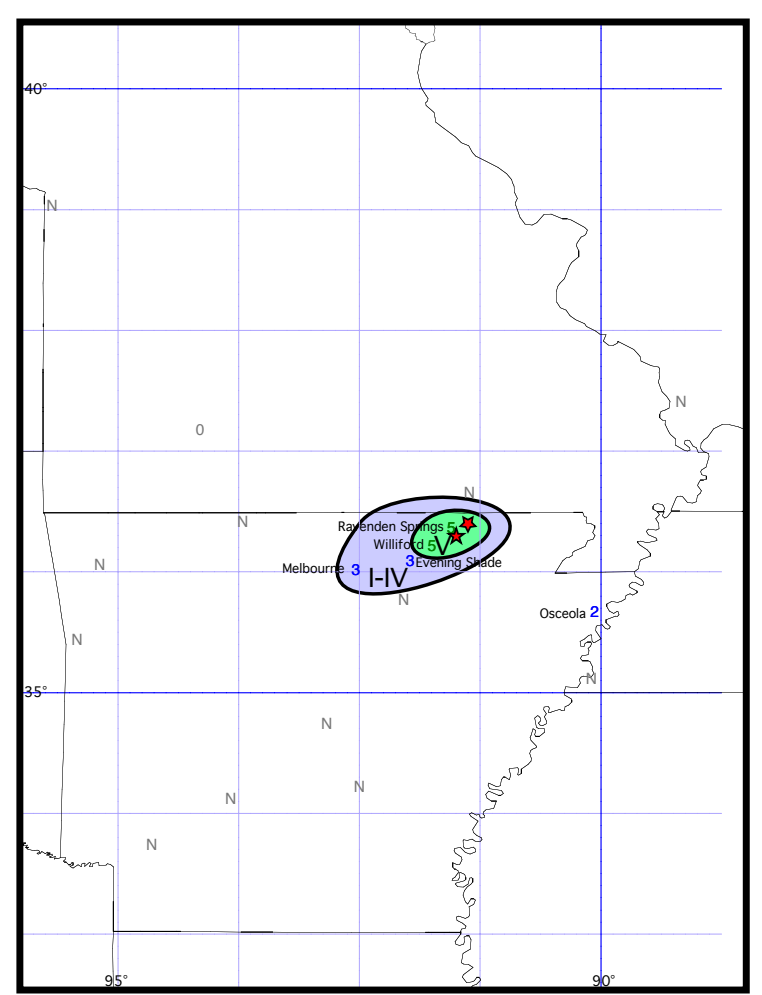

Isoseismal map. Numbers are $\mathrm{MMI}$ assignments; $\mathrm{F}$ denotes that the event was felt, but that the information is not sufficient to assign an $\mathrm{MMl} ; 0$ denotes that the event was reported as not felt; and $\mathrm{N}$ denotes that the event was not mentioned and is presumed "not felt". Click here to view damage reports and intensity assignments listed in Appendix 1, Part 14. The thick black isoseismal lines enclose isoseismal areas (V: green; IV: blue; etc.). The upwardpointing red star is Stover and Coffman's (1993) epicenter location; the downward-pointing star is our preferred location (see Table 1).

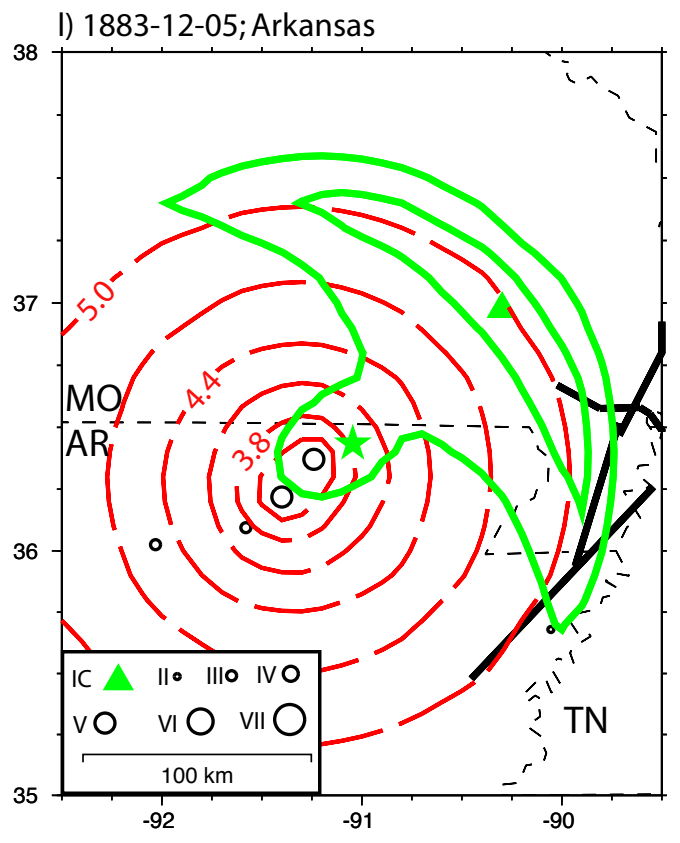

The epicentral region. IC is the intensity center. Our preferred location is shown as a green star. The thick black lines represent Johnston and Schweig's (1996) NMSZ segments. Black circles are sites with MMI assignments; 7.0 (MMI-site corrections) $<8.0$ are plotted as MMI VII, and so on. The contours of $\mathrm{M}_{\mathrm{I}}$ (dashed red lines) are the best estimates of $\mathbf{M}$ from the $\mathrm{MMI}$ assignments for assumed epicenters on that contour. The rms $\left[\mathrm{M}_{\mathrm{l}}\right]$ contours corresponding to the $67 \%$ (innermost contour) and 95\% confidence levels (outermost contour) for location from Bakun and Wentworth (1999) are shown as solid green lines; there is an 0.67 probability that the epicenter lies within the $67 \%$ contour and an 0.95 probability that the epicenter lies within the $95 \%$ contour.

Comments. Four of the five intensity assignments are in north central Arkansas and we arbitrarily adopt a location just south of the Arkansas-Missouri border. $M_{1}$ is 3.8 and $\mathbf{M}$ is 3.1 to 4.4 at the $95 \%$ confidence range. 


\section{\#15) 1884 September 19 19:14 UTC (Ohio)}

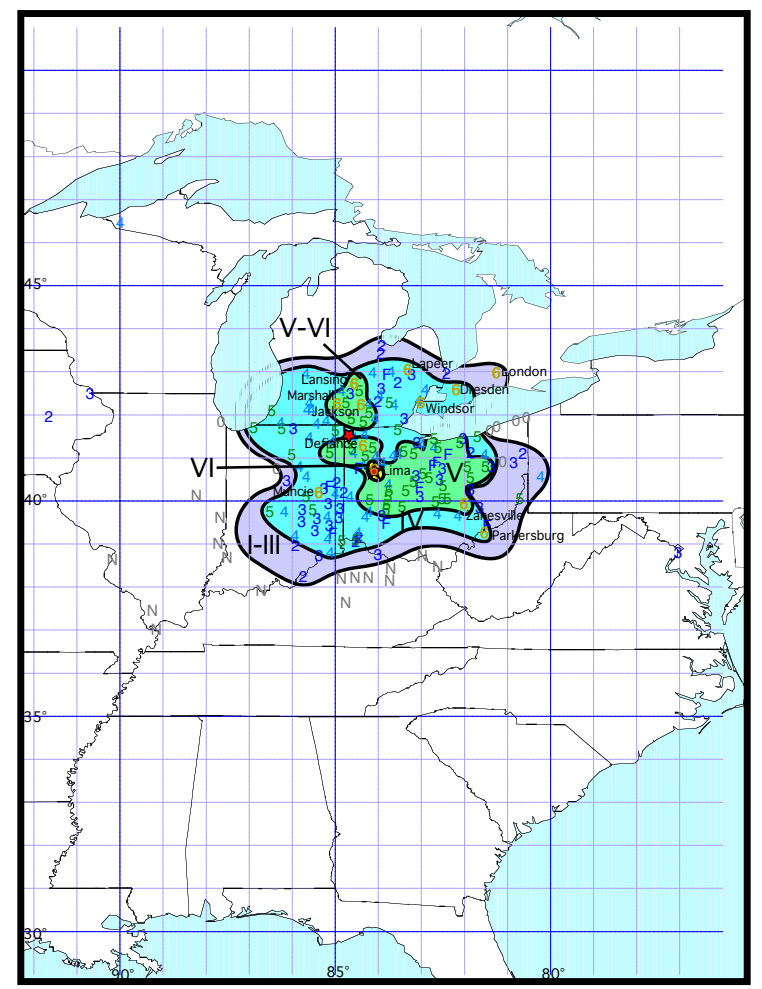

Isoseismal map. Numbers are $\mathrm{MMI}$ assignments; $\mathrm{F}$ denotes that the event was felt, but that the information is not sufficient to assign an $\mathrm{MMl} ; 0$ denotes that the event was reported as not felt; and $\mathrm{N}$ denotes that the event was not mentioned and is presumed "not felt". Click here to view damage reports and intensity assignments listed in Appendix 1, Part 15. The thick black isoseismal lines enclose isoseismal areas (V: green; IV: blue; etc.). The upward-pointing red star is Stover and Coffman's (1993) epicenter location; the downward-pointing star is our preferred location (see Table 1).

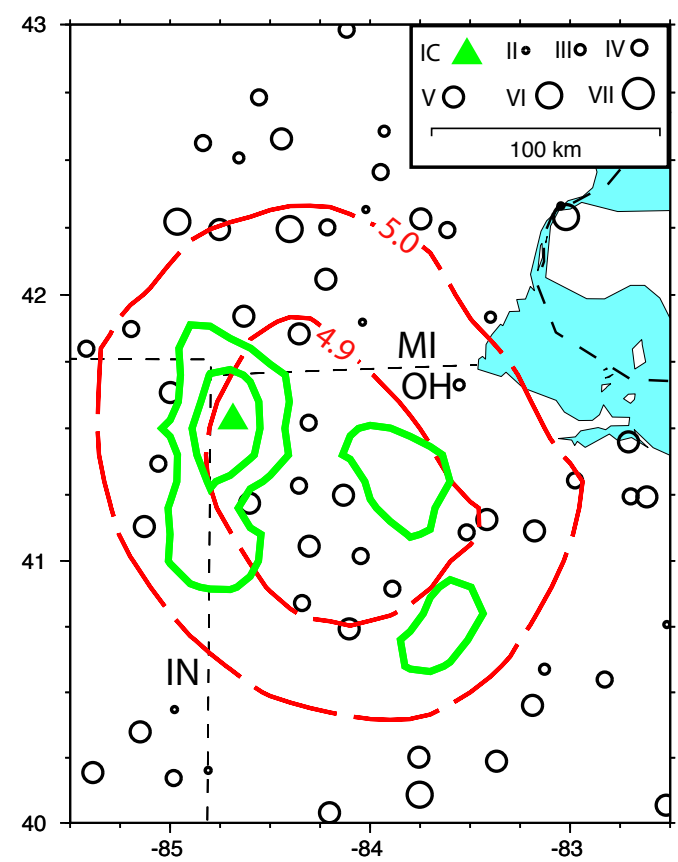

The epicentral region. IC is the intensity center. Black circles are sites with MMl assignments; 7.0 (MMI -site corrections) $<8.0$ are plotted as MMI VII, and so on. The contours of $M_{l}$ (dashed red lines) are the best estimates of $\mathbf{M}$ from the $\mathrm{MMI}$ assignments for assumed epicenters on that contour. The rms $\left[\mathrm{M}_{\mathrm{l}}\right]$ contours corresponding to the $67 \%$ (innermost contour) and $95 \%$ confidence levels (outermost contour) for location from Bakun and Wentworth (1999) are shown as solid green lines; there is an 0.67 probability that the epicenter lies within the $67 \%$ contour and an 0.95 probability that the epicenter lies within the $95 \%$ contour.

Comments. Although widely felt, there is no clear locus of higher intensity assignments. $M_{1}$ is 4.9 for source locations over most of northwest Ohio, and in particular at the intensity center, our preferred location. $\mathbf{M}$ is 4.5 to 5.2 at the $95 \%$ confidence range. 


\section{\#16) 1887 August 2 18:36 UTC (Illinois)}

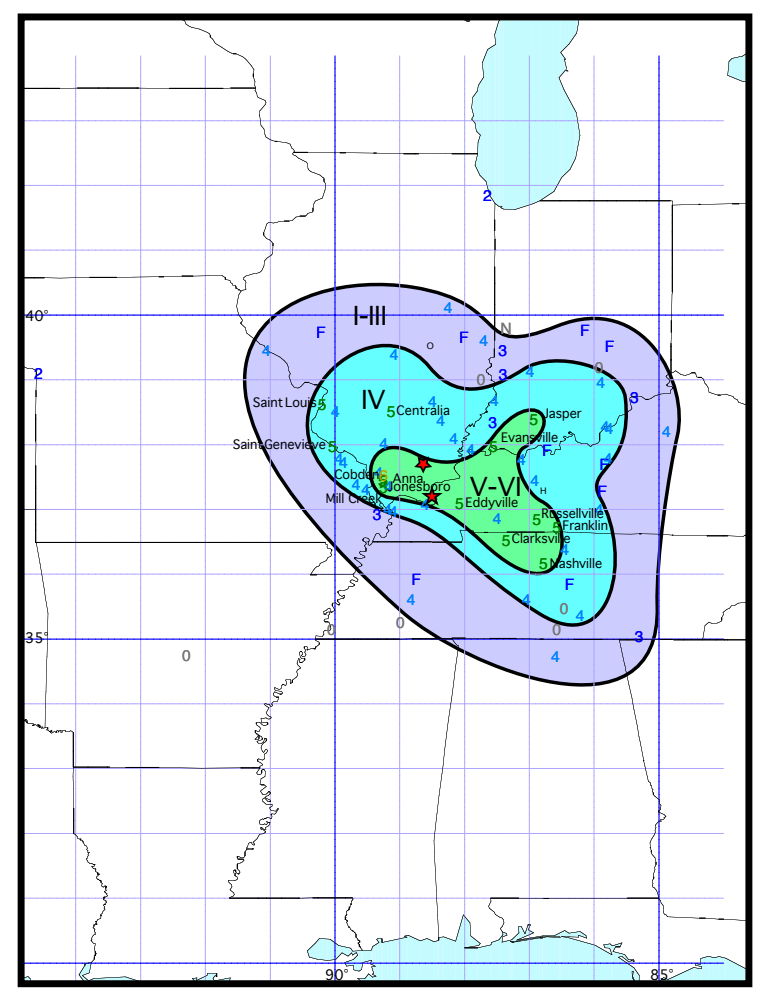

Isoseismal map. Numbers are MMI assignments; $\mathrm{F}$ denotes that the event was felt, but that the information is not sufficient to assign an $\mathrm{MMl} ; 0$ denotes that the event was reported as not felt; and $\mathrm{N}$ denotes that the event was not mentioned and is presumed "not felt". Click here to view damage reports and intensity assignments listed in Appendix 1, Part16. The thick black isoseismal lines enclose isoseismal areas (V: green; IV: blue; etc.). The upwardpointing red star is Stover and Coffman's (1993) epicenter location; the downward-pointing star is our preferred location (see Table 1).

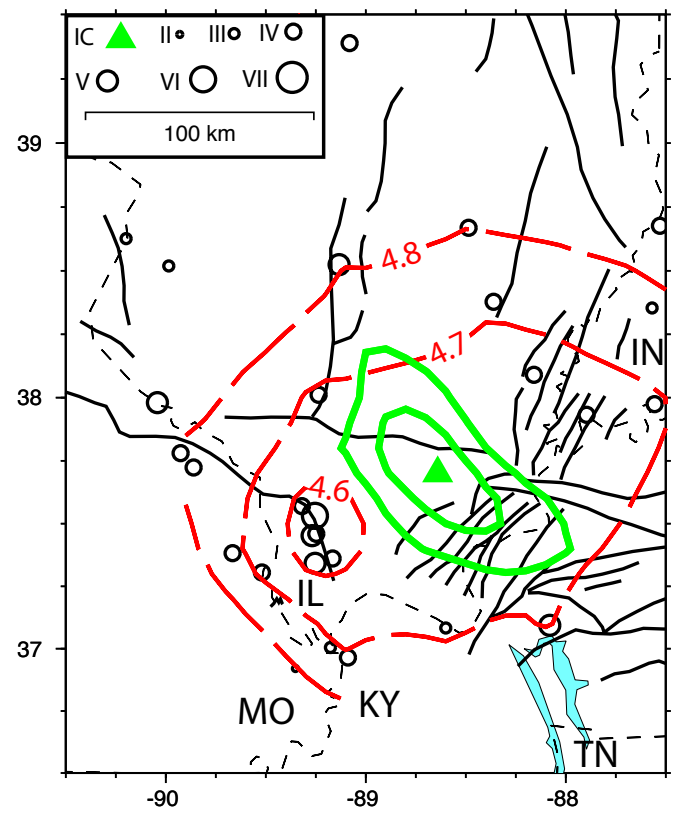

The epicentral region. IC is the intensity center. Faults are shown as black lines. Black circles are sites with MMl assignments; 7.0 (MMI-site corrections) $<8.0$ are plotted as MMI VII, and so on. The contours of $M_{I}$ (dashed red lines) are the best estimates of $\mathbf{M}$ from the MMl assignments for assumed epicenters on that contour. The rms $\left[\mathrm{M}_{\mathrm{l}}\right]$ contours corresponding to the $67 \%$ (innermost contour) and $95 \%$ confidence levels (outermost contour) for location from Bakun and Wentworth (1999) are shown as solid green lines; there is an 0.67 probability that the epicenter lies within the $67 \%$ contour and an 0.95 probability that the epicenter lies within the $95 \%$ contour.

Comments. The intensity center is constrained to near the eastern end of the right-lateral strike-slip Cottage Grove fault system. Faulting in the basement core of the Cottage Grove fault system is evident in seismic reflection data (John McBride, personal communication, 2003). $M_{1}$ is 4.6 at the intensity center and $\mathbf{M}$ is 4.2 to 4.9 at the $95 \%$ confidence range. 


\section{\#17) 1891 September 27 04:55 UTC (Illinois)}

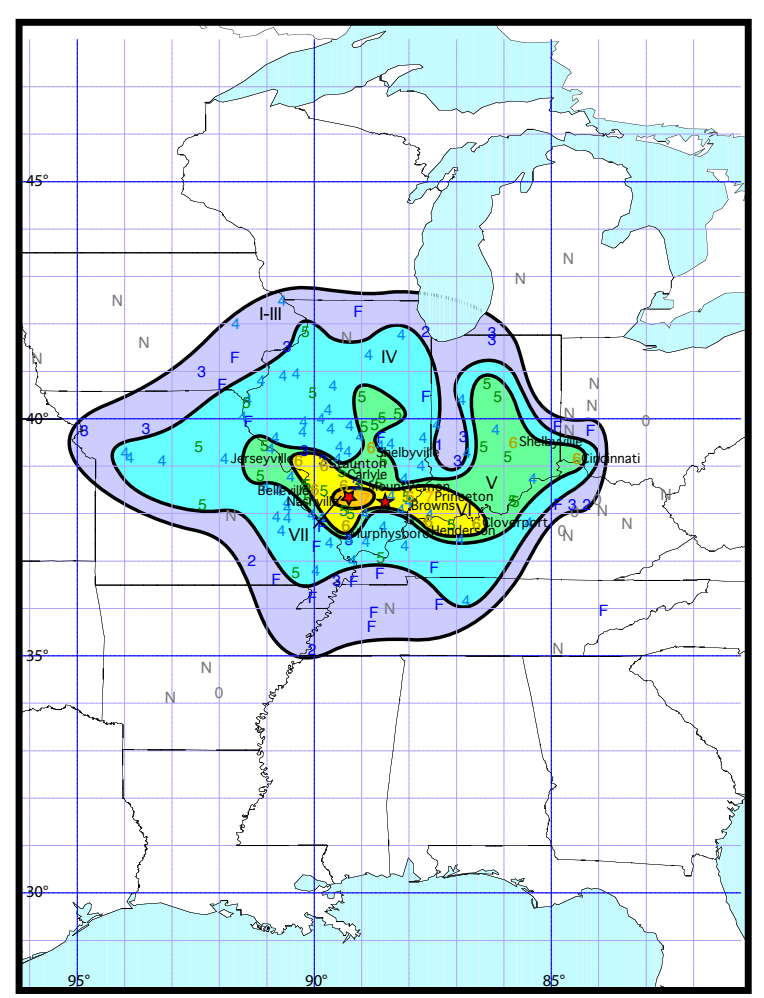

Isoseismal map. Numbers are MMI assignments; $\mathrm{F}$ denotes that the event was felt, but that the information is not sufficient to assign an MMl; 0 denotes that the event was reported as not felt; and $\mathrm{N}$ denotes that the event was not mentioned and is presumed "not felt". Click here to view damage reports and intensity assignments listed in Appendix 1, Part 17. The thick black isoseismal lines enclose isoseismal areas (V: green; IV: blue; etc.). The upwardpointing red star is Stover and Coffman's (1993) epicenter location; the downward-pointing star is our preferred location (see Table 1).

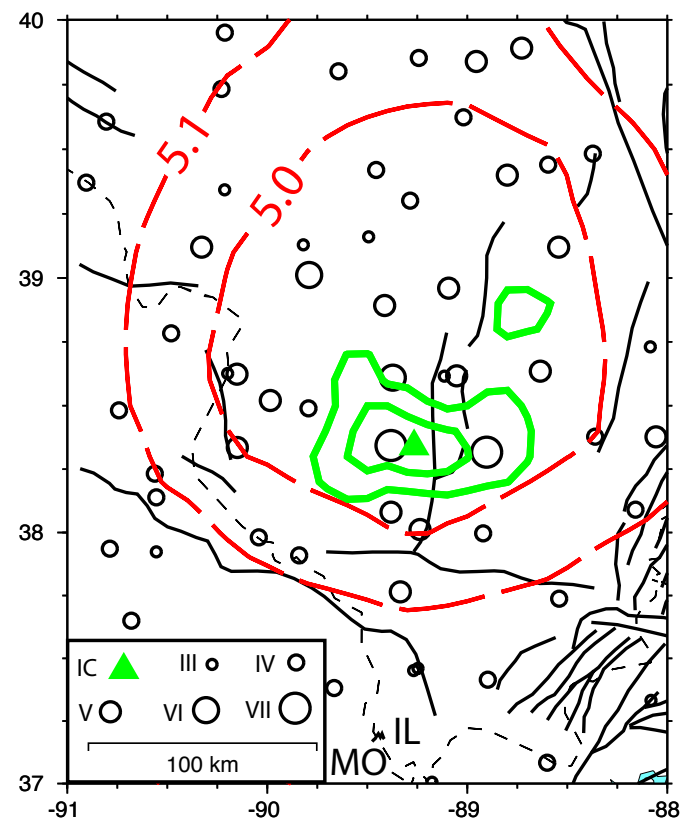

The epicentral region. IC is the intensity center. Faults are shown as black lines. Black circles are sites with MMl assignments; 7.0 (MMI-site corrections) $<8.0$ are plotted as MMI VII, and so on. The contours of $M_{1}$ (dashed red lines) are the best estimates of $\mathbf{M}$ from the MMl assignments for assumed epicenters on that contour. The rms $\left[\mathrm{M}_{\mathrm{l}}\right]$ contours corresponding to the $67 \%$ (innermost contour) and $95 \%$ confidence levels (outermost contour) for location from Bakun and Wentworth (1999) are shown as solid green lines; there is an 0.67 probability that the epicenter lies within the $67 \%$ contour and an 0.95 probability that the epicenter lies within the $95 \%$ contour.

Comments. The intensity data constrain the location to near the Du Quoin Monocline. $M_{l}$ is 4.9 and $\mathbf{M}$ is 4.6 to 5.2 at the $95 \%$ confidence range. 


\section{\#18) 1899 April 30 02:05 UTC (Indiana)}

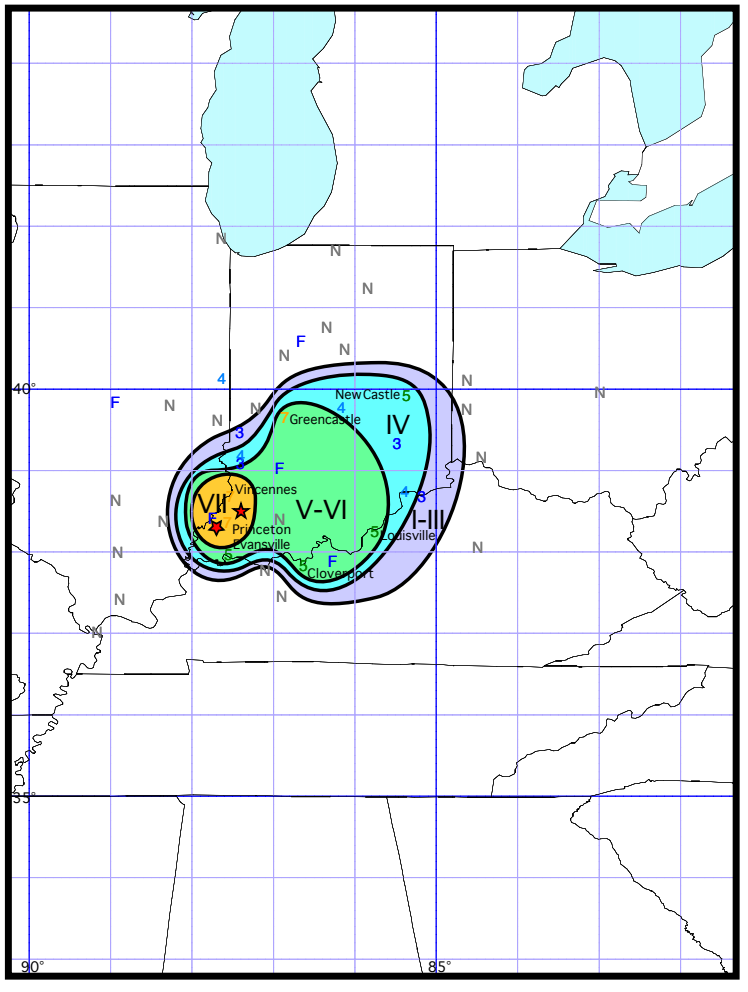

Isoseismal map. Numbers are $\mathrm{MMI}$ assignments; $\mathrm{F}$ denotes that the event was felt, but that the information is not sufficient to assign an $\mathrm{MMl} ; 0$ denotes that the event was reported as not felt; and $\mathrm{N}$ denotes that the event was not mentioned and is presumed "not felt". Click here to view damage reports and intensity assignments listed in Appendix 1, Part18. The thick black isoseismal lines enclose isoseismal areas (V: green; IV: blue; etc.). The upwardpointing red star is Stover and Coffman's (1993) epicenter location; the downward-pointing star is our preferred location (see Table 1).

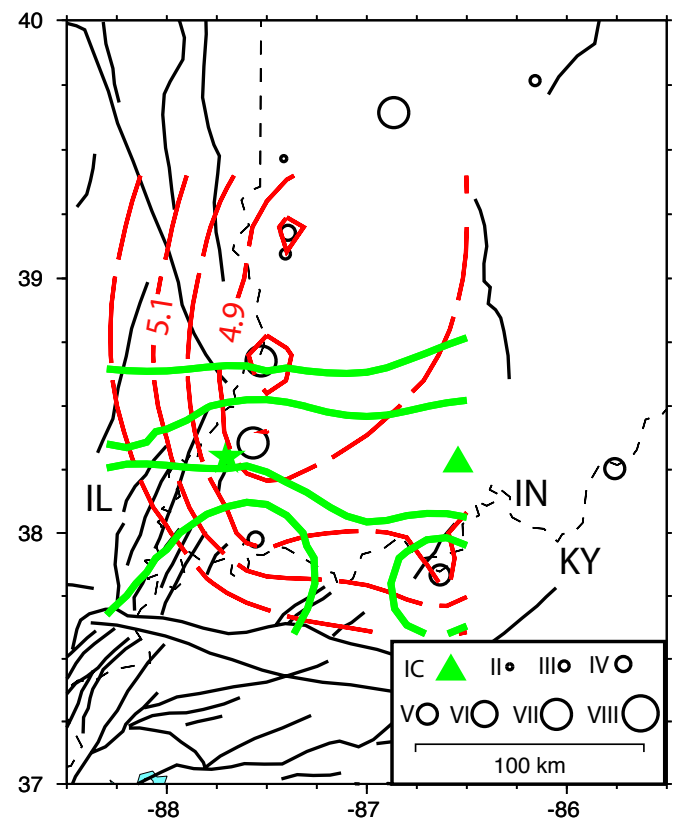

The epicentral region. IC is the intensity center. Our preferred location is shown as a green star. Faults are shown as black lines. Black circles are sites with $\mathrm{MMI}$ assignments; 7.0 (MMl -site corrections) $<8.0$ are plotted as MMI VII, and so on. The contours of $M_{\mathrm{I}}$ (dashed red lines) are the best estimates of $\mathbf{M}$ from the $\mathrm{MMI}$ assignments for assumed epicenters on that contour. The rms $\left[\mathrm{M}_{\mathrm{l}}\right]$ contours corresponding to the $67 \%$ (innermost contour) and $95 \%$ confidence levels (outermost contour) for location from Bakun and Wentworth (1999) are shown as solid green lines; there is an 0.67 probability that the epicenter lies within the $67 \%$ contour and an 0.95 probability that the epicenter lies within the $95 \%$ contour.

Comments. There is poor E-W resolution of the source location and the intensity center is 101 kilometers east of our preferred location on the north end of the Wabash Valley fault system. The MMI VII intensity assignments at Princeton and Vincennes, Indiana, are not far from the preferred epicenter. Our preferred location latitude, $38.3^{\circ} \mathrm{N}$, is consistent with Bear et al.'s (1997) conclusion from analyses of seismic reflection profiles that the N-S extent of significant fault offsets on the Wabash Valley fault system is restricted to the region between $38^{\circ} \mathrm{N}$ and $38.35^{\circ} \mathrm{N} . \mathrm{M}_{1}$ is 4.9 and $\mathbf{M}$ is 4.4 to 5.3 at the $95 \%$ confidence range. 


\section{\#19) 1903 February 9 00:21 UTC (Illinois)}

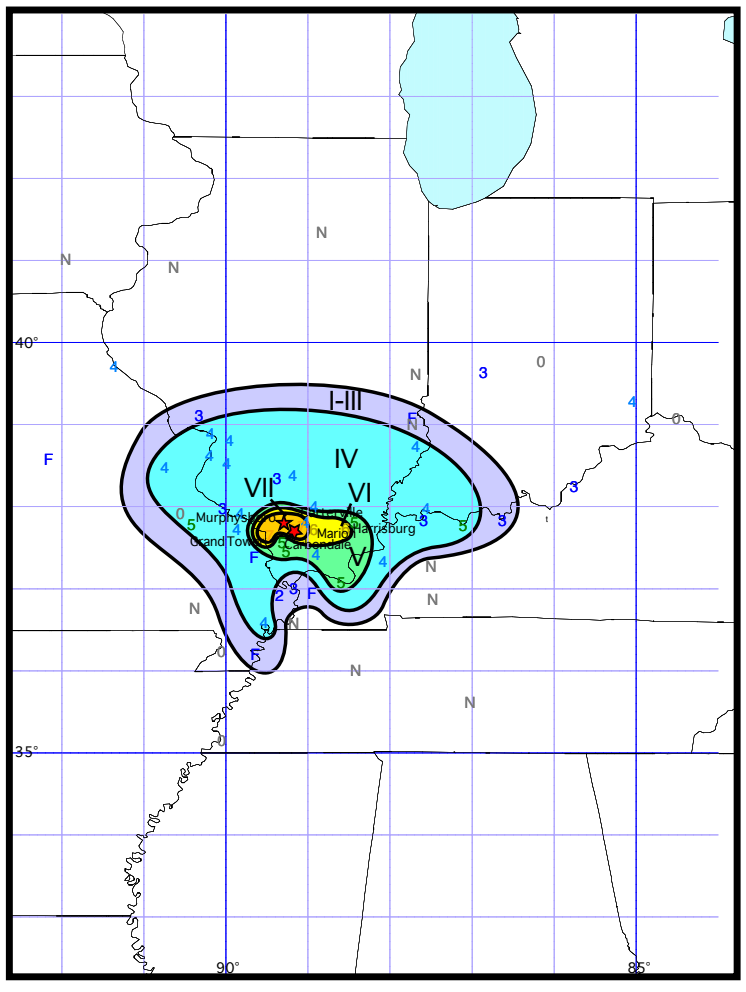

Isoseismal map. Numbers are MMI assignments; F denotes that the event was felt, but that the information is not sufficient to assign an MMl; 0 denotes that the event was reported as not felt; and $\mathrm{N}$ denotes that the event was not mentioned and is presumed "not felt". Click here to view damage reports and intensity assignments listed in Appendix 1, Part 19. The thick black isoseismal lines enclose isoseismal areas (V: green; IV: blue; etc.). The upward-pointing red star is Stover and Coffman's (1993) epicenter location; the downward-pointing star is our preferred location (see Table 1).

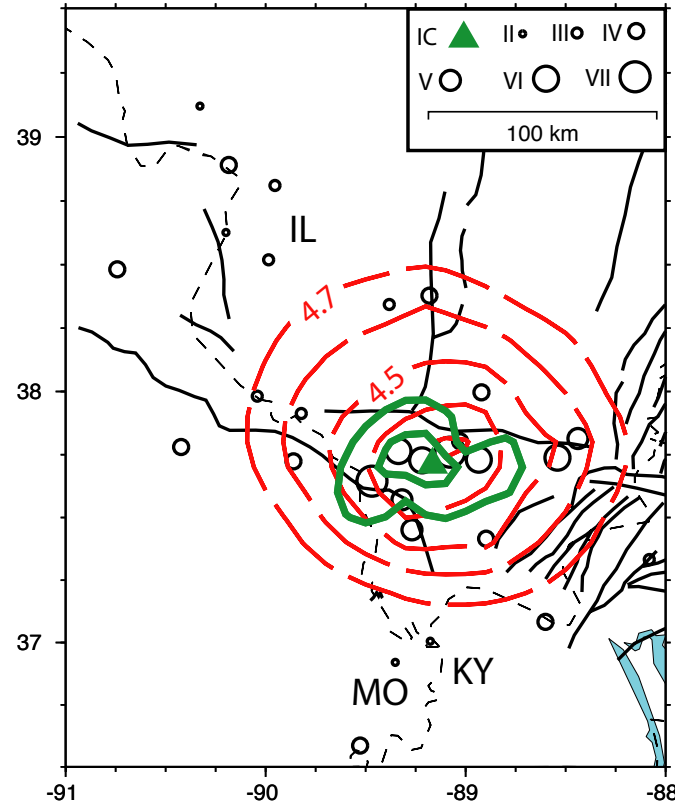

The epicentral region. IC is the intensity center. Faults are shown as black lines. Black circles are sites with $\mathrm{MMI}$ assignments; 7.0 (MMI-site corrections) $<8.0$ are plotted as MMI VII, and so on. The contours of $M_{l}$ (dashed red lines) are the best estimates of $\mathbf{M}$ from the $\mathrm{MMI}$ assignments for assumed epicenters on that contour. The rms $\left[\mathrm{M}_{\mathrm{l}}\right]$ contours corresponding to the $67 \%$ (innermost contour) and $95 \%$ confidence levels (outermost contour) for location from Bakun and Wentworth (1999) are shown as solid green lines; there is an 0.67 probability that the epicenter lies within the $67 \%$ contour and an 0.95 probability that the epicenter lies within the $95 \%$ contour.

Comments. The intensity center is located between the Cottage Grove fault system and the SW-dipping reverse Ste. Genevieve fault zone. The intensity data permit a location on the Cottage Grove fault system or on the Ste. Genevieve fault zone. $M_{1}$ is 4.4 and $\mathbf{M}$ is 4.0 to 4.7 at the $95 \%$ confidence range. 


\section{\#20) 1903 November 4 19:14 UTC (Missouri)}

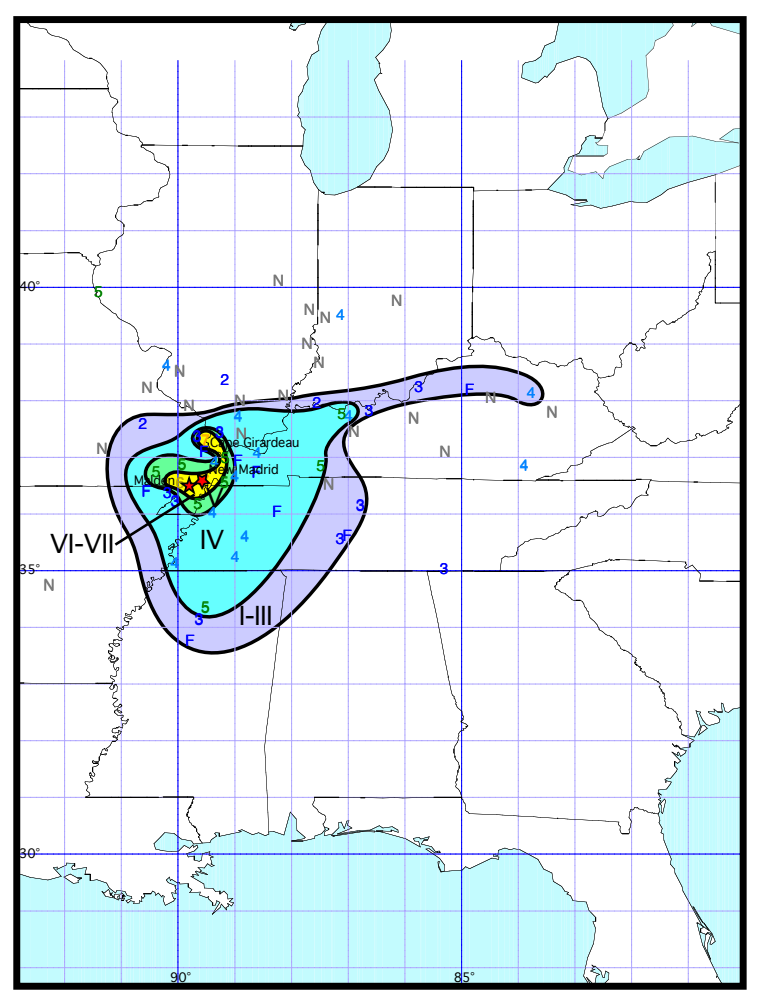

Isoseismal map. Numbers are MMI assignments; $F$ denotes that the event was felt, but that the information is not sufficient to assign an $\mathrm{MMl} ; 0$ denotes that the event was reported as not felt; and $\mathrm{N}$ denotes that the event was not mentioned and is presumed "not felt". Click here to view damage reports and intensity assignments listed in Appendix 1, Part 20. The thick black isoseismal lines enclose isoseismal areas (V: green; IV: blue; etc.). The upward-pointing red star is Stover and Coffman's (1993) epicenter location; the downward-pointing star is our preferred location (see Table 1).

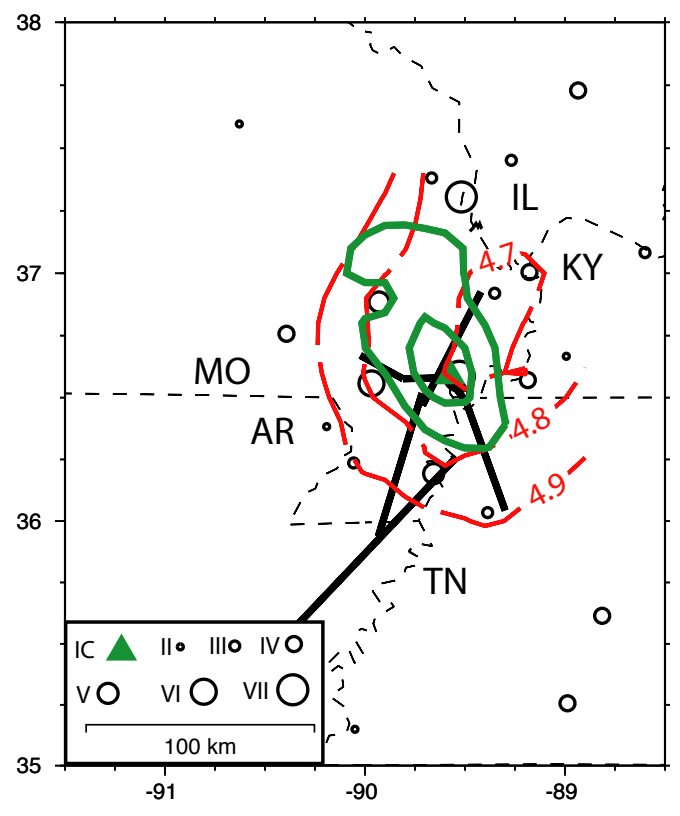

The epicentral region. IC is the intensity center. Faults are shown as black lines. The thick black lines represent Johnston and Schweig's (1996) NMSZ segments. Black circles are sites with MMl assignments; 7.0 (MMI-site corrections) $<8.0$ are plotted as MMI VII, and so on. The contours of $M_{l}$ (dashed red lines) are the best estimates of $\mathbf{M}$ from the $\mathrm{MMI}$ assignments for assumed epicenters on that contour. The rms $\left[\mathrm{M}_{\mathrm{l}}\right]$ contours corresponding to the $67 \%$ (innermost contour) and $95 \%$ confidence levels (outermost contour) for location from Bakun and Wentworth (1999) are shown as solid green lines; there is an 0.67 probability that the epicenter lies within the $67 \%$ contour and an 0.95 probability that the epicenter lies within the $95 \%$ contour.

Comments. The thirty-eight intensity assignments constrain the location to the north half of the NMSZ, and the intensity center is located on the Reelfoot blind thrust. $M_{1}$ is 4.7 and $\mathbf{M}$ is 4.3 to 5.0 at the $95 \%$ confidence range. 


\section{\#21) 1905 August 22 05:08 UTC (Missouri)}

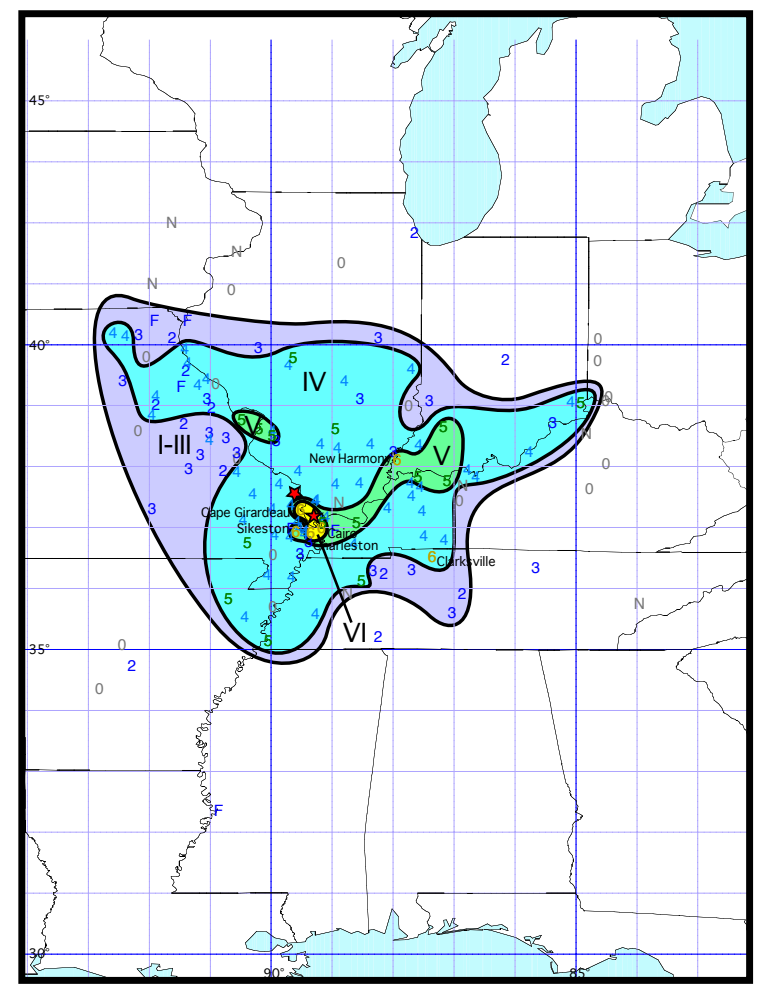

Isoseismal map. Numbers are $\mathrm{MMI}$ assignments; $\mathrm{F}$ denotes that the event was felt, but that the information is not sufficient to assign an $\mathrm{MMl} ; 0$ denotes that the event was reported as not felt; and $\mathrm{N}$ denotes that the event was not mentioned and is presumed "not felt". Click here to view damage reports and intensity assignments listed in Appendix 1, Part 21. The thick black isoseismal lines enclose isoseismal areas (V: green; IV: blue; etc.). The upward-pointing red star is Stover and Coffman's (1993) epicenter location; the downward-pointing star is our preferred location (see Table 1).

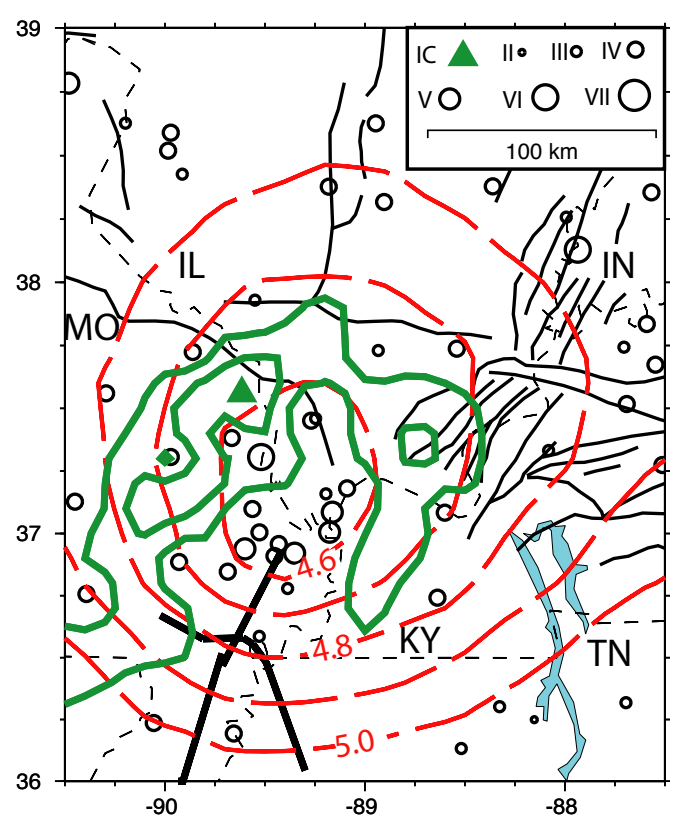

The epicentral region. IC is the intensity center. Faults are shown as black lines. The thick black lines represent Johnston and Schweig's (1996) NMSZ segments. Black circles are sites with MMI assignments; 7.0 (MMI -site corrections) $<8.0$ are plotted as MMI VII, and so on. The contours of $M_{l}$ (dashed red lines) are the best estimates of $\mathbf{M}$ from the $\mathrm{MMI}$ assignments for assumed epicenters on that contour. The rms $\left[\mathrm{M}_{\mathrm{l}}\right]$ contours corresponding to the $67 \%$ (innermost contour) and $95 \%$ confidence levels (outermost contour) for location from Bakun and Wentworth (1999) are shown as solid green lines; there is an 0.67 probability that the epicenter lies within the $67 \%$ contour and an 0.95 probability that the epicenter lies within the $95 \%$ contour.

Comments. The intensity center is located southwest of the Ste. Genevieve fault zone, and we associate the 1905 event with this fault. $M_{1}$ is 4.6 and $\mathbf{M}$ is 4.2 to 4.9 at the $95 \%$ confidence range. 


\section{\#22) 1906 January 8 00:15 UTC (Kansas)}

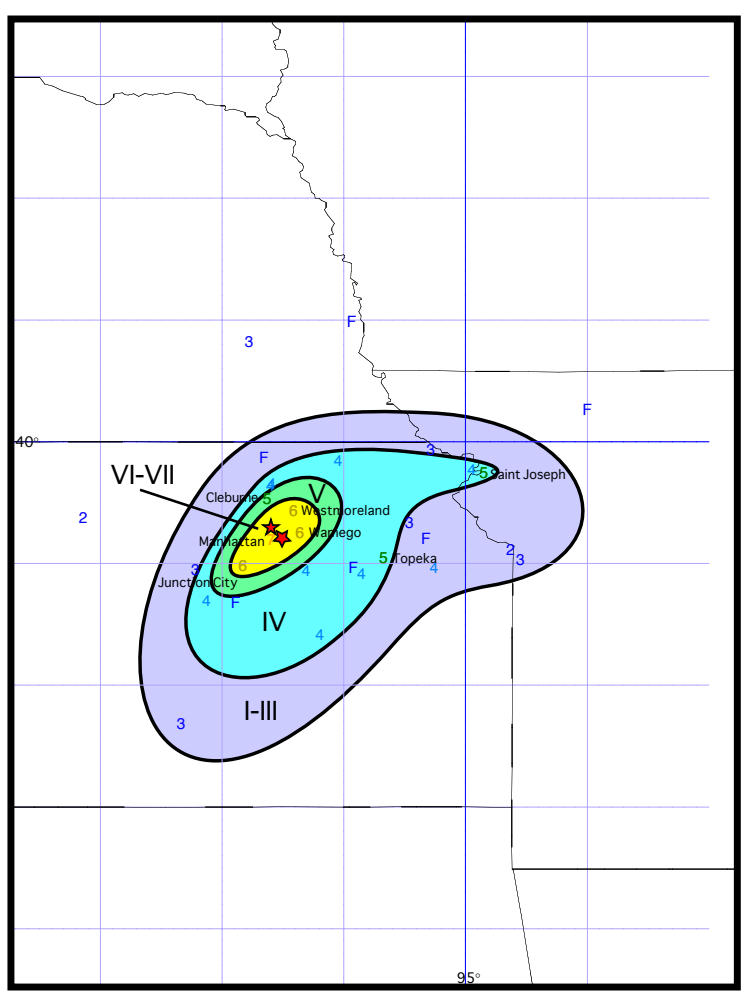

Isoseismal map. Numbers are $\mathrm{MMI}$ assignments; $\mathrm{F}$ denotes that the event was felt, but that the information is not sufficient to assign an $\mathrm{MMl} ; 0$ denotes that the event was reported as not felt; and $\mathrm{N}$ denotes that the event was not mentioned and is presumed "not felt". Click here to view damage reports and intensity assignments listed in Appendix 1, Part 22. The thick black isoseismal lines enclose isoseismal areas (V: green; IV: blue; etc.). The upwardpointing red star is Stover and Coffman's (1993) epicenter location; the downward-pointing star is our preferred location (see Table 1).

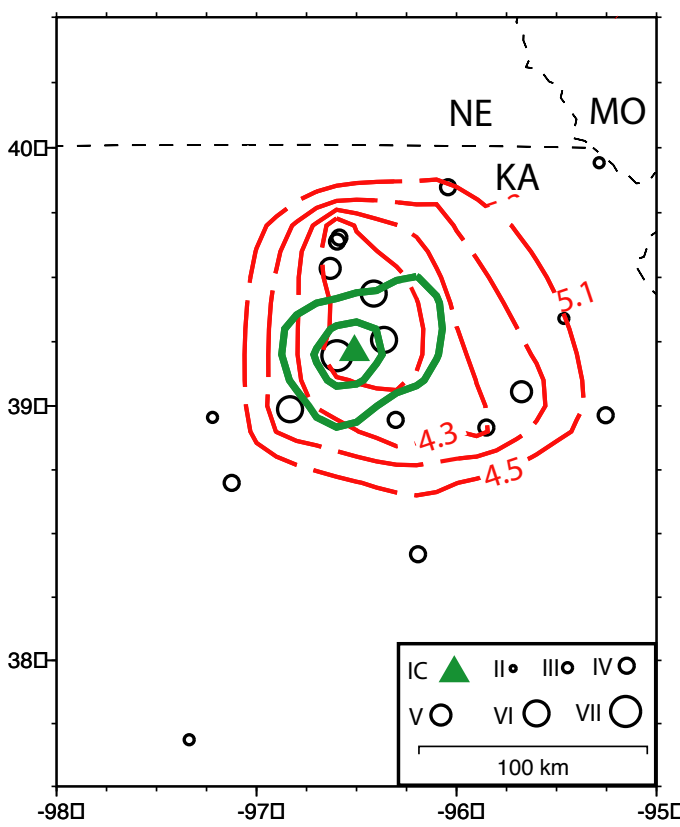

The epicentral region. IC is the intensity center. Black circles are sites with $\mathrm{MMI}$ assignments; $7.0 \leq$ (MMI -site corrections) $<8.0$ are plotted as MMI VII, and so on. The contours of $M_{l}$ (dashed red lines) are the best estimates of $\mathbf{M}$ from the MMI assignments for assumed epicenters on that contour. The rms $\left[\mathrm{M}_{\mathrm{l}}\right]$ contours corresponding to the $67 \%$ (innermost contour) and $95 \%$ confidence levels (outermost contour) for location from Bakun and Wentworth (1999) are shown as solid green lines; there is an 0.67 probability that the epicenter lies within the $67 \%$ contour and an 0.95 probability that the epicenter lies within the $95 \%$ contour.

Comments. This event, located near Manhattan in northeast Kansas, occurred near the location of the larger M5.2 event that occurred on 24 April 1867. $M_{1}$ is 4.1 and $\mathbf{M}$ is 3.7 to 4.4 at the $95 \%$ confidence range. 


\section{\#23) 1909 May 26 14:42 UTC (Illinois)}

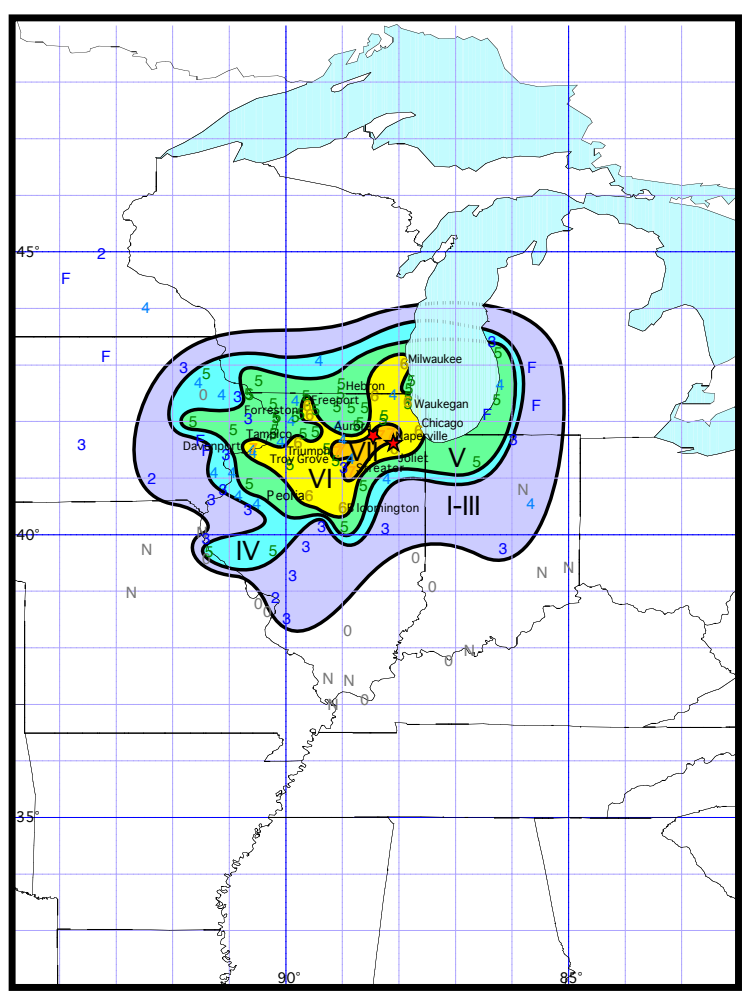

Isoseismal map. Numbers are MMI assignments; $\mathrm{F}$ denotes that the event was felt, but that the information is not sufficient to assign an $\mathrm{MMl} ; 0$ denotes that the event was reported as not felt; and $\mathrm{N}$ denotes that the event was not mentioned and is presumed "not felt". Click here to view damage reports and intensity assignments listed in Appendix 1, Part 23. The thick black isoseismal lines enclose isoseismal areas (V: green; IV: blue; etc.). The upward-pointing red star is Stover and Coffman's (1993) epicenter location; the downward-pointing star is our preferred location (see Table 1).

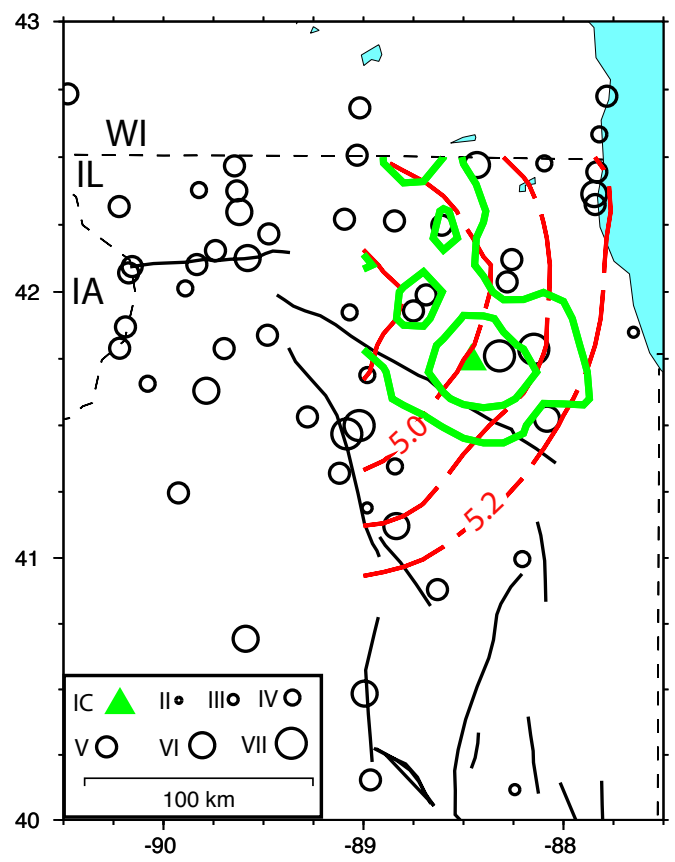

The epicentral region. IC is the intensity center. Faults are shown as black lines. Black circles are sites with MMI assignments; 7.0 (MMI -site corrections) $<8.0$ are plotted as $\mathrm{MMI}$ VII, and so on. The contours of $M_{I}$ (dashed red lines) are the best estimates of $\mathbf{M}$ from the MMl assignments for assumed epicenters on that contour. The rms $\left[M_{1}\right]$ contours corresponding to the $67 \%$ (innermost contour) and $95 \%$ confidence levels (outermost contour) for location from Bakun and Wentworth (1999) are shown as solid green lines; there is an 0.67 probability that the epicenter lies within the $67 \%$ contour and an 0.95 probability that the epicenter lies within the $95 \%$ contour.

Comments. The intensity center is located near the Sandwich fault zone, mapped from surface exposures only (Nelson, 1995); there is no information that the Sandwich fault zone is cored in the basement (John McBride, personal communication, 2003). $M_{1}$ is 5.0 and $\mathbf{M}$ is 4.6 to 5.3 at the $95 \%$ confidence range. 


\section{\#24) 1909 July 19 04:34 UTC (Illinois)}

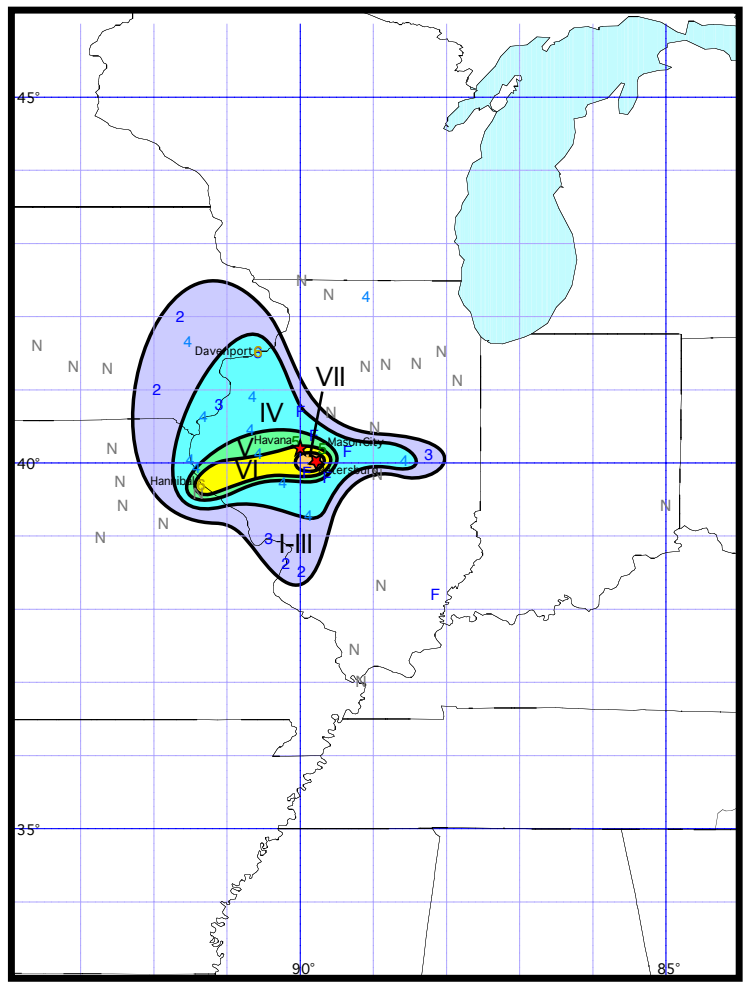

Isoseismal map. Numbers are MMI assignments; F denotes that the event was felt, but that the information is not sufficient to assign an MMl; 0 denotes that the event was reported as not felt; and $\mathrm{N}$ denotes that the event was not mentioned and is presumed "not felt". Click here to view damage reports and intensity assignments listed in Appendix 1, Part 24. The thick black isoseismal lines enclose isoseismal areas (V: green; IV: blue; etc.). The upward-pointing red star is Stover and Coffman's (1993) epicenter location; the downward-pointing star is our preferred location (see Table 1).

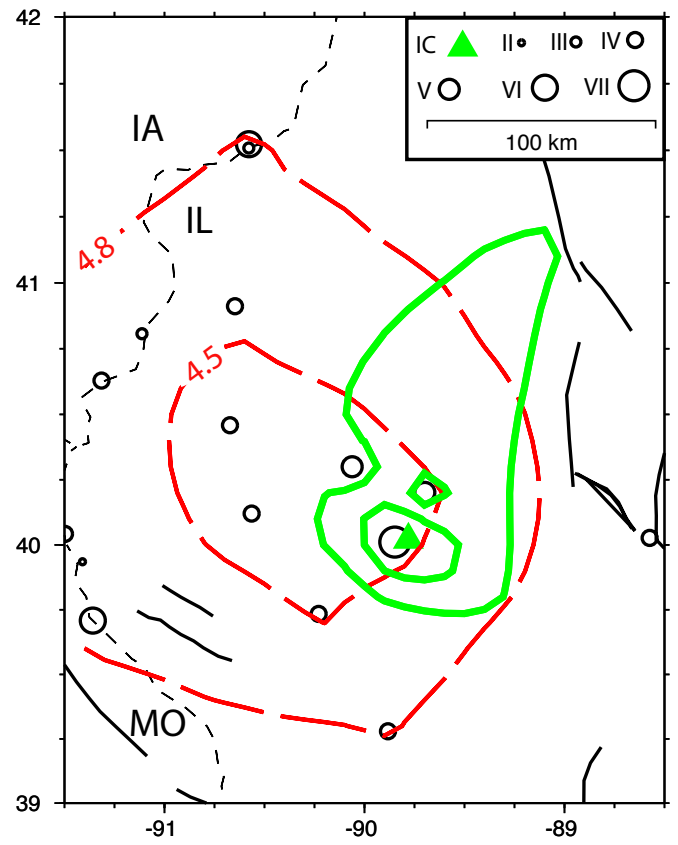

The epicentral region. IC is the intensity center. Faults are shown as black lines. Black circles are sites with MMl assignments; 7.0 (MMI-site corrections) $<8.0$ are plotted as $\mathrm{MMI}$ VII, and so on. The contours of $M_{I}$ (dashed red lines) are the best estimates of $\mathbf{M}$ from the $\mathrm{MMI}$ assignments for assumed epicenters on that contour. The rms $\left[\mathrm{M}_{\mathrm{l}}\right]$ contours corresponding to the $67 \%$ (innermost contour) and $95 \%$ confidence levels (outermost contour) for location from Bakun and Wentworth (1999) are shown as solid green lines; there is an 0.67 probability that the epicenter lies within the $67 \%$ contour and an 0.95 probability that the epicenter lies within the $95 \%$ contour.

Comments. The intensity center is not located near any structural features identified by Nelson (1995). $\mathbf{M}_{1}$ is 4.5 and $\mathbf{M}$ is 4.0 to 4.9 at the $95 \%$ confidence range. 


\section{\#25) 1909 September 27 09:45 UTC (Illinois)}

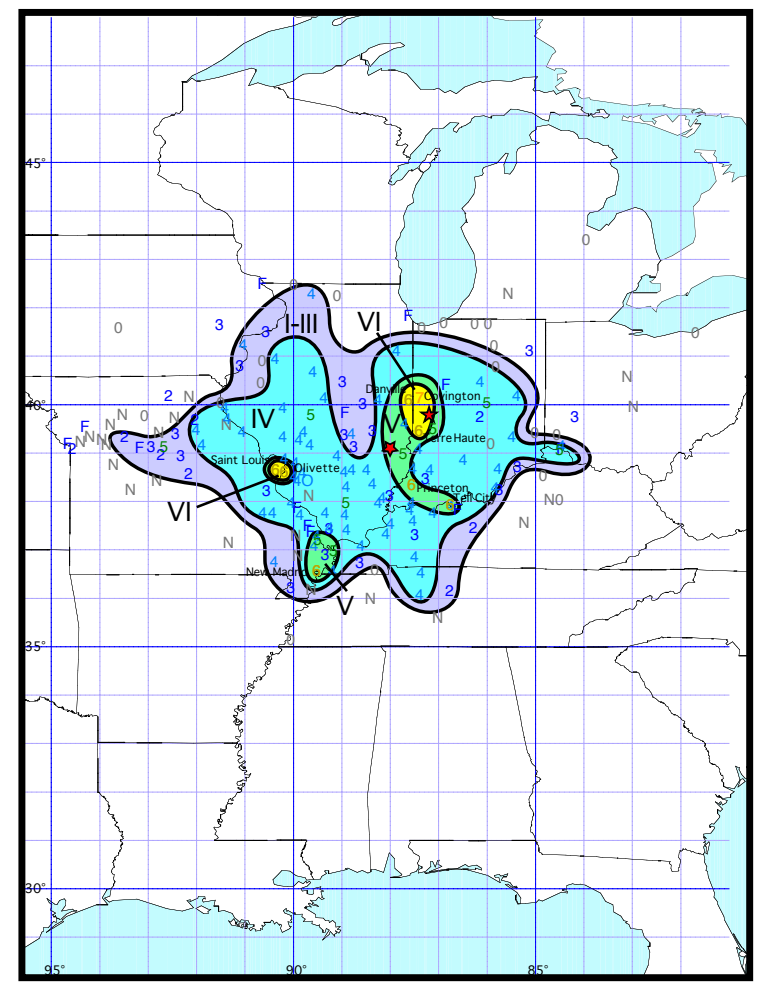

Isoseismal map. Numbers are $\mathrm{MMI}$ assignments; $\mathrm{F}$ denotes that the event was felt, but that the information is not sufficient to assign an $\mathrm{MMl} ; 0$ denotes that the event was reported as not felt; and $\mathrm{N}$ denotes that the event was not mentioned and is presumed "not felt". Click here to view damage reports and intensity assignments listed in Appendix 1, Part 25. The thick black isoseismal lines enclose isoseismal areas (V: green; IV: blue; etc.). The upward-pointing red star is Stover and Coffman's (1993) epicenter location; the downward-pointing star is our preferred location (see Table 1).

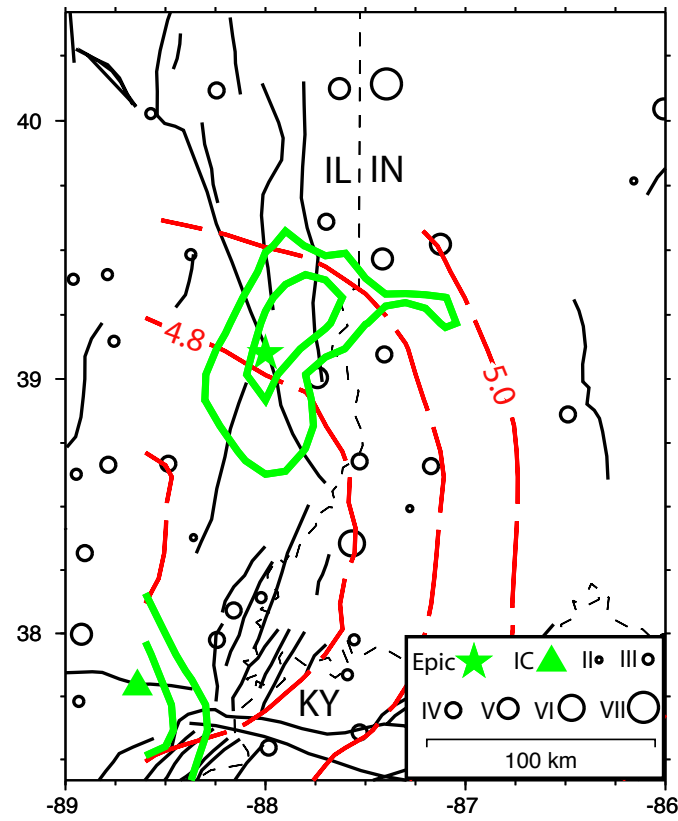

The epicentral region. IC is the intensity center. Our preferred location is shown as a green star. Faults are shown as black lines. Black circles are sites with MMI assignments; 7.0 (MMl -site corrections) $<8.0$ are plotted as MMI VII, and so on. The contours of $\mathrm{M}_{\mathrm{I}}$ (dashed red lines) are the best estimates of $\mathbf{M}$ from the $\mathbf{M M I}$ assignments for assumed epicenters on that contour. The rms $\left[M_{1}\right]$ contours corresponding to the $67 \%$ (innermost contour) and 95\% confidence levels (outermost contour) for location from Bakun and Wentworth (1999) are shown as solid green lines; there is an 0.67 probability that the epicenter lies within the $67 \%$ contour and an 0.95 probability that the epicenter lies within the $95 \%$ contour.

Comments. The location is poorly constrained because the spatial pattern of MMI assignments is not consistent with any particular source location. For example, the intensity center for this particular grid search is near the east end of the Cottage Grove fault system, because, with distance weighting and conflicting intensity data, the minimum rms[MI] is often off the edge of the network of intensity assignments. For a more global search, the intensity center is located north of $40^{\circ} \mathrm{N}$ where there are no $\mathrm{MMI}$ assignments. There is a local $\mathrm{rms}\left[\mathrm{M}_{1}\right]$ minimum near the center of the felt region, however, and our preferred location within this region is on the La Salle Anticlinorium. $M_{1}$ is 4.8 and $\mathbf{M}$ is 4.4 to 5.1 at the $95 \%$ confidence range for this somewhatarbitrary location. 


\section{\#26) 1911 March 31 16:57 UTC (Arkansas)}

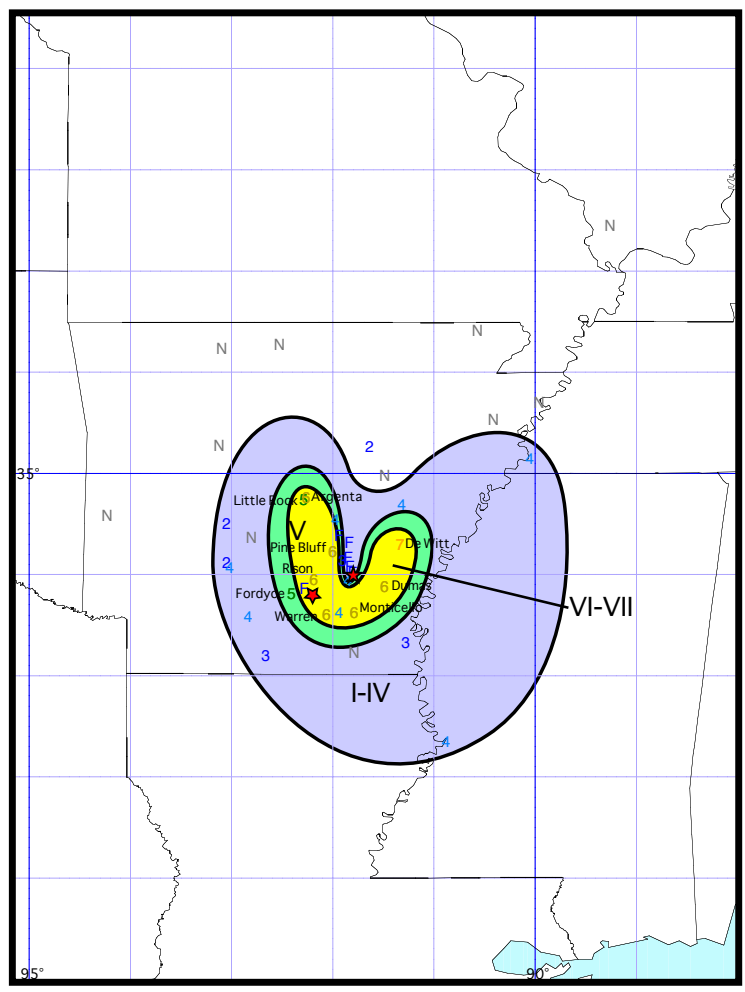

Isoseismal map. Numbers are MMI assignments; F denotes that the event was felt, but that the information is not sufficient to assign an $\mathrm{MMl} ; 0$ denotes that the event was reported as not felt; and $\mathrm{N}$ denotes that the event was not mentioned and is presumed "not felt". Click here to view damage reports and intensity assignments listed in Appendix 1, Part 26. The thick black isoseismal lines enclose isoseismal areas (V: green; IV: blue; etc.). The upward-pointing red star is Stover and Coffman's (1993) epicenter location; the downward-pointing star is our preferred location (see Table 1).

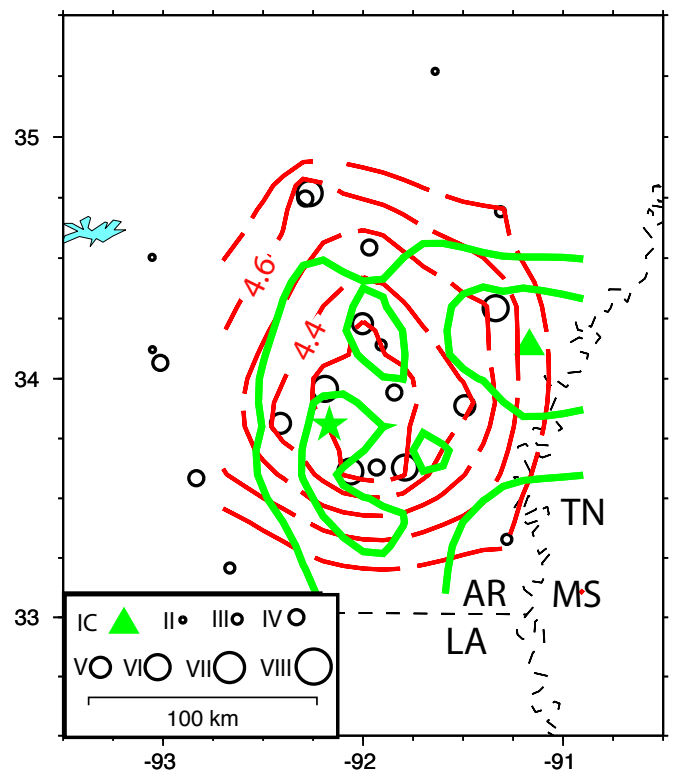

The epicentral region. IC is the intensity center. Our preferred location is shown as a green star. Black circles are sites with MMI assignments; 7.0 (MMI -site corrections) $<8.0$ are plotted as MMI VII, and so on. The contours of $M_{\mathrm{I}}$ (dashed red lines) are the best estimates of $\mathbf{M}$ from the MMI assignments for assumed epicenters on that contour. The rms $\left[\mathrm{M}_{\mathrm{l}}\right]$ contours corresponding to the $67 \%$ (innermost contour) and $95 \%$ confidence levels (outermost contour) for location from Bakun and Wentworth (1999) are shown as solid green lines; there is an 0.67 probability that the epicenter lies within the $67 \%$ contour and an 0.95 probability that the epicenter lies within the $95 \%$ contour.

Comments. The intensity center is located in southeast Arkansas. $\mathbf{M}_{1}$ is 4.3 and $\mathbf{M}$ is 3.8 to 4.7 at the $95 \%$ confidence range. 


\section{\#27) 1917 April 9 20:52 UTC (Illinois)}

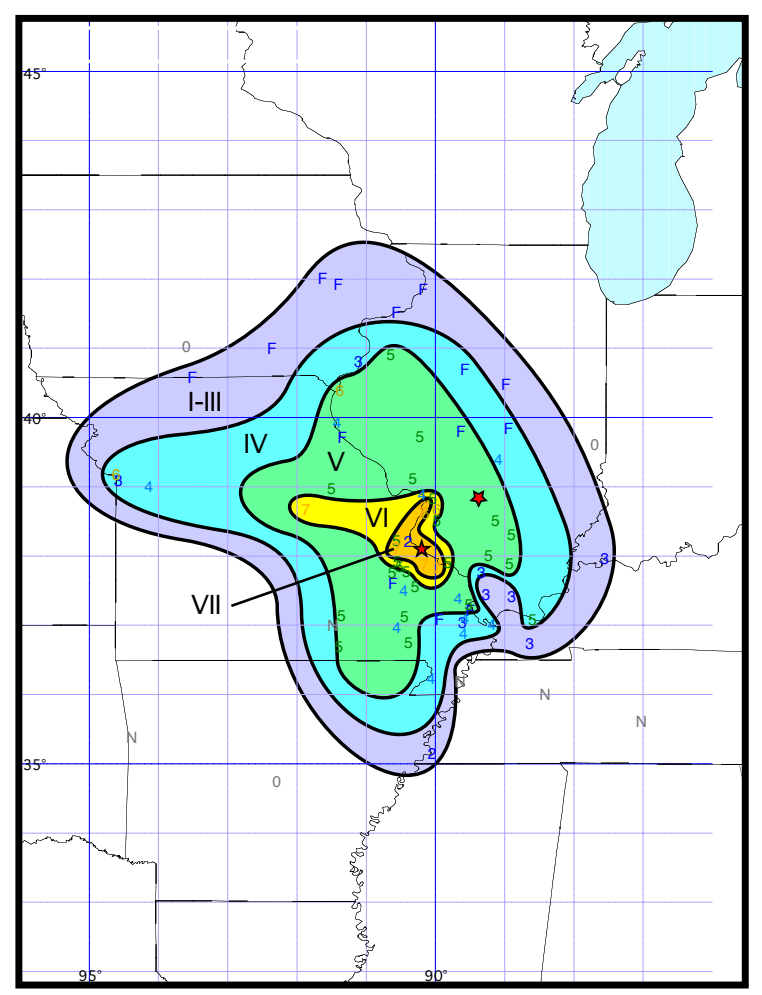

Isoseismal map. Numbers are MMI assignments; F denotes that the event was felt, but that the information is not sufficient to assign an $\mathrm{MMl} ; 0$ denotes that the event was reported as not felt; and $\mathrm{N}$ denotes that the event was not mentioned and is presumed "not felt". Click here to view damage reports and intensity assignments listed in Appendix 1, Part 27. The thick black isoseismal lines enclose isoseismal areas (V: green; IV: blue; etc.). The upwardpointing red star is Stover and Coffman's (1993) epicenter location; the downward-pointing star is our preferred location (see Table 1).

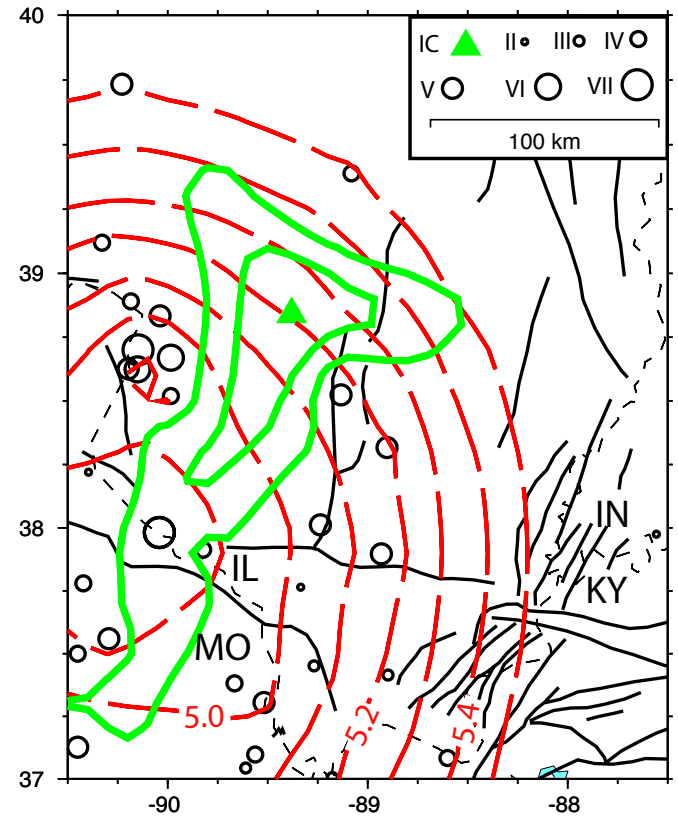

The epicentral region. IC is the intensity center. Faults are shown as black lines. Black circles are sites with MMl assignments; 7.0 (MMI-site corrections) $<8.0$ are plotted as MMI VII, and so on. The contours of $M_{I}$ (dashed red lines) are the best estimates of $\mathbf{M}$ from the MMl assignments for assumed epicenters on that contour. The rms $\left[\mathrm{M}_{\mathrm{l}}\right]$ contours corresponding to the $67 \%$ (innermost contour) and $95 \%$ confidence levels (outermost contour) for location from Bakun and Wentworth (1999) are shown as solid green lines; there is an 0.67 probability that the epicenter lies within the $67 \%$ contour and an 0.95 probability that the epicenter lies within the $95 \%$ contour.

Comments. The intensity center is located west of the north end of the Du Quoin Monocline and the south end of the Louden Anticline, which is cored by a major basement fault (John McBride, personal communication, 2003). Although the 1917 event is commonly located near the maximum reported intensity at Ste. Genevieve (e.g., Stover and Coffman, 1993), the low intensity assignments near Ste. Genevieve are not consistent with a nearby source. $M_{1}$ is 5.2 for a location on the Du Quoin Monocline and $\mathbf{M}$ is 4.8 to 5.5 at the $95 \%$ confidence range. $M_{1}$ is 5.3 for a location on the Louden Anticline [near Stover and Coffman's

(1993) location] and $\mathbf{M}$ is 4.9 to 5.6 at the $95 \%$ confidence range. 
\#28) 1922 March 22 22:29 UTC (Illinois)

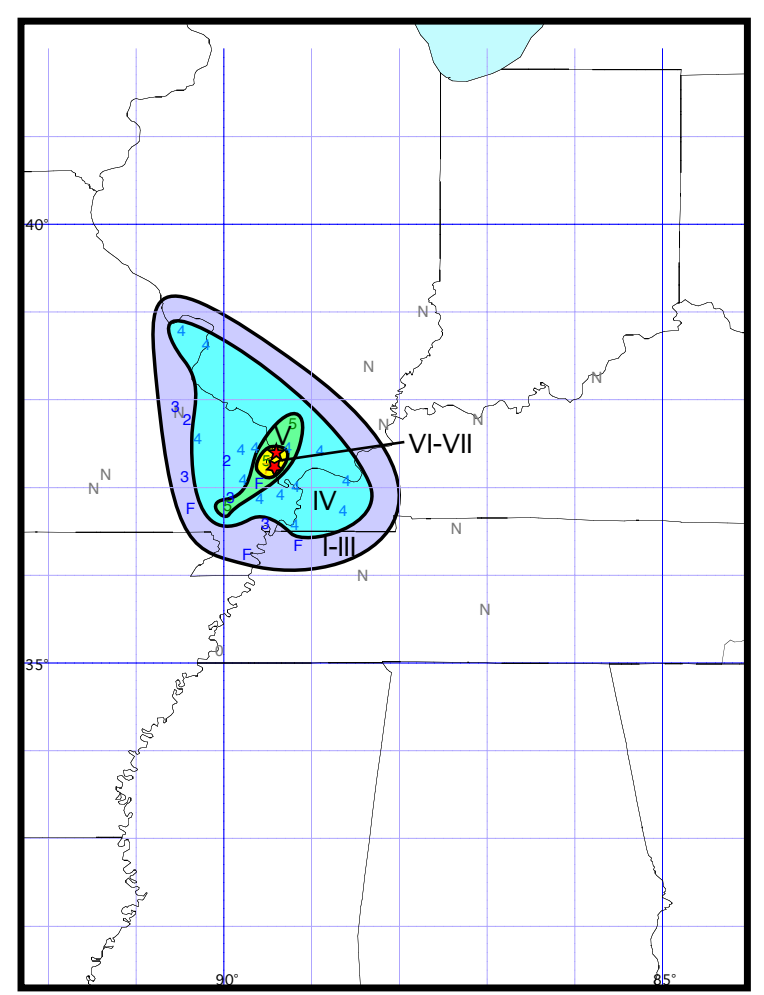

Isoseismal map. Numbers are $\mathrm{MMI}$ assignments; $\mathrm{F}$ denotes that the event was felt, but that the information is not sufficient to assign an $\mathrm{MMl} ; 0$ denotes that the event was reported as not felt; and $\mathrm{N}$ denotes that the event was not mentioned and is presumed "not felt". Click here to view damage reports and intensity assignments listed in Appendix 1, Part 28. The thick black isoseismal lines enclose isoseismal areas (V: green; IV: blue; etc.). The upwardpointing red star is Stover and Coffman's (1993) epicenter location; the downward-pointing star is our preferred location (see Table 1).

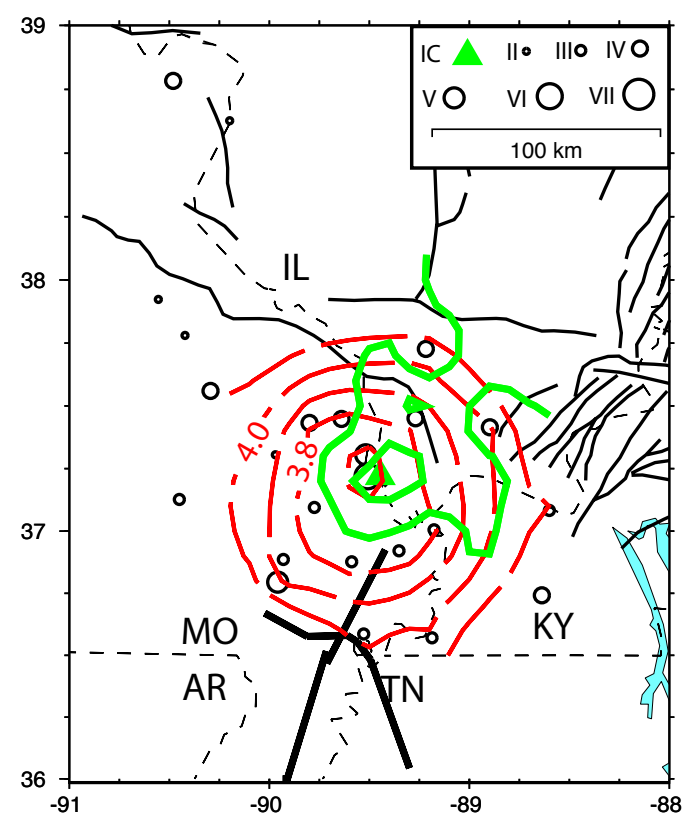

The epicentral region. IC is the intensity center. Faults are shown as black lines. The thick black lines represent Johnston and Schweig's (1996) NMSZ segments. Black circles are sites with MMI assignments; 7.0 (MMI-site corrections) $<8.0$ are plotted as MMI VII, and so on. The contours of $M_{\text {I }}$ (dashed red lines) are the best estimates of $\mathbf{M}$ from the $\mathrm{MMI}$ assignments for assumed epicenters on that contour. The rms $\left[\mathrm{M}_{\mathrm{J}}\right]$ contours corresponding to the $67 \%$ (innermost contour) and $95 \%$ confidence levels (outermost contour) for location from Bakun and Wentworth (1999) are shown as solid green lines; there is an 0.67 probability that the epicenter lies within the $67 \%$ contour and an 0.95 probability that the epicenter lies within the $95 \%$ contour.

Comments. The intensity center is located to the south of the SW-dipping reverse Ste. Genevieve fault zone. $M_{1}$ is 3.7 and $\mathbf{M}$ is 3.2 to 4.1 at the $95 \%$ confidence range. 


\section{\#29) 1922 November 27 03:31 UTC (Illinois)}

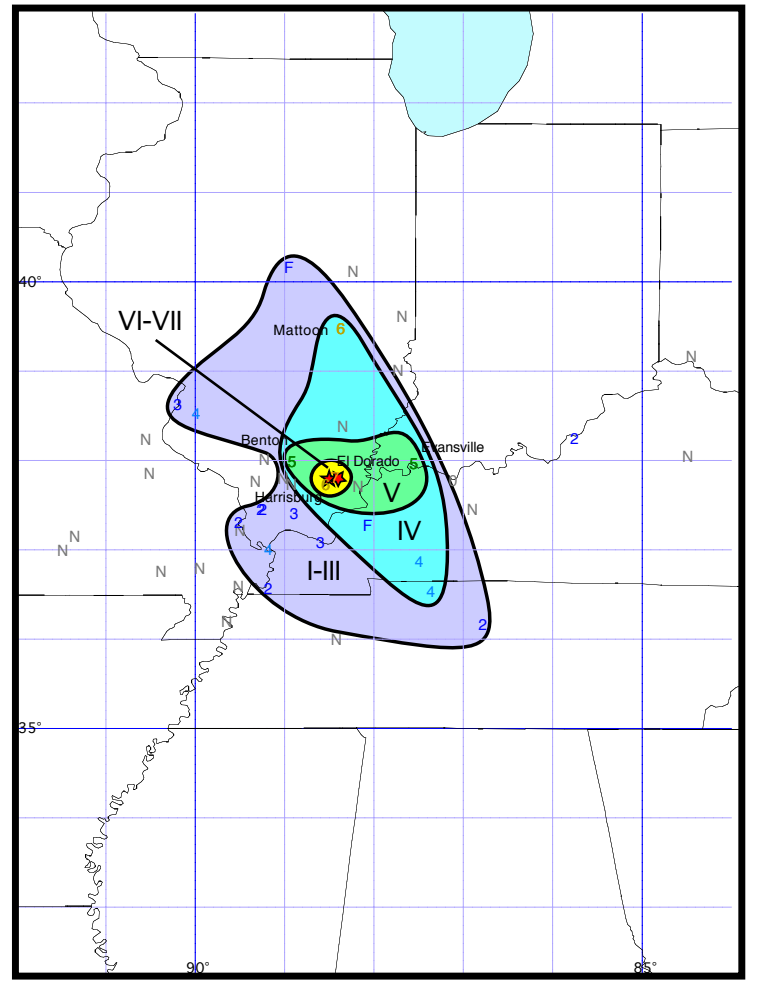

Isoseismal map. Numbers are $\mathrm{MMI}$ assignments; $\mathrm{F}$ denotes that the event was felt, but that the information is not sufficient to assign an $\mathrm{MMl} ; 0$ denotes that the event was reported as not felt; and $\mathrm{N}$ denotes that the event was not mentioned and is presumed "not felt". Click here to view damage reports and intensity assignments listed in Appendix 1, Part 29. The thick black isoseismal lines enclose isoseismal areas (V: green; IV: blue; etc.). The upward-pointing red star is Stover and Coffman's (1993) epicenter location; the downward-pointing star is our preferred location (see Table 1).

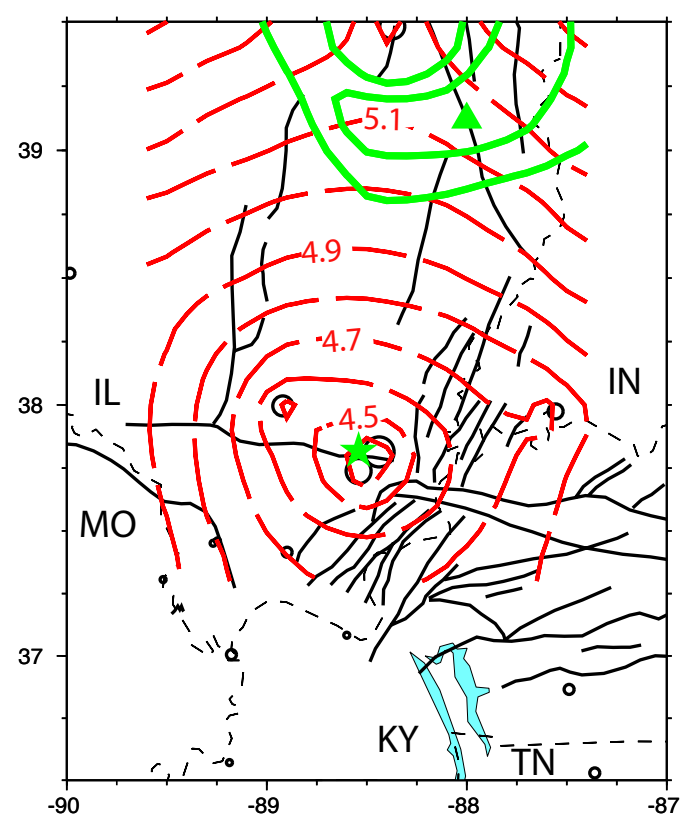

The epicentral region. IC is the intensity center. Our preferred location is shown as a green star. Faults are shown as black lines. Black circles are sites with MMI assignments; 7.0 (MMl -site corrections) $<8.0$ are plotted as MMI VII, and so on. The contours of $M_{\mathrm{I}}$ (dashed red lines) are the best estimates of $\mathbf{M}$ from the $\mathrm{MMI}$ assignments for assumed epicenters on that contour. The rms $\left[M_{l}\right]$ contours corresponding to the $67 \%$ (innermost contour) and 95\% confidence levels (outermost contour) for location from Bakun and Wentworth (1999) are shown as solid green lines; there is an 0.67 probability that the epicenter lies within the $67 \%$ contour and an 0.95 probability that the epicenter lies within the $95 \%$ contour.

Comments. The location is poorly constrained by the intensity data, but the intensity center is located on the Charleston Monocline, part of the La Salle Anticlinorium. The damage, however, is centered near the east end of the Cottage Grove fault system. $M_{1}$ is 4.4 for an assumed location on east end of the Cottage Grove fault system and $\mathbf{M}$ is 3.8 to 4.9 at the $95 \%$ confidence range. 


\section{\#30) 1923 October 28 17:10 UTC (Arkansas)}

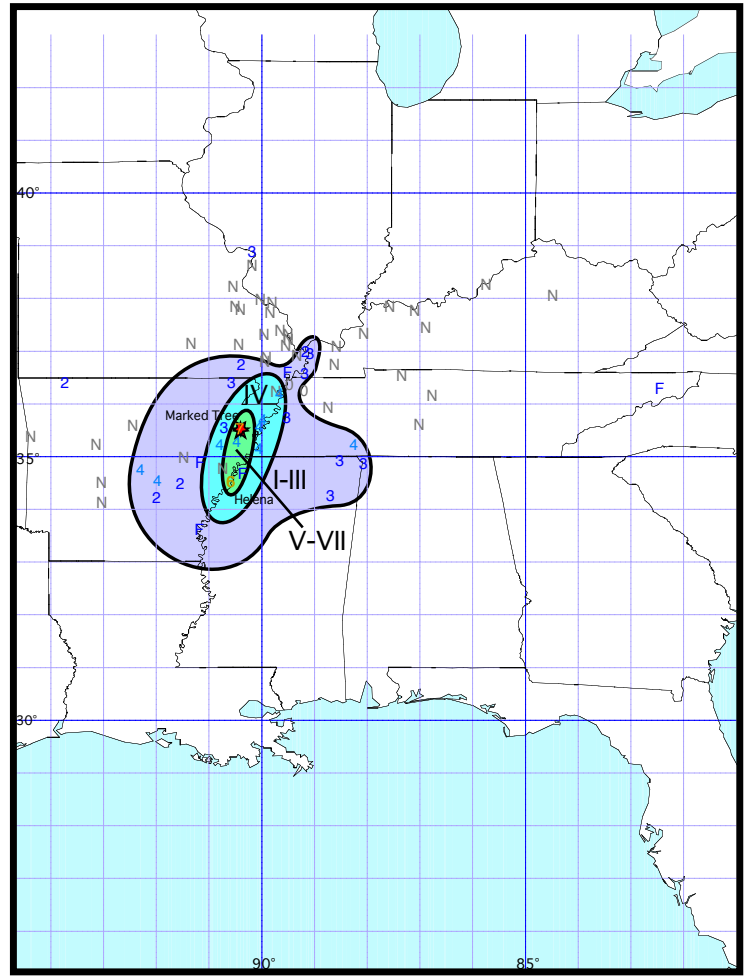

Isoseismal map. Numbers are MMI assignments; $\mathrm{F}$ denotes that the event was felt, but that the information is not sufficient to assign an $\mathrm{MMl} ; 0$ denotes that the event was reported as not felt; and $\mathrm{N}$ denotes that the event was not mentioned and is presumed "not felt". Click here to view damage reports and intensity assignments listed in Appendix 1, Part 30. The thick black isoseismal lines enclose isoseismal areas (V: green; IV: blue; etc.). The upward-pointing red star is Stover and Coffman's (1993) epicenter location; the downward-pointing star is our preferred location (see Table 1).

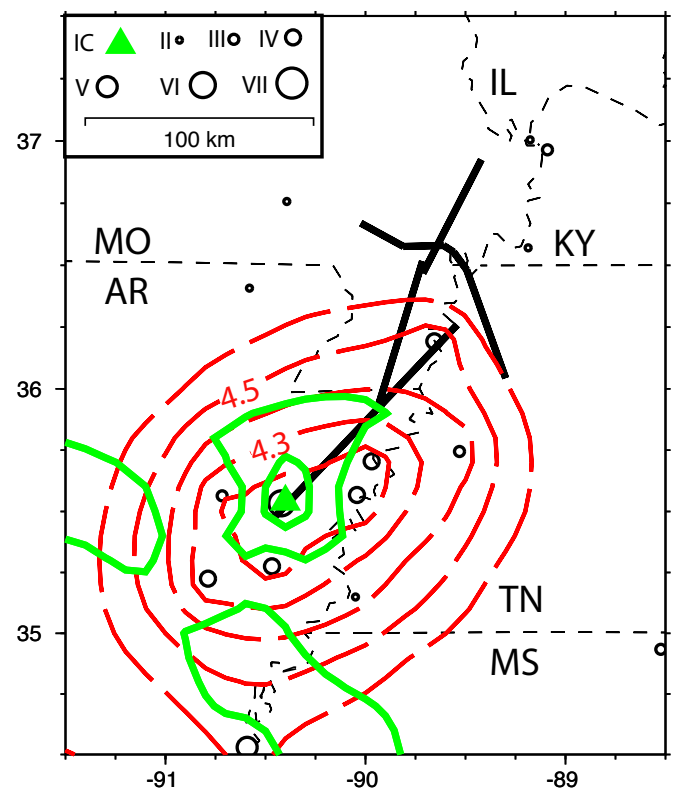

The epicentral region. IC is the intensity center. The thick black lines represent Johnston and Schweig's (1996) NMSZ segments. Black circles are sites with MMI assignments; 7.0 (MMl -site corrections) $<8.0$ are plotted as MMI VII, and so on. The contours of $M_{l}$ (dashed red lines) are the best estimates of $\mathbf{M}$ from the $\mathrm{MMI}$ assignments for assumed epicenters on that contour. The rms $\left[\mathrm{M}_{\mathrm{l}}\right]$ contours corresponding to the $67 \%$ (innermost contour) and 95\% confidence levels (outermost contour) for location from Bakun and Wentworth (1999) are shown as solid green lines; there is an 0.67 probability that the epicenter lies within the $67 \%$ contour and an 0.95 probability that the epicenter lies within the $95 \%$ contour.

Comments. The intensity center is located on the Blytheville Arch segment of the NMSZ. $M_{1}$ is 4.1 and $\mathbf{M}$ is 3.6 to 4.5 at the $95 \%$ confidence range. 


\section{\#31) 1925 April 27 04:05 UTC (Indiana)}

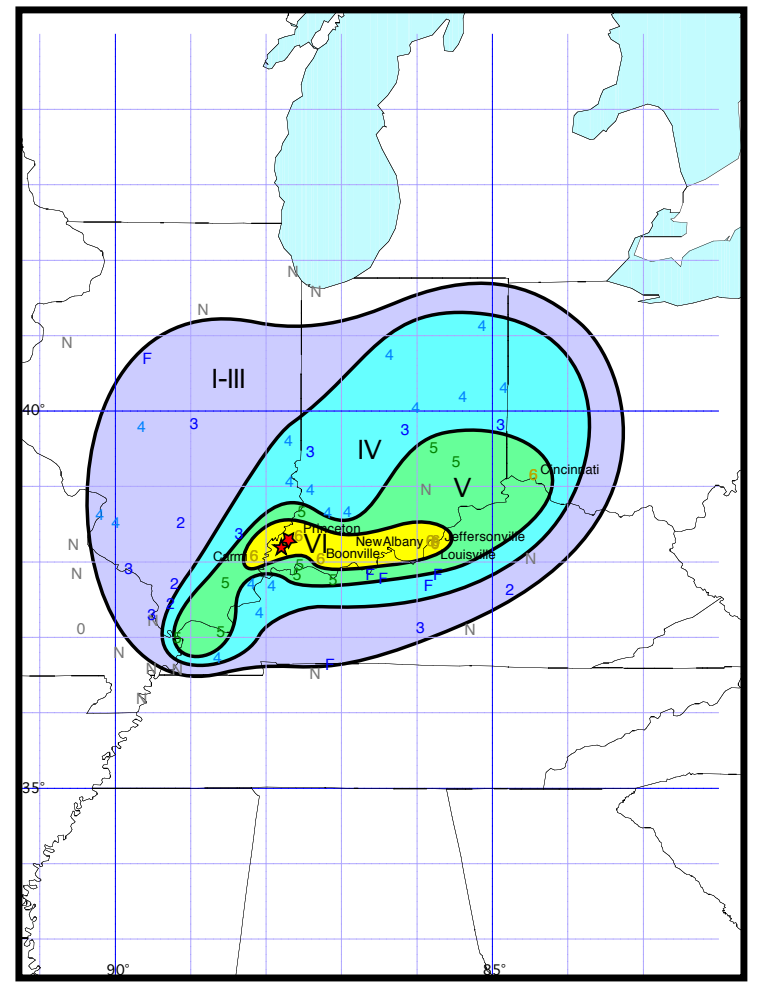

Isoseismal map. Numbers are $\mathrm{MMI}$ assignments; $\mathrm{F}$ denotes that the event was felt, but that the information is not sufficient to assign an $\mathrm{MMl} ; 0$ denotes that the event was reported as not felt; and $\mathrm{N}$ denotes that the event was not mentioned and is presumed "not felt". Click here to view damage reports and intensity assignments listed in Appendix 1, Part 31. The thick black isoseismal lines enclose isoseismal areas (V: green; IV: blue; etc.). The upward-pointing red star is Stover and Coffman's (1993) epicenter location; the downward-pointing star is our preferred location (see Table 1).

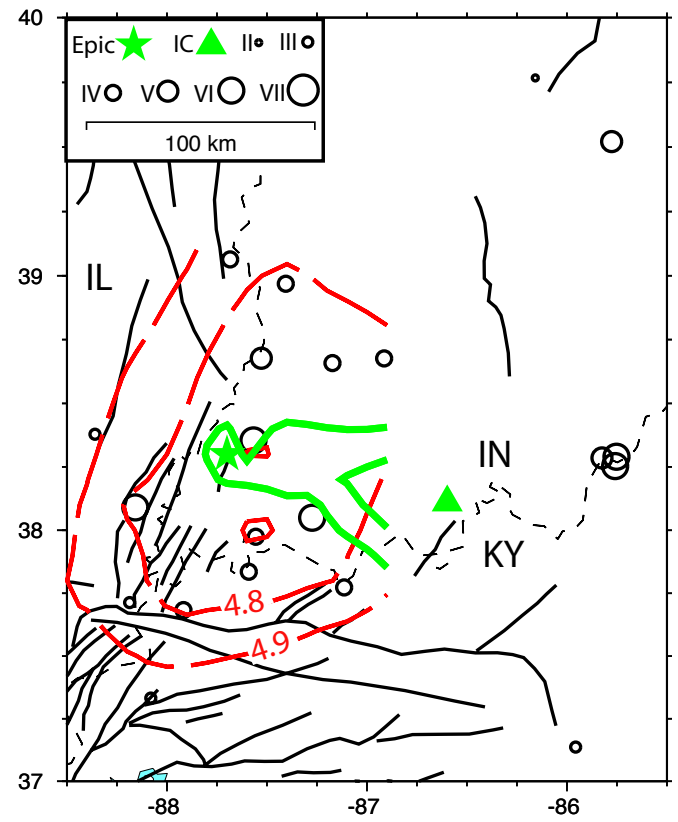

The epicentral region. IC is the intensity center. Our preferred location is shown as a green star. Faults are shown as black lines. Black circles are sites with MMI assignments; 7.0 (MMl -site corrections) $<8.0$ are plotted as MMI VII, and so on. The contours of $M_{\mathrm{I}}$ (dashed red lines) are the best estimates of $\mathbf{M}$ from the $\mathrm{MMI}$ assignments for assumed epicenters on that contour. The rms $\left[\mathrm{M}_{\mathrm{l}}\right]$ contours corresponding to the $67 \%$ (innermost contour) and 95\% confidence levels (outermost contour) for location from Bakun and Wentworth (1999) are shown as solid green lines; there is an 0.67 probability that the epicenter lies within the $67 \%$ contour and an 0.95 probability that the epicenter lies within the $95 \%$ contour.

Comments. This event appears to be a smaller version of the 30 April 1899 event, and we have adopted the same preferred epicenter at the north end of the Wabash Valley fault system. $\mathbf{M}_{\mathbf{l}}$ is 4.7 and $\mathbf{M}$ is 4.3 to 5.0 at the $95 \%$ confidence range. 


\section{\#32) 1927 May 7 08:28 UTC (Arkansas)}

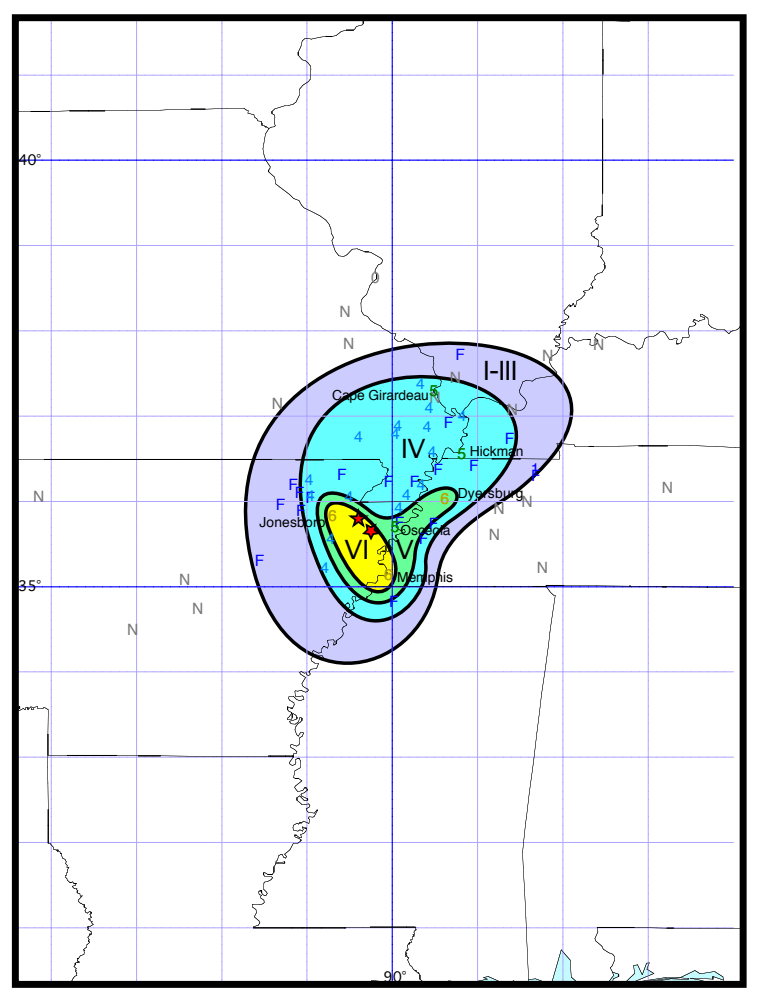

Isoseismal map. Numbers are MMI assignments; $\mathrm{F}$ denotes that the event was felt, but that the information is not sufficient to assign an MMl; 0 denotes that the event was reported as not felt; and $\mathrm{N}$ denotes that the event was not mentioned and is presumed "not felt". Click here to view damage reports and intensity assignments listed in Appendix 1, Part 32. The thick black isoseismal lines enclose isoseismal areas (V: green; IV: blue; etc.). The upwardpointing red star is Stover and Coffman's (1993) epicenter location; the downward-pointing star is our preferred location (see Table 1).

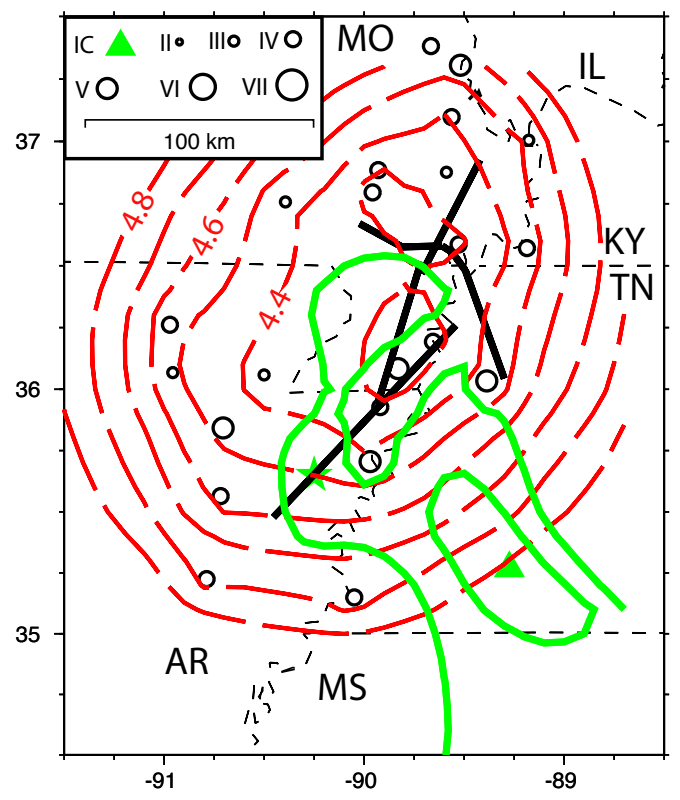

The epicentral region. IC is the intensity center. Our preferred location is shown as a green star. The thick black lines represent Johnston and Schweig's (1996) NMSZ segments. Black circles are sites with MMI assignments; 7.0 (MMI-site corrections) $<8.0$ are plotted as MMI VII, and so on. The contours of $\mathrm{M}_{\mathrm{I}}$ (dashed red lines) are the best estimates of $\mathbf{M}$ from the $\mathrm{MMI}$ assignments for assumed epicenters on that contour. The rms $\left[\mathrm{M}_{\mathrm{l}}\right]$ contours corresponding to the $67 \%$ (innermost contour) and 95\% confidence levels (outermost contour) for location from Bakun and Wentworth (1999) are shown as solid green lines; there is an 0.67 probability that the epicenter lies within the $67 \%$ contour and an 0.95 probability that the epicenter lies within the $95 \%$ contour.

Comments. The intensity data are consistent with a location near the south half of the NMSZ. $M_{1}$ is 4.5 for a location on the Blytheville Arch segment and $\mathbf{M}$ is 4.0 to 4.9 at the $95 \%$ confidence range. 


\section{\#33) 1931 December 17 03:36 UTC (Mississippi)}

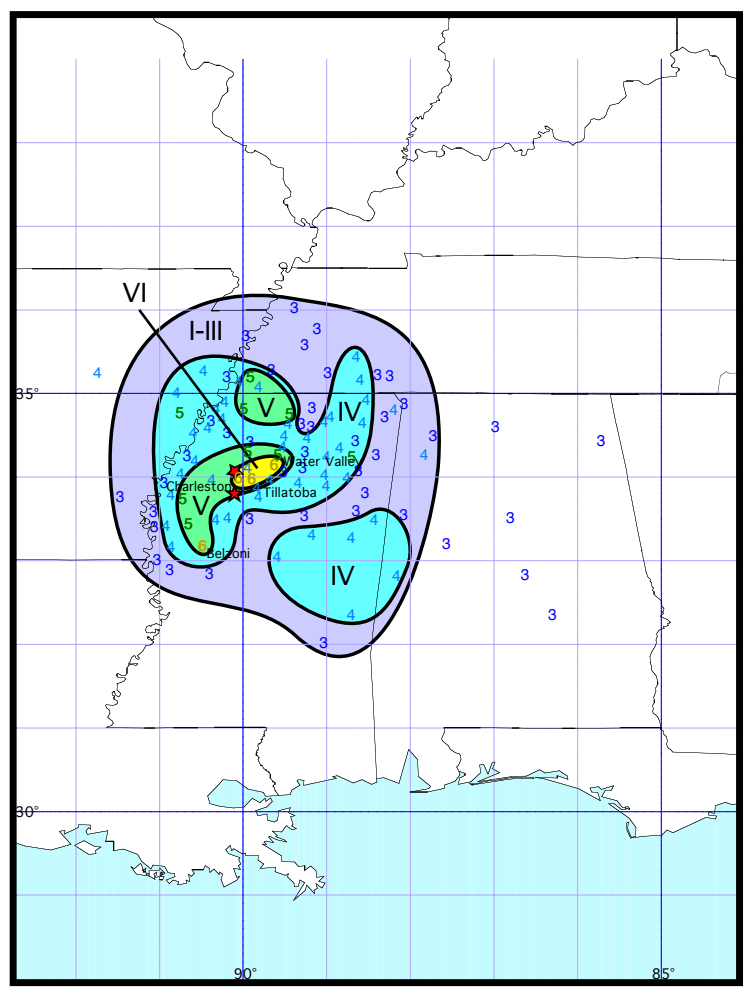

Isoseismal map. Numbers are MMI assignments; F denotes that the event was felt, but that the information is not sufficient to assign an MMl; 0 denotes that the event was reported as not felt; and $\mathrm{N}$ denotes that the event was not mentioned and is presumed "not felt". Click here to view damage reports and intensity assignments listed in Appendix 1, Part 33. The thick black isoseismal lines enclose isoseismal areas (V: green; IV: blue; etc.). The upwardpointing red star is Stover and Coffman's (1993) epicenter location; the downward-pointing star is our preferred location (see Table 1).

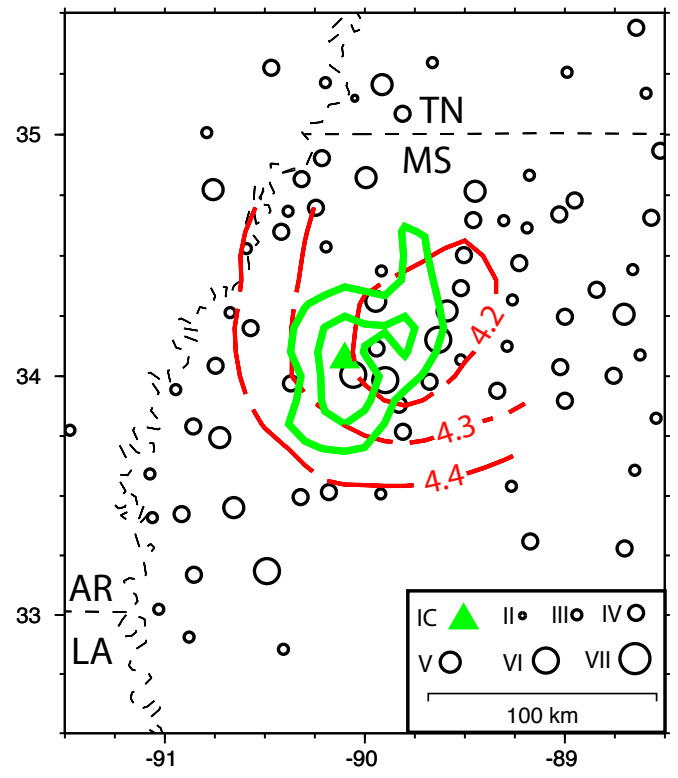

The epicentral region. IC is the intensity center. Black circles are sites with MMI assignments; 7.0 (MMI-site corrections) < 8.0 are plotted as MMI VII, and so on. The contours of $M_{1}$ (dashed red lines) are the best estimates of $\mathbf{M}$ from the $\mathrm{MMI}$ assignments for assumed epicenters on that contour. The rms $\left[\mathrm{M}_{\mathrm{l}}\right]$ contours corresponding to the $67 \%$ (innermost contour) and $95 \%$ confidence levels (outermost contour) for location from Bakun and Wentworth (1999) are shown as solid green lines; there is an 0.67 probability that the epicenter lies within the $67 \%$ contour and an 0.95 probability that the epicenter lies within the $95 \%$ contour.

Comments. The location is tightly constrained by the intensity data. $M_{1}$ is 4.2 and $\mathbf{M}$ is 3.8 to 4.5 at the $95 \%$ confidence range. 


\section{\#34) 1934 August 20 00:47 UTC (Missouri)}

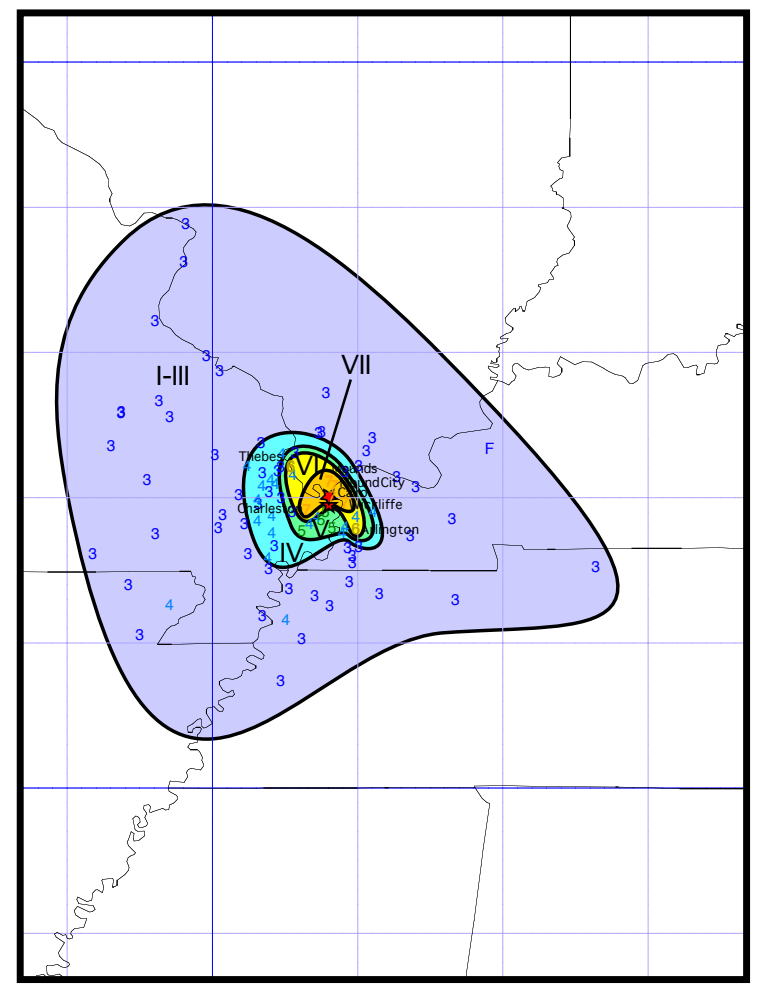

Isoseismal map. Numbers are $\mathrm{MMI}$ assignments; $\mathrm{F}$ denotes that the event was felt, but that the information is not sufficient to assign an $\mathrm{MMl} ; 0$ denotes that the event was reported as not felt; and $\mathrm{N}$ denotes that the event was not mentioned and is presumed "not felt". Click here to view damage reports and intensity assignments listed in Appendix 1, Part 34. The thick black isoseismal lines enclose isoseismal areas (V: green; IV: blue; etc.). The upward-pointing red star is Stover and Coffman's (1993) epicenter location; the downward-pointing star is our preferred location (see Table 1).

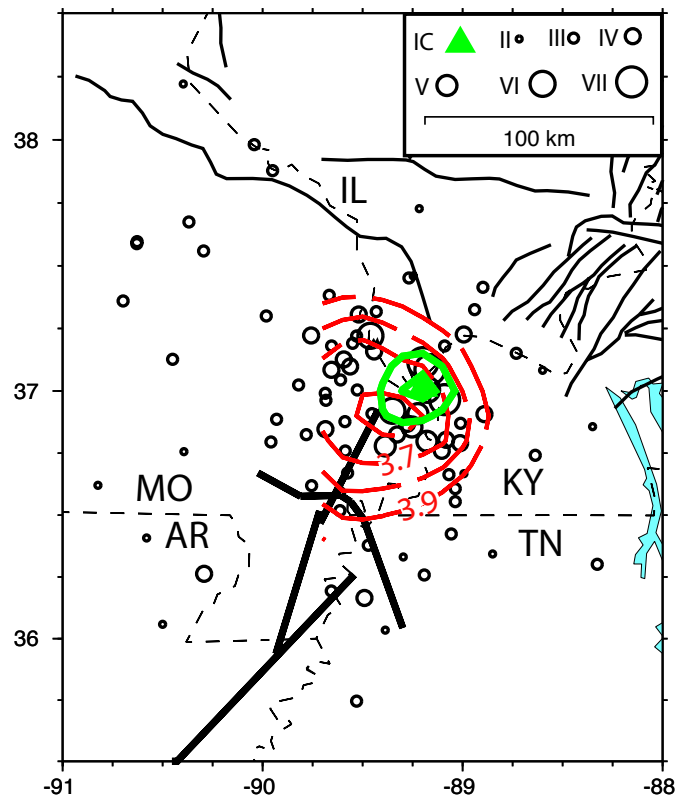

The epicentral region. IC is the intensity center. Faults are shown as black lines. The thick black lines represent Johnston and Schweig's (1996) NMSZ segments. Black circles are sites with MMI assignments; 7.0 (MMI -site corrections) $<8.0$ are plotted as MMI VII, and so on. The contours of $M_{l}$ (dashed red lines) are the best estimates of $\mathbf{M}$ from the $\mathrm{MMI}$ assignments for assumed epicenters on that contour. The rms $\left[\mathrm{M}_{\mathrm{l}}\right]$ contours corresponding to the $67 \%$ (innermost contour) and $95 \%$ confidence levels (outermost contour) for location from Bakun and Wentworth (1999) are shown as solid green lines; there is an 0.67 probability that the epicenter lies within the $67 \%$ contour and an 0.95 probability that the epicenter lies within the $95 \%$ contour.

Comments. The intensity center is located near the junction of the Reelfoot rift and the Rough Creek graben, and near a NE-SW alignment of epicenters of recent small earthquakes (Wheeler, 1997). McBride et al. (1993) have associated this alignment of epicenters and the nearby 1984 swarm of earthquakes on the Olmstead fault in Illinois. $\mathbf{M}_{\mathbf{l}}$ is 3.7 and $\mathbf{M}$ is 3.3 to 4.0 at the $95 \%$ confidence range. 


\section{\#35) 1937 March 2 14:47 UTC (Ohio)}

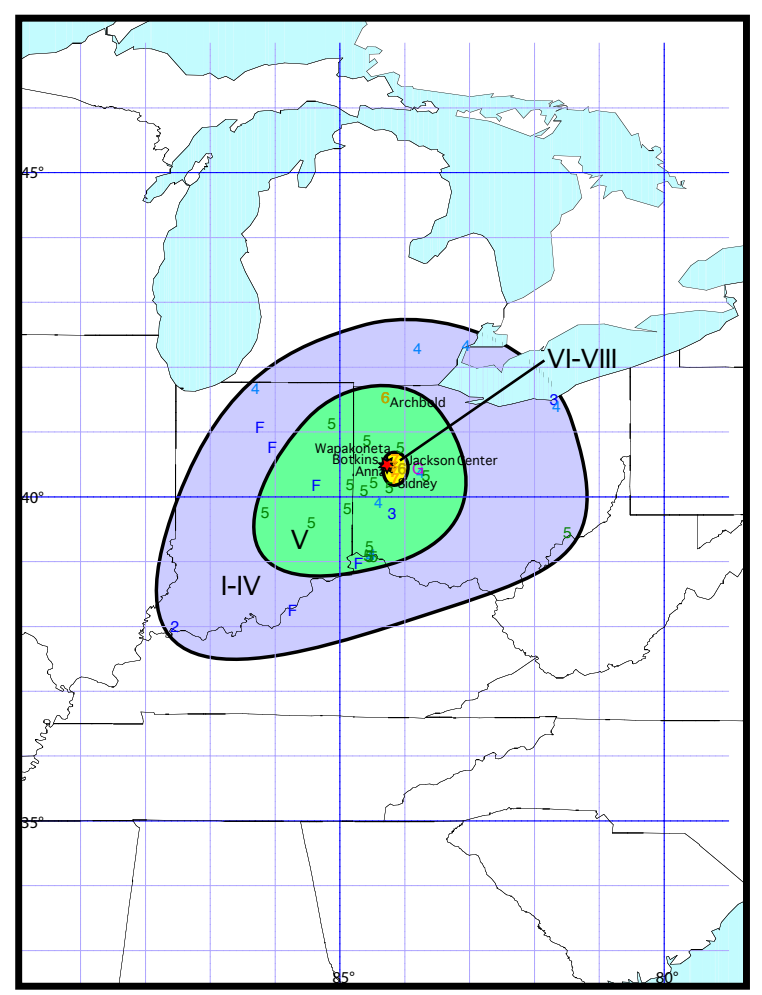

Isoseismal map. Numbers are $\mathrm{MMI}$ assignments; $\mathrm{F}$ denotes that the event was felt, but that the information is not sufficient to assign an MMl; 0 denotes that the event was reported as not felt; and $\mathrm{N}$ denotes that the event was not mentioned and is presumed "not felt". Click here to view damage reports and intensity assignments listed in Appendix 1, Part 35. The thick black isoseismal lines enclose isoseismal areas (V: green; IV: blue; etc.). The upward-pointing red star is Stover and Coffman's (1993) epicenter location; the downwardpointing star is our preferred location (see Table 1).

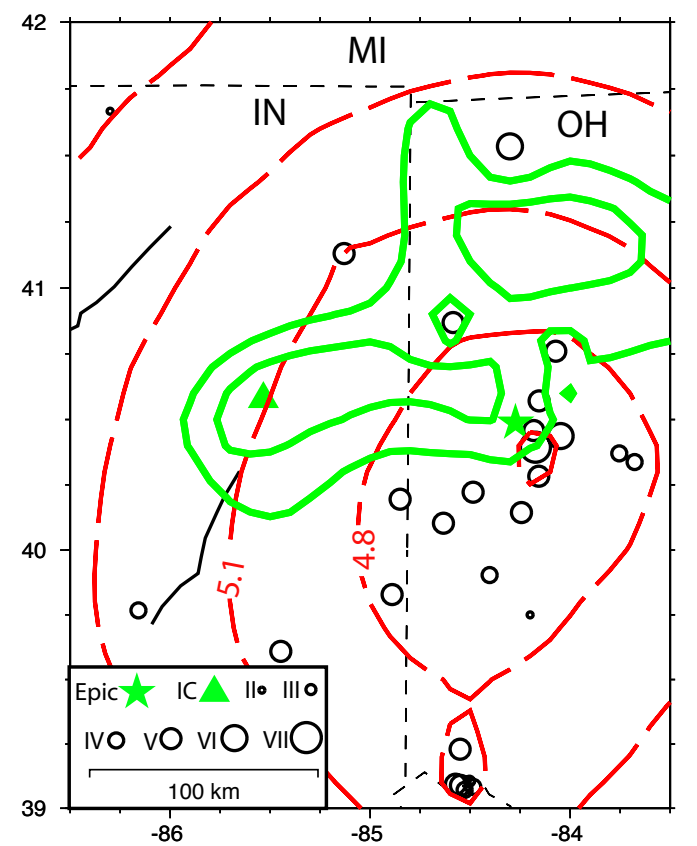

The epicentral region. IC is the intensity center. Our preferred location is shown as a green star. Black circles are sites with $\mathrm{MMI}$ assignments; 7.0 (MMI -site corrections) $<8.0$ are plotted as MMI VII, and so on. The contours of $M_{l}$ (dashed red lines) are the best estimates of $\mathbf{M}$ from the $\mathrm{MMI}$ assignments for assumed epicenters on that contour. The rms $\left[\mathrm{M}_{\mathrm{l}}\right]$ contours corresponding to the $67 \%$ (innermost contour) and $95 \%$ confidence levels (outermost contour) for location from Bakun and Wentworth (1999) are shown as solid green lines; there is an 0.67 probability that the epicenter lies within the $67 \%$ contour and an 0.95 probability that the epicenter lies within the $95 \%$ contour.

Comments. The largest of several felt earthquakes in the 1930s near Anna, Ohio, occurred on 2 March 1937 and 9 March 1937. Dewey and Gordon (1984) used a Joint-Epicentral Determination method and obtained essentially the same epicenter location for the two events [our preferred locations are those obtained by Dewey and Gordon (1984)]. Stover and Coffman (1993) note that the 9 March 1937 event was stronger than the 2 March 1937 event. $M_{1}$ is 4.5 and $\mathbf{M}$ is 4.1 to 4.8 at the $95 \%$ confidence range for the 2 March 1937 event. 


\section{\#36) 1937 March 9 05:44 UTC (Ohio)}

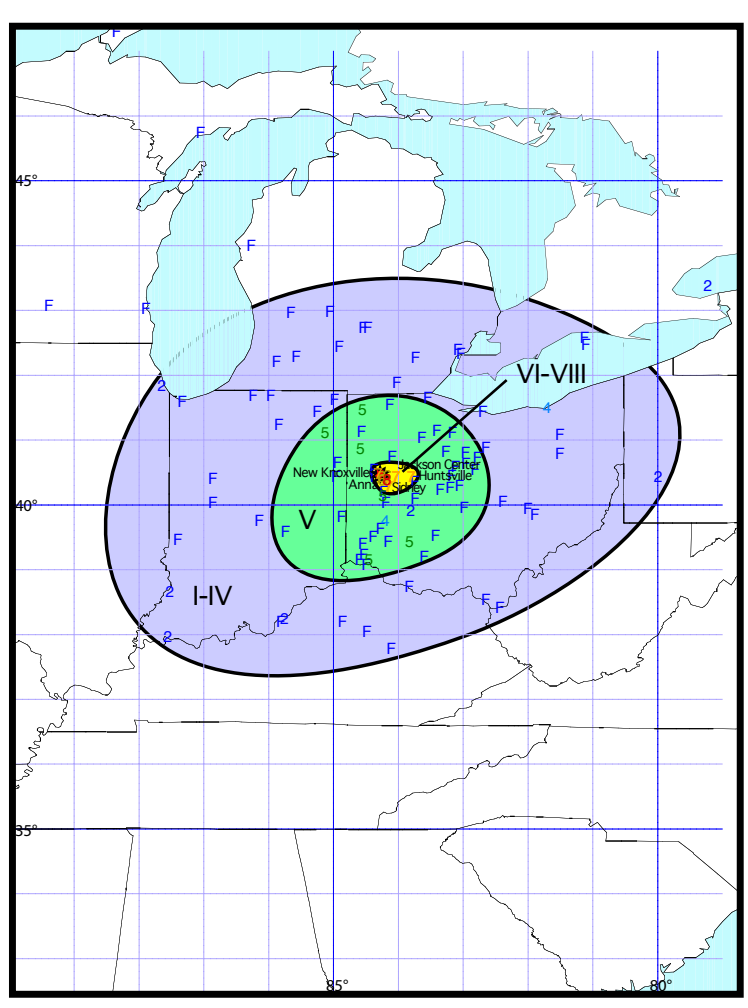

Isoseismal map. Numbers are MMI assignments; $\mathrm{F}$ denotes that the event was felt, but that the information is not sufficient to assign an $\mathrm{MMl} ; 0$ denotes that the event was reported as not felt; and $\mathrm{N}$ denotes that the event was not mentioned and is presumed "not felt". Click here to view damage reports and intensity assignments listed in Appendix 1, Part 36. The thick black isoseismal lines enclose isoseismal areas (V: green; IV: blue; etc.). The upward-pointing red star is Stover and Coffman's (1993) epicenter location; the downward-pointing star is our preferred location (see Table 1).

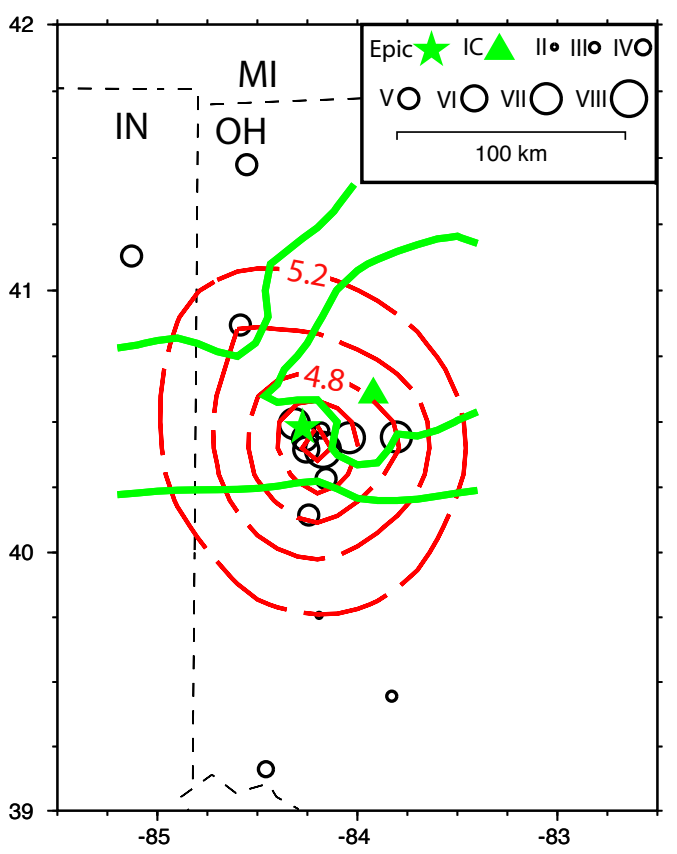

The epicentral region. IC is the intensity center. Our preferred location is shown as a green star. Black circles are sites with $\mathrm{MMI}$ assignments; 7.0 (MMI -site corrections) $<8.0$ are plotted as MMI VII, and so on. The contours of $M_{l}$ (dashed red lines) are the best estimates of $\mathbf{M}$ from the $\mathrm{MMI}$ assignments for assumed epicenters on that contour. The rms $\left[\mathrm{M}_{\mathrm{l}}\right]$ contours corresponding to the $67 \%$ (innermost contour) and $95 \%$ confidence levels (outermost contour) for location from Bakun and Wentworth (1999) are shown as solid green lines; there is an 0.67 probability that the epicenter lies within the $67 \%$ contour and an 0.95 probability that the epicenter lies within the $95 \%$ contour.

Comments. The largest of several felt earthquakes in the 1930s near Anna, Ohio, occurred on 2 March 1937 and 9 March 1937. Dewey and Gordon (1984) used a Joint-Epicentral Determination method and obtained essentially the same epicenter location for the two events [our preferred location is that obtained by Dewey and Gordon (1984)]. $\mathbf{M}_{1}$ is 4.6 and $\mathbf{M}$ is 4.1 to 5.0 at the $95 \%$ confidence range for the 9 March 1937 event. 


\section{\#37) 1938 September 17 03:34 UTC (Arkansas)}

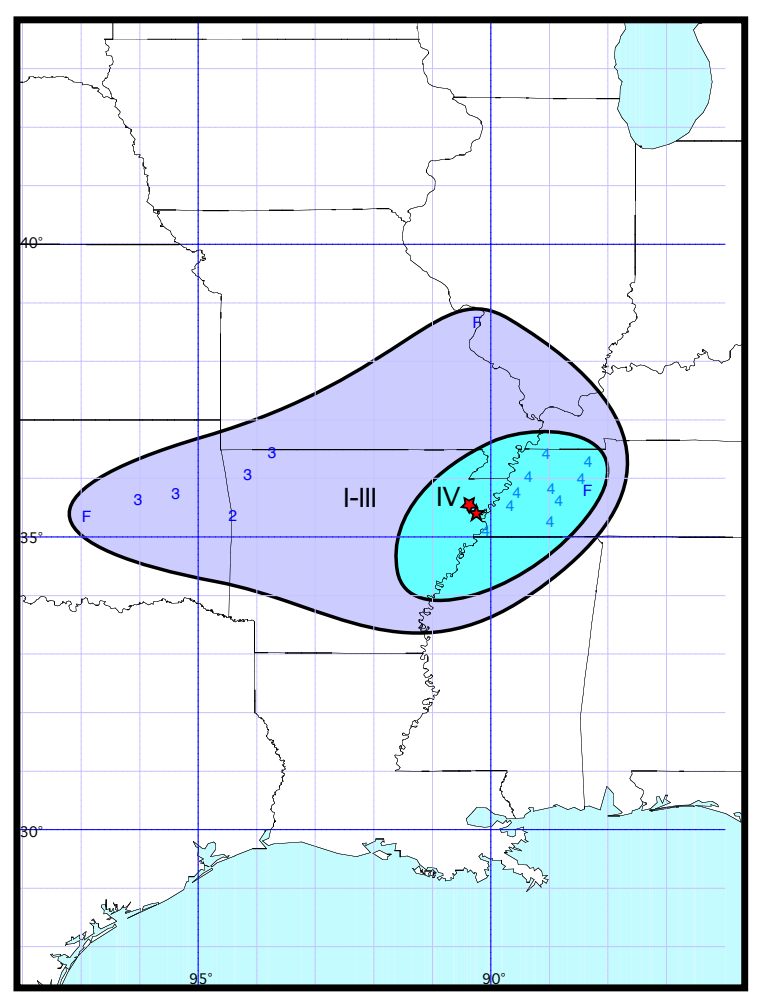

Isoseismal map. Numbers are MMI assignments; $\mathrm{F}$ denotes that the event was felt, but that the information is not sufficient to assign an $\mathrm{MMl} ; 0$ denotes that the event was reported as not felt; and $\mathrm{N}$ denotes that the event was not mentioned and is presumed "not felt". Click here to view damage reports and intensity assignments listed in Appendix 1, Part 37. The thick black isoseismal lines enclose isoseismal areas (V: green; IV: blue; etc.). The upwardpointing red star is Stover and Coffman's (1993) epicenter location; the downward-pointing star is our preferred location (see Table 1).

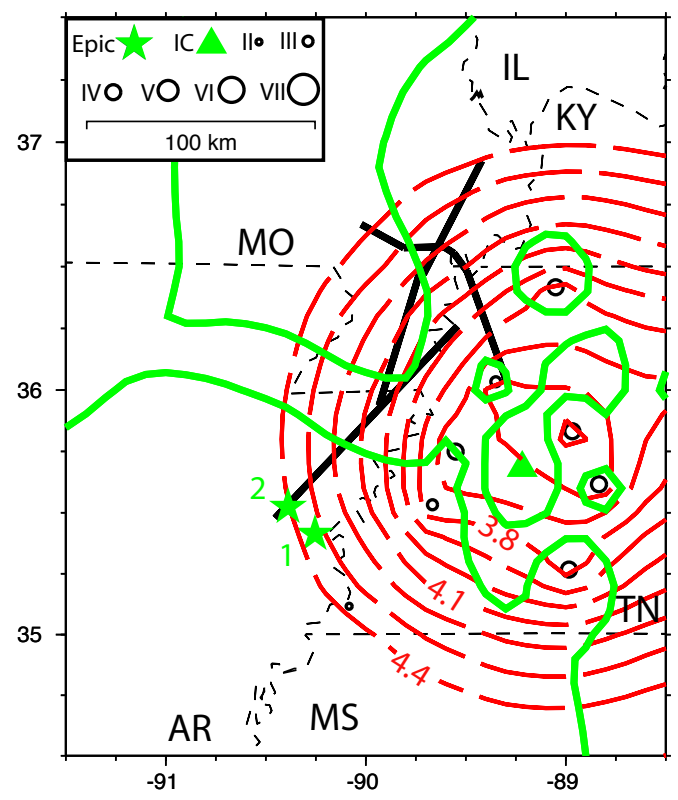

The epicentral region. IC is the intensity center. Our preferred location is shown as green star \#2. The thick black lines represent Johnston and Schweig's (1996) NMSZ segments. Black circles are sites with MMI assignments; 7.0 (MMI-site corrections) $<8.0$ are plotted as MMI VII, and so on. The contours of $M_{I}$ (dashed red lines) are the best estimates of $\mathbf{M}$ from the $\mathrm{MMI}$ assignments for assumed epicenters on that contour. The rms $\left[\mathrm{M}_{\mathrm{l}}\right]$ contours corresponding to the $67 \%$ (innermost contour) and 95\% confidence levels (outermost contour) for location from Bakun and Wentworth (1999) are shown as solid green lines; there is an 0.67 probability that the epicenter lies within the $67 \%$ contour and an 0.95 probability that the epicenter lies within the $95 \%$ contour.

Comments. The intensity data are consistent with a location near the south half of the NMSZ. Dewey and Gordon's (1984) instrumental location (star \#1) is 18 kilometers southeast of our preferred location on the south end of the Blytheville Arch segment of the NMSZ (star \#2). $M_{1}$ is 4.4 and $\mathbf{M}$ is 3.9 to 4.8 at the $95 \%$ confidence range. 


\section{\#38) 1952 April 9 16:29 UTC (Oklahoma)}

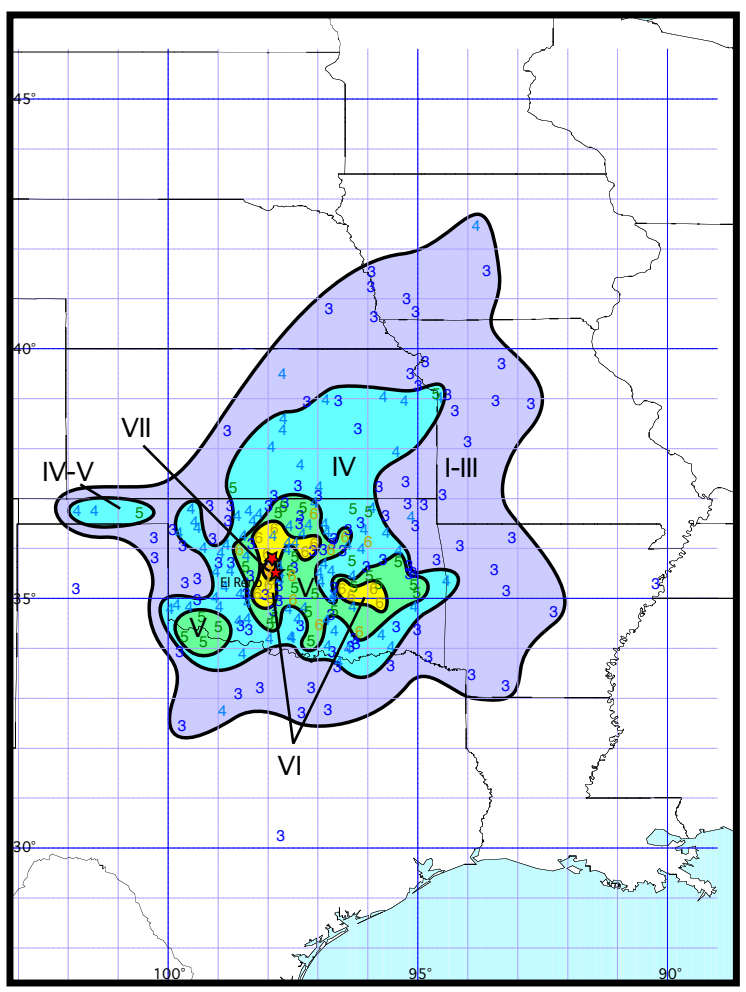

Isoseismal map. Numbers are $\mathrm{MMI}$ assignments; $\mathrm{F}$ denotes that the event was felt, but that the information is not sufficient to assign an $\mathrm{MMl} ; 0$ denotes that the event was reported as not felt; and $\mathrm{N}$ denotes that the event was not mentioned and is presumed "not felt". Click here to view damage reports and intensity assignments listed in Appendix 1, Part 38. The thick black isoseismal lines enclose isoseismal areas (V: green; IV: blue; etc.). The upward-pointing red star is Stover and Coffman's (1993) epicenter location; the downward-pointing star is our preferred location (see Table 1).

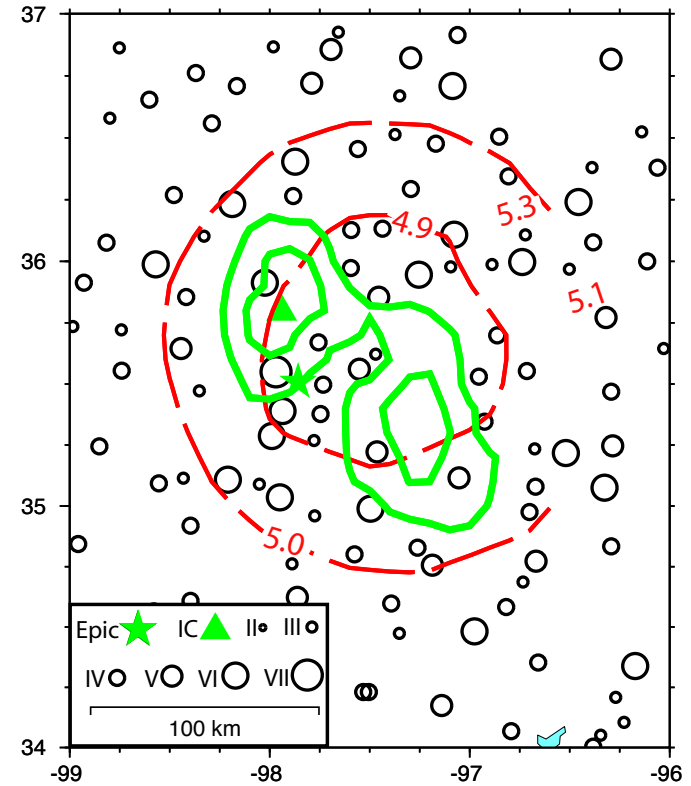

The epicentral region. IC is the intensity center. Our preferred location is shown as a green star. Black circles are sites with MMI assignments; 7.0 (MMI -site corrections) $<8.0$ are plotted as MMI VII, and so on. The contours of $M_{l}$ (dashed red lines) are the best estimates of $\mathbf{M}$ from the $\mathrm{MMI}$ assignments for assumed epicenters on that contour. The rms $\left[\mathrm{M}_{\mathrm{l}}\right]$ contours corresponding to the $67 \%$ (innermost contour) and $95 \%$ confidence levels (outermost contour) for location from Bakun and Wentworth (1999) are shown as solid green lines; there is an 0.67 probability that the epicenter lies within the $67 \%$ contour and an 0.95 probability that the epicenter lies within the $95 \%$ contour.

Comments. Damage was centered at El Reno, Oklahoma. The earthquake was caused by slip on the Nemaha fault (Stover and Coffman, 1993). The intensity center is located 30.6 kilometers north of the epicenter listed by Stover and Coffman (1993). $M_{1}$ is 4.9 for both locations and $\mathbf{M}$ is 4.5 to 5.2 at the $95 \%$ confidence range. 


\begin{tabular}{|c|c|c|c|c|c|c|}
\hline \multirow[b]{2}{*}{ \# } & \multirow[b]{2}{*}{ (yr-mo-day) } & \multicolumn{3}{|c|}{ Location } & \multicolumn{2}{|c|}{ Magnitude } \\
\hline & & State $^{\S}$ & $\begin{array}{l}\text { Lat } \\
\left({ }^{\circ} \mathbf{N}\right)\end{array}$ & $\begin{array}{l}\text { Long } \\
\left({ }^{\circ} \mathbf{W}\right)\end{array}$ & $\mathbf{M}$ & Reference \\
\hline 1 & $1811-12-16$ & Arkansas (NMSZ) & 36.00 & 89.96 & 7.6 & Bakun and Hopper, 2004) \\
\hline 2 & 1811-12-16 "dawn" & Tennessee (NMSZ) & 36.25 & 89.50 & $7.0^{+}$ & Hough and Martin (2002) \\
\hline 3 & 1811-12-17 "noon" & Tennessee & 35.10 & 90.00 & 6.1 & Hough and Martin (2002) \\
\hline 4 & $1812-01-23$ & Missouri (NMSZ) & 36.80 & 89.50 & 7.5 & Bakun and Hopper, 2004) \\
\hline 5 & 1812-01-27 "9AM" & Ohio?? & 38.94 & 84.02 & $3.7^{++}$ & Hough (2001) \\
\hline 6 & $1812-02-07$ & Tennessee (NMSZ) & 36.30 & 89.40 & 7.8 & Bakun and Hopper, 2004) \\
\hline 7 & 1812-02-07 "8:30PM" & Ohio?? & 38.94 & 84.02 & 4.5 & Hough $(2001)$ \\
\hline 8 & 1812-02-07 "10:40PM" & Ohio?? & 38.94 & 84.02 & 5.3 & Hough (2001) \\
\hline 9 & $1827-07-05$ & Indiana (Ill. Basin) & 37.90 & 87.90 & 4.7 & Table 1 \\
\hline 10 & $1827-08-07$ & Indiana (Ill. Basin) & 37.90 & 87.90 & 3.5 & Table 1 \\
\hline 11 & 1838-06-09 & Illinois (Ill. Basin) & 38.59 & 90.22 & 3.9 & Table 1 \\
\hline 12 & 1843-01-05 & Arkansas (NMSZ) & 35.90 & 89.90 & 6.2 & Bakun and Hopper, 2004) \\
\hline 13 & $1843-02-17$ & Arkansas (NMSZ) & 35.90 & 89.90 & 4.2 & Table 1 \\
\hline 14 & $1850-04-05$ & Indiana (Ill. Basin) & 38.30 & 87.70 & 4.6 & Table 1 \\
\hline 15 & $1857-10-08$ & Illinois (Ill. Basin) & 38.66 & 89.16 & 4.5 & Table 1 \\
\hline 16 & $1865-08-17$ & Arkansas (NMSZ) & 35.54 & 90.40 & 4.7 & Table 1 \\
\hline 17 & $1867-04-24$ & Kansas & 38.98 & 96.12 & 5.2 & Table 1 \\
\hline 18 & $1876-09-25$ & Illinois (Ill. Basin) & 38.66 & 87.55 & 4.3 & Table 1 \\
\hline 19 & $1877-11-15$ & Nebraska & 41.95 & 97.63 & 5.6 & Table 1 \\
\hline 20 & $1878-11-19$ & Arkansas (NMSZ) & 35.65 & 90.25 & 5.0 & Table 1 \\
\hline 21 & $1882-10-22$ & Oklahoma & 34.45 & 96.63 & 5.7 & Table 1 \\
\hline 22 & $1883-01-11$ & Missouri (NMSZ) & 36.80 & 89.50 & 4.2 & Table 1 \\
\hline 23 & $1883-12-05$ & Arkansas & 36.40 & 91.10 & 3.8 & Table 1 \\
\hline 24 & 1884-09-19 & Ohio & 41.53 & 84.69 & 4.9 & Table 1 \\
\hline 25 & $1887-08-02$ & Illinois (Ill. Basin) & 37.70 & 88.64 & 4.6 & Table 1 \\
\hline 26 & $1891-09-27$ & Illinois (Ill. Basin) & 38.34 & 89.27 & 4.9 & Table 1 \\
\hline 27 & $1895-10-31$ & Illinois (Ill. Basin) & 37.82 & 89.32 & 6.2 & Bakun and Hopper, 2004) \\
\hline 28 & $1899-04-30$ & Indiana (Ill. Basin) & 38.30 & 87.70 & 4.9 & Table 1 \\
\hline 29 & 1903-02-09 & Illinois (Ill. Basin) & 37.71 & 89.17 & 4.4 & Table 1 \\
\hline 30 & 1903-11-04 & Missouri (NMSZ) & 36.59 & 89.58 & 4.7 & Table 1 \\
\hline 31 & $1905-08-22$ & Missouri (Ill. Basin) & 37.56 & 89.62 & 4.6 & Table 1 \\
\hline 32 & $1906-01-08$ & Kansas & 39.21 & 96.51 & 4.1 & Table 1 \\
\hline 33 & $1909-05-26$ & Illinois & 41.74 & 88.46 & 5.0 & Table 1 \\
\hline 34 & 1909-07-19 & Illinois (Ill. Basin) & 40.02 & 89.78 & 4.5 & Table 1 \\
\hline 35 & 1909-09-27 & Indiana (Ill. Basin) & 39.10 & 88.00 & 4.8 & Table 1 \\
\hline 36 & $1911-03-31$ & Arkansas & 33.80 & 92.20 & 4.3 & Table 1 \\
\hline 37 & 1917-04-09 & Illinois (Ill. Basin) & 38.84 & 89.38 & 5.2 & Table 1 \\
\hline 38 & $1922-03-22$ & Illinois (Ill. Basin) & 37.22 & 89.45 & 3.7 & Table 1 \\
\hline 39 & $1922-11-27$ & Illinois (Ill. Basin) & 37.80 & 88.40 & 4.4 & Table 1 \\
\hline 40 & $1923-10-28$ & Arkansas (NMSZ) & 35.54 & 90.40 & 4.1 & Table 1 \\
\hline 41 & $1925-04-27$ & Indiana (Ill. Basin) & 38.30 & 87.70 & 4.7 & Table 1 \\
\hline 42 & 1927-05-07 & Arkansas (NMSZ) & 35.65 & 90.25 & 4.5 & Table 1 \\
\hline 43 & $1931-12-16$ & Mississippi & 34.07 & 90.10 & 4.2 & Table 1 \\
\hline 44 & $1934-08-20$ & Missouri (Ill. Basin) & 37.01 & 89.20 & 3.7 & Table 1 \\
\hline 45 & 1937-03-02 & Ohio & 40.49 & 84.27 & 4.5 & Table 1 \\
\hline 46 & 1937-03-09 & Ohio & 40.47 & 84.28 & 4.6 & Table 1 \\
\hline 47 & $1938-09-17$ & Arkansas (NMSZ) & 35.55 & 90.37 & 4.4 & Table 1 \\
\hline 48 & 1952-04-09 & Oklahoma & 35.80 & 97.92 & 4.9 & Table 1 \\
\hline 49 & $1962-02-02$ & Missouri (NMSZ) & 36.37 & 89.51 & 4.2 & Herrmann (1979) \\
\hline 50 & $1963-03-03$ & Missouri (NMSZ) & 36.64 & 90.05 & 4.7 & Herrmann (1979) \\
\hline
\end{tabular}




\section{Table 2. Significant Historical Earthquakes in the Central United States}

\begin{tabular}{|c|c|c|c|c|c|c|}
\hline 51 & $1965-08-14$ & Illinois (Ill. Basin) & 37.23 & 89.31 & 3.6 & Herrmann (1979) \\
\hline 52 & $1965-10-21$ & Missouri & 37.48 & 90.94 & 4.6 & Herrmann (1979) \\
\hline 53 & $1967-06-04$ & Mississippi & 33.55 & 90.84 & 4.3 & Herrmann (1979) \\
\hline 54 & $1967-07-21$ & Missouri & 37.44 & 90.44 & 4.0 & Herrmann (1979) \\
\hline 55 & 1968-11-09 & Illinois (Ill. Basin) & 37.96 & 88.46 & 5.3 & Herrmann (1979) \\
\hline 56 & 1969-01-01 & Arkansas & 34.99 & 92.69 & 4.3 & Herrmann (1979) \\
\hline 57 & $1970-11-17$ & Arkansas (NMSZ) & 35.86 & 89.95 & 4.1 & Herrmann (1979) \\
\hline 58 & $1972-09-15$ & Illinois & 41.65 & 89.37 & 4.1 & Herrmann (1979) \\
\hline 59 & $1973-11-30$ & Tennessee & 35.89 & 83.99 & 4.1 & Herrmann (1979) \\
\hline 60 & $1974-02-15$ & Texas-Oklahoma & 36.40 & 100.69 & 4.4 & Herrmann (1979) \\
\hline 61 & $1974-04-03$ & Illinois (Ill. Basin) & 38.55 & 88.07 & 4.3 & Herrmann (1979) \\
\hline 62 & $1975-06-13$ & Missouri (NMSZ) & 36.54 & 89.68 & 3.7 & Herrmann (1979) \\
\hline 63 & 1975-07-09 & Minnesota & 45.50 & 96.10 & 4.3 & Herrmann (1979) \\
\hline 64 & $1976-03-25 a$ & Arkansas (NMSZ) & 35.59 & 90.48 & 4.6 & Herrmann (1979) \\
\hline 65 & $1976-03-25 b$ & Arkansas (NMSZ) & 35.60 & 90.50 & 4.2 & Herrmann (1979) \\
\hline 66 & $1980-07-27$ & Kentucky & 38.19 & 83.89 & 5.0 & Herrmann et al . (1982) \\
\hline 67 & $1982-01-21$ & Arkansas & 35.17 & 92.21 & 4.4 & Nguyen and Herrmann (1992) \\
\hline 68 & $1986-01-31$ & Ohio & 41.65 & 81.16 & 4.9 & Nguyen and Herrmann (1992) \\
\hline 69 & $1986-07-12$ & Ohio & 40.55 & 84.39 & 4.4 & Schwartz and Christensen (1988) \\
\hline 70 & $1987-06-10$ & Illinois (Ill. Basin) & 38.71 & 87.95 & 5.0 & Taylor et al. (1989) \\
\hline 71 & $1988-09-07$ & Kentucky & 38.14 & 83.88 & 4.2 & Stover and Coffman (1993) \\
\hline 72 & $1990-09-26$ & Missouri (Ill. Basin) & 37.17 & 89.58 & 4.3 & Herrmann and Ammon (1997) \\
\hline 73 & $1991-05-04$ & Missouri (NMSZ) & 36.56 & 89.80 & 4.1 & Herrmann and Ammon (1997) \\
\hline 74 & $2002-06-18$ & Indiana (Ill. Basin) & 37.987 & 87.78 & 4.6 & Kim $(2003)$ \\
\hline \multicolumn{7}{|c|}{$\begin{array}{l}\text { NMSZ }=\text { New Madrid Seismic Zone; Ill. Basin = Illinois Basin } \\
\text { Hough and Martin (2002) note that } \mathbf{M} \text { for the "dawn aftershock" is close to that of the January } \\
\text { main shock (event \#4 in this table). That is, } \mathbf{M} \text { may be as large as } 7.5 \text { for the dawn aftershock. }\end{array}$} \\
\hline
\end{tabular}




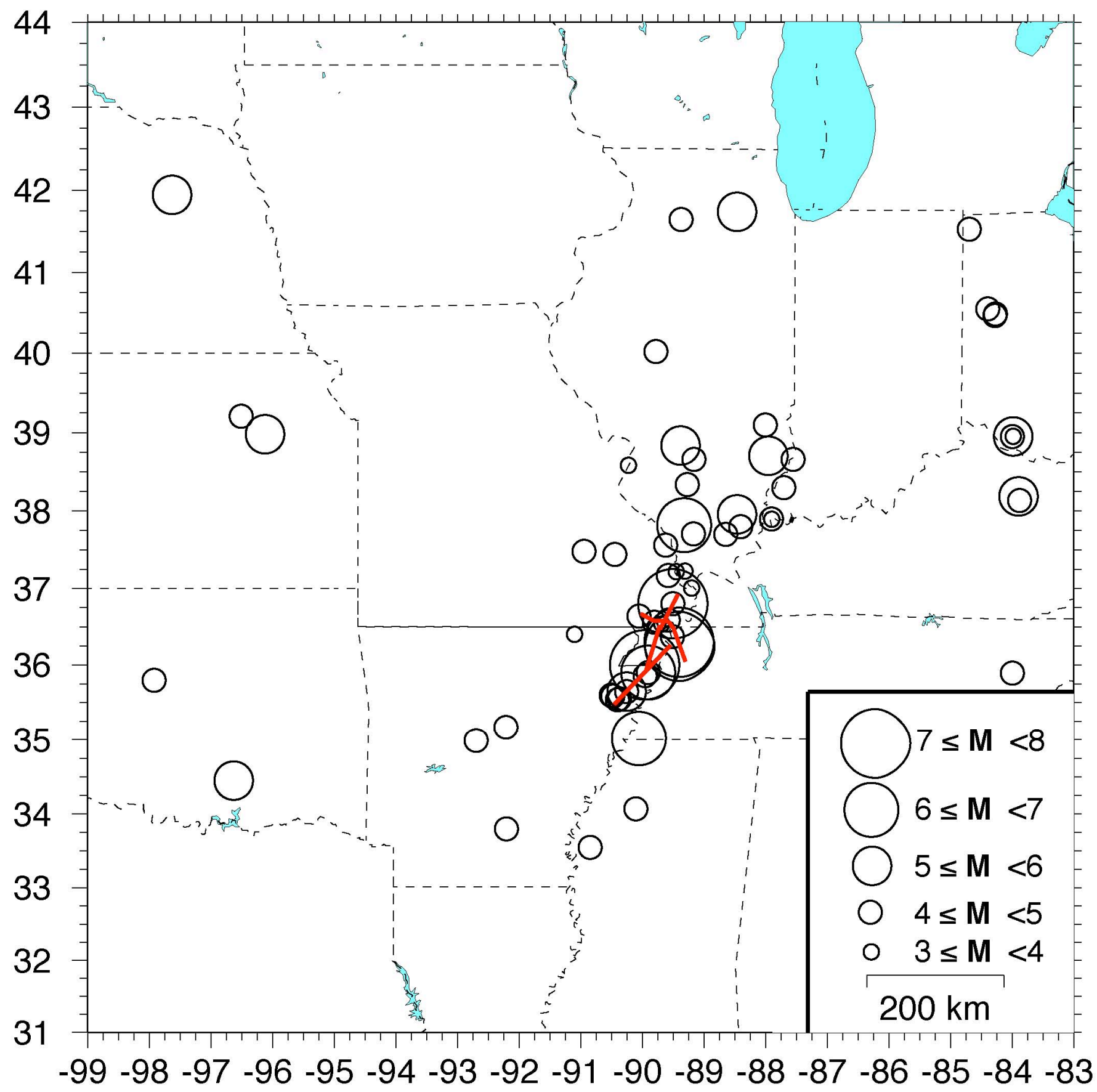

Figure 2. Locations (circles) of significant historical earthquakes in the CUS (Table 2). Symbol size is proportional to $\mathbf{M}$ (see key). Fault segments of the NMSZ are shown in red. 


\section{Appendix 1, Part 01. Damage Reports and Intensity Assignments}

\section{\#1 1827 July 5 11:30 UTC (Indiana)}

6 IN New Harmony $\left(38.1297^{\circ} \mathrm{N}, 87.935^{\circ} \mathrm{W}\right.$ )—Cracked a brick store, greatly alarmed some. (Street and Green, 1984).

5 IL Shawneetown $\left(37.7131^{\circ} \mathrm{N}, 88.1867^{\circ} \mathrm{W}\right)$-A violent shock. Shook loose articles to the floor. (Street and Green, 1984).

$5 \quad$ MO New Madrid $\left(36.5864^{\circ} \mathrm{N}, 89.5278^{\circ} \mathrm{W}\right)$ - The earthquake was said to be violent. (Street and Green, 1984).

4 IL Kaskaskia $\left(37.9214^{\circ} \mathrm{N}, 89.9131^{\circ} \mathrm{W}\right)$-THE EARTHQUAKE Kaskaskia, July 11 . A severe shock of an Earthquake of about one minute's duration, was felt in this town at about 6 o'clock on the morning of the 5 th of July. It is understood that the seat of the shock was at that ill fated place, New Madrid, where it was, it is said, very violent.-Reporter. (Ann Metzger, personal comm., 2000 June 2).

IL Kaskaskia $\left(37.9214^{\circ} \mathrm{N}, 89.9131^{\circ} \mathrm{W}\right)$-A severe earthquake shock was felt. (Street and Green, 1984).

IN Vincennes $\left(38.6772^{\circ} \mathrm{N}, 87.5286^{\circ} \mathrm{W}\right)$-Severe. (Street and Green, 1984).

KY Bowling Green $\left(36.9903^{\circ} \mathrm{N}, 86.4436^{\circ} \mathrm{W}\right)$-Sensibly felt by many. (Street and Green, 1984).

KY Frankfort $\left(38.2008^{\circ} \mathrm{N}, 84.8733^{\circ} \mathrm{W}\right)$-Sensibly felt by many. (Street and Green, 1984).

MO Saint Louis $\left(38.6272^{\circ} \mathrm{N}, 90.1978^{\circ} \mathrm{W}\right)-\mathrm{A}$ severe shock. (Street and Green, 1984).

$\mathrm{OH} \quad$ Cincinnati $\left(39.1619^{\circ} \mathrm{N}, 84.4569^{\circ} \mathrm{W}\right)$-Rattled windows and furniture, alarmed many. (Street and Green, 1984).

AR Little Rock $\left(34.7464^{\circ} \mathrm{N}, 92.2894^{\circ} \mathrm{W}\right)$-Not mentioned. (Street and Green, 1984).

IN Terre Haute $\left(39.4667^{\circ} \mathrm{N}, 87.4139^{\circ} \mathrm{W}\right)$-Not mentioned. (Street and Green, 1984).

KY Lexington $\left(38.0492^{\circ} \mathrm{N}, 84.5003^{\circ} \mathrm{W}\right)$-Not mentioned. (Street and Green, 1984).

TN Fayetteville $\left(35.1519^{\circ} \mathrm{N}, 86.5706^{\circ} \mathrm{W}\right)$-Not reported. (Street and Green, 1984).

TN Nashville $\left(36.1658^{\circ} \mathrm{N}, 86.7844^{\circ} \mathrm{W}\right)$-Not reported. (Street and Green, 1984).

N TN Sparta $\left(35.9258^{\circ} \mathrm{N}, 85.4642^{\circ} \mathrm{W}\right)$-Not reported. (Street and Green, 1984).

F KY Louisville $\left(38.2542^{\circ} \mathrm{N}, 85.7594^{\circ} \mathrm{W}\right)$-Felt. (Street and Green, 1984).

F KY South Union $\left(36.8764^{\circ} \mathrm{N}, 86.6564^{\circ} \mathrm{W}\right)$ - Had an earthquake this morning. (Street and Green, 1984). 


\section{Appendix 1, Part 02. Damage Reports and Intensity Assignments}

\#2 1827 August 7 04:30 UTC (Indlana)

IN New Albany $\left(38.3077^{\circ} \mathrm{N}, 85.8288^{\circ} \mathrm{W}\right.$ )—Many citizens were startled from their pillows. (Street and Green, 1984$)$.

IN New Harmony $\left(38.1146^{\circ} \mathrm{N}, 87.9009^{\circ} \mathrm{W}\right)$-Aroused citizens from their sleep. (Street and Green, 1984).

KY Louisville $\left(38.2528^{\circ} \mathrm{N}, 85.7516^{\circ} \mathrm{W}\right)$-Sensibly felt. (Street and Green, 1984).

IL Vandalia $\left(38.9606^{\circ} \mathrm{N}, 89.0936^{\circ} \mathrm{W}\right)$-Not reported. (Street and Green, 1984).

IN Lawrenceburg $\left(39.1551^{\circ} \mathrm{N}, 84.8762^{\circ} \mathrm{W}\right)$-Not reported. (Street and Green, 1984).

IN Terre Haute $\left(39.4270^{\circ} \mathrm{N}, 87.3927^{\circ} \mathrm{W}\right)$-Not reported. (Street and Green, 1984).

KY Frankfort $\left(38.2008^{\circ} \mathrm{N}, 84.8709^{\circ} \mathrm{W}\right)$-Not reported. (Street and Green, 1984).

KY Lexington $\left(38.0005^{\circ} \mathrm{N}, 84.4783^{\circ} \mathrm{W}\right)$-Not reported. (Street and Green, 1984).

$\mathrm{OH} \quad$ Cincinnati $\left(39.1054^{\circ} \mathrm{N}, 84.5022^{\circ} \mathrm{W}\right)$-Not reported. (Street and Green, 1984).

TN Fayetteville $\left(35.1567^{\circ} \mathrm{N}, 86.5789^{\circ} \mathrm{W}\right)$-Not reported. (Street and Green, 1984).

TN Franklin $\left(35.9225^{\circ} \mathrm{N}, 86.8884^{\circ} \mathrm{W}\right)$-Not reported. (Street and Green, 1984).

TN Sparta $\left(35.9445^{\circ} \mathrm{N}, 85.4352^{\circ} \mathrm{W}\right)$-Not reported. (Street and Green, 1984).

IL Kaskaskia $\left(37.9489^{\circ} \mathrm{N}, 89.9219^{\circ} \mathrm{W}\right)$-Felt. (Street and Green, 1984).

IN Vincennes $\left(38.6280^{\circ} \mathrm{N}, 87.5003^{\circ} \mathrm{W}\right)$-A shock of earthquake was felt - no damage was done. (Street and Green, 1984).

KY Bowling Green $\left(37.0162^{\circ} \mathrm{N}, 86.4612^{\circ} \mathrm{W}\right)$-Felt. (Street and Green, 1984).

MO Saint Louis $\left(38.6313^{\circ} \mathrm{N}, 90.1922^{\circ} \mathrm{W}\right)$-Felt. (Street and Green, 1984). 


\section{Appendix 1, Part 03. Damage Reports and Intensity Assignments}

\section{\#3 1838 June 9 14:45 UTC (Illinols)}

$7 \quad$ MO Saint Louis $\left(38.6272^{\circ} \mathrm{N}, 90.1978^{\circ} \mathrm{W}\right)$ - Threw chimneys down. (Street and Green, 1984).

MO Saint Louis $\left(38.6272^{\circ} \mathrm{N}, 90.1978^{\circ} \mathrm{W}\right)$-A report of a chimney being thrown down at St. Louis. (Stover and Coffman, 1993).

5 IL Belleville $\left(38.5200^{\circ} \mathrm{N}, 89.9839^{\circ} \mathrm{W}\right)$-The most severe shock since 1811 . [No report from Belleville for the the 1811 Dec 16 08:11 UTC shock, but at Clinton, about a mile north of Belleville, it was "very violent." - V.] (Street and Green, 1984).

$5 \mathrm{KY} \quad$ Louisville $\left(38.2542^{\circ} \mathrm{N}, 85.7594^{\circ} \mathrm{W}\right)$ - In some instances persons on upper stories of buildings were much frightened, moved chairs and light articles. (Street and Green, 1984).

4 IL Alton $\left(38.8906^{\circ} \mathrm{N}, 90.1842^{\circ} \mathrm{W}\right)$-Sensibly felt, violently shook doors, windows, etc. (Street and Green, 1984$)$.

4 MO Saint Charles $\left(38.7839^{\circ} \mathrm{N}, 90.4811^{\circ} \mathrm{W}\right)$-Severely felt. (Stover and Coffman, 1993).

MO Saint Charles $\left(38.7839^{\circ} \mathrm{N}, 90.4811^{\circ} \mathrm{W}\right)$-Felt. (Street and Green, 1984).

3 IL Shawneetown $\left(37.7131^{\circ} \mathrm{N}, 88.1867^{\circ} \mathrm{W}\right)$-Sensibly felt. (Street and Green, 1984).

IL Vandalia $\left(38.9606^{\circ} \mathrm{N}, 89.0936^{\circ} \mathrm{W}\right)$-Sensibly felt. (Street and Green, 1984).

IN Indianapolis $\left(39.7683^{\circ} \mathrm{N}, 86.1581^{\circ} \mathrm{W}\right)$-Awakened some. (Street and Green, 1984).

IN Vincennes $\left(38.6772^{\circ} \mathrm{N}, 87.5286^{\circ} \mathrm{W}\right)$-Sensibly felt in this place. (Street and Green, 1984).

IN Vevay $\left(38.7478^{\circ} \mathrm{N}, 85.0672^{\circ} \mathrm{W}\right)$-Not reported. (Street and Green, 1984).

$\mathrm{N} \quad \mathrm{KY} \quad$ Paris $\left(38.2097^{\circ} \mathrm{N}, 84.2531^{\circ} \mathrm{W}\right)$-Not mentioned. (Street and Green, 1984).

$\mathrm{N} \quad \mathrm{OH}$ Cincinnati $\left(39.1619^{\circ} \mathrm{N}, 84.4569^{\circ} \mathrm{W}\right)$-Not reported. (Street and Green, 1984).

$\mathrm{N}$ TN Franklin $\left(35.9250^{\circ} \mathrm{N}, 86.8689^{\circ} \mathrm{W}\right)$-Not mentioned. (Street and Green, 1984).

N TN Nashville $\left(36.1658^{\circ} \mathrm{N}, 86.7844^{\circ} \mathrm{W}\right)$-Not mentioned. (Street and Green, 1984).

F IL Carrollton $\left(39.3022^{\circ} \mathrm{N}, 90.4069^{\circ} \mathrm{W}\right)$-Felt. (Street and Green, 1984). 


\section{Appendix 1, Part 04. Damage Reports and Intensity Assignments}

\section{\#4 1843 Feb. 17 05:00 UTC (Arkansas)}

3 IL Alton $\left(38.9404^{\circ} \mathrm{N}, 90.1276^{\circ} \mathrm{W}\right)$ - “Another Earthquake - The shock of an earthquake was again felt in this place on Thursday night, at about 11 o'clock. The vibrations are believed to have continued about half a minute, but with less severity than those accompanying the shock(s)? on the 4th inst." [Report of main shock on Jan. 4 as felt at Alton:

"Earthquake -- At about 9 o'clock, on Wednesday evening, the 4th inst., the shock of an Earthquake was sensibly felt in this city -- the vibrations continuing, with considerable severity, for several seconds." from the Alton (Illinois)

Telegraph of Jan. 7, 1843. The Jan. 4 shock is here assigned MMI IV, hence the Feb. 16 shock is assigned III.] (Alton Telegraph, Feb. 25, 1843).

Nashville $\left(36.1667^{\circ} \mathrm{N}, 86.8167^{\circ} \mathrm{W}\right)$ - “Press reports, stating the tims as '...about 11 o'clock' p.m., indicate that the shock was light at Nashville." (Moneymaker, 1954 (Knoxville Register, February 23, 1843)).

F AL Flora $\left(33.1858^{\circ} \mathrm{N}, 86.8625^{\circ} \mathrm{W}\right)$-Felt. (Coffman and von Hake, 1973).

F KY Louisville $\left(38.2500^{\circ} \mathrm{N}, 85.75^{\circ} \mathrm{W}\right)$-Felt. (Coffman and von Hake, 1973).

F MO Saint Louis $\left(38.6667^{\circ} \mathrm{N}, 90.19^{\circ} \mathrm{W}\right.$ )-Felt. (Coffman and von Hake, 1973).

$\mathrm{F} \quad \mathrm{OH}$ Cincinnati $\left(39.1054^{\circ} \mathrm{N}, 84.5022^{\circ} \mathrm{W}\right)$-Felt. (Coffman and von Hake, 1973). 


\section{Appendix 1, Part 05. Damage Reports and Intensity Assignments}

\section{\#5 1850 April 5 02:05 UTC (Indlana)}

$5 \quad \mathrm{KY} \quad$ Louisville $\left(38.2500^{\circ} \mathrm{N}, 85.75^{\circ} \mathrm{W}\right)$-No damage other than frightening the people; a good many took refuge in the streets. (Street and Green, 1984).

3 IN New Albany $\left(38.3077^{\circ} \mathrm{N}, 85.8288^{\circ} \mathrm{W}\right)$-Sensibly felt. (Street and Green, 1984).

$3 \quad \mathrm{KY} \quad$ Frankfort $\left(38.2008^{\circ} \mathrm{N}, 84.8709^{\circ} \mathrm{W}\right)$-Several shocks were distinctly felt. (Street and Green, 1984).

KY Paducah $\left(37.0585^{\circ} \mathrm{N}, 88.6608^{\circ} \mathrm{W}\right)$-Sensibly felt. (Street and Green, 1984).

TN Clarksville $\left(36.5310^{\circ} \mathrm{N}, 87.35^{\circ} \mathrm{W}\right)$-Shook houses and dishes. (Street and Green, 1984).

TN Franklin $\left(35.9225^{\circ} \mathrm{N}, 86.8884^{\circ} \mathrm{W}\right)$-A distinct shock was felt; it lasted one minute. (Street and Green, 1984).

TN Nashville $\left(36.1667^{\circ} \mathrm{N}, 86.8167^{\circ} \mathrm{W}\right)$-Felt slightly. (Street and Green, 1984).

AR Little Rock $\left(34.7461^{\circ} \mathrm{N}, 92.2765^{\circ} \mathrm{W}\right)$-Not reported. (Street and Green, 1984).

IL Belleville $\left(38.5137^{\circ} \mathrm{N}, 89.9902^{\circ} \mathrm{W}\right)$-Not reported. (Street and Green, 1984).

KY Lexington $\left(38.0333^{\circ} \mathrm{N}, 84.5167^{\circ} \mathrm{W}\right)$-Not mentioned. (Street and Green, 1984).

MO Cape Girardeau $\left(37.3168^{\circ} \mathrm{N}, 89.5427^{\circ} \mathrm{W}\right)$-Not reported. (Street and Green, 1984).

MO Saint Louis $\left(38.6667^{\circ} \mathrm{N}, 90.19^{\circ} \mathrm{W}\right)$-Not mentioned. (Street and Green, 1984).

$\mathrm{OH} \quad$ Cincinnati $\left(39.1054^{\circ} \mathrm{N}, 84.5022^{\circ} \mathrm{W}\right)$-Not mentioned. (Street and Green, 1984).

IN Jeffersonville $\left(38.3028^{\circ} \mathrm{N}, 85.7334^{\circ} \mathrm{W}\right)$-Felt. (Street and Green, 1984).

KY Eddyville $\left(37.0484^{\circ} \mathrm{N}, 88.0195^{\circ} \mathrm{W}\right)$-Felt. (Street and Green, 1984).

KY Hopkinsville $\left(36.8687^{\circ} \mathrm{N}, 87.4789^{\circ} \mathrm{W}\right)$-Felt. (Street and Green, 1984).

KY South Union $\left(36.8776^{\circ} \mathrm{N}, 86.6572^{\circ} \mathrm{W}\right)$-Felt. (Street and Green, 1984).

TN Memphis $\left(35.1167^{\circ} \mathrm{N}, 90.0833^{\circ} \mathrm{W}\right)$-Felt (Street and Green, 1984). 


\section{Appendix 1, Part 06. Damage Reports and Intensity Assignments}

\section{\#6 1857 Oct. 8 10:00 UTC (Illinols)}

7 IL Centralia $\left(38.5250^{\circ} \mathrm{N}, 89.1333^{\circ} \mathrm{W}\right)$-So violent as to demolish chimneys. (Street and Green, 1984).

IL Centralia $\left(38.5250^{\circ} \mathrm{N}, 89.1333^{\circ} \mathrm{W}\right)$-At Centralia, the first of three reported shocks threw down chimneys. (Stover and Coffman, 1993).

5 IL Belleville $\left(38.5200^{\circ} \mathrm{N}, 89.9839^{\circ} \mathrm{W}\right.$ )-Rattled windows and severely shook houses, one instance each of damaged chimney and plastering. (Street and Green, 1984).

5 IL Chester $\left(37.9136^{\circ} \mathrm{N}, 89.8219^{\circ} \mathrm{W}\right)$-Everyone alarmed; doors unlatched and thrown open; glass and crockery broken. (Street and Green, 1984).

$5 \quad$ IL Hillsboro $\left(39.1611^{\circ} \mathrm{N}, 89.4936^{\circ} \mathrm{W}\right)$-Awakened people immediately from their sleep and shook houses violently. (Street and Green, 1984).

$5 \quad$ MO Bridgeton $\left(38.7439^{\circ} \mathrm{N}, 90.4136^{\circ} \mathrm{W}\right)$ - “From the St. Louis Democrat, 9th .... A gentleman from Bridgeton, fourteen miles from the city, says that the shock there also was excessively violent, and that the motion was an undulating one, accompanied with vertical vibrations of the earth." (Ann Metzger, personal comm., 2000 June 2).

MO Bridgeton $\left(38.7439^{\circ} \mathrm{N}, 90.4136^{\circ} \mathrm{W}\right)$-Excessively violent motion described as undulating with vertical vibrations. (Street and Green, 1984).

Saint Louis $\left(38.6272^{\circ} \mathrm{N}, 90.1978^{\circ} \mathrm{W}\right)$-From the St. Louis Democrat, 9th. The Earthquake. Severe Shocks - Great Consternation - Rumors, Incidents, \&c. On the morning of yesterday, at twenty minutes past 4 o'clock, nearly the whole population of this city and region were startled from repose by the roar and commotion of a violent earthquake. The first premonition is said to have been given by a slight concussion about midnight. But at the time stated, those who were awake heard a low and distant rumbling which failed to arouse attention till it rapidly increased to the volume of sound of heavy rains [trains?] of cars thundering through every street of the city. Some liken the noise to a protracted reverberating explosion, others to the roar of a whirlwind, others to the mere passing of market wagons but all agree that it was tremendous. When at its height, the buildings began to rock appallingly. Thousands sprang from their beds in alarm, and rushed into the streets. The northern sky was clear, but from the southward a heavy mist was swiftly advancing, and in a moment obscured the street lamps. - In many instances the lamps were in an instant unaccountably extinguished. The violent shock lasted full three-fourths of a minute, and was immediately succeeded by a roar and attendant shock of less severity. Many describe both as one, and aver that the heavy shock lasted full three minutes. In about five minutes afterward the noise and concussion were repeated with comparative mildness, but very perceptibly.

We conversed with many on the occurrence, and their statements, of course various, attest and corroborate the above. A citizen living on Gratio and Fourth streets, in a heavily built house, whose walls are of eighteen inches thickness, and who was sleeping on the first floor, describes the shock as excessively violent, and the motion as a horizontal vibration from east to west. A mirror hanging on a north and south wall, swayed from and towards the wall, through an arc of several inches. He ran into the street, expecting the fall, if not of his own house, of a frailer wall near, and found a dense fog swiftly rolling from the southward, and shortly enveloping everything.

An intelligent gentleman, living on Center, between Thirteenth and Fourteenth streets, states that the heavy rumbling, as if by a host of coal wagons, proceeded from the southward, that things shook from north to south, and with an appalling violence, that then a dense mist appeared, and in ten minutes occurred another shock, the accompanying noise being more from the eastward. A well known physician in his vicinity, was affrighted at hearing the brick walls of his residence positively cracking and snapping around him.

We are apprised that a slight shock was felt on Monday, the court house being perceptibly jarred, though no vehicle was at the time passing.

Another gentleman, living within sixty fee [sic] of the Pacific mills, avers that during the noise just preceding the shock, the loud din usually made by the engine and stone at the mills, could no longer be heard. The course of the noise seemed to him from the southwestward. Immediately, the doors and windows of his house were so violently shaken that he at first imagined burglars were entering - an illusion also experienced by many others.

At the city hall, which is deemed a frail structure, the officers ran out of the police office, fearing that it would fall. The watchman at the Merchant's bank on Chestnut street, fled from beneath its walls, which he found vibrating fearfully.

A member of the night police, on sixteenth and O'Fallon streets, was about returning home, when he was startled by the sound as of a heavy and prolonged explosion, and instantly felt himself being heaved by the ground, and nearly tripped from his feet. The concussion appeared to him to proceed from the eastward, as if it began on the Illinois shore, and then crossing the river passed off to the northward, reverberating like a deafening thunderclap.

A watchman on Franklin avenue and Sixteenth street states that with the noise he felt the ground undulate with a motion so long and heavy as caused him to stagger several feet before recovering his balance. The spring boards in the lumberyard near were at once in noisy motion, and so continued for some minutes after the lst shock. Immediately, the houses were lighted and people were rushing into the street.

The keeper of the calaboose was awakened, as he at once conceived, by the desperate and prospering efforts of his prisoners to escape,- - He imagined that the walls were being sundered, and that he distinctly heard the doors being wrenched open. The illusion was, of course, transient.

Of course, more or less damage must have 63curred to weak walls, and many breakages of crockery, glassware, \&c. An instance is furnished at the Missouri exchange, kept by A.B. Jones on commercial alley and Walnut street. Some dozen glasses and decanters were thrown from shelves running north and south, and broken. Mr. Jones deems this clear proof that the shock came from the westward.

At a hotel on Third street a thief was engaged in extracting thirty cents from a boarder's pocket, when the commotion so agitated his conscience and person, that he dropped the dimes, and called upon the waking owner of 


\section{Appendix 1, Part 06. Damage Reports and Intensity Assignments}

wrenched open. The illusion was, of course, transient.

Of course, more or less damage must have occurred to weak walls, and many breakages of crockery, glassware, \&c. An instance is furnished at the Missouri exchange, kept by A.B. Jones on commercial alley and Walnut street. Some dozen glasses and decanters were thrown from shelves running north and south, and broken. Mr. Jones deems this clear proof that the shock came from the westward.

At a hotel on Third street a thief was engaged in extracting thirty cents from a boarder's pocket, when the commotion so agitated his conscience and person, that he dropped the dimes, and called upon the waking owner of them to flee, for the house was falling. He, of course, fled.

A gentleman from Bridgeton, fourteen miles from the city, says that the shock there also was excessively violent, and that the motion was an undulating one, accompanied with vertical vibrations of the earth.

A son of holy church sprang from his couch, and ran instantly to his parish priest, begging for prayers, for that the crack of doom had surely come! The father sought was not at home, but another vouchsafed to console the terrified sinner, and conduct him in hope to his home.

The river, of course, was not exempt from the commotion. Waves several feet in height are said to suddenly have risen and dashed upon the banks rending [sic] and again returning.

Mr. Smizer, living out on the Meramec River, states that between the shocks, he saw a meteor as large as the full moon, and very brilliant, shoot across the sky from south to north, accompanied with a roaring, crackling sound and disappearing with a loud explosion.

The five-story building erected by Mr. Marksdale on the corner of Pine and Fifth streets, was rocked to and fro with alarming violence. Its rooms are mostly occupied by young men for sleeping apartments, and the way they tumbled down the several flights of stairs was said by those who witnessed the scene to be both ludicrous and fearful. One of the sleepers asserts that the vibrations at the top of the building could not have been less than a foot.

All over the city, immediately after the first shock, the windows and doors were thrown open, and great numbers of the people rushed into the streets. The dogs barked and ran howling away from the rumbling as it approached. The pendulums of many clocks were stopped, and many citizens state that on going out into the air they found a great difficulty in respiration.

We are informed by a physician that a lady of his acquaintance, upon being awakened by the shaking of her bed, supposed that a burglar was under it, and forthwith jumped out and cried for help.

A gentleman in Illinois, who was returning to St. Louis, when some miles from the ferry, reports that the earthquake was accompanied with vivid lightening and loud thunder and that the animals were so much alarmed that they added their lamentations to those of the people, who were in great terror, and believed that the day of doom was at hand. It appears, from all that we hear from our sister state, that the shock came from the northern part, which is highly probable.

From the St. Louis Democrat, 9th. ... THE EARTHQUAKE - Some brag, little thinking of the anxiety such a report would create, yesterday afternoon started a report that a third of Memphis was destroyed by the earthquake. It had a great run and was circulated in every quarter. But it was thought that this was but a sufficiently egregious hoax, and they improved upon it by submerging New Orleans altogether. The whole thing was without foundation. - St. Louis, 9th. (Columbia, Missouri Statesman October 16, 1857 p. 3, c. 2\&3.). MO Saint Louis $\left(38.6272^{\circ} \mathrm{N}, 90.1978^{\circ} \mathrm{W}\right)$-Severe Earthquake, About twenty minutes past four this morning, the vicinity of St. Louis was visibly shaken by an earthquake, unequaled in severity by any within the range of our experience. There were two distinct shocks, with an interval of seven minutes between them.- the first was more violent. It was preceded by a deep, loud rumbling sound as of underground thunder, which filled space with its volume and impressing all who heard it, with an idea of mighty irresistible power. The shock, which instantly followed, lasted several seconds, and made windows rattle and houses quiver with its rapid vibrations. The premonitory sound, and the movement which followed in its wake, both appeared to come from the east (some say southeast) and to roll away in an opposite direction. We imagine there are few of our citizens who did not have the good fortune to experience the phenomenon, as the rumbling was long and loud enough to rouse one from even the deepest slumber. Some were so alarmed as to meditate an abandonment of their houses.

Both shocks were felt at Kirkwood and at Meramec Station on the Pacific railroad, where they were quite as violent as in this city; and we learn that during the interval between the concussions, a meteor of unusual size and brilliancy, shot across the sky from the south towards the north. It was seen simultaneously by persons at Kirkwood and Meramec, the two points being seven miles apart. Those who "timed" the last shock inform us that it lasted thirtyeight seconds. - St. Louis News. (Liberty, Liberty Tribune, October 16, 1857, p. 2, c. 4.). streets, pendulum clocks stopped, glasses were thrown from shelves and broken; one brick house damaged. (Street and Green, 1984).

Saint Louis $\left(38.6272^{\circ} \mathrm{N}, 90.1978^{\circ} \mathrm{W}\right)$-At St. Louis, it moved furniture, dislocated bricks, and felled plaster. The largest buildings rocked and articles fell from mantles. Reports indicate that the Mississippi River was in tumult. (Stover and Coffman, 1993).

Keokuk $\left(40.3972^{\circ} \mathrm{N}, 91.3847^{\circ} \mathrm{W}\right)$-Disturbed the slumbers of the people. (Street and Green, 1984). 


\section{Appendix 1, Part 06. Damage Reports and Intensity Assignments}

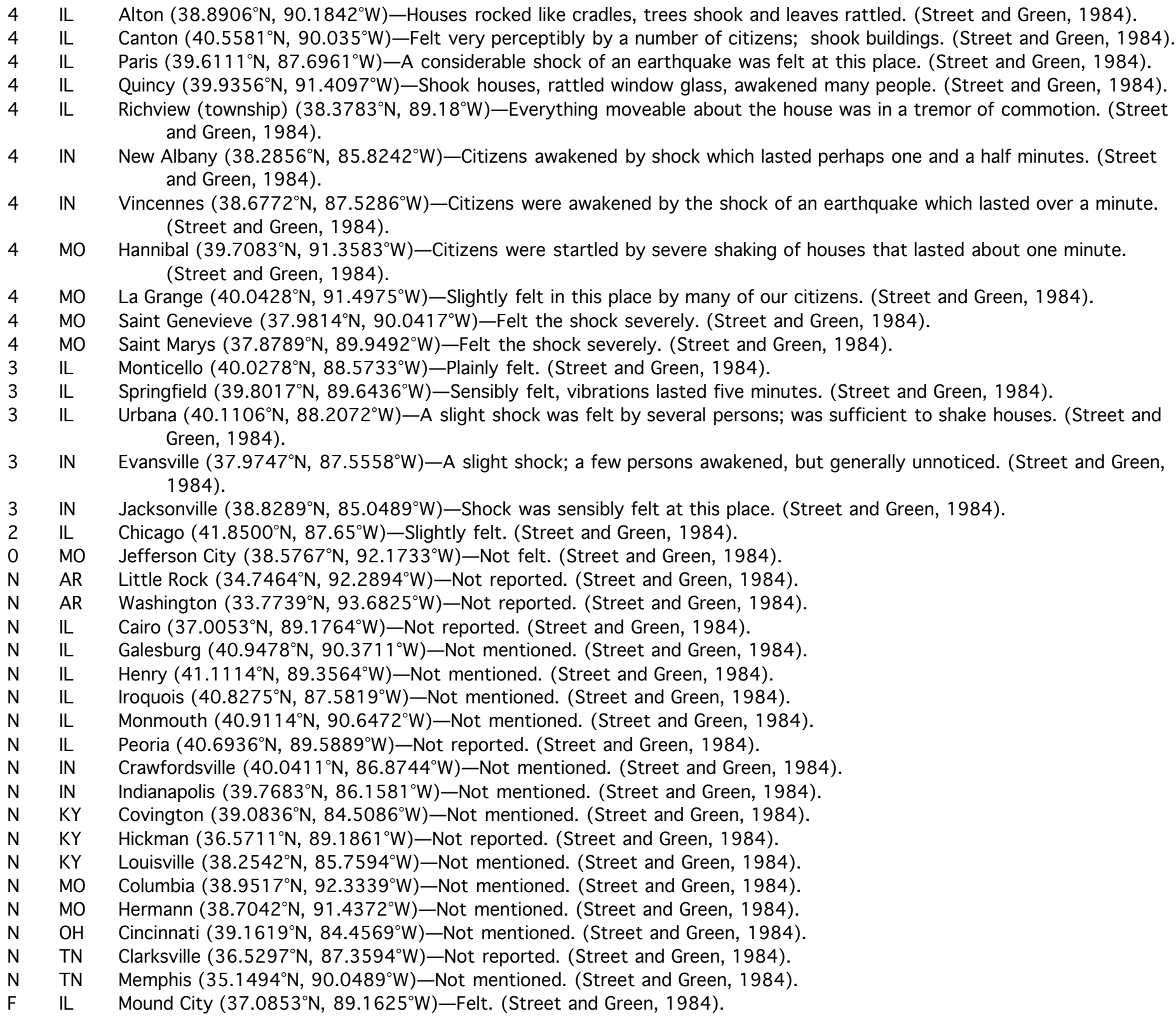




\section{Appendix 1, Part 07. Damage Reports and Intensity Assignments}

\section{\#7 1865 Aug. 17 15:00 UTC (Arkansas)}

7 TN Memphis $\left(35.1494^{\circ} \mathrm{N}, 90.0489^{\circ} \mathrm{W}\right.$ )-Tumbled down chimney tops, upset loose articles; people ran out of buildings. (Street and Green, 1984).

TN Memphis $\left(35.1494^{\circ} \mathrm{N}, 90.0489^{\circ} \mathrm{W}\right)$-At Memphis, chimneys were thrown down. (Stover and Coffman, 1993).

6 MO New Madrid $\left(36.6278^{\circ} \mathrm{N}, 89.5061^{\circ} \mathrm{W}\right.$ ) -At New Madrid, Mo., chimneys were damaged and waves formed on the river, that were like those made by a passing steamboat. The earth appeared to undulate. (Stover and Coffman, 1993).

$4 \quad \mathrm{MO}$

3 MO

3 MS

3 TN

$\mathrm{N} \quad \mathrm{IL}$

N IL

$\mathrm{N}$ IL

N KY

N $\mathrm{KY}$

$\mathrm{N} \mathrm{OH}$

$\mathrm{N}$ TN

$\mathrm{N}$ TN

F IL

F IL

F MS

MS

F $\quad$ MS
Charleston $\left(36.9208^{\circ} \mathrm{N}, 89.3506^{\circ} \mathrm{W}\right)$-Scared some, rattled dishes. (Street and Green, 1984).

Saint Louis $\left(38.6272^{\circ} \mathrm{N}, 90.1978^{\circ} \mathrm{W}\right)-$ A slight shock was sensibly felt. (Street and Green, 1984).

Holly Springs $\left(34.7675^{\circ} \mathrm{N}, 89.4486^{\circ} \mathrm{W}\right.$ )-Plainly felt. (Street and Green, 1984).

Lagrange $\left(35.0453^{\circ} \mathrm{N}, 89.2436^{\circ} \mathrm{W}\right)$-Plainly felt. (Street and Green, 1984).

Belleville $\left(38.5200^{\circ} \mathrm{N}, 89.9839^{\circ} \mathrm{W}\right)$-Not reported. (Street and Green, 1984).

Champaign $\left(40.1164^{\circ} \mathrm{N}, 88.2433^{\circ} \mathrm{W}\right)$-Not reported. (Street and Green, 1984).

Robinson $\left(39.0053^{\circ} \mathrm{N}, 87.7392^{\circ} \mathrm{W}\right)$-Not reported. (Street and Green, 1984).

Louisville $\left(38.2542^{\circ} \mathrm{N}, 85.7594^{\circ} \mathrm{W}\right)$-Not mentioned. (Street and Green, 1984).

Owensboro $\left(37.7742^{\circ} \mathrm{N}, 87.1133^{\circ} \mathrm{W}\right)$-Not reported. (Street and Green, 1984).

Cincinnati $\left(39.1619^{\circ} \mathrm{N}, 84.4569^{\circ} \mathrm{W}\right)$-Not mentioned. (Street and Green, 1984).

Clarksville $\left(36.5297^{\circ} \mathrm{N}, 87.3594^{\circ} \mathrm{W}\right)$-Not reported. (Street and Green, 1984).

Nashville $\left(36.1658^{\circ} \mathrm{N}, 86.7844^{\circ} \mathrm{W}\right)$-Not mentioned. (Street and Green, 1984).

Du Quoin $\left(38.0114^{\circ} \mathrm{N}, 89.2361^{\circ} \mathrm{W}\right)$-Felt. (Street and Green, 1984).

Springfield $\left(39.8017^{\circ} \mathrm{N}, 89.6436^{\circ} \mathrm{W}\right)$-Felt. (Street and Green, 1984).

Jackson $\left(32.2986^{\circ} \mathrm{N}, 90.1847^{\circ} \mathrm{W}\right)$-At New Madrid, Mo., chimneys were damaged and waves formed on the river, that were like those made by a passing steamboat. The earth appeared to undulate. (Stover and Coffman, 1993). Jackson $\left(32.2986^{\circ} \mathrm{N}, 90.1847^{\circ} \mathrm{W}\right)$-Not mentioned. (Street and Green, 1984).

Oxford $\left(34.3664^{\circ} \mathrm{N}, 89.5192^{\circ} \mathrm{W}\right)$-Felt. (Street and Green, 1984). 


\section{Appendix 1, Part 08. Damage Reports and Intensity Assignments}

\section{April 24 20:22 UTC (Kansas)}

$7 \mathrm{KS}$

KS

$7 \mathrm{KS}$

6 IA

IA

$6 \mathrm{KS}$

KS

KS

$6 \mathrm{KS}$

$6 \mathrm{KS}$

KS

KS

KS

$6 \mathrm{KS}$

Leavenworth $\left(39.2757^{\circ} \mathrm{N}, 94.9902^{\circ} \mathrm{W}\right)$-Plaster cracked entire length of ceiling, large portion fell to floor; man shaken off load of hay; two contiguous buildings lifted up, separated two inches, settled back; dishes, tumblers knocked off shelves; visible agitation of water in river; clocks stopped at 2:30 p.m.; nearly everything toppled over in private homes; plaster fell in brick law office, several other buildings; six-foot saws leaning against wall moved out six inches; rumbling like thunder; stove pipe forced apart, some joints overlapping four inches; several chimneys overthrown; tables danced, dishes thrown to floor; piles of sheeting toppled down from counters in post office; plaster badly cracked in Billiard Hall; woman received electrical shock from spring water, smoke seen to come from bank; shocks moved from west to east. (Dubois and Wilson, 1978).

Leavenworth $\left(39.2757^{\circ} \mathrm{N}, 94.9902^{\circ} \mathrm{W}\right)$ - "Two contiguous blocks in Leavenworth are reported to have been lifted up and separated several inches, but they settled back again apparently uninjured." (Parker, 1868).

Louisville $\left(39.2574^{\circ} \mathrm{N}, 96.3207^{\circ} \mathrm{W}\right)$-Horses fell down in streets; chimneys toppled and fell. (Dubois and Wilson, 1978).

Dubuque $\left(42.5053^{\circ} \mathrm{N}, 90.6983^{\circ} \mathrm{W}\right)$-Three shocks felt; openings formed in brick walls; furniture displaced; persons in chairs undulated backwards and forwards; windows rattled, pictures shook, chandelier swayed; not felt severely by persons on ground floor, but much felt by occupants of second and third stories; panic, people fled to the streets; plastering came down in courthouse and other buildings; gas burners vibrated like pendulums; cases shook in newspaper room. (Dubois and Wilson, 1978).

Dubuque $\left(42.5053^{\circ} \mathrm{N}, 90.6983^{\circ} \mathrm{W}\right)$ - "Plaster fell and many fled outside." (Coffman and von Hake, 1973).

Atchison $\left(39.5196^{\circ} \mathrm{N}, 95.1462^{\circ} \mathrm{W}\right)$-Every building rocked to and fro; lamps thrown from tables and mantels; bottles in drug store thrown down; people fled from buildings to streets; water in White Clay Creek moved rapidly after a standstill for several days; no damage reported to buildings; vibration passed westward or northward; wave moved from south to north; first oscillation followed by heavier more perceptibly felt swell. (Dubois and Wilson, 1978). Atchison $\left(39.5196^{\circ} \mathrm{N}, 95.1462^{\circ} \mathrm{W}\right)$-add (Parker, 1912).

Atchison $\left(39.5196^{\circ} \mathrm{N}, 95.1462^{\circ} \mathrm{W}\right)$-Felt (Merriam, 1956).

Kansas City $\left(39.1177^{\circ} \mathrm{N}, 94.6307^{\circ} \mathrm{W}\right)$-Books unshelved; tables moved; pendant articles swung (bridles and harness); two clock doors suddenly opened; crack in wall opened and shut; water in tumblers spilled; plastering shaken off in one or two houses; general panic, people fled to streets; every movable article of furniture and crockery rattled and shook about. (Dubois and Wilson, 1978).

Lawrence $\left(38.9641^{\circ} \mathrm{N}, 95.2536^{\circ} \mathrm{W}\right)$ - "Two large stones were loosened from the top of the Unitarian church in Lawrence and precipitated to the ground, and the walls of many buildings in different places were cracked, but not one is known to have been thrown down." (Parker, 1868).

Lawrence $\left(38.9641^{\circ} \mathrm{N}, 95.2536^{\circ} \mathrm{W}\right)$-Three shocks felt over a period of 30 seconds; earth trembled and vibrated; doors and windows violently shaken; type thrown down in printer's office; butcher's spring balance drawn down $11 / 2$ pounds; bottles shaken off druggist's shelves; plaster broken off; loud rumbling noise; three - four loose stones knocked off Unitarian Church; rattled crockery, glassware, shook bundles from shelves; building with stone walls 30 inches thick shook very perceptibly;p people fled to streets; one stove overturned in a house; books fell off shelves. (Dubois and Wilson, 1978).

Lawrence $\left(38.9641^{\circ} \mathrm{N}, 95.2536^{\circ} \mathrm{W}\right)$-add (Parker, 1912).

Lawrence $\left(38.9641^{\circ} \mathrm{N}, 95.2536^{\circ} \mathrm{W}\right)$ - “Earthquake in Kansas. (1) Notice of the earthquake by Wm. H. R. Lykins, from a letter to the editors, dated Lawrence, Kansas, April 25, 1867. - Yesterday the 24th of April at 3 P.M., this locality was visited by an earthquake quite severe for this latitude. it was accompanied $b$ the usual loud rumbling noise similar to that caused by the passing of half a dozen heavy omnibuses. The earth did not seem to rise or rock, but to tremble or vibrate. No dust was raised nor was there any unusual atmospheric disturbance perceptible; the weather being clear and cool. Doors and windows were violently shaken, type thrown down in printing offices, bottles shaken off druggists' shelves, plaster broken off and in some instances walls slightly cracked. Persons out of doors did not feel amy movement of the ground, but could see the buildings tremble. A butcher informed me his spring balance was drawn down a pound and a half by the shock. It commenced with a slight trembling, gradually increasing to its maximum and then gradually dying away, lasting, as near as I could judge, about thirty seconds, though some estimate its duration at one and a half minutes. Some professed to have felt three distinct shocks, but the majority described it as a gradually increasing and decreasing vibration. The same shock was felt simultaneously one hundred miles west and north of us; from places farther than this we have no information." [Part (2) of this American Journal of Science article is by Wm. G. Williams and discusses the earthquake in Marysville, Kansas.] (Lykins, 1867).

Manhattan $\left(39.1957^{\circ} \mathrm{N}, 96.5976^{\circ} \mathrm{W}\right)$ - Two-foot waver observed to move south to north on Kansas River; clocks stopped; no wave observed on Blue River; stacked photographs pitched over to SW; cattle alarmed; oscillation of houses seemed to approach the "overtopping point;" inhabitants severely frightened; some people felt electric shocks; stone buildings with weak walls fractured but did not fall; aftershock occurred between 3 and 4 a.m. Thursday (one day later). (Dubois and Wilson, 1978). 


\section{Appendix 1, Part 08. Damage Reports and Intensity Assignments}

KS

KS

$6 \mathrm{KS}$

Manhattan $\left(39.1957^{\circ} \mathrm{N}, 96.5976^{\circ} \mathrm{W}\right)$ - "Also felt strongly at Manhattan where a wave 2 feet high was observed on the Kansas River; stones loosened on buildings and walls cracked." (Coffman and von Hake, 1973).

Manhattan $\left(39.1957^{\circ} \mathrm{N}, 96.5976^{\circ} \mathrm{W}\right)$ - At Manhattan the water of [the Kansas] river was observed to roll in a heavy wave, at least two feet high from the southerly to the northerly bank." (Parker, 1868).

Paola $\left(38.5737^{\circ} \mathrm{N}, 94.8675^{\circ} \mathrm{W}\right)$-Plaster fell from ceiling of large schoolhouse; buildings rocked; large brick building which housed the Republican newspaper office much injured, one side knocked down and destroyed; west to southeast motion; those in eastern part of town nearly thrown down if standing; sound like rolling of large train over railroad. (Dubois and Wilson, 1978).

Topeka $\left(39.0555^{\circ} \mathrm{N}, 95.6754^{\circ} \mathrm{W}\right)$-Waves in ceiling of Lincoln College were observed to run southwest to northeast; people fled to streets; stone church rocked; ceiling of Methodist Church bent up and down like waves on a pond; floor heaved and sank lower than its normal level; horses broke loose from hitching racks and ran toward open country; all but one glass window broken in schoolhouse "below this city." (Dubois and Wilson, 1978).

Topeka $\left(39.0555^{\circ} \mathrm{N}, 95.6754^{\circ} \mathrm{W}\right)$ - "At Topeka, a funeral service was occurring in one of the churches which was crowded to overflowing. As the stone building was rocked to and fro, the people made a hasty escape in every available direction, many of them jumping through the broken windows." (Parker, 1868).

Topeka $\left(39.0555^{\circ} \mathrm{N}, 95.6754^{\circ} \mathrm{W}\right)$ - "Waves in the ceiling of Lincoln College were observed to run from the southwest toward the northeast." (Parker, 1868).

Wamego $\left(39.2575^{\circ} \mathrm{N}, 96.3628^{\circ} \mathrm{W}\right)$-Shaking and rocking of every house; general alarm, people fled from buildings; plaster broken in houses; glasses shaken from lamps; walls cracked; three miles south of Wamego in Wabaunsee County, "On the farm of John Cotton, ... during the earthquake the earth opened and water was thrown out of the opening in considerable quantities. At another place not far distant from the above, the earth opened and fir and smoke issued out. So one of our papers states." (Dubois and Wilson, 1978).

Chillicothe $\left(39.7548^{\circ} \mathrm{N}, 93.5117^{\circ} \mathrm{W}\right)$-Severe enough to cause plaster to fall from ceilings of several homes. (Dubois and Wilson, 1978).

Kansas City $\left(39.0333^{\circ} \mathrm{N}, 94.55^{\circ} \mathrm{W}\right)$-Felt with equal force at Kansas City, Lexington, Sedalia, St. Joseph. (Dubois and Wilson, 1978).

Lexington $\left(39.1478^{\circ} \mathrm{N}, 93.8434^{\circ} \mathrm{W}\right)$-Felt with equal force at Kansas City, Lexington, Sedalia, St. Joseph. [Kansas City and Saint Joseph are assigned VI based on other reports, so assign Sedalia and Lexington VI, also.] (Dubois and Wilson, 1978).

Saint Joseph $\left(39.7500^{\circ} \mathrm{N}, 94.85^{\circ} \mathrm{W}\right)$-Rumbling noise; shaking of entire surface of terra firma; drove everyone into streets; four-story brick buildings shaken from cornice to foundation stone; windows broken, plastering thrown down; ladies fainted, men turned pale; solid brick blocks swayed to and fro like reeds; buildings shook, walls cracked, rocked, jarred; brick walls of new school house, standing on elevated piece of ground where street had been cut down, cracked several feet from ground and bank on which it stood was also rent in a distinct seam. (Dubois and Wilson, 1978).

Saint Joseph $\left(39.7500^{\circ} \mathrm{N}, 94.85^{\circ} \mathrm{W}\right)$-Felt with equal force at Kansas City, Lexington, Sedalia, St. Joseph. (Dubois and Wilson, 1978).

Sedalia $\left(38.7004^{\circ} \mathrm{N}, 93.229^{\circ} \mathrm{W}\right)$-Felt with equal force at Kansas City, Lexington, Sedalia, St. Joseph. [Kansas City and Saint Joseph are assigned VI based on other reports, so assign Sedalia and Lexington VI, also.] (Dubois and Wilson, 1978).

Emporia $\left(38.4196^{\circ} \mathrm{N}, 96.1925^{\circ} \mathrm{W}\right)$-Low rumbling sound followed by vibrations; houses shook, windows rattled; panic, people fled from buildings; brick and stone houses more severely affected than frame houses; small boxes fell off shelves. (Dubois and Wilson, 1978).

Holton $\left(39.4665^{\circ} \mathrm{N}, 95.7381^{\circ} \mathrm{W}\right)$-Goods and wares fell off shelves; shook buildings; people fled to the streets. (Dubois and Wilson, 1978).

Irving $\left(39.6389^{\circ} \mathrm{N}, 96.5972^{\circ} \mathrm{W}\right)$ - Rumbling sound heard before shock; houses shaken severely; inmates rushed out of doors; lasted 30 seconds. (Dubois and Wilson, 1978).

Junction City $\left(38.9873^{\circ} \mathrm{N}, 96.8314^{\circ} \mathrm{W}\right)$ - “About half past two o'clock this afternoon a very perceptible shock of earthquake awakened things in town for a few seconds. The building occupied by this office rocked to and fro, we judge moving several inches. At all events, its inmates indiscriminately scrambled downstairs. It was amusing to see the court and spectators getting downstairs also. Judge S. B. White and several of the attorneys demolished a front window in their eagerness to escape from the building. The shock seems not to have extended over a quarter of a mile in width, but it was strongly felt at Wyandotte, Lawrence, Topeka, and west of us, at Solomon. A well which was being dug in town was destroyed by it, but fortunately none of the workmen were in it." - Junction City Union, April 27, 1867. (Parker, 1912).

KS

Junction City $\left(38.9873^{\circ} \mathrm{N}, 96.8314^{\circ} \mathrm{W}\right)$-Very heavy shock; rocked buildings to and fro, moving several inches; destroyed well being dug in town; shock seems not to have extended over a quarter of a mile in width. (Dubois and Wilson, 1978).

KS

Junction City $\left(38.9873^{\circ} \mathrm{N}, 96.8314^{\circ} \mathrm{W}\right)$-Felt (Merriam, 1956). 


\section{Appendix 1, Part 08. Damage Reports and Intensity Assignments}

5 KS Lecompton $\left(39.0136^{\circ} \mathrm{N}, 95.4376^{\circ} \mathrm{W}\right)$-Panic, people fled to streets; Lane University building quivered; windows and doors danced. (Dubois and Wilson, 1978).

5 KS Marysville $\left(39.8682^{\circ} \mathrm{N}, 96.6637^{\circ} \mathrm{W}\right)$ - “Earthquake in Kansas...(2) Notice of the earthquake by Prof. Wm. G. Williams, from a letter to the editors, dated Marysville, Marshall County, Kansas, April 25, 1867. - At two o'clock and thirty minutes yesterday afternoon the shock of an earthquake was felt probably in every house and place of business in and near town. It was accompanied by the usual rumbling sound, and lasted a time variously estimated from one to three minutes.

No serious injury was done to persons, or property, beyond a temporary alarm on the part of a few. In stores, bottles and packages were made to rattle and in some cases were shaken from the shelves and broken. Windows, doors, shutters, stove-pipes and all loose or hanging articles, rattled, waved, or swung back and forth fearfully.

In several instances persons in the second stories of stores and houses hearing the noise, and seeing and feeling the unwonted motions, ran down to stop the supposed disorder and tumult below, while those below ran up to stop that above. One lady knowing it to be an earthquake seized her infant child and hastened down stairs with a view to get out of doors for safety. A gentleman fishing in Spring Creek near town was leaning against a tree, feeling it shake and looking up, he saw it and other trees trembling and moving as if agitated by wind, although no breath of air was stirring. With my assistant teacher and some seventy scholars I was in the second story of our High School edifice. It is of stone and high pitched. The whole structure, desks, stove-pipes and other furniture were much shaken. The rumbling noises below much resembled those of heavy trucks on plank floors. I have had no opportunity to learn how extensively the shock was felt." [Part (1) of this American Journal of Science article is by Wm.H.R. Lykins and discusses the earthquake in Lawrence, Kansas.] (Williams, 1867).

KS

Marysville $\left(39.8682^{\circ} \mathrm{N}, 96.6637^{\circ} \mathrm{W}\right)$-Temporary alarm on part of a few; felt by people on first and second floors; fisherman on Spring Creek felt tree shake, saw all the others trembling; stone high school much shaken, along with desks, stove-pipes, and other furniture; rumbling sound like heavy trunks being dragged across planks; windows, doors, shutters, stove-pipes, all loose or hanging articles rattled, waved, swung back and forth fearfully; bottles and packages rattled, some shaken off shelves and broken. (Dubois and Wilson, 1978).

Marysville $\left(39.8682^{\circ} \mathrm{N}, 96.6637^{\circ} \mathrm{W}\right)$ - "Doors and shutters swung back and forth. A two-story building was strongly shaken in the upper story and there was a loud rumbling noise." (Coffman and von Hake, 1973).

Montgomery County $\left(37.1893^{\circ} \mathrm{N}, 95.7418^{\circ} \mathrm{W}\right)$-Shook buildings; knocked dishes off shelves; people in moving vehicles did not feel it (witness was Topeka Weather Bureau man in 1906). (Dubois and Wilson, 1978).

Mound City $\left(38.1530^{\circ} \mathrm{N}, 94.8405^{\circ} \mathrm{W}\right)$ - Houses violently shaken; doors opened; water shaken from buckets; loose articles tumbled around. (Dubois and Wilson, 1978).

Oskaloosa $\left(39.2029^{\circ} \mathrm{N}, 95.3333^{\circ} \mathrm{W}\right)$ - Houses vibrated; movable items shaken and jostled; public panic, people fled to streets; rumbling noise; cupola of new school house reeled like drunken man. (Dubois and Wilson, 1978).

Ottawa $\left(38.6197^{\circ} \mathrm{N}, 95.2772^{\circ} \mathrm{W}\right)$ - Houses emptied of occupants; building shaken. (Dubois and Wilson, 1978).

Solomon $\left(38.9126^{\circ} \mathrm{N}, 97.3773^{\circ} \mathrm{W}\right.$ ) - Train on Pacific RR violently rocked by shock, locomotive was stopped and trainmen abandoned cab for fear the boiler was about to blow up. (Dubois and Wilson, 1978).

Solomon $\left(38.9126^{\circ} \mathrm{N}, 97.3773^{\circ} \mathrm{W}\right)$-Felt (Merriam, 1956).

Warrensburg $\left(38.7880^{\circ} \mathrm{N}, 93.7321^{\circ} \mathrm{W}\right)$-Walls of church heaved "as if moved by a shock from SW;" glassware shook about; plastering fell from ceiling; buildings moved; no damage. (Dubois and Wilson, 1978).

Warrensburg $\left(38.7880^{\circ} \mathrm{N}, 93.7321^{\circ} \mathrm{W}\right)$ - "Rev. R. D. Parker... observed the walls of the church heave as if moved by a shock from the southwest." (Parker, 1868).

Des Moines $\left(41.5857^{\circ} \mathrm{N}, 93.6189^{\circ} \mathrm{W}\right.$ )-Rocked persons sitting in chairs. Shook buildings. (Dubois and Wilson, 1978).

lola $\left(37.9477^{\circ} \mathrm{N}, 95.4212^{\circ} \mathrm{W}\right)$-Shook houses; rattled crockery. (Dubois and Wilson, 1978).

Olathe $\left(38.8878^{\circ} \mathrm{N}, 94.8367^{\circ} \mathrm{W}\right)$ - Houses seen to totter, wave back and forth; shingles on roofs broke loose, fell to ground; glassware rattled; deep rumbling sound. (Dubois and Wilson, 1978).

White Cloud $\left(39.9423^{\circ} \mathrm{N}, 95.2862^{\circ} \mathrm{W}\right)$-Two distinct severe shocks felt. (Dubois and Wilson, 1978).

Wyandotte $\left(39.1144^{\circ} \mathrm{N}, 94.7662^{\circ} \mathrm{W}\right)$-Doors jarred open; windows rattled and jarred; people fled to streets; houses swayed; dishes shook; people awakened from naps. (Dubois and Wilson, 1978).

Wapello $\left(41.1814^{\circ} \mathrm{N}, 91.1853^{\circ} \mathrm{W}\right)$-Motion of tremor described as "not violent, but easy swinging, giving one a sensation something like the first effects of a dram of whisky." (Dubois and Wilson, 1978).

Salina $\left(38.8280^{\circ} \mathrm{N}, 97.6147^{\circ} \mathrm{W}\right)$-Shaking lasted 10 seconds, no damage reported. (Dubois and Wilson, 1978).

Wathena $\left(39.7754^{\circ} \mathrm{N}, 94.9449^{\circ} \mathrm{W}\right)$-Small earthquake visited this section at 3:05 p.m., lasted 10 seconds. (Dubois and Wilson, 1978).

Fort Scott $\left(37.8136^{\circ} \mathrm{N}, 94.7138^{\circ} \mathrm{W}\right)$-Slight trembling in buildings, not alarming. (Dubois and Wilson, 1978).

Carthage $\left(39.1969^{\circ} \mathrm{N}, 84.4792^{\circ} \mathrm{W}\right)$ - "Carthage, Ohio, reported 'an acre of ground sank ten feet.' However, it seems doubtful that this was related to the earthquake." (Docekal, 1970).

Carthage $\left(39.1969^{\circ} \mathrm{N}, 84.4792^{\circ} \mathrm{W}\right)$ - "An acre of ground three miles south of Carthage on the Miami canal, is reported to have sunk ten feet, showing that the shock extended to Ohio. The ground sunk bodily, leaving a perpendicular wall of ten feet or more on all sides. The canal bank was seriously endangered by the subsidence." (Parker, 1868). 


\section{Appendix 1, Part 08. Damage Reports and Intensity Assignments}

F IL Cairo $\left(37.0484^{\circ} \mathrm{N}, 89.2041^{\circ} \mathrm{W}\right)$-Felt (Heinrich, 1941).

F IL Chicago $\left(41.8333^{\circ} \mathrm{N}, 87.6667^{\circ} \mathrm{W}\right)$-Felt (Heinrich, 1941).

F $\quad$ MO Saint Louis $\left(38.6667^{\circ} \mathrm{N}, 90.19^{\circ} \mathrm{W}\right)$-Shock felt here about 3:00 p.m. (Dubois and Wilson, 1978).

MO Saint Louis $\left(38.6667^{\circ} \mathrm{N}, 90.19^{\circ} \mathrm{W}\right)$-Felt (Merriam, 1956).

F NE Omaha $\left(41.2633^{\circ} \mathrm{N}, 95.9338^{\circ} \mathrm{W}\right)$-Felt (Merriam, 1956). 


\section{Appendix 1, Part 09. Damage Reports and Intensity Assignments}

\section{\#9 1876 Sept. 25 06:15 UTC (Illinols)}

7 IN Vincennes $\left(38.6772^{\circ} \mathrm{N}, 87.5286^{\circ} \mathrm{W}\right)$-Everybody jumped out of bed frightened, many chimneys were thrown down. (Street and Green, 1984).

IN Vincennes $\left(38.6772^{\circ} \mathrm{N}, 87.5286^{\circ} \mathrm{W}\right)$ - The second shock [this shock at 06:15 followed one at 06:00] threw down chimneys at Vincennes, Ind. (Stover and Coffman, 1993).

5 IN Evansville $\left(37.9747^{\circ} \mathrm{N}, 87.5558^{\circ} \mathrm{W}\right)$-Awakened and alarmed people all over town, some ran out to the streets. (Street and Green, 1984).

IN Evansville $\left(37.9747^{\circ} \mathrm{N}, 87.5558^{\circ} \mathrm{W}\right)$-The second shock [this shock at 06:15 followed one at 06:00] ... alarmed residents at Evansville, Ind. (Stover and Coffman, 1993).

5 KY Louisville $\left(38.2542^{\circ} \mathrm{N}, 85.7594^{\circ} \mathrm{W}\right)$-Knocked pictures from walls, threw dishes to the floors; many people left their beds in alarm. (Street and Green, 1984).

KY Louisville $\left(38.2542^{\circ} \mathrm{N}, 85.7594^{\circ} \mathrm{W}\right)$ - The second shock [this shock at 06:15 followed one at 06:00] ... caused slight damage at Louisville. (Stover and Coffman, 1993).

$5 \mathrm{KY}$

Owensboro $\left(37.7742^{\circ} \mathrm{N}, 87.1133^{\circ} \mathrm{W}\right)$ - In one or two instances crockery was thrown to the floor and broken. (Street and Green, 1984).

KY

Owensboro $\left(37.7742^{\circ} \mathrm{N}, 87.1133^{\circ} \mathrm{W}\right)$ - The second shock [this shock at 06:15 followed one at 06:00] ... caused slight damage at ... Owensboro, Ky. (Stover and Coffman, 1993).

Carmi $\left(38.0908^{\circ} \mathrm{N}, 88.1586^{\circ} \mathrm{W}\right)$-Many citizens were awakened. (Street and Green, 1984).

$4 \quad \mathrm{IL}$

Friendsville $\left(38.5157^{\circ} \mathrm{N}, 87.8076^{\circ} \mathrm{W}\right)-(06: 00$ and 06:15) These earthquakes were felt most strongly between Friendsville and Mt. Carmel, III., and Evansville, Ind. They were described as "heavy" at Friendsville. (Stover and Coffman, 1993).

Robinson $\left(39.0053^{\circ} \mathrm{N}, 87.7392^{\circ} \mathrm{W}\right.$ ) -Quite a number of our citizens were awakened, some got out of bed to investigate. (Street and Green, 1984).

New Albany $\left(38.2856^{\circ} \mathrm{N}, 85.8242^{\circ} \mathrm{W}\right)$-Dishes and cupboards rattled with the fury of a storm. (Street and Green, 1984).

Sullivan $\left(39.0953^{\circ} \mathrm{N}, 87.4058^{\circ} \mathrm{W}\right.$ )-Awakened many people. (Street and Green, 1984).

Worthington $\left(39.1250^{\circ} \mathrm{N}, 86.9794^{\circ} \mathrm{W}\right)$-Very perceptible, aroused nearly all citizens. (Street and Green, 1984).

Indianapolis $\left(39.7683^{\circ} \mathrm{N}, 86.1581^{\circ} \mathrm{W}\right)$-Was distinctly noticed in this city. (Street and Green, 1984).

Du Quoin $\left(38.0114^{\circ} \mathrm{N}, 89.2361^{\circ} \mathrm{W}\right)$-Not reported. (Street and Green, 1984).

Jonesboro $\left(37.4517^{\circ} \mathrm{N}, 89.2681^{\circ} \mathrm{W}\right)$-Not reported. (Street and Green, 1984).

Quincy $\left(39.9356^{\circ} \mathrm{N}, 91.4097^{\circ} \mathrm{W}\right)$-Not mentioned. (Street and Green, 1984).

IL $\quad$ Salem $\left(38.6269^{\circ} \mathrm{N}, 88.9456^{\circ} \mathrm{W}\right)$-Not reported. (Street and Green, 1984).

KY Hickman $\left(36.5711^{\circ} \mathrm{N}, 89.1861^{\circ} \mathrm{W}\right)$-Not reported. (Street and Green, 1984).

KY Lebanon $\left(37.5697^{\circ} \mathrm{N}, 85.2528^{\circ} \mathrm{W}\right)$-Not mentioned. (Street and Green, 1984).

KY Lexington $\left(38.0492^{\circ} \mathrm{N}, 84.5003^{\circ} \mathrm{W}\right)$-Not mentioned. (Street and Green, 1984).

KY Mayfield $\left(36.7417^{\circ} \mathrm{N}, 88.6367^{\circ} \mathrm{W}\right)$-Not reported. (Street and Green, 1984).

MO Hillsboro $\left(38.2322^{\circ} \mathrm{N}, 90.5628^{\circ} \mathrm{W}\right)$-Not reported. (Street and Green, 1984).

MO Saint Genevieve $\left(37.9814^{\circ} \mathrm{N}, 90.0417^{\circ} \mathrm{W}\right)$-Not mentioned. (Street and Green, 1984).

$\mathrm{OH} \quad$ Cincinnati $\left(39.1619^{\circ} \mathrm{N}, 84.4569^{\circ} \mathrm{W}\right)$-Not mentioned. (Street and Green, 1984).

IL Belleville $\left(38.5200^{\circ} \mathrm{N}, 89.9839^{\circ} \mathrm{W}\right)$-Felt. (Street and Green, 1984).

IL Mount Carmel $\left(38.4108^{\circ} \mathrm{N}, 87.7614^{\circ} \mathrm{W}\right)$-Felt. (Street and Green, 1984).

IL Springfield $\left(39.8017^{\circ} \mathrm{N}, 89.6436^{\circ} \mathrm{W}\right)$-Felt. (Street and Green, 1984).

F MO Saint Louis $\left(38.6272^{\circ} \mathrm{N}, 90.1978^{\circ} \mathrm{W}\right)$ - They [shocks at 06:00 and 06:15 (this shock)] were felt from St. Louis, Mo., to Indianapolis, Ind., and Louisville, Ky. (Stover and Coffman, 1993).

MO Saint Louis $\left(38.6272^{\circ} \mathrm{N}, 90.1978^{\circ} \mathrm{W}\right)$-Not mentioned. (Street and Green, 1984). 


\section{Appendix 1, Part 10. Damage Reports and Intensity Assignments}

\section{\#10 1877 Nov. 15 17:45 UTC (Nebraska)}

7 NE Columbus $\left(41.4297^{\circ} \mathrm{N}, 97.3681^{\circ} \mathrm{W}\right)$-Most damage seemed to be at Columbus where a severe shock lasting 30 seconds split the courthouse walls in 9 places and schoolhouse walls were badly damaged, giving rise to panic. (Burchett, 1979).

$\mathrm{NE}$ Columbus $\left(41.4297^{\circ} \mathrm{N}, 97.3681^{\circ} \mathrm{W}\right)$-Damage was most severe at Columbus, in Colfax County, northwest of the epicenter, where the 30-second shock split the courthouse walls in nine places and damaged the schoolhouse walls. (Stover and Coffman, 1993).

$\mathrm{NE} \quad$ Columbus $\left(41.4297^{\circ} \mathrm{N}, 97.3681^{\circ} \mathrm{W}\right)$-Greatest damage seems to have been experienced at Columbus, Nebraska, 35 miles northwest of the epicenter. There, the courthouse walls split in nine places, and school house walls were badly rent, giving rise to panic. (Footnote: Columbus, Nebraska, is built upon terrace-fill alluvium of the Platte River Valley. This may partly account for the damage.) (Docekal, 1970).

NE Columbus $\left(41.4297^{\circ} \mathrm{N}, 97.3681^{\circ} \mathrm{W}\right)$-Most damage in Columbus where Count House was 'split in 9 places.' (Wollard, 1968).

Sioux City $\left(42.4972^{\circ} \mathrm{N}, 96.4029^{\circ} \mathrm{W}\right)$-At Sioux City considerable commotion was created. Walls were cracked, window glass broken, and quite a panic created in the public schools, and at St. Mary's church where a congregation were assembled to witness confirmation ceremonies. (Sioux Falls Pantograph, 1877 Nov 21).

IA Sioux City $\left(42.4972^{\circ} \mathrm{N}, 96.4029^{\circ} \mathrm{W}\right)$-At Sioux City, lowa, severe shocks lasting 15 seconds caused panic in a church and in a high school building where one wall cracked. (Burchett, 1979).

IA Sioux City $\left(42.4972^{\circ} \mathrm{N}, 96.4029^{\circ} \mathrm{W}\right)$-About $200 \mathrm{~km}$ north of Lincoln, at Sioux City, lowa, a high school sustained cracks in a wall. (Stover and Coffman, 1993).

IA Sioux City $\left(42.4972^{\circ} \mathrm{N}, 96.4029^{\circ} \mathrm{W}\right)$-At Sioux City, lowa, severe shocks were felt for 15 seconds. Occupants of a church panicked, as did those in a high school building, where one wall cracked. (Footnote [Docekal]: An intensity of V M.M. is assigned to three records: North Platte, Nebraska; Yankton, South Dakota; and Sioux City, lowa. Revision to VI M.M. for North Platte is indicated, and possibly for Sioux City.) (Docekal, 1970).

North Platte $\left(41.1326^{\circ} \mathrm{N}, 100.7746^{\circ} \mathrm{W}\right)$-North Platte experienced two severe shocks lasting 40 seconds which cracked walls and overturned printing cases. (Burchett, 1979).

NE North Platte $\left(41.1326^{\circ} \mathrm{N}, 100.7746^{\circ} \mathrm{W}\right)$-Two severe shocks about $350 \mathrm{~km}$ west of Lincoln, at North Platte, cracked walls and overturned printing cases. (Stover and Coffman, 1993).

NE North Platte $\left(41.1326^{\circ} \mathrm{N}, 100.7746^{\circ} \mathrm{W}\right)$-The third area reporting damage is associated with the Cambridge Arch of southwestern Nebraska: North Platte, located at the crest of the arch, felt two shocks; each lasted 20 seconds, separated by an interval of 5 seconds. Cracks in the courthouse wall and one well were reported. Printing cases were overturned, houses were rocked perceptibly, and the occupants of a schoolhouse stampeded. (Footnote [Docekal]: An intensity of V M.M. is assigned to three records: North Platte, Nebraska; Yankton, South Dakota; and Sioux City, lowa. Revision to VI M.M. for North Platte is indicated, and possibly for Sioux City.) (Docekal, 1970).

Yankton $\left(42.8821^{\circ} \mathrm{N}, 97.3986^{\circ} \mathrm{W}\right)$-The Press and Dakotan describes the shock which occurred at Yankton as follows: 'There was a very perceptible tremor of this solid earth at 11:30 this morning, shaking buildings, rattling tinware, and even entering the sanctuary of home and tumbling little nick-nacks from their quiet repose on brackets and wall to the floor. The shock was felt in every inhabited tenement in town, but did not meet with such general recognition from those who chanced to be walking on the streets. In the court house it was very sensibly felt. Court had just adjourned, but the room was filled with lawyers and citizens whose bewildered faces for the moment were a study for the artist. The jurymen in the rooms below and the prisoners confined in the basement all felt the shock. In the high school the pupils became alarmed and the school rooms emptied in half a minute. Slates were tumbled from the desks and consternation took the place of order and quiet for the moment. At the Merchants a portion of the plastering in the dining room ceiling was precipitated to the floor and a chambermaid employed in the upper story was so much affected that she fainted. Pennington's block received a severe shaking and its occupants generally sought refuge on the pavement. On the hill west of town it was particularly severe, but as no one was injured and no particular damage inflicted, the matter has been the subject of considerable levity. Everyone you meet has had an experience varying from that of his neighbor, and each has been anxious to tell where he was, how he felt, what he observed, tapering off usually with an unsuccessful attempt at a laugh, It was so funny, you know. (Sioux Falls Pantograph, 1877 Nov 21 ).

SD

SD

SD

Yankton $\left(42.8821^{\circ} \mathrm{N}, 97.3986^{\circ} \mathrm{W}\right)$ - Southeastern South Dakota was strongly shaken. At Yankton the shock was severe in the valley, lasting 20 seconds. Buildings rocked and some glass broke. (Burchett, 1979).

Yankton $\left(42.8821^{\circ} \mathrm{N}, 97.3986^{\circ} \mathrm{W}\right)$-This earthquake was recorded in Yankton newspapers of the time. At the time of this earthquake, the only newspapers in South Dakota were in Yankton and the Black Hills. (Letter dated 1976 April 8 from Janice Fleming, librarian at the South Dakota Dept. of Education and Cultural Affairs, Historical Resource Center).

Yankton $\left(42.8821^{\circ} \mathrm{N}, 97.3986^{\circ} \mathrm{W}\right)$-At Yankton, the shock was severe the valley, lasting 20 seconds. (Presumably, it was noticed to a lesser extent on the bluffs, as was true for the earthquake of October 9, 1972.) Glass was broken and some buildings were said to have 'tipped perceptibly.' (Footnote [Docekal]: An intensity of V M.M. is assigned to three records: North Platte, Nebraska; Yankton, South Dakota; and Sioux City, lowa. Revision to VI M.M. for North Platte is indicated, and possibly for Sioux City.) (Docekal, 1970). 


\section{Appendix 1, Part 10. Damage Reports and Intensity Assignments}

5 IA

IA

$5 \quad \mathrm{KS}$

KS

KS

KS

KS

$4 \mathrm{CO}$

$4 \mathrm{MN}$

NE

$4 \quad \mathrm{NE}$

$4 \quad \mathrm{NE}$

NE

$4 \quad \mathrm{NE}$

NE

$4 \quad \mathrm{NE}$

$\mathrm{NE}$

$4 \mathrm{NE}$

NE

$4 \mathrm{NE}$

NE

$4 \mathrm{NE}$

$4 \mathrm{SD}$

Council Bluffs $\left(41.2616^{\circ} \mathrm{N}, 95.8251^{\circ} \mathrm{W}\right)$-At Council Bluffs, lowa, severe quick successive shocks lasting 2 minutes threatened a brick building, causing people to dash into the street for safety. (Burchett, 1979).

Council Bluffs $\left(41.2616^{\circ} \mathrm{N}, 95.8251^{\circ} \mathrm{W}\right)$-Across the Missouri River [from Omaha, Nebraska], at Council Bluffs, lowa, a succession of quick, severe shocks threatened a brick building. Occupants dashed into the street for safety. (Docekal, 1970).

Atchison $\left(39.5594^{\circ} \mathrm{N}, 95.1304^{\circ} \mathrm{W}\right)$ - Yesterday at five minutes before twelve o'clock ... an earthquake. There was no mistaking the fact - every two-story building in town swayed backward and forward, and in several buildings there was a grand rush made to the street. It was noticed very distinctly in every department of the Champion building, and the employees in every room saw and felt the vibration. In the Wagner building, on the corner of Fourth and Commercial streets, the occupants vacated the structure like a panic-stricken mob, and they came rushing pell mell down the stairs like the water comes down at Ladore. Another building in which the effects were distinctly felt was in Murphy's block. In the city clerk's office the desks swayed back and forth as if impelled by some motive power, and the gas fixtures trembled and shook for ten minutes. In Leu's block and the Blair and Galbraith block the shock was also acutely felt, but no damage done. (The Atchison Daily Champion, 1877 Nov 16).

Atchison $\left(39.5594^{\circ} \mathrm{N}, 95.1304^{\circ} \mathrm{W}\right)$-There were two shocks, one at 11:45 A.M. and the other at 12:30 P.M., causing buildings to sway and people to run into the streets at Atchison, Kansas. (Merriam, 1956).

Atchison $\left(39.5594^{\circ} \mathrm{N}, 95.1304^{\circ} \mathrm{W}\right)$-Originally, intensities of III-IV M.M. were assigned to Atchison and Topeka in the present study. It is now believed that intensities of IV M.M. were definitely felt at both places. (Docekal, 1970).

Atchison $\left(39.5594^{\circ} \mathrm{N}, 95.1304^{\circ} \mathrm{W}\right)$-At Atchison Kan., several distinct shocks of earthquake were felt about noon yesterday. (Black Hills Daily Times, 1877 Nov 16, p. 1, col. 2, under the heading "Telegraphic Briefs").

Atchison $\left(39.5594^{\circ} \mathrm{N}, 95.1304^{\circ} \mathrm{W}\right)$-Felt. (Burchett, 1979).

Julesburg $\left(40.9708^{\circ} \mathrm{N}, 102.2575^{\circ} \mathrm{W}\right)$ - Julesburg, Colorado, [was] assigned values of III-IV M.M. (Docekal, 1970).

Mankato $\left(44.1538^{\circ} \mathrm{N}, 93.996^{\circ} \mathrm{W}\right)$-A slight shock of an earthquake, or tidal wave, or something else, occurred in this city just before 12 o'clock meridian yesterday, (Thursday.) It is said that in some parts of the city the vibrations were very distinct, even swaying articles to and fro, and frightening small children and extending to grown-up people. Its duration was less than one minute. What was it?

At the Normal school, the trepidation took form in the children rushing out of doors, and the teachers examining the building to see if any openings had been made. It is said that a slight shock was also felt on Wednesday, but it did not arrest our attention. (Mankato Union, 1877 Nov 16).

4 NE Big Springs $\left(41.0696^{\circ} \mathrm{N}, 102.0933^{\circ} \mathrm{W}\right)$-Docekal assigned III-IV M.M. (Docekal, 1970).

Big Springs $\left(41.0696^{\circ} \mathrm{N}, 102.0933^{\circ} \mathrm{W}\right)$-Felt. (Burchett, 1979).

Fremont $\left(41.4416^{\circ} \mathrm{N}, 96.4945^{\circ} \mathrm{W}\right)$-At Fremont, Nebraska, a severe shock rocked the courthouse and hotel perceptibly. (Burchett, 1979).

Ogallala $\left(41.1275^{\circ} \mathrm{N}, 101.7107^{\circ} \mathrm{W}\right)$-Docekal assigned III-IV M.M. (Docekal, 1970).

Ogallala $\left(41.1275^{\circ} \mathrm{N}, 101.7107^{\circ} \mathrm{W}\right)$-Felt. (Burchett, 1979).

Omaha $\left(41.2590^{\circ} \mathrm{N}, 95.9409^{\circ} \mathrm{W}\right)$-At Omaha 3 strong shocks over 45 seconds shook buildings. The motion seemed to come from the east. (Burchett, 1979).

Omaha $\left(41.2590^{\circ} \mathrm{N}, 95.9409^{\circ} \mathrm{W}\right)$-At Omaha, Nebraska, three shocks, each lasting 10 seconds in a total span of 45 seconds, shook buildings. The motion appeared to come from the east. (Docekal, 1970).

Paxton (Alkali) $\left(41.1268^{\circ} \mathrm{N}, 101.3585^{\circ} \mathrm{W}\right)$-Docekal assigned III-IV M.M. (Docekal, 1970).

Paxton (Alkali) $\left(41.1268^{\circ} \mathrm{N}, 101.3585^{\circ} \mathrm{W}\right)$-Felt. (Burchett, 1979).

Potter $\left(41.2347^{\circ} \mathrm{N}, 103.3061^{\circ} \mathrm{W}\right)$-At Potter ... an intensity of IV M.M. is recorded. (Docekal, 1970).

Potter $\left(41.2347^{\circ} \mathrm{N}, 103.3061^{\circ} \mathrm{W}\right)$-Felt. (Burchett, 1979).

Sidney $\left(41.1428^{\circ} \mathrm{N}, 102.9775^{\circ} \mathrm{W}\right)$-Docekal assigned III-IV M.M. (Docekal, 1970).

Sidney $\left(41.1380^{\circ} \mathrm{N}, 102.9856^{\circ} \mathrm{W}\right)$-Felt. (Burchett, 1979).

West Point $\left(41.8450^{\circ} \mathrm{N}, 96.7318^{\circ} \mathrm{W}\right)$-At West Point, Nebraska, 2 shocks swayed buildings and rattled windows. (Burchett, 1979).

Sioux Falls $\left(43.5461^{\circ} \mathrm{N}, 96.7269^{\circ} \mathrm{W}\right)$-The A---- Rocks at Sioux Falls are made to Tremble

Last Thursday about noon some gentlemen in the Recorder's office in the upper story of the brick building owned by J.B. Yound \& Co., noticed that the building was being jarred as if by the movement of a safe or something heavy on the lower floor. On learning that nothing of the kind had occurred down stairs they all agreed that mother Earth had been trembling a little. Several others in the village also noticed the shock. But it attracted no general attention and would have been forgotten but for the reports that have since come in from other places, leaving no doubt about Sioux Falls having had her solid foundations jarred....

The shock or tremor lasted about one minute, and appeared to come from the northwest. It seems to have been general as the dispatches speak of it at Ft. Randall, 85 miles west to points 200 miles east. (Sioux Falls Pantograph, 1877 Nov 21). 


\section{Appendix 1, Part 10. Damage Reports and Intensity Assignments}

$3 \mathrm{KS}$

KS

$3 \mathrm{KS}$

KS

KS

KS

$3 \mathrm{MO}$

MO

$3 \mathrm{NE}$

$3 \quad \mathrm{NE}$

$\mathrm{NE}$

Kansas City $\left(39.1157^{\circ} \mathrm{N}, 94.6271^{\circ} \mathrm{W}\right)$-On Thursday, November 15,1877 , the shock of an earthquake was distinctly felt in this city (Kansas City, Kan.) about fifteen minutes before twelve o'clock. a majority of persons were not conscious of any perturbations of nature, but people living on high ground and those occupying brick buildings felt the shock distinctly. Topeka, Lawrence, Atchison and other points in the state were more or less shaken up. The shock was not as severe as that of the earthquakes of $1876\{1875\}$. (The Wyandott Herald, 1877 Nov 22).

Kansas City $\left(39.1157^{\circ} \mathrm{N}, 94.6271^{\circ} \mathrm{W}\right)$-Felt. (Burchett, 1979).

Topeka $\left(39.0553^{\circ} \mathrm{N}, 95.6802^{\circ} \mathrm{W}\right.$ )-Persons who were engaged in the upper rooms of the Santa Fe depot yesterday state that about ten minutes before twelve o'clock they felt a shock of earthquake, which made the building rock gently from north to south. In one room there were three gentlemen, and all of a sudden each found the others looking at him and asking, 'What is that?' In other rooms nearly the same thing happened, all saying they felt very dizzy or seasick, or rushed to the window to see if there was a train passing. Not an engine was in sight, and some one said, 'Earthquake.' In one room a door was slammed shut, and some say the chairs rocked. In the shops the shock was also felt, but not downstairs in the depot building. We talked with several gentlemen in the building, and all agree that it was an earthquake. We have, however, been unable to find any one uptown who felt it, except a colored man who thought he heard it, but at the time supposed it was the report of two guns which had been discharged. A lady who came in on the Santa Fe train said that while she was sitting in the depot at Lawrence she felt something, but didn't know what it was. (The Commonwealth, Topeka, Kansas, 1877 Nov 16).

Topeka $\left(39.0553^{\circ} \mathrm{N}, 95.6802^{\circ} \mathrm{W}\right)$-Originally, intensities of III-IV M.M. were assigned to Atchison and Topeka in the present study. It is now believed that intensities of IV M.M. were definitely felt at both places. (Docekal, 1970).

Topeka $\left(39.0553^{\circ} \mathrm{N}, 95.6802^{\circ} \mathrm{W}\right)$-At Topeka a severe shock of earthquake was felt about ten minutes before twelve yesterday. (Black Hills Daily Times, 1877 Nov 16, p. 1, col. 2, under the heading "Telegraphic Briefs").

Topeka $\left(39.0553^{\circ} \mathrm{N}, 95.6802^{\circ} \mathrm{W}\right)$-Felt. (Burchett, 1979).

Saint Joseph $\left(39.7688^{\circ} \mathrm{N}, 94.8385^{\circ} \mathrm{W}\right.$ ) - It was felt with intensity III at St. Joseph, Mo. (Coffman and von Hake, 1973).

Saint Joseph $\left(39.7688^{\circ} \mathrm{N}, 94.8385^{\circ} \mathrm{W}\right)$-Felt. (Burchett, 1979).

Clarks $\left(41.2328^{\circ} \mathrm{N}, 97.8461^{\circ} \mathrm{W}\right)$-At Clarks, buildings rocked for nearly a minute. (Burchett, 1979).

Lincoln $\left(40.7893^{\circ} \mathrm{N}, 96.6938^{\circ} \mathrm{W}\right)$ - Two distinct shocks 10 seconds apart rocked buildings at Lincoln, and people reported 'sickening sensations.' However, no damage occurred. (Docekal, 1970).

Lincoln $\left(40.7893^{\circ} \mathrm{N}, 96.6938^{\circ} \mathrm{W}\right)$-Lincoln experienced 2 shocks 10 seconds apart which rocked buildings and people reported sickening sensations. (Burchett, 1979).

Minneapolis $\left(44.9835^{\circ} \mathrm{N}, 93.2683^{\circ} \mathrm{W}\right)$-Earthquake shocks were felt yesterday about noon throughout Nebraska, Dakota Territory, Western lowa and Kansas. Walls cracked, plastering fell and windows wee broken. (Minneapolis Tribune, 1877 Nov 16).

Boonesboro (Boone) $\left(42.0694^{\circ} \mathrm{N}, 93.8781^{\circ} \mathrm{W}\right)$-Felt. (Burchett, 1979).

Denison $\left(42.0196^{\circ} \mathrm{N}, 95.3636^{\circ} \mathrm{W}\right)$-Felt. (Burchett, 1979).

Dubuque $\left(42.5150^{\circ} \mathrm{N}, 90.6819^{\circ} \mathrm{W}\right)$-Felt. (Burchett, 1979$)$.

lowa City $\left(41.6549^{\circ} \mathrm{N}, 91.5112^{\circ} \mathrm{W}\right)$-Felt. (Burchett, 1979).

Logan $\left(41.6243^{\circ} \mathrm{N}, 95.7525^{\circ} \mathrm{W}\right)$-Felt. (Burchett, 1979).

Monticello $\left(42.2326^{\circ} \mathrm{N}, 91.1989^{\circ} \mathrm{W}\right)$-Felt. (Burchett, 1979).

Ogden $\left(42.0351^{\circ} \mathrm{N}, 94.0063^{\circ} \mathrm{W}\right)$-Felt. (Burchett, 1979).

Tabor $\left(40.9004^{\circ} \mathrm{N}, 95.6729^{\circ} \mathrm{W}\right)$-Felt. (Burchett, 1979).

Lawrence $\left(38.9644^{\circ} \mathrm{N}, 95.2418^{\circ} \mathrm{W}\right)$-Felt. (Burchett, 1979).

Albert Lea $\left(43.6537^{\circ} \mathrm{N}, 93.3707^{\circ} \mathrm{W}\right)$-Felt. (Burchett, 1979).

Winnebago City $\left(43.7755^{\circ} \mathrm{N}, 94.1632^{\circ} \mathrm{W}\right)$-Felt. (Burchett, 1979).

Camp Sheridan $\left(42.9968^{\circ} \mathrm{N}, 102.5545^{\circ} \mathrm{W}\right)$-Another [report] from 'Camp Sheridan', near the Nebraska-South Dakota line, is dated November 16, 1877. H.F. Reid (unpublished) considered these dates erroneous; his assessment of them is accepted in this study. (Docekal, 1970).

De Sota $\left(41.5454^{\circ} \mathrm{N}, 96.22^{\circ} \mathrm{W}\right)$-Felt. (Burchett, 1979).

Fort Hartsuff $\left(41.7228^{\circ} \mathrm{N}, 99.0228^{\circ} \mathrm{W}\right)$-Felt. (Burchett, 1979).

Fort McPherson $\left(41.0161^{\circ} \mathrm{N}, 100.5175^{\circ} \mathrm{W}\right)$-Felt. (Burchett, 1979).

Genoa $\left(41.4468^{\circ} \mathrm{N}, 97.764^{\circ} \mathrm{W}\right)$-Felt. (Burchett, 1979).

Grand Island $\left(40.9219^{\circ} \mathrm{N}, 98.3411^{\circ} \mathrm{W}\right)$-Felt. (Burchett, 1979).

Kearney Junction $\left(40.7136^{\circ} \mathrm{N}, 99.0779^{\circ} \mathrm{W}\right)$-Felt. (Burchett, 1979).

Plattsmouth $\left(40.9992^{\circ} \mathrm{N}, 95.9139^{\circ} \mathrm{W}\right)$-Felt. (Burchett, 1979).

Sutton $\left(40.6540^{\circ} \mathrm{N}, 97.8735^{\circ} \mathrm{W}\right)$-Felt. (Burchett, 1979).

Wisner $\left(41.9980^{\circ} \mathrm{N}, 96.917^{\circ} \mathrm{W}\right)$-Felt. (Burchett, 1979).

Fort Randall $\left(43.0244^{\circ} \mathrm{N}, 98.6239^{\circ} \mathrm{W}\right)$-The dispatches speak of it at Ft. Randall, 85 miles west. (Sioux Falls Pantograph, 1877 Nov 21 ).

Fort Randall $\left(43.0244^{\circ} \mathrm{N}, 98.6239^{\circ} \mathrm{W}\right)$-Felt. (Burchett, 1979). 


\section{Appendix 1, Part 10. Damage Reports and Intensity Assignments}

F SD Olivet $\left(43.2928^{\circ} \mathrm{N}, 97.7184^{\circ} \mathrm{W}\right)$-Felt. (Burchett, 1979).

F SD Springfield $\left(42.8687^{\circ} \mathrm{N}, 97.9288^{\circ} \mathrm{W}\right)$-Felt. (Burchett, 1979).

F WI La Crosse $\left(43.7989^{\circ} \mathrm{N}, 91.2175^{\circ} \mathrm{W}\right)$-Felt. (Burchett, 1979). 


\section{Appendix 1, Part 11. Damage Reports and Intensity Assignments}

\section{\#11 1878 Nov. 19 05:52UTC (Arkansas)}

6 AR Batesville $\left(35.7697^{\circ} \mathrm{N}, 91.6408^{\circ} \mathrm{W}\right)$-Awoke nearly every person, materially injured several of the stone brick buildings in town. (Street and Green, 1984).

AR Batesville $\left(35.7697^{\circ} \mathrm{N}, 91.6408^{\circ} \mathrm{W}\right)$-Several stone buildings were damaged in Stone County at Batesville, Ark. (Stover and Coffman, 1993).

Harrisburg $\left(35.5642^{\circ} \mathrm{N}, 90.7167^{\circ} \mathrm{W}\right)$-Tops of chimneys toppled off, and clocks stopped. (Street and Green, 1984).

AR Harrisburg $\left(35.5642^{\circ} \mathrm{N}, 90.7167^{\circ} \mathrm{W}\right)$ - The tops of chimneys were toppled on Poinsett County at Harrisburg, Ark. (Stover and Coffman, 1993).

Jacksonport $\left(35.6417^{\circ} \mathrm{N}, 91.3094^{\circ} \mathrm{W}\right)$-Shook houses and overturned furniture, caused the White river to overflow its banks. (Street and Green, 1984).

Memphis $\left(35.1494^{\circ} \mathrm{N}, 90.0489^{\circ} \mathrm{W}\right)$ - One aged brick building was cracked for several feet, broke a few glass windows; people left their beds and residences. (Street and Green, 1984).

Cairo $\left(37.0053^{\circ} \mathrm{N}, 89.1764^{\circ} \mathrm{W}\right)$ - Loose bricks fell from chimneys at Cairo, Ill. (Stover and Coffman, 1993).

IL

Cairo $\left(37.0053^{\circ} \mathrm{N}, 89.1764^{\circ} \mathrm{W}\right)$-A severe shock that aroused nearly all of the people. (Street and Green, 1984).

$5 \quad \mathrm{MO}$

$4 \quad \mathrm{AR}$

$4 \quad K Y$

Marianna $\left(34.7736^{\circ} \mathrm{N}, 90.7575^{\circ} \mathrm{W}\right)$-Severe shock that rattled windows and caused houses to tremble; created intense excitement. (Street and Green, 1984).

Columbus $\left(36.7597^{\circ} \mathrm{N}, 89.1033^{\circ} \mathrm{W}\right)$-Vigorously shaken up. (Street and Green, 1984).

Hickman $\left(36.5711^{\circ} \mathrm{N}, 89.1861^{\circ} \mathrm{W}\right)$-Some were frightened enough to leave their beds. (Street and Green, 1984).

Moscow $\left(36.6069^{\circ} \mathrm{N}, 89.0361^{\circ} \mathrm{W}\right)$-Vigorously shaken up. (Street and Green, 1984).

Charleston $\left(36.9208^{\circ} \mathrm{N}, 89.3506^{\circ} \mathrm{W}\right)$-A heavy shock that awakened nearly everybody in town. (Street and Green, 1984).

Glasgow $\left(39.2272^{\circ} \mathrm{N}, 92.8464^{\circ} \mathrm{W}\right)$-Awakened many. (Street and Green, 1984).

Ironton $\left(37.5972^{\circ} \mathrm{N}, 90.6272^{\circ} \mathrm{W}\right)$-Alarmed some. (Street and Green, 1984).

Lexington $\left(39.1847^{\circ} \mathrm{N}, 93.8797^{\circ} \mathrm{W}\right)$-Severe enough to awaken many (Street and Green, 1984).

Mountain View $\left(35.8683^{\circ} \mathrm{N}, 92.1175^{\circ} \mathrm{W}\right)$-Felt very perceptibly. (Street and Green, 1984).

Anna $\left(37.4603^{\circ} \mathrm{N}, 89.2469^{\circ} \mathrm{W}\right)$-Distinctly felt by some. (Street and Green, 1984).

Jonesboro $\left(37.4517^{\circ} \mathrm{N}, 89.2681^{\circ} \mathrm{W}\right)$-Distinctly felt by some. (Street and Green, 1984).

Saint Louis $\left(38.6272^{\circ} \mathrm{N}, 90.1978^{\circ} \mathrm{W}\right.$ ) -An earthquake was felt distinctly by those who happened to be awake. (Street and Green, 1984).

IL Du Quoin $\left(38.0114^{\circ} \mathrm{N}, 89.2361^{\circ} \mathrm{W}\right)$-A slight shock. (Street and Green, 1984).

IL Shawnee $\left(37.7499^{\circ} \mathrm{N}, 88.105^{\circ} \mathrm{W}\right)$-Felt by a few. (Street and Green, 1984).

KS Leavenworth $\left(39.3111^{\circ} \mathrm{N}, 94.9222^{\circ} \mathrm{W}\right)$-Felt, although not very distinct. (Street and Green, 1984).

AR Arkadelphia $\left(34.1208^{\circ} \mathrm{N}, 93.0536^{\circ} \mathrm{W}\right)$-Not felt. (Street and Green, 1984).

AR Clarksville $\left(35.4714^{\circ} \mathrm{N}, 93.4664^{\circ} \mathrm{W}\right)$-Not felt. (Street and Green, 1984).

AR Fayetteville $\left(36.0625^{\circ} \mathrm{N}, 94.1572^{\circ} \mathrm{W}\right)$-Not felt. (Street and Green, 1984).

$\mathrm{OH} \quad$ Cincinnati $\left(39.1619^{\circ} \mathrm{N}, 84.4569^{\circ} \mathrm{W}\right)$-Not felt. (Street and Green, 1984).

IL Robinson $\left(39.0053^{\circ} \mathrm{N}, 87.7392^{\circ} \mathrm{W}\right)$-Not reported. (Street and Green, 1984).

IL $\quad$ Salem $\left(38.6269^{\circ} \mathrm{N}, 88.9456^{\circ} \mathrm{W}\right)$-Not reported. (Street and Green, 1984).

KY Louisville $\left(38.2542^{\circ} \mathrm{N}, 85.7594^{\circ} \mathrm{W}\right)$-Not mentioned as being felt. (Street and Green, 1984).

KY Owensboro $\left(37.7742^{\circ} \mathrm{N}, 87.1133^{\circ} \mathrm{W}\right)$-Not mentioned as being felt locally. (Street and Green, 1984).

TN Jackson $\left(35.6144^{\circ} \mathrm{N}, 88.8139^{\circ} \mathrm{W}\right)$-Not reported. (Street and Green, 1984).

F AL Tuscaloosa $\left(33.2097^{\circ} \mathrm{N}, 87.5692^{\circ} \mathrm{W}\right)$-Felt. (Street and Green, 1984).

F AR Van Buren $\left(35.4367^{\circ} \mathrm{N}, 94.3481^{\circ} \mathrm{W}\right.$ )-Felt. (Street and Green, 1984).

F KY Paducah $\left(37.0833^{\circ} \mathrm{N}, 88.6^{\circ} \mathrm{W}\right)$-Felt. (Street and Green, 1984). 


\section{Appendix 1, Part 12. Damage Reports and Intensity Assignments}

\section{\#12 1882 Oct. 22 22:15 UTC (Oklahoma)}

6 AR Fort Smith $\left(35.3692^{\circ} \mathrm{N}, 94.4147^{\circ} \mathrm{W}\right)$ - “Ft. Smith reported three shocks which rattled furniture and crockery, rang bells and shook bricks from chimneys. ... Bricks were shaken loose from walls and chimneys at both Ft. Smith and Bonham.” (Carlson, 1984).

AR Fort Smith $\left(35.3692^{\circ} \mathrm{N}, 94.4147^{\circ} \mathrm{W}\right)$ - "The most severe damage was limited to the shaking of loose bricks from chimneys at Fort Smith, Ark. (northwest of Little Rock), and the knocking of bricks from the top of a wall at Bonham, Tex. (northeast of Dallas). Even though few felt reports were received from Oklahoma residents, ref. 342 [Carlson, S.M., 1984, Investigations of recent and historical seismicity in east Texas: The University of Texas at Austin, Master of Arts Thesis, 197p.] suggests that the epicenter is in southeast Oklahoma instead of northeast Texas. Felt over a wide area, including Arkansas, Kansas, Missouri, Oklahoma, and Texas. (Stover and Coffman, 1993).

AR Fort Smith $\left(35.3692^{\circ} \mathrm{N}, 94.4147^{\circ} \mathrm{W}\right)$ - "Houses were shaken at Fort Smith, Ark. It was difficult to obtain the probable epicenter because of insufficient reports from the region most affected." (Coffman and von Hake, 1973).

Bonham $\left(33.5559^{\circ} \mathrm{N}, 96.1994^{\circ} \mathrm{W}\right)$ - "At Bonham, loose bricks were shaken from the top of a wall. ... Bricks were shaken loose from walls and chimneys at both Ft. Smith and Bonham." (Carlson, 1984).

TX Bonham $\left(33.5559^{\circ} \mathrm{N}, 96.1994^{\circ} \mathrm{W}\right)$ - "The most severe damage was limited to the shaking of loose bricks from chimneys at Fort Smith, Ark. (northwest of Little Rock), and the knocking of bricks from the top of a wall at Bonham, Tex. (northeast of Dallas). Even though few felt reports were received from Oklahoma residents, ref. 342 suggests that the epicenter is in southeast Oklahoma instead of northeast Texas. Felt over a wide area, including Arkansas, Kansas, Missouri, Oklahoma, and Texas. (Stover and Coffman, 1993).

Bonham $\left(33.5559^{\circ} \mathrm{N}, 96.1994^{\circ} \mathrm{W}\right)$ - “Loose bricks were shaken from the top of a wall at Bonham.” (Docekal, 1970).

Sherman $\left(33.6419^{\circ} \mathrm{N}, 96.6092^{\circ} \mathrm{W}\right)$ - "Both the MWR [Monthly Weather Review] and Docekal [1970] mention that a bell rang on an engine and cotton bales swayed at Compress, Texas. This is a misinterpretation of a report published in the Dallas Weekly Herald (October 26, 1882) which described how the earthquake was felt in Sherman, $80 \mathrm{~km}$ north of Dallas. The article states: 'At the compress it was more plainly observed than at any other point, the movement being so violent that it rang the call-bell on the engine and cotton bales on the platform were seen to sway north and south.' Evidently the compress being described was a factory or machine for baling cotton in Sherman and not a separate city as reported by the MWR. The report from Sherman also states that at the Eagle mills, machinery was seen to vibrate and belts creaked as if the engine was being started." (Carlson, 1984).

TX

5 AR

5 TX

\section{TX}

$4 \mathrm{KS}$

KS

$3 \mathrm{AR}$

$3 \mathrm{KS}$

KS

$3 \mathrm{MO}$

$$
\text { MO }
$$

$2 \mathrm{AR}$

0 TX

N TX

F AR

AR

F KS

F $\quad \mathrm{MO}$

F TX

Sherman $\left(33.6419^{\circ} \mathrm{N}, 96.6092^{\circ} \mathrm{W}\right)$ - "At Sherman, Tex., heavy machinery vibrated, bricks were thrown from chimneys, and movable objects overturned." (Coffman and von Hake, 1973).

Fayetteville $\left(36.0655^{\circ} \mathrm{N}, 94.1557^{\circ} \mathrm{W}\right)$ - "At Fayetteville the vibrations threw bottles from shelves. ... Objects were thrown from shelves and off walls at both Fayetteville and Paris." (Carlson, 1984).

Paris $\left(33.6630^{\circ} \mathrm{N}, 95.5442^{\circ} \mathrm{W}\right.$ ) - "Docekal assigned the epicenter of the earthquake to Paris based on an account of a wall being thrown down. However, the MWR [Monthly Weather Review] (1882), as well as newspaper accounts such as the Galveston Daily News (October 24, 1882) state that a clock was thrown from the side of a wall at Paris. ... Objects were thrown from shelves and off walls at both Fayetteville and Paris." (Carlson, 1984).

Paris $\left(33.6630^{\circ} \mathrm{N}, 95.5442^{\circ} \mathrm{W}\right)$-Felt. (Rockwood, 1883).

Wichita $\left(37.6854^{\circ} \mathrm{N}, 97.3357^{\circ} \mathrm{W}\right)$ - “At Wichita, windows rattled, walls swayed and furniture moved." (Carlson, 1984). Wichita $\left(37.6854^{\circ} \mathrm{N}, 97.3357^{\circ} \mathrm{W}\right)$-Felt. (Rockwood, 1883).

Mount Ida $\left(34.5366^{\circ} \mathrm{N}, 93.6739^{\circ} \mathrm{W}\right)$ - “A distinct shock accompanied by a rumbling was felt.” (Carlson, 1984).

Leavenworth $\left(39.2757^{\circ} \mathrm{N}, 94.9902^{\circ} \mathrm{W}\right)$ - “At Leavenworth, three shocks were felt which rattled windows and shook chandeliers." (Carlson, 1984).

Leavenworth $\left(39.2757^{\circ} \mathrm{N}, 94.9902^{\circ} \mathrm{W}\right)$-Felt. (Rockwood, 1883).

Warrenton $\left(38.7863^{\circ} \mathrm{N}, 91.239^{\circ} \mathrm{W}\right)$ - “At Warrenton, ... windows rattled. The report from Warrenton is the furthest from the purported epicenter, being over 800 km northeast of Paris." (Carlson, 1984).

Warrenton $\left(38.7863^{\circ} \mathrm{N}, 91.239^{\circ} \mathrm{W}\right)-\mathrm{A}$ light shock. (Rockwood, 1883).

Rogers $\left(36.3333^{\circ} \mathrm{N}, 94.1097^{\circ} \mathrm{W}\right)$ - “Rogers reported a slight shock.” (Carlson, 1984).

Clarksville $\left(33.6413^{\circ} \mathrm{N}, 94.9863^{\circ} \mathrm{W}\right)$ - "The earthquake was apparently not felt in Clarksville, $40 \mathrm{~km}$ east of Paris, and in fact, the Clarksville Standard (October 27, 1882) took a whimsical approach to the issue: 'Nothing less than a first-class city is entitled to an earthquake, in this region, where earthquakes are scarce. We wish it distinctly understood that one-hors towns like Clarksville set up no claims to this sort of eminence."' (Carlson, 1984).

Dallas $\left(32.7870^{\circ} \mathrm{N}, 96.7983^{\circ} \mathrm{W}\right)$ - “The only report published in Dallas newspapers was the one written in Sherman; there was no mention of the event being felt in Dallas itself, only $80 \mathrm{~km}$ south of Sherman." (Carlson, 1984).

Little Rock $\left(34.7461^{\circ} \mathrm{N}, 92.2765^{\circ} \mathrm{W}\right)$ - “Little Rock felt two shocks.” (Carlson, 1984).

Little Rock $\left(34.7461^{\circ} \mathrm{N}, 92.2765^{\circ} \mathrm{W}\right)$-Felt. (Rockwood, 1883).

Wellington $\left(37.2655^{\circ} \mathrm{N}, 97.3992^{\circ} \mathrm{W}\right)$ - “Wellington reported feeling one shock." (Carlson, 1984).

Seligman $\left(36.5305^{\circ} \mathrm{N}, 93.9145^{\circ} \mathrm{W}\right.$ ) - "In Missouri, the earthquake was felt at Seligman (just across the border from Rogers, Arkansas)." (Carlson, 1984).

Greenville $\left(33.1334^{\circ} \mathrm{N}, 96.11^{\circ} \mathrm{W}\right)$-Felt. (Carlson, 1984). 


\section{Appendix 1, Part 12. Damage Reports and Intensity Assignments}

$\begin{array}{rrr} & \text { TX } & \text { Greenville }\left(33.1334^{\circ} \mathrm{N}, 96.11^{\circ} \mathrm{W}\right) \text {-Felt. (Rockwood, 1883). } \\ \text { F } & \text { TX } & \text { McKinney }\left(33.1975^{\circ} \mathrm{N}, 96.615^{\circ} \mathrm{W}\right) \text {-Felt. (Carlson, 1984). }\end{array}$ 


\section{Appendix 1, Part 13. Damage Reports and Intensity Assignments}

\section{\#13 1883 Jan. 11 07:12 UTC (Arkansas)}

6 KY Hopkinsville $\left(36.8656^{\circ} \mathrm{N}, 87.4886^{\circ} \mathrm{W}\right)$-Broke windows and threw things from mantelpieces. (Street and Green, 1984).

5 IL Cairo $\left(37.0053^{\circ} \mathrm{N}, 89.1764^{\circ} \mathrm{W}\right)$-Severe; many people in upper stories went to the streets. (Street and Green, 1984).

$5 \mathrm{KY}$ Paducah $\left(37.0833^{\circ} \mathrm{N}, 88.6^{\circ} \mathrm{W}\right)$-Severe; slightly cracked several brick walls and threw people from chairs. (Street and Green, 1984).

$5 \quad \mathrm{MO}$

Charleston $\left(36.9208^{\circ} \mathrm{N}, 89.3506^{\circ} \mathrm{W}\right.$ )-Aroused nearly all sleepers, turned a chair over and knocked books off shelves. (Street and Green, 1984).

IL $\quad$ Anna $\left(37.4603^{\circ} \mathrm{N}, 89.2469^{\circ} \mathrm{W}\right)$-Rattled windows. (Street and Green, 1984).

IL Jonesboro $\left(37.4517^{\circ} \mathrm{N}, 89.2681^{\circ} \mathrm{W}\right)$-Rattled buildings, windows, etc., in a lively manner. (Street and Green, 1984$)$.

IL Metropolis $\left(37.1511^{\circ} \mathrm{N}, 88.7319^{\circ} \mathrm{W}\right)$-Created general alarm. (Street and Green, 1984).

KY Crofton $\left(37.0478^{\circ} \mathrm{N}, 87.485^{\circ} \mathrm{W}\right)$-A severe shock was felt. (Street and Green, 1984).

KY Marion $\left(37.3328^{\circ} \mathrm{N}, 88.0811^{\circ} \mathrm{W}\right)$-Shook gas lights out, and aroused people from their slumbers. (Street and Green, 1984$)$.

MO Cape Girardeau $\left(37.3058^{\circ} \mathrm{N}, 89.5181^{\circ} \mathrm{W}\right)$-The citizens were aroused from their slumbers. (Street and Green, 1984).

MO Ironton $\left(37.5972^{\circ} \mathrm{N}, 90.6272^{\circ} \mathrm{W}\right)$-Rattled things up lively. (Street and Green, 1984).

MO Saint Marys $\left(37.8789^{\circ} \mathrm{N}, 89.9492^{\circ} \mathrm{W}\right)$-People were awakened from their slumbers. (Street and Green, 1984).

TN Jackson $\left(35.6144^{\circ} \mathrm{N}, 88.8139^{\circ} \mathrm{W}\right)$-Severe. (Street and Green, 1984).

IN Evansville $\left(37.9747^{\circ} \mathrm{N}, 87.5558^{\circ} \mathrm{W}\right)$-Felt by quite a few. (Street and Green, 1984).

Henderson $\left(37.8361^{\circ} \mathrm{N}, 87.59^{\circ} \mathrm{W}\right)$-Failed to awaken sleepers, but a number of citizens were aware of it. (Street and Green, 1984).

Saint Genevieve $\left(37.9814^{\circ} \mathrm{N}, 90.0417^{\circ} \mathrm{W}\right)$-One or two persons were awakened by the shock. (Street and Green, 1984).

Clarksville $\left(36.5297^{\circ} \mathrm{N}, 87.3594^{\circ} \mathrm{W}\right)$-Plainly felt. (Street and Green, 1984).

Milan $\left(35.9197^{\circ} \mathrm{N}, 88.7589^{\circ} \mathrm{W}\right)$-A slight shock was felt by a number of citizens. (Street and Green, 1984).

Princeton $\left(37.1092^{\circ} \mathrm{N}, 87.8819^{\circ} \mathrm{W}\right)$-Felt slightly. (Street and Green, 1984).

Perryville $\left(37.7242^{\circ} \mathrm{N}, 89.8611^{\circ} \mathrm{W}\right)$-A light shock was felt. (Street and Green, 1984).

Batesville $\left(35.7697^{\circ} \mathrm{N}, 91.6408^{\circ} \mathrm{W}\right)$-Not reported. (Street and Green, 1984).

Little Rock $\left(34.7464^{\circ} \mathrm{N}, 92.2894^{\circ} \mathrm{W}\right)$-Not reported. (Street and Green, 1984).

Osceola $\left(35.7050^{\circ} \mathrm{N}, 89.9694^{\circ} \mathrm{W}\right)$-Not reported. (Street and Green, 1984).

Belleville $\left(38.5200^{\circ} \mathrm{N}, 89.9839^{\circ} \mathrm{W}\right)$-Not reported. (Street and Green, 1984).

Champaign $\left(40.1164^{\circ} \mathrm{N}, 88.2433^{\circ} \mathrm{W}\right)$-Not reported. (Street and Green, 1984).

Chicago $\left(41.8500^{\circ} \mathrm{N}, 87.65^{\circ} \mathrm{W}\right)$-Not mentioned. (Street and Green, 1984).

Fairfield $\left(38.3789^{\circ} \mathrm{N}, 88.3597^{\circ} \mathrm{W}\right)$-Not reported. (Street and Green, 1984).

Paris $\left(39.6111^{\circ} \mathrm{N}, 87.6961^{\circ} \mathrm{W}\right)$-Not reported. (Street and Green, 1984).

IL

IN

KY

KY

MO

$\mathrm{MO}$

$\mathrm{OH}$

Robinson $\left(39.0053^{\circ} \mathrm{N}, 87.7392^{\circ} \mathrm{W}\right)$-Not mentioned. (Street and Green, 1984).

Cannelton $\left(37.9114^{\circ} \mathrm{N}, 86.7444^{\circ} \mathrm{W}\right)$-Not reported. (Street and Green, 1984).

Cloverport $\left(37.8333^{\circ} \mathrm{N}, 86.6328^{\circ} \mathrm{W}\right)$-Not reported. (Street and Green, 1984).

Louisville $\left(38.2542^{\circ} \mathrm{N}, 85.7594^{\circ} \mathrm{W}\right)$-Not mentioned. (Street and Green, 1984).

Bloomfield $\left(36.8858^{\circ} \mathrm{N}, 89.9292^{\circ} \mathrm{W}\right)$-Not reported. (Street and Green, 1984).

Hillsboro $\left(38.2322^{\circ} \mathrm{N}, 90.5628^{\circ} \mathrm{W}\right)$-Not reported. (Street and Green, 1984).

Cincinnati $\left(39.1619^{\circ} \mathrm{N}, 84.4569^{\circ} \mathrm{W}\right)$-Not mentioned. (Street and Green, 1984).

IL Mound City $\left(37.0853^{\circ} \mathrm{N}, 89.1625^{\circ} \mathrm{W}\right.$ )—Dashed small boats about on the river in a dangerous manner. (Street and Green, 1984).

IL Shawneetown $\left(37.7131^{\circ} \mathrm{N}, 88.1867^{\circ} \mathrm{W}\right)$-Felt. (Street and Green, 1984).

IL Shelbyville $\left(39.4064^{\circ} \mathrm{N}, 88.79^{\circ} \mathrm{W}\right)$-Felt. (Street and Green, 1984).

KY Hickman $\left(36.5711^{\circ} \mathrm{N}, 89.1861^{\circ} \mathrm{W}\right)$-Felt. (Street and Green, 1984).

F MO

F TN

F TN

Saint Louis $\left(38.6272^{\circ} \mathrm{N}, 90.1978^{\circ} \mathrm{W}\right)$-Felt tremor. (Street and Green, 1984).

Memphis $\left(35.1494^{\circ} \mathrm{N}, 90.0489^{\circ} \mathrm{W}\right)$-Felt. (Street and Green, 1984).

Nashville $\left(36.1658^{\circ} \mathrm{N}, 86.7844^{\circ} \mathrm{W}\right)$-Felt. (Street and Green, 1984). 


\section{Appendix 1, Part 14. Damage Reports and Intensity Assignments}

\section{\#14 1883 Dec. 5 15:20 UTC (Arkansas)}

5 AR Ravenden Springs $\left(36.3711^{\circ} \mathrm{N}, 91.2404^{\circ} \mathrm{W}\right)$-Broke glassware and crockery, loosened large rocks along a railroad cut for the Kansas City, Springfield and Memphis railroad line. (Street and Green, 1984).

5 AR Ravenden Springs $\left(36.3711^{\circ} \mathrm{N}, 91.2404^{\circ} \mathrm{W}\right)$-Broke glassware and crockery, loosened large rocks along a railroad cut for the Kansas City, Springfield and Memphis railroad line. (Street and Green, 1984).

5 AR Williford $\left(36.2187^{\circ} \mathrm{N}, 91.4^{\circ} \mathrm{W}\right)$-Sufficient to topple glassware from shelves, and to cause inhabitants to flee in terror. (Street and Green, 1984).

3 AR Evening Shade $\left(36.0939^{\circ} \mathrm{N}, 91.5798^{\circ} \mathrm{W}\right)$-Shook the houses, windows, stoves, for about 5 seconds. (Street and Green, 1984).

3 AR Melbourne $\left(36.0252^{\circ} \mathrm{N}, 92.0315^{\circ} \mathrm{W}\right)$-Distinctly heard and felt, shook houses. (Street and Green, 1984).

AR Melbourne $\left(36.0252^{\circ} \mathrm{N}, 92.0315^{\circ} \mathrm{W}\right)$-Buildings shook. (Coffman and von Hake, 1973).

AR Melbourne $\left(36.0252^{\circ} \mathrm{N}, 92.0315^{\circ} \mathrm{W}\right)$-Buildings shook at Melbourne. (Coffman and von Hake, 1973).

$2 \mathrm{AR}$

MO Osceola $\left(35.6793^{\circ} \mathrm{N}, 90.0546^{\circ} \mathrm{W}\right)$-A slight shock was felt here. (Street and Green, 1984).

AR

AR

AR

AR

AR

AR

$A R$

AR

IL

MO

Springfield $\left(37.1833^{\circ} \mathrm{N}, 93.3167^{\circ} \mathrm{W}\right)$-Not felt in Missouri. (Street and Green, 1984).

Arkadelphia $\left(34.1245^{\circ} \mathrm{N}, 93.0725^{\circ} \mathrm{W}\right)$-Not reported. (Street and Green, 1984).

Batesville $\left(35.7720^{\circ} \mathrm{N}, 91.6374^{\circ} \mathrm{W}\right)$-Not reported. (Street and Green, 1984).

Fayetteville $\left(36.0655^{\circ} \mathrm{N}, 94.1557^{\circ} \mathrm{W}\right)$-Not mentioned. (Street and Green, 1984).

Lead Hill $\left(36.4197^{\circ} \mathrm{N}, 92.9729^{\circ} \mathrm{W}\right)$-Not mentioned. (Street and Green, 1984).

Little Rock $\left(34.7461^{\circ} \mathrm{N}, 92.2765^{\circ} \mathrm{W}\right)$-Not mentioned. (Street and Green, 1984).

Pine Bluff $\left(34.2193^{\circ} \mathrm{N}, 92.0061^{\circ} \mathrm{W}\right)$-Not reported. (Street and Green, 1984).

Van Buren $\left(35.4441^{\circ} \mathrm{N}, 94.3428^{\circ} \mathrm{W}\right)$-Not reported. (Street and Green, 1984).

Washington $\left(33.7463^{\circ} \mathrm{N}, 93.7261^{\circ} \mathrm{W}\right)$-Not mentioned. (Street and Green, 1984).

Jonesboro $\left(37.4146^{\circ} \mathrm{N}, 89.3426^{\circ} \mathrm{W}\right)$-Not reported. (Street and Green, 1984).

Doniphan $\left(36.6579^{\circ} \mathrm{N}, 91.0956^{\circ} \mathrm{W}\right)$-Not mentioned. (Street and Green, 1984).

Kansas City $\left(39.0333^{\circ} \mathrm{N}, 94.55^{\circ} \mathrm{W}\right)$-Not mentioned. (Street and Green, 1984).

Noshow-Not mentioned. (Street and Green, 1984).

Memphis $\left(35.1167^{\circ} \mathrm{N}, 90.0833^{\circ} \mathrm{W}\right)$-Not mentioned. (Street and Green, 1984). 


\section{Appendix 1, Part 15. Damage Reports and Intensity Assignments}

\section{\#15 1884 Sept. 19 19:14 UTC (Ohlo)}

6 IN Muncie $\left(40.1933^{\circ} \mathrm{N}, 85.3864^{\circ} \mathrm{W}\right)$-Persons in upper stories fled to the streets; broke dishes and cracked glass windows. (Street and Green, 1984).

IN Muncie $\left(40.1933^{\circ} \mathrm{N}, 85.3864^{\circ} \mathrm{W}\right)$-Windows and dishes were broken at ... Muncie, Ind. (Stover and Coffman, 1993).

IN Muncie $\left(40.1738^{\circ} \mathrm{N}, 85.3819^{\circ} \mathrm{W}\right)$-Muncie, Delaware county: an earthquake shock was distinctly felt here at 2.30 p.m. on the 19th. It was accompanied by a loud rumbling sound, that caused buildings to shake. (Monthly Weather Review, 1884). Jackson $\left(42.2458^{\circ} \mathrm{N}, 84.4014^{\circ} \mathrm{W}\right)$-Shook buildings and shattered glass. (Street and Green, 1984).

$6 \mathrm{MI}$ Lansing $\left(42.7325^{\circ} \mathrm{N}, 84.5556^{\circ} \mathrm{W}\right)$-Shattered window panes in different parts of the city. (Street and Green, 1984).

$\mathrm{Ml}$ Lansing $\left(42.7325^{\circ} \mathrm{N}, 84.5556^{\circ} \mathrm{W}\right)$-Windows and dishes were broken at ... Lansing, Mich. (Stover and Coffman, 1993).

$\mathrm{Ml}$

Lansing $\left(42.7500^{\circ} \mathrm{N}, 84.5833^{\circ} \mathrm{W}\right)$ - Lansing, Ingham county: at about 3 p.m., on the 19 th, this city and vicinity were perceptibly shaken by an earthquake. The large capitol building trembled noticeably. (Monthly Weather Review, 1884). Lapeer $\left(43.0514^{\circ} \mathrm{N}, 83.3189^{\circ} \mathrm{W}\right)$-Broke window glass. (Street and Green, 1984).

Marshall $\left(42.2722^{\circ} \mathrm{N}, 84.9633^{\circ} \mathrm{W}\right)$-A perceptible shock of momentary duration was felt, no damage except for the breaking of glass. (Street and Green, 1984).

$6 \mathrm{OH}$ Defiance $\left(41.2844^{\circ} \mathrm{N}, 84.3558^{\circ} \mathrm{W}\right)$-People hastily abandoned their homes, glass was broken in a number of buildings. (Street and Green, 1984).

$\mathrm{OH}$ Defiance $\left(41.2844^{\circ} \mathrm{N}, 84.3558^{\circ} \mathrm{W}\right)$-Windows and dishes were broken at Defiance..., Ohio. (Stover and Coffman, 1993).

$\mathrm{OH}$ Defiance $\left(41.3033^{\circ} \mathrm{N}, 84.3544^{\circ} \mathrm{W}\right)$-Defiance, Defiance county: at a few minutes before 3 p.m. on the 19 th a perceptible shock of earthquake was felt at this place and in the surrounding country. (Monthly Weather Review, 1884).

Lima $\left(40.7425^{\circ} \mathrm{N}, 84.1053^{\circ} \mathrm{W}\right)$-Slight damage occurred at Lima, where the shock was 'of considerable violence and caused much excitement.' (Stover and Coffman, 1993).

$\mathrm{OH} \quad$ Lima $\left(40.7609^{\circ} \mathrm{N}, 84.071^{\circ} \mathrm{W}\right)$ - Lima, Allen county: the earthquake of the 19 th was felt about 3 p.m. It was of considerable violence, and caused much excitement. (Monthly Weather Review, 1884).

$\mathrm{OH}$

Lima $\left(40.7425^{\circ} \mathrm{N}, 84.1053^{\circ} \mathrm{W}\right)$-People were alarmed, doors swung shut. (Street and Green, 1984).

Zanesville $\left(39.9403^{\circ} \mathrm{N}, 82.0133^{\circ} \mathrm{W}\right)$-Residents rushed out of their homes in terror, in some of the houses plastering fell to the floor. (Street and Green, 1984).

$\mathrm{OH}$

Zanesville $\left(39.9403^{\circ} \mathrm{N}, 82.0133^{\circ} \mathrm{W}\right)$-Plaster was shaken from ceilings east ... of Columbus at Zanesville, Ohio. (Stover and Coffman, 1993).

Zanesville $\left(39.9495^{\circ} \mathrm{N}, 82.008^{\circ} \mathrm{W}\right)$-Zanesville, Muskingum county: at about 2.45 p.m. on the 19th, two earthquake shocks, lasting ten seconds, were distinctly felt. (Monthly Weather Review, 1884).

Dresden $\left(42.5900^{\circ} \mathrm{N}, 82.2^{\circ} \mathrm{W}\right)-\mathrm{A}$ distinct shock that rattled dishes and tossed furniture. (Street and Green, 1984).

ON

Dresden $\left(42.5833^{\circ} \mathrm{N}, 82.1833^{\circ} \mathrm{W}\right)$-Dresden: at 3.20 p.m., on the 19 th, a distinct shock of earthquake was felt at this place. (Monthly Weather Review, 1884).

London $\left(42.9900^{\circ} \mathrm{N}, 81.26^{\circ} \mathrm{W}\right)$ - A distinct shock that in some instances rattled dishes and tossed furniture. (Street and Green, 1984).

ON

London $\left(42.9833^{\circ} \mathrm{N}, 81.2333^{\circ} \mathrm{W}\right)$-London: a perceptible shock of earthquake was felt in this city at 3.25 p.m. on the 19 th. (Monthly Weather Review, 1884).

$6 \mathrm{ON}$

Windsor $\left(42.2900^{\circ} \mathrm{N}, 83.02^{\circ} \mathrm{W}\right)$ - It frightened the occupants and they ran outside; loosened small bits of plaster from ceilings. (Street and Green, 1984).

ON

Windsor $\left(42.3000^{\circ} \mathrm{N}, 83.0167^{\circ} \mathrm{W}\right)$-Windsor; quite a heavy shock of earthquake was experienced here at $2.45 \mathrm{p} . \mathrm{m}$. on the 19th. (Monthly Weather Review, 1884).

Parkersburg $\left(39.2659^{\circ} \mathrm{N}, 81.5367^{\circ} \mathrm{W}\right)$-Parkersburg, Wood county: an earthquake shock was distinctly felt for several seconds on the afternoon of the 19th. In the vicinity of the court-house the shock was sufficient to shake plaster from the ceilings. (Monthly Weather Review, 1884).

Parkersburg $\left(39.2667^{\circ} \mathrm{N}, 81.5617^{\circ} \mathrm{W}\right)$-Plaster was shaken from ceilings ... southeast of Columbus at ... Parkersburg, W. Va. (Stover and Coffman, 1993).

Anderson $\left(40.1053^{\circ} \mathrm{N}, 85.6803^{\circ} \mathrm{W}\right)$-People fled from their houses in fear. (Street and Green, 1984).

IN Angola $\left(41.6347^{\circ} \mathrm{N}, 84.9994^{\circ} \mathrm{W}\right)$-Three quite severe shocks were experienced. (Street and Green, 1984).

IN Beaver Dam $\left(41.0861^{\circ} \mathrm{N}, 86.0133^{\circ} \mathrm{W}\right)$-Broke glassware. (Street and Green, 1984).

Danville $\left(39.7606^{\circ} \mathrm{N}, 86.5264^{\circ} \mathrm{W}\right)$-Caused pictures on walls to swing back and forth, people rushed into the streets; broke chandeliers. (Street and Green, 1984).

Fort Wayne $\left(41.1306^{\circ} \mathrm{N}, 85.1289^{\circ} \mathrm{W}\right)$-Broke crockery and dishes, and in some instances people ran from buildings. (Street and Green, 1984).

IN

Fort Wayne $\left(41.1306^{\circ} \mathrm{N}, 85.1289^{\circ} \mathrm{W}\right)$-Windows and dishes were broken at ... Fort Wayne...,Ind. (Stover and Coffman, 1993).

IN Fort Wayne $\left(41.0667^{\circ} \mathrm{N}, 85.1667^{\circ} \mathrm{W}\right)$-Fort Wayne, Allen county: a slight shock of earthquake, lasting about twenty seconds, was felt about 3 p.m. on the 19th. It was more perceptibly felt in the larger buildings than in the smaller ones, and considerable alarm was caused among the pupils in the schools. (Monthly Weather Review, 1884). some jumped out of windows; loose articles were knocked over. (Street and Green, 1984). 


\section{Appendix 1, Part 15. Damage Reports and Intensity Assignments}

some jumped out of windows; loose articles were knocked over. (Street and Green, 1984).

IN

Lawrenceburg $\left(39.1551^{\circ} \mathrm{N}, 84.8762^{\circ} \mathrm{W}\right)$-Lawrenceburg, Dearborn county: shortly before 3 p.m., on the 19 th a severe shock of earthquake was felt at this place. The court-house, a massive stone building, was violently shaken, the chandeliers swaying back and forth for several seconds. The school building was more severely shaken than the court-house. In one of the rooms of the former a clock was thrown to the floor, and the teachers and pupils were frightened from the building. The duration of the shock is variously estimated at less than thirty seconds. (Monthly Weather Review, 1884).

$5 \quad \mathrm{IN}$

$5 \quad \mathrm{IN}$

5 MI

5 MI

MI

$5 \mathrm{Ml}$

$5 \quad \mathrm{Ml}$

MI

$5 \mathrm{MI}$

$5 \mathrm{Ml}$

$5 \mathrm{Ml}$

$5 \mathrm{MI}$

$5 \mathrm{OH}$

$5 \mathrm{OH}$

$\mathrm{OH}$

5

$\mathrm{OH}$

$\mathrm{OH}$

5

Michigan City $\left(41.7075^{\circ} \mathrm{N}, 86.895^{\circ} \mathrm{W}\right)$-Several houses and stores were vacated. (Street and Green, 1984).

South Bend $\left(41.6833^{\circ} \mathrm{N}, 86.25^{\circ} \mathrm{W}\right)$-Some people from upper floors rushed downstairs to the streets. (Street and Green, 1984).

Albion $\left(42.2832^{\circ} \mathrm{N}, 84.754^{\circ} \mathrm{W}\right)$-Furniture rolled about and dishes were thrown from shelves. (Street and Green, 1984$)$.

Ann Arbor $\left(42.2833^{\circ} \mathrm{N}, 83.7458^{\circ} \mathrm{W}\right)$-Quite a sensible shock, rang doorbells, pails of water slopped over, and school children frightened outdoors. (Street and Green, 1984).

Ann Arbor $\left(42.2328^{\circ} \mathrm{N}, 83.7015^{\circ} \mathrm{W}\right)$-Ann Arbor, Washtenaw county: an earthquake shock, lasting from five to eight seconds, occurred at 2.36 p.m. on the 19th. Building trembled, windows rattled, and chandeliers and tables were perceptibly shaken. The shock was also felt at Chelsea, in this county. (Monthly Weather Review, 1884).

Cambridge $\left(42.0589^{\circ} \mathrm{N}, 84.2211^{\circ} \mathrm{W}\right)$-Alarmed the neighborhood, knocked over small loose articles. (Street and Green, 1984).

East Saginaw-East Saginaw, Saginaw county: a distinct earthquake shock was felt at 2.35 p.m. (local time) on the 19th. Buildings were violently shaken, and furniture, etc., displaced; many persons were frightened from their houses and ran into the streets. (Monthly Weather Review, 1884).

East Saginaw-A distinct earthquake that rocked furniture; people rushed into the streets in fright. (Street and Green, 1984).

Hillsdale $\left(41.9200^{\circ} \mathrm{N}, 84.6306^{\circ} \mathrm{W}\right)$-Distinctly felt; houses trembled, dishes and stovepipes were shaken out of place. (Street and Green, 1984).

Hudson $\left(41.8550^{\circ} \mathrm{N}, 84.3539^{\circ} \mathrm{W}\right.$ )-Many people rushed out into the streets, rang doorbells and stopped clocks. (Street and Green, 1984).

Mason $\left(42.5792^{\circ} \mathrm{N}, 84.4436^{\circ} \mathrm{W}\right)$-Many people were frightened out of buildings. (Street and Green, 1984).

Saint Joseph $\left(42.1097^{\circ} \mathrm{N}, 86.48^{\circ} \mathrm{W}\right)$-Quite a severe shock was felt here. (Street and Green, 1984).

Caledonia $\left(40.6346^{\circ} \mathrm{N}, 82.9695^{\circ} \mathrm{W}\right)$-Caledonia, Marion county: the earthquake shock of the 19 th was felt at 2.45 p.m., and lasted about five seconds. Buildings were violently shaken. (Monthly Weather Review, 1884).

Cecil $\left(41.2186^{\circ} \mathrm{N}, 84.6022^{\circ} \mathrm{W}\right)$-A violent shock, a few instances of people rushing out of buildings, goods were thrown from shelves. (Street and Green, 1984).

Cecil $\left(41.2256^{\circ} \mathrm{N}, 84.5618^{\circ} \mathrm{W}\right)$-At Cecil, Paulding county: the goods in the stores were thrown from the shelving. (Monthly Weather Review, 1884).

Cleveland $\left(41.5000^{\circ} \mathrm{N}, 81.7^{\circ} \mathrm{W}\right)$-Cleveland: at $2.47 \mathrm{p} . \mathrm{m}$. (local time) on the $19 \mathrm{th}$, three distinct shocks of earthquake were felt. The direction of the vibrations was from west to east, the duration being about five seconds. The first was the most noticeable and of the longest duration. In some parts of the city the shocks were scarcely noticeable, while in others the disturbance was sufficient to displace furniture, etc., and to cause chandeliers to vibrate. (Monthly Weather Review, 1884).

Cleveland $\left(41.4994^{\circ} \mathrm{N}, 81.6956^{\circ} \mathrm{W}\right)-\mathrm{A}$ distinct shock was felt, caused much consternation among those on upper floors. (Street and Green, 1984).

Clifton $\left(39.7959^{\circ} \mathrm{N}, 83.8251^{\circ} \mathrm{W}\right)$-Cincinnati: two distinct shocks of earthquake were felt in this city at $2.37 \mathrm{p} . \mathrm{m}$. (local time) of the 19th. The vibrations were most perceptible in tall buildings and on the neighboring hills, the motion being apparently from south to north, and lasting from two to three seconds. In some of the suburbs the shock was more severe than in the city. In Clifton the disturbance caused the door-bells to ring. At Cumminsville, the shock caused considerable alarm. (Monthly Weather Review, 1884).

Cumminsville $\left(39.1000^{\circ} \mathrm{N}, 84.53^{\circ} \mathrm{W}\right)$-Cincinnati: two distinct shocks of earthquake were felt in this city at 2.37 p.m. (local time) of the 19th. The vibrations were most perceptible in tall buildings and on the neighboring hills, the motion being apparently from south to north, and lasting from two to three seconds. In some of the suburbs the shock was more severe than in the city. In Clifton the disturbance caused the door-bells to ring. At Cumminsville, the shock caused considerable alarm. (Monthly Weather Review, 1884).

Dupont $\left(41.0564^{\circ} \mathrm{N}, 84.3045^{\circ} \mathrm{W}\right)$-Knocked down crockery. (Street and Green, 1984).

Elyria $\left(41.3683^{\circ} \mathrm{N}, 82.1078^{\circ} \mathrm{W}\right)$-Moved furniture out of place. (Street and Green, 1984).

Fostoria $\left(41.1569^{\circ} \mathrm{N}, 83.4169^{\circ} \mathrm{W}\right)$-Shook jars off drug store shelves. (Street and Green, 1984).

Fostoria $\left(41.1696^{\circ} \mathrm{N}, 83.3998^{\circ} \mathrm{W}\right)$-Fostoria, Seneca county: a slight earthquake shock was felt at $2.19 \mathrm{p} . \mathrm{m}$. on the 19 th. (Monthly Weather Review, 1884).

Granville $\left(40.0681^{\circ} \mathrm{N}, 82.5197^{\circ} \mathrm{W}\right)$-People deserted their homes. (Street and Green, 1984).

Holgate $\left(41.2489^{\circ} \mathrm{N}, 84.1331^{\circ} \mathrm{W}\right)$-Stopped clocks. (Street and Green, 1984).

London $\left(39.8864^{\circ} \mathrm{N}, 83.4483^{\circ} \mathrm{W}\right.$ ) - Caused general alarm, some people ran out of their houses. (Street and Green, 1984).

Marysville $\left(40.2364^{\circ} \mathrm{N}, 83.3672^{\circ} \mathrm{W}\right)$-Teachers and children made a hasty exit from the school, others were badly frightened. (Street and Green, 1984). 


\section{Appendix 1, Part 15. Damage Reports and Intensity Assignments}

$5 \mathrm{OH}$

$\mathrm{OH}$

$5 \mathrm{OH}$

$\mathrm{OH}$

$5 \mathrm{OH}$

$\mathrm{OH}$

$5 \mathrm{OH}$

$\mathrm{OH}$

$5 \mathrm{OH}$

$\mathrm{OH}$

$5 \mathrm{OH}$

$\mathrm{OH}$

$5 \mathrm{OH}$

$5 \mathrm{OH}$

$5 \mathrm{OH}$

$5 \mathrm{OH}$

$5 \mathrm{OH}$

$\mathrm{OH}$

$5 \mathrm{OH}$

$\mathrm{OH}$

$5 \mathrm{OH}$

$\mathrm{OH}$

$5 \mathrm{OH}$

$\mathrm{OH}$

$5 \mathrm{OH}$

$5 \mathrm{OH}$

5 WV

WV

WV

$4 \quad$ IN

IN

4 IN

Massillon $\left(40.8053^{\circ} \mathrm{N}, 81.5187^{\circ} \mathrm{W}\right)$-Massillon, Stark county: an earthquake shock occurred at about 3.15 p.m. on the 19 th. It was most distinctly felt in the larger buildings; in some instances considerable alarm was caused. (Monthly Weather Review, 1884).

Massillon $\left(40.8053^{\circ} \mathrm{N}, 81.5187^{\circ} \mathrm{W}\right)$-Felt. (Street and Green, 1984).

Millersburg $\left(40.5427^{\circ} \mathrm{N}, 81.867^{\circ} \mathrm{W}\right)$-Millersburg, Holmes county: much excitement was caused by the earthquake shock which occurred at 3 p.m. on the 19th. Windows rattled, and crockery, etc., were shaken from their places. (Monthly Weather Review, 1884).

Millersburg $\left(40.5544^{\circ} \mathrm{N}, 81.9181^{\circ} \mathrm{W}\right)$-Felt. (Street and Green, 1984).

Mount Gilead $\left(40.5492^{\circ} \mathrm{N}, 82.8275^{\circ} \mathrm{W}\right)$-Caused minor cracks in brick work in a few instances, books and glassware fell to the floor, hundreds of people flocked to the street. (Street and Green, 1984).

Mount Gilead $\left(40.5627^{\circ} \mathrm{N}, 82.7673^{\circ} \mathrm{W}\right)$-Mount Gilead, Morrow county: three distinct earthquake shocks occurred on the afternoon of the 19th. (Monthly Weather Review, 1884).

Mount Vernon $\left(40.3673^{\circ} \mathrm{N}, 82.4985^{\circ} \mathrm{W}\right)$-Mount Vernon, Knox county: at 3.20 p.m. an earthquake shock, lasting about ten seconds, was distinctly felt. The shock was much stronger in the northern part of the town, and caused considerable alarm among the pupils at the Union school building. (Monthly Weather Review, 1884).

Mount Vernon $\left(40.3933^{\circ} \mathrm{N}, 82.4858^{\circ} \mathrm{W}\right)$-Quite severe, no damage was done, quite visibly affected moveable household goods. (Street and Green, 1984).

Newark $\left(40.0581^{\circ} \mathrm{N}, 82.4014^{\circ} \mathrm{W}\right)-\mathrm{A}$ terrible earthquake that caused alarm and moved chairs. (Street and Green, 1984).

Newark $\left(40.0753^{\circ} \mathrm{N}, 82.3872^{\circ} \mathrm{W}\right)$-Newark, Licking county: at 2.42 p.m. (local time), on the 19 th, several earthquake shocks of considerable violence were felt here. (Monthly Weather Review, 1884).

Norwalk $\left(41.2425^{\circ} \mathrm{N}, 82.6158^{\circ} \mathrm{W}\right)$-Quite a number of people were so frightened they ran out into the street, dishes were broken in the cupboards. (Street and Green, 1984).

Norwalk $\left(41.2425^{\circ} \mathrm{N}, 82.6158^{\circ} \mathrm{W}\right)$-Windows and dishes were broken at ... Norwalk, Ohio. (Stover and Coffman, 1993).

Pataskala $\left(39.9956^{\circ} \mathrm{N}, 82.6744^{\circ} \mathrm{W}\right)$-People deserted their homes. (Street and Green, 1984).

Prospect $\left(40.4503^{\circ} \mathrm{N}, 83.1886^{\circ} \mathrm{W}\right)$-Severe enough that a number of people ran out of their houses. (Street and Green, 1984).

Sandusky $\left(41.4489^{\circ} \mathrm{N}, 82.7081^{\circ} \mathrm{W}\right)$-Rattled tinware, shook houses, and some people ran into their yards. (Street and Green, 1984).

Springfield $\left(39.9242^{\circ} \mathrm{N}, 83.8089^{\circ} \mathrm{W}\right)$-Moved chairs and tables, in one or two instances people ran out into the streets. (Street and Green, 1984).

Tiffin $\left(41.1144^{\circ} \mathrm{N}, 83.1781^{\circ} \mathrm{W}\right)$-Broke crockery, upset vases and clocks. (Street and Green, 1984).

Tiffin $\left(41.1274^{\circ} \mathrm{N}, 83.174^{\circ} \mathrm{W}\right)$-Tiffin, Seneca county: a slight shock of earthquake was felt in the southern part of this town at 2.45 p.m. on the 19th. (Monthly Weather Review, 1884).

Toledo $\left(41.6639^{\circ} \mathrm{N}, 83.5553^{\circ} \mathrm{W}\right)$-Threw mirrors, bottles, etc. to the floor in the residential sections; people all over town rushed into the streets. (Street and Green, 1984).

Toledo $\left(41.6667^{\circ} \mathrm{N}, 83.5^{\circ} \mathrm{W}\right)-$ Toledo: an earthquake shock lasting fifteen seconds was distinctly felt at $2.42 \mathrm{p} . \mathrm{m}$. (local time), on the 19th. (Monthly Weather Review, 1884).

Troy $\left(40.0394^{\circ} \mathrm{N}, 84.2033^{\circ} \mathrm{W}\right)$-Distinct shocks, occupants of the courthouse left in haste. (Street and Green, 1984).

Troy $\left(40.0351^{\circ} \mathrm{N}, 84.2067^{\circ} \mathrm{W}\right)$-Troy, Miami county: at 2.40 p.m. on the 19 th two distinct shocks of earthquake were felt here. The shocks were most noticeable in the upper stories of buildings, being unnoticed by many persons on the streets. (Monthly Weather Review, 1884).

Urbana $\left(40.1137^{\circ} \mathrm{N}, 83.7786^{\circ} \mathrm{W}\right)$-Urbana, Champaign county: at about $3.30 \mathrm{p} . \mathrm{m}$. on the 19th an earthquake shock was sensibly felt at this place. Buildings were considerably shaken and furniture, etc., displaced. (Monthly Weather Review, 1884).

Urbana $\left(40.1083^{\circ} \mathrm{N}, 83.7525^{\circ} \mathrm{W}\right)$-Furniture was displaced and buildings were heavily shaken at Urbana, Ohio, in Champaign county, and at many other towns in the region. (Stover and Coffman, 1993).

West Liberty $\left(40.2522^{\circ} \mathrm{N}, 83.7558^{\circ} \mathrm{W}\right)$ - Many occupants of buildings rushed out into the streets. (Street and Green, 1984).

Wooster $\left(40.8050^{\circ} \mathrm{N}, 81.9353^{\circ} \mathrm{W}\right)$ - Raised considerable excitement, construction workers sought the ground throughout the city. (Street and Green, 1984).

Wheeling $\left(40.0639^{\circ} \mathrm{N}, 80.7211^{\circ} \mathrm{W}\right)$-Created intense excitement; in some parts of the city, people ran into the streets; broke crockery and glassware. (Street and Green, 1984).

Wheeling $\left(40.0639^{\circ} \mathrm{N}, 80.7211^{\circ} \mathrm{W}\right)$-Windows and dishes were broken at ... Wheeling, W. Va. (Stover and Coffman, 1993).

Wheeling $\left(40.0740^{\circ} \mathrm{N}, 80.6526^{\circ} \mathrm{W}\right)$-Wheeling: a slight earthquake shock was felt here at about $2.30 \mathrm{p} . \mathrm{m}$. on the 19 th. (Monthly Weather Review, 1884).

Auburn $\left(41.3669^{\circ} \mathrm{N}, 85.0589^{\circ} \mathrm{W}\right)-\mathrm{A}$ heavy shock that caused much excitement, no damage was done, a few people left buildings. (Street and Green, 1984).

Auburn $\left(41.3404^{\circ} \mathrm{N}, 85.0377^{\circ} \mathrm{W}\right)$-Auburn, De Kalb county: quite a heavy shock of earthquake was felt here at $2.15 \mathrm{p} . \mathrm{m}$. on the 19th. Buildings were perceptibly shaken from east to west; the shock lasted about ten seconds. (Monthly Weather Review, 1884).

Columbus $\left(39.2014^{\circ} \mathrm{N}, 85.9214^{\circ} \mathrm{W}\right)$-Rattled chandeliers, a few left buildings. (Street and Green, 1984). 


\section{Appendix 1, Part 15. Damage Reports and Intensity Assignments}

$4 \quad$ IN

$4 \quad \mathrm{IN}$

IN

$4 \quad \mathrm{IN}$

$4 \quad \mathrm{IN}$

4 IN

$4 \quad \mathrm{IN}$

4 IN

IN

4 IN

$$
\text { IN }
$$

4 MI

$$
\begin{aligned}
& \mathrm{Ml} \\
& \mathrm{Ml} \\
& \mathrm{Ml} \\
& \mathrm{MI} \\
& \mathrm{Ml} \\
& \mathrm{Ml}
\end{aligned}
$$

Connersville $\left(39.6331^{\circ} \mathrm{N}, 85.1699^{\circ} \mathrm{W}\right)$-Connersville, Fayettte county: about 2.45 p.m. on the 19 th a very distinct shock of earthquake was felt in this town. The oscillations continued ten seconds. Pictures, chandeliers, etc., were observed to swing back and forth. (Monthly Weather Review, 1884).

Indianapolis $\left(39.7500^{\circ} \mathrm{N}, 86.1667^{\circ} \mathrm{W}\right)$-Indianapolis: at $2.30 \mathrm{p} . \mathrm{m}$. (local time) on the 19 th, a slight shock of earthquake was felt in this city. The shock was most noticeable in the upper portions of high buildings. In one instance a chandelier was broken by the motion of the building. (Monthly Weather Review, 1884).

Indianapolis $\left(39.7683^{\circ} \mathrm{N}, 86.1581^{\circ} \mathrm{W}\right.$ )-Distinctly felt, a few people left buildings. (Street and Green, 1984). Ligonier $\left(41.4658^{\circ} \mathrm{N}, 85.5875^{\circ} \mathrm{W}\right)$-Rattled dishes and windows. (Street and Green, 1984).

Marion $\left(40.5583^{\circ} \mathrm{N}, 85.6592^{\circ} \mathrm{W}\right)$-Severe enough to cause many people to start for the streets. (Street and Green, 1984 ). Milan $\left(39.1266^{\circ} \mathrm{N}, 85.1566^{\circ} \mathrm{W}\right)$-Milan, Ripley county: quite a heavy shock of earthquake was felt here and at North Milan, two miles above this place, at about 2 p.m. on the 19th. It was also felt at Sunman in this county. (Monthly Weather Review, 1884).

Vevay $\left(38.7913^{\circ} \mathrm{N}, 85.0986^{\circ} \mathrm{W}\right)$ - The following communication has been received from Professor Boerner, of Vevay, Indiana:

VEVAY, IND., September 22, 1884

The CHIEF SIGNAL OFFICER U.S. ARMY, Washington, D.C.

Sir: I have the honor to transmit to you the report of an earthquake, and its attendant phenomena, as experienced at this station.

Sept. 19th, 2.30 p.m.: a moderate shock of earthquake was felt in this vicinity; while the vibration was not of great intensity, still, many of our people became highly alarmed. The shock was not very perceptible, beyond the rattling of windows and weights of window sashes inside their casings, the jarring of dishes in pantries, the oscillations oh hanging lamps; and many persons did not notice the disturbance at all. I have endeavored to obtain the experience of different persons: some lying on beds distinctly felt the tremor and hastily arose, in great fright, while others, walking on the streets, felt a sensation of unsteadiness. The direction of the disturbance was from north to south, with a duration of 3 seconds; it was preceded by a barometric depression of .09 inch and followed by an increased pressure of .02 inch.

Very respectfully, your obedient servant

CHAS. G. BOERNER, Observer (Monthly Weather Review, 1884).

Wabash $\left(40.7978^{\circ} \mathrm{N}, 85.8206^{\circ} \mathrm{W}\right)$-Badly frightened the people, but no serious damage. (Street and Green, 1984).

Wabash $\left(40.7780^{\circ} \mathrm{N}, 85.8437^{\circ} \mathrm{W}\right)$-Wabash, Wabash county: shortly before $3 \mathrm{p} . \mathrm{m}$., on the 19 th, quite a severe earthquake shock, lasting five seconds, was felt in this locality. (Monthly Weather Review, 1884).

Winchester $\left(40.1719^{\circ} \mathrm{N}, 84.9814^{\circ} \mathrm{W}\right)$-Windows and residents were badly shaken up. (Street and Green, 1984).

Winchester $\left(40.1690^{\circ} \mathrm{N}, 84.9904^{\circ} \mathrm{W}\right)$-Winchester, Randolph county: a car on a side track of the Grand Rapids and Indiana Railroad was set in motion by the disturbance. (Monthly Weather Review, 1884).

Adrian $\left(41.9041^{\circ} \mathrm{N}, 84.062^{\circ} \mathrm{W}\right)$-Adrian, Lenawee county: at 2.30 p.m. of the 19 th, a strong earthquake shock, lasting nearly one minute, was felt. It was preceded by a rumbling noise, and caused windows, furniture, etc., to rattle. (Monthly Weather Review, 1884). Adrian $\left(41.8975^{\circ} \mathrm{N}, 84.0372^{\circ} \mathrm{W}\right)-\mathrm{A}$ slight Shock. (Street and Green, 1984).

Bronson $\left(41.8722^{\circ} \mathrm{N}, 85.1947^{\circ} \mathrm{W}\right)$-Windows rattled and scholars were badly frightened. (Street and Green, 1984).

Charlotte $\left(42.5636^{\circ} \mathrm{N}, 84.8358^{\circ} \mathrm{W}\right)$-A number of inhabitants were badly frightened. (Street and Green, 1984).

Corunna $\left(42.9819^{\circ} \mathrm{N}, 84.1178^{\circ} \mathrm{W}\right)$-Caused great alarm. (Street and Green, 1984).

Detroit $\left(42.3314^{\circ} \mathrm{N}, 83.0458^{\circ} \mathrm{W}\right)$-Frightened many, occupants on upper floor ran to the streets. (Street and Green, 1984$)$.

Detroit $\left(42.3314^{\circ} \mathrm{N}, 83.0458^{\circ} \mathrm{W}\right)$-Detroit: at 2.41 p.m., (local time), of the 19 th, an earthquake shock was felt in all parts of this city. The duration of the shock was about twenty seconds. In some localities the shock was more perceptible than in others, being especially noticeable in the higher buildings. Captains of steamers state that there was a noticeable rise in the river at the time the shock occurred. (Monthly Weather Review, 1884).

Flint $\left(43.0125^{\circ} \mathrm{N}, 83.6875^{\circ} \mathrm{W}\right)$-Caused considerable commotion, but no damage was done. (Street and Green, 1984).

Grand Rapids $\left(42.9633^{\circ} \mathrm{N}, 85.6681^{\circ} \mathrm{W}\right.$ )-Woke sleeping people up, jarring chandeliers, scaring some, etc. (Street and Green, 1984).

Grass Lake $\left(42.2508^{\circ} \mathrm{N}, 84.2131^{\circ} \mathrm{W}\right)$-Frightened some. (Street and Green, 1984).

Grass Lake $\left(42.2795^{\circ} \mathrm{N}, 84.178^{\circ} \mathrm{W}\right)$-Grass lake, Jackson county: an earthquake shock was felt here on the afternoon of the 19th. (Monthly Weather Review, 1884).

Kalamazoo $\left(42.2917^{\circ} \mathrm{N}, 85.5872^{\circ} \mathrm{W}\right)$-Felt by many, rattled dishes in a few instances. (Street and Green, 1984).

Mount Clemens $\left(42.5776^{\circ} \mathrm{N}, 82.8941^{\circ} \mathrm{W}\right)$-The shock was quite perceptible, created considerable excitement. (Street and Green, 1984).

Niles $\left(41.8297^{\circ} \mathrm{N}, 86.2542^{\circ} \mathrm{W}\right)$-Shook houses, spilled water out of pails. (Street and Green, 1984).

Pinckney $\left(42.4567^{\circ} \mathrm{N}, 83.9464^{\circ} \mathrm{W}\right)$-Rattled crockery and perceptibly shook buildings. (Street and Green, 1984).

Plymouth $\left(46.4647^{\circ} \mathrm{N}, 89.9794^{\circ} \mathrm{W}\right)$-Jarred houses. (Street and Green, 1984).

Schoolcraft $\left(42.1142^{\circ} \mathrm{N}, 85.6378^{\circ} \mathrm{W}\right)$-Rattled dishes and shook houses. (Street and Green, 1984).

Sturgis $\left(41.7992^{\circ} \mathrm{N}, 85.4192^{\circ} \mathrm{W}\right)$-Jarred the windows. (Street and Green, 1984).

Vicksburg $\left(42.1200^{\circ} \mathrm{N}, 85.5328^{\circ} \mathrm{W}\right)$-Doors rattled and houses trembled. (Street and Green, 1984).

Ypsilanti $\left(42.2411^{\circ} \mathrm{N}, 83.6131^{\circ} \mathrm{W}\right)$-Floors trembled, windows rattled, but no damage was reported. (Street and Green, 1984). 


\section{Appendix 1, Part 15. Damage Reports and Intensity Assignments}

1984).

MI

$4 \mathrm{OH}$

$\mathrm{OH}$

$4 \mathrm{OH}$

$\mathrm{OH}$

$4 \mathrm{OH}$

$4 \mathrm{OH}$

$\mathrm{OH}$

$4 \mathrm{OH}$

$\mathrm{OH}$

$4 \mathrm{OH}$

$4 \mathrm{OH}$

$\mathrm{OH}$

$4 \mathrm{OH}$

$4 \mathrm{OH}$

$\mathrm{OH}$

$4 \mathrm{OH}$

$4 \mathrm{OH}$

$4 \mathrm{OH}$

$4 \mathrm{OH}$

$4 \mathrm{OH}$

$4 \mathrm{OH}$

$4 \mathrm{OH}$

$4 \mathrm{OH}$

$4 \mathrm{OH}$

$\mathrm{OH}$

$4 \mathrm{OH}$

4 PA

3 DC

$\mathrm{DC}$

3 IA

IA

3 IN

3 IN

IN

Ypsilanti $\left(42.2315^{\circ} \mathrm{N}, 83.6208^{\circ} \mathrm{W}\right)$ - Ypsilanti, Washtenaw county: a severe earthquake shock was felt here on the afternoon of the 19th. (Monthly Weather Review, 1884).

Akron $\left(41.0814^{\circ} \mathrm{N}, 81.5192^{\circ} \mathrm{W}\right)$-Felt by all. (Street and Green, 1984).

Akron $\left(41.0833^{\circ} \mathrm{N}, 81.5^{\circ} \mathrm{W}\right)$-Akron, Summit county: two distinct shocks of earthquake were felt here at $2.40 \mathrm{p} . \mathrm{m}$. on the 19th. (Monthly Weather Review, 1884).

Ansonia-Ansonia, Crawford county: at about 2.30 p.m. on the 19th, an earthquake shock occurred, which shook buildings violently. It was also felt at Crestline, in this county. (Monthly Weather Review, 1884).

Ansonia $\left(40.2191^{\circ} \mathrm{N}, 84.6464^{\circ} \mathrm{W}\right)$-Greenville, Darke county: the earthquake of the 19th was felt here about 4 p.m. and was generally observed. The shock was also felt at Ansonia, in this county. (Monthly Weather Review, 1884).

Arcadia $\left(41.1083^{\circ} \mathrm{N}, 83.5169^{\circ} \mathrm{W}\right)$-People were badly frightened, doors and windows rattled. (Street and Green, 1984).

Archbold $\left(41.5347^{\circ} \mathrm{N}, 84.301^{\circ} \mathrm{W}\right)$-Archbold, Fulton county: at 2.13 p.m. (standard time) on the 19th, an earthquake shock was felt, lasting about twenty seconds, and causing buildings to shake. (Monthly Weather Review, 1884).

Archbold $\left(41.5347^{\circ} \mathrm{N}, 84.301^{\circ} \mathrm{W}\right)$-Shook buildings, no damage. (Street and Green, 1984).

Bellefontaine $\left(40.3705^{\circ} \mathrm{N}, 83.7537^{\circ} \mathrm{W}\right)$-Bellefontaine, Logan county: a heavy shock of earthquake was felt here at 3 p.m. on the 19th. Three distinct vibrations were felt, accompanied by a heavy rumbling sound. (Monthly Weather Review, 1884).

Bellefontaine $\left(40.3611^{\circ} \mathrm{N}, 83.7597^{\circ} \mathrm{W}\right)$-Felt. (Street and Green, 1984).

Bluffton $\left(40.8953^{\circ} \mathrm{N}, 83.8889^{\circ} \mathrm{W}\right)$-Shook houses, rattled windows and doors, the people were badly frightened. (Street and Green, 1984).

Bryan $\left(41.4711^{\circ} \mathrm{N}, 84.5599^{\circ} \mathrm{W}\right)$-Bryan, Williams county: a few minutes before 3 p.m. on the 19th an earthquake shock, accompanied by a low, rumbling noise, occurred at this place. The shock lasted for several seconds. The larger buildings in the town were considerably shaken. (Monthly Weather Review, 1884).

Bryan $\left(41.4747^{\circ} \mathrm{N}, 84.5525^{\circ} \mathrm{W}\right)$-Felt. (Street and Green, 1984 ).

Clyde $\left(41.3042^{\circ} \mathrm{N}, 82.9753^{\circ} \mathrm{W}\right)$-Rattled windows and scared some. (Street and Green, 1984).

Dayton $\left(39.7500^{\circ} \mathrm{N}, 84.2^{\circ} \mathrm{W}\right)$-Dayton, Montgomery county: an earthquake shock occurred at about 3.30 p.m. on the 19 th; it was distinctly felt in buildings of two and three stories. A rumbling noise was heard throughout the city. (Monthly Weather Review, 1884).

Dayton $\left(39.7589^{\circ} \mathrm{N}, 84.1917^{\circ} \mathrm{W}\right)$-Distinctly felt in two and three-story buildings. (Street and Green, 1984).

Delphos $\left(40.8395^{\circ} \mathrm{N}, 84.3454^{\circ} \mathrm{W}\right)$-Employees left a large five-story manufacturing plant. (Street and Green, 1984).

Findlay $\left(41.0405^{\circ} \mathrm{N}, 83.6441^{\circ} \mathrm{W}\right)$-Findlay, Hancock county: a light earthquake shock occurred at $2.55 \mathrm{p} . \mathrm{m}$. on the 19 th. It continued about fifteen seconds, causing buildings to shake, and upsetting insecure articles. (Monthly Weather Review, 1884).

Glendale $\left(39.2706^{\circ} \mathrm{N}, 84.4594^{\circ} \mathrm{W}\right)$-Shook every loose thing up lively. (Street and Green, 1984).

Greenville $\left(40.0948^{\circ} \mathrm{N}, 84.6463^{\circ} \mathrm{W}\right)$-Greenville, Darke county: the earthquake of the 19th was felt here about 4 p.m. and was generally observed. The shock was also felt at Ansonia, in this county. (Monthly Weather Review, 1884).

Lancaster $\left(39.6979^{\circ} \mathrm{N}, 82.6126^{\circ} \mathrm{W}\right)$-Lancaster, Fairfield county: a very perceptible shock of earthquake was felt here and in the neighboring towns at about 3 p.m. on the 19th. (Monthly Weather Review, 1884).

Miamisburg $\left(39.6428^{\circ} \mathrm{N}, 84.2867^{\circ} \mathrm{W}\right)$-Plainly felt, windows were shaken, dishes and crockery rattled in cupboards. (Street and Green, 1984).

Monroeville $\left(41.2442^{\circ} \mathrm{N}, 82.6964^{\circ} \mathrm{W}\right)$-Startled quite a number of people. (Street and Green, 1984).

Moxahala $\left(39.6625^{\circ} \mathrm{N}, 82.1364^{\circ} \mathrm{W}\right)$-Buildings and contents were considerably shaken. (Street and Green, 1984).

Ottawa $\left(41.0192^{\circ} \mathrm{N}, 84.0472^{\circ} \mathrm{W}\right)$-Rattled tableware and almost caused a panic among the people. (Street and Green, 1984).

Ottawa $\left(41.0236^{\circ} \mathrm{N}, 84.0612^{\circ} \mathrm{W}\right)$-Ottawa, Putnam county: considerable excitement was caused by an earthquake shock at 3 p.m. on the 19th, it lasted nearly one minute. (Monthly Weather Review, 1884).

Paulding $\left(41.1270^{\circ} \mathrm{N}, 84.5617^{\circ} \mathrm{W}\right)$-Paulding county: at 2.15 p.m. on the 19 th, a severe earthquake shock was felt. (Monthly Weather Review, 1884).

Leetsdale $\left(40.5655^{\circ} \mathrm{N}, 80.2129^{\circ} \mathrm{W}\right)$-Leetsdale, Allegheny county: two shocks of earthquake were felt here at 2.35 p.m. on the 19th. They were sufficient to cause windows, crockery, etc., to rattle. (Monthly Weather Review, 1884).

Washington $\left(38.8000^{\circ} \mathrm{N}, 77.04^{\circ} \mathrm{W}\right)$-Felt in the upper floors of several buildings. (Street and Green, 1984).

Washington $\left(38.8000^{\circ} \mathrm{N}, 77.04^{\circ} \mathrm{W}\right)$-Also felt ... at Washington, D.C. by workmen on top of the unfinished Washington Monument. (Stover and Coffman, 1993).

Dubuque $\left(42.5053^{\circ} \mathrm{N}, 90.6983^{\circ} \mathrm{W}\right)$-Dubuque: an earthquake is reported to have been felt by the printers in the upper portion of the "Herald" office at 2.05 p.m. on the 19th. The building was perceptibly shaken. (Monthly Weather Review, 1884).

Dubuque $\left(42.5006^{\circ} \mathrm{N}, 90.6644^{\circ} \mathrm{W}\right)$-Felt by a few on upper floors. (Street and Green, 1984).

Albany $\left(40.2941^{\circ} \mathrm{N}, 85.2622^{\circ} \mathrm{W}\right)$-Albany, Delaware county: the earthquake on the 19th caused large buildings to shake very perceptibly. (Monthly Weather Review, 1884).

Elkhart $\left(41.6819^{\circ} \mathrm{N}, 85.9767^{\circ} \mathrm{W}\right)$-The swaying of the buildings was distinctly felt by those in upper stories. (Street and Green, 1984).

Elkhart $\left(41.7101^{\circ} \mathrm{N}, 85.9729^{\circ} \mathrm{W}\right)$-Elkhart, Elkhart county; an earthquake shock was distinctly felt here on the afternoon of the 19th. (Monthly Weather Review, 1884). 


\section{Appendix 1, Part 15. Damage Reports and Intensity Assignments}

the 19th. (Monthly Weather Review, 1884).

3 IN

$3 \quad \mathrm{IN}$

$3 \quad \mathrm{IN}$

$3 \quad \mathrm{IN}$

3 IN

$3 \quad \mathrm{IN}$

3 IN

3 IN

IN

3 IN

$3 \quad \mathrm{IN}$

$3 \mathrm{KY}$

$3 \mathrm{MI}$

3 MI

$3 \mathrm{MI}$

$3 \mathrm{MI}$

$3 \mathrm{OH}$

$3 \mathrm{OH}$

$\mathrm{OH}$

$3 \mathrm{OH}$

$\mathrm{OH}$

$3 \mathrm{OH}$

$\mathrm{OH}$

$3 \mathrm{OH}$

$3 \mathrm{OH}$

$3 \mathrm{OH}$

$3 \mathrm{OH}$

$3 \mathrm{OH}$

$3 \mathrm{OH}$

$3 \mathrm{OH}$

$3 \mathrm{OH}$

Greenfield $\left(39.8012^{\circ} \mathrm{N}, 85.7647^{\circ} \mathrm{W}\right)$-Greenfield, Hancock county: a slight earthquake shock was felt throughout this county at 2.20 p.m. on the 19th. (Monthly Weather Review, 1884).

Greensburg $\left(39.3259^{\circ} \mathrm{N}, 85.4737^{\circ} \mathrm{W}\right)$-Greensburg, Decatur county: at about 2:30 p.m. on the 29th [sic], a slight earthquake was felt here. It was more distinctly felt by persons inside of buildings; there were three separate shocks following in quick succession and lasting for several seconds. (Monthly Weather Review, 1884).

Hagerstown $\left(39.9361^{\circ} \mathrm{N}, 85.1597^{\circ} \mathrm{W}\right)$-Hagerstown, Wayne county: a light, but very perceptible earthquake shock was felt in this vicinity on the afternoon of the 19th. It was also sensibly felt at Rushville in Rush county. (Monthly Weather Review, 1884).

Kokomo $\left(40.4864^{\circ} \mathrm{N}, 86.1336^{\circ} \mathrm{W}\right)$-Felt, but not recognized as an earthquake; felt like a heavy wagon going by. (Street and Green, 1984).

Liberty $\left(39.6231^{\circ} \mathrm{N}, 84.9168^{\circ} \mathrm{W}\right)$-Liberty, Union county: at 2.22 p.m. on the 19 th two earthquake shocks, lasting several minutes, were felt here. (Monthly Weather Review, 1884).

Madison $\left(38.7358^{\circ} \mathrm{N}, 85.38^{\circ} \mathrm{W}\right)-\mathrm{A}$ distinct shock. (Street and Green, 1984).

Metamora $\left(39.4231^{\circ} \mathrm{N}, 85.1394^{\circ} \mathrm{W}\right)$-Metamora, Franklin county: at 2.15 p.m. (standard time) on the 19 th a perceptible shaking of the earth, accompanied by a rumbling noise, was felt in this vicinity. (Monthly Weather Review, 1884).

Richmond $\left(39.8289^{\circ} \mathrm{N}, 84.8903^{\circ} \mathrm{W}\right)$-A rocking sensation that was noticeable. (Street and Green, 1984).

Richmond $\left(39.8327^{\circ} \mathrm{N}, 84.8925^{\circ} \mathrm{W}\right)$-Richmond, Wayne county: the earthquake on the afternoon of the 19th was noticeable throughout the town. (Monthly Weather Review, 1884).

Rushville $\left(39.6047^{\circ} \mathrm{N}, 85.4282^{\circ} \mathrm{W}\right)$ - Hagerstown, Wayne county: a light, but very perceptible earthquake shock was felt in this vicinity on the afternoon of the 19th. It was also sensibly felt at Rushville in Rush county. (Monthly Weather Review, 1884).

Shelbyville $\left(39.5244^{\circ} \mathrm{N}, 85.7821^{\circ} \mathrm{W}\right)$-Shelbyville, Shelby county; at $2.15 \mathrm{p} . \mathrm{m}$. (central standard time), on the 19 th, a slight shock of earthquake was felt here. The tremor was most noticeable in the upper stories of buildings, and was scarcely noticed by pedestrians. The duration of the shock was about three seconds. (Monthly Weather Review, 1884).

Augusta $\left(38.7717^{\circ} \mathrm{N}, 84.0058^{\circ} \mathrm{W}\right)$-Felt by several citizens who mentioned it at the time. (Street and Green, 1984).

Eaton Rapids $\left(42.5092^{\circ} \mathrm{N}, 84.6558^{\circ} \mathrm{W}\right)$-A slight shock - caused some excitement. (Street and Green, 1984).

Howell $\left(42.6072^{\circ} \mathrm{N}, 83.9294^{\circ} \mathrm{W}\right)$-Startled the city, shook buildings, lasted ten seconds. (Street and Green, 1984).

Monroe $\left(41.9164^{\circ} \mathrm{N}, 83.3978^{\circ} \mathrm{W}\right)$-Plainly felt. (Street and Green, 1984).

Thornville $\left(42.9425^{\circ} \mathrm{N}, 83.2239^{\circ} \mathrm{W}\right)$-Thornville, Lapeer county: two distinct earthquake shocks occurred on the afternoon of the 19th, the motion being from north to south. (Monthly Weather Review, 1884).

Avon $\left(41.4517^{\circ} \mathrm{N}, 82.0356^{\circ} \mathrm{W}\right)$-Felt two distinct shocks resembling those of an earthquake. (Street and Green, 1984).

Canton $\left(40.7989^{\circ} \mathrm{N}, 81.3786^{\circ} \mathrm{W}\right)$-Felt by some, but many did not feel it. (Street and Green, 1984).

Canton $\left(40.8333^{\circ} \mathrm{N}, 81.3667^{\circ} \mathrm{W}\right)$-Canton, Stark county: a few minutes before 3 p.m. on the afternoon of the 19 th, a slight shock of earthquake was felt. The walls of several buildings moved perceptibly. (Monthly Weather Review, 1884).

Columbus $\left(40.1009^{\circ} \mathrm{N}, 83.0359^{\circ} \mathrm{W}\right)$-Columbus: the Signal Service observer reports tat at 2.42 p.m. (local time) of the 19 th, an earthquake occurred. Chandeliers were observed to sway from north to south, the motion continuing for at least two minutes after the occurrence of the shock. It was most noticeable in the upper stories of the larger buildings, and many persons in the streets at the time the shock occurred did not notice it. Some observers state that a rumbling noise preceded the shock. (Monthly Weather Review, 1884).

Columbus $\left(39.9611^{\circ} \mathrm{N}, 82.9989^{\circ} \mathrm{W}\right)$-Not sufficient power to seriously disturb any person or property. (Street and Green, 1984).

Coshocton $\left(40.2719^{\circ} \mathrm{N}, 81.8597^{\circ} \mathrm{W}\right)$-Buildings were shaken slightly. (Street and Green, 1984).

Coshocton $\left(40.2836^{\circ} \mathrm{N}, 81.8923^{\circ} \mathrm{W}\right)$-Coshocton, Coshocton county: on the 19th at 2.15 p.m. (standard time), a distinct shock of earthquake was felt. The vibrations were quite perceptible in several large buildings. (Monthly Weather Review, 1884).

Cumberland $\left(39.8512^{\circ} \mathrm{N}, 81.6502^{\circ} \mathrm{W}\right)$-Cumberland, Guernsey county: at about 4 p.m. on the 19 th, a distinct shock of earthquake occurred, lasting about thirty seconds; the motion was apparently from east to west. (Monthly Weather Review, 1884).

Fredericktown $\left(40.4948^{\circ} \mathrm{N}, 82.5798^{\circ} \mathrm{W}\right)$-Frederickstown, Knox county: an earthquake shock, lasting about thirty seconds, was distinctly felt at 2.40 p.m. on the 19th. (Monthly Weather Review, 1884).

Fremont $\left(41.3584^{\circ} \mathrm{N}, 83.102^{\circ} \mathrm{W}\right)$-Fremont, Sandusky county: an earthquake shock of several seconds duration was felt here at 2.45 p.m. on the 19th. (Monthly Weather Review, 1884).

Mansfield $\left(40.7583^{\circ} \mathrm{N}, 82.5156^{\circ} \mathrm{W}\right)$-Plainly felt. (Street and Green, 1984).

Marion $\left(40.5886^{\circ} \mathrm{N}, 83.1286^{\circ} \mathrm{W}\right)$ - In some places articles were shaken up enough to make a noise. (Street and Green, 1984 ).

Maryville-Maryville, Union county: about 3 p.m. of the 19th, a perceptible shock of earthquake occurred, lasting fifteen seconds. (Monthly Weather Review, 1884).

Salem $\left(40.9008^{\circ} \mathrm{N}, 80.8569^{\circ} \mathrm{W}\right)$-Created considerable surprise, but no alarm. (Street and Green, 1984).

Xenia $\left(39.6719^{\circ} \mathrm{N}, 83.9144^{\circ} \mathrm{W}\right)$-Xenia, Green county: at 3 p.m. on the 19 th, two distinct shocks of earthquake were perceptibly felt throughout the town. (Monthly Weather Review, 1884). 


\section{Appendix 1, Part 15. Damage Reports and Intensity Assignments}

$2 \mathrm{IA}$

IA

$2 \quad \mathrm{IN}$

IN

$2 \quad \mathrm{IN}$

IN

$2 \mathrm{KY}$

$2 \mathrm{KY}$

KY

$2 \mathrm{MI}$

MI

$2 \mathrm{Ml}$

MI

$2 \mathrm{Ml}$

2 MI

MI

$2 \mathrm{MI}$

$2 \mathrm{OH}$

$\mathrm{OH}$
Cedar Rapids $\left(41.9717^{\circ} \mathrm{N}, 91.6587^{\circ} \mathrm{W}\right)$-Cedar Rapids, Linn county: at about 2 p.m. on the 19 th the door of the composing room in the "Republican" office swung open. The building trembled, and papers on a table were thrown to the floor. The disturbance was supposed to have been due to an earthquake. (Monthly Weather Review, 1884).

Cedar Rapids $\left(42.0083^{\circ} \mathrm{N}, 91.6439^{\circ} \mathrm{W}\right.$ )-Swung doors back and forth in the newspaper office, otherwise not felt. (Street and Green, 1984).

Portland $\left(40.4227^{\circ} \mathrm{N}, 84.9712^{\circ} \mathrm{W}\right)$-Portland, Jay county; the earthquake of the 19th was felt at this place, the shock being very slight. It was also felt at Red Key, in this county. (Monthly Weather Review, 1884).

Portland $\left(40.4344^{\circ} \mathrm{N}, 84.9778^{\circ} \mathrm{W}\right)-\mathrm{A}$ slight shock. (Street and Green, 1984).

Seymour $\left(38.9653^{\circ} \mathrm{N}, 85.9275^{\circ} \mathrm{W}\right)$-Seymour, Jackson county: a very slight shock of earthquake occurred about 3 p.m. on the 19th. (Monthly Weather Review, 1884).

Seymour $\left(38.9592^{\circ} \mathrm{N}, 85.8903^{\circ} \mathrm{W}\right)$-An earthquake shock was felt. (Street and Green, 1984).

Covington $\left(39.0715^{\circ} \mathrm{N}, 84.5279^{\circ} \mathrm{W}\right)$-Covington, Kenton county: the earthquake of the 19th was felt at this place, but the shock was very slight. It is also reported to have been felt in Newport, opposite Covington. (Monthly Weather Review, 1884).

Louisville $\left(38.2500^{\circ} \mathrm{N}, 85.75^{\circ} \mathrm{W}\right)$-Louisville: the Signal Service observer reports that two slight shocks of earthquake, of about ten seconds duration, were felt in some portions of the city at about 2.15 p.m. on the 19th. The shocks were noticed by but few people, and were not perceptible at the signal office. Persons who observed the shocks state that the direction of movement was from e. to w., or from ne. to sw. (Monthly Weather Review, 1884).

Louisville $\left(38.2542^{\circ} \mathrm{N}, 85.7594^{\circ} \mathrm{W}\right)$-Noticed by only a very few people. (Street and Green, 1984).

Bay City $\left(43.6096^{\circ} \mathrm{N}, 83.9211^{\circ} \mathrm{W}\right)$-Bay City, Bay county: a slight earthquake shock occurred here at 2.45 p.m. on the 19 th. (Monthly Weather Review, 1884).

Bay City $\left(43.5944^{\circ} \mathrm{N}, 83.8889^{\circ} \mathrm{W}\right)-\mathrm{A}$ shock was felt. (Street and Green, 1984).

Chelsea $\left(42.3181^{\circ} \mathrm{N}, 84.0206^{\circ} \mathrm{W}\right)-\mathrm{A}$ mild shock was felt. (Street and Green, 1984).

Chelsea $\left(42.3127^{\circ} \mathrm{N}, 84.0401^{\circ} \mathrm{W}\right)$-Ann Arbor, Washtenaw county: an earthquake shock, lasting from five to eight seconds, occurred at 2.36 p.m. on the 19th. Building trembled, windows rattled, and chandeliers and tables were perceptibly shaken. The shock was also felt at Chelsea, in this county. (Monthly Weather Review, 1884).

Davisburg $\left(42.7500^{\circ} \mathrm{N}, 83.55^{\circ} \mathrm{W}\right)$-A slight shock was felt. (Street and Green, 1984).

Port Huron $\left(42.9708^{\circ} \mathrm{N}, 82.425^{\circ} \mathrm{W}\right)$-A slight shock was felt. (Street and Green, 1984).

Port Huron $\left(42.9914^{\circ} \mathrm{N}, 82.4588^{\circ} \mathrm{W}\right)$-Port Huron: a slight shock of earthquake was felt on the afternoon of the 19 th. (Monthly Weather Review, 1884).

Saginaw $\left(43.4194^{\circ} \mathrm{N}, 83.9508^{\circ} \mathrm{W}\right)$-Felt by a few on the streets, as well by some in taller buildings. (Street and Green, 1984 ).

Cincinnati $\left(39.1619^{\circ} \mathrm{N}, 84.4569^{\circ} \mathrm{W}\right)$-Slight. (Street and Green, 1984).

Cincinnati $\left(39.1054^{\circ} \mathrm{N}, 84.5022^{\circ} \mathrm{W}\right)$-Cincinnati: two distinct shocks of earthquake were felt in this city at $2.37 \mathrm{p} . \mathrm{m}$. (local time) of the 19th. The vibrations were most perceptible in tall buildings and on the neighboring hills, the motion being apparently from south to north, and lasting from two to three seconds. In some of the suburbs the shock was more severe than in the city. In Clifton the disturbance caused the door-bells to ring. At Cumminsville, the shock caused considerable alarm. (Monthly Weather Review, 1884).

Medina $\left(41.1384^{\circ} \mathrm{N}, 81.8607^{\circ} \mathrm{W}\right)-$ Medina, Medina county: a slight shock of earthquake was felt here at 3 p.m., of the 19 th. (Monthly Weather Review, 1884).

Union City $\left(40.2019^{\circ} \mathrm{N}, 84.8092^{\circ} \mathrm{W}\right)$-Felt slightly. (Street and Green, 1984).

Youngstown $\left(41.0997^{\circ} \mathrm{N}, 80.6497^{\circ} \mathrm{W}\right)$ - Had a slight shock. (Street and Green, 1984).

Chicago $\left(41.8500^{\circ} \mathrm{N}, 87.65^{\circ} \mathrm{W}\right)$-Not felt here nor elsewhere in the state. (Street and Green, 1984).

Logansport $\left(40.7544^{\circ} \mathrm{N}, 86.3567^{\circ} \mathrm{W}\right)$ - It was not felt here. (Street and Green, 1984).

Alliance $\left(40.9153^{\circ} \mathrm{N}, 81.1061^{\circ} \mathrm{W}\right)$-The earthquake was not felt at all. (Street and Green, 1984).

Ashtabula $\left(41.8679^{\circ} \mathrm{N}, 80.7949^{\circ} \mathrm{W}\right)$-Felt nothing. (Street and Green, 1984).

Conneaut $\left(41.9475^{\circ} \mathrm{N}, 80.5545^{\circ} \mathrm{W}\right)$-Felt nothing. (Street and Green, 1984).

Painesville $\left(41.7244^{\circ} \mathrm{N}, 81.2458^{\circ} \mathrm{W}\right)$-Felt nothing. (Street and Green, 1984).

Willoughby $\left(41.6397^{\circ} \mathrm{N}, 81.4067^{\circ} \mathrm{W}\right)$-Felt nothing. (Street and Green, 1984).

Cairo $\left(37.0053^{\circ} \mathrm{N}, 89.1764^{\circ} \mathrm{W}\right)$-Not mentioned. (Street and Green, 1984).

Champaign $\left(40.1164^{\circ} \mathrm{N}, 88.2433^{\circ} \mathrm{W}\right)$-Not reported. (Street and Green, 1984).

Jonesboro $\left(37.4517^{\circ} \mathrm{N}, 89.2681^{\circ} \mathrm{W}\right)$-Not reported. (Street and Green, 1984).

Paris $\left(39.6111^{\circ} \mathrm{N}, 87.6961^{\circ} \mathrm{W}\right)$-Not reported. (Street and Green, 1984).

Robinson $\left(39.0053^{\circ} \mathrm{N}, 87.7392^{\circ} \mathrm{W}\right)$-Not mentioned. (Street and Green, 1984).

Cannelton $\left(37.9114^{\circ} \mathrm{N}, 86.7444^{\circ} \mathrm{W}\right)$-Not reported. (Street and Green, 1984).

Vincennes $\left(38.6772^{\circ} \mathrm{N}, 87.5286^{\circ} \mathrm{W}\right)$-Not reported. (Street and Green, 1984).

Ashland $\left(38.4783^{\circ} \mathrm{N}, 82.6381^{\circ} \mathrm{W}\right)$-Not mentioned. (Street and Green, 1984).

Danville $\left(37.6456^{\circ} \mathrm{N}, 84.7722^{\circ} \mathrm{W}\right.$ )-Not mentioned. (Street and Green, 1984).

Flemingsburg $\left(38.4222^{\circ} \mathrm{N}, 83.7339^{\circ} \mathrm{W}\right)$-Not mentioned. (Street and Green, 1984).

Frankfort $\left(38.2008^{\circ} \mathrm{N}, 84.8733^{\circ} \mathrm{W}\right)$-Not mentioned. (Street and Green, 1984).

Georgetown $\left(38.2097^{\circ} \mathrm{N}, 84.5589^{\circ} \mathrm{W}\right)$-Not mentioned. (Street and Green, 1984). 


\title{
Appendix 1, Part 15. Damage Reports and Intensity Assignments
}

\author{
N KY Owingsville $\left(38.1490^{\circ} \mathrm{N}, 83.7573^{\circ} \mathrm{W}\right)$-Not mentioned. (Street and Green, 1984). \\ $\mathrm{N} \quad \mathrm{KY} \quad$ Paris $\left(38.2097^{\circ} \mathrm{N}, 84.2531^{\circ} \mathrm{W}\right)$-Not mentioned. (Street and Green, 1984). \\ N MO Saint Louis $\left(38.6272^{\circ} \mathrm{N}, 90.1978^{\circ} \mathrm{W}\right)$-Not mentioned. (Street and Green, 1984). \\ $\mathrm{N} \quad \mathrm{OH}$ Portsmouth $\left(38.7317^{\circ} \mathrm{N}, 82.9978^{\circ} \mathrm{W}\right)$-Not reported. (Street and Green, 1984). \\ F IN Redkey $\left(40.3388^{\circ} \mathrm{N}, 85.1543^{\circ} \mathrm{W}\right)$-Portland, Jay county; the earthquake of the 19th was felt at this place, the shock being \\ very slight. It was also felt at Red Key, in this county. (Monthly Weather Review, 1884). \\ IN Redkey $\left(40.3489^{\circ} \mathrm{N}, 85.15^{\circ} \mathrm{W}\right)$-People ran into the streets. (Street and Green, 1984). \\ F IN Sunman $\left(39.2351^{\circ} \mathrm{N}, 85.081^{\circ} \mathrm{W}\right)$-Milan, Ripley county: quite a heavy shock of earthquake was felt here and at North Milan, \\ two miles above this place, at about 2 p.m. on the 19th. It was also felt at Sunman in this county. (Monthly Weather \\ Review, 1884). \\ Newport $\left(39.0831^{\circ} \mathrm{N}, 84.4841^{\circ} \mathrm{W}\right)$-Covington, Kenton county: the earthquake of the 19th was felt at this place, but the \\ shock was very slight. It is also reported to have been felt in Newport, opposite Covington. (Monthly Weather Review, \\ 1884). \\ Swartz Creek $\left(42.9417^{\circ} \mathrm{N}, 83.8258^{\circ} \mathrm{W}\right)$-Swartz Creek, Genesee county: an earthquake shock was felt in this vicinity at 2.30 \\ p.m. on the 19th. (Monthly Weather Review, 1884). \\ $\mathrm{F} \quad \mathrm{OH}$ \\ $\mathrm{F} \quad \mathrm{OH}$ \\ $\mathrm{F} \quad \mathrm{OH}$ \\ $\mathrm{F} \quad \mathrm{OH}$ \\ $\mathrm{OH}$ \\ $\mathrm{F} \quad \mathrm{OH}$ \\ $\mathrm{F} \quad \mathrm{OH}$ \\ $\mathrm{F} \quad \mathrm{OH}$ \\ Crestline $\left(40.8198^{\circ} \mathrm{N}, 82.755^{\circ} \mathrm{W}\right)$-Ansonia, Crawford county: at about $2.30 \mathrm{p.m}$. on the 19 th, an earthquake shock occurred, \\ which shook buildings violently. It was also felt at Crestline, in this county. (Monthly Weather Review, 1884). \\ Delaware $\left(40.2986^{\circ} \mathrm{N}, 83.0681^{\circ} \mathrm{W}\right)$-Felt. (Street and Green, 1984). \\ Elgin $\left(40.7409^{\circ} \mathrm{N}, 84.4753^{\circ} \mathrm{W}\right)$-Elgin, Lorain county: two shocks of earthquake were felt at 2.50 p.m., on the 19 th. They \\ occurred in quick succession, the second being the heavier. (Monthly Weather Review, 1884). \\ Marietta $\left(39.4288^{\circ} \mathrm{N}, 81.4931^{\circ} \mathrm{W}\right)$-Marietta, Washington county: the earthquake shock on the afternoon of the 19 th was \\ felt at this place and in surrounding localities. (Monthly Weather Review, 1884). \\ Marietta $\left(39.4153^{\circ} \mathrm{N}, 81.455^{\circ} \mathrm{W}\right)$-Not mentioned. (Street and Green, 1984). \\ New London $\left(41.0800^{\circ} \mathrm{N}, 82.4^{\circ} \mathrm{W}\right)$-Felt. (Street and Green, 1984). \\ Shelby $\left(40.8814^{\circ} \mathrm{N}, 82.6619^{\circ} \mathrm{W}\right)-$ Felt. (Street and Green, 1984$)$. \\ Wilmington $\left(39.4630^{\circ} \mathrm{N}, 83.837^{\circ} \mathrm{W}\right)$-Wilmington, Clinton county: an earthquake shock was felt at about 2.45 p.m. on the \\ 19th; the vibration was from east to west. (Monthly Weather Review, 1884).
}




\section{Appendix 1, Part 16. Damage Reports and Intensity Assignments}

\section{\#16 1887 Aug. 2 18:36UTC (Illinois)}

6 IL Cobden $\left(37.5314^{\circ} \mathrm{N}, 89.2533^{\circ} \mathrm{W}\right)$-Very severe, broke windows and dishes. (Street and Green, 1984).

5 IL Anna $\left(37.4603^{\circ} \mathrm{N}, 89.2469^{\circ} \mathrm{W}\right.$ ) - Shook up a number of people, many went outdoors. (Street and Green, 1984).

5 IL Centralia $\left(38.5250^{\circ} \mathrm{N}, 89.1333^{\circ} \mathrm{W}\right)$-Very heavy shock. (Street and Green, 1984).

5 IL Jonesboro $\left(37.4517^{\circ} \mathrm{N}, 89.2681^{\circ} \mathrm{W}\right)$-Cracked brick walls at Jonesboro, Ill. (Stover and Coffman, 1993).

IL Jonesboro $\left(37.4517^{\circ} \mathrm{N}, 89.2681^{\circ} \mathrm{W}\right)$-Sufficient to cause pictures to fall from the walls. (Street and Green, 1984$)$.

$5 \mathrm{IL}$

Mill Creek $\left(37.3417^{\circ} \mathrm{N}, 89.2525^{\circ} \mathrm{W}\right)$-Caused alarm, many ran out of their homes. (Street and Green, 1984).

$5 \quad$ IN

Evansville $\left(37.9747^{\circ} \mathrm{N}, 87.5558^{\circ} \mathrm{W}\right)-\mathrm{A}$ slight earthquake, windows and doors rattled, people went to the streets. (Street and Green, 1984).

$5 \quad \mathrm{IN}$

$5 \mathrm{KY}$

Jasper $\left(38.3914^{\circ} \mathrm{N}, 86.9311^{\circ} \mathrm{W}\right)-\mathrm{A}$ violent shock, cracked brick walls. (Street and Green, 1984).

$5 \mathrm{KY}$

Eddyville $\left(37.0944^{\circ} \mathrm{N}, 88.0803^{\circ} \mathrm{W}\right)-\mathrm{A}$ violent shock. (Street and Green, 1984).

$5 \quad K Y$

Franklin $\left(36.7222^{\circ} \mathrm{N}, 86.5772^{\circ} \mathrm{W}\right)$-Caused pictures to fall from walls, shook furniture in a lively manner. (Street and Green, 1984).

$5 \quad \mathrm{MO}$

Russellville $\left(36.8453^{\circ} \mathrm{N}, 86.8872^{\circ} \mathrm{W}\right)$ - Houses severely shaken, cracked the walls of the county office building. (Street and Green, 1984).

(Street and Green, 1984).

5 MO Saint Louis $\left(38.6272^{\circ} \mathrm{N}, 90.1978^{\circ} \mathrm{W}\right)$-Felt in every portion of the city, rattled windows and shook buildings, disturbed light furniture. (Street and Green, 1984).

Clarksville $\left(36.5297^{\circ} \mathrm{N}, 87.3594^{\circ} \mathrm{W}\right)$-Awakened most, frightened some who left their homes, cracked plaster in one home. (Street and Green, 1984).

Nashville $\left(36.1658^{\circ} \mathrm{N}, 86.7844^{\circ} \mathrm{W}\right)$-A well defined earthquake shock, rattled windows, caused some people to run out of houses, loosen some plastering. (Street and Green, 1984).

Huntsville $\left(34.7303^{\circ} \mathrm{N}, 86.5861^{\circ} \mathrm{W}\right)$-Aroused sleepers. (Street and Green, 1984).

IL $\quad$ Alto Pass $\left(37.5703^{\circ} \mathrm{N}, 89.3175^{\circ} \mathrm{W}\right)$-A distinct shock that awakened many citizens. (Street and Green, 1984).

IL

IL

Belleville $\left(38.5200^{\circ} \mathrm{N}, 89.9839^{\circ} \mathrm{W}\right)$-Severe earthquake shock felt. (Street and Green, 1984).

Cairo $\left(37.0053^{\circ} \mathrm{N}, 89.1764^{\circ} \mathrm{W}\right)-\mathrm{A}$ severe shock was felt. (Street and Green, 1984).

Carmi $\left(38.0908^{\circ} \mathrm{N}, 88.1586^{\circ} \mathrm{W}\right.$ )-Distinctly felt by a large portion of citizens; shook doors. (Street and Green, 1984 ).

Champaign $\left(40.1164^{\circ} \mathrm{N}, 88.2433^{\circ} \mathrm{W}\right)$-Felt perceptibly by several persons, shook beds sufficiently to wake up occupants. (Street and Green, 1984).

Dongola $\left(37.3611^{\circ} \mathrm{N}, 89.1658^{\circ} \mathrm{W}\right)$-Sufficient to cause some citizens to leave their beds. (Street and Green, 1984).

IL

IL

IL

IL

IL

IN

IN

IN

IN

Du Quoin $\left(38.0114^{\circ} \mathrm{N}, 89.2361^{\circ} \mathrm{W}\right)$-A very perceptible shock was felt by many. (Street and Green, 1984).

Fairfield $\left(38.3789^{\circ} \mathrm{N}, 88.3597^{\circ} \mathrm{W}\right)$-Woke up most sleepers, shook buildings. (Street and Green, 1984).

Flora $\left(38.6689^{\circ} \mathrm{N}, 88.4855^{\circ} \mathrm{W}\right)$-Greatly alarmed some. (Street and Green, 1984).

Pana $\left(39.3889^{\circ} \mathrm{N}, 89.08^{\circ} \mathrm{W}\right)$-Rattled doors and windows, many were awakened. (Street and Green, 1984).

Paris $\left(39.6111^{\circ} \mathrm{N}, 87.6961^{\circ} \mathrm{W}\right)$-Quite a few persons felt the vibrations. (Street and Green, 1984).

Mount Vernon $\left(37.9322^{\circ} \mathrm{N}, 87.895^{\circ} \mathrm{W}\right)$-A heavy earthquake shock was felt. (Street and Green, 1984).

New Albany $\left(38.2856^{\circ} \mathrm{N}, 85.8242^{\circ} \mathrm{W}\right)$-Shook houses and frightened some people. (Street and Green, 1984).

Seymour $\left(38.9592^{\circ} \mathrm{N}, 85.8903^{\circ} \mathrm{W}\right)$-Decidedly perceptible, greatly alarmed some. (Street and Green, 1984).

Vincennes $\left(38.6772^{\circ} \mathrm{N}, 87.5286^{\circ} \mathrm{W}\right)$-A number of people were awakened, buildings were jarred and crockery on pantry shelves rattled. (Street and Green, 1984).

IN

Worthington $\left(39.1250^{\circ} \mathrm{N}, 86.9794^{\circ} \mathrm{W}\right)$-Very perceptible shock, awakened sleepers. (Street and Green, 1984).

KY

KY

Colesburg $\left(37.7847^{\circ} \mathrm{N}, 85.7739^{\circ} \mathrm{W}\right)$-A slight earthquake, sufficient to awaken many. (Street and Green, 1984).

Frankfort $\left(38.2008^{\circ} \mathrm{N}, 84.8733^{\circ} \mathrm{W}\right)$-Very perceptible earthquake, shook things pretty lively. (Street and Green, 1984).

KY

Glasgow $\left(36.9958^{\circ} \mathrm{N}, 85.9119^{\circ} \mathrm{W}\right)$-Rattled glassware in a lively manner, people awakened all over town. (Street and Green, 1984).

$4 \quad K Y$

Hartford $\left(37.4511^{\circ} \mathrm{N}, 86.9092^{\circ} \mathrm{W}\right)$-Noticeable tremor, shook houses, caused some uneasiness. (Street and Green, 1984).

$4 \quad \mathrm{KY}$

Hopkinsville $\left(36.8656^{\circ} \mathrm{N}, 87.4886^{\circ} \mathrm{W}\right)$-Awakened sleepers, almost shook bric-a-brac from the mantles. (Street and Green, 1984).

Brewer $\left(37.7808^{\circ} \mathrm{N}, 89.9253^{\circ} \mathrm{W}\right)$-Rattled things up right lively. (Street and Green, 1984).

Cape Girardeau $\left(37.3058^{\circ} \mathrm{N}, 89.5181^{\circ} \mathrm{W}\right)$ - Heavy shock, caused fright. (Street and Green, 1984).

Jackson $\left(37.3822^{\circ} \mathrm{N}, 89.6661^{\circ} \mathrm{W}\right)$-A pretty vigorous shake. (Street and Green, 1984).

Louisiana $\left(39.4489^{\circ} \mathrm{N}, 91.0514^{\circ} \mathrm{W}\right)$-A very distinctive shock, rattled windows and houses. (Street and Green, 1984).

Perryville $\left(37.7242^{\circ} \mathrm{N}, 89.8611^{\circ} \mathrm{W}\right)$-Caused crockery and loose furniture to dance and clash. (Street and Green, 1984).

Columbia $\left(35.6150^{\circ} \mathrm{N}, 87.0353^{\circ} \mathrm{W}\right)$-Felt by many, entire households aroused from their slumbers. (Street and Green, 1984). 


\section{Appendix 1, Part 16. Damage Reports and Intensity Assignments}

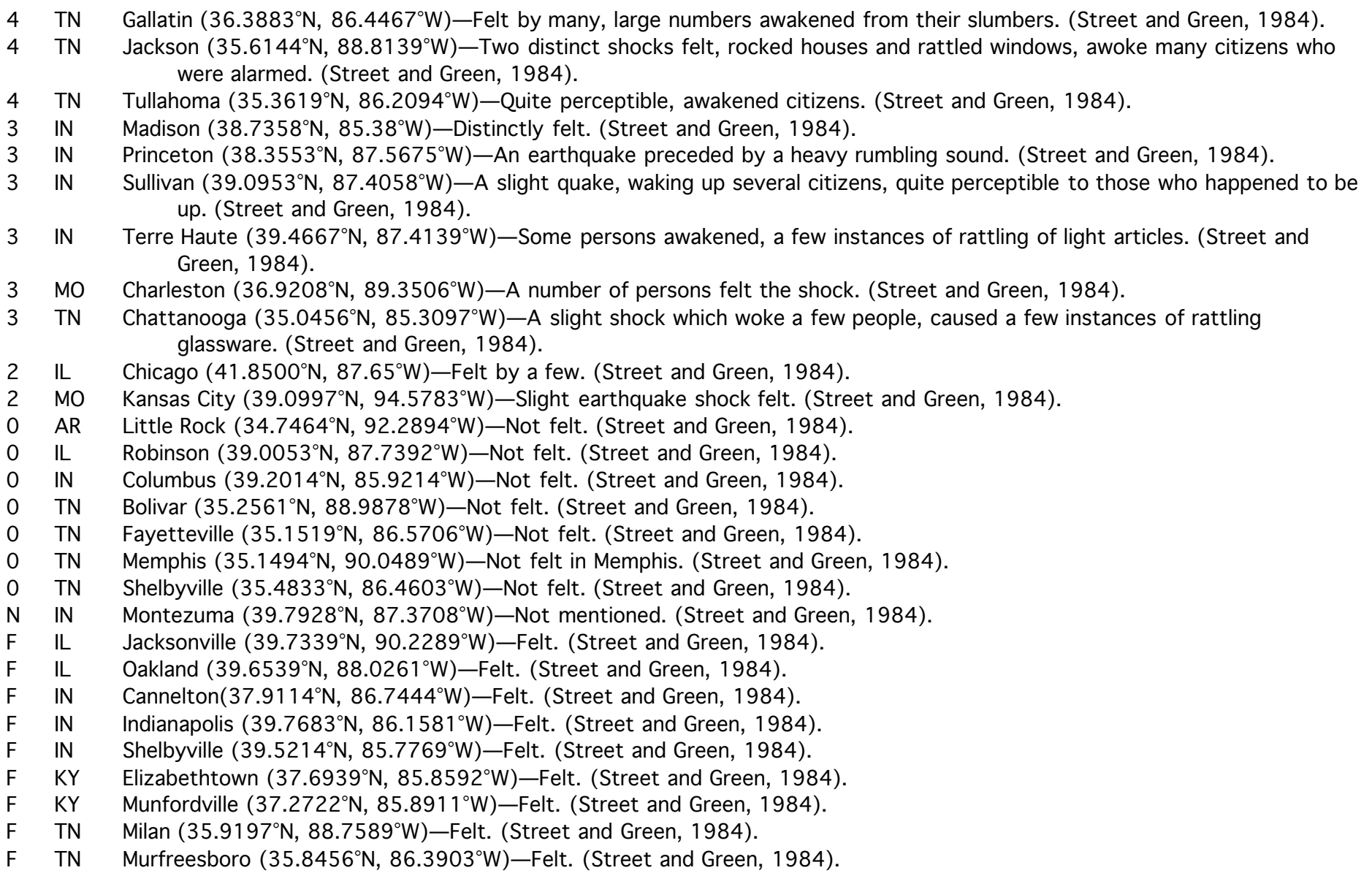




\section{Appendix 1, Part 17. Damage Reports and Intensity Assignments}

\section{\#17 1891 Sept. 27 04:55 UTC (Illinols)}

7 IL Mount Vernon $\left(38.3172^{\circ} \mathrm{N}, 88.9031^{\circ} \mathrm{W}\right)$-Several chimneys were toppled at Mount Vernon, and the ceiling and sidewalls of the Methodist Church were damaged. (Stover and Coffman, 1993).

IL Mount Vernon $\left(38.3172^{\circ} \mathrm{N}, 88.9031^{\circ} \mathrm{W}\right)$ - Many chimneys were shaken down; sidewalls of Methodist church were badly damaged. (Street and Green, 1984). Nashville $\left(38.3436^{\circ} \mathrm{N}, 89.3806^{\circ} \mathrm{W}\right)$-Demolition of some chimneys. (Street and Green, 1984).

IL Nashville $\left(38.3436^{\circ} \mathrm{N}, 89.3806^{\circ} \mathrm{W}\right)$-Chimney damage ... was reported at Browns and Nashville, III., and Cloverport, Ky. (Stover and Coffman, 1993).

$7 \quad \mathrm{IN}$

$6 \quad \mathrm{IL}$

IL

$6 \mathrm{IL}$

$6 \quad \mathrm{IL}$

IL

IL

IL Princeton $\left(38.3553^{\circ} \mathrm{N}, 87.5675^{\circ} \mathrm{W}\right)$-Shook down an old barn. (Street and Green, 1984). Belleville $\left(38.5200^{\circ} \mathrm{N}, 89.9839^{\circ} \mathrm{W}\right)$-Moved furniture and shook beds. (Street and Green, 1984). Browns $\left(38.3769^{\circ} \mathrm{N}, 87.9831^{\circ} \mathrm{W}\right.$ ) -Bricks fell from chimneys. (Street and Green, 1984).

Browns $\left(38.3769^{\circ} \mathrm{N}, 87.9831^{\circ} \mathrm{W}\right)$-Chimney damage ... was reported at Browns and Nashville, III., and Cloverport, Ky. (Street and Green, 1984).

Carlyle $\left(38.6103^{\circ} \mathrm{N}, 89.3725^{\circ} \mathrm{W}\right)$ - Houses were badly shaken, glass was broken, but no serious damage. (Street and Green, 1984).

Jerseyville $\left(39.1200^{\circ} \mathrm{N}, 90.3283^{\circ} \mathrm{W}\right)$-Plastering fell. (Street and Green, 1984).

Jerseyville $\left(39.1200^{\circ} \mathrm{N}, 90.3283^{\circ} \mathrm{W}\right)$-Plaster was knocked down at Jerseyville, Murphysboro, and Warsaw, Ill. (Stover and Coffman, 1993).

Murphysboro $\left(37.7644^{\circ} \mathrm{N}, 89.335^{\circ} \mathrm{W}\right)$-Plastering fell and people ran out into the streets. (Street and Green, 1984).

Murphysboro $\left(37.7644^{\circ} \mathrm{N}, 89.335^{\circ} \mathrm{W}\right)$ - Plaster was knocked down at Jerseyville, Murphysboro, and Warsaw, Ill. (Stover and Coffman, 1993).

Shelbyville $\left(39.4000^{\circ} \mathrm{N}, 88.8^{\circ} \mathrm{W}\right)$-Moved furniture. (Street and Green, 1984).

Staunton $\left(39.0122^{\circ} \mathrm{N}, 89.7911^{\circ} \mathrm{W}\right)$-Moved furniture. (Street and Green, 1984).

Shelbyville $\left(39.5000^{\circ} \mathrm{N}, 85.8^{\circ} \mathrm{W}\right)$ - A few people ran out doors, toppled furniture. (Street and Green, 1984).

Cloverport $\left(37.7947^{\circ} \mathrm{N}, 86.5793^{\circ} \mathrm{W}\right)$-One chimney toppled; several people ran out into the streets. (Street and Green, 1984).

Cloverport $\left(37.7947^{\circ} \mathrm{N}, 86.5793^{\circ} \mathrm{W}\right)$ - Chimney damage also was reported at Browns and Nashville, Ill., and Cloverport, Ky. (Stover and Coffman, 1993).

Henderson $\left(37.8361^{\circ} \mathrm{N}, 87.59^{\circ} \mathrm{W}\right)$-Broke lamps and dishes. (Street and Green, 1984).

Cincinnati $\left(39.1619^{\circ} \mathrm{N}, 84.4569^{\circ} \mathrm{W}\right)$-Moved beds, knocked over loose articles, and badly frightened some. (Street and Green, 1984).

Clinton $\left(41.8444^{\circ} \mathrm{N}, 90.1886^{\circ} \mathrm{W}\right)$-Rattled windows, moved beds, and frightened some. (Street and Green, 1984).

Albion $\left(38.3775^{\circ} \mathrm{N}, 88.0561^{\circ} \mathrm{W}\right)$-People rushed into the streets. (Street and Green, 1984).

Bloomington $\left(40.4842^{\circ} \mathrm{N}, 88.9936^{\circ} \mathrm{W}\right)$-Some people rushed out into the street. (Street and Green, 1984).

Canton $\left(40.5581^{\circ} \mathrm{N}, 90.035^{\circ} \mathrm{W}\right)$-Citizens were alarmed and ran from their houses. (Street and Green, 1984).

Cerro Gordo $\left(39.8906^{\circ} \mathrm{N}, 88.7281^{\circ} \mathrm{W}\right)$-Violently awakened and frightened many people. (Street and Green, 1984).

Champaign $\left(40.1164^{\circ} \mathrm{N}, 88.2433^{\circ} \mathrm{W}\right)$-Pictures shaken from walls. (Street and Green, 1984).

Decatur $\left(39.8403^{\circ} \mathrm{N}, 88.9547^{\circ} \mathrm{W}\right)$-Light articles toppled over on mantles. (Street and Green, 1984).

Du Quoin $\left(38.0114^{\circ} \mathrm{N}, 89.2361^{\circ} \mathrm{W}\right)$-Guests ran out of hotels. (Street and Green, 1984).

East Saint Louis $\left(38.6244^{\circ} \mathrm{N}, 90.1508^{\circ} \mathrm{W}\right)$-Items knocked from shelves. (Street and Green, 1984).

Effingham $\left(39.1200^{\circ} \mathrm{N}, 88.5433^{\circ} \mathrm{W}\right)$-Hundreds of sleepers were roused and went to the streets; caused timbers in buildings to crack. (Street and Green, 1984).

Greenville $\left(38.8922^{\circ} \mathrm{N}, 89.4131^{\circ} \mathrm{W}\right)$-Violent, a large proportion of the inhabitants were aroused from their slumbers. (Street and Green, 1984).

Mascoutah $\left(38.4903^{\circ} \mathrm{N}, 89.7931^{\circ} \mathrm{W}\right)$-Many fled from their homes. (Street and Green, 1984).

Monticello $\left(40.0278^{\circ} \mathrm{N}, 88.5733^{\circ} \mathrm{W}\right)$-Many people ran into the streets. (Street and Green, 1984).

Odin $\left(38.6172^{\circ} \mathrm{N}, 89.0522^{\circ} \mathrm{W}\right)$-Tremendous earthquake felt here. (Street and Green, 1984).

Pinckneyville $\left(38.0803^{\circ} \mathrm{N}, 89.3819^{\circ} \mathrm{W}\right)$ - Many people ran out of their homes. (Street and Green, 1984).

Vandalia $\left(38.9606^{\circ} \mathrm{N}, 89.0936^{\circ} \mathrm{W}\right)$ - Many people fled from their houses for safety. (Street and Green, 1984).

Warsaw $\left(40.3592^{\circ} \mathrm{N}, 91.4344^{\circ} \mathrm{W}\right)$-Cracked plastering in several buildings and in a few instances it fell from the ceilings. (Street and Green, 1984).

Warsaw $\left(40.3592^{\circ} \mathrm{N}, 91.4344^{\circ} \mathrm{W}\right)$-Plaster was knocked down at Jerseyville, Murphysboro, and Warsaw, III. (Stover and Coffman, 1993).

Waterloo $\left(38.3358^{\circ} \mathrm{N}, 90.1497^{\circ} \mathrm{W}\right)$-Shook bottles from shelves. (Street and Green, 1984).

Xenia $\left(38.6358^{\circ} \mathrm{N}, 88.6347^{\circ} \mathrm{W}\right)$-Plaster damage; inhabitants terror stricken. (Street and Green, 1984).

Columbus $\left(39.2014^{\circ} \mathrm{N}, 85.9214^{\circ} \mathrm{W}\right)$-Some people ran out into the streets. (Street and Green, 1984).

Kokomo $\left(40.4864^{\circ} \mathrm{N}, 86.1336^{\circ} \mathrm{W}\right)$-Ornaments were shaken from mantles, woke everybody, rattled windows and dishes. (Street and Green, 1984).

Logansport $\left(40.7544^{\circ} \mathrm{N}, 86.3567^{\circ} \mathrm{W}\right)$ - Instances of people running from their homes. (Street and Green, 1984). 


\section{Appendix 1, Part 17. Damage Reports and Intensity Assignments}

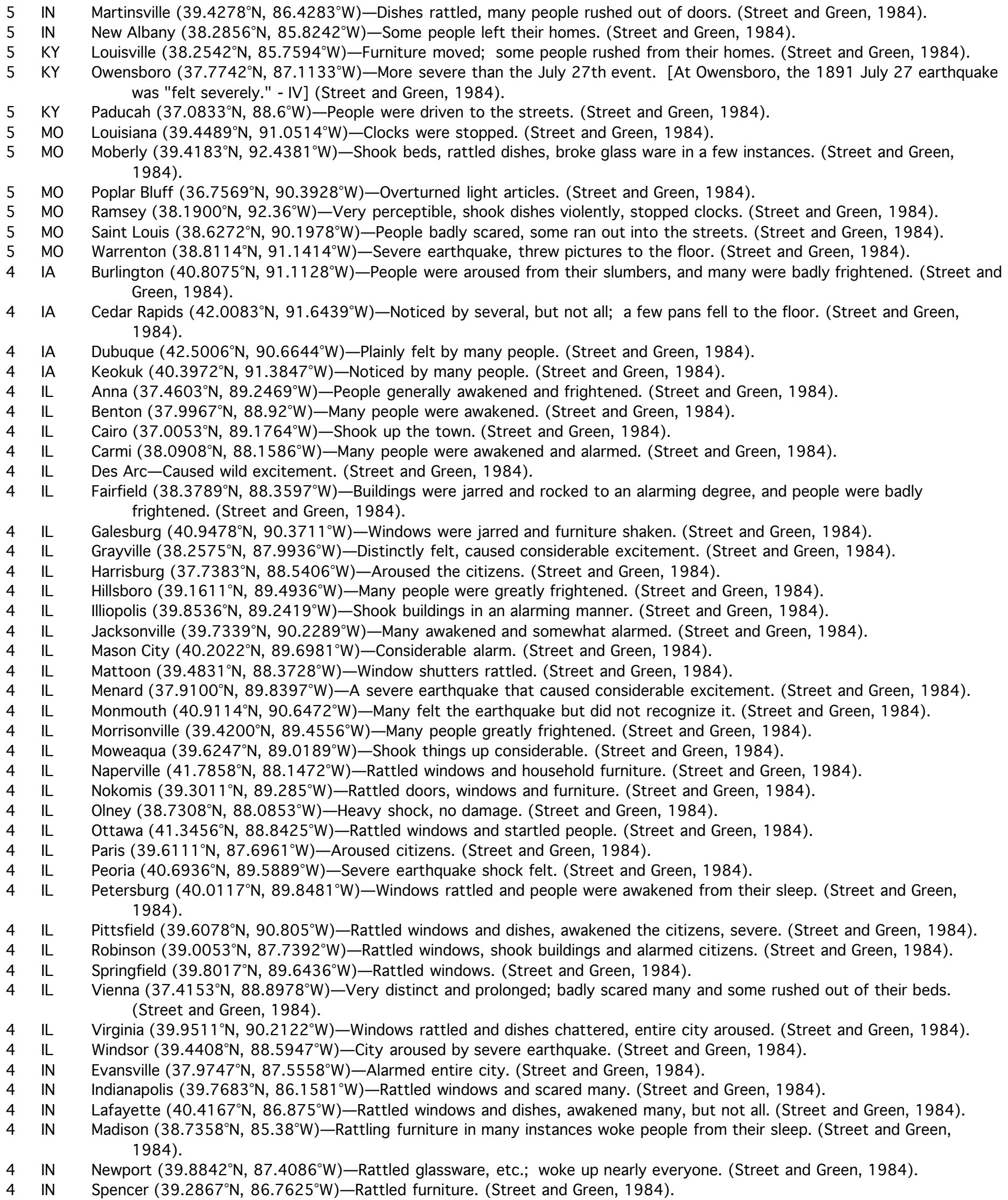




\section{Appendix 1, Part 17. Damage Reports and Intensity Assignments}

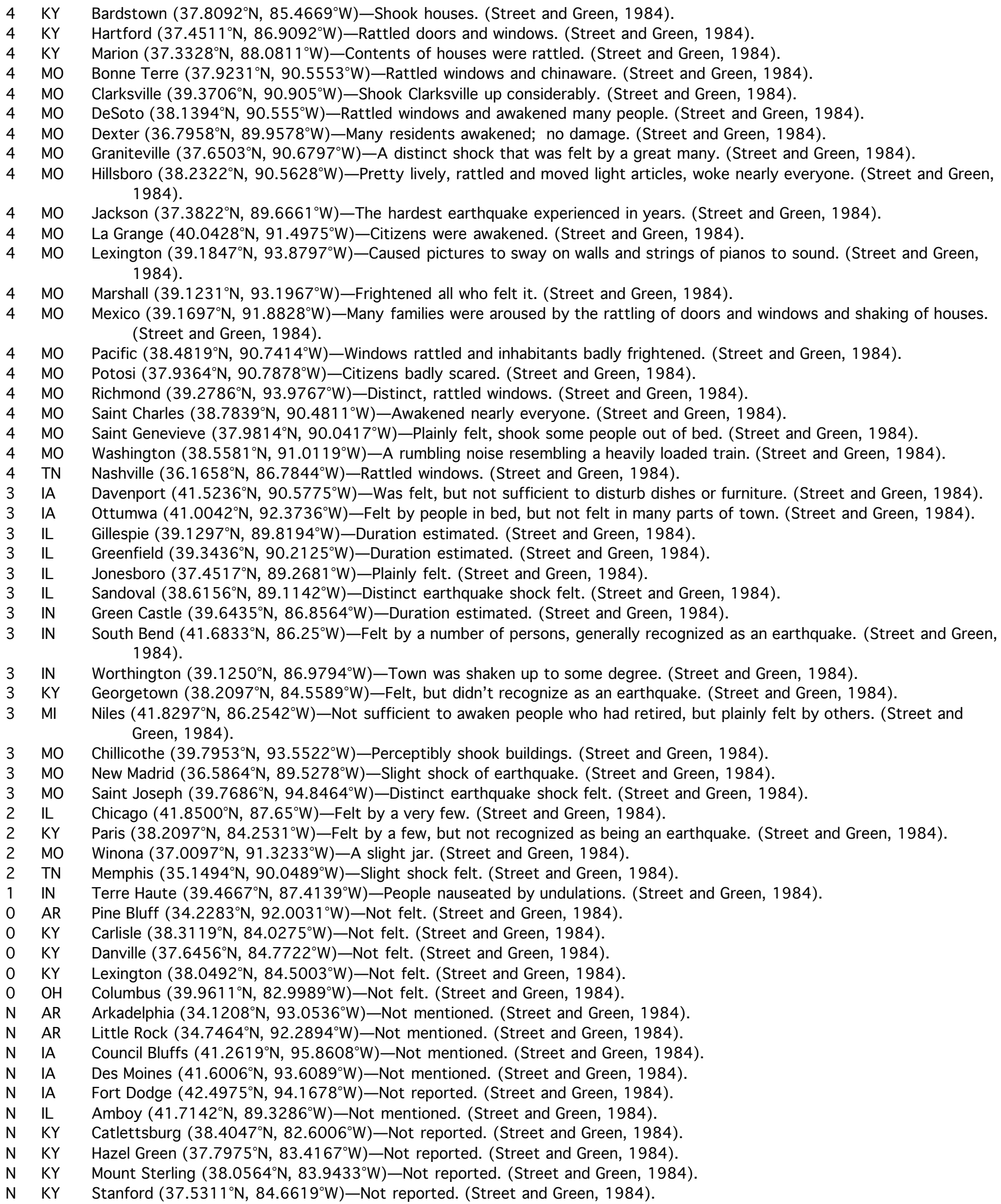




\section{Appendix 1, Part 17. Damage Reports and Intensity Assignments}

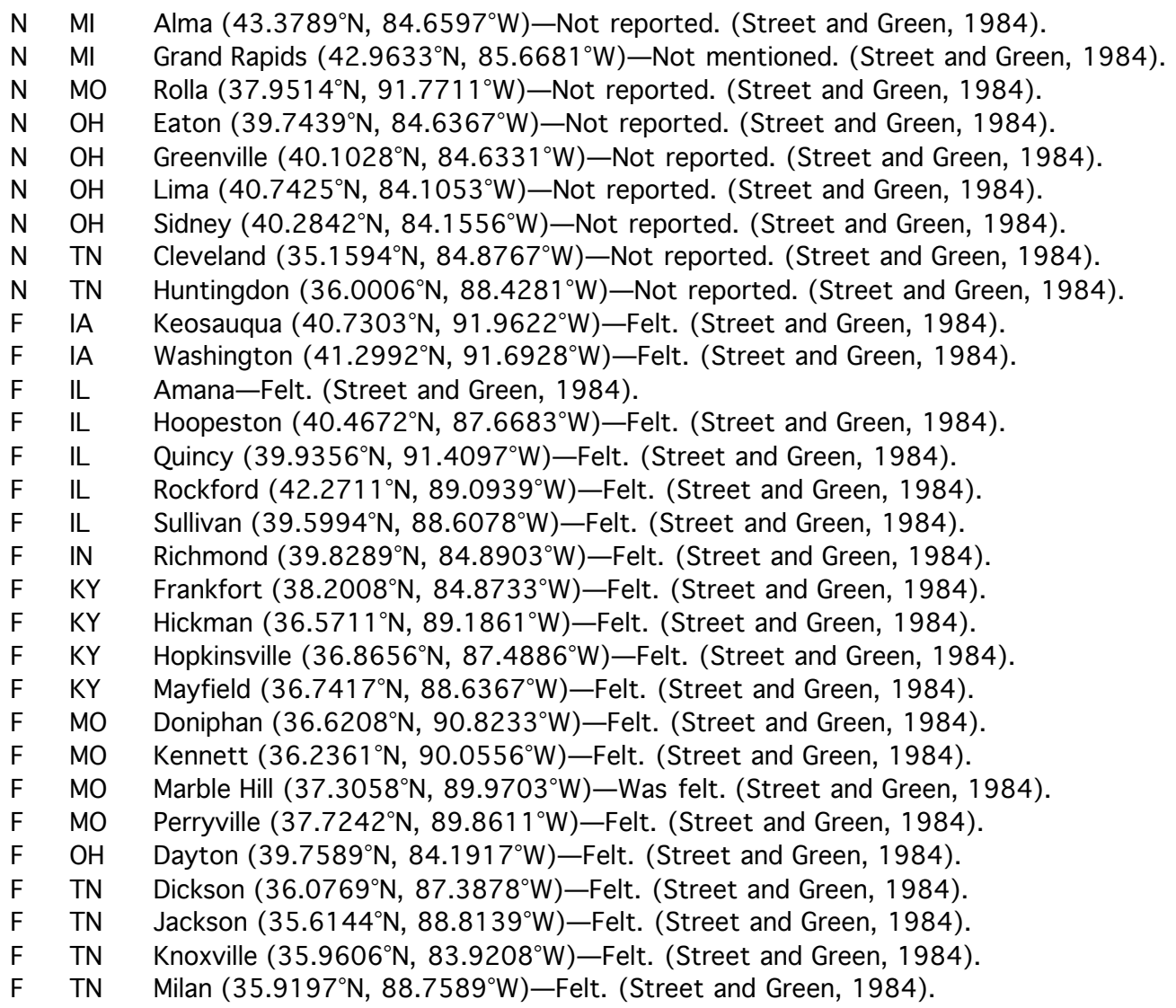




\section{Appendix 1, Part 18. Damage Reports and Intensity Assignments}

\section{\#18 1899 April 30 02:05 UTC (Indlana)}

7 IN Greencastle $\left(39.6444^{\circ} \mathrm{N}, 86.8647^{\circ} \mathrm{W}\right)$-Toppled chimneys. (Street and Green, 1984).

IN Greencastle $\left(39.6444^{\circ} \mathrm{N}, 86.8647^{\circ} \mathrm{W}\right)$-Toppled chimneys also were reported at Greencastle, Putnam county, northeast of Terre Haute. (Stover and Coffman, 1993).

7 IN Princeton $\left(38.3553^{\circ} \mathrm{N}, 87.5675^{\circ} \mathrm{W}\right)$-Many chimney tops were shaken off. (Street and Green, 1984).

IN Princeton $\left(38.3553^{\circ} \mathrm{N}, 87.5675^{\circ} \mathrm{W}\right)$-The tops of many chimneys were shaken down at Princeton in Gibson County. (Stover and Coffman, 1993).

7 IN Vincennes $\left(38.6772^{\circ} \mathrm{N}, 87.5286^{\circ} \mathrm{W}\right)$-Knocked down a number of chimneys, and damaged brick walls. (Street and Green, 1984).

IN Vincennes $\left(38.6772^{\circ} \mathrm{N}, 87.5286^{\circ} \mathrm{W}\right)$-Brick walls cracked and several chimneys fell at Vincennes (Stover and Coffman, 1993).

$5 \quad$ IN

Evansville $\left(37.9747^{\circ} \mathrm{N}, 87.5558^{\circ} \mathrm{W}\right)$ - Hundreds ran from their homes, but no damage was done. (Street and Green, 1984$)$.

New Castle $\left(39.9289^{\circ} \mathrm{N}, 85.3703^{\circ} \mathrm{W}\right)$-People ran out of their houses. (Street and Green, 1984).

Cloverport $\left(37.8333^{\circ} \mathrm{N}, 86.6328^{\circ} \mathrm{W}\right)$-Pictures on walls were thrown down. (Street and Green, 1984).

Louisville $\left(38.2542^{\circ} \mathrm{N}, 85.7594^{\circ} \mathrm{W}\right)$-Many people ran from their houses. (Street and Green, 1984).

Danville $\left(40.1244^{\circ} \mathrm{N}, 87.63^{\circ} \mathrm{W}\right)$-Rattled window panes and dishes in many houses. (Street and Green, 1984).

Indianapolis $\left(39.7683^{\circ} \mathrm{N}, 86.1581^{\circ} \mathrm{W}\right)$-Rattled windows; clearly felt. (Street and Green, 1984).

Madison $\left(38.7358^{\circ} \mathrm{N}, 85.38^{\circ} \mathrm{W}\right)$-Severe enough to stop clocks and to cause alarm. (Street and Green, 1984).

Shelburn $\left(39.1783^{\circ} \mathrm{N}, 87.3936^{\circ} \mathrm{W}\right)$-Caused considerable excitement throughout the town. (Street and Green, 1984).

Jeffersonville $\left(37.9591^{\circ} \mathrm{N}, 83.8621^{\circ} \mathrm{W}\right)$-The shock was "heavy" at Jeffersonville, near Louisville, Ky. (Stover and Coffman, 1993).

Greensburg $\left(39.3372^{\circ} \mathrm{N}, 85.4836^{\circ} \mathrm{W}\right)$-Distinctly felt by a number of citizens. (Street and Green, 1984).

Greenup-A distinct earthquake was felt. (Street and Green, 1984).

Sullivan $\left(39.0953^{\circ} \mathrm{N}, 87.4058^{\circ} \mathrm{W}\right)$-A distinct shock - no damage was done. (Street and Green, 1984).

Terre Haute $\left(39.4667^{\circ} \mathrm{N}, 87.4139^{\circ} \mathrm{W}\right)$-Six distinct shocks were felt. (Street and Green, 1984).

KY Carrollton $\left(38.6808^{\circ} \mathrm{N}, 85.1794^{\circ} \mathrm{W}\right)$-Distinctly felt for a few seconds. (Street and Green, 1984).

IL $\quad$ Benton $\left(37.9967^{\circ} \mathrm{N}, 88.92^{\circ} \mathrm{W}\right)$-Not reported. (Street and Green, 1984).

IL $\quad$ Cairo $\left(37.0053^{\circ} \mathrm{N}, 89.1764^{\circ} \mathrm{W}\right)$-Not mentioned. (Street and Green, 1984).

IL $\quad$ Chicago $\left(41.8500^{\circ} \mathrm{N}, 87.65^{\circ} \mathrm{W}\right)$-Not mentioned. (Street and Green, 1984).

IL Fairfield $\left(38.3789^{\circ} \mathrm{N}, 88.3597^{\circ} \mathrm{W}\right)$-Not reported. (Street and Green, 1984).

IL $\quad$ Paris $\left(39.6111^{\circ} \mathrm{N}, 87.6961^{\circ} \mathrm{W}\right)$-Not reported. (Street and Green, 1984).

IL $\quad$ Salem $\left(38.6269^{\circ} \mathrm{N}, 88.9456^{\circ} \mathrm{W}\right)$-Not mentioned. (Street and Green, 1984).

IL Tuscola $\left(39.7992^{\circ} \mathrm{N}, 88.2831^{\circ} \mathrm{W}\right)$-Not reported. (Street and Green, 1984).

IL Vienna $\left(37.4153^{\circ} \mathrm{N}, 88.8978^{\circ} \mathrm{W}\right)$-Not reported. (Street and Green, 1984).

IN $\quad \operatorname{Argos}\left(41.6972^{\circ} \mathrm{N}, 86.245^{\circ} \mathrm{W}\right)$-Not reported. (Street and Green, 1984).

IN Jasper $\left(38.3914^{\circ} \mathrm{N}, 86.9311^{\circ} \mathrm{W}\right)$-Not reported. (Street and Green, 1984).

IN Kokomo $\left(40.4864^{\circ} \mathrm{N}, 86.1336^{\circ} \mathrm{W}\right)$-Not reported. (Street and Green, 1984).

IN Lafayette $\left(40.4167^{\circ} \mathrm{N}, 86.875^{\circ} \mathrm{W}\right)$-Not reported. (Street and Green, 1984).

IN Logansport $\left(40.7544^{\circ} \mathrm{N}, 86.3567^{\circ} \mathrm{W}\right)$-Not mentioned. (Street and Green, 1984).

IN Rockville $\left(39.7625^{\circ} \mathrm{N}, 87.2292^{\circ} \mathrm{W}\right)$-Not reported. (Street and Green, 1984).

IN Warsaw $\left(41.2381^{\circ} \mathrm{N}, 85.8531^{\circ} \mathrm{W}\right)$-Not mentioned. (Street and Green, 1984).

KY Hartford $\left(37.4511^{\circ} \mathrm{N}, 86.9092^{\circ} \mathrm{W}\right)$-Not mentioned. (Street and Green, 1984).

KY Lexington $\left(38.0492^{\circ} \mathrm{N}, 84.5003^{\circ} \mathrm{W}\right)$-Not mentioned. (Street and Green, 1984).

KY Owensboro $\left(37.7742^{\circ} \mathrm{N}, 87.1133^{\circ} \mathrm{W}\right)$-Not mentioned. (Street and Green, 1984).

$\mathrm{OH}$ Cincinnati $\left(39.1619^{\circ} \mathrm{N}, 84.4569^{\circ} \mathrm{W}\right)$-Not mentioned. (Street and Green, 1984).

$\mathrm{OH} \quad$ Columbus $\left(39.9611^{\circ} \mathrm{N}, 82.9989^{\circ} \mathrm{W}\right)$-Not mentioned. (Street and Green, 1984).

$\mathrm{OH} \quad$ Eaton $\left(39.7439^{\circ} \mathrm{N}, 84.6367^{\circ} \mathrm{W}\right)$-Not mentioned. (Street and Green, 1984).

$\mathrm{OH} \quad$ Greenville $\left(40.1028^{\circ} \mathrm{N}, 84.6331^{\circ} \mathrm{W}\right)$-Not reported. (Street and Green, 1984).

IL Decatur $\left(39.8403^{\circ} \mathrm{N}, 88.9547^{\circ} \mathrm{W}\right)$-Felt. (Street and Green, 1984).

IL Mount Carmel $\left(38.4108^{\circ} \mathrm{N}, 87.7614^{\circ} \mathrm{W}\right)$-Felt. (Street and Green, 1984).

IN Bloomfield $\left(39.0269^{\circ} \mathrm{N}, 86.9375^{\circ} \mathrm{W}\right)$-Felt. (Street and Green, 1984).

IN Delphi $\left(40.5875^{\circ} \mathrm{N}, 86.675^{\circ} \mathrm{W}\right)$-Felt. (Street and Green, 1984).

F KY Irvington $\left(37.8803^{\circ} \mathrm{N}, 86.2839^{\circ} \mathrm{W}\right)$-Felt. (Street and Green, 1984). 


\section{Appendix 1, Part 19. Damage Reports and Intensity Assignments}

\section{\#19 1903 Feb. 9 00:21 UTC (Illinols)}

7 IL Carbondale $\left(37.7272^{\circ} \mathrm{N}, 89.2167^{\circ} \mathrm{W}\right)$-Toppled a few chimneys. (Street and Green, 1984).

7 IL Carterville $\left(37.7600^{\circ} \mathrm{N}, 89.0772^{\circ} \mathrm{W}\right)$-Considerable damage was done by brick falling from chimneys. (Street and Green, 1984).

IL Carterville $\left(37.7600^{\circ} \mathrm{N}, 89.0772^{\circ} \mathrm{W}\right)$-Damaged chimneys east of Murphysboro, at Carterville and Harrisburg, III. (Stover and Coffman, 1993).

Grand Tower $\left(37.6446^{\circ} \mathrm{N}, 89.4687^{\circ} \mathrm{W}\right)$-A number of chimneys shaken down, a large number of windows broken. (Street and Green, 1984).

$\mathrm{IL}$

Grand Tower $\left(37.6446^{\circ} \mathrm{N}, 89.4687^{\circ} \mathrm{W}\right)$-This earthquake threw down chimneys in Jackson County at Grand Tower. (Stover and Coffman, 1993).

Murphysboro $\left(37.7644^{\circ} \mathrm{N}, 89.335^{\circ} \mathrm{W}\right)$-Shook down a number of chimneys \& broke dishes. (Street and Green, 1984).

IL Murphysboro $\left(37.7644^{\circ} \mathrm{N}, 89.335^{\circ} \mathrm{W}\right)$-This earthquake threw down chimneys ... at ...Murphysboro, III. (Stover and Coffman, 1993).

Harrisburg $\left(37.7383^{\circ} \mathrm{N}, 88.5406^{\circ} \mathrm{W}\right)$-Stopped clocks, people ran into the streets shouting, some brick chimneys were damaged. (Street and Green, 1984).

IL

Harrisburg $\left(37.7383^{\circ} \mathrm{N}, 88.5406^{\circ} \mathrm{W}\right)$-Damaged chimneys east of Murphysboro, at Carterville and Harrisburg, III. (Stover and Coffman, 1993).

Marion $\left(37.7306^{\circ} \mathrm{N}, 88.9331^{\circ} \mathrm{W}\right)$-Shook down chimneys on hotel, some people ran into the streets. (Street and Green, 1984).

Alto Pass $\left(37.5703^{\circ} \mathrm{N}, 89.3175^{\circ} \mathrm{W}\right)$-Distinctly felt by everyone in the vicinity, many ran terror-stricken from their homes. (Street and Green, 1984).

IL Jonesboro $\left(37.4517^{\circ} \mathrm{N}, 89.2681^{\circ} \mathrm{W}\right)$-Alarmed people; many left their homes. (Street and Green, 1984).

Owensboro $\left(37.7742^{\circ} \mathrm{N}, 87.1133^{\circ} \mathrm{W}\right)$-Windows shakened and dishes rattled, felt throughout the city; shook pictures from the walls and ornaments from tables. (Street and Green, 1984).

Paducah $\left(37.0833^{\circ} \mathrm{N}, 88.6^{\circ} \mathrm{W}\right)$-Rattle buildings, windows, lights, some citizens ran outdoors; a few instances of dishes being shaken off tables. (Street and Green, 1984).

Farmington $\left(37.7808^{\circ} \mathrm{N}, 90.4217^{\circ} \mathrm{W}\right)$-Two distinct shocks; many people ran from their homes. (Street and Green, 1984).

\section{Alton $\left(38.8906^{\circ} \mathrm{N}, 90\right.$.
Green, 1984$)$.}

Belleville $\left(38.5200^{\circ} \mathrm{N}, 89.9839^{\circ} \mathrm{W}\right)$-Many residents were badly frightened. (Street and Green, 1984).

IL

Benton $\left(37.9967^{\circ} \mathrm{N}, 88.92^{\circ} \mathrm{W}\right)-\mathrm{A}$ severe earthquake shock. (Street and Green, 1984).

Chester $\left(37.9136^{\circ} \mathrm{N}, 89.8219^{\circ} \mathrm{W}\right)$ - Lasted three seconds and rattled windows. (Street and Green, 1984).

IL

Edwardsville $\left(38.8114^{\circ} \mathrm{N}, 89.953^{\circ} \mathrm{W}\right)$-Sufficient to rattle dishes and swing doors. (Street and Green, 1984).

Herrin $\left(37.8031^{\circ} \mathrm{N}, 89.0275^{\circ} \mathrm{W}\right)$-Buildings were considerably shaken. (Street and Green, 1984).

Lawrenceville $\left(38.7292^{\circ} \mathrm{N}, 87.6817^{\circ} \mathrm{W}\right.$ ) -Opened and closed doors, frightened many people. (Street and Green, 1984).

Richview $\left(38.3783^{\circ} \mathrm{N}, 89.18^{\circ} \mathrm{W}\right)-\mathrm{A}$ severe earthquake that shook furniture and windows. (Street and Green, 1984).

Vienna $\left(37.4153^{\circ} \mathrm{N}, 88.8978^{\circ} \mathrm{W}\right)$-Quite a jar, lots of people scared, but no special damage. (Street and Green, 1984).

Evansville $\left(37.9747^{\circ} \mathrm{N}, 87.5558^{\circ} \mathrm{W}\right)$-Badly frightened some. (Street and Green, 1984).

Lawrenceville $\left(39.2778^{\circ} \mathrm{N}, 85.0394^{\circ} \mathrm{W}\right)$-Distinct shock; many people frightened. (Street and Green, 1984).

Marion $\left(37.3328^{\circ} \mathrm{N}, 88.0811^{\circ} \mathrm{W}\right)$-Created some alarm; felt in all parts of the city. (Street and Green, 1984).

Hannibal $\left(39.7083^{\circ} \mathrm{N}, 91.3583^{\circ} \mathrm{W}\right)$-Two distinct shocks sufficiently strong to rock furniture in houses. (Street and Green, 1984).

$\mathrm{MO}$

Hannibal $\left(39.7083^{\circ} \mathrm{N}, 91.3583^{\circ} \mathrm{W}\right)$ - It was strongly felt from Jeffersonville, Mo. to Louisville, Ky., and from Cairo, Ill., to Hannibal, Mo. (Stover and Coffman, 1993).

Perryville $\left(37.7242^{\circ} \mathrm{N}, 89.8611^{\circ} \mathrm{W}\right)$-Rattle windows. (Street and Green, 1984).

Saint Louis $\left(38.6272^{\circ} \mathrm{N}, 90.1978^{\circ} \mathrm{W}\right)$-Felt my many; rattle windows and light articles. (Street and Green, 1984).

Cairo $\left(37.0053^{\circ} \mathrm{N}, 89.1764^{\circ} \mathrm{W}\right)-\mathrm{A}$ slight shock was felt, rattle windows. (Street and Green, 1984).

Cairo $\left(37.0053^{\circ} \mathrm{N}, 89.1764^{\circ} \mathrm{W}\right)$ - It was strongly felt from Jeffersonville, Mo. to Louisville, Ky., and from Cairo, Ill., to Hannibal, Mo. (Stover and Coffman, 1993).

IL Jerseyville $\left(39.1200^{\circ} \mathrm{N}, 90.3283^{\circ} \mathrm{W}\right)$-A shock lasting as long as a minute. (Street and Green, 1984).

IL Nashville $\left(38.3436^{\circ} \mathrm{N}, 89.3806^{\circ} \mathrm{W}\right)$-Two distinct earthquake shocks were felt. (Street and Green, 1984).

IN Greencastle $\left(39.6444^{\circ} \mathrm{N}, 86.8647^{\circ} \mathrm{W}\right)$-Felt by a number of persons. (Street and Green, 1984).

KY Cloverport $\left(37.8333^{\circ} \mathrm{N}, 86.6328^{\circ} \mathrm{W}\right)$-Caused some excitement. (Street and Green, 1984).

KY Henderson $\left(37.8361^{\circ} \mathrm{N}, 87.59^{\circ} \mathrm{W}\right)$-Distinctly felt. (Street and Green, 1984).

KY Louisville $\left(38.2542^{\circ} \mathrm{N}, 85.7594^{\circ} \mathrm{W}\right)$ - Rattled a few windows and caused dishes to rattle in some instances. (Street and Green, 1984). 


\section{Appendix 1, Part 19. Damage Reports and Intensity Assignments}

KY Louisville $\left(38.2542^{\circ} \mathrm{N}, 85.7594^{\circ} \mathrm{W}\right)$-It was strongly felt from Jeffersonville, Mo. to Louisville, Ky., and from Cairo, Ill., to Hannibal, Mo. (Stover and Coffman, 1993).

MO Saint Genevieve $\left(37.9814^{\circ} \mathrm{N}, 90.0417^{\circ} \mathrm{W}\right)$-Two distinct shocks felt. (Street and Green, 1984).

MO Charleston $\left(36.9208^{\circ} \mathrm{N}, 89.3506^{\circ} \mathrm{W}\right)$-A very slight earthquake was felt. (Street and Green, 1984).

IN Indianapolis $\left(39.7683^{\circ} \mathrm{N}, 86.1581^{\circ} \mathrm{W}\right)$-Not felt. (Street and Green, 1984).

KY Covington $\left(39.0836^{\circ} \mathrm{N}, 84.5086^{\circ} \mathrm{W}\right)$-Not felt. (Street and Green, 1984).

MO Bonne Terre $\left(37.9231^{\circ} \mathrm{N}, 90.5553^{\circ} \mathrm{W}\right)$-Not felt. (Street and Green, 1984).

MO Kennett $\left(36.2361^{\circ} \mathrm{N}, 90.0556^{\circ} \mathrm{W}\right)$-No one appears to have felt it. (Street and Green, 1984).

TN Memphis $\left(35.1494^{\circ} \mathrm{N}, 90.0489^{\circ} \mathrm{W}\right)$-Not felt. (Street and Green, 1984).

IA Fairfield $\left(41.0086^{\circ} \mathrm{N}, 91.9625^{\circ} \mathrm{W}\right)$-Not reported. (Street and Green, 1984).

IL Monmouth $\left(40.9114^{\circ} \mathrm{N}, 90.6472^{\circ} \mathrm{W}\right)$-Not mentioned. (Street and Green, 1984).

IL Ottawa $\left(41.3456^{\circ} \mathrm{N}, 88.8425^{\circ} \mathrm{W}\right)$-Not mentioned. (Street and Green, 1984).

IL $\quad$ Paris $\left(39.6111^{\circ} \mathrm{N}, 87.6961^{\circ} \mathrm{W}\right)$-Not mentioned. (Street and Green, 1984).

IL Robinson $\left(39.0053^{\circ} \mathrm{N}, 87.7392^{\circ} \mathrm{W}\right)$-Not mentioned. (Street and Green, 1984).

KY Earlington $\left(37.2742^{\circ} \mathrm{N}, 87.5119^{\circ} \mathrm{W}\right)$-Not reported. (Street and Green, 1984).

KY Hickman $\left(36.5711^{\circ} \mathrm{N}, 89.1861^{\circ} \mathrm{W}\right)$-Not mentioned. (Street and Green, 1984).

KY Hopkinsville $\left(36.8656^{\circ} \mathrm{N}, 87.4886^{\circ} \mathrm{W}\right)$-Not reported. (Street and Green, 1984).

MO Poplar Bluff $\left(36.7569^{\circ} \mathrm{N}, 90.3928^{\circ} \mathrm{W}\right)$-Not mentioned. (Street and Green, 1984).

TN Columbia $\left(35.6150^{\circ} \mathrm{N}, 87.0353^{\circ} \mathrm{W}\right)$-Not mentioned. (Street and Green, 1984).

TN Huntingdon $\left(36.0006^{\circ} \mathrm{N}, 88.4281^{\circ} \mathrm{W}\right)$-Not mentioned. (Street and Green, 1984).

IL Grand Prairie Church $\left(39.0800^{\circ} \mathrm{N}, 87.74^{\circ} \mathrm{W}\right)$-Felt. (Street and Green, 1984).

F KY Blandville $\left(36.9436^{\circ} \mathrm{N}, 88.9639^{\circ} \mathrm{W}\right)$-An earthquake, but no damage. (Street and Green, 1984).

F MO Caruthersville $\left(36.1931^{\circ} \mathrm{N}, 89.6556^{\circ} \mathrm{W}\right)$-Felt. (Street and Green, 1984).

F MO Jackson $\left(37.3822^{\circ} \mathrm{N}, 89.6661^{\circ} \mathrm{W}\right)$-An earthquake shock was felt. (Street and Green, 1984).

F MO Jefferson City $\left(38.5767^{\circ} \mathrm{N}, 92.1733^{\circ} \mathrm{W}\right)$-Felt. (Street and Green, 1984). 


\section{Appendix 1, Part 20. Damage Reports and Intensity Assignments}

\section{\#20 1903 Nov. 4 19:14UTC (Missouri)}

$7 \quad \mathrm{MO}$

MO

$7 \quad \mathrm{MO}$

MO

$6 \mathrm{MO}$

MO

5 IL

$5 \quad \mathrm{IL}$

IL

$5 \quad \mathrm{KY}$

$5 \quad K Y$

$5 \mathrm{KY}$

$5 \quad \mathrm{MO}$

$5 \quad \mathrm{MO}$

$5 \mathrm{MO}$

5 MS

MS

IL

IN

KY

KY

$K Y$

$K Y$

$K Y$

$\mathrm{MO}$

$\mathrm{MO}$

TN

TN

TN

TN

AR

IL

KY

$\mathrm{KY}$

MO

MO

MS

TN

TN

TN

IL

IN

MO

AR

IL

IL

IL

IL

IL

IL

Cape Girardeau $\left(37.3058^{\circ} \mathrm{N}, 89.5181^{\circ} \mathrm{W}\right)$-Knocked bricks off a number of chimneys - three times more severe than the first shock an hour earlier. [ At Cape Girardeau the 1903 November 4 18:18 UTC shock was "a severe shock." - IV] (Street and Green, 1984).

Cape Girardeau $\left(37.3058^{\circ} \mathrm{N}, 89.5181^{\circ} \mathrm{W}\right.$ )-Chimneys were downed at Cape Girardeau. (Stover and Coffman, 1993).

New Madrid $\left(36.5864^{\circ} \mathrm{N}, 89.5278^{\circ} \mathrm{W}\right)$-Toppled chimneys, cracked the walls of a new church and a bank, cracked plastering, broke plate glass windows; this one was more violent than the one an hour earlier. [At New Madrid, the 1903

November 4 18:18 UTC shock "toppled chimneys and frightened people." - VII] (Street and Green, 1984). New Madrid (36.5864 ${ }^{\circ} \mathrm{N}, 89.5278^{\circ} \mathrm{W}$ )—Chimneys were downed at ... New Madrid, Mo. (Stover and Coffman, 1993). Malden $\left(36.5569^{\circ} \mathrm{N}, 89.9664^{\circ} \mathrm{W}\right)$-Of sufficient force to damage brick chimneys. (Street and Green, 1984). Malden $\left(36.5569^{\circ} \mathrm{N}, 89.9664^{\circ} \mathrm{W}\right)$-Minor damage ... was reported at Malden, Mo. (Stover and Coffman, 1993). Cairo $\left(37.0053^{\circ} \mathrm{N}, 89.1764^{\circ} \mathrm{W}\right)$-Nearly everyone felt the shock, the most distinct of the two shocks that day; nearly everyone ran out of their homes badly frightened. (Street and Green, 1984).

Quincy $\left(39.9356^{\circ} \mathrm{N}, 91.4097^{\circ} \mathrm{W}\right)$-A few loose bricks were dislodged from wobbly chimneys. (Street and Green, 1984). Quincy $\left(39.9356^{\circ} \mathrm{N}, 91.4097^{\circ} \mathrm{W}\right)$-Minor damage ... was reported at ... Quincy, III. (Stover and Coffman, 1993). Hickman $\left(36.5711^{\circ} \mathrm{N}, 89.1861^{\circ} \mathrm{W}\right)$-Many people ran out doors, rattled things about considerably. (Street and Green, 1984).

Hopkinsville $\left(36.8656^{\circ} \mathrm{N}, 87.4886^{\circ} \mathrm{W}\right)$-Violently rocked buildings, rattled windows and dishes. (Street and Green, 1984). Owensboro $\left(37.7742^{\circ} \mathrm{N}, 87.1133^{\circ} \mathrm{W}\right)$-Alarmed some, tables and sideboards tumbled. (Street and Green, 1984).

Bloomfield $\left(36.8858^{\circ} \mathrm{N}, 89.9292^{\circ} \mathrm{W}\right)$-Violently shook houses and windows. (Street and Green, 1984).

Caruthersville $\left(36.1931^{\circ} \mathrm{N}, 89.6556^{\circ} \mathrm{W}\right)$-Rocked houses frightfully, many fled. (Street and Green, 1984).

Poplar Bluff $\left(36.7569^{\circ} \mathrm{N}, 90.3928^{\circ} \mathrm{W}\right)$-Plainly felt by many - much more severe than the one earlier. [At Poplar Bluff, the 1903 November 4 18:18 UTC shock was "plainly observed by many." - IV] (Street and Green, 1984).

Oxford $\left(34.3664^{\circ} \mathrm{N}, 89.5192^{\circ} \mathrm{W}\right)$-Cracked the Lafayette county court house wall. (Street and Green, 1984).

Oxford $\left(34.3664^{\circ} \mathrm{N}, 89.5192^{\circ} \mathrm{W}\right)$-Minor damage ... was reported at ... Oxford, Miss. (Stover and Coffman, 1993).

Marion $\left(37.7306^{\circ} \mathrm{N}, 88.9331^{\circ} \mathrm{W}\right)$-Created a sensation in the public schools. (Street and Green, 1984).

Brazil $\left(39.5236^{\circ} \mathrm{N}, 87.125^{\circ} \mathrm{W}\right)$-Rattled windows and rocked houses. (Street and Green, 1984).

Barbourville $\left(36.8664^{\circ} \mathrm{N}, 83.8889^{\circ} \mathrm{W}\right)$-Violently rattle windows. (Street and Green, 1984).

Clinton $\left(36.6672^{\circ} \mathrm{N}, 88.9933^{\circ} \mathrm{W}\right)$-So violently as to frighten a number of people. (Street and Green, 1984).

Owingsville $\left(38.1447^{\circ} \mathrm{N}, 83.7642^{\circ} \mathrm{W}\right)$-Rattled dishes and windows. (Street and Green, 1984).

Paducah $\left(37.0833^{\circ} \mathrm{N}, 88.6^{\circ} \mathrm{W}\right)$-Walls and floors rocked and crockery rattled. (Street and Green, 1984).

Philpot $\left(37.7331^{\circ} \mathrm{N}, 86.9889^{\circ} \mathrm{W}\right)$ - Shook several articles from shelves in drugstore. (Street and Green, 1984).

Charleston $\left(36.9208^{\circ} \mathrm{N}, 89.3506^{\circ} \mathrm{W}\right)$-Frightened the timid. (Street and Green, 1984).

Saint Louis $\left(38.6272^{\circ} \mathrm{N}, 90.1978^{\circ} \mathrm{W}\right)$-Felt by and frightened many in office buildings, lasted about 15 seconds. (Street and Green, 1984).

Bolivar $\left(35.2561^{\circ} \mathrm{N}, 88.9878^{\circ} \mathrm{W}\right)$-Rattled doors, windows, etc. (Street and Green, 1984).

Dyersburg $\left(36.0344^{\circ} \mathrm{N}, 89.3856^{\circ} \mathrm{W}\right)$-Sloshed water out of glasses, caused some apprehension. (Street and Green, 1984). Jackson $\left(35.6144^{\circ} \mathrm{N}, 88.8139^{\circ} \mathrm{W}\right)$-Rattled windows and doors. (Street and Green, 1984).

Memphis $\left(35.1494^{\circ} \mathrm{N}, 90.0489^{\circ} \mathrm{W}\right)$-Rattled dishes, swung pictures on walls. (Street and Green, 1984).

Piggott $\left(36.3828^{\circ} \mathrm{N}, 90.1906^{\circ} \mathrm{W}\right)$-Distinctly felt. (Street and Green, 1984).

Jonesboro $\left(37.4517^{\circ} \mathrm{N}, 89.2681^{\circ} \mathrm{W}\right)$-Distinct shock. (Street and Green, 1984).

Cloverport $\left(37.8333^{\circ} \mathrm{N}, 86.6328^{\circ} \mathrm{W}\right)$-Rattled glassware and furniture slightly. (Street and Green, 1984).

Louisville $\left(38.2542^{\circ} \mathrm{N}, 85.7594^{\circ} \mathrm{W}\right)$-Distinct shock - felt in various parts of the city. (Street and Green, 1984).

Jackson $\left(37.3822^{\circ} \mathrm{N}, 89.6661^{\circ} \mathrm{W}\right)-\mathrm{A}$ "shake" lasting half a minute. (Street and Green, 1984).

Kennett $\left(36.2361^{\circ} \mathrm{N}, 90.0556^{\circ} \mathrm{W}\right)$-Twenty seconds in duration. (Street and Green, 1984).

Water Valley $\left(34.1514^{\circ} \mathrm{N}, 89.6314^{\circ} \mathrm{W}\right)-\mathrm{A}$ distinct shock was felt. (Street and Green, 1984).

Ashwood $\left(35.5794^{\circ} \mathrm{N}, 87.1439^{\circ} \mathrm{W}\right)$-Perceptible shock was felt. (Street and Green, 1984).

Chattanooga $\left(35.0456^{\circ} \mathrm{N}, 85.3097^{\circ} \mathrm{W}\right)$-Rattled windows audibly. (Street and Green, 1984).

Nashville $\left(36.1658^{\circ} \mathrm{N}, 86.7844^{\circ} \mathrm{W}\right)$-A distinct shock was felt. (Street and Green, 1984).

Richview $\left(38.3783^{\circ} \mathrm{N}, 89.18^{\circ} \mathrm{W}\right)$-Felt by those on upper floors. (Street and Green, 1984).

Evansville $\left(37.9747^{\circ} \mathrm{N}, 87.5558^{\circ} \mathrm{W}\right)$-A slight shock was felt. (Street and Green, 1984).

Ironton $\left(37.5972^{\circ} \mathrm{N}, 90.6272^{\circ} \mathrm{W}\right)-$ Two light shocks were felt. (Street and Green, 1984).

Little Rock $\left(34.7464^{\circ} \mathrm{N}, 92.2894^{\circ} \mathrm{W}\right)$-Not mentioned. (Street and Green, 1984).

Belleville $\left(38.5200^{\circ} \mathrm{N}, 89.9839^{\circ} \mathrm{W}\right)$-Not reported. (Street and Green, 1984).

Benton $\left(37.9967^{\circ} \mathrm{N}, 88.92^{\circ} \mathrm{W}\right)$-Not reported. (Street and Green, 1984).

Carmi $\left(38.0908^{\circ} \mathrm{N}, 88.1586^{\circ} \mathrm{W}\right)$-Not reported. (Street and Green, 1984).

Champaign $\left(40.1164^{\circ} \mathrm{N}, 88.2433^{\circ} \mathrm{W}\right)$-Not mentioned. (Street and Green, 1984).

Chester $\left(37.9136^{\circ} \mathrm{N}, 89.8219^{\circ} \mathrm{W}\right)$-Not reported. (Street and Green, 1984).

Paris $\left(39.6111^{\circ} \mathrm{N}, 87.6961^{\circ} \mathrm{W}\right)$-Not mentioned. (Street and Green, 1984). 


\section{Appendix 1, Part 20. Damage Reports and Intensity Assignments}

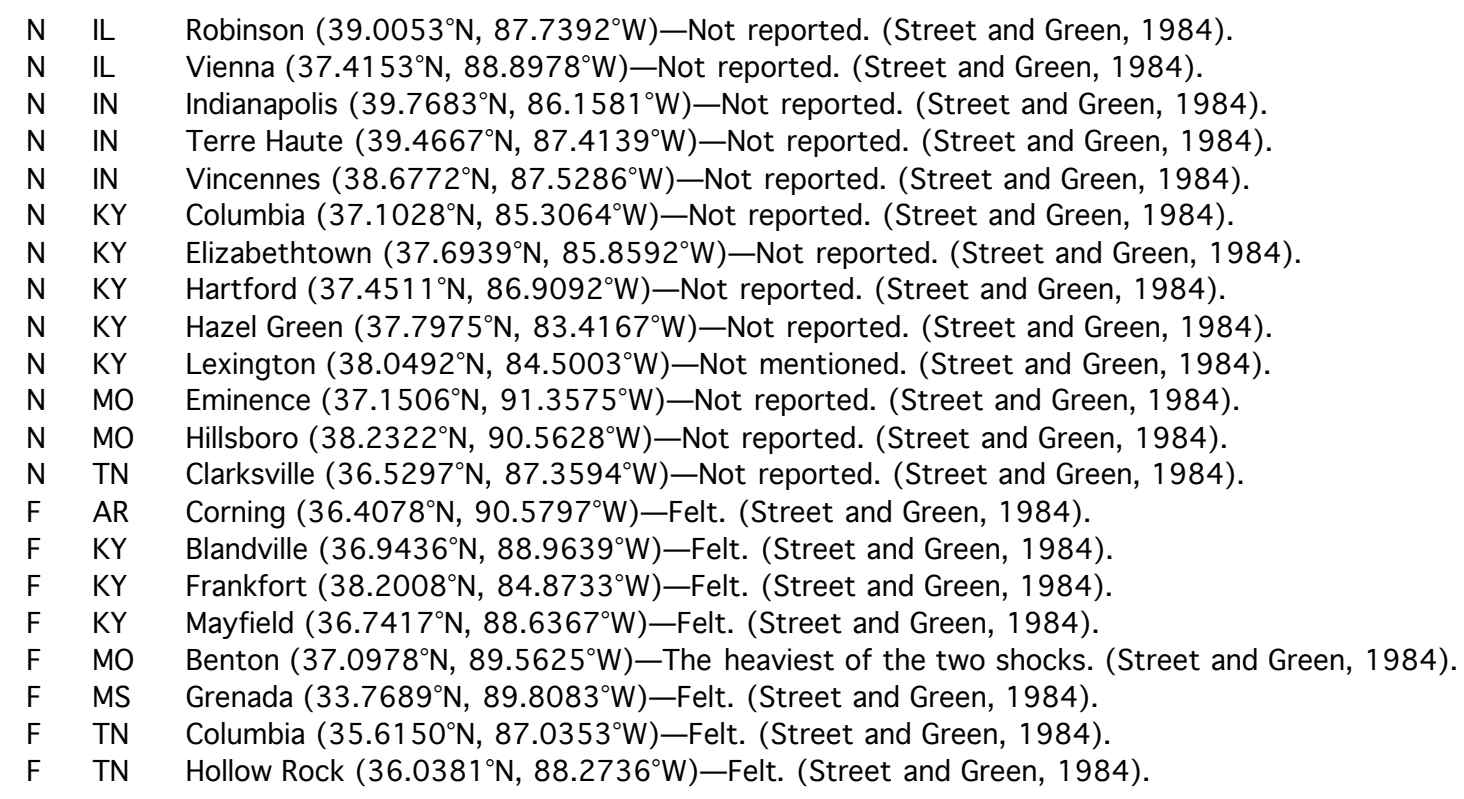




\section{Appendix 1, Part 21. Damage Reports and Intensity Assignments}

\section{\#21 1905 Aug. 22 05:08UTC (Missouri)}

6 IL Cairo $\left(37.0053^{\circ} \mathrm{N}, 89.1764^{\circ} \mathrm{W}\right)$-Of considerable severity; people rushed from clubs, two brick chimneys shaken down, dishes broken in several homes. (Street and Green, 1984).

IL $\quad$ Cairo $\left(37.0053^{\circ} \mathrm{N}, 89.1764^{\circ} \mathrm{W}\right)$-Chimneys were shaken down at Cairo, Pulaski County, Ill. (Stover and Coffman, 1993).

6 IN New Harmony $\left(38.1297^{\circ} \mathrm{N}, 87.935^{\circ} \mathrm{W}\right)$-Smashed windows in houses. (Street and Green, 1984).

6 MO Cape Girardeau $\left(37.3058^{\circ} \mathrm{N}, 89.5181^{\circ} \mathrm{W}\right)$-Awakened nearly everyone, cracked many older buildings; many people found it difficult to walk. (Street and Green, 1984).

6 MO Charleston $\left(36.9208^{\circ} \mathrm{N}, 89.3506^{\circ} \mathrm{W}\right)$-Cracked and shook down plaster, broke bric-a-brac and other loose articles, broke a few chimneys, caused people to rush out of their homes. (Street and Green, 1984).

MO

Charleston $\left(36.9208^{\circ} \mathrm{N}, 89.3506^{\circ} \mathrm{W}\right)$-Chimneys ... were broken or partly collapsed at nearby Charleston, Mo. (Stover and Coffman, 1993).

$6 \quad \mathrm{MO}$

Sikeston $\left(36.9386^{\circ} \mathrm{N}, 89.5988^{\circ} \mathrm{W}\right)$ - "Chimneys were shaken down at ... Sikeston, Mo." (Stover and Coffman, 1993).

6 TN

Clarksville $\left(36.5297^{\circ} \mathrm{N}, 87.3594^{\circ} \mathrm{W}\right)$-Quite a large number of people were awakened; chimneys were shaken partly down at two houses. (Street and Green, 1984).

TN Clarksville $\left(36.5297^{\circ} \mathrm{N}, 87.3594^{\circ} \mathrm{W}\right)$-Chimneys ... were broken or partly collapsed at ... Clarksville, Tenn. (Stover and Coffman, 1993).

Jonesboro $\left(35.8422^{\circ} \mathrm{N}, 90.7042^{\circ} \mathrm{W}\right)$-Cracked a kitchen flue. (Street and Green, 1984).

Belleville $\left(38.5200^{\circ} \mathrm{N}, 89.9839^{\circ} \mathrm{W}\right)$-Some residents left their houses, beds \& furniture shook, thousands of persons felt the shock. (Street and Green, 1984).

Mound City $\left(37.0853^{\circ} \mathrm{N}, 89.1625^{\circ} \mathrm{W}\right)$-Sleepers awakened, some ran outdoors. (Street and Green, 1984).

Salem $\left(38.6269^{\circ} \mathrm{N}, 88.9456^{\circ} \mathrm{W}\right)$-Sufficient to awakened many from their slumbers and to break dishes. (Street and Green, 1984).

Springfield $\left(39.8017^{\circ} \mathrm{N}, 89.6436^{\circ} \mathrm{W}\right)$-Rattled dishes and windows; some dishes were broken and some pictures were displaced from the walls. (Street and Green, 1984).

Cochran $\left(39.0522^{\circ} \mathrm{N}, 84.9206^{\circ} \mathrm{W}\right)$-Quite severe. (Street and Green, 1984).

Washington $\left(38.6592^{\circ} \mathrm{N}, 87.1728^{\circ} \mathrm{W}\right)$-Quite severe. (Street and Green, 1984).

IN

Henderson $\left(37.8361^{\circ} \mathrm{N}, 87.59^{\circ} \mathrm{W}\right)$-Severely frightened several persons, light articles thrown down, glassware broken. (Street and Green, 1984).

Owensboro $\left(37.7742^{\circ} \mathrm{N}, 87.1133^{\circ} \mathrm{W}\right)$-Hundreds of people were aroused, windows rattled in frames, light articles were moved and few were broken. (Street and Green, 1984).

Paducah $\left(37.0833^{\circ} \mathrm{N}, 88.6^{\circ} \mathrm{W}\right)$-People aroused all over the city, broke dishes, overturned lumber piles. (Street and Green, 1984).

Poplar Bluff $\left(36.7569^{\circ} \mathrm{N}, 90.3928^{\circ} \mathrm{W}\right)$-Awakened nearly everyone, moved pictures on walls, moved heavy furniture. (Street and Green, 1984).

Saint Charles $\left(38.7839^{\circ} \mathrm{N}, 90.4811^{\circ} \mathrm{W}\right)$-Two severe shocks rattled dishes and windows; many people fled into the streets. (Street and Green, 1984).

Saint Louis $\left(38.6272^{\circ} \mathrm{N}, 90.1978^{\circ} \mathrm{W}\right)$-Awakened sleeping persons, rattled windows, moved furniture; many people left their homes. (Street and Green, 1984).

McKenzie $\left(36.1325^{\circ} \mathrm{N}, 88.5186^{\circ} \mathrm{W}\right)$-Aroused people from their sleep and caused them to leave their homes. (Street and Green, 1984).

Memphis $\left(35.1494^{\circ} \mathrm{N}, 90.0489^{\circ} \mathrm{W}\right.$ ) -Alarmed people - many rushed into the streets. (Street and Green, 1984).

AR

IL

Marked Tree $\left(35.5328^{\circ} \mathrm{N}, 90.4206^{\circ} \mathrm{W}\right)$-Rattled dishes and windows. (Street and Green, 1984).

Anna $\left(37.4603^{\circ} \mathrm{N}, 89.2469^{\circ} \mathrm{W}\right)$-Caused great uneasiness. (Street and Green, 1984).

Campbell Hill $\left(37.9300^{\circ} \mathrm{N}, 89.5489^{\circ} \mathrm{W}\right)$-Many people startled from their sleep. (Street and Green, 1984).

Chatham $\left(39.6761^{\circ} \mathrm{N}, 89.7044^{\circ} \mathrm{W}\right)$-Several families were aroused and some were frightened. (Street and Green, 1984).

Fairfield $\left(38.3789^{\circ} \mathrm{N}, 88.3597^{\circ} \mathrm{W}\right)$-Of considerable severity; sufficient to awaken sleepers. (Street and Green, 1984).

Goose Island-Aroused the people. (Street and Green, 1984).

Harrisburg $\left(37.7383^{\circ} \mathrm{N}, 88.5406^{\circ} \mathrm{W}\right)$-Felt my many people, and in some cases caused doors to slam. (Street and Green, 1984).

Marion $\left(37.7306^{\circ} \mathrm{N}, 88.9331^{\circ} \mathrm{W}\right)$-Caused considerable excitement, rattled windows and rocked buildings. (Street and Green, 1984).

IL $\quad$ Mount Vernon $\left(38.3172^{\circ} \mathrm{N}, 88.9031^{\circ} \mathrm{W}\right)$-Frightened everyone. (Street and Green, 1984).

IL Olmsted $\left(37.1806^{\circ} \mathrm{N}, 89.0889^{\circ} \mathrm{W}\right)$-All people were much disturbed. (Street and Green, 1984).

IL Paris $\left(39.6111^{\circ} \mathrm{N}, 87.6961^{\circ} \mathrm{W}\right)$-Several citizens awakened from sleep; dishes rattled. (Street and Green, 1984).

IL Quincy $\left(39.9356^{\circ} \mathrm{N}, 91.4097^{\circ} \mathrm{W}\right)$-Hundreds were awakened, beds and houses shook. (Street and Green, 1984).

IL Richview $\left(38.3783^{\circ} \mathrm{N}, 89.18^{\circ} \mathrm{W}\right)$-Rattled windows and dishes all over town. (Street and Green, 1984).

IL $\quad$ Ridge Prairie $\left(38.5900^{\circ} \mathrm{N}, 89.97^{\circ} \mathrm{W}\right)$-An earthquake of considerable severity. (Street and Green, 1984).

IL Shelbyville $\left(39.4064^{\circ} \mathrm{N}, 88.79^{\circ} \mathrm{W}\right.$ )-Awakened people, many greatly alarmed. (Street and Green, 1984). 


\section{Appendix 1, Part 21. Damage Reports and Intensity Assignments}

4 IL Villa Ridge $\left(37.1586^{\circ} \mathrm{N}, 89.1947^{\circ} \mathrm{W}\right)$-Put the entire population on its feet. (Street and Green, 1984).

4 IN Cold Springs $\left(39.0714^{\circ} \mathrm{N}, 85.0731^{\circ} \mathrm{W}\right)$-An earthquake of great intensity awakened people from their slumbers. (Street and Green, 1984).

4 IN Princeton $\left(38.3553^{\circ} \mathrm{N}, 87.5675^{\circ} \mathrm{W}\right)$-Very perceptible; dishes rattled. (Street and Green, 1984).

4 IN Tell City $\left(37.9514^{\circ} \mathrm{N}, 86.7678^{\circ} \mathrm{W}\right)$-Shook buildings and frightened people. (Street and Green, 1984).

4 KY Cloverport $\left(37.8333^{\circ} \mathrm{N}, 86.6328^{\circ} \mathrm{W}\right)$-A distinct, tough slight, shock; moved light articles such as china and glassware. (Street and Green, 1984). Corydon $\left(37.7433^{\circ} \mathrm{N}, 87.7039^{\circ} \mathrm{W}\right)$-Buildings were severely shaken (Street and Green, 1984).

Dixon $\left(37.5178^{\circ} \mathrm{N}, 87.6903^{\circ} \mathrm{W}\right)-\mathrm{A}$ severe earthquake was felt, many buildings were shaken considerably. (Street and Green, 1984).

Earlington $\left(37.2742^{\circ} \mathrm{N}, 87.5119^{\circ} \mathrm{W}\right)$-Awakened light sleepers, rattled dishes. (Street and Green, 1984).

Elkton $\left(36.8100^{\circ} \mathrm{N}, 87.1542^{\circ} \mathrm{W}\right)$-Rattled dishes and windows. (Street and Green, 1984).

Hopkinsville $\left(36.8656^{\circ} \mathrm{N}, 87.4886^{\circ} \mathrm{W}\right.$ )-Awakened people and caused pictures on walls to sway back and forth. (Street and Green, 1984).

Louisville $\left(38.2542^{\circ} \mathrm{N}, 85.7594^{\circ} \mathrm{W}\right)$-Rattled dishes so violently that it awakened people; caused pictures to swing on walls. (Street and Green, 1984).

Marion $\left(37.3328^{\circ} \mathrm{N}, 88.0811^{\circ} \mathrm{W}\right)$-People were aroused sufficiently to get up and discuss the event. (Street and Green, 1984).

Mayfield $\left(36.7417^{\circ} \mathrm{N}, 88.6367^{\circ} \mathrm{W}\right)$-Large buildings rocked on their foundations, pictures on walls played a merry tattoo. (Street and Green, 1984).

Robards $\left(37.6739^{\circ} \mathrm{N}, 87.5467^{\circ} \mathrm{W}\right)$ - Houses shaken severely. (Street and Green, 1984).

Benton $\left(37.0978^{\circ} \mathrm{N}, 89.5625^{\circ} \mathrm{W}\right)$-Sufficiently severe to waken most sleepers. (Street and Green, 1984).

Bertrand $\left(36.9094^{\circ} \mathrm{N}, 89.4525^{\circ} \mathrm{W}\right)$-Aroused the citizens and was the sole topic of conversation. (Street and Green, 1984).

Blodgett $\left(37.0042^{\circ} \mathrm{N}, 89.5269^{\circ} \mathrm{W}\right)$-Experienced a pronounced earthquake shock. (Street and Green, 1984).

Bloomfield $\left(36.8858^{\circ} \mathrm{N}, 89.9292^{\circ} \mathrm{W}\right)$ - Houses trembled, doors creaked and furniture shook perceptibly. (Street and Green, 1984).

Bonne Terre $\left(37.9231^{\circ} \mathrm{N}, 90.5553^{\circ} \mathrm{W}\right)$-Two distinct earthquake shocks noticeable to hundreds of citizens. (Street and Green, 1984).

Bowling Green $\left(39.3419^{\circ} \mathrm{N}, 91.195^{\circ} \mathrm{W}\right)$-Many of our citizens felt a very perceptible earthquake. (Street and Green, 1984). Brashear $\left(40.1489^{\circ} \mathrm{N}, 92.3789^{\circ} \mathrm{W}\right)$-Many people felt a slight earthquake. (Street and Green, 1984).

Caruthersville $\left(36.1931^{\circ} \mathrm{N}, 89.6556^{\circ} \mathrm{W}\right)$-A very serious earthquake. (Street and Green, 1984).

Diehlstadt $\left(36.9583^{\circ} \mathrm{N}, 89.4308^{\circ} \mathrm{W}\right)$-Gave people a scare. (Street and Green, 1984).

Fredericktown $\left(37.5597^{\circ} \mathrm{N}, 90.2939^{\circ} \mathrm{W}\right)$-Felt an earthquake of unusual severity and length. (Street and Green, 1984).

Fulton $\left(38.8467^{\circ} \mathrm{N}, 91.9478^{\circ} \mathrm{W}\right)$-Felt by a number of people, awakened sleeping persons, rattled dishes. (Street and Green, 1984).

Greenville $\left(37.1272^{\circ} \mathrm{N}, 90.45^{\circ} \mathrm{W}\right)$-Shook things up considerably. (Street and Green, 1984).

Hannibal $\left(39.7083^{\circ} \mathrm{N}, 91.3583^{\circ} \mathrm{W}\right)$-A number of inhabitants felt the earthquake, a few instances of people being jarred from bed. (Street and Green, 1984). 1984).

Kirksville $\left(40.1947^{\circ} \mathrm{N}, 92.5831^{\circ} \mathrm{W}\right)$-Caused considerable uneasiness, many people got up and dressed. (Street and Green, 1984).

Louisiana $\left(39.4489^{\circ} \mathrm{N}, 91.0514^{\circ} \mathrm{W}\right)$-Felt by a large number, rattled dishes and windows in some instances. (Street and Green, 1984).

Marble Hill $\left(37.3058^{\circ} \mathrm{N}, 89.9703^{\circ} \mathrm{W}\right)$-A heavy earthquake was felt. (Street and Green, 1984).

Mexico $\left(39.1697^{\circ} \mathrm{N}, 91.8828^{\circ} \mathrm{W}\right)$-Very perceptible, in some homes people were aroused; loosened plaster in one home. (Street and Green, 1984).

Morehouse $\left(36.8472^{\circ} \mathrm{N}, 89.6853^{\circ} \mathrm{W}\right)$-Distinct shock felt by many. (Street and Green, 1984).

Perryville $\left(37.7242^{\circ} \mathrm{N}, 89.8611^{\circ} \mathrm{W}\right)$-Strong enough to awaken many. (Street and Green, 1984).

Union (38.4456 $\left.\mathrm{N}, 91.0056^{\circ} \mathrm{W}\right)$ - Many of the citizens were aroused. (Street and Green, 1984).

Brownsville $\left(35.5939^{\circ} \mathrm{N}, 89.2622^{\circ} \mathrm{W}\right)$-Shook houses and rattled dishes. (Street and Green, 1984).

Champaign $\left(40.1164^{\circ} \mathrm{N}, 88.2433^{\circ} \mathrm{W}\right)$-A number of people felt the tremor. (Street and Green, 1984).

Effingham $\left(39.1200^{\circ} \mathrm{N}, 88.5433^{\circ} \mathrm{W}\right)$-A distinct earthquake shock was experienced. (Street and Green, 1984).

Freeburg $\left(38.4275^{\circ} \mathrm{N}, 89.9136^{\circ} \mathrm{W}\right)$-Distinctly felt. (Street and Green, 1984).

Grayville $\left(38.2575^{\circ} \mathrm{N}, 87.9936^{\circ} \mathrm{W}\right)$-Distinct earthquake shock felt. (Street and Green, 1984).

Virginia $\left(39.9511^{\circ} \mathrm{N}, 90.2122^{\circ} \mathrm{W}\right)$-Distinctive. (Street and Green, 1984).

Madison $\left(38.7358^{\circ} \mathrm{N}, 85.38^{\circ} \mathrm{W}\right)$-Residents were startled by a slight earthquake. (Street and Green, 1984).

Sullivan $\left(39.0953^{\circ} \mathrm{N}, 87.4058^{\circ} \mathrm{W}\right)$-Distinctly felt. (Street and Green, 1984). 


\title{
Appendix 1, Part 21. Damage Reports and Intensity Assignments
}

\author{
MO East Prairie $\left(36.7797^{\circ} \mathrm{N}, 89.3856^{\circ} \mathrm{W}\right)$-Felt distinctly. (Street and Green, 1984). \\ MO Edina $\left(40.1675^{\circ} \mathrm{N}, 92.1725^{\circ} \mathrm{W}\right)$-Felt distinctly. (Street and Green, 1984). \\ MO \\ Hillsboro $\left(38.2322^{\circ} \mathrm{N}, 90.5628^{\circ} \mathrm{W}\right)$-A number felt it, but the majority were too much asleep. (Street and Green, 1984). \\ Houston $\left(37.3261^{\circ} \mathrm{N}, 91.9558^{\circ} \mathrm{W}\right)$-A slight earthquake shock was felt by a number of persons. (Street and Green, 1984). \\ Moberly $\left(39.4183^{\circ} \mathrm{N}, 92.4381^{\circ} \mathrm{W}\right)$-Two distinct earthquake shocks. (Street and Green, 1984). \\ New Madrid $\left(36.5864^{\circ} \mathrm{N}, 89.5278^{\circ} \mathrm{W}\right)$-Felt by people who were awake. (Street and Green, 1984). \\ Pacific $\left(38.4819^{\circ} \mathrm{N}, 90.7414^{\circ} \mathrm{W}\right)$-Awakened several citizens. (Street and Green, 1984). \\ Silex $\left(39.1233^{\circ} \mathrm{N}, 91.0542^{\circ} \mathrm{W}\right)$-Distinctly felt by a number of citizens. (Street and Green, 1984). \\ Steelville $\left(37.9681^{\circ} \mathrm{N}, 91.3547^{\circ} \mathrm{W}\right)$-Awakened a number of citizens. (Street and Green, 1984). \\ Sullivan $\left(38.2081^{\circ} \mathrm{N}, 91.1603^{\circ} \mathrm{W}\right)$-A number of people felt the shock. (Street and Green, 1984). \\ Washington $\left(38.5581^{\circ} \mathrm{N}, 91.0119^{\circ} \mathrm{W}\right)$-Three distinct shocks were felt. (Street and Green, 1984). \\ Columbia $\left(35.6150^{\circ} \mathrm{N}, 87.0353^{\circ} \mathrm{W}\right)$-Several Columbians felt the shocks. (Street and Green, 1984). \\ Erin $\left(36.3183^{\circ} \mathrm{N}, 87.6947^{\circ} \mathrm{W}\right)$-Distinct. (Street and Green, 1984). \\ Gainesboro $\left(36.3556^{\circ} \mathrm{N}, 85.6589^{\circ} \mathrm{W}\right)$-Was felt here by some. (Street and Green, 1984). \\ Paris $\left(36.3019^{\circ} \mathrm{N}, 88.3267^{\circ} \mathrm{W}\right)$-Distinctly felt, lasted about 30 seconds. (Street and Green, 1984). \\ Little Rock $\left(34.7464^{\circ} \mathrm{N}, 92.2894^{\circ} \mathrm{W}\right)$-A slight earthquake shock was felt by a few. (Street and Green, 1984). \\ Chicago $\left(41.8500^{\circ} \mathrm{N}, 87.65^{\circ} \mathrm{W}\right)$-Barely felt. (Street and Green, 1984). \\ Indianapolis $\left(39.7683^{\circ} \mathrm{N}, 86.1581^{\circ} \mathrm{W}\right.$ )-More or less perceptible. (Street and Green, 1984). \\ Auxvasse $\left(39.0181^{\circ} \mathrm{N}, 91.8969^{\circ} \mathrm{W}\right)$-Felt by a few. (Street and Green, 1984). \\ Canton $\left(40.1250^{\circ} \mathrm{N}, 91.625^{\circ} \mathrm{W}\right)$-Felt by a few. (Street and Green, 1984). \\ Hermann $\left(38.7042^{\circ} \mathrm{N}, 91.4372^{\circ} \mathrm{W}\right)$-A slight earthquake felt by people not fast asleep. (Street and Green, 1984). \\ New London $\left(39.5853^{\circ} \mathrm{N}, 91.4008^{\circ} \mathrm{W}\right)$-Several people claim to have felt the earthquake. (Street and Green, 1984). \\ Potosi $\left(37.9364^{\circ} \mathrm{N}, 90.7878^{\circ} \mathrm{W}\right)-\mathrm{A}$ few people noticed the tremors. (Street and Green, 1984). \\ Troy $\left(38.9794^{\circ} \mathrm{N}, 90.9806^{\circ} \mathrm{W}\right)-\mathrm{A}$ slight earthquake was felt. (Street and Green, 1984). \\ Franklin $\left(35.9250^{\circ} \mathrm{N}, 86.8689^{\circ} \mathrm{W}\right)$-Slight earthquake. (Street and Green, 1984). \\ Johnsville-Slight earthquake. (Street and Green, 1984). \\ Savannah $\left(35.2247^{\circ} \mathrm{N}, 88.2492^{\circ} \mathrm{W}\right)$-Slight earthquake. (Street and Green, 1984). \\ Springville $\left(36.2492^{\circ} \mathrm{N}, 88.1531^{\circ} \mathrm{W}\right)$-Slight earthquake felt. (Street and Green, 1984). \\ Conway $\left(35.0886^{\circ} \mathrm{N}, 92.4419^{\circ} \mathrm{W}\right)$-Not felt. (Street and Green, 1984). \\ Malvern $\left(34.3622^{\circ} \mathrm{N}, 92.8128^{\circ} \mathrm{W}\right)$-Not felt. (Street and Green, 1984). \\ Osceola $\left(35.7050^{\circ} \mathrm{N}, 89.9694^{\circ} \mathrm{W}\right)$-Not felt. (Street and Green, 1984). \\ Monmouth $\left(40.9114^{\circ} \mathrm{N}, 90.6472^{\circ} \mathrm{W}\right)$-Not felt. (Street and Green, 1984). \\ Ottawa $\left(41.3456^{\circ} \mathrm{N}, 88.8425^{\circ} \mathrm{W}\right)$-Not felt. (Street and Green, 1984). \\ $\begin{array}{ll}\text { IL } & \text { Robinson }\left(39.0053^{\circ} \mathrm{N}, 87.7392^{\circ} \mathrm{W}\right) \text {-Not felt. (Street and Green, 1984). } \\ \mathrm{KY} & \text { Covington }\left(39.0836^{\circ} \mathrm{N}, 84.5086^{\circ} \mathrm{W}\right) \text {-Not felt. (Street and Green, 1984). }\end{array}$ \\ KY Danville $\left(37.6456^{\circ} \mathrm{N}, 84.7722^{\circ} \mathrm{W}\right)$-Not felt. (Street and Green, 1984). \\ KY Hartford $\left(37.4511^{\circ} \mathrm{N}, 86.9092^{\circ} \mathrm{W}\right)$-Not felt. (Street and Green, 1984). \\ KY Lexington $\left(38.0492^{\circ} \mathrm{N}, 84.5003^{\circ} \mathrm{W}\right)$-Not felt. (Street and Green, 1984). \\ MO Cedar City $\left(38.5972^{\circ} \mathrm{N}, 92.1794^{\circ} \mathrm{W}\right)$-Not felt. (Street and Green, 1984). \\ MO Clarksville $\left(39.3706^{\circ} \mathrm{N}, 90.905^{\circ} \mathrm{W}\right)$-Not felt. (Street and Green, 1984). \\ MO DeSoto $\left(38.1394^{\circ} \mathrm{N}, 90.555^{\circ} \mathrm{W}\right)$-Not felt. (Street and Green, 1984). \\ MO Jonesboro-Not felt. (Street and Green, 1984). \\ MO Molden $\left(36.5569^{\circ} \mathrm{N}, 89.9664^{\circ} \mathrm{W}\right)$-Not felt. (Street and Green, 1984). \\ MO Shelbyville $\left(39.8058^{\circ} \mathrm{N}, 92.0414^{\circ} \mathrm{W}\right)$-Not felt. (Street and Green, 1984). \\ $\mathrm{OH} \quad$ Cincinnati $\left(39.1619^{\circ} \mathrm{N}, 84.4569^{\circ} \mathrm{W}\right)$-Not felt. (Street and Green, 1984). \\ $\mathrm{OH} \quad$ Eaton $\left(39.7439^{\circ} \mathrm{N}, 84.6367^{\circ} \mathrm{W}\right)$-Not felt. (Street and Green, 1984). \\ $\mathrm{OH} \quad$ Greenville $\left(40.1028^{\circ} \mathrm{N}, 84.6331^{\circ} \mathrm{W}\right)$-Not felt. (Street and Green, 1984). \\ IA Cedar Rapids $\left(42.0083^{\circ} \mathrm{N}, 91.6439^{\circ} \mathrm{W}\right)$-Not mentioned. (Street and Green, 1984). \\ IA Davenport $\left(41.5236^{\circ} \mathrm{N}, 90.5775^{\circ} \mathrm{W}\right)$-Not mentioned. (Street and Green, 1984). \\ IA Fairfield $\left(41.0086^{\circ} \mathrm{N}, 91.9625^{\circ} \mathrm{W}\right)$-Not mentioned. (Street and Green, 1984). \\ IL Vienna $\left(37.4153^{\circ} \mathrm{N}, 88.8978^{\circ} \mathrm{W}\right)$-Not reported. (Street and Green, 1984). \\ KY Owenton $\left(38.5364^{\circ} \mathrm{N}, 84.8419^{\circ} \mathrm{W}\right)$-Not reported. (Street and Green, 1984). \\ KY Whitesville $\left(37.6831^{\circ} \mathrm{N}, 86.8714^{\circ} \mathrm{W}\right)$-Not reported. (Street and Green, 1984). \\ TN Maryville $\left(35.7564^{\circ} \mathrm{N}, 83.9706^{\circ} \mathrm{W}\right)$-Not reported. (Street and Green, 1984). \\ TN Milan $\left(35.9197^{\circ} \mathrm{N}, 88.7589^{\circ} \mathrm{W}\right)$-Not reported. (Street and Green, 1984). \\ IA Keokuk $\left(40.3972^{\circ} \mathrm{N}, 91.3847^{\circ} \mathrm{W}\right)$-Felt. (Street and Green, 1984). \\ KY Blandville $\left(36.9436^{\circ} \mathrm{N}, 88.9639^{\circ} \mathrm{W}\right)$-Felt. (Street and Green, 1984). \\ MO Vandalia $\left(39.3108^{\circ} \mathrm{N}, 91.4883^{\circ} \mathrm{W}\right)$-Was felt. (Street and Green, 1984). \\ MO \\ Vanduser $\left(36.9906^{\circ} \mathrm{N}, 89.6856^{\circ} \mathrm{W}\right)$-Experienced an earthquake shock. (Street and Green, 1984). \\ Wyaconda $\left(40.3897^{\circ} \mathrm{N}, 91.9269^{\circ} \mathrm{W}\right)$-Felt. (Street and Green, 1984).
}


Appendix 1, Part 21. Damage Reports and Intensity Assignments

F MS Vicksburg $\left(32.3525^{\circ} \mathrm{N}, 90.8778^{\circ} \mathrm{W}\right)$-Felt. (Street and Green, 1984). 


\section{Appendix 1, Part 22. Damage Reports and Intensity Assignments}

\section{\#22 1906 Jan. 8 00:15UTC (Kansas)}

$7 \quad \mathrm{KS}$

Manhattan $\left(39.1957^{\circ} \mathrm{N}, 96.5976^{\circ} \mathrm{W}\right)$-Walls cracked; people rushed from homes in frenzied fear; brick chimneys dislodged from school, depot, houses; dishes thrown together on tables; houses rocked and swayed; shelf contents shaken to floor; direction of wave motion was SW to NE; persons in the dining room of the Gilett Hotel rushed out into streets; lateral motion followed by vertical movement; aftershock 20 minutes later; vase, lamp or bottle broken in every house; tremor preceded by rumbling sound; two distinct waves; SE to NE motion; aftershock January 23 at 8:00 a.m. (Dubois and Wilson, 1978).

KS

KS

KS

KS

$6 \mathrm{KS}$

KS

KS

KS

$6 \mathrm{KS}$

KS

KS

KS

Manhattan $\left(39.1957^{\circ} \mathrm{N}, 96.5976^{\circ} \mathrm{W}\right)$ - “At Manhattan, 'The extent of movement of the surface was considerable. Though but few chimneys fell, yet in nearly every house was a vase, a lamp, a bottle or something that was tipped over and broken.'” (Heinrich, 1941).

Manhattan $\left(39.1957^{\circ} \mathrm{N}, 96.5976^{\circ} \mathrm{W}\right)$ - "The earth movement at Manhattan sent residents fleeing from their houses. Only a few chimneys fell, but something was broken in almost every house." (Stover and Coffman, 1993).

Manhattan $\left(39.1957^{\circ} \mathrm{N}, 96.5976^{\circ} \mathrm{W}\right)$ - "Manhattan, Kans. It was strong enough to throw down some chimneys and produce some cracks in walls. ... At Manhattan, a roar preceded the shock by 10 seconds." (Coffman and von Hake, 1973).

Manhattan $\left(39.1957^{\circ} \mathrm{N}, 96.5976^{\circ} \mathrm{W}\right)$ - "Ground motion was observed at Manhattan, where chimneys toppled, people fled their houses, and plaster cracked." (Merriam, 1956).

Junction City $\left(38.9873^{\circ} \mathrm{N}, 96.8314^{\circ} \mathrm{W}\right)$-Panic, people fled to streets; articles shaken from shelves and tables; windows rattled; plaster knocked from walls. (Dubois and Wilson, 1978).

Junction City $\left(38.9873^{\circ} \mathrm{N}, 96.8314^{\circ} \mathrm{W}\right)$ - "Plaster was knocked from walls in surrounding [Manhattan] towns of Junction City, Wamego, and Westmoreland." (Stover and Coffman, 1993).

Junction City $\left(38.9873^{\circ} \mathrm{N}, 96.8314^{\circ} \mathrm{W}\right)$ - “At Wamego, 15 miles west [of Manhattan], and Junction City, 19 miles southwest, plaster was knocked from walls." (Coffman and von Hake, 1973).

Junction City $\left(38.9873^{\circ} \mathrm{N}, 96.8314^{\circ} \mathrm{W}\right)$ - “A slight shock was felt at Wichita, Emporia, Junction City, Alma, Beloit, and Kansas City." (Merriam, 1956).

Wamego $\left(39.2575^{\circ} \mathrm{N}, 96.3628^{\circ} \mathrm{W}\right)$-Plaster shaken from ceilings; things tumbled about generally; pictures shaken from walls; bottles shaken from shelves; "The amount of damage will be considerable." (Dubois and Wilson, 1978).

Wamego $\left(39.2575^{\circ} \mathrm{N}, 96.3628^{\circ} \mathrm{W}\right)$ - "Plaster was knocked from walls in surrounding [Manhattan] towns of Junction City, Wamego, and Westmoreland." (Stover and Coffman, 1993).

Wamego $\left(39.2575^{\circ} \mathrm{N}, 96.3628^{\circ} \mathrm{W}\right)$ - "At Wamego, 15 miles west [of Manhattan], and Junction City, 19 miles southwest, plaster was knocked from walls." (Coffman and von Hake, 1973).

Wamego $\left(39.2575^{\circ} \mathrm{N}, 96.3628^{\circ} \mathrm{W}\right)$ - “Two shock occurred." (Merriam, 1956).

Westmoreland $\left(39.4377^{\circ} \mathrm{N}, 96.4143^{\circ} \mathrm{W}\right)$ - "Plaster was knocked from walls in surrounding [Manhattan] towns of Junction City, Wamego, and Westmoreland." (Stover and Coffman, 1993).

Westmoreland $\left(39.4377^{\circ} \mathrm{N}, 96.4143^{\circ} \mathrm{W}\right)$-Plastering jarred off courthouse in places. (Dubois and Wilson, 1978).

Cleburne $\left(39.5353^{\circ} \mathrm{N}, 96.6306^{\circ} \mathrm{W}\right)$-Some dishes broke; some people were very much disturbed, thinking an explosion had occurred; more severe than at Irving. (Dubois and Wilson, 1978).

Topeka $\left(39.0555^{\circ} \mathrm{N}, 95.6754^{\circ} \mathrm{W}\right)$-Roaring sound followed by the shock; shook houses, windows, doors, dishes; glass lamps shaken; man awakened; china thrown from pantry shelves; baby fell from lounge; slight shock resulting in curious inquiries at telephone office; people filled the streets; two shocks, three shocks at Union Pacific Hotel. (Dubois and Wilson, 1978).

Topeka $\left(39.0555^{\circ} \mathrm{N}, 95.6754^{\circ} \mathrm{W}\right)$ - “About 6:20 P.M. the earthquake, accompanied by a roaring sound, shook Topeka. Houses and buildings vibrated; dishes and windows rattled; water in glasses showed motion. ... Three shocks were felt at the Union Pacific Hotel in Topeka." (Merriam, 1956).

Topeka $\left(39.0555^{\circ} \mathrm{N}, 95.6754^{\circ} \mathrm{W}\right.$ ) — "At Topeka [a roar] followed the shock in 10 seconds." (Coffman and von Hake, 1973).

Saint Joseph $\left(39.7500^{\circ} \mathrm{N}, 94.85^{\circ} \mathrm{W}\right.$ )—Rattled dishes and tinware; detached pictures from wall; frightened small children; shock came from south and lasted ten seconds; no serious damage; tables did freakish stunts, floors swayed, dishes danced; plates on racks attached to wall fell to floor. (Dubois and Wilson, 1978).

Saint Joseph $\left(39.7500^{\circ} \mathrm{N}, 94.85^{\circ} \mathrm{W}\right)$ - "The shock was also reported felt in St. Joseph, Missouri, with an intensity such that 'dishes and tinware rattled and small children were frightened.' Reid Papers." (Heinrich, 1941).

Alma $\left(38.9461^{\circ} \mathrm{N}, 96.304^{\circ} \mathrm{W}\right)$-Walls rocked, floors weaved; windows rattled, chinaware jumped; people felt weak in the knees; followed by a second shock at 10:30 p.m. which was slight, and caused no alarm; low rumbling sound preceded shock; lasted $10 \mathrm{sec}$; started from NW. (Dubois and Wilson, 1978).

Alma $\left(38.9461^{\circ} \mathrm{N}, 96.304^{\circ} \mathrm{W}\right)$ - “A slight shock was felt at Wichita, Emporia, Junction City, Alma, Beloit, and Kansas City." (Merriam, 1956).

Auburn $\left(38.9164^{\circ} \mathrm{N}, 95.8502^{\circ} \mathrm{W}\right)$-Stove lids rattled; houses shook; some reports from Dover, in Shawnee Co. (Dubois and Wilson, 1978).

Auburn $\left(38.9164^{\circ} \mathrm{N}, 95.8502^{\circ} \mathrm{W}\right)$ - “Auburn and Dover were also affected.” (Merriam, 1956).

Blue Rapids $\left(39.6537^{\circ} \mathrm{N}, 96.5851^{\circ} \mathrm{W}\right)$-Many people felt trembling or rocking; leaves swayed on house plants; not severe; in Great Western Mines, 500-6-- tons of roof rock fell. (Dubois and Wilson, 1978). 


\section{Appendix 1, Part 22. Damage Reports and Intensity Assignments}

4 KS Emporia $\left(38.4196^{\circ} \mathrm{N}, 96.1925^{\circ} \mathrm{W}\right)$-Many people frightened, several ran outdoors; dishes rattled, houses shook; more severe four miles north of town, lighter to the east, hardly felt south of Emporia; three distinct shocks lasting 60 seconds felt all over Lyon County; no damage reported; traveled northward. (Dubois and Wilson, 1978).

KS Emporia $\left(38.4196^{\circ} \mathrm{N}, 96.1925^{\circ} \mathrm{W}\right)$ - “A slight shock was felt at Wichita, Emporia, Junction City, Alma, Beloit, and Kansas City." (Merriam, 1956).

$4 \quad \mathrm{KS}$

Hope $\left(38.6998^{\circ} \mathrm{N}, 97.1243^{\circ} \mathrm{W}\right)$-Buildings trembled; doors slammed shut in houses. (Dubois and Wilson, 1978).

$4 \mathrm{KS}$

Irving $\left(39.6389^{\circ} \mathrm{N}, 96.5972^{\circ} \mathrm{W}\right)$-Rattled dishes on supper table; beds shaken violently; some people quite alarmed; similar reports from Bigelow; two shocks. (Dubois and Wilson, 1978).

$4 \mathrm{KS}$

Lawrence $\left(38.9641^{\circ} \mathrm{N}, 95.2536^{\circ} \mathrm{W}\right)$ - “No doubt about shaking here, although severer to the west." Did not cause alarm. (Dubois and Wilson, 1978).

Seneca $\left(39.8483^{\circ} \mathrm{N}, 96.0422^{\circ} \mathrm{W}\right)$ - Jarred windows; rattled dishes. (Dubois and Wilson, 1978).

Wathena $\left(39.7754^{\circ} \mathrm{N}, 94.9449^{\circ} \mathrm{W}\right)$-Severe earthquake accompanied by rumbling sound noticed here; traveled N-S; houses shaken; dishes rattled. (Dubois and Wilson, 1978).

$3 \mathrm{KS}$

Abilene $\left(38.9556^{\circ} \mathrm{N}, 97.219^{\circ} \mathrm{W}\right)$-Slight shock at 7:00 p.m.; rattled dishes; movement plainly perceptible; water in glasses showed motion. (Dubois and Wilson, 1978).

KS Abilene $\left(38.9556^{\circ} \mathrm{N}, 97.219^{\circ} \mathrm{W}\right)$ - “Abilene and Marysville rocked." (Merriam, 1956).

$3 \quad \mathrm{KS}$

Valley Falls $\left(39.3413^{\circ} \mathrm{N}, 95.4622^{\circ} \mathrm{W}\right.$ ) -Slight but distinct shocks every day or so from January 7 to January 23 . (Dubois and Wilson, 1978).

$3 \mathrm{KS}$

$3 \mathrm{KS}$

White Cloud $\left(39.9423^{\circ} \mathrm{N}, 95.2862^{\circ} \mathrm{W}\right)$-Felt, but "not very severe." (Dubois and Wilson, 1978).

Wichita $\left(37.6854^{\circ} \mathrm{N}, 97.3357^{\circ} \mathrm{W}\right)$-Slight shock felt; three shocks lasting 3-4 seconds. (Dubois and Wilson, 1978).

KS Wichita $\left(37.6854^{\circ} \mathrm{N}, 97.3357^{\circ} \mathrm{W}\right)$ - “A slight shock was felt at Wichita, Emporia, Junction City, Alma, Beloit, and Kansas City." (Merriam, 1956).

KS Wichita $\left(37.6854^{\circ} \mathrm{N}, 97.3357^{\circ} \mathrm{W}\right)$-Felt (Coffman and von Hake, 1973).

3 MO Kansas City $\left(39.0333^{\circ} \mathrm{N}, 94.55^{\circ} \mathrm{W}\right)$-Shook chandeliers; rattled dishes; not severe enough to cause alarm; lasted 23-60 seconds; motion from south and north. (Dubois and Wilson, 1978).

MO Kansas City $\left(39.0333^{\circ} \mathrm{N}, 94.55^{\circ} \mathrm{W}\right)$ - “At Kansas City, Missouri, 'The movement, which appeared to be from north and south, lasted about 23 seconds, shook chandeliers and rattled dishes.'” (Heinrich, 1941).

3 NE Lincoln $\left(40.8247^{\circ} \mathrm{N}, 96.7778^{\circ} \mathrm{W}\right)$-Shook globes and chandelier fastenings; distinctly felt although no damage was reported. (Dubois and Wilson, 1978).

$2 \mathrm{KS}$

Beloit (39.3832 $\left.\mathrm{N}, 98.1404^{\circ} \mathrm{W}\right)$ - “A slight shock was felt at Wichita, Emporia, Junction City, Alma, Beloit, and Kansas City.” (Merriam, 1956).

KS Beloit $\left(39.3832^{\circ} \mathrm{N}, 98.1404^{\circ} \mathrm{W}\right)$-Felt (Coffman and von Hake, 1973).

2 KS Kansas City $\left(39.1177^{\circ} \mathrm{N}, 94.6307^{\circ} \mathrm{W}\right)$ - “A slight shock was felt at Wichita, Emporia, Junction City, Alma, Beloit, and Kansas City." (Merriam, 1956).

G KS

Skiddy $\left(38.8681^{\circ} \mathrm{N}, 96.7942^{\circ} \mathrm{W}\right)$-Most of the wells at Skiddy have gone dry; they used to be half full before the earthquake. (Dubois and Wilson, 1978).

F KS

F KS

F KS

F KS

F $\quad$ MO

F NE

Dover (38.9646 $\left.\mathrm{N}, 95.9282^{\circ} \mathrm{W}\right)$ - “Auburn and Dover were also affected." (Merriam, 1956).

Herington $\left(38.6768^{\circ} \mathrm{N}, 96.8954^{\circ} \mathrm{W}\right)$ - “Two shock occurred.” (Merriam, 1956).

Marysville $\left(39.8682^{\circ} \mathrm{N}, 96.6637^{\circ} \mathrm{W}\right)$ - “Abilene and Marysville rocked.” (Merriam, 1956).

Oskaloosa $\left(39.2029^{\circ} \mathrm{N}, 95.3333^{\circ} \mathrm{W}\right)$ - “Two shock occurred.” (Merriam, 1956).

Bethany $\left(40.2629^{\circ} \mathrm{N}, 94.0089^{\circ} \mathrm{W}\right)$-Felt (Coffman and von Hake, 1973).

Plattsmouth $\left(40.9845^{\circ} \mathrm{N}, 95.9428^{\circ} \mathrm{W}\right)$-Felt (Coffman and von Hake, 1973). 


\section{Appendix 1, Part 23. Damage Reports and Intensity Assignments}

\section{\#23 1909 May 26 14:42UTC (Illinols)}

7 IA Davenport $\left(41.5236^{\circ} \mathrm{N}, 90.5775^{\circ} \mathrm{W}\right)$-Two distinct shocks were felt, windows in homes and many stores were broken. (Street and Green, 1984).

7 IL Aurora $\left(41.7606^{\circ} \mathrm{N}, 88.32^{\circ} \mathrm{W}\right)$-Some chimneys were knocked over, broke gas line connections. (Street and Green, 1984 ).

IL AURORA $\left(41.7606^{\circ} \mathrm{N}, 88.32^{\circ} \mathrm{W}\right)$ - Many chimneys fell, a stove overturned, and gas line connections broke at Aurora, west of Chicago. (Stover and Coffman, 1993).

IL $\quad$ AURORA $\left(41.7606^{\circ} \mathrm{N}, 88.32^{\circ} \mathrm{W}\right.$ ) (National Earthquake Information Center, Earthquake Data Base System).

7 IL Naperville $\left(41.7858^{\circ} \mathrm{N}, 88.1472^{\circ} \mathrm{W}\right)$-Several chimneys were knocked over. (Street and Green, 1984).

IL Naperville $\left(41.7858^{\circ} \mathrm{N}, 88.1472^{\circ} \mathrm{W}\right)$-Several chimneys were downed at ... Naperville. (Stover and Coffman, 1993$)$.

7 IL Streator $\left(41.1208^{\circ} \mathrm{N}, 88.8353^{\circ} \mathrm{W}\right.$ )-Many chimneys were shaken down and many people ran out of their homes. (Street and Green, 1984).

IL $\quad$ Streator $\left(41.1208^{\circ} \mathrm{N}, 88.8353^{\circ} \mathrm{W}\right)$-Several chimneys were downed at ... Streator. (Stover and Coffman, 1993 ).

7 IL Triumph $\left(41.4994^{\circ} \mathrm{N}, 89.0219^{\circ} \mathrm{W}\right)$-Many windows were broken and chimneys were thrown down. (Street and Green, 1984).

IL Triumph $\left(41.4994^{\circ} \mathrm{N}, 89.0219^{\circ} \mathrm{W}\right)$-Several chimneys were downed at ... Triumph. (Stover and Coffman, 1993).

7 IL Troy Grove $\left(41.4678^{\circ} \mathrm{N}, 89.0831^{\circ} \mathrm{W}\right.$ )-Many windows were broken and many chimneys were thrown down. (Street and Green, 1984).

IL

Troy Grove $\left(41.4678^{\circ} \mathrm{N}, 89.0831^{\circ} \mathrm{W}\right)$-Several chimneys were downed at ...Troy Grove. (Stover and Coffman, 1993).

$6 \mathrm{IL}$ Bloomington $\left(40.4842^{\circ} \mathrm{N}, 88.9936^{\circ} \mathrm{W}\right)$-Brick walls cracked at Bloomington. (Stover and Coffman, 1993).

IL BLOOMINGTON $\left(40.4842^{\circ} \mathrm{N}, 88.9936^{\circ} \mathrm{W}\right)$ (National Earthquake Information Center, Earthquake Data Base System). Chicago $\left(41.8500^{\circ} \mathrm{N}, 87.65^{\circ} \mathrm{W}\right)$-Cracked chimneys (Street and Green, 1984).

IL CHICAGO $\left(41.8500^{\circ} \mathrm{N}, 87.65^{\circ} \mathrm{W}\right)$ (National Earthquake Information Center, Earthquake Data Base System).

Forreston $\left(42.1261^{\circ} \mathrm{N}, 89.5792^{\circ} \mathrm{W}\right)$-Shook down two chimneys. (Street and Green, 1984).

IL

Forreston $\left(42.1261^{\circ} \mathrm{N}, 89.5792^{\circ} \mathrm{W}\right)$-Several chimneys were downed at Forreston. (Stover and Coffman, 1993).

Freeport $\left(42.2967^{\circ} \mathrm{N}, 89.6211^{\circ} \mathrm{W}\right)$-Cracked plaster on walls, knocked pictures from walls, threw dishes to the floor, damaged many chimneys, alarmed people in boats on the Pecatonica river, moved heavy furniture, and stopped clocks. (Street and Green, 1984).

IL

Freeport $\left(42.2967^{\circ} \mathrm{N}, 89.6211^{\circ} \mathrm{W}\right)$-Sidewalks cracked and many chimneys were damaged at Freeport. (Stover and Coffman, 1993).

IL $\quad$ FREEPORT $\left(42.2967^{\circ} \mathrm{N}, 89.6211^{\circ} \mathrm{W}\right)$ (National Earthquake Information Center, Earthquake Data Base System).

Joliet $\left(41.5250^{\circ} \mathrm{N}, 88.0817^{\circ} \mathrm{W}\right)$-Damaged a few chimneys, knocked light articles to the floor, overturned furniture. (Street and Green, 1984).

Peoria $\left(40.6936^{\circ} \mathrm{N}, 89.5889^{\circ} \mathrm{W}\right)$-Felt distinctly by all, rattled windows and shook plastering down, moved furniture, some ran into the streets. (Street and Green, 1984).

Tampico $\left(41.6303^{\circ} \mathrm{N}, 89.7861^{\circ} \mathrm{W}\right)$-Did considerable damage. (Street and Green, 1984).

Waukegan $\left(42.3636^{\circ} \mathrm{N}, 87.8447^{\circ} \mathrm{W}\right)$-People ran out of their houses in some cases, books fell from their shelves, furniture quivered, and bricks were knocked out of walls at the firehouse. (Street and Green, 1984).

IL Waukegan $\left(42.3636^{\circ} \mathrm{N}, 87.8447^{\circ} \mathrm{W}\right)$-One [chimney] fell at Waukegan. (Stover and Coffman, 1993).

Milwaukee $\left(43.0389^{\circ} \mathrm{N}, 87.9064^{\circ} \mathrm{W}\right)$-Moved heavy typesetting equipment as well as other furniture. (Street and Green, 1984).

Cedar Rapids $\left(42.0083^{\circ} \mathrm{N}, 91.6439^{\circ} \mathrm{W}\right.$ )-Jarred buildings slightly, rattled windows and doors, students at Coe College rushed out of doors. (Street and Green, 1984).

Dubuque $\left(42.5006^{\circ} \mathrm{N}, 90.6644^{\circ} \mathrm{W}\right)$-Frightened many, broke some crockery, but primarily rattled dishes and windows. (Street and Green, 1984).

DUBUQUE $\left(42.5006^{\circ} \mathrm{N}, 90.6644^{\circ} \mathrm{W}\right)$ (National Earthquake Information Center, Earthquake Data Base System).

Elkader $\left(42.8539^{\circ} \mathrm{N}, 91.4053^{\circ} \mathrm{W}\right)$-Articles were shaken from tables and dressers; caused intense excitement. (Street and Green, 1984).

Lowden $\left(41.8575^{\circ} \mathrm{N}, 90.9281^{\circ} \mathrm{W}\right)$-Stopped clocks, threw dishes off of tables. (Street and Green, 1984).

Lyons $\left(41.8700^{\circ} \mathrm{N}, 90.19^{\circ} \mathrm{W}\right)$-Dishes were knocked off tables. (Street and Green, 1984).

Sabula $\left(42.0711^{\circ} \mathrm{N}, 90.1739^{\circ} \mathrm{W}\right)$-Brought people out of their homes in alarm, cracked chimneys, knocked pictures from walls. (Street and Green, 1984).

\section{Belvidere $\left(42.2639^{\circ} \mathrm{N}, 88.8442^{\circ} \mathrm{W}\right)$
$\quad$ (Street and Green, 1984$)$.}

Carpentersville $\left(42.1211^{\circ} \mathrm{N}, 88.2578^{\circ} \mathrm{W}\right)$-Cracked windows and threw dishes to the floors (Street and Green, 1984).

Cedarville $\left(42.3758^{\circ} \mathrm{N}, 89.6331^{\circ} \mathrm{W}\right)$-Stopped clocks (Street and Green, 1984).

Clinton $\left(40.1536^{\circ} \mathrm{N}, 88.9644^{\circ} \mathrm{W}\right)$ - Rattled dishes from shelves, and sprung doors so that they would not close. (Street and Green, 1984).

$5 \quad \mathrm{IL}$

De Kalb $\left(41.9294^{\circ} \mathrm{N}, 88.7503^{\circ} \mathrm{W}\right)$-A few dishes were jarred to the floor, and people on the east end ran into the streets. (Street and Green, 1984). 


\section{Appendix 1, Part 23. Damage Reports and Intensity Assignments}

(Street and Green, 1984).

5 IL Dixon $\left(41.8389^{\circ} \mathrm{N}, 89.4794^{\circ} \mathrm{W}\right)$-Shook out gas fires and rattled dishes from the tables. (Street and Green, 1984$)$.

5 IL East Dubuque $\left(42.4922^{\circ} \mathrm{N}, 90.6428^{\circ} \mathrm{W}\right)$-Jarred dishes off tables. (Street and Green, 1984).

5 IL Elgin $\left(42.0372^{\circ} \mathrm{N}, 88.2811^{\circ} \mathrm{W}\right)$-People rushed out doors, several persons at the YMCA were knocked to the floor. (Street and Green, 1984).

$5 \quad \mathrm{IL}$

Elizabeth $\left(42.3178^{\circ} \mathrm{N}, 90.2214^{\circ} \mathrm{W}\right)-$ Knocked dishes and sacks of flour from shelves. (Street and Green, 1984).

5 IL

German Valley $\left(42.2156^{\circ} \mathrm{N}, 89.4733^{\circ} \mathrm{W}\right)$-Greatly disturbed goods on shelves of general store; people ran out of doors. (Street and Green, 1984).

5 IL Jacksonville $\left(39.7339^{\circ} \mathrm{N}, 90.2289^{\circ} \mathrm{W}\right)$-Quite severe, only slight damage. (Street and Green, 1984).

Kewanee $\left(41.2456^{\circ} \mathrm{N}, 89.9247^{\circ} \mathrm{W}\right)$-Small articles were shaken from desks; windows rattled. (Street and Green, 1984).

La Moille $\left(41.5317^{\circ} \mathrm{N}, 89.2797^{\circ} \mathrm{W}\right)$-Dishes were thrown from their places. (Street and Green, 1984).

La Salle $\left(41.3200^{\circ} \mathrm{N}, 89.12^{\circ} \mathrm{W}\right)$ - Threw glassware from their places, many rushed out into the streets, one instance of plastering falling from ceiling. (Street and Green, 1984).

Lanark $\left(42.1022^{\circ} \mathrm{N}, 89.8333^{\circ} \mathrm{W}\right)$-People greatly frightened and ran into the streets, dishes and other articles were shaken from their places. (Street and Green, 1984).

Marengo $\left(42.2486^{\circ} \mathrm{N}, 88.6083^{\circ} \mathrm{W}\right)$-Cracked ceilings, rocked pictures on walls, frightened residents who ran out doors. (Street and Green, 1984).

Monmouth $\left(40.9114^{\circ} \mathrm{N}, 90.6472^{\circ} \mathrm{W}\right)$ - A decided shake causing buildings to rock and crack, a few instances of plaster being cracked. (Street and Green, 1984).

North Chicago $\left(42.3256^{\circ} \mathrm{N}, 87.8411^{\circ} \mathrm{W}\right)$-Occupants fled from flats and businesses in alarm. (Street and Green, 1984).

IL Orangeville $\left(42.4683^{\circ} \mathrm{N}, 89.6439^{\circ} \mathrm{W}\right)$-Cracked cement sidewalks, depot building was severely shaken. (Street and Green, 1984).

Pontiac $\left(40.8808^{\circ} \mathrm{N}, 88.6297^{\circ} \mathrm{W}\right)$-Violent; articles were shaken from walls. (Street and Green, 1984).

IL

PONTIAC $\left(40.8808^{\circ} \mathrm{N}, 88.6297^{\circ} \mathrm{W}\right)$ (National Earthquake Information Center, Earthquake Data Base System).

Rockford $\left(42.2711^{\circ} \mathrm{N}, 89.0939^{\circ} \mathrm{W}\right)$ - Threw dishes to the floor; a few people rushed outdoors in fright. (Street and Green, 1984).

Savanna $\left(42.0944^{\circ} \mathrm{N}, 90.1567^{\circ} \mathrm{W}\right)$-Sufficient to alarm people into rushing outdoors. (Street and Green, 1984).

Shannon $\left(42.1547^{\circ} \mathrm{N}, 89.7397^{\circ} \mathrm{W}\right)$-So severe people ran out of stores and residences. (Street and Green, 1984).

Sterling $\left(41.7886^{\circ} \mathrm{N}, 89.6961^{\circ} \mathrm{W}\right)$-One distinct shock, people rushed from their homes in fear; chandeliers were knocked down and pictures fell from walls. (Street and Green, 1984).

Sycamore $\left(41.9889^{\circ} \mathrm{N}, 88.6867^{\circ} \mathrm{W}\right)$-Quake was severe enough to stop several clocks. (Street and Green, 1984).

Zion $\left(42.4461^{\circ} \mathrm{N}, 87.8328^{\circ} \mathrm{W}\right)-$ People rushed out into the streets. (Street and Green, 1984).

Knox $\left(41.2958^{\circ} \mathrm{N}, 86.625^{\circ} \mathrm{W}\right)$-Of sufficient force to cause people to rush from buildings to seek safety. (Street and Green, 1984).

Muskegon $\left(43.2342^{\circ} \mathrm{N}, 86.2483^{\circ} \mathrm{W}\right)$-Dishes were brought chattering to the floor, bric-a-brac were perceptibly shaken. (Street and Green, 1984).

South Haven $\left(42.4031^{\circ} \mathrm{N}, 86.2736^{\circ} \mathrm{W}\right)$-Rattled windows violently and broke china. (Street and Green, 1984).

Hannibal $\left(39.7083^{\circ} \mathrm{N}, 91.3583^{\circ} \mathrm{W}\right)$-Generally rattled dishes and windows; in higher buildings jarred articles to the floors. (Street and Green, 1984).

Beloit $\left(42.5083^{\circ} \mathrm{N}, 89.0317^{\circ} \mathrm{W}\right)$ - Rocked buildings violently, people in city experienced difficulty in remaining on their feet. (Street and Green, 1984).

WI Beloit $\left(42.5083^{\circ} \mathrm{N}, 89.0317^{\circ} \mathrm{W}\right)$ - Houses were jostled out of plumb at Beloit, Wis., about 240 km northwest of Chicago. (Stover and Coffman, 1993).

Janesville $\left(42.6828^{\circ} \mathrm{N}, 89.0186^{\circ} \mathrm{W}\right)$-Many citizens were badly frightened and some ran out of doors, moved light furniture. (Street and Green, 1984).

Kenosha $\left(42.5847^{\circ} \mathrm{N}, 87.8211^{\circ} \mathrm{W}\right)$-Caused people to rush out into the streets, jostled windows. (Street and Green, 1984). Platteville $\left(42.7342^{\circ} \mathrm{N}, 90.4783^{\circ} \mathrm{W}\right)$-At Platteville, Wis., about $130 \mathrm{~km}$ northwest of Chicago, an old building was cracked. (Stover and Coffman, 1993).

WI Platteville $\left(42.7342^{\circ} \mathrm{N}, 90.4783^{\circ} \mathrm{W}\right)$-Office buildings were rocked considerably, generally felt. (Street and Green, 1984$)$.

WI PLATTEVILLE $\left(42.7400^{\circ} \mathrm{N}, 90.48^{\circ} \mathrm{W}\right)$ (National Earthquake Information Center, Earthquake Data Base System).

Racine $\left(42.7261^{\circ} \mathrm{N}, 87.7828^{\circ} \mathrm{W}\right)$-Every person was alarmed, electric light and other fixtures on walls were knocked out of place. (Street and Green, 1984).

Dyersville $\left(42.4844^{\circ} \mathrm{N}, 91.1228^{\circ} \mathrm{W}\right)$-Short and distinct, dishes rattled and buildings swayed. (Street and Green, 1984).

Morning Sun $\left(41.0961^{\circ} \mathrm{N}, 91.2575^{\circ} \mathrm{W}\right)$-Rattled bottles and tinware. (Street and Green, 1984).

Strawberry Point $\left(42.6836^{\circ} \mathrm{N}, 91.5339^{\circ} \mathrm{W}\right)$-Buildings were badly shaken. (Street and Green, 1984).

Antioch $\left(42.4772^{\circ} \mathrm{N}, 88.0956^{\circ} \mathrm{W}\right)$-Awakened people. (Street and Green, 1984).

Bushnell $\left(40.5528^{\circ} \mathrm{N}, 90.5061^{\circ} \mathrm{W}\right)$-Occupants of second floors ran to the streets. (Street and Green, 1984).

Caber $\left(40.9958^{\circ} \mathrm{N}, 88.2053^{\circ} \mathrm{W}\right)$-Plainly felt by nearly everybody. (Street and Green, 1984).

Chadwick $\left(42.0133^{\circ} \mathrm{N}, 89.8906^{\circ} \mathrm{W}\right)$-Rattled dishes and tinware (Street and Green, 1984).

Erie $\left(41.6564^{\circ} \mathrm{N}, 90.0792^{\circ} \mathrm{W}\right)$-Windows rattled and buildings shook. (Street and Green, 1984). 


\section{Appendix 1, Part 23. Damage Reports and Intensity Assignments}

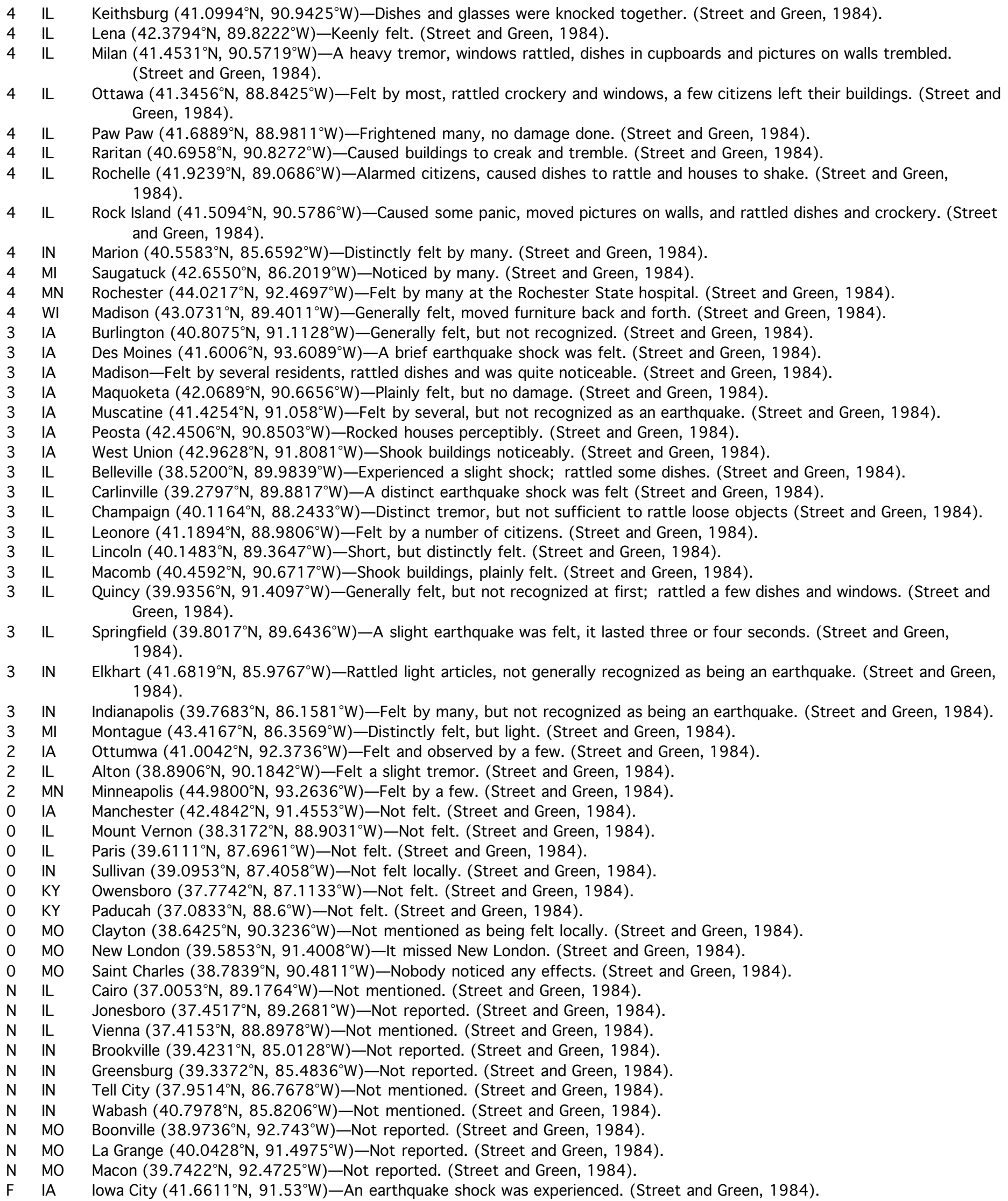




\section{Appendix 1, Part 23. Damage Reports and Intensity Assignments}

F IA Lone Tree $\left(41.4881^{\circ} \mathrm{N}, 91.4258^{\circ} \mathrm{W}\right)$-Felt. (Street and Green, 1984).

F IA Mason City $\left(43.1536^{\circ} \mathrm{N}, 93.2008^{\circ} \mathrm{W}\right)$-Felt. (Street and Green, 1984).

F Ml Benton Harbor $\left(42.1167^{\circ} \mathrm{N}, 86.4542^{\circ} \mathrm{W}\right)$-Felt. (Street and Green, 1984).

F $\quad$ MI Grand Rapids $\left(42.9633^{\circ} \mathrm{N}, 85.6681^{\circ} \mathrm{W}\right)$-Felt. (Street and Green, 1984).

F $\quad$ Ml Kalamazoo $\left(42.2917^{\circ} \mathrm{N}, 85.5872^{\circ} \mathrm{W}\right)$-Felt. (Street and Green, 1984).

F MN Henderson $\left(44.5283^{\circ} \mathrm{N}, 93.9075^{\circ} \mathrm{W}\right)$-Felt. (Street and Green, 1984). 


\section{Appendix 1, Part 24. Damage Reports and Intensity Assignments}

\section{\#24 1909 July 19 04:34UTC (Illinois)}

7 IL Petersburg $\left(40.0117^{\circ} \mathrm{N}, 89.8481^{\circ} \mathrm{W}\right)$-Chimneys were demolished on more than 100 buildings in Menard County at Petersburg, northwest of Springfield. At a farm west of Petersburg, 20 windows broke and bricks pushed out above the doors. (Stover and Coffman, 1993).

IL $\quad$ Petersburg $\left(40.0117^{\circ} \mathrm{N}, 89.8481^{\circ} \mathrm{W}\right)$-Dishes were thrown from shelves, pictures on walls were disarranged. (Street and Green, 1984).

IL PETERSBURG (NEAR) $\left(40.0117^{\circ} \mathrm{N}, 89.8481^{\circ} \mathrm{W}\right)$ (National Earthquake Information Center, Earthquake Data Base System)

Davenport $\left(41.5236^{\circ} \mathrm{N}, 90.5775^{\circ} \mathrm{W}\right)$-Fallen chimneys ... were reported northwest of Springfield at Davenport, lowa. (Stover and Coffman, 1993).

IA Davenport $\left(41.5236^{\circ} \mathrm{N}, 90.5775^{\circ} \mathrm{W}\right)$-Felt by many. (Street and Green, 1984).

IA DAVENPORT $\left(41.5236^{\circ} \mathrm{N}, 90.5775^{\circ} \mathrm{W}\right)$ (National Earthquake Information Center, Earthquake Data Base System).

Hannibal $\left(39.7083^{\circ} \mathrm{N}, 91.3583^{\circ} \mathrm{W}\right)$-Fallen chimneys also were reported northwest of Springfield at Davenport, lowa, and west of Springfield at Hannibal, Mo. (Stover and Coffman, 1993).

MO Hannibal $\left(39.7083^{\circ} \mathrm{N}, 91.3583^{\circ} \mathrm{W}\right)$-Bric-a-brac fell and opened doors were closed. (Street and Green, 1984).

MO HANNIBAL $\left(39.7083^{\circ} \mathrm{N}, 91.3583^{\circ} \mathrm{W}\right.$ ) (National Earthquake Information Center, Earthquake Data Base System).

HAVANA $\left(40.3000^{\circ} \mathrm{N}, 90.0608^{\circ} \mathrm{W}\right.$ ) (National Earthquake Information Center, Earthquake Data Base System).

IL Havana $\left(40.3000^{\circ} \mathrm{N}, 90.0608^{\circ} \mathrm{W}\right)$-Felt. (Street and Green, 1984).

Mason City $\left(40.2022^{\circ} \mathrm{N}, 89.6981^{\circ} \mathrm{W}\right)$-Rattled windows, shook doors; hundreds rushed into the streets. (Street and Green, 1984).

Fort Madison $\left(40.6297^{\circ} \mathrm{N}, 91.315^{\circ} \mathrm{W}\right)$-Noticed by hundreds of people; moved pictures on walls, rattled dishes and vibrated beds. (Street and Green, 1984).

lowa City $\left(41.6611^{\circ} \mathrm{N}, 91.53^{\circ} \mathrm{W}\right)$-Shook beds and tables, rattled dishes, felt by the majority of residents, many awakened from their sleep. (Street and Green, 1984).

Carlinville $\left(39.2797^{\circ} \mathrm{N}, 89.8817^{\circ} \mathrm{W}\right)$-Stopped clocks, rattled dishes and shook furniture. (Street and Green, 1984).

Jacksonville $\left(39.7339^{\circ} \mathrm{N}, 90.2289^{\circ} \mathrm{W}\right)$-Moved furniture and rattled dishes. (Street and Green, 1984).

Macomb $\left(40.4592^{\circ} \mathrm{N}, 90.6717^{\circ} \mathrm{W}\right)$-Awakened a number of citizens, bric-a-brac was disturbed, shook windows. (Street and Green, 1984).

Maple City-A slight shock was noticed by many residents. (Street and Green, 1984).

IL

IL

IL

Monmouth $\left(40.9114^{\circ} \mathrm{N}, 90.6472^{\circ} \mathrm{W}\right)$-Noticed by many residents, rattled windows. (Street and Green, 1984).

Monticello $\left(40.0278^{\circ} \mathrm{N}, 88.5733^{\circ} \mathrm{W}\right)$-Rocked beds. (Street and Green, 1984).

Quincy $\left(39.9356^{\circ} \mathrm{N}, 91.4097^{\circ} \mathrm{W}\right)$-Awakened those who had retired, rattled dishes, lamps, etc., nearly shook people out of bed. (Street and Green, 1984).

Rockford $\left(42.2711^{\circ} \mathrm{N}, 89.0939^{\circ} \mathrm{W}\right)$-Plainly perceptible, awakened many by the rattling of windows and dishes. (Street and Green, 1984).

$\mathrm{IL}$

Rushville $\left(40.1211^{\circ} \mathrm{N}, 90.5631^{\circ} \mathrm{W}\right)$ - Many residents were greatly worked up. (Street and Green, 1984).

MO

IA

La Grange $\left(40.0428^{\circ} \mathrm{N}, 91.4975^{\circ} \mathrm{W}\right)$-Rattled windows; floors and doors were jarred. (Street and Green, 1984).

Burlington $\left(40.8075^{\circ} \mathrm{N}, 91.1128^{\circ} \mathrm{W}\right)$-Felt by a number of persons. (Street and Green, 1984).

Champaign $\left(40.1164^{\circ} \mathrm{N}, 88.2433^{\circ} \mathrm{W}\right)$-Distinctly felt the quake. (Street and Green, 1984).

IL

Grafton $\left(38.9700^{\circ} \mathrm{N}, 90.4314^{\circ} \mathrm{W}\right)$-Felt by several persons. (Street and Green, 1984).

Rock Island $\left(41.5094^{\circ} \mathrm{N}, 90.5786^{\circ} \mathrm{W}\right)$-Felt very distinctly. (Street and Green, 1984).

Cedar Rapids $\left(42.0083^{\circ} \mathrm{N}, 91.6439^{\circ} \mathrm{W}\right)$-A slight tremor was noticed. (Street and Green, 1984).

Fairfield $\left(41.0086^{\circ} \mathrm{N}, 91.9625^{\circ} \mathrm{W}\right)$-A slight shock was felt. (Street and Green, 1984).

Belleville $\left(38.5200^{\circ} \mathrm{N}, 89.9839^{\circ} \mathrm{W}\right)$-Felt lightly only by persons who were lying down. (Street and Green, 1984).

MO Saint Louis $\left(38.6272^{\circ} \mathrm{N}, 90.1978^{\circ} \mathrm{W}\right)$-A slight shock was felt, but not of sufficient force to rattle dishes and such. (Street and Green, 1984).

IA Des Moines $\left(41.6006^{\circ} \mathrm{N}, 93.6089^{\circ} \mathrm{W}\right)$-Not mentioned. (Street and Green, 1984).

IA Knoxville $\left(41.3208^{\circ} \mathrm{N}, 93.1092^{\circ} \mathrm{W}\right)$-Not reported. (Street and Green, 1984).

IA Oskaloosa $\left(41.2964^{\circ} \mathrm{N}, 92.6442^{\circ} \mathrm{W}\right)$-Not reported. (Street and Green, 1984).

IL Bloomington $\left(40.4842^{\circ} \mathrm{N}, 88.9936^{\circ} \mathrm{W}\right)$-Not mentioned. (Street and Green, 1984).

IL $\quad$ Cairo $\left(37.0053^{\circ} \mathrm{N}, 89.1764^{\circ} \mathrm{W}\right)$-Not mentioned. (Street and Green, 1984).

IL Decatur $\left(39.8403^{\circ} \mathrm{N}, 88.9547^{\circ} \mathrm{W}\right)$-Not mentioned. (Street and Green, 1984).

IL Freeport $\left(42.2967^{\circ} \mathrm{N}, 89.6211^{\circ} \mathrm{W}\right)$-Not reported. (Street and Green, 1984).

IL Joliet $\left(41.5250^{\circ} \mathrm{N}, 88.0817^{\circ} \mathrm{W}\right)$-Not reported. (Street and Green, 1984).

IL Jonesboro $\left(37.4517^{\circ} \mathrm{N}, 89.2681^{\circ} \mathrm{W}\right)$-Not reported. (Street and Green, 1984).

IL Kankakee $\left(41.1200^{\circ} \mathrm{N}, 87.8611^{\circ} \mathrm{W}\right)$-Not reported. (Street and Green, 1984).

IL La Salle $\left(41.3200^{\circ} \mathrm{N}, 89.12^{\circ} \mathrm{W}\right)$-Not mentioned. (Street and Green, 1984).

IL Morris $\left(41.3572^{\circ} \mathrm{N}, 88.4211^{\circ} \mathrm{W}\right)$-Not mentioned. (Street and Green, 1984).

IL Mount Vernon $\left(38.3172^{\circ} \mathrm{N}, 88.9031^{\circ} \mathrm{W}\right)$-Not mentioned. (Street and Green, 1984).

IL Ottawa $\left(41.3456^{\circ} \mathrm{N}, 88.8425^{\circ} \mathrm{W}\right)$-Not reported. (Street and Green, 1984). 


\title{
Appendix 1, Part 24. Damage Reports and Intensity Assignments
}

\author{
IL Peoria $\left(40.6936^{\circ} \mathrm{N}, 89.5889^{\circ} \mathrm{W}\right)$-Not mentioned. (Street and Green, 1984). \\ IL Warren $\left(42.4964^{\circ} \mathrm{N}, 89.9894^{\circ} \mathrm{W}\right)$-Not mentioned. (Street and Green, 1984). \\ IN Brookville $\left(39.4231^{\circ} \mathrm{N}, 85.0128^{\circ} \mathrm{W}\right)$-Not mentioned. (Street and Green, 1984). \\ MO Boonville $\left(38.9736^{\circ} \mathrm{N}, 92.743^{\circ} \mathrm{W}\right)$-Not reported. (Street and Green, 1984). \\ MO Kirksville $\left(40.1947^{\circ} \mathrm{N}, 92.5831^{\circ} \mathrm{W}\right)$-Not reported. (Street and Green, 1984). \\ MO Macon $\left(39.7422^{\circ} \mathrm{N}, 92.4725^{\circ} \mathrm{W}\right)$-Not reported. (Street and Green, 1984). \\ MO Mexico $\left(39.1697^{\circ} \mathrm{N}, 91.8828^{\circ} \mathrm{W}\right)$-Not reported. (Street and Green, 1984). \\ MO Moberly $\left(39.4183^{\circ} \mathrm{N}, 92.4381^{\circ} \mathrm{W}\right.$ )—Not reported. (Street and Green, 1984). \\ MO New London $\left(39.5853^{\circ} \mathrm{N}, 91.4008^{\circ} \mathrm{W}\right)$-Not reported. (Street and Green, 1984). \\ IA Analaiva-Felt. (Street and Green, 1984). \\ F IL Centerville $\left(38.2006^{\circ} \mathrm{N}, 88.1661^{\circ} \mathrm{W}\right)$-Felt the quake. (Street and Green, 1984). \\ F IL Farmington $\left(40.6981^{\circ} \mathrm{N}, 90.0058^{\circ} \mathrm{W}\right)$-Felt. (Street and Green, 1984). \\ F IL Forest City $\left(40.3700^{\circ} \mathrm{N}, 89.8275^{\circ} \mathrm{W}\right)$-Felt. (Street and Green, 1984). \\ F IL Lincoln $\left(40.1483^{\circ} \mathrm{N}, 89.3647^{\circ} \mathrm{W}\right)$-Felt. (Street and Green, 1984). \\ F IL Pleasant Plains $\left(39.8728^{\circ} \mathrm{N}, 89.9211^{\circ} \mathrm{W}\right)$-Felt. (Street and Green, 1984). \\ F IL Springfield $\left(39.8017^{\circ} \mathrm{N}, 89.6436^{\circ} \mathrm{W}\right)$-Felt. (Street and Green, 1984).
}




\section{Appendix 1, Part 25. Damage Reports and Intensity Assignments}

\section{\#25 1909 Sept. 27 09:45 UTC (Illinois)}

7 IN Covington $\left(40.1417^{\circ} \mathrm{N}, 87.3947^{\circ} \mathrm{W}\right)$ - A few chimneys were jarred down and window panes broken out. (Street and Green, 1984).

IN Covington $\left(40.1417^{\circ} \mathrm{N}, 87.3947^{\circ} \mathrm{W}\right)$-At Covington, north of Terre Haute in Fountain County, a few chimneys were downed and windows were broken. (Stover and Coffman, 1993).

Danville $\left(40.1244^{\circ} \mathrm{N}, 87.63^{\circ} \mathrm{W}\right)$-Furniture was upset, bottles, and tableware rattled and in many instances broken. (Street and Green, 1984).

6 IN Princeton $\left(38.3553^{\circ} \mathrm{N}, 87.5675^{\circ} \mathrm{W}\right)$-Chimneys were jarred loose, dishes and shelve goods were knocked down, and many people ran out into the streets. (Street and Green, 1984).

IN

Princeton $\left(38.3553^{\circ} \mathrm{N}, 87.5675^{\circ} \mathrm{W}\right)$-Chimneys were "jarred loose" south of Vincennes at Princeton, Ind. (Stover and Coffman, 1993).

Tell City $\left(37.9514^{\circ} \mathrm{N}, 86.7678^{\circ} \mathrm{W}\right)$-Many people were aroused, many light articles fell. (Street and Green, 1984).

Terre Haute $\left(39.4667^{\circ} \mathrm{N}, 87.4139^{\circ} \mathrm{W}\right)$-Many persons were awakened, bits of plaster were shaken to the floor, pictures were shaken off the walls, bric-a-brac was broken, and two chimneys fell. (Street and Green, 1984).

IN Terre Haute $\left(39.4667^{\circ} \mathrm{N}, 87.4139^{\circ} \mathrm{W}\right)$-At Terre Haute (Vigo County), two chimneys were thrown down, plaster was cracked, and pictures were shaken from walls. (Stover and Coffman, 1993).

New Madrid $\left(36.5864^{\circ} \mathrm{N}, 89.5278^{\circ} \mathrm{W}\right)$-Felt a little harder than at Saint Louis. [At Saint Louis, "Vibrations so severe that in some instances sleepers were almost thrown out of their beds; light articles thrown down; the brick wall of one house was shaken down." - VI] (Street and Green, 1984).

Olivette $\left(38.6653^{\circ} \mathrm{N}, 90.3758^{\circ} \mathrm{W}\right)$-A brick chimney was shaken to pieces and fell. (Street and Green, 1984).

MO

Olivette $\left(38.6653^{\circ} \mathrm{N}, 90.3758^{\circ} \mathrm{W}\right)$-One chimney was shaken to pieces at Olivette, Mo. (a suburb of St. Louis). (Stover and Coffman, 1993).

Saint Louis $\left(38.6272^{\circ} \mathrm{N}, 90.1978^{\circ} \mathrm{W}\right)$-Vibrations so severe that in some instances sleepers were almost thrown out of their beds; light articles thrown down; the brick wall of one house was shaken down. (Street and Green, 1984).

MO Saint Louis $\left(38.6272^{\circ} \mathrm{N}, 90.1978^{\circ} \mathrm{W}\right)$-A brick wall was shaken down at St. Louis, Mo. (Stover and Coffman, 1993).

Benton $\left(37.9967^{\circ} \mathrm{N}, 88.92^{\circ} \mathrm{W}\right)$-Dishes shaken from their places, many persons were hurried from their beds badly frightened. (Street and Green, 1984).

Cairo $\left(37.0053^{\circ} \mathrm{N}, 89.1764^{\circ} \mathrm{W}\right)-\mathrm{A}$ few cracked walls on close inspection were observed; stopped clocks. (Street and Green, 1984).

Robinson $\left(39.0053^{\circ} \mathrm{N}, 87.7392^{\circ} \mathrm{W}\right)$-Quite a heavy shock of earthquake was felt. (Street and Green, 1984).

Springfield $\left(39.8017^{\circ} \mathrm{N}, 89.6436^{\circ} \mathrm{W}\right)$-People badly frightened, some ran into the streets; beds, pictures, and furniture were moved. (Street and Green, 1984).

Brazil $\left(39.5236^{\circ} \mathrm{N}, 87.125^{\circ} \mathrm{W}\right.$ ) - A few old brick buildings cracked, dishes shaken from racks, stove pipes knocked down, doors and windows were opened. (Street and Green, 1984).

Noblesville $\left(40.0456^{\circ} \mathrm{N}, 86.0086^{\circ} \mathrm{W}\right)$ - Many people were awakened, a few homes experienced broken windows. (Street and Green, 1984).

Covington $\left(39.0836^{\circ} \mathrm{N}, 84.5086^{\circ} \mathrm{W}\right)$-Dishes knocked from their places in some houses. (Street and Green, 1984).

Fayette $\left(39.1458^{\circ} \mathrm{N}, 92.6836^{\circ} \mathrm{W}\right)$-Broke a large plate glass. (Street and Green, 1984).

Illmo $\left(37.2197^{\circ} \mathrm{N}, 89.5089^{\circ} \mathrm{W}\right)$ - Two very severe earthquake shocks were felt. (Street and Green, 1984).

Muscatine $\left(41.2518^{\circ} \mathrm{N}, 91.0318^{\circ} \mathrm{W}\right)$ - Many felt the shocks, but did not recognize them as being due to an earthquake; pictures swung on walls. (Street and Green, 1984).

Alton $\left(38.8906^{\circ} \mathrm{N}, 90.1842^{\circ} \mathrm{W}\right)$-Three severe shocks felt by several. (Street and Green, 1984). Anna $\left(37.4603^{\circ} \mathrm{N}, 89.2469^{\circ} \mathrm{W}\right)-\mathrm{A}$ heavy earthquake shock was felt. (Street and Green, 1984).

Bee Branch $\left(38.6647^{\circ} \mathrm{N}, 88.7856^{\circ} \mathrm{W}\right)$-Quite a number felt the earthquake shock. (Street and Green, 1984).

Belleville $\left(38.5200^{\circ} \mathrm{N}, 89.9839^{\circ} \mathrm{W}\right)$-Awakened most, rattled dishes and windows. (Street and Green, 1984).

IL

Carlinville $\left(39.2797^{\circ} \mathrm{N}, 89.8817^{\circ} \mathrm{W}\right)$-Felt by most, rattled windows and doors and otherwise shook up things considerably. (Street and Green, 1984).

Carmi $\left(38.0908^{\circ} \mathrm{N}, 88.1586^{\circ} \mathrm{W}\right)$-Residents were aroused. (Street and Green, 1984).

Champaign $\left(40.1164^{\circ} \mathrm{N}, 88.2433^{\circ} \mathrm{W}\right)$-Distinctly felt by a great many. (Street and Green, 1984).

Edwardsville $\left(38.8114^{\circ} \mathrm{N}, 89.953^{\circ} \mathrm{W}\right)$ - Heavy enough to rattle windows and dishes. (Street and Green, 1984).

Fairfield $\left(38.3789^{\circ} \mathrm{N}, 88.3597^{\circ} \mathrm{W}\right)$-Frightened many, caused dishes and other objects to rattle around in cupboards. (Street and Green, 1984).

IL Flora $\left(38.6689^{\circ} \mathrm{N}, 88.4855^{\circ} \mathrm{W}\right)$-Stopped town clock. (Street and Green, 1984).

IL Freeburg $\left(38.4275^{\circ} \mathrm{N}, 89.9136^{\circ} \mathrm{W}\right)$-Hard shock. (Street and Green, 1984).

IL Freeport $\left(42.2967^{\circ} \mathrm{N}, 89.6211^{\circ} \mathrm{W}\right)$-Many people were awakened. (Street and Green, 1984).

IL Galesburg $\left(40.9478^{\circ} \mathrm{N}, 90.3711^{\circ} \mathrm{W}\right)$-Caused dishes and stoves to rattle. (Street and Green, 1984).

IL Girard $\left(39.4464^{\circ} \mathrm{N}, 89.7808^{\circ} \mathrm{W}\right)$-Felt my many; sufficient to rattle dishes. (Street and Green, 1984).

IL Greenfield $\left(39.3436^{\circ} \mathrm{N}, 90.2125^{\circ} \mathrm{W}\right)$-Felt by many citizens. (Street and Green, 1984).

IL Iron $\left(37.9739^{\circ} \mathrm{N}, 88.2414^{\circ} \mathrm{W}\right)$-Very noticeable earthquake. (Street and Green, 1984). 


\section{Appendix 1, Part 25. Damage Reports and Intensity Assignments}

4 IL Kankakee $\left(41.1200^{\circ} \mathrm{N}, 87.8611^{\circ} \mathrm{W}\right)$-Noticed in several places and great enough to disarrange pictures on walls. (Street and

$4 \quad \mathrm{IL}$

4 IL

$4 \mathrm{IL}$

$4 \mathrm{IL}$

$4 \mathrm{IL}$

$4 \quad \mathrm{IL}$

$4 \quad \mathrm{IL}$

$4 \quad \mathrm{IL}$

$4 \mathrm{IL}$

$4 \quad \mathrm{IL}$

$4 \quad \mathrm{IL}$
Green, 1984).
Lebanon $\left(38.6039^{\circ} \mathrm{N}, 89.8072^{\circ} \mathrm{W}\right)$-Quite a number of residents were awakened. (Street and Green, 1984).

Lincoln $\left(40.1483^{\circ} \mathrm{N}, 89.3647^{\circ} \mathrm{W}\right)$-Many persons were aroused. (Street and Green, 1984).

Litchfield $\left(39.1753^{\circ} \mathrm{N}, 89.6542^{\circ} \mathrm{W}\right)$-Many greatly alarmed by swaying of houses. (Street and Green, 1984).

Marbletop-All awakened. (Street and Green, 1984).

Marion $\left(37.7306^{\circ} \mathrm{N}, 88.9331^{\circ} \mathrm{W}\right.$ ) - Experienced a severe earthquake shock that rattled houses and contents. (Street and Green, 1984).

Mount Vernon $\left(38.3172^{\circ} \mathrm{N}, 88.9031^{\circ} \mathrm{W}\right)$-Awakened everyone; several persons frightened enough to get out of bed. (Street and Green, 1984).

Murphysboro $\left(37.7644^{\circ} \mathrm{N}, 89.335^{\circ} \mathrm{W}\right)$-Rattled dishes. (Street and Green, 1984).

Paris $\left(39.6111^{\circ} \mathrm{N}, 87.6961^{\circ} \mathrm{W}\right)$-Awoke most people, rattled dishes and windows. (Street and Green, 1984).

Peoria $\left(40.6936^{\circ} \mathrm{N}, 89.5889^{\circ} \mathrm{W}\right)$-Felt slightly, awoke many people, rattled windows and knocked down tinware and crockery in a few instances. (Street and Green, 1984).

Quincy $\left(39.9356^{\circ} \mathrm{N}, 91.4097^{\circ} \mathrm{W}\right)$-Nearly everyone was awakened, windows rattled and people were tossed about in their beds. (Street and Green, 1984).

Salem $\left(38.6269^{\circ} \mathrm{N}, 88.9456^{\circ} \mathrm{W}\right)$-Shock was distinct, and lasted several seconds; aroused several hundred Salem residents. (Street and Green, 1984).

Shelbyville $\left(39.4064^{\circ} \mathrm{N}, 88.79^{\circ} \mathrm{W}\right)$-Many people were awakened. (Street and Green, 1984).

Vandalia $\left(38.9606^{\circ} \mathrm{N}, 89.0936^{\circ} \mathrm{W}\right)$-Sufficient to arouse people from their slumbers and cause doors and windows to rattle. (Street and Green, 1984).

Vienna $\left(37.4153^{\circ} \mathrm{N}, 88.8978^{\circ} \mathrm{W}\right)$-Many citizens were awakened by a severe earthquake shock. (Street and Green, 1984$)$.

Virginia $\left(39.9511^{\circ} \mathrm{N}, 90.2122^{\circ} \mathrm{W}\right)$-Sufficient to rattle dishes, disturb pictures on the walls and wake inhabitants. (Street and Green, 1984).

Bedford $\left(38.8611^{\circ} \mathrm{N}, 86.4872^{\circ} \mathrm{W}\right)$-Three vibrations were plainly felt, strong enough to almost jar bottles from shelves. (Street and Green, 1984).

Cannelton $\left(37.9114^{\circ} \mathrm{N}, 86.7444^{\circ} \mathrm{W}\right)$ - The majority of people were aroused, heavy articles of furniture were shaken. (Street and Green, 1984).

Cummings Valley-Caused a great deal of talk. (Street and Green, 1984).

Evansville $\left(37.9747^{\circ} \mathrm{N}, 87.5558^{\circ} \mathrm{W}\right)$-Caused pictures to sway on walls and houses to creak. (Street and Green, 1984).

Greensburg $\left(39.3372^{\circ} \mathrm{N}, 85.4836^{\circ} \mathrm{W}\right)$-Awakened and frightened a number of persons, caused dishes on cupboard shelves to rattle. (Street and Green, 1984).

Kokomo $\left(40.4864^{\circ} \mathrm{N}, 86.1336^{\circ} \mathrm{W}\right)$-Many residents were so disturbed that they got up; doors and windows rattled, furniture swayed. (Street and Green, 1984).

Metropolis City-Awakened light sleepers; rattled dishes and window panes. (Street and Green, 1984).

Muncie $\left(40.1933^{\circ} \mathrm{N}, 85.3864^{\circ} \mathrm{W}\right)-\mathrm{A}$ severe earthquake shock, many people made haste to arise and dress. (Street and Green, 1984).

New Albany $\left(38.2856^{\circ} \mathrm{N}, 85.8242^{\circ} \mathrm{W}\right)$-Many awakened by violent shaking of houses. (Street and Green, 1984).

Scottsburg $\left(38.6856^{\circ} \mathrm{N}, 85.7703^{\circ} \mathrm{W}\right)$-The shock was felt; one person thrown out of bed. (Street and Green, 1984).

Sullivan $\left(39.0953^{\circ} \mathrm{N}, 87.4058^{\circ} \mathrm{W}\right)$-Everyone plainly felt the violent shock, beds were moved, frightened people jumped from their beds. (Street and Green, 1984).

Vincennes $\left(38.6772^{\circ} \mathrm{N}, 87.5286^{\circ} \mathrm{W}\right)$-Rocked buildings. (Street and Green, 1984).

Washington $\left(38.6592^{\circ} \mathrm{N}, 87.1728^{\circ} \mathrm{W}\right)-\mathrm{A}$ violent trembling, many residents were aroused. (Street and Green, 1984).

Henderson $\left(37.8361^{\circ} \mathrm{N}, 87.59^{\circ} \mathrm{W}\right)$-Awakened and scared most; tilted a railroad tank so far that several gallons of water spilled out. (Street and Green, 1984).

Hickman $\left(36.5711^{\circ} \mathrm{N}, 89.1861^{\circ} \mathrm{W}\right)$-Awakened many and rattled dishes. (Street and Green, 1984).

Hopkinsville $\left(36.8656^{\circ} \mathrm{N}, 87.4886^{\circ} \mathrm{W}\right)$ - Houses were rocked and windows were shaken. (Street and Green, 1984).

Marion $\left(37.3328^{\circ} \mathrm{N}, 88.0811^{\circ} \mathrm{W}\right)$-Buildings were shaken, windows rattled, and people were awakened. (Street and Green, 1984).

Owensboro $\left(37.7742^{\circ} \mathrm{N}, 87.1133^{\circ} \mathrm{W}\right)$ - Many people were awakened and got out of bed to investigate. (Street and Green, 1984).

Paducah $\left(37.0833^{\circ} \mathrm{N}, 88.6^{\circ} \mathrm{W}\right)$-Windows and doors rattled, nearly everyone was awakened. (Street and Green, 1984).

Sebree $\left(37.6069^{\circ} \mathrm{N}, 87.5286^{\circ} \mathrm{W}\right)$-Aroused many - severe. (Street and Green, 1984).

Sturgis $\left(37.5467^{\circ} \mathrm{N}, 87.9839^{\circ} \mathrm{W}\right)$-Scared people a little. (Street and Green, 1984).

Benton $\left(37.0978^{\circ} \mathrm{N}, 89.5625^{\circ} \mathrm{W}\right)$-Received quite a shock. (Street and Green, 1984).

Bismarck $\left(37.7692^{\circ} \mathrm{N}, 90.6247^{\circ} \mathrm{W}\right)$-Disturbed some people from their slumber. (Street and Green, 1984).

Cape Girardeau $\left(37.3058^{\circ} \mathrm{N}, 89.5181^{\circ} \mathrm{W}\right)$-Roused many sleepers; no damage. (Street and Green, 1984).

Farmington $\left(37.7808^{\circ} \mathrm{N}, 90.4217^{\circ} \mathrm{W}\right)$-Felt my many. (Street and Green, 1984).

Hannibal $\left(39.7083^{\circ} \mathrm{N}, 91.3583^{\circ} \mathrm{W}\right)$-Awakened many. (Street and Green, 1984).

Louisiana $\left(39.4489^{\circ} \mathrm{N}, 91.0514^{\circ} \mathrm{W}\right)$-Violent; rattled dishes and other articles. (Street and Green, 1984). 


\section{Appendix 1, Part 25. Damage Reports and Intensity Assignments}

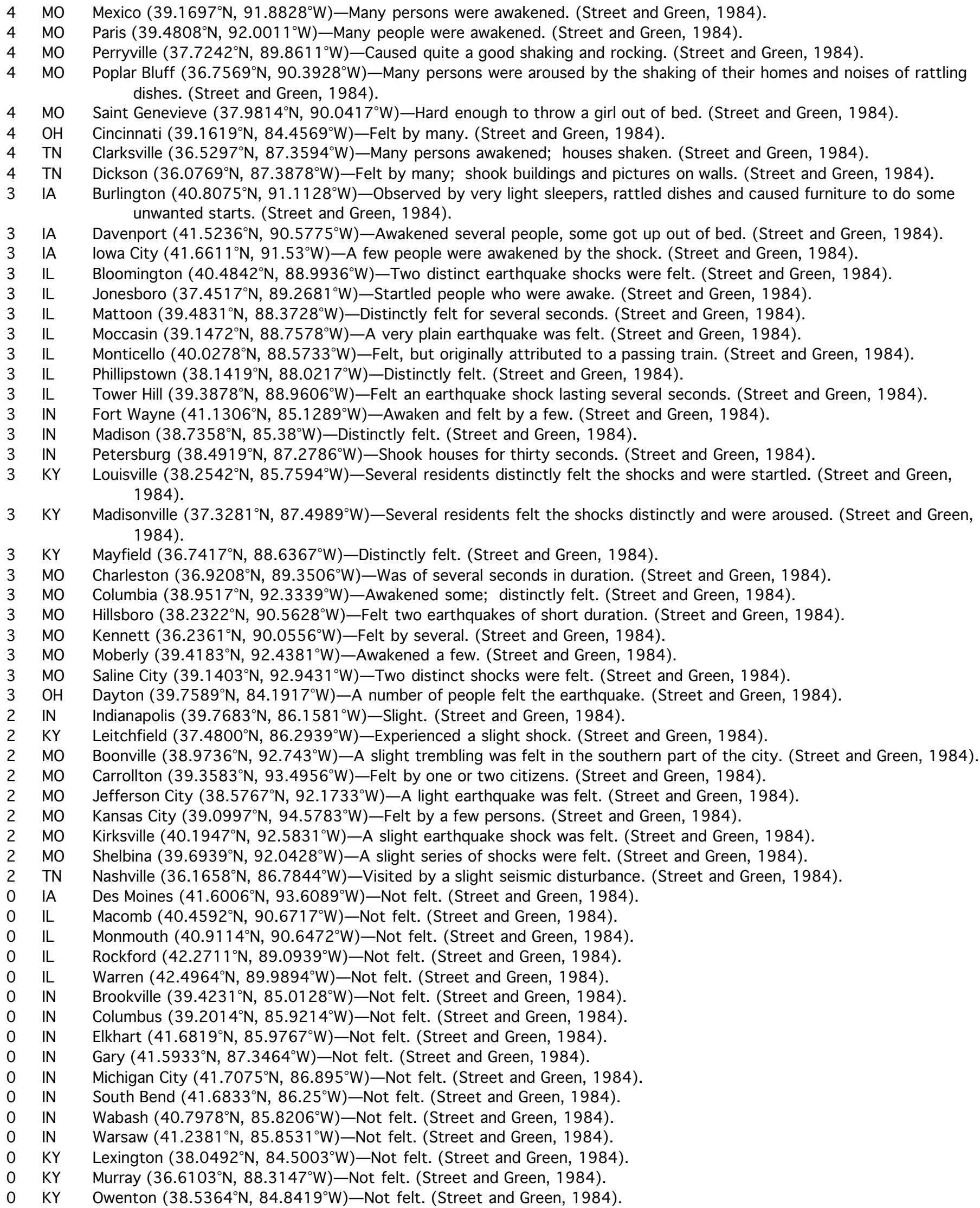




\title{
Appendix 1, Part 25. Damage Reports and Intensity Assignments
}

\author{
MI Saginaw $\left(43.4194^{\circ} \mathrm{N}, 83.9508^{\circ} \mathrm{W}\right)$-Not felt. (Street and Green, 1984). \\ MO Brookfield $\left(39.7844^{\circ} \mathrm{N}, 93.0733^{\circ} \mathrm{W}\right)$-Not felt. (Street and Green, 1984). \\ MO La Grange $\left(40.0428^{\circ} \mathrm{N}, 91.4975^{\circ} \mathrm{W}\right)$-Not felt. (Street and Green, 1984). \\ $\mathrm{OH} \quad$ Cleveland $\left(41.4994^{\circ} \mathrm{N}, 81.6956^{\circ} \mathrm{W}\right)$-Not felt. (Street and Green, 1984). \\ $\mathrm{OH} \quad$ Hamilton $\left(39.3994^{\circ} \mathrm{N}, 84.5614^{\circ} \mathrm{W}\right)$-Not felt. (Street and Green, 1984). \\ TN Memphis $\left(35.1494^{\circ} \mathrm{N}, 90.0489^{\circ} \mathrm{W}\right)$-Not felt. (Street and Green, 1984). \\ IL $\quad$ Sparta $\left(38.1231^{\circ} \mathrm{N}, 89.7017^{\circ} \mathrm{W}\right)$-Not mentioned. (Street and Green, 1984). \\ KY Lebanon $\left(37.5697^{\circ} \mathrm{N}, 85.2528^{\circ} \mathrm{W}\right)$-Not reported. (Street and Green, 1984). \\ KY Versailles $\left(38.0525^{\circ} \mathrm{N}, 84.73^{\circ} \mathrm{W}\right)$-Not mentioned. (Street and Green, 1984). \\ MI Kalamazoo $\left(42.2917^{\circ} \mathrm{N}, 85.5872^{\circ} \mathrm{W}\right)$-Not reported. (Street and Green, 1984). \\ MO Bloomfield $\left(36.8858^{\circ} \mathrm{N}, 89.9292^{\circ} \mathrm{W}\right)$-Not reported. (Street and Green, 1984). \\ MO Braymer $\left(39.5869^{\circ} \mathrm{N}, 93.7958^{\circ} \mathrm{W}\right)$-Not reported. (Street and Green, 1984). \\ $\mathrm{MO}$ \\ MO \\ $\mathrm{MO}$ \\ $\mathrm{MO}$ \\ $\mathrm{MO}$ \\ $\mathrm{MO}$ \\ $\mathrm{MO}$ \\ MO \\ $\mathrm{MO}$ \\ $\mathrm{MO}$ \\ $\mathrm{MO}$ \\ $\mathrm{MO}$ \\ $\mathrm{MO}$ \\ $\mathrm{MO}$ \\ $\mathrm{OH}$ \\ $\mathrm{OH}$ \\ TN \\ TN \\ IA \\ IL \\ Caruthersville $\left(36.1931^{\circ} \mathrm{N}, 89.6556^{\circ} \mathrm{W}\right)$-Not mentioned. (Street and Green, 1984). \\ Chillicothe $\left(39.7953^{\circ} \mathrm{N}, 93.5522^{\circ} \mathrm{W}\right)$-Not mentioned. (Street and Green, 1984). \\ Edina $\left(40.1675^{\circ} \mathrm{N}, 92.1725^{\circ} \mathrm{W}\right)$-Not reported. (Street and Green, 1984). \\ Eminence $\left(37.1506^{\circ} \mathrm{N}, 91.3575^{\circ} \mathrm{W}\right)$-Not mentioned. (Street and Green, 1984). \\ Excelsior Springs $\left(39.3392^{\circ} \mathrm{N}, 94.2258^{\circ} \mathrm{W}\right)$-Not reported. (Street and Green, 1984). \\ Lexington $\left(39.1847^{\circ} \mathrm{N}, 93.8797^{\circ} \mathrm{W}\right)$-Not reported. (Street and Green, 1984). \\ Liberty $\left(39.2461^{\circ} \mathrm{N}, 94.4189^{\circ} \mathrm{W}\right)$-Not reported. (Street and Green, 1984). \\ Macon $\left(39.7422^{\circ} \mathrm{N}, 92.4725^{\circ} \mathrm{W}\right)-$ Not reported. (Street and Green, 1984). \\ Marble Hill $\left(37.3058^{\circ} \mathrm{N}, 89.9703^{\circ} \mathrm{W}\right)$-Not reported. (Street and Green, 1984). \\ New London $\left(39.5853^{\circ} \mathrm{N}, 91.4008^{\circ} \mathrm{W}\right)$-Not mentioned. (Street and Green, 1984). \\ Richmond $\left(39.2786^{\circ} \mathrm{N}, 93.9767^{\circ} \mathrm{W}\right)$-Not reported. (Street and Green, 1984). \\ Salisbury $\left(39.4239^{\circ} \mathrm{N}, 92.8014^{\circ} \mathrm{W}\right)$-Not mentioned. (Street and Green, 1984). \\ Versailles $\left(38.4314^{\circ} \mathrm{N}, 92.8408^{\circ} \mathrm{W}\right)$-Not reported. (Street and Green, 1984). \\ Warrensburg $\left(38.7628^{\circ} \mathrm{N}, 93.7358^{\circ} \mathrm{W}\right)$-Not reported. (Street and Green, 1984). \\ Warsaw $\left(38.2431^{\circ} \mathrm{N}, 93.3817^{\circ} \mathrm{W}\right)$-Not mentioned. (Street and Green, 1984). \\ Columbus $\left(39.9611^{\circ} \mathrm{N}, 82.9989^{\circ} \mathrm{W}\right)$-Not reported. (Street and Green, 1984). \\ Marion $\left(40.5886^{\circ} \mathrm{N}, 83.1286^{\circ} \mathrm{W}\right)$-Not mentioned. (Street and Green, 1984). \\ Columbia $\left(35.6150^{\circ} \mathrm{N}, 87.0353^{\circ} \mathrm{W}\right)$-Not reported. (Street and Green, 1984). \\ Huntingdon $\left(36.0006^{\circ} \mathrm{N}, 88.4281^{\circ} \mathrm{W}\right.$ )—Not mentioned. (Street and Green, 1984). \\ Dubuque $\left(42.5006^{\circ} \mathrm{N}, 90.6644^{\circ} \mathrm{W}\right)$-Felt. (Street and Green, 1984). \\ Chicago $\left(41.8500^{\circ} \mathrm{N}, 87.65^{\circ} \mathrm{W}\right)$-Felt at the University of Illinois astronomical laboratory. (Street and Green, 1984). \\ Decatur $\left(39.8403^{\circ} \mathrm{N}, 88.9547^{\circ} \mathrm{W}\right)$-Two earthquakes felt. (Street and Green, 1984). \\ IN Lafayette $\left(40.4167^{\circ} \mathrm{N}, 86.875^{\circ} \mathrm{W}\right)$-Felt. (Street and Green, 1984). \\ KY Cloverport $\left(37.8333^{\circ} \mathrm{N}, 86.6328^{\circ} \mathrm{W}\right)$-Felt. (Street and Green, 1984). \\ KY Newport $\left(39.0914^{\circ} \mathrm{N}, 84.4958^{\circ} \mathrm{W}\right)$-Felt. (Street and Green, 1984). \\ MO Jackson $\left(37.3822^{\circ} \mathrm{N}, 89.6661^{\circ} \mathrm{W}\right)$-Felt. (Street and Green, 1984). \\ MO Lathrop $\left(39.5483^{\circ} \mathrm{N}, 94.3297^{\circ} \mathrm{W}\right)$-Felt. (Street and Green, 1984). \\ MO Marshall $\left(39.1231^{\circ} \mathrm{N}, 93.1967^{\circ} \mathrm{W}\right)$-Felt. (Street and Green, 1984). \\ F $\quad$ MO Oak Ridge $\left(37.5011^{\circ} \mathrm{N}, 89.7297^{\circ} \mathrm{W}\right)$-Felt. (Street and Green, 1984). \\ F $\quad$ MO Parkville $\left(39.1950^{\circ} \mathrm{N}, 94.6819^{\circ} \mathrm{W}\right)$-Felt. (Street and Green, 1984). \\ F $\quad$ MO Saint Marys $\left(37.8789^{\circ} \mathrm{N}, 89.9492^{\circ} \mathrm{W}\right)$-Three earthquake shocks were felt (Street and Green, 1984).
}

$\mathrm{MO}$

IL 


\section{Appendix 1, Part 26. Damage Reports and Intensity Assignments}

\section{\#26 1911 March 31 16:57UTC (Arkansas)}

7 AR De Witt $\left(34.2928^{\circ} \mathrm{N}, 91.3378^{\circ} \mathrm{W}\right)$-Damaged the courthouse as well as all two and three-story buildings. (Street and Green, 1984).

6 AR Argenta $\left(34.7694^{\circ} \mathrm{N}, 92.2669^{\circ} \mathrm{W}\right)$-Shook plaster off the ceiling of the high school and caused considerable alarm. (Street and Green, 1984).

AR Argenta $\left(34.7694^{\circ} \mathrm{N}, 92.2669^{\circ} \mathrm{W}\right)$-Minor damage also occurred at Argenta, Dumas, Monticello, Rison, and Warren, Ark. (Stover and Coffman, 1993).

6 AR Dumas $\left(33.8869^{\circ} \mathrm{N}, 91.4917^{\circ} \mathrm{W}\right)$-Minor damage also occurred at Argenta, Dumas, Monticello, Rison, and Warren, Ark. (Stover and Coffman, 1993).

AR Dumas $\left(33.8869^{\circ} \mathrm{N}, 91.4917^{\circ} \mathrm{W}\right)$-A heavy shock, shook water from pails in town, violently rocked buildings, threw people from chairs. (Street and Green, 1984).

Monticello $\left(33.6289^{\circ} \mathrm{N}, 91.7908^{\circ} \mathrm{W}\right)$-Earthquake shocks were felt, knocked plastering from ceiling of courthouse and public schools and cracked plastering in several houses. (Street and Green, 1984).

AR Monticello $\left(33.6289^{\circ} \mathrm{N}, 91.7908^{\circ} \mathrm{W}\right)$-Minor damage also occurred at Argenta, Dumas, Monticello, Rison, and Warren, Ark. (Stover and Coffman, 1993).

Pine Bluff $\left(34.2283^{\circ} \mathrm{N}, 92.0031^{\circ} \mathrm{W}\right)$-The earthquake cracked walls, broke windows and dishes, and sent people rushing into the streets at Pine bluff, Ark., south of Little rock in Jefferson county. Walls cracked at the 15th Avenue school at Pine bluff, and plaster fell on the pupils. (Stover and Coffman, 1993).

AR

$6 \quad \mathrm{AR}$

AR

$6 \mathrm{AR}$

AR

$5 \quad \mathrm{AR}$

5 AR

4 AR

4 AR

4 AR

4 AR

4 AR

4 AR

4 MS

4 TN

3 AR

3 AR

3 AR

2 AR

$2 \mathrm{AR}$

$2 \mathrm{AR}$

$\mathrm{N}$ AR

$\mathrm{N}$ AR

$\mathrm{N}$ AR

$\mathrm{N}$ AR

$\mathrm{N}$ AR

$\mathrm{N}$ AR

$\mathrm{N}$ AR

$\mathrm{N}$ AR

$\mathrm{N}$ AR

$\mathrm{N}$ AR

$\mathrm{N}$ IL

F AR

F AR

Pine Bluff $\left(34.2283^{\circ} \mathrm{N}, 92.0031^{\circ} \mathrm{W}\right)$-Excited people crowded the streets in panic and refused to return to their homes. (Street and Green, 1984).

Rison $\left(33.9583^{\circ} \mathrm{N}, 92.19^{\circ} \mathrm{W}\right)$-Stopped all clocks, people rushed into the streets, cracked walls of several brick buildings, toppled flues, broke glass windows (Street and Green, 1984).

Rison $\left(33.9583^{\circ} \mathrm{N}, 92.19^{\circ} \mathrm{W}\right.$ )-Minor damage also occurred at Argenta, Dumas, Monticello, Rison, and Warren, Ark. (Stover and Coffman, 1993).

Warren $\left(33.6125^{\circ} \mathrm{N}, 92.0644^{\circ} \mathrm{W}\right)$-Caused wild excitement, occupants of buildings rushed into the streets, threw stove pipes down. (Street and Green, 1984).

Warren $\left(33.6125^{\circ} \mathrm{N}, 92.0644^{\circ} \mathrm{W}\right)$ - Minor damage also occurred at Argenta, Dumas, Monticello, Rison, and Warren, Ark. (Stover and Coffman, 1993).

Fordyce $\left(33.8136^{\circ} \mathrm{N}, 92.4128^{\circ} \mathrm{W}\right)$-Severely shook the town, people rushed out of office buildings and homes for safety, however, no material damage was done. (Street and Green, 1984).

Little Rock $\left(34.7464^{\circ} \mathrm{N}, 92.2894^{\circ} \mathrm{W}\right)$-Moved furniture and caused considerable excitement. (Street and Green, 1984).

Camden $\left(33.5844^{\circ} \mathrm{N}, 92.8342^{\circ} \mathrm{W}\right)-\mathrm{A}$ heavy shock, however, no material damage. (Street and Green, 1984).

Clarendon $\left(34.6931^{\circ} \mathrm{N}, 91.3136^{\circ} \mathrm{W}\right)$-Shook buildings and caused considerable excitement. (Street and Green, 1984).

Daleville $\left(34.0656^{\circ} \mathrm{N}, 93.0142^{\circ} \mathrm{W}\right)$-A slight shock was felt by most merchants. (Street and Green, 1984).

England $\left(34.5442^{\circ} \mathrm{N}, 91.9689^{\circ} \mathrm{W}\right)$-Shook buildings and rattled window panes. (Street and Green, 1984).

Star City $\left(33.9428^{\circ} \mathrm{N}, 91.8433^{\circ} \mathrm{W}\right)$ - A considerable tremor was felt, noticed by nearly everyone. (Street and Green, 1984 ).

Wilmar $\left(33.6289^{\circ} \mathrm{N}, 91.9314^{\circ} \mathrm{W}\right)$-Opened and closed doors, rattled pots and pans, caused people to rush into the streets stricken with fear. (Street and Green, 1984).

Vicksburg $\left(32.3525^{\circ} \mathrm{N}, 90.8778^{\circ} \mathrm{W}\right)$-Felt by citizens in many parts of the city. (Street and Green, 1984).

Memphis $\left(35.1494^{\circ} \mathrm{N}, 90.0489^{\circ} \mathrm{W}\right)$-Jarred nerves. (Street and Green, 1984).

El Dorado $\left(33.2075^{\circ} \mathrm{N}, 92.6661^{\circ} \mathrm{W}\right)$-Felt by a number of citizens, but no damage. (Street and Green, 1984).

Ladd $\left(34.1408^{\circ} \mathrm{N}, 91.9089^{\circ} \mathrm{W}\right)$-A distinct shock was felt, everyone was excited. (Street and Green, 1984).

Lake Village $\left(33.3286^{\circ} \mathrm{N}, 91.2817^{\circ} \mathrm{W}\right)$-A distinct shock. (Street and Green, 1984).

Arkadelphia $\left(34.1208^{\circ} \mathrm{N}, 93.0536^{\circ} \mathrm{W}\right)$-A slight shock; many people did not feel the shock. (Street and Green, 1984).

Hot Springs $\left(34.5036^{\circ} \mathrm{N}, 93.055^{\circ} \mathrm{W}\right)$-Felt by a few individuals in larger buildings. (Street and Green, 1984).

Judsonia $\left(35.2700^{\circ} \mathrm{N}, 91.6397^{\circ} \mathrm{W}\right)$-A light shock. (Street and Green, 1984).

Corning $\left(36.4078^{\circ} \mathrm{N}, 90.5797^{\circ} \mathrm{W}\right)$-Not reported. (Street and Green, 1984).

Cotter $\left(36.2711^{\circ} \mathrm{N}, 92.5353^{\circ} \mathrm{W}\right)$-Not reported. (Street and Green, 1984).

Des Arc $\left(34.9769^{\circ} \mathrm{N}, 91.495^{\circ} \mathrm{W}\right)$-Not reported. (Street and Green, 1984).

Hamburg $\left(33.2281^{\circ} \mathrm{N}, 91.7975^{\circ} \mathrm{W}\right)$-Not mentioned. (Street and Green, 1984).

Harrison $\left(36.2297^{\circ} \mathrm{N}, 93.1075^{\circ} \mathrm{W}\right)$-Not reported. (Street and Green, 1984).

Malvern $\left(34.3622^{\circ} \mathrm{N}, 92.8128^{\circ} \mathrm{W}\right)$-Not mentioned. (Street and Green, 1984).

Marked Tree $\left(35.5328^{\circ} \mathrm{N}, 90.4206^{\circ} \mathrm{W}\right)$-Not reported. (Street and Green, 1984).

Mena $\left(34.5861^{\circ} \mathrm{N}, 94.2394^{\circ} \mathrm{W}\right)-$ Not mentioned. (Street and Green, 1984).

Osceola $\left(35.7050^{\circ} \mathrm{N}, 89.9694^{\circ} \mathrm{W}\right)$-Not reported. (Street and Green, 1984).

Russellville $\left(35.2783^{\circ} \mathrm{N}, 93.1336^{\circ} \mathrm{W}\right)$-Not reported. (Street and Green, 1984).

Jonesboro $\left(37.4517^{\circ} \mathrm{N}, 89.2681^{\circ} \mathrm{W}\right)$-Not reported. (Street and Green, 1984).

Altheimer $\left(34.3192^{\circ} \mathrm{N}, 91.8472^{\circ} \mathrm{W}\right)$-Felt. (Street and Green, 1984).

Kingsland $\left(33.8583^{\circ} \mathrm{N}, 92.2939^{\circ} \mathrm{W}\right)$-Felt. (Street and Green, 1984). 


\section{Appendix 1, Part 26. Damage Reports and Intensity Assignments}

F AR Noble Lake $\left(34.1731^{\circ} \mathrm{N}, 91.8542^{\circ} \mathrm{W}\right)$-Felt. (Street and Green, 1984).

F AR Sherrill $\left(34.3853^{\circ} \mathrm{N}, 91.9506^{\circ} \mathrm{W}\right)$-Felt. (Street and Green, 1984).

F AR Tarry $\left(34.0758^{\circ} \mathrm{N}, 91.8414^{\circ} \mathrm{W}\right)$-Felt. (Street and Green, 1984).

F AR Yorktown $\left(34.0208^{\circ} \mathrm{N}, 91.8167^{\circ} \mathrm{W}\right)$-Felt. (Street and Green, 1984). 


\section{Appendix 1, Part 27. Damage Reports and Intensity Assignments}

\section{\#27 1917 April 9 20:52UTC (Illinois)}

7 IL Granite City $\left(38.7014^{\circ} \mathrm{N}, 90.1486^{\circ} \mathrm{W}\right)$-Dwellings so violently shakened that in many instances the buildings had shifted. (Street and Green, 1984).

IL Granite City $\left(38.7014^{\circ} \mathrm{N}, 90.1486^{\circ} \mathrm{W}\right)$-At Granite City, Mo., buildings shifted on their foundations. (Stover and Coffman, 1993).

$7 \mathrm{MO}$

MO

$7 \quad \mathrm{MO}$

$7 \mathrm{MO}$

MO

$7 \mathrm{MO}$

MO

De Soto $\left(38.1057^{\circ} \mathrm{N}, 90.5611^{\circ} \mathrm{W}\right)$-At DeSoto, Mo., in Jefferson County, bricks fell from chimneys and the walls of several buildings were cracked. (Stover and Coffman, 1993).

De Soto $\left(38.1394^{\circ} \mathrm{N}, 90.555^{\circ} \mathrm{W}\right)$-Cracked post office and school building walls, knocked plastering off ceiling in school, and slightly damaged several business houses. (Street and Green, 1984).

Mokane $\left(38.6750^{\circ} \mathrm{N}, 91.8742^{\circ} \mathrm{W}\right)$-Shattered most of the windows in the business district. (Street and Green, 1984).

Saint Genevieve $\left(37.8817^{\circ} \mathrm{N}, 90.1554^{\circ} \mathrm{W}\right)$ - Many windows were broken and buildings rocked at Ste. Genevieve..., south of St. Louis near the Illinois border. (Stover and Coffman, 1993).

Saint Genevieve $\left(37.8817^{\circ} \mathrm{N}, 90.1554^{\circ} \mathrm{W}\right)$ - Rocked buildings, rattled windows, and people ran into the streets. (Street and Green, 1984).

Saint Louis $\left(38.6272^{\circ} \mathrm{N}, 90.1978^{\circ} \mathrm{W}\right)$-People were thrown from their feet and bumped against each other on downtown streets, windows were broken and several chimneys were knocked down in the western suburbs. (Street and Green, 1984).

Saint Louis $\left(38.6272^{\circ} \mathrm{N}, 90.1978^{\circ} \mathrm{W}\right)$-At St. Louis, Mo., several chimneys were knocked down, windows were broken, and people were thrown to the pavement. (Stover and Coffman, 1993).

Saint Mary $\left(37.8325^{\circ} \mathrm{N}, 89.977^{\circ} \mathrm{W}\right)$-Many windows were broken and buildings rocked at ...St. Mary, Mo., south of St. Louis near the Illinois border. (Stover and Coffman, 1993).

Keokuk $\left(40.3972^{\circ} \mathrm{N}, 91.3847^{\circ} \mathrm{W}\right)-$ Minor damage to several dwellings. (Street and Green, 1984).

Collinsville $\left(38.6703^{\circ} \mathrm{N}, 89.9844^{\circ} \mathrm{W}\right)$-Greatly frightened children, overturned furniture. (Street and Green, 1984).

East Saint Louis $\left(38.6244^{\circ} \mathrm{N}, 90.1508^{\circ} \mathrm{W}\right)$-Broke windows and dishes. (Street and Green, 1984).

Riverside $\left(39.1775^{\circ} \mathrm{N}, 94.6128^{\circ} \mathrm{W}\right)$-Knocked down a chimney. (Street and Green, 1984).

Belleville $\left(38.5200^{\circ} \mathrm{N}, 89.9839^{\circ} \mathrm{W}\right)$-Distinctly felt by people all over the city; people rushed from buildings. (Street and Green, 1984).

Centralia $\left(38.5250^{\circ} \mathrm{N}, 89.1333^{\circ} \mathrm{W}\right)$-Very severe. (Street and Green, 1984).

Chester $\left(37.9136^{\circ} \mathrm{N}, 89.8219^{\circ} \mathrm{W}\right)$-Violent shaking of walls and light articles. (Street and Green, 1984).

Du Quoin $\left(38.0114^{\circ} \mathrm{N}, 89.2361^{\circ} \mathrm{W}\right)$-Very severe. (Street and Green, 1984).

Jacksonville $\left(39.7339^{\circ} \mathrm{N}, 90.2289^{\circ} \mathrm{W}\right)$-Sufficient to cause people to rush from buildings. (Street and Green, 1984).

Jerseyville $\left(39.1200^{\circ} \mathrm{N}, 90.3283^{\circ} \mathrm{W}\right)$-Shook lamps from posts of the city lighting system. (Street and Green, 1984).

Monmouth $\left(40.9114^{\circ} \mathrm{N}, 90.6472^{\circ} \mathrm{W}\right)$-Many buildings shaken, rocked linotype machines. (Street and Green, 1984).

Mount Vernon $\left(38.3172^{\circ} \mathrm{N}, 88.9031^{\circ} \mathrm{W}\right)$-Very severe. (Street and Green, 1984).

Wanda $\left(38.8344^{\circ} \mathrm{N}, 90.0386^{\circ} \mathrm{W}\right)$-Pupils ran from school in panic. (Street and Green, 1984).

West Frankfort $\left(37.8978^{\circ} \mathrm{N}, 88.9314^{\circ} \mathrm{W}\right)$-Very severe. (Street and Green, 1984).

Paducah $\left(37.0833^{\circ} \mathrm{N}, 88.6^{\circ} \mathrm{W}\right)$-Vibrated water pipes and tanks violently. (Street and Green, 1984).

Alton $\left(36.6942^{\circ} \mathrm{N}, 91.3992^{\circ} \mathrm{W}\right)$-Rattled windows and moved furniture. (Street and Green, 1984).

Bismarck $\left(37.7692^{\circ} \mathrm{N}, 90.6247^{\circ} \mathrm{W}\right)$-Violent shock, many citizens rushed out of their buildings. (Street and Green, 1984).

Bonne Terre $\left(37.9231^{\circ} \mathrm{N}, 90.5553^{\circ} \mathrm{W}\right.$ )-Moved light articles, people rushed out of doors, broke a glass window. (Street and Green, 1984).

Cape Girardeau $\left(37.3058^{\circ} \mathrm{N}, 89.5181^{\circ} \mathrm{W}\right)$-Quite severe - stopped clocks. (Street and Green, 1984).

Eminence $\left(37.1506^{\circ} \mathrm{N}, 91.3575^{\circ} \mathrm{W}\right)$-Building rocked and shook enough to scare people out of them. (Street and Green, 1984).

Farmington $\left(37.7808^{\circ} \mathrm{N}, 90.4217^{\circ} \mathrm{W}\right)$-Goods were shaken from store shelves, everyone rushed to the streets. (Street and Green, 1984).

Flat River $\left(37.8511^{\circ} \mathrm{N}, 90.5206^{\circ} \mathrm{W}\right)$-People rushed panic stricken out on the streets; loosened rocks in the mines. (Street and Green, 1984).

Fredericktown $\left(37.5597^{\circ} \mathrm{N}, 90.2939^{\circ} \mathrm{W}\right)$-Broke a few windows, shook goods from shelves in a few stores, badly scared people. (Street and Green, 1984).

Greenville $\left(37.1272^{\circ} \mathrm{N}, 90.45^{\circ} \mathrm{W}\right)$-People ran from stores and offices; the county courthouse was vacated. (Street and Green, 1984).

Hillsboro $\left(38.2322^{\circ} \mathrm{N}, 90.5628^{\circ} \mathrm{W}\right)$-Made houses shake so that a good many people ran out of buildings. (Street and Green, 1984).

Montgomery City $\left(38.9775^{\circ} \mathrm{N}, 91.5047^{\circ} \mathrm{W}\right)$-Described as being violent. (Street and Green, 1984).

Poplar Bluff $\left(36.7569^{\circ} \mathrm{N}, 90.3928^{\circ} \mathrm{W}\right)$-Many people rushed from buildings. (Street and Green, 1984).

Alton $\left(38.8906^{\circ} \mathrm{N}, 90.1842^{\circ} \mathrm{W}\right)$-People left buildings in some instances. (Street and Green, 1984).

Cairo $\left(37.0053^{\circ} \mathrm{N}, 89.1764^{\circ} \mathrm{W}\right)$ - Many persons badly frightened. (Street and Green, 1984).

Pana $\left(39.3889^{\circ} \mathrm{N}, 89.08^{\circ} \mathrm{W}\right)$-Patients tossed in hospital beds, dishes clinked and were jostled. (Street and Green, 1984). 


\section{Appendix 1, Part 27. Damage Reports and Intensity Assignments}

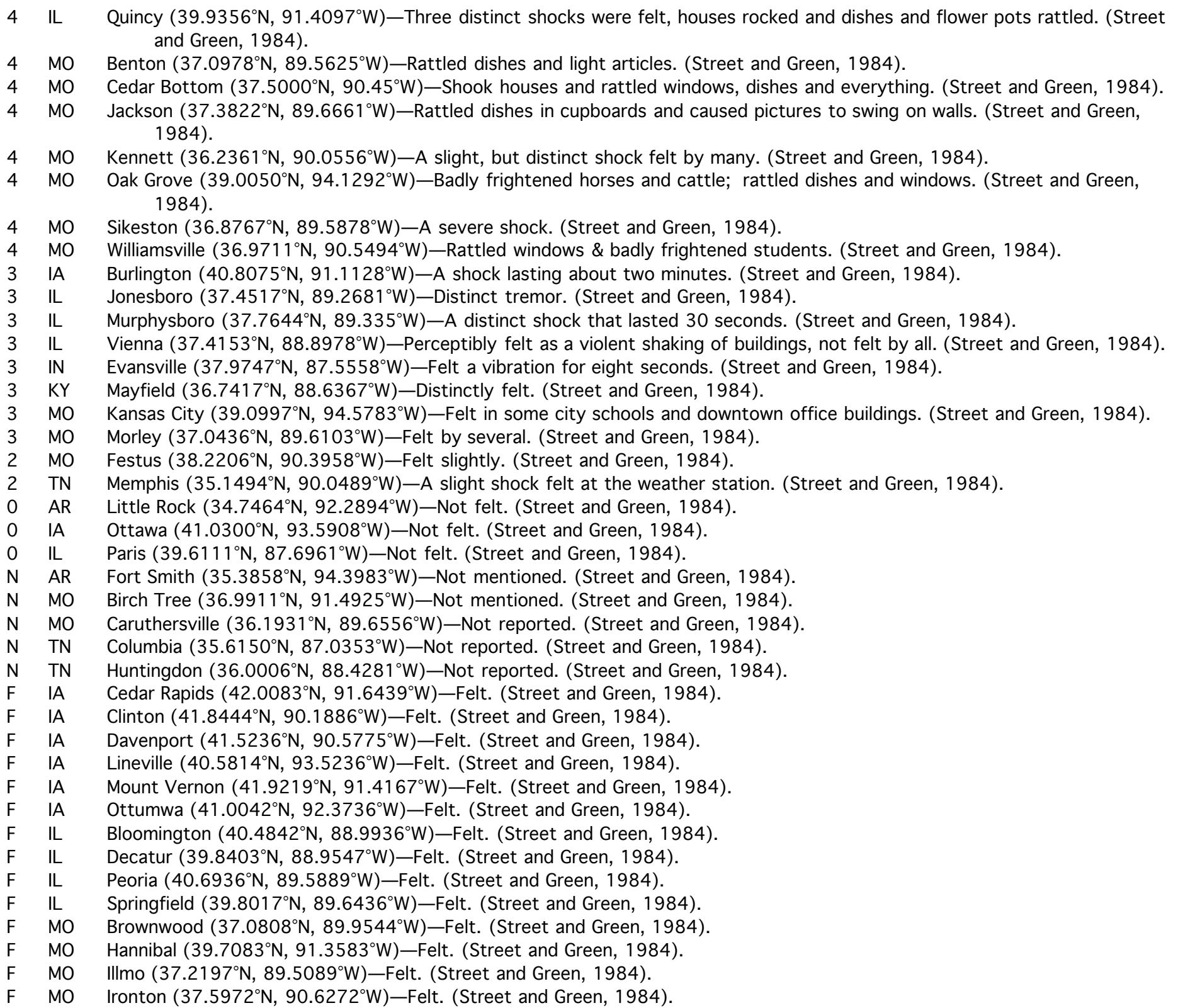




\section{Appendix 1, Part 28. Damage Reports and Intensity Assignments}

\section{\#28 1922 March 22 22:29UTC (Illinols)}

$7 \quad \mathrm{MO}$ and Green, 1984).

MO

$5 \quad \mathrm{IL}$

IL

MO

MO

IL

IL

IL

KY

KY

KY
MO
MO
MO
MO
MO
MO
MO
MO
MO
MO
MO
MO
MO
MO
TN
IL
IL
IL
KY
KY
MO
MO
MO
TN
TN
TN
MO

MO

F MO

F TN

IIImo $\left(37.2197^{\circ} \mathrm{N}, 89.5089^{\circ} \mathrm{W}\right)$-People rushed out of stores, 25 chimneys were knocked down, glass was broken. (Street people rushing out of stores. (Stover and Coffman, 1993).

Carbondale $\left(37.7272^{\circ} \mathrm{N}, 89.2167^{\circ} \mathrm{W}\right)$-Dishes fell off shelves. (Street and Green, 1984).

Carbondale $\left(37.7272^{\circ} \mathrm{N}, 89.2167^{\circ} \mathrm{W}\right)$-Dishes fell from shelves at Carbondale, III. (Stover and Coffman, 1993).

Cape Girardeau $\left(37.3058^{\circ} \mathrm{N}, 89.5181^{\circ} \mathrm{W}\right)$-Chimneys wobbled. (Street and Green, 1984).

Dexter $\left(36.7958^{\circ} \mathrm{N}, 89.9578^{\circ} \mathrm{W}\right.$ ) -Distinct, people ran outside. (Street and Green, 1984).

Cairo $\left(37.0053^{\circ} \mathrm{N}, 89.1764^{\circ} \mathrm{W}\right)-\mathrm{A}$ distinct shock, rattle windows and doors. (Street and Green, 1984).

Jonesboro $\left(37.4517^{\circ} \mathrm{N}, 89.2681^{\circ} \mathrm{W}\right)$-Severe. (Street and Green, 1984).

Vienna $\left(37.4153^{\circ} \mathrm{N}, 88.8978^{\circ} \mathrm{W}\right)$-Shook buildings, rattled dishes, and made citizens feel uneasy. (Street and Green, 1984). Hickman $\left(36.5711^{\circ} \mathrm{N}, 89.1861^{\circ} \mathrm{W}\right)$-Felt with considerable force. (Street and Green, 1984).

Mayfield $\left(36.7417^{\circ} \mathrm{N}, 88.6367^{\circ} \mathrm{W}\right)$-Rattled window panes and made houses quiver, more severe than the later one. [At Mayfield for the southern Illinois shock of 1922 Mar 23 02:22 UTC = Mar 22 8:22 p.m. CST (aftershock of this shock Mar 22 04:29 p.m. CST)"windows all over town were shaken." - IV] (Street and Green, 1984).

Paducah $\left(37.0833^{\circ} \mathrm{N}, 88.6^{\circ} \mathrm{W}\right)$-Rattled windows and doors. (Street and Green, 1984).

Charleston $\left(36.9208^{\circ} \mathrm{N}, 89.3506^{\circ} \mathrm{W}\right)-$ Frightened some. (Street and Green, 1984).

Fredericktown $\left(37.5597^{\circ} \mathrm{N}, 90.2939^{\circ} \mathrm{W}\right)$-Shook windows violently. (Street and Green, 1984).

Fruitland $\left(37.4486^{\circ} \mathrm{N}, 89.6386^{\circ} \mathrm{W}\right)$-Rattled things considerably. (Street and Green, 1984).

Millersville $\left(37.4328^{\circ} \mathrm{N}, 89.7994^{\circ} \mathrm{W}\right)$-Severe. (Street and Green, 1984).

Perkins $\left(37.0947^{\circ} \mathrm{N}, 89.7753^{\circ} \mathrm{W}\right)$-Felt by most everyone. (Street and Green, 1984).

Saint Charles $\left(38.7839^{\circ} \mathrm{N}, 90.4811^{\circ} \mathrm{W}\right)$-Rattled windows. (Street and Green, 1984).

Saint Louis $\left(38.6272^{\circ} \mathrm{N}, 90.1978^{\circ} \mathrm{W}\right)$-Felt in all parts of the city. (Street and Green, 1984).

Sikeston $\left(36.8767^{\circ} \mathrm{N}, 89.5878^{\circ} \mathrm{W}\right)$-Rattled windows, shook buildings. (Street and Green, 1984).

Bloomfield $\left(36.8858^{\circ} \mathrm{N}, 89.9292^{\circ} \mathrm{W}\right)$-Distinctly felt. (Street and Green, 1984).

Bonne Terre $\left(37.9231^{\circ} \mathrm{N}, 90.5553^{\circ} \mathrm{W}\right)$-Distinctly felt. (Street and Green, 1984).

Greenville $\left(37.1272^{\circ} \mathrm{N}, 90.45^{\circ} \mathrm{W}\right)-$ Slight, but plainly noticeable. (Street and Green, 1984).

New Madrid $\left(36.5864^{\circ} \mathrm{N}, 89.5278^{\circ} \mathrm{W}\right)-\mathrm{A}$ distinct earthquake was felt. (Street and Green, 1984).

Farmington $\left(37.7808^{\circ} \mathrm{N}, 90.4217^{\circ} \mathrm{W}\right)-$ Not so generally noticed. (Street and Green, 1984).

Marble Hill $\left(37.3058^{\circ} \mathrm{N}, 89.9703^{\circ} \mathrm{W}\right)$-Very light. (Street and Green, 1984).

Memphis $\left(35.1494^{\circ} \mathrm{N}, 90.0489^{\circ} \mathrm{W}\right)-$ Was not felt. (Street and Green, 1984).

Fairfield $\left(38.3789^{\circ} \mathrm{N}, 88.3597^{\circ} \mathrm{W}\right)$-Not reported. (Street and Green, 1984).

Robinson $\left(39.0053^{\circ} \mathrm{N}, 87.7392^{\circ} \mathrm{W}\right)-$ Not reported. (Street and Green, 1984).

Shawneetown $\left(37.7131^{\circ} \mathrm{N}, 88.1867^{\circ} \mathrm{W}\right)-$ Not reported. (Street and Green, 1984).

Louisville $\left(38.2542^{\circ} \mathrm{N}, 85.7594^{\circ} \mathrm{W}\right)-$ Not mentioned. (Street and Green, 1984).

Owensboro $\left(37.7742^{\circ} \mathrm{N}, 87.1133^{\circ} \mathrm{W}\right)$-Not mentioned. (Street and Green, 1984).

Birch Tree $\left(36.9911^{\circ} \mathrm{N}, 91.4925^{\circ} \mathrm{W}\right)$-Not reported. (Street and Green, 1984).

Eminence $\left(37.1506^{\circ} \mathrm{N}, 91.3575^{\circ} \mathrm{W}\right)-$ Not reported. (Street and Green, 1984).

Flat River $\left(37.8511^{\circ} \mathrm{N}, 90.5206^{\circ} \mathrm{W}\right)-$ Not reported. (Street and Green, 1984).

Clarksville $\left(36.5297^{\circ} \mathrm{N}, 87.3594^{\circ} \mathrm{W}\right)-$ Not mentioned. (Street and Green, 1984).

Columbia $\left(35.6150^{\circ} \mathrm{N}, 87.0353^{\circ} \mathrm{W}\right)-$ Not reported. (Street and Green, 1984).

Huntingdon $\left(36.0006^{\circ} \mathrm{N}, 88.4281^{\circ} \mathrm{W}\right)-$ Not reported. (Street and Green, 1984).

Hayti $\left(36.2336^{\circ} \mathrm{N}, 89.7494^{\circ} \mathrm{W}\right)$-Lighter than the one at 8:30. [At Hayti, the southern Illinois shock of $1922 \mathrm{Mar} 23$ 02:22 UTC = Mar 22 8:22 p.m. CST (aftershock of this shock Mar 22 04:29 p.m. CST) is described as "harder and longer than the earlier one."] (Street and Green, 1984).

Morley $\left(37.0436^{\circ} \mathrm{N}, 89.6103^{\circ} \mathrm{W}\right)-$ Felt. (Street and Green, 1984$)$.

Poplar Bluff $\left(36.7569^{\circ} \mathrm{N}, 90.3928^{\circ} \mathrm{W}\right)$-Felt. (Street and Green, 1984).

Troy $\left(36.3386^{\circ} \mathrm{N}, 89.1639^{\circ} \mathrm{W}\right)-F e l t$. (Street and Green, 1984). 


\section{Appendix 1, Part 29. Damage Reports and Intensity Assignments}

\section{\#29 1922 Nov. 27 03:31UTC (Illinols)}

7 IL Eldorado $\left(37.8136^{\circ} \mathrm{N}, 88.4381^{\circ} \mathrm{W}\right)$-The earthquake broke several windows and downed chimneys at Eldorado. (Stover and Coffman, 1993).

IL Eldorado $\left(37.8136^{\circ} \mathrm{N}, 88.4381^{\circ} \mathrm{W}\right)$-Chimneys of residences tumbled to the ground. (Street and Green, 1984).

6 IL Harrisburg $\left(37.7383^{\circ} \mathrm{N}, 88.5406^{\circ} \mathrm{W}\right)$-Generally scared people, caused stove pipes to fall, demolished one chimney flue. (Street and Green, 1984).

IL Harrisburg $\left(37.7383^{\circ} \mathrm{N}, 88.5406^{\circ} \mathrm{W}\right)$-One chimney flue was demolished and stovepipes fell at Harrisburg, $8 \mathrm{~km}$ southwest of Eldorado. (Stover and Coffman, 1993).

Mattoon $\left(39.4831^{\circ} \mathrm{N}, 88.3728^{\circ} \mathrm{W}\right)$-Broke windows and dishes. (Street and Green, 1984).

IL Benton $\left(37.9967^{\circ} \mathrm{N}, 88.92^{\circ} \mathrm{W}\right)$-Dishes were knocked off shelves and broken, and buildings rocked. (Street and Green, 1984).

Evansville $\left(37.9747^{\circ} \mathrm{N}, 87.5558^{\circ} \mathrm{W}\right)$-Slight earthquake shocks were felt, shook windows and dishes and caused a few pictures to fall off walls. (Street and Green, 1984).

Belleville $\left(38.5200^{\circ} \mathrm{N}, 89.9839^{\circ} \mathrm{W}\right)$-Felt by many citizens, was not severe. (Street and Green, 1984).

Cairo $\left(37.0053^{\circ} \mathrm{N}, 89.1764^{\circ} \mathrm{W}\right)-\mathrm{A}$ distinct shock, closed and opened doors, but frightened no one. (Street and Green, 1984).

Hopkinsville $\left(36.8656^{\circ} \mathrm{N}, 87.4886^{\circ} \mathrm{W}\right)$-Distinct tremors were felt; windows, furniture, and dishes were rattled. (Street and Green, 1984).

Clarksville $\left(36.5297^{\circ} \mathrm{N}, 87.3594^{\circ} \mathrm{W}\right)$-Felt by many, but not all citizens. (Street and Green, 1984).

Vienna $\left(37.4153^{\circ} \mathrm{N}, 88.8978^{\circ} \mathrm{W}\right)$-Felt by a number of our citizens. (Street and Green, 1984).

Paducah $\left(37.0833^{\circ} \mathrm{N}, 88.6^{\circ} \mathrm{W}\right)-\mathrm{A}$ distinct shock was felt that was accompanied by a slight shaking of homes and the rattling of window panes. (Street and Green, 1984).

Saint Louis $\left(38.6272^{\circ} \mathrm{N}, 90.1978^{\circ} \mathrm{W}\right)$-Rattled windows; the majority of people who felt it, probably attributed the shaking to a passing truck. (Street and Green, 1984).

IL Anna $\left(37.4603^{\circ} \mathrm{N}, 89.2469^{\circ} \mathrm{W}\right)$-So light as to be scarcely perceptible. (Street and Green, 1984).

IL Jonesboro $\left(37.4517^{\circ} \mathrm{N}, 89.2681^{\circ} \mathrm{W}\right)$-Some people noticed a slight shock. (Street and Green, 1984).

KY Hickman $\left(36.5711^{\circ} \mathrm{N}, 89.1861^{\circ} \mathrm{W}\right)-\mathrm{A}$ slight earthquake was felt by a very few people. (Street and Green, 1984).

KY Louisville $\left(38.2542^{\circ} \mathrm{N}, 85.7594^{\circ} \mathrm{W}\right)$-A slight trembling was felt in various sections of the city. (Street and Green, 1984).

MO Cape Girardeau $\left(37.3058^{\circ} \mathrm{N}, 89.5181^{\circ} \mathrm{W}\right)$-Felt slightly. (Street and Green, 1984).

TN Nashville $\left(36.1658^{\circ} \mathrm{N}, 86.7844^{\circ} \mathrm{W}\right)$-Felt by a few. (Street and Green, 1984).

KY

IL

Owensboro $\left(37.7742^{\circ} \mathrm{N}, 87.1133^{\circ} \mathrm{W}\right)$-No distinct shake was felt by any Owensboro citizen. (Street and Green, 1984).

Champaign $\left(40.1164^{\circ} \mathrm{N}, 88.2433^{\circ} \mathrm{W}\right)$-Not reported. (Street and Green, 1984).

IL Du Quoin $\left(38.0114^{\circ} \mathrm{N}, 89.2361^{\circ} \mathrm{W}\right)$-No disturbances were reported. (Street and Green, 1984).

IL Fairfield $\left(38.3789^{\circ} \mathrm{N}, 88.3597^{\circ} \mathrm{W}\right)$-Not reported. (Street and Green, 1984).

IL Herrin $\left(37.8031^{\circ} \mathrm{N}, 89.0275^{\circ} \mathrm{W}\right)$-No disturbances were reported. (Street and Green, 1984).

IL Marion $\left(37.7306^{\circ} \mathrm{N}, 88.9331^{\circ} \mathrm{W}\right)$-No disturbances were reported. (Street and Green, 1984).

IL $\quad$ Murphysboro $\left(37.7644^{\circ} \mathrm{N}, 89.335^{\circ} \mathrm{W}\right)$-No disturbances were reported. (Street and Green, 1984).

IL $\quad$ Paris $\left(39.6111^{\circ} \mathrm{N}, 87.6961^{\circ} \mathrm{W}\right)$-Not mentioned. (Street and Green, 1984).

IL Robinson $\left(39.0053^{\circ} \mathrm{N}, 87.7392^{\circ} \mathrm{W}\right)$-Not reported. (Street and Green, 1984).

IL Shawneetown $\left(37.7131^{\circ} \mathrm{N}, 88.1867^{\circ} \mathrm{W}\right)$-Not reported. (Street and Green, 1984).

KY Hartford $\left(37.4511^{\circ} \mathrm{N}, 86.9092^{\circ} \mathrm{W}\right)$-Not reported. (Street and Green, 1984).

KY Lexington $\left(38.0492^{\circ} \mathrm{N}, 84.5003^{\circ} \mathrm{W}\right)$-Not mentioned. (Street and Green, 1984).

MO Birch Tree $\left(36.9911^{\circ} \mathrm{N}, 91.4925^{\circ} \mathrm{W}\right)$-Not reported. (Street and Green, 1984).

MO Caruthersville $\left(36.1931^{\circ} \mathrm{N}, 89.6556^{\circ} \mathrm{W}\right)$-Not mentioned. (Street and Green, 1984).

MO Dexter $\left(36.7958^{\circ} \mathrm{N}, 89.9578^{\circ} \mathrm{W}\right)$-Not reported. (Street and Green, 1984).

MO Eminence $\left(37.1506^{\circ} \mathrm{N}, 91.3575^{\circ} \mathrm{W}\right)$-Not reported. (Street and Green, 1984).

MO Flat River $\left(37.8511^{\circ} \mathrm{N}, 90.5206^{\circ} \mathrm{W}\right)$-Not reported. (Street and Green, 1984).

MO Hillsboro $\left(38.2322^{\circ} \mathrm{N}, 90.5628^{\circ} \mathrm{W}\right)$-Not reported. (Street and Green, 1984).

MO Illmo $\left(37.2197^{\circ} \mathrm{N}, 89.5089^{\circ} \mathrm{W}\right)$-Not reported. (Street and Green, 1984).

MO New Madrid $\left(36.5864^{\circ} \mathrm{N}, 89.5278^{\circ} \mathrm{W}\right)$-Not mentioned. (Street and Green, 1984).

MO Poplar Bluff $\left(36.7569^{\circ} \mathrm{N}, 90.3928^{\circ} \mathrm{W}\right)$-Not mentioned. (Street and Green, 1984).

$\mathrm{OH}$ Cincinnati $\left(39.1619^{\circ} \mathrm{N}, 84.4569^{\circ} \mathrm{W}\right)$-Not mentioned. (Street and Green, 1984).

TN Huntingdon $\left(36.0006^{\circ} \mathrm{N}, 88.4281^{\circ} \mathrm{W}\right)$-Not reported. (Street and Green, 1984).

IL Clinton $\left(40.1536^{\circ} \mathrm{N}, 88.9644^{\circ} \mathrm{W}\right)$-Felt. (Street and Green, 1984).

F KY Crayne $\left(37.2706^{\circ} \mathrm{N}, 88.0825^{\circ} \mathrm{W}\right)$-Felt. (Street and Green, 1984). 


\section{Appendix 1, Part 30. Damage Reports and Intensity Assignments}

\section{\#30 1923 Oct. 28 17:10UTC (Arkansas)}

$7 \quad \mathrm{AR}$

6 AR

4 AR

4 AR

4 AR

4 AR

4 AR

4 AR

$4 \quad \mathrm{MO}$

$4 \quad \mathrm{TN}$

$4 \quad \mathrm{TN}$

$3 \mathrm{AL}$

3 AR

$3 \quad \mathrm{AR}$

3 IL

$3 \mathrm{KY}$

$3 \mathrm{KY}$

3 MS

3 MS

3 TN

$2 \mathrm{AR}$

2 AR

2 AR

2 IL

$2 \mathrm{MO}$

O TN

O TN

N AR

N AR

$\mathrm{N}$ AR

$\mathrm{N}$ AR

N AR

$\mathrm{N}$ AR

$\mathrm{N}$ AR

$\mathrm{N}$ IL

N KY

N KY

N KY

$\mathrm{N} \quad \mathrm{KY}$

N KY

N KY

N KY

$\mathrm{N} \quad \mathrm{KY}$

$\mathrm{N} \quad \mathrm{MO}$

$\mathrm{N} \quad \mathrm{MO}$

$\mathrm{N} \quad \mathrm{MO}$

$\mathrm{N} \quad \mathrm{MO}$

$\mathrm{N} \quad \mathrm{MO}$

$\mathrm{N} \quad \mathrm{MO}$

$\mathrm{N} \quad \mathrm{MO}$

$\mathrm{N} \quad \mathrm{MO}$

$\mathrm{N} \quad \mathrm{MO}$

$\mathrm{N} \quad \mathrm{MO}$

$\mathrm{N} \quad \mathrm{MO}$

$\mathrm{N} \quad \mathrm{MO}$

Marked Tree $\left(35.5328^{\circ} \mathrm{N}, 90.4206^{\circ} \mathrm{W}\right)$-Shattered windows, cracked brick walls, and shook down several chimneys. (Street and Green, 1984).

Helena $\left(34.5294^{\circ} \mathrm{N}, 90.5914^{\circ} \mathrm{W}\right)-$ Small bits of plaster fell. (Street and Green, 1984).

Earle $\left(35.2750^{\circ} \mathrm{N}, 90.4667^{\circ} \mathrm{W}\right)$-Rocked houses; loud rumbling, some people were frightened. (Street and Green, 1984).

England $\left(34.5442^{\circ} \mathrm{N}, 91.9689^{\circ} \mathrm{W}\right)$-Rattled Windows. (Street and Green, 1984).

Little Rock (34.7464 $\left.{ }^{\circ} \mathrm{N}, 92.2894^{\circ} \mathrm{W}\right)$-Felt by many people. (Street and Green, 1984).

Osceola $\left(35.7050^{\circ} \mathrm{N}, 89.9694^{\circ} \mathrm{W}\right)$-Felt by many. (Street and Green, 1984).

Wilson $\left(35.5681^{\circ} \mathrm{N}, 90.0419^{\circ} \mathrm{W}\right)$-Felt by many. (Street and Green, 1984).

Wynne $\left(35.2244^{\circ} \mathrm{N}, 90.7867^{\circ} \mathrm{W}\right)$-Felt by many. (Street and Green, 1984).

Caruthersville $\left(36.1931^{\circ} \mathrm{N}, 89.6556^{\circ} \mathrm{W}\right)$-A well defined earthquake shock was felt, caused doors and windows, dishes, etc. to rattle with a heavy rumbling sound. (Street and Green, 1984).

Memphis $\left(35.1494^{\circ} \mathrm{N}, 90.0489^{\circ} \mathrm{W}\right)$ - Rattled windows and dishes, caused beds to sway and light fixtures to quiver, excited thousands of people. (Street and Green, 1984).

Savannah $\left(35.2247^{\circ} \mathrm{N}, 88.2492^{\circ} \mathrm{W}\right)$-Felt by many. (Street and Green, 1984).

Riverton $\left(34.8806^{\circ} \mathrm{N}, 88.0767^{\circ} \mathrm{W}\right)$-Felt by several. (Street and Green, 1984).

Corning $\left(36.4078^{\circ} \mathrm{N}, 90.5797^{\circ} \mathrm{W}\right)$-Felt by several who reported hearing a rumbling sound. (Street and Green, 1984). Harrisburg $\left(35.5642^{\circ} \mathrm{N}, 90.7167^{\circ} \mathrm{W}\right)$-Shocks were felt here; they lasted only a few seconds. (Street and Green, 1984$)$. Alton $\left(38.8906^{\circ} \mathrm{N}, 90.1842^{\circ} \mathrm{W}\right)-\mathrm{A}$ distinct tremor. (Street and Green, 1984).

Hickman $\left(36.5711^{\circ} \mathrm{N}, 89.1861^{\circ} \mathrm{W}\right)$-Felt by several; faintly heard. (Street and Green, 1984).

Wickliffe $\left(36.9647^{\circ} \mathrm{N}, 89.0892^{\circ} \mathrm{W}\right)$-Felt by several. (Street and Green, 1984).

Corinth $\left(34.9342^{\circ} \mathrm{N}, 88.5222^{\circ} \mathrm{W}\right)$-Felt by several. (Street and Green, 1984).

Tupelo $\left(34.2575^{\circ} \mathrm{N}, 88.7033^{\circ} \mathrm{W}\right)$-Plainly felt. (Street and Green, 1984).

Ripley $\left(35.7453^{\circ} \mathrm{N}, 89.5297^{\circ} \mathrm{W}\right)$-A series of shocks were distinctly felt. (Street and Green, 1984).

Eureka Springs $\left(36.4011^{\circ} \mathrm{N}, 93.7378^{\circ} \mathrm{W}\right)$-Felt by one person. (Street and Green, 1984).

Pine Bluff $\left(34.2283^{\circ} \mathrm{N}, 92.0031^{\circ} \mathrm{W}\right)$-A slight earth tremor was felt. (Street and Green, 1984).

Stuttgart $\left(34.5003^{\circ} \mathrm{N}, 91.5525^{\circ} \mathrm{W}\right)$-Mild. (Street and Green, 1984).

Cairo $\left(37.0053^{\circ} \mathrm{N}, 89.1764^{\circ} \mathrm{W}\right)$-Felt by a few. (Street and Green, 1984).

Poplar Bluff $\left(36.7569^{\circ} \mathrm{N}, 90.3928^{\circ} \mathrm{W}\right)$-Felt by a few. (Street and Green, 1984).

Obion $\left(36.2589^{\circ} \mathrm{N}, 89.1917^{\circ} \mathrm{W}\right)$-Not felt in this section. (Street and Green, 1984).

Tiptonville $\left(36.3783^{\circ} \mathrm{N}, 89.4719^{\circ} \mathrm{W}\right)$-Not felt in this section. (Street and Green, 1984).

Arkadelphia $\left(34.1208^{\circ} \mathrm{N}, 93.0536^{\circ} \mathrm{W}\right)$-Not mentioned. (Street and Green, 1984).

Clinton $\left(35.5914^{\circ} \mathrm{N}, 92.4603^{\circ} \mathrm{W}\right)$-Not mentioned. (Street and Green, 1984).

Dardanelle $\left(35.2231^{\circ} \mathrm{N}, 93.1578^{\circ} \mathrm{W}\right)$-Not mentioned. (Street and Green, 1984).

Des Arc $\left(34.9769^{\circ} \mathrm{N}, 91.495^{\circ} \mathrm{W}\right)$-Not mentioned. (Street and Green, 1984).

Fort Smith $\left(35.3858^{\circ} \mathrm{N}, 94.3983^{\circ} \mathrm{W}\right)$-Not mentioned. (Street and Green, 1984).

Hot Springs $\left(34.5036^{\circ} \mathrm{N}, 93.055^{\circ} \mathrm{W}\right)$-Not mentioned. (Street and Green, 1984).

Marianna $\left(34.7736^{\circ} \mathrm{N}, 90.7575^{\circ} \mathrm{W}\right)$-Not reported. (Street and Green, 1984).

Chester $\left(37.9136^{\circ} \mathrm{N}, 89.8219^{\circ} \mathrm{W}\right)$-Not reported. (Street and Green, 1984).

Hartford $\left(37.4511^{\circ} \mathrm{N}, 86.9092^{\circ} \mathrm{W}\right)$-Not reported. (Street and Green, 1984).

Henderson $\left(37.8361^{\circ} \mathrm{N}, 87.59^{\circ} \mathrm{W}\right)$-Not reported. (Street and Green, 1984).

Lexington $\left(38.0492^{\circ} \mathrm{N}, 84.5003^{\circ} \mathrm{W}\right)$-Not mentioned. (Street and Green, 1984).

Louisville $\left(38.2542^{\circ} \mathrm{N}, 85.7594^{\circ} \mathrm{W}\right)$-Not mentioned. (Street and Green, 1984).

Marion $\left(37.3328^{\circ} \mathrm{N}, 88.0811^{\circ} \mathrm{W}\right)$-Not reported. (Street and Green, 1984).

Mayfield $\left(36.7417^{\circ} \mathrm{N}, 88.6367^{\circ} \mathrm{W}\right)$-Not mentioned. (Street and Green, 1984).

Owensboro $\left(37.7742^{\circ} \mathrm{N}, 87.1133^{\circ} \mathrm{W}\right)$-Not reported. (Street and Green, 1984).

Paducah $\left(37.0833^{\circ} \mathrm{N}, 88.6^{\circ} \mathrm{W}\right)$-Not reported. (Street and Green, 1984).

Benton $\left(37.0978^{\circ} \mathrm{N}, 89.5625^{\circ} \mathrm{W}\right)$-Not reported. (Street and Green, 1984).

Bloomfield $\left(36.8858^{\circ} \mathrm{N}, 89.9292^{\circ} \mathrm{W}\right)$-Not reported. (Street and Green, 1984).

Cape Girardeau $\left(37.3058^{\circ} \mathrm{N}, 89.5181^{\circ} \mathrm{W}\right)$-Not reported. (Street and Green, 1984).

Charleston $\left(36.9208^{\circ} \mathrm{N}, 89.3506^{\circ} \mathrm{W}\right)$-Not reported. (Street and Green, 1984).

Dexter $\left(36.7958^{\circ} \mathrm{N}, 89.9578^{\circ} \mathrm{W}\right)$-Not reported. (Street and Green, 1984).

Eminence $\left(37.1506^{\circ} \mathrm{N}, 91.3575^{\circ} \mathrm{W}\right)$-Not mentioned. (Street and Green, 1984).

Farmington $\left(37.7808^{\circ} \mathrm{N}, 90.4217^{\circ} \mathrm{W}\right)$-Not reported. (Street and Green, 1984).

Flat River $\left(37.8511^{\circ} \mathrm{N}, 90.5206^{\circ} \mathrm{W}\right)$-Not reported. (Street and Green, 1984).

Greenville $\left(37.1272^{\circ} \mathrm{N}, 90.45^{\circ} \mathrm{W}\right)$-Not reported. (Street and Green, 1984).

Hayti $\left(36.2336^{\circ} \mathrm{N}, 89.7494^{\circ} \mathrm{W}\right)$-Not reported. (Street and Green, 1984).

Hillsboro $\left(38.2322^{\circ} \mathrm{N}, 90.5628^{\circ} \mathrm{W}\right)$-Not reported. (Street and Green, 1984).

Illmo $\left(37.2197^{\circ} \mathrm{N}, 89.5089^{\circ} \mathrm{W}\right)$-Not mentioned. (Street and Green, 1984). 


\title{
Appendix 1, Part 30. Damage Reports and Intensity Assignments
}

\author{
Jackson $\left(37.3822^{\circ} \mathrm{N}, 89.6661^{\circ} \mathrm{W}\right)$-Not reported. (Street and Green, 1984). \\ Marble Hill $\left(37.3058^{\circ} \mathrm{N}, 89.9703^{\circ} \mathrm{W}\right)$-Not mentioned. (Street and Green, 1984). \\ Perryville $\left(37.7242^{\circ} \mathrm{N}, 89.8611^{\circ} \mathrm{W}\right)$-Not reported. (Street and Green, 1984). \\ Saint Genevieve $\left(37.9814^{\circ} \mathrm{N}, 90.0417^{\circ} \mathrm{W}\right)$-Not reported. (Street and Green, 1984). \\ Saint Louis $\left(38.6272^{\circ} \mathrm{N}, 90.1978^{\circ} \mathrm{W}\right)$-Not mentioned. (Street and Green, 1984). \\ Clarksville $\left(36.5297^{\circ} \mathrm{N}, 87.3594^{\circ} \mathrm{W}\right)$-Not reported. (Street and Green, 1984). \\ Columbia $\left(35.6150^{\circ} \mathrm{N}, 87.0353^{\circ} \mathrm{W}\right)$-Not reported. (Street and Green, 1984). \\ Milan $\left(35.9197^{\circ} \mathrm{N}, 88.7589^{\circ} \mathrm{W}\right)$-Not reported. (Street and Green, 1984). \\ Nashville $\left(36.1658^{\circ} \mathrm{N}, 86.7844^{\circ} \mathrm{W}\right)$-Not mentioned. (Street and Green, 1984). \\ Arkansas City $\left(33.6086^{\circ} \mathrm{N}, 91.2067^{\circ} \mathrm{W}\right)$-Two shocks were felt. (Street and Green, 1984). \\ Brinkley $\left(34.8878^{\circ} \mathrm{N}, 91.1944^{\circ} \mathrm{W}\right)$-Felt. (Street and Green, 1984). \\ New Madrid $\left(36.5864^{\circ} \mathrm{N}, 89.5278^{\circ} \mathrm{W}\right)$-A shock was felt. (Street and Green, 1984). \\ Tunica $\left(34.6844^{\circ} \mathrm{N}, 90.3828^{\circ} \mathrm{W}\right)$-Felt. (Street and Green, 1984). \\ Jonesboro $\left(36.2942^{\circ} \mathrm{N}, 82.4736^{\circ} \mathrm{W}\right)$-Felt. (Street and Green, 1984).
}




\section{Appendix 1, Part 31. Damage Reports and Intensity Assignments}

\section{\#31 1925 April 27 04:05UTC (Indlana)}

6 IL Carmi $\left(38.0908^{\circ} \mathrm{N}, 88.1586^{\circ} \mathrm{W}\right)$-Several local homes were slightly damaged, the extent in most instances being chimneys shaken down. (Street and Green, 1984).

IL $\quad$ Carmi $\left(38.0908^{\circ} \mathrm{N}, 88.1586^{\circ} \mathrm{W}\right)$-Chimneys were downed at Princeton and at Carmi, III., 100 km southwest (Stover and Coffman, 1993).

6 IN Boonville $\left(38.0492^{\circ} \mathrm{N}, 87.2742^{\circ} \mathrm{W}\right)$-Broke windows. (Street and Green, 1984).

6 IN Jeffersonville $\left(38.2900^{\circ} \mathrm{N}, 85.7517^{\circ} \mathrm{W}\right)$-Broke windows and threw dishes to the floor. (Street and Green, 1984).

6 IN New Albany $\left(38.2856^{\circ} \mathrm{N}, 85.8242^{\circ} \mathrm{W}\right)$-Broke windows. (Street and Green, 1984).

6 IN Princeton $\left(38.3553^{\circ} \mathrm{N}, 87.5675^{\circ} \mathrm{W}\right)$-Broke windows, crockery; two chimneys tumbled down. (Street and Green, 1984$)$.

IN Princeton $\left(38.3553^{\circ} \mathrm{N}, 87.5675^{\circ} \mathrm{W}\right)$-Chimneys were downed at Princeton and at Carmi, III., $100 \mathrm{~km}$ southwest. (Stover and Coffman, 1993).

6 KY Louisville $\left(38.2542^{\circ} \mathrm{N}, 85.7594^{\circ} \mathrm{W}\right)$-Felt all over Louisville, swung doors open, broke chimneys. (Street and Green, 1984$)$.

$6 \mathrm{OH}$ Cincinnati $\left(39.1619^{\circ} \mathrm{N}, 84.4569^{\circ} \mathrm{W}\right)$-Furniture was shifted, and pictures were moved on the walls. (Street and Green, 1984).

5 IL Cairo $\left(37.0053^{\circ} \mathrm{N}, 89.1764^{\circ} \mathrm{W}\right)$-Jarred pictures from their places on the walls. (Street and Green, 1984).

5 IL Harrisburg $\left(37.7383^{\circ} \mathrm{N}, 88.5406^{\circ} \mathrm{W}\right)$-Very noticeable, felt in moving cars, frightened many residents. (Street and Green, 1984).

5 IN Evansville $\left(37.9747^{\circ} \mathrm{N}, 87.5558^{\circ} \mathrm{W}\right)$-An earth tremor of approximately 30 seconds was felt, sent dishes crashing to the floor. (Street and Green, 1984).

IN Evansville $\left(37.9747^{\circ} \mathrm{N}, 87.5558^{\circ} \mathrm{W}\right)$-Crowds fled from the theaters at Evansville, Ind. (Stover and Coffman, 1993$)$. Greensburg $\left(39.3372^{\circ} \mathrm{N}, 85.4836^{\circ} \mathrm{W}\right)$-Moved beds and other furniture slightly, rattled and jarred dishes. (Street and Green, 1984).

$5 \quad$ IN Shelbyville $\left(39.5214^{\circ} \mathrm{N}, 85.7769^{\circ} \mathrm{W}\right)$-Moved furniture. (Street and Green, 1984).

5 IN Vincennes $\left(38.6772^{\circ} \mathrm{N}, 87.5286^{\circ} \mathrm{W}\right)$ - Houses rattled, windows shook, dishes topped over, and beds rolled their sleepers out of bed; people fled to the streets. (Street and Green, 1984).

$5 \quad \mathrm{KY} \quad$ Henderson $\left(37.8361^{\circ} \mathrm{N}, 87.59^{\circ} \mathrm{W}\right)$-A severe shock, windows rattled and medicine bottles fell from shelves. (Street and Green, 1984).

Owensboro $\left(37.7742^{\circ} \mathrm{N}, 87.1133^{\circ} \mathrm{W}\right)$-Frightened some, moved beds. (Street and Green, 1984).

$5 \mathrm{KY}$ Paducah $\left(37.0833^{\circ} \mathrm{N}, 88.6^{\circ} \mathrm{W}\right)$-Toppled bric-a-brac from tables and mantles; aroused many people. (Street and Green, 1984).

Belleville $\left(38.5200^{\circ} \mathrm{N}, 89.9839^{\circ} \mathrm{W}\right)$-Felt by a large number of persons, rattled dishes and windows in some instances. (Street and Green, 1984).

Paris $\left(39.6111^{\circ} \mathrm{N}, 87.6961^{\circ} \mathrm{W}\right)$-Felt by hundreds. (Street and Green, 1984). Shawneetown $\left(37.7131^{\circ} \mathrm{N}, 88.1867^{\circ} \mathrm{W}\right.$ )-Aroused light sleepers, and brought the wide-awake to a sudden pause. (Street and Green, 1984).

IL Springfield $\left(39.8017^{\circ} \mathrm{N}, 89.6436^{\circ} \mathrm{W}\right)$-Knocked over small articles. (Street and Green, 1984).

IL Trimble $\left(39.0633^{\circ} \mathrm{N}, 87.6844^{\circ} \mathrm{W}\right)$-The community was disturbed by a heavy shock. (Street and Green, 1984). Carlisle $\left(38.9683^{\circ} \mathrm{N}, 87.4056^{\circ} \mathrm{W}\right)$-Many people who were asleep woke up and got out of bed. (Street and Green, 1984). Fort Wayne $\left(41.1306^{\circ} \mathrm{N}, 85.1289^{\circ} \mathrm{W}\right)$-Shook homes, rattled dishes, etc., frightened many. (Street and Green, 1984).

IN Logansport $\left(40.7544^{\circ} \mathrm{N}, 86.3567^{\circ} \mathrm{W}\right)$-Noticed by some, one instance of dishes falling from shelves. (Street and Green, 1984).

Loogootee $\left(38.6769^{\circ} \mathrm{N}, 86.9142^{\circ} \mathrm{W}\right)$-Plainly felt, shook windows and rattled bottles in medicine shelves. (Street and Green, 1984).

IN Muncie $\left(40.1933^{\circ} \mathrm{N}, 85.3864^{\circ} \mathrm{W}\right)$-Rattled dishes (Street and Green, 1984).

IN Noblesville $\left(40.0456^{\circ} \mathrm{N}, 86.0086^{\circ} \mathrm{W}\right)$-Felt by many. (Street and Green, 1984).

IN Salem $\left(40.3103^{\circ} \mathrm{N}, 84.8433^{\circ} \mathrm{W}\right)$-Frightened many, moved pictures and mirrors on walls. (Street and Green, 1984).

IN Washington $\left(38.6592^{\circ} \mathrm{N}, 87.1728^{\circ} \mathrm{W}\right)$-Severe tremors were felt. (Street and Green, 1984).

KY Marion $\left(37.3328^{\circ} \mathrm{N}, 88.0811^{\circ} \mathrm{W}\right)$-Severely rattled furniture, dishes and windows. (Street and Green, 1984).

KY Mayfield $\left(36.7417^{\circ} \mathrm{N}, 88.6367^{\circ} \mathrm{W}\right)$ - Many felt the vibrations, but did not realize that they were due to an earthquake. (Street and Green, 1984).

KY Morganfield $\left(37.6833^{\circ} \mathrm{N}, 87.9167^{\circ} \mathrm{W}\right)$-Many residents were awakened. (Street and Green, 1984).

MO Saint Louis $\left(38.6272^{\circ} \mathrm{N}, 90.1978^{\circ} \mathrm{W}\right)$-Rattled windows and dishes. (Street and Green, 1984).

IL $\quad$ Chester $\left(37.9136^{\circ} \mathrm{N}, 89.8219^{\circ} \mathrm{W}\right)$-Felt, but not severe. (Street and Green, 1984).

IL Decatur $\left(39.8403^{\circ} \mathrm{N}, 88.9547^{\circ} \mathrm{W}\right)$ - Several residents felt two slight shocks. (Street and Green, 1984).

IL Fairfield $\left(38.3789^{\circ} \mathrm{N}, 88.3597^{\circ} \mathrm{W}\right)$-Distinct. (Street and Green, 1984).

IN Indianapolis $\left(39.7683^{\circ} \mathrm{N}, 86.1581^{\circ} \mathrm{W}\right)$-A slight tremor was felt by several. (Street and Green, 1984).

IN Richmond $\left(39.8289^{\circ} \mathrm{N}, 84.8903^{\circ} \mathrm{W}\right)$-Plainly felt by several persons. (Street and Green, 1984).

IN Terre Haute $\left(39.4667^{\circ} \mathrm{N}, 87.4139^{\circ} \mathrm{W}\right)$-Shook houses and beds enough to startle occupants. (Street and Green, 1984).

KY Cave City $\left(37.1367^{\circ} \mathrm{N}, 85.9569^{\circ} \mathrm{W}\right)$-A number of persons were aroused from their sleep. (Street and Green, 1984).

MO Cape Girardeau $\left(37.3058^{\circ} \mathrm{N}, 89.5181^{\circ} \mathrm{W}\right)-\mathrm{A}$ number of residents reported the tremors. (Street and Green, 1984$)$. 


\title{
Appendix 1, Part 31. Damage Reports and Intensity Assignments
}

\author{
IL Carbondale $\left(37.7272^{\circ} \mathrm{N}, 89.2167^{\circ} \mathrm{W}\right)$-Reported a slight tremor. (Street and Green, 1984). \\ IL Centralia $\left(38.5250^{\circ} \mathrm{N}, 89.1333^{\circ} \mathrm{W}\right)$-Reported a slight tremor. (Street and Green, 1984). \\ IL Jonesboro $\left(37.4517^{\circ} \mathrm{N}, 89.2681^{\circ} \mathrm{W}\right)$-A slight tremor was felt. (Street and Green, 1984). \\ KY Danville $\left(37.6456^{\circ} \mathrm{N}, 84.7722^{\circ} \mathrm{W}\right)$-Reportedly felt by a resident sitting on a front porch. (Street and Green, 1984). \\ MO Greenville $\left(37.1272^{\circ} \mathrm{N}, 90.45^{\circ} \mathrm{W}\right)$-The tremors were not felt in the vicinity of Greenville. (Street and Green, 1984). \\ IL Chicago $\left(41.8500^{\circ} \mathrm{N}, 87.65^{\circ} \mathrm{W}\right)$-Not mentioned. (Street and Green, 1984). \\ IL Monmouth $\left(40.9114^{\circ} \mathrm{N}, 90.6472^{\circ} \mathrm{W}\right)$-Not mentioned. (Street and Green, 1984). \\ IL Ottawa $\left(41.3456^{\circ} \mathrm{N}, 88.8425^{\circ} \mathrm{W}\right)$-Not reported. (Street and Green, 1984). \\ IN Gary $\left(41.5933^{\circ} \mathrm{N}, 87.3464^{\circ} \mathrm{W}\right)$-Not mentioned. (Street and Green, 1984). \\ IN Seymour $\left(38.9592^{\circ} \mathrm{N}, 85.8903^{\circ} \mathrm{W}\right)$-Not mentioned. (Street and Green, 1984). \\ KY Columbia $\left(37.1028^{\circ} \mathrm{N}, 85.3064^{\circ} \mathrm{W}\right)$-Not reported. (Street and Green, 1984). \\ KY Hickman $\left(36.5711^{\circ} \mathrm{N}, 89.1861^{\circ} \mathrm{W}\right)$-Not reported. (Street and Green, 1984). \\ KY Lexington $\left(38.0492^{\circ} \mathrm{N}, 84.5003^{\circ} \mathrm{W}\right)$-Not mentioned. (Street and Green, 1984). \\ MO Caruthersville $\left(36.1931^{\circ} \mathrm{N}, 89.6556^{\circ} \mathrm{W}\right)$-Not reported. (Street and Green, 1984). \\ MO Dexter $\left(36.7958^{\circ} \mathrm{N}, 89.9578^{\circ} \mathrm{W}\right)$-Not reported. (Street and Green, 1984). \\ MO Flat River $\left(37.8511^{\circ} \mathrm{N}, 90.5206^{\circ} \mathrm{W}\right)$-Not reported. (Street and Green, 1984). \\ MO Hillsboro $\left(38.2322^{\circ} \mathrm{N}, 90.5628^{\circ} \mathrm{W}\right)$-Not reported. (Street and Green, 1984). \\ MO Illmo $\left(37.2197^{\circ} \mathrm{N}, 89.5089^{\circ} \mathrm{W}\right)$-Not reported. (Street and Green, 1984). \\ MO New Madrid $\left(36.5864^{\circ} \mathrm{N}, 89.5278^{\circ} \mathrm{W}\right)$-Not reported. (Street and Green, 1984). \\ TN Clarksville $\left(36.5297^{\circ} \mathrm{N}, 87.3594^{\circ} \mathrm{W}\right)$-Not reported. (Street and Green, 1984). \\ IL Peoria $\left(40.6936^{\circ} \mathrm{N}, 89.5889^{\circ} \mathrm{W}\right)$-Earth tremors were felt here. (Street and Green, 1984). \\ F KY Cloverport $\left(37.8333^{\circ} \mathrm{N}, 86.6328^{\circ} \mathrm{W}\right)$-Felt. (Street and Green, 1984). \\ F KY Elizabethtown $\left(37.6939^{\circ} \mathrm{N}, 85.8592^{\circ} \mathrm{W}\right)$-Felt. (Street and Green, 1984). \\ F KY Guthrie $\left(36.6483^{\circ} \mathrm{N}, 87.1664^{\circ} \mathrm{W}\right)$-Felt. (Street and Green, 1984). \\ F KY Hardinsburg $\left(37.7800^{\circ} \mathrm{N}, 86.4606^{\circ} \mathrm{W}\right)$-Felt. (Street and Green, 1984). \\ F KY Lebanon Junction $\left(37.8344^{\circ} \mathrm{N}, 85.7319^{\circ} \mathrm{W}\right)$-Felt. (Street and Green, 1984).
}




\section{Appendix 1, Part 32. Damage Reports and Intensity Assignments}

\section{\#32 1927 May 7 08:28UTC (Arkansas)}

6 AR

6 TN

6 TN

TN

$5 \quad \mathrm{AR}$

$5 \quad \mathrm{KY}$

$5 \quad \mathrm{MO}$

4 AR

4 AR

4 AR

$4 \quad \mathrm{AR}$

$4 \quad \mathrm{AR}$

$4 \quad \mathrm{AR}$

$4 \mathrm{IL}$

$4 \quad \mathrm{MO}$

$4 \mathrm{MO}$

$4 \mathrm{MO}$

$4 \mathrm{MO}$

$4 \mathrm{MO}$

$4 \quad \mathrm{MO}$

$4 \quad \mathrm{MO}$

$4 \mathrm{MO}$

$4 \quad \mathrm{MO}$

1 TN

$0 \quad$ MO

N AR

$\mathrm{N}$ AR

$\mathrm{N}$ AR

$\mathrm{N}$ AR

N IL

N IL

N KY

N KY

$\mathrm{N} \quad \mathrm{MO}$

$\mathrm{N} \quad \mathrm{MO}$

$\mathrm{N} \quad \mathrm{MO}$

$\mathrm{N}$ MO

$\mathrm{N}$ TN

$\mathrm{N}$ TN

$\mathrm{N}$ TN

$\mathrm{N}$ TN

N TN

F AR

F AR

F AR

F AR

F AR

F AR

Jonesboro $\left(35.8422^{\circ} \mathrm{N}, 90.7042^{\circ} \mathrm{W}\right)$-A severe shock, at least one chimney was damaged. (Street and Green, 1984). Dyersburg $\left(36.0344^{\circ} \mathrm{N}, 89.3856^{\circ} \mathrm{W}\right)$-Shattered windows. (Street and Green, 1984).

Memphis $\left(35.1494^{\circ} \mathrm{N}, 90.0489^{\circ} \mathrm{W}\right)$-Windowpanes and dishes were broken in the Memphis, Tenn., area. (Stover and Coffman, 1993).

Memphis $\left(35.1494^{\circ} \mathrm{N}, 90.0489^{\circ} \mathrm{W}\right)$-Earth quivers were felt. (Street and Green, 1984).

Osceola $\left(35.7050^{\circ} \mathrm{N}, 89.9694^{\circ} \mathrm{W}\right)$-Caused many Osceloans to rise hurriedly and rush out to investigate. (Street and Green, 1984).

Hickman $\left(36.5711^{\circ} \mathrm{N}, 89.1861^{\circ} \mathrm{W}\right)$-Awoke almost everyone in town, moved furniture. (Street and Green, 1984).

Cape Girardeau $\left(37.3058^{\circ} \mathrm{N}, 89.5181^{\circ} \mathrm{W}\right.$ ) - Sufficiently strong to awaken residents and topple small objects. (Street and Green, 1984).

Blytheville $\left(35.9272^{\circ} \mathrm{N}, 89.9189^{\circ} \mathrm{W}\right)$-Many people were awakened by a severe shock. (Street and Green, 1984).

Harrisburg $\left(35.5642^{\circ} \mathrm{N}, 90.7167^{\circ} \mathrm{W}\right)-\mathrm{A}$ heavy earthquake shock, houses were much shaken. (Street and Green, 1984).

Paragould $\left(36.0583^{\circ} \mathrm{N}, 90.5^{\circ} \mathrm{W}\right)$-Two severe tremors were felt, much uneasiness was felt among the residents, shook buildings, china, etc. (Street and Green, 1984).

Pocahontas $\left(36.2614^{\circ} \mathrm{N}, 90.9711^{\circ} \mathrm{W}\right)$-Awoke most people, created alarm, rattled windows and furniture. (Street and Green, 1984).

Walnut Ridge $\left(36.0683^{\circ} \mathrm{N}, 90.9558^{\circ} \mathrm{W}\right)$-A severe shock; windows, dishes and other loose articles in houses rattled. (Street and Green, 1984).

Wynne $\left(35.2244^{\circ} \mathrm{N}, 90.7867^{\circ} \mathrm{W}\right)$ - Many residents were awakened, violently shook houses, windows and dishes. (Street and Green, 1984).

Cairo $\left(37.0053^{\circ} \mathrm{N}, 89.1764^{\circ} \mathrm{W}\right)$-Awakened sound sleepers, rattled dishes on shelves. (Street and Green, 1984).

Benton $\left(37.0978^{\circ} \mathrm{N}, 89.5625^{\circ} \mathrm{W}\right)$-Quite a number of sleepers were awakened. (Street and Green, 1984).

Bloomfield $\left(36.8858^{\circ} \mathrm{N}, 89.9292^{\circ} \mathrm{W}\right)$-Awakened many, moved pictures on walls. (Street and Green, 1984).

Caruthersville $\left(36.1931^{\circ} \mathrm{N}, 89.6556^{\circ} \mathrm{W}\right)$-Awaken many residents from their sound sleep. (Street and Green, 1984).

Dexter $\left(36.7958^{\circ} \mathrm{N}, 89.9578^{\circ} \mathrm{W}\right)$-Felt by many. (Street and Green, 1984).

Jackson $\left(37.3822^{\circ} \mathrm{N}, 89.6661^{\circ} \mathrm{W}\right)$-Quite a number of people were awakened by beds being shaken and windows being rattled. (Street and Green, 1984).

New Madrid $\left(36.5864^{\circ} \mathrm{N}, 89.5278^{\circ} \mathrm{W}\right)$-Aroused many of our citizens. (Street and Green, 1984).

Poplar Bluff $\left(36.7569^{\circ} \mathrm{N}, 90.3928^{\circ} \mathrm{W}\right)$-Many residents were awakened and some were frightened. (Street and Green, 1984).

Sikeston $\left(36.8767^{\circ} \mathrm{N}, 89.5878^{\circ} \mathrm{W}\right)$-Many people were awakened. (Street and Green, 1984).

Steele $\left(36.0839^{\circ} \mathrm{N}, 89.8292^{\circ} \mathrm{W}\right.$ )-Aroused the entire population, every building in town was rocked. (Street and Green, 1984).

Reelfoot Lake $\left(36.3900^{\circ} \mathrm{N}, 88.35^{\circ} \mathrm{W}\right)$-In the area of Reelfoot Lake, Tenn., the earthquake left "gravel pilings." (Stover and Coffman, 1993).

Saint Louis $\left(38.6272^{\circ} \mathrm{N}, 90.1978^{\circ} \mathrm{W}\right)$-The shock was not felt in Saint Louis. (Street and Green, 1984).

Conway $\left(35.0886^{\circ} \mathrm{N}, 92.4419^{\circ} \mathrm{W}\right)$-Not mentioned. (Street and Green, 1984).

Fayetteville $\left(36.0625^{\circ} \mathrm{N}, 94.1572^{\circ} \mathrm{W}\right)$-Not mentioned. (Street and Green, 1984).

Hot Springs $\left(34.5036^{\circ} \mathrm{N}, 93.055^{\circ} \mathrm{W}\right)$-Not mentioned. (Street and Green, 1984).

Little Rock $\left(34.7464^{\circ} \mathrm{N}, 92.2894^{\circ} \mathrm{W}\right)$-Not mentioned. (Street and Green, 1984).

Jonesboro $\left(37.4517^{\circ} \mathrm{N}, 89.2681^{\circ} \mathrm{W}\right)$-Not mentioned. (Street and Green, 1984).

Shawneetown $\left(37.7131^{\circ} \mathrm{N}, 88.1867^{\circ} \mathrm{W}\right)$-Not reported. (Street and Green, 1984).

Henderson $\left(37.8361^{\circ} \mathrm{N}, 87.59^{\circ} \mathrm{W}\right)$-Not reported. (Street and Green, 1984).

Paducah $\left(37.0833^{\circ} \mathrm{N}, 88.6^{\circ} \mathrm{W}\right)$-Not mentioned. (Street and Green, 1984).

Eminence $\left(37.1506^{\circ} \mathrm{N}, 91.3575^{\circ} \mathrm{W}\right)$-Not reported. (Street and Green, 1984).

Flat River $\left(37.8511^{\circ} \mathrm{N}, 90.5206^{\circ} \mathrm{W}\right)$-Not reported. (Street and Green, 1984).

Hillsboro $\left(38.2322^{\circ} \mathrm{N}, 90.5628^{\circ} \mathrm{W}\right)$-Not reported. (Street and Green, 1984).

Illmo $\left(37.2197^{\circ} \mathrm{N}, 89.5089^{\circ} \mathrm{W}\right)$-Not reported. (Street and Green, 1984).

Huntingdon $\left(36.0006^{\circ} \mathrm{N}, 88.4281^{\circ} \mathrm{W}\right)$-Not reported. (Street and Green, 1984).

Jackson $\left(35.6144^{\circ} \mathrm{N}, 88.8139^{\circ} \mathrm{W}\right)$-Not reported. (Street and Green, 1984).

Milan $\left(35.9197^{\circ} \mathrm{N}, 88.7589^{\circ} \mathrm{W}\right)-N o t$ reported. (Street and Green, 1984).

Nashville $\left(36.1658^{\circ} \mathrm{N}, 86.7844^{\circ} \mathrm{W}\right)$-Not mentioned. (Street and Green, 1984).

Savannah $\left(35.2247^{\circ} \mathrm{N}, 88.2492^{\circ} \mathrm{W}\right)$-Not reported. (Street and Green, 1984).

Alicia $\left(35.8931^{\circ} \mathrm{N}, 91.0828^{\circ} \mathrm{W}\right)$-Felt. (Street and Green, 1984).

Bald Knob $\left(35.3097^{\circ} \mathrm{N}, 91.5678^{\circ} \mathrm{W}\right)$-Felt. (Street and Green, 1984).

Black Rock $\left(36.1083^{\circ} \mathrm{N}, 91.0972^{\circ} \mathrm{W}\right)$-Felt. (Street and Green, 1984).

Hoxie $\left(36.0503^{\circ} \mathrm{N}, 90.975^{\circ} \mathrm{W}\right)$-Felt. (Street and Green, 1984).

Imboden $\left(36.2025^{\circ} \mathrm{N}, 91.1744^{\circ} \mathrm{W}\right)$-Felt. (Street and Green, 1984).

Knobel $\left(36.3200^{\circ} \mathrm{N}, 90.6019^{\circ} \mathrm{W}\right)$-Felt. (Street and Green, 1984). 


\section{Appendix 1, Part 32. Damage Reports and Intensity Assignments}

F AR Luxora $\left(35.7561^{\circ} \mathrm{N}, 89.9281^{\circ} \mathrm{W}\right)$-Felt. (Street and Green, 1984).

F AR Strawberry $\left(35.9675^{\circ} \mathrm{N}, 91.3211^{\circ} \mathrm{W}\right)$-Felt. (Street and Green, 1984).

F IL Carbondale $\left(37.7272^{\circ} \mathrm{N}, 89.2167^{\circ} \mathrm{W}\right)$-Felt. (Street and Green, 1984).

F KY Mayfield $\left(36.7417^{\circ} \mathrm{N}, 88.6367^{\circ} \mathrm{W}\right)$-Reportedly felt. (Street and Green, 1984).

F $\quad$ MO Charleston $\left(36.9208^{\circ} \mathrm{N}, 89.3506^{\circ} \mathrm{W}\right)$-Felt. (Street and Green, 1984).

F MO Hayti $\left(36.2336^{\circ} \mathrm{N}, 89.7494^{\circ} \mathrm{W}\right)$-Felt. (Street and Green, 1984).

F MO Kennett $\left(36.2361^{\circ} \mathrm{N}, 90.0556^{\circ} \mathrm{W}\right)$-Felt. (Street and Green, 1984).

F MS Hernando $\left(34.8239^{\circ} \mathrm{N}, 89.9936^{\circ} \mathrm{W}\right)$-Felt. (Street and Green, 1984).

F TN Covington $\left(35.5642^{\circ} \mathrm{N}, 89.6464^{\circ} \mathrm{W}\right)$-Shaken. (Street and Green, 1984).

F TN Paris $\left(36.3019^{\circ} \mathrm{N}, 88.3267^{\circ} \mathrm{W}\right)$-Felt. (Street and Green, 1984).

F TN Ripley $\left(35.7453^{\circ} \mathrm{N}, 89.5297^{\circ} \mathrm{W}\right)$-Felt. (Street and Green, 1984).

F TN Tiptonville $\left(36.3783^{\circ} \mathrm{N}, 89.4719^{\circ} \mathrm{W}\right)$-Felt. (Street and Green, 1984).

F TN Union City $\left(36.4242^{\circ} \mathrm{N}, 89.0569^{\circ} \mathrm{W}\right)$-Felt. (Street and Green, 1984). 


\section{Appendix 1, Part 33. Damage Reports and Intensity Assignments}

\section{\#33 1931 Dec. 17 03:36UTC (Mississippi)}

$6 \quad$ MS

6 MS

6 MS

5 AR

5 MS

5 MS

$5 \quad M S$

5 MS

5 MS

5 MS

5 MS

5 TN

$4 \mathrm{AL}$

$4 \mathrm{AL}$

4 AR

4 AR

4 AR

4 AR

4 MS

4 MS

4 MS

4 MS

4 MS

4 MS

4 MS

4 MS

4 MS

4 MS

4 MS

4 MS

4 MS

4 MS

4 MS

4 MS

4 MS

4 MS

4 MS

4 MS

4 MS

4 MS

4 MS

4 MS

4 MS

4 MS

4 MS

4 MS

4 MS

4 MS

4 MS

4 MS

4 MS

4 MS

4 MS

4 MS

Belzoni $\left(33.1842^{\circ} \mathrm{N}, 90.4892^{\circ} \mathrm{W}\right)-$ Several buildings were damaged slightly and some plaster was thrown down. (Neumann and Bodle, 1932).

Charleston $\left(34.0067^{\circ} \mathrm{N}, 90.0567^{\circ} \mathrm{W}\right)$-Cracks were made in the walls and foundation of the Agricultural High School and several chimneys were thrown down. (Neumann and Bodle, 1932).

Tillatoba $\left(33.9847^{\circ} \mathrm{N}, 89.8967^{\circ} \mathrm{W}\right)-$ One chimney fell, doors opened, a vase was thrown to the floor. (Neumann and Bodle, 1932).

Water Valley $\left(34.1514^{\circ} \mathrm{N}, 89.6314^{\circ} \mathrm{W}\right)$-Several chimneys were damaged. (Neumann and Bodle, 1932).

Marianna $\left(34.7736^{\circ} \mathrm{N}, 90.7575^{\circ} \mathrm{W}\right)$ (Neumann and Bodle, 1932).

Batesville $\left(34.3114^{\circ} \mathrm{N}, 89.9442^{\circ} \mathrm{W}\right)$ (Neumann and Bodle, 1932).

Cleveland $\left(33.7439^{\circ} \mathrm{N}, 90.7247^{\circ} \mathrm{W}\right)$ (Neumann and Bodle, 1932).

Hernando $\left(34.8239^{\circ} \mathrm{N}, 89.9936^{\circ} \mathrm{W}\right.$ ) (Neumann and Bodle, 1932).

Holly Springs $\left(34.7675^{\circ} \mathrm{N}, 89.4486^{\circ} \mathrm{W}\right.$ ) (Neumann and Bodle, 1932).

Indianola $\left(33.4508^{\circ} \mathrm{N}, 90.655^{\circ} \mathrm{W}\right.$ ) (Neumann and Bodle, 1932).

Taylor $\left(34.2722^{\circ} \mathrm{N}, 89.5886^{\circ} \mathrm{W}\right)$ (Neumann and Bodle, 1932).

Tupelo $\left(34.2575^{\circ} \mathrm{N}, 88.7033^{\circ} \mathrm{W}\right)$ (Neumann and Bodle, 1932).

Raleigh $\left(35.2058^{\circ} \mathrm{N}, 89.9136^{\circ} \mathrm{W}\right)$ (Neumann and Bodle, 1932).

Gainesville $\left(32.8208^{\circ} \mathrm{N}, 88.1589^{\circ} \mathrm{W}\right)$ (Neumann and Bodle, 1932).

Hackleburg $\left(34.2772^{\circ} \mathrm{N}, 87.8286^{\circ} \mathrm{W}\right)$ (Neumann and Bodle, 1932).

Earle $\left(35.2750^{\circ} \mathrm{N}, 90.4667^{\circ} \mathrm{W}\right)$ (Neumann and Bodle, 1932).

Forrest City $\left(35.0081^{\circ} \mathrm{N}, 90.7897^{\circ} \mathrm{W}\right)$ (Neumann and Bodle, 1932).

Helena $\left(34.5294^{\circ} \mathrm{N}, 90.5914^{\circ} \mathrm{W}\right)$ (Neumann and Bodle, 1932).

Searcy $\left(35.2506^{\circ} \mathrm{N}, 91.7361^{\circ} \mathrm{W}\right)$ (Neumann and Bodle, 1932).

Abbeville $\left(34.5031^{\circ} \mathrm{N}, 89.5031^{\circ} \mathrm{W}\right.$ ) (Neumann and Bodle, 1932).

Ackerman $\left(33.3100^{\circ} \mathrm{N}, 89.1728^{\circ} \mathrm{W}\right.$ ) (Neumann and Bodle, 1932).

Blue Mountain $\left(34.6708^{\circ} \mathrm{N}, 89.0264^{\circ} \mathrm{W}\right)$ (Neumann and Bodle, 1932).

Booneville $\left(34.6581^{\circ} \mathrm{N}, 88.5667^{\circ} \mathrm{W}\right.$ ) (Neumann and Bodle, 1932).

Clarksdale $\left(34.2000^{\circ} \mathrm{N}, 90.5708^{\circ} \mathrm{W}\right)$ (Neumann and Bodle, 1932).

Clayton $\left(34.6000^{\circ} \mathrm{N}, 90.4164^{\circ} \mathrm{W}\right.$ ) (Neumann and Bodle, 1932).

Coffeeville $\left(33.9767^{\circ} \mathrm{N}, 89.6756^{\circ} \mathrm{W}\right.$ ) (Neumann and Bodle, 1932).

Columbus $\left(33.4956^{\circ} \mathrm{N}, 88.4272^{\circ} \mathrm{W}\right)$ (Neumann and Bodle, 1932).

Corinth $\left(34.9342^{\circ} \mathrm{N}, 88.5222^{\circ} \mathrm{W}\right)$ (Neumann and Bodle, 1932).

Duncan $\left(34.0444^{\circ} \mathrm{N}, 90.7447^{\circ} \mathrm{W}\right)$ (Neumann and Bodle, 1932).

Enid $\left(34.1164^{\circ} \mathrm{N}, 89.9397^{\circ} \mathrm{W}\right.$ ) (Neumann and Bodle, 1932).

Etta $\left(34.4703^{\circ} \mathrm{N}, 89.2275^{\circ} \mathrm{W}\right)$ (Neumann and Bodle, 1932).

Fair Point (Neumann and Bodle, 1932).

Gorin (Neumann and Bodle, 1932).

Greenwood $\left(33.5161^{\circ} \mathrm{N}, 90.1794^{\circ} \mathrm{W}\right.$ ) (Neumann and Bodle, 1932).

Grenada $\left(33.7689^{\circ} \mathrm{N}, 89.8083^{\circ} \mathrm{W}\right)$ (Neumann and Bodle, 1932).

Hardy Station $\left(33.8819^{\circ} \mathrm{N}, 89.8294^{\circ} \mathrm{W}\right)$ (Neumann and Bodle, 1932).

Hollandale $\left(33.1689^{\circ} \mathrm{N}, 90.8539^{\circ} \mathrm{W}\right)$ (Neumann and Bodle, 1932).

Houlka $\left(34.0381^{\circ} \mathrm{N}, 89.0219^{\circ} \mathrm{W}\right)$ (Neumann and Bodle, 1932).

Houston $\left(33.8983^{\circ} \mathrm{N}, 88.9992^{\circ} \mathrm{W}\right)$ (Neumann and Bodle, 1932).

Itta Bena $\left(33.4950^{\circ} \mathrm{N}, 90.3197^{\circ} \mathrm{W}\right)$ (Neumann and Bodle, 1932).

luka $\left(34.8117^{\circ} \mathrm{N}, 88.19^{\circ} \mathrm{W}\right)$ (Neumann and Bodle, 1932$)$.

Kosciusko $\left(33.0575^{\circ} \mathrm{N}, 89.5875^{\circ} \mathrm{W}\right)$ (Neumann and Bodle, 1932).

Lake Cormorant $\left(34.9042^{\circ} \mathrm{N}, 90.2144^{\circ} \mathrm{W}\right)$ (Neumann and Bodle, 1932).

Meridian $\left(32.3642^{\circ} \mathrm{N}, 88.7036^{\circ} \mathrm{W}\right.$ ) (Neumann and Bodle, 1932).

Okolona $\left(34.0017^{\circ} \mathrm{N}, 88.7553^{\circ} \mathrm{W}\right)$ (Neumann and Bodle, 1932).

Oxford $\left(34.3664^{\circ} \mathrm{N}, 89.5192^{\circ} \mathrm{W}\right)$ (Neumann and Bodle, 1932).

Pace $\left(33.7914^{\circ} \mathrm{N}, 90.8569^{\circ} \mathrm{W}\right.$ ) (Neumann and Bodle, 1932).

Pittsboro $\left(33.9403^{\circ} \mathrm{N}, 89.3375^{\circ} \mathrm{W}\right.$ ) (Neumann and Bodle, 1932).

Pontotoc $\left(34.2478^{\circ} \mathrm{N}, 88.9986^{\circ} \mathrm{W}\right)$ (Neumann and Bodle, 1932).

Prichard $\left(34.6994^{\circ} \mathrm{N}, 90.2442^{\circ} \mathrm{W}\right)$ (Neumann and Bodle, 1932).

Ripley $\left(34.7297^{\circ} \mathrm{N}, 88.9506^{\circ} \mathrm{W}\right)$ (Neumann and Bodle, 1932).

Robinsonville $\left(34.8172^{\circ} \mathrm{N}, 90.3161^{\circ} \mathrm{W}\right)$ (Neumann and Bodle, 1932).

Sherman $\left(34.3592^{\circ} \mathrm{N}, 88.8411^{\circ} \mathrm{W}\right)$ (Neumann and Bodle, 1932).

Stoneville $\left(33.4239^{\circ} \mathrm{N}, 90.915^{\circ} \mathrm{W}\right.$ ) (Neumann and Bodle, 1932).

Sumner $\left(33.9708^{\circ} \mathrm{N}, 90.3686^{\circ} \mathrm{W}\right.$ ) (Neumann and Bodle, 1932). 


\title{
Appendix 1, Part 33. Damage Reports and Intensity Assignments
}

\author{
Waterford $\left(34.6475^{\circ} \mathrm{N}, 89.4572^{\circ} \mathrm{W}\right)$ (Neumann and Bodle, 1932). \\ Germantown $\left(35.0867^{\circ} \mathrm{N}, 89.81^{\circ} \mathrm{W}\right)$ (Neumann and Bodle, 1932). \\ Henderson $\left(35.4392^{\circ} \mathrm{N}, 88.6414^{\circ} \mathrm{W}\right)$ (Neumann and Bodle, 1932). \\ Memphis $\left(35.1494^{\circ} \mathrm{N}, 90.0489^{\circ} \mathrm{W}\right)$ (Neumann and Bodle, 1932). \\ Selmer $\left(35.1700^{\circ} \mathrm{N}, 88.5922^{\circ} \mathrm{W}\right)$ (Neumann and Bodle, 1932). \\ Birmingham $\left(33.5206^{\circ} \mathrm{N}, 86.8025^{\circ} \mathrm{W}\right)$ (Neumann and Bodle, 1932). \\ Clanton $\left(32.8386^{\circ} \mathrm{N}, 86.6294^{\circ} \mathrm{W}\right.$ ) (Neumann and Bodle, 1932). \\ Decatur $\left(34.6058^{\circ} \mathrm{N}, 86.9833^{\circ} \mathrm{W}\right)$ (Neumann and Bodle, 1932). \\ Fort Payne $\left(34.4442^{\circ} \mathrm{N}, 85.7197^{\circ} \mathrm{W}\right)$ (Neumann and Bodle, 1932). \\ Millport $\left(33.5633^{\circ} \mathrm{N}, 88.0814^{\circ} \mathrm{W}\right)$ (Neumann and Bodle, 1932). \\ Montgomery $\left(32.3667^{\circ} \mathrm{N}, 86.3^{\circ} \mathrm{W}\right.$ ) (Neumann and Bodle, 1932). \\ Riverton $\left(34.8806^{\circ} \mathrm{N}, 88.0767^{\circ} \mathrm{W}\right)$ (Neumann and Bodle, 1932). \\ Russellville $\left(34.5078^{\circ} \mathrm{N}, 87.7286^{\circ} \mathrm{W}\right.$ ) (Neumann and Bodle, 1932). \\ Tuscaloosa $\left(33.2097^{\circ} \mathrm{N}, 87.5692^{\circ} \mathrm{W}\right)$ (Neumann and Bodle, 1932). \\ Marion $\left(35.2144^{\circ} \mathrm{N}, 90.1964^{\circ} \mathrm{W}\right)$ (Neumann and Bodle, 1932). \\ Osceola $\left(35.7050^{\circ} \mathrm{N}, 89.9694^{\circ} \mathrm{W}\right.$ ) (Neumann and Bodle, 1932). \\ Winchester $\left(33.7744^{\circ} \mathrm{N}, 91.4744^{\circ} \mathrm{W}\right)$ (Neumann and Bodle, 1932). \\ Aberdeen $\left(33.8250^{\circ} \mathrm{N}, 88.5436^{\circ} \mathrm{W}\right)$ (Neumann and Bodle, 1932). \\ Ashland $\left(34.8328^{\circ} \mathrm{N}, 89.1758^{\circ} \mathrm{W}\right)$ (Neumann and Bodle, 1932). \\ Askew $\left(34.5369^{\circ} \mathrm{N}, 90.1933^{\circ} \mathrm{W}\right)$ (Neumann and Bodle, 1932). \\ Carrollton $\left(33.5081^{\circ} \mathrm{N}, 89.9203^{\circ} \mathrm{W}\right.$ ) (Neumann and Bodle, 1932). \\ Eupora $\left(33.5406^{\circ} \mathrm{N}, 89.2669^{\circ} \mathrm{W}\right)$ (Neumann and Bodle, 1932). \\ Farrell $\left(34.2642^{\circ} \mathrm{N}, 90.6722^{\circ} \mathrm{W}\right.$ ) (Neumann and Bodle, 1932). \\ Fulton $\left(34.2739^{\circ} \mathrm{N}, 88.4092^{\circ} \mathrm{W}\right)$ (Neumann and Bodle, 1932). \\ Glen Allan $\left(33.0239^{\circ} \mathrm{N}, 91.03^{\circ} \mathrm{W}\right)$ (Neumann and Bodle, 1932). \\ Greenville $\left(33.4100^{\circ} \mathrm{N}, 91.0617^{\circ} \mathrm{W}\right)$ (Neumann and Bodle, 1932). \\ Gunnison $\left(33.9442^{\circ} \mathrm{N}, 90.945^{\circ} \mathrm{W}\right)$ (Neumann and Bodle, 1932). \\ Guntown (34.4431 $\mathrm{N}, 88.6597^{\circ} \mathrm{W}$ ) (Neumann and Bodle, 1932). \\ Hickory Flat $\left(34.6158^{\circ} \mathrm{N}, 89.1883^{\circ} \mathrm{W}\right.$ ) (Neumann and Bodle, 1932). \\ Holcut $\left(34.7297^{\circ} \mathrm{N}, 88.3058^{\circ} \mathrm{W}\right)$ (Neumann and Bodle, 1932). \\ Lafayette Springs $\left(34.3172^{\circ} \mathrm{N}, 89.2611^{\circ} \mathrm{W}\right)$ (Neumann and Bodle, 1932). \\ Nettleton $\left(34.0889^{\circ} \mathrm{N}, 88.6222^{\circ} \mathrm{W}\right)$ (Neumann and Bodle, 1932). \\ Paulding $\left(32.0306^{\circ} \mathrm{N}, 89.0375^{\circ} \mathrm{W}\right)$ (Neumann and Bodle, 1932). \\ Pine Valley $\left(34.0683^{\circ} \mathrm{N}, 89.5203^{\circ} \mathrm{W}\right)$ (Neumann and Bodle, 1932). \\ Potts Camp $\left(34.6461^{\circ} \mathrm{N}, 89.3053^{\circ} \mathrm{W}\right)$ (Neumann and Bodle, 1932). \\ Rolling Fork $\left(32.9064^{\circ} \mathrm{N}, 90.8781^{\circ} \mathrm{W}\right)$ (Neumann and Bodle, 1932). \\ Sardis $\left(34.4369^{\circ} \mathrm{N}, 89.9158^{\circ} \mathrm{W}\right)$ (Neumann and Bodle, 1932). \\ Sarepta $\left(34.1244^{\circ} \mathrm{N}, 89.2875^{\circ} \mathrm{W}\right)$ (Neumann and Bodle, 1932). \\ Scott $\left(33.5917^{\circ} \mathrm{N}, 91.0742^{\circ} \mathrm{W}\right)$ (Neumann and Bodle, 1932). \\ Tunica $\left(34.6844^{\circ} \mathrm{N}, 90.3828^{\circ} \mathrm{W}\right)$ (Neumann and Bodle, 1932). \\ West Point $\left(33.6075^{\circ} \mathrm{N}, 88.6503^{\circ} \mathrm{W}\right)$ (Neumann and Bodle, 1932). \\ Yazoo City $\left(32.8550^{\circ} \mathrm{N}, 90.4056^{\circ} \mathrm{W}\right)$ (Neumann and Bodle, 1932). \\ Adamsville $\left(35.2358^{\circ} \mathrm{N}, 88.3906^{\circ} \mathrm{W}\right)$ (Neumann and Bodle, 1932). \\ Alamo $\left(35.7847^{\circ} \mathrm{N}, 89.1172^{\circ} \mathrm{W}\right)$ (Neumann and Bodle, 1932). \\ Arlington $\left(35.2961^{\circ} \mathrm{N}, 89.6614^{\circ} \mathrm{W}\right)$ (Neumann and Bodle, 1932). \\ Bolivar $\left(35.2561^{\circ} \mathrm{N}, 88.9878^{\circ} \mathrm{W}\right)$ (Neumann and Bodle, 1932). \\ Brownsville $\left(35.5939^{\circ} \mathrm{N}, 89.2622^{\circ} \mathrm{W}\right)$ (Neumann and Bodle, 1932). \\ Dyersburg $\left(36.0344^{\circ} \mathrm{N}, 89.3856^{\circ} \mathrm{W}\right)$ (Neumann and Bodle, 1932). \\ Savannah $\left(35.2247^{\circ} \mathrm{N}, 88.2492^{\circ} \mathrm{W}\right.$ ) (Neumann and Bodle, 1932).
}




\section{Appendix 1, Part 34. Damage Reports and Intensity Assignments}

\section{\#34 1934 Aug. 20 00:47UTC (Missouri)}

7 IL Cairo $\left(37.0053^{\circ} \mathrm{N}, 89.1764^{\circ} \mathrm{W}\right)$-Same effects as at Charleston, Missouri. (Neumann, 1936).

IL Cairo $\left(37.0053^{\circ} \mathrm{N}, 89.1764^{\circ} \mathrm{W}\right)$-Destructive intensity covered an area of $600 \mathrm{~km}^{2}$, including Charleston, Mo., Arlington and Wickliffe, Ky., and Cairo and Mounds, III. (Stover and Coffman, 1993).

7 IL Mound City $\left(37.0853^{\circ} \mathrm{N}, 89.1625^{\circ} \mathrm{W}\right)$-Same effects as at Charleston, Missouri. (Neumann, 1936).

7 IL Mounds $\left(37.1142^{\circ} \mathrm{N}, 89.1978^{\circ} \mathrm{W}\right)$-Same effects as at Charleston, Missouri. (Neumann, 1936).

IL Mounds $\left(37.1142^{\circ} \mathrm{N}, 89.1978^{\circ} \mathrm{W}\right)$-Destructive intensity covered an area of $600 \mathrm{~km}^{2}$, including Charleston, Mo., Arlington and Wickliffe, Ky., and Cairo and Mounds, III. (Stover and Coffman, 1993).

$7 \quad \mathrm{KY}$

KY

$7 \quad \mathrm{MO}$

MO

$6 \quad \mathrm{IL}$

$6 \mathrm{KY}$

KY

$5 \quad \mathrm{MO}$

5 MO

$5 \mathrm{MO}$

$5 \mathrm{MO}$

4 AR

$4 \mathrm{KY}$

$4 \mathrm{KY}$

$4 \quad \mathrm{KY}$

$4 \mathrm{KY}$

$4 \quad \mathrm{MO}$

$4 \quad \mathrm{MO}$

$4 \mathrm{MO}$

$4 \mathrm{MO}$

$4 \quad \mathrm{MO}$

$4 \mathrm{MO}$

$4 \mathrm{MO}$

$4 \mathrm{MO}$

$4 \mathrm{MO}$

$4 \mathrm{MO}$

$4 \mathrm{MO}$

$4 \quad \mathrm{MO}$

$4 \mathrm{MO}$

$4 \mathrm{TN}$

3 AR

AR

3 AR

AR

3 IL

$$
\text { IL }
$$

Wickliffe $\left(36.9647^{\circ} \mathrm{N}, 89.0892^{\circ} \mathrm{W}\right)$-Same effects as at Charleston, Missouri. (Neumann, 1936).

Wickliffe $\left(36.9647^{\circ} \mathrm{N}, 89.0892^{\circ} \mathrm{W}\right)$-Destructive intensity covered an area of $600 \mathrm{~km}^{2}$, including Charleston, Mo., Arlington and Wickliffe, Ky., and Cairo and Mounds, III. (Stover and Coffman, 1993).

Charleston $\left(36.9208^{\circ} \mathrm{N}, 89.3506^{\circ} \mathrm{W}\right)$-Windows were broken, chimneys were overthrown or damaged, and articles were knocked from shelves. (Neumann, 1936).

Charleston $\left(36.9208^{\circ} \mathrm{N}, 89.3506^{\circ} \mathrm{W}\right)$ - In the area near Charleston, Mississippi County, Mo., chimneys were thrown down or lost bricks, windows were broken, and plaster was cracked. (Stover and Coffman, 1993).

Thebes $\left(37.2208^{\circ} \mathrm{N}, 89.4608^{\circ} \mathrm{W}\right)$ (Neumann, 1936).

Arlington $\left(36.7903^{\circ} \mathrm{N}, 89.0128^{\circ} \mathrm{W}\right)$-Destructive intensity covered an area of $600 \mathrm{~km}^{2}$, including Charleston, Mo., Arlington and Wickliffe, Ky., and Cairo and Mounds, III. (Stover and Coffman, 1993).

Arlington $\left(36.7903^{\circ} \mathrm{N}, 89.0128^{\circ} \mathrm{W}\right)($ Neumann, 1936).

Crosno $\left(36.7975^{\circ} \mathrm{N}, 89.1772^{\circ} \mathrm{W}\right)$ (Neumann, 1936).

East Prairie $\left(36.7797^{\circ} \mathrm{N}, 89.3856^{\circ} \mathrm{W}\right)$ (Neumann, 1936).

Henson $\left(36.8561^{\circ} \mathrm{N}, 89.2525^{\circ} \mathrm{W}\right)$ (Neumann, 1936).

Wyatt $\left(36.9092^{\circ} \mathrm{N}, 89.2225^{\circ} \mathrm{W}\right)$ (Neumann, 1936).

Rector $\left(36.2631^{\circ} \mathrm{N}, 90.2925^{\circ} \mathrm{W}\right)$ (Neumann, 1936).

Bardwell $\left(36.8706^{\circ} \mathrm{N}, 89.0097^{\circ} \mathrm{W}\right)$ (Neumann, 1936).

Berkley $\left(36.8036^{\circ} \mathrm{N}, 89.0822^{\circ} \mathrm{W}\right)$ (Neumann, 1936).

Columbus $\left(36.7597^{\circ} \mathrm{N}, 89.1033^{\circ} \mathrm{W}\right)$ (Neumann, 1936).

Cunningham $\left(36.9075^{\circ} \mathrm{N}, 88.8897^{\circ} \mathrm{W}\right)$ (Neumann, 1936).

Allenville $\left(37.2217^{\circ} \mathrm{N}, 89.7575^{\circ} \mathrm{W}\right)$ (Neumann, 1936).

Anniston $\left(36.8258^{\circ} \mathrm{N}, 89.3278^{\circ} \mathrm{W}\right)$ (Neumann, 1936).

Benton $\left(37.0978^{\circ} \mathrm{N}, 89.5625^{\circ} \mathrm{W}\right)$ (Neumann, 1936).

Cape Girardeau $\left(37.3058^{\circ} \mathrm{N}, 89.5181^{\circ} \mathrm{W}\right)$ (Neumann, 1936).

Commerce $\left(37.1589^{\circ} \mathrm{N}, 89.4428^{\circ} \mathrm{W}\right)$ (Neumann, 1936).

Lilbourn $\left(36.5922^{\circ} \mathrm{N}, 89.6153^{\circ} \mathrm{W}\right)$ (Neumann, 1936).

Matthews $\left(36.7592^{\circ} \mathrm{N}, 89.5867^{\circ} \mathrm{W}\right)$ (Neumann, 1936).

Morehouse $\left(36.8472^{\circ} \mathrm{N}, 89.6853^{\circ} \mathrm{W}\right)$ (Neumann, 1936).

New Hamburg $\left(37.1264^{\circ} \mathrm{N}, 89.5933^{\circ} \mathrm{W}\right)$ (Neumann, 1936).

Oran $\left(37.0850^{\circ} \mathrm{N}, 89.6553^{\circ} \mathrm{W}\right)$ (Neumann, 1936).

Samos $\left(36.8681^{\circ} \mathrm{N}, 89.2764^{\circ} \mathrm{W}\right)$ (Neumann, 1936).

Sikeston $\left(36.8767^{\circ} \mathrm{N}, 89.5878^{\circ} \mathrm{W}\right)$ (Neumann, 1936).

Vanduser $\left(36.9906^{\circ} \mathrm{N}, 89.6856^{\circ} \mathrm{W}\right)$ (Neumann, 1936).

Miston $\left(36.1647^{\circ} \mathrm{N}, 89.4903^{\circ} \mathrm{W}\right)$ (Neumann, 1936).

Corning $\left(36.4078^{\circ} \mathrm{N}, 90.5797^{\circ} \mathrm{W}\right)$ (Neumann, 1936).

Corning (36.4078 $\left.\mathrm{N}, 90.5797^{\circ} \mathrm{W}\right)$-Felt north to Alton, Ill.,; east to Paducah and Marion, Ky.; south to Paris and Ripley,

Tenn., and Corning and Paragould, Ark.; and west to Poplar Bluff and Greeneville, Mo. (Stover and Coffman, 1993).

Paragould $\left(36.0583^{\circ} \mathrm{N}, 90.5^{\circ} \mathrm{W}\right)$ (Neumann, 1936).

Paragould (36.0583 $\mathrm{N}, 90.5^{\circ} \mathrm{W}$ )-Felt north to Alton, Ill.,; east to Paducah and Marion, Ky.; south to Paris and Ripley, Tenn., and Corning and Paragould, Ark.; and west to Poplar Bluff and Greeneville, Mo. (Stover and Coffman, 1993).

Alton $\left(38.8906^{\circ} \mathrm{N}, 90.1842^{\circ} \mathrm{W}\right)$ (Neumann, 1936).

Alton $\left(38.8906^{\circ} \mathrm{N}, 90.1842^{\circ} \mathrm{W}\right)$ (Stover and Coffman, 1993).

Anna $\left(37.4603^{\circ} \mathrm{N}, 89.2469^{\circ} \mathrm{W}\right)$ (Neumann, 1936).

Belknap $\left(37.3250^{\circ} \mathrm{N}, 88.9389^{\circ} \mathrm{W}\right)$ (Neumann, 1936).

Carbondale $\left(37.7272^{\circ} \mathrm{N}, 89.2167^{\circ} \mathrm{W}\right)$ (Neumann, 1936).

Grand Chain $\left(37.2264^{\circ} \mathrm{N}, 88.993^{\circ} \mathrm{W}\right)$ (Neumann, 1936).

Jonesboro $\left(37.4517^{\circ} \mathrm{N}, 89.2681^{\circ} \mathrm{W}\right)$ (Neumann, 1936).

McClure $\left(37.3178^{\circ} \mathrm{N}, 89.4314^{\circ} \mathrm{W}\right)$ (Neumann, 1936).

Metropolis $\left(37.1511^{\circ} \mathrm{N}, 88.7319^{\circ} \mathrm{W}\right)$ (Neumann, 1936).

Olmsted $\left(37.1806^{\circ} \mathrm{N}, 89.0889^{\circ} \mathrm{W}\right)$ (Neumann, 1936).

Vienna $\left(37.4153^{\circ} \mathrm{N}, 88.8978^{\circ} \mathrm{W}\right)$ (Neumann, 1936). 


\section{Appendix 1, Part 34. Damage Reports and Intensity Assignments}

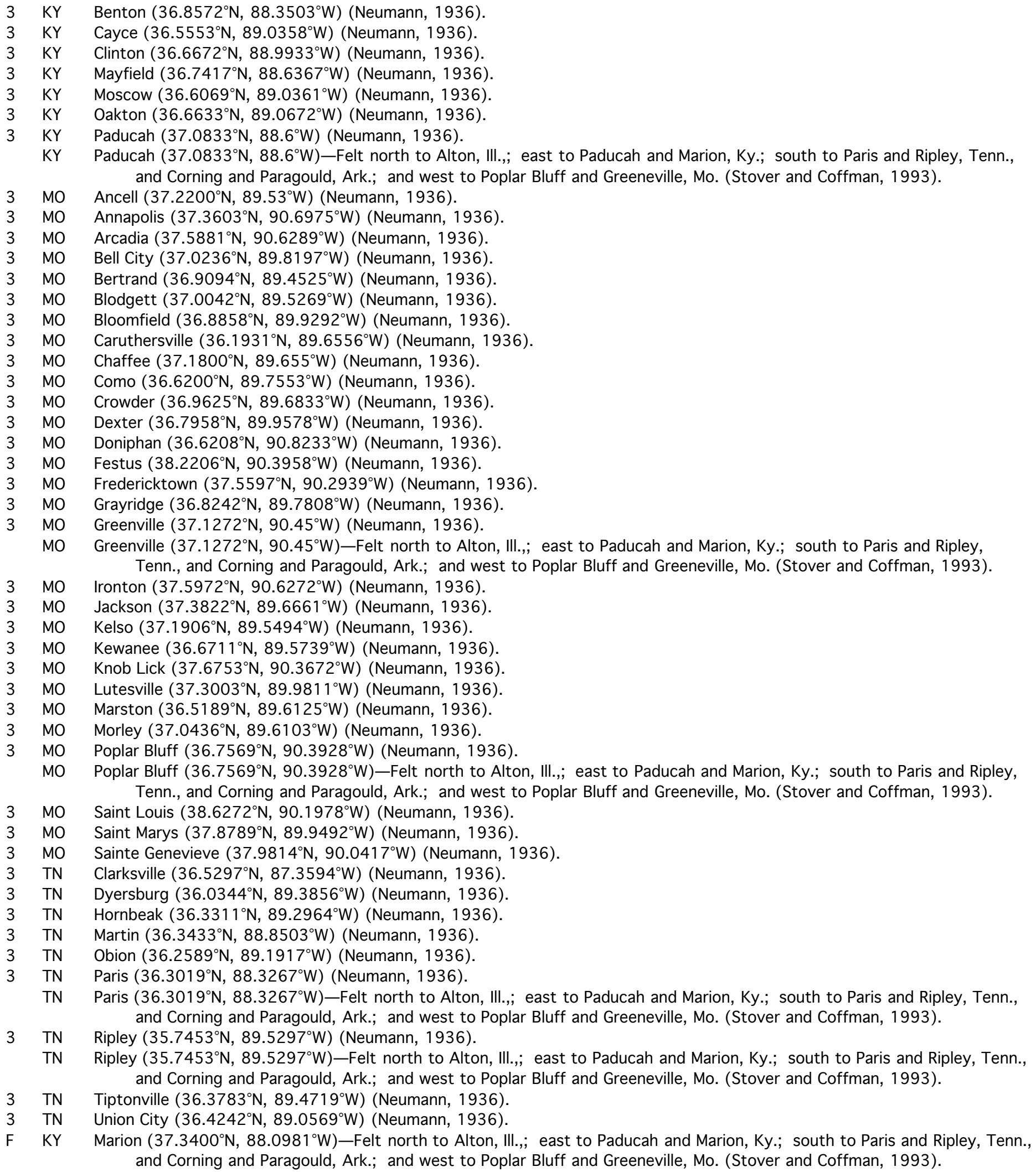




\section{Appendix 1, Part 35. Damage Reports and Intensity Assignments}

\section{\#35 1937 March 2 14:47UTC (Ohio)}

$7 \square$ OH口 Anna $\left(40.3944^{\circ} \mathrm{N}, 84.1728^{\circ} \mathrm{W}\right)$-Walls of brick buildings cracked, plaster shaken down, various pieces of furniture upset. Walls of public school building so badly cracked that the building was declared unsafe. Chimneys snapped off at the roof; others destroyed by a twisting motion. Minor damage to St. Jacob's Lutheran church and the Methodist Episcopal church. ...

In the vicinity of Anna, rotary movement resulted from both earthquakes. ... The senior author examined carefully the rotational effect in three cemeteries, one about two miles to the south of Anna, one on the northern edge of the village, and the third a mile beyond.... Of the twenty-four tombstones examined in the cemetery to the south, all but three had been rotated in a clockwise direction. In the cemetery on the northern edge of town, all seemed to have been rotated $\mathrm{n}$ a counterclockwise direction. At the third, some were rotated in one direction and some in another. ... the caretaker in the cemetery south of the village stated that many stones had been rotated by the first earthquake in the same directions as those indicated by the way they were found. (Westland and Heinrich, 1940).

$\mathrm{OH}$

Anna $\left(40.3944^{\circ} \mathrm{N}, 84.1728^{\circ} \mathrm{W}\right)$-Damage was heaviest to brick chimneys and buildings at Anna and Sidney - many chimneys fell, walls cracked, and plaster fell. Springs and other water wells increased their flow, but output from oil and gas wells was decreased. At the Anna public school, walls of the building were cracked so severely that it was declared unsafe; two churches sustained minor damage. ... Several tombstones were rotated in three cemeteries near Anna. (Stover and Coffman, 1993).

Anna $\left(40.3944^{\circ} \mathrm{N}, 84.1728^{\circ} \mathrm{W}\right)$ - The school was damaged so badly that it was declared unsafe. Many chimneys were thrown down and other minor damage was inflicted at Anna, Sidney, and Wapakoneta. (Neumann, 1940).

Botkins $\left(40.4581^{\circ} \mathrm{N}, 84.1812^{\circ} \mathrm{W}\right)$-Tops of chimneys knocked off and some plaster cracked, chimneys badly damaged, furniture overthrown. (Westland and Heinrich, 1940).

Botkins $\left(40.4581^{\circ} \mathrm{N}, 84.1812^{\circ} \mathrm{W}\right)$-Chimneys also were damaged at ... Botkins and Jackson Center and in southern Auglaize County, at Wapakoneta. (Stover and Coffman, 1993).

Sidney $\left(40.2842^{\circ} \mathrm{N}, 84.1556^{\circ} \mathrm{W}\right)$ - Many chimneys were thrown down and other minor damage was inflicted at Anna, Sidney, and Wapakoneta. (Neumann, 1940).

Sidney $\left(40.2842^{\circ} \mathrm{N}, 84.1556^{\circ} \mathrm{W}\right)$ - “Local damage consisted of broken chimneys and loosened plaster in several buildings." (Westland and Heinrich, 1940).

Wapakoneta $\left(40.5709^{\circ} \mathrm{N}, 84.1543^{\circ} \mathrm{W}\right)$-Plate glass windows broken, chimneys toppled, plaster knocked from walls. "sitting in auto, motor idling, felt rocking sensation of car." (Westland and Heinrich, 1940).

Wapakoneta $\left(40.5678^{\circ} \mathrm{N}, 84.1936^{\circ} \mathrm{W}\right)$-Many chimneys were thrown down and other minor damage was inflicted at Anna, Sidney, and Wapakoneta. (Neumann, 1940).

Wapakoneta $\left(40.5678^{\circ} \mathrm{N}, 84.1936^{\circ} \mathrm{W}\right)$-Chimneys also were damaged at ... Botkins and Jackson Center and in southern Auglaize County, at Wapakoneta. (Stover and Coffman, 1993).

Archbold $\left(41.5347^{\circ} \mathrm{N}, 84.301^{\circ} \mathrm{W}\right)$ - "An old frame dwelling was twisted so that the walls separated, wall paper cracked and some plaster cracked." (Westland and Heinrich, 1940).

Jackson Center $\left(40.4379^{\circ} \mathrm{N}, 84.0478^{\circ} \mathrm{W}\right)$ - "Walls and chimneys cracked, merchandise thrown off shelves in store, chimneys damaged." (Westland and Heinrich, 1940).

Jackson Center $\left(40.4379^{\circ} \mathrm{N}, 84.0478^{\circ} \mathrm{W}\right.$ ) - Chimneys also were damaged at ... Botkins and Jackson Center and in southern Auglaize County, at Wapakoneta. (Stover and Coffman, 1993).

Jackson Center $\left(40.4379^{\circ} \mathrm{N}, 84.0478^{\circ} \mathrm{W}\right)$ (Neumann, 1940).

Fort Wayne $\left(41.1306^{\circ} \mathrm{N}, 85.1289^{\circ} \mathrm{W}\right)$-Plaster fell in buildings as far away as Fort Wayne, Ind. (Stover and Coffman, 1993).

Fort Wayne $\left(41.1306^{\circ} \mathrm{N}, 85.1289^{\circ} \mathrm{W}\right)$-At Fort Wayne, Ind., objects were thrown from shelves and some plaster fell. (Coffman and von Hake, 1973).

Fort Wayne $\left(41.1306^{\circ} \mathrm{N}, 85.1289^{\circ} \mathrm{W}\right)$ (Neumann, 1940).

Fort Wayne $\left(41.1306^{\circ} \mathrm{N}, 85.1289^{\circ} \mathrm{W}\right)$-Tall Lincoln Tower swayed. According to J. Howard Ackley, program director at Radio Station WOWO, the needle jumped from one groove to another on the record of a phonograph which was playing. (Westland and Heinrich, 1940).

Indianapolis $\left(39.7683^{\circ} \mathrm{N}, 86.1581^{\circ} \mathrm{W}\right)$-Plaster cracked at Indianapolis. (Stover and Coffman, 1993).

Indianapolis $\left(39.7683^{\circ} \mathrm{N}, 86.1581^{\circ} \mathrm{W}\right)$-Some plaster was cracked at Indianapolis. (Coffman and von Hake, 1973).

Indianapolis $\left(39.7683^{\circ} \mathrm{N}, 86.1581^{\circ} \mathrm{W}\right)$ (Neumann, 1940).

Indianapolis $\left(39.7683^{\circ} \mathrm{N}, 86.1581^{\circ} \mathrm{W}\right)$-Perceptible in the taller buildings. (Westland and Heinrich, 1940).

Indianapolis $\left(39.7683^{\circ} \mathrm{N}, 86.1581^{\circ} \mathrm{W}\right)$ - “Reports of the earthquake came from as far away as St. Louis, Indianapolis, Detroit and Louisville." (Reis, 2002).

Richmond $\left(39.8289^{\circ} \mathrm{N}, 84.8903^{\circ} \mathrm{W}\right)$ (Neumann, 1940).

Rushville $\left(39.6092^{\circ} \mathrm{N}, 85.4464^{\circ} \mathrm{W}\right)$ (Neumann, 1940).

Union City $\left(40.1959^{\circ} \mathrm{N}, 84.8489^{\circ} \mathrm{W}\right)$ (Neumann, 1940).

Ludlow $\left(39.0889^{\circ} \mathrm{N}, 84.5483^{\circ} \mathrm{W}\right)$ - "Police reported crowds in the streets of Ludlow - afraid to go back inside buildings." (Reis, 2002).

Newport $\left(39.0831^{\circ} \mathrm{N}, 84.4841^{\circ} \mathrm{W}\right)$ - “People fled the Newport courthouse fearing the building might collapse. ... An account the next day said workers reported that one flood-weakened house in Newport's west end collapsed after the earthquake." (Reis, 2002). 


\section{Appendix 1, Part 35. Damage Reports and Intensity Assignments}

the next day said workers reported that one flood-weakened house in Newport's west end collapsed after the earthquake." (Reis, 2002).

$5 \mathrm{OH}$

$5 \mathrm{OH}$

$\mathrm{OH}$

$\mathrm{OH}$

$\mathrm{OH}$

$\mathrm{OH}$

$\mathrm{OH}$

$\mathrm{OH}$

$\mathrm{OH}$

$\mathrm{OH}$

IN

$4 \mathrm{KY}$

$4 \mathrm{Ml}$

MI

$4 \mathrm{MI}$

MI

$4 \mathrm{OH}$

$4 \mathrm{OH}$

$4 \mathrm{OH}$

$4 \mathrm{OH}$

$3 \mathrm{OH}$

$3 \mathrm{OH}$

$\mathrm{OH}$

$2 \quad \mathrm{IN}$

IN

G $\mathrm{OH}$

$\mathrm{G} \quad \mathrm{OH}$

F IN

F IN

F IN

F $\quad K Y$

F KY

F $\quad$ MO
Greenville $\left(40.1028^{\circ} \mathrm{N}, 84.6331^{\circ} \mathrm{W}\right)$ (Neumann, 1940).

Lima $\left(40.7609^{\circ} \mathrm{N}, 84.071^{\circ} \mathrm{W}\right)$ (Neumann, 1940).

Lima $\left(40.7609^{\circ} \mathrm{N}, 84.071^{\circ} \mathrm{W}\right)$-At Lima and Bellefontaine, alarm was general, but damage was minor. (Coffman and von Hake, 1973).

North College Hill $\left(39.2300^{\circ} \mathrm{N}, 84.55^{\circ} \mathrm{W}\right)$ (Neumann, 1940).

Piqua $\left(40.1447^{\circ} \mathrm{N}, 84.2425^{\circ} \mathrm{W}\right)$ (Neumann, 1940).

Sedamsville $\left(39.0933^{\circ} \mathrm{N}, 84.5731^{\circ} \mathrm{W}\right)$ (Neumann, 1940).

Van Wert $\left(40.8694^{\circ} \mathrm{N}, 84.5842^{\circ} \mathrm{W}\right)$ (Neumann, 1940).

Versailles $\left(40.2225^{\circ} \mathrm{N}, 84.4844^{\circ} \mathrm{W}\right)$ (Neumann, 1940).

Washington Courthouse $\left(39.4603^{\circ} \mathrm{N}, 81.4942^{\circ} \mathrm{W}\right)$ (Neumann, 1940).

Zanesfield $\left(40.3383^{\circ} \mathrm{N}, 83.6772^{\circ} \mathrm{W}\right)$ (Neumann, 1940).

South Bend $\left(41.6667^{\circ} \mathrm{N}, 86.3^{\circ} \mathrm{W}\right)$-Dog barked, chandeliers swayed, furniture moved, a floor lamp swayed, thousands felt it and thousands didn't. (Westland and Heinrich, 1940).

Covington $\left(39.0715^{\circ} \mathrm{N}, 84.5279^{\circ} \mathrm{W}\right)$ - "State highway department officials reported severe shaking on the seventh floor of the Coppin Building in Covington. similar reports came from the Bank of Alexandria, Speers Hospital in Dayton and in Independence." (Reis, 2002).

Ann Arbor $\left(42.2807^{\circ} \mathrm{N}, 83.7983^{\circ} \mathrm{W}\right)$ - The shock was sharply felt at Ann Arbor, Mich. (Coffman and von Hake, 1973).

Ann Arbor $\left(42.2807^{\circ} \mathrm{N}, 83.7983^{\circ} \mathrm{W}\right)$-Lamp chain rattled. (Westland and Heinrich, 1940).

Detroit $\left(42.3314^{\circ} \mathrm{N}, 83.0458^{\circ} \mathrm{W}\right)$-Felt quite generally. News reports from this city say the shock was felt in Windsor, Ontario. (Westland and Heinrich, 1940).

Detroit $\left(42.3314^{\circ} \mathrm{N}, 83.0458^{\circ} \mathrm{W}\right)$ - "Reports of the earthquake came from as far away as St. Louis, Indianapolis, Detroit and Louisville." (Reis, 2002).

Bellefontaine $\left(40.3705^{\circ} \mathrm{N}, 83.7537^{\circ} \mathrm{W}\right)$-At Lima and Bellefontaine, alarm was general, but damage was minor. (Coffman and von Hake, 1973).

Cincinnati $\left(39.1054^{\circ} \mathrm{N}, 84.5022^{\circ} \mathrm{W}\right)$ - The shock was generally felt at Cincinnati, and less so in Cleveland. (Coffman and von Hake, 1973).

Independence $\left(41.3836^{\circ} \mathrm{N}, 81.6532^{\circ} \mathrm{W}\right)$ - "State highway department officials reported severe shaking on the seventh floor of the Coppin Building in Covington. similar reports came from the Bank of Alexandria, Speers Hospital in Dayton and in Independence." (Reis, 2002).

Phillipsburg $\left(39.9045^{\circ} \mathrm{N}, 84.4013^{\circ} \mathrm{W}\right)$-Windows and stove rattled, but no damage done. (Westland and Heinrich, 1940).

Cleveland $\left(41.5000^{\circ} \mathrm{N}, 81.7^{\circ} \mathrm{W}\right)$ - The shock was generally felt at Cincinnati, and less so in Cleveland. (Coffman and von Hake, 1973).

Dayton $\left(39.7500^{\circ} \mathrm{N}, 84.2^{\circ} \mathrm{W}\right)$-Desk and typewriters seemed to shake, "felt as if the entire building was trembling. Did not notice windows rattling or any other noise; lasted only a few seconds, I believe." (Westland and Heinrich, 1940).

Dayton $\left(39.7500^{\circ} \mathrm{N}, 84.2^{\circ} \mathrm{W}\right)$ - "State highway department officials reported severe shaking on the seventh floor of the Coppin Building in Covington. similar reports came from the Bank of Alexandria, Speers Hospital in Dayton and in Independence." (Reis, 2002).

Evansville $\left(38.0000^{\circ} \mathrm{N}, 87.55^{\circ} \mathrm{W}\right)$-Felt by several persons in tall buildings. (Westland and Heinrich, 1940).

Evansville $\left(38.0000^{\circ} \mathrm{N}, 87.55^{\circ} \mathrm{W}\right)$-Perceptible in the taller buildings. (Westland and Heinrich, 1940).

Huntsville $\left(40.4457^{\circ} \mathrm{N}, 83.8151^{\circ} \mathrm{W}\right)$-At Huntsville, fifteen miles east of Anna, a gas well diminished its supply after the first [March 2] earthquake. ... After the second shock ... a spring dry for eight years began "spouting water like a well." (Westland and Heinrich, 1940).

New Knoxville $\left(40.4998^{\circ} \mathrm{N}, 84.298^{\circ} \mathrm{W}\right)$-At New Knoxville, twenty-five miles southwest of Lima, artesian wells that before the March 2 earthquake spouted eight feet high began spouting fifteen feet high. (Westland and Heinrich, 1940).

Muncie $\left(40.1738^{\circ} \mathrm{N}, 85.3819^{\circ} \mathrm{W}\right)$-Telephone service disrupted. (Westland and Heinrich, 1940).

Peru $\left(40.7571^{\circ} \mathrm{N}, 86.0595^{\circ} \mathrm{W}\right)$ - “At Peru and Rochester, circus winter headquarters, elephants trumpeted, lions and tigers roared, as the earth shook. It took two hour to quiet the animals." (Westland and Heinrich, 1940).

Rochester $\left(41.0726^{\circ} \mathrm{N}, 86.2508^{\circ} \mathrm{W}\right)$ - “At Peru and Rochester, circus winter headquarters, elephants trumpeted, lions and tigers roared, as the earth shook. It took two hour to quiet the animals." (Westland and Heinrich, 1940).

Boone County $\left(38.9737^{\circ} \mathrm{N}, 84.7296^{\circ} \mathrm{W}\right)$ - “In Boone County, Burlington High School was evacuated as a precaution." (Reis, 2002).

Louisville $\left(38.2500^{\circ} \mathrm{N}, 85.75^{\circ} \mathrm{W}\right)$ - "Reports of the earthquake came from as far away as St. Louis, Indianapolis, Detroit and Louisville." (Reis, 2002).

Saint Louis $\left(38.6667^{\circ} \mathrm{N}, 90.19^{\circ} \mathrm{W}\right)$ - “Reports of the earthquake came from as far away as St. Louis, Indianapolis, Detroit and Louisville." (Reis, 2002). 


\section{Appendix 1, Part 36. Damage Reports and Intensity Assignments}

\section{\#36 1937 March 9 05:44 UTC (Ohlo)}

8D OHD ANNA $\left(40.3944^{\circ} \mathrm{N}, 84.1728^{\circ} \mathrm{W}\right)$-Damage in the town of Anna was much greater [than from the March 2, 1937 shock] and could possibly be considered as reaching VIII (Wood-Neumann Scale). The three-story schoolhouse was badly cracked, and the Methodist and Lutheran churches were further damaged. Almost every chimney was broken or twisted, and many foundations and walls were cracked. ...

In the vicinity of Anna, rotary movement resulted from both earthquakes. ... The senior author examined carefully the rotational effect in three cemeteries, one about two miles to the south of Anna, one on the northern edge of the village, and the third a mile beyond. ... Of the twenty-four tombstones examined in the cemetery to the south, all but three had been rotated in a clockwise direction. In the cemetery on the northern edge of town, all seemed to have been rotated $\mathrm{n}$ a counterclockwise direction. At the third, some were rotated in one direction and some in another. ... The caretaker in the cemetery south of the village stated that many stones had been rotated by the first earthquake in the same directions as those indicated by the way they were found. (Westland and Heinrich, 1940).

$\mathrm{OH}$

$\mathrm{OH}$

$\mathrm{OH}$

$7 \mathrm{OH}$

$\mathrm{OH}$

$7 \mathrm{OH}$

$7 \mathrm{OH}$

$\mathrm{OH}$

$\mathrm{OH}$

$6 \mathrm{OH}$

$6 \mathrm{OH}$

$6 \mathrm{OH}$

$5 \quad$ IN

$5 \mathrm{OH}$

$5 \mathrm{OH}$

$5 \mathrm{OH}$

$5 \mathrm{OH}$

$5 \mathrm{OH}$

$4 \mathrm{OH}$

$4 \mathrm{OH}$

2 IL

IL

2 IN

IN

$2 \mathrm{IN}$

IN

$2 \mathrm{KY}$

$K Y$

$2 \mathrm{MO}$

MO

ANNA $\left(40.3944^{\circ} \mathrm{N}, 84.1728^{\circ} \mathrm{W}\right)$ - The three-story schoolhouse at Anna was cracked severely, and the churches that were damaged in the Mar. 2 shock were further damaged. Almost every chimney was broken or twisted, and house foundations and walls were cracked. (Stover and Coffman, 1993).

ANNA $\left(40.3944^{\circ} \mathrm{N}, 84.1728^{\circ} \mathrm{W}\right)$-Additional damage [following shock on March 2] was done to the school, and two small brick churches were more seriously damaged, while many dwellings suffered minor damage. (National Earthquake Information Center, Earthquake Data Base System).

ANNA $\left(40.3944^{\circ} \mathrm{N}, 84.1728^{\circ} \mathrm{W}\right)$-Reached destructive intensity in the region of Anna, Ohio. (Heinrich, R.R., 1941, A contribution to the seismic history of Missouri: Seismological Society of America Bulletin, v. 31, no. 3, p. 187-224.). HUNTSVILLE $\left(40.4433^{\circ} \mathrm{N}, 83.805^{\circ} \mathrm{W}\right.$ ) (National Earthquake Information Center, Earthquake Data Base System).

HUNTSVILLE $\left(40.4433^{\circ} \mathrm{N}, 83.805^{\circ} \mathrm{W}\right)$-At Huntsville, fifteen miles east of Anna, a gas well diminished its supply after the first [March 2] earthquake. ... After the second shock ... a spring dry for eight years began "spouting water like a well." (Westland and Heinrich, 1940).

JACKSON CENTER $\left(40.4400^{\circ} \mathrm{N}, 84.04^{\circ} \mathrm{W}\right)$-Felt strongest. (National Earthquake Information Center, Earthquake Data Base System).

NEW KNOXVILLE $\left(40.4936^{\circ} \mathrm{N}, 84.3147^{\circ} \mathrm{W}\right)$ (National Earthquake Information Center, Earthquake Data Base System).

NEW KNOXVILLE $\left(40.4936^{\circ} \mathrm{N}, 84.3147^{\circ} \mathrm{W}\right)$-At New Knoxville, twenty-five miles southwest of Lima, artesian wells that before the March 2 earthquake spouted eight feet high began spouting fifteen feet high. ... After the second shock ... the flow of the artesian wells was increased to a stream about eighteen feet high. (Westland and Heinrich, 1940).

SIDNEY $\left(40.2842^{\circ} \mathrm{N}, 84.1556^{\circ} \mathrm{W}\right)$ - A few chimneys fell at Sidney, about $12 \mathrm{~km}$ south of Anna, and plaster was damaged. (Stover and Coffman, 1993).

SIDNEY $\left(40.2842^{\circ} \mathrm{N}, 84.1556^{\circ} \mathrm{W}\right)$-Felt strongest. (National Earthquake Information Center, Earthquake Data Base System). BOTKINS $\left(40.4678^{\circ} \mathrm{N}, 84.1805^{\circ} \mathrm{W}\right)$-Felt strongest. (National Earthquake Information Center, Earthquake Data Base System). KETTLERSVILLE $\left(40.4389^{\circ} \mathrm{N}, 84.2614^{\circ} \mathrm{W}\right)$-Felt strongest. (National Earthquake Information Center, Earthquake Data Base System).

MCCARTYVILLE $\left(40.3947^{\circ} \mathrm{N}, 84.2558^{\circ} \mathrm{W}\right)$-Felt strongest. (National Earthquake Information Center, Earthquake Data Base System).

FORT WAYNE $\left(41.1306^{\circ} \mathrm{N}, 85.1289^{\circ} \mathrm{W}\right)$-Felt. (National Earthquake Information Center, Earthquake Data Base System). BRYAN $\left(41.4747^{\circ} \mathrm{N}, 84.5525^{\circ} \mathrm{W}\right)$-Felt strongest. (National Earthquake Information Center, Earthquake Data Base System). CINCINNATI $\left(39.1619^{\circ} \mathrm{N}, 84.4569^{\circ} \mathrm{W}\right)$-Felt. (National Earthquake Information Center, Earthquake Data Base System). PIQUA $\left(40.1447^{\circ} \mathrm{N}, 84.2425^{\circ} \mathrm{W}\right)$-Felt strongest. (National Earthquake Information Center, Earthquake Data Base System). VAN WERT $\left(40.8694^{\circ} \mathrm{N}, 84.5842^{\circ} \mathrm{W}\right)$-Felt strongest. (National Earthquake Information Center, Earthquake Data Base System).

WILMINGTON $\left(39.4453^{\circ} \mathrm{N}, 83.8286^{\circ} \mathrm{W}\right)$-Felt strongest. (National Earthquake Information Center, Earthquake Data Base System).

CLEVELAND $\left(41.4994^{\circ} \mathrm{N}, 81.6956^{\circ} \mathrm{W}\right)$-Felt. (National Earthquake Information Center, Earthquake Data Base System). DAYTON $\left(39.7589^{\circ} \mathrm{N}, 84.1917^{\circ} \mathrm{W}\right)$-Felt strongest. (National Earthquake Information Center, Earthquake Data Base System). CHICAGO $\left(41.8500^{\circ} \mathrm{N}, 87.65^{\circ} \mathrm{W}\right)$-People favorably situated felt the earthquake. (Westland and Heinrich, 1940).

CHICAGO $\left(41.8500^{\circ} \mathrm{N}, 87.65^{\circ} \mathrm{W}\right.$ ) (National Earthquake Information Center, Earthquake Data Base System).

EVANSVILLE $\left(37.9747^{\circ} \mathrm{N}, 87.5558^{\circ} \mathrm{W}\right)$-People favorably situated felt the earthquake. (Westland and Heinrich, 1940). EVANSVILLE $\left(37.9747^{\circ} \mathrm{N}, 87.5558^{\circ} \mathrm{W}\right)$-Felt. (National Earthquake Information Center, Earthquake Data Base System). VINCENNES $\left(38.6772^{\circ} \mathrm{N}, 87.5286^{\circ} \mathrm{W}\right)$-People favorably situated felt the earthquake. (Westland and Heinrich, 1940). VINCENNES $\left(38.6772^{\circ} \mathrm{N}, 87.5286^{\circ} \mathrm{W}\right.$ )-Felt. (National Earthquake Information Center, Earthquake Data Base System). LOUISVILLE $\left(38.2542^{\circ} \mathrm{N}, 85.7594^{\circ} \mathrm{W}\right)$-People favorably situated felt the earthquake. (Westland and Heinrich, 1940). LOUISVILLE $\left(38.2542^{\circ} \mathrm{N}, 85.7594^{\circ} \mathrm{W}\right)$-Felt. (National Earthquake Information Center, Earthquake Data Base System). SAINT LOUIS $\left(38.6272^{\circ} \mathrm{N}, 90.1978^{\circ} \mathrm{W}\right)$-People favorably situated felt the earthquake. (Westland and Heinrich, 1940). SAINT LOUIS $\left(38.6272^{\circ} \mathrm{N}, 90.1978^{\circ} \mathrm{W}\right.$ ) -Felt slightly in St. Louis. (Heinrich, R.R., 1941, A contribution to the seismic history of Missouri: Seismological Society of America Bulletin, v. 31, no. 3, p. 187-224.). 


\section{Appendix 1, Part 36. Damage Reports and Intensity Assignments}

$2 \mathrm{OH}$

$\mathrm{OH}$

$2 \mathrm{ON}$

ON

2 PA

PA

F IN

F IN

F IN

F IN

F IN

F IN

F IN

F IN

F IN

F IN

F IN

F IN

F IN

F IN

F KY

F KY

F KY

F KY

F KY

F MI

F MI

F MI

F MI

F MI

F MI

F MI

F MI

F MI

F MI

F MI

F MI

F MI

F MI

$\mathrm{F} \quad \mathrm{OH}$

$\mathrm{F} \quad \mathrm{OH}$

$\mathrm{F} \mathrm{OH}$

$\mathrm{F} \quad \mathrm{OH}$

$\mathrm{F} \quad \mathrm{OH}$

F $\mathrm{OH}$

$\mathrm{F} \quad \mathrm{OH}$

$\mathrm{F} \quad \mathrm{OH}$

$\mathrm{F} \mathrm{OH}$

$\mathrm{F} \mathrm{OH}$

$\mathrm{F} \quad \mathrm{OH}$

$\mathrm{F} \quad \mathrm{OH}$

F $\mathrm{OH}$

$\mathrm{F} \mathrm{OH}$

$\mathrm{F} \quad \mathrm{OH}$

$\mathrm{F} \mathrm{OH}$

$\mathrm{F} \quad \mathrm{OH}$

$\mathrm{F} \quad \mathrm{OH}$

$\mathrm{F} \quad \mathrm{OH}$

F $\mathrm{OH}$ $\begin{array}{ll}\text { MO } & \text { SAINT LOUIS }\left(38.6272^{\circ} \mathrm{N}, 90.1978^{\circ} \mathrm{W}\right) \text {-Felt. (National Earthquake Information Center, Earthquake Data Base System). } \\ \mathrm{OH} & \text { SPRINGFIELD }\left(39.9242^{\circ} \mathrm{N}, 83.8089^{\circ} \mathrm{W}\right) \text {-People favorably situated felt the earthquake. (Westland and Heinrich, 1940). }\end{array}$ SPRINGFIELD $\left(39.9242^{\circ} \mathrm{N}, 83.8089^{\circ} \mathrm{W}\right)$-Felt. (National Earthquake Information Center, Earthquake Data Base System). TORONTO $\left(43.3900^{\circ} \mathrm{N}, 79.23^{\circ} \mathrm{W}\right)$-People favorably situated felt the earthquake. (Westland and Heinrich, 1940). TORONTO $\left(43.3900^{\circ} \mathrm{N}, 79.23^{\circ} \mathrm{W}\right.$ ) -Felt. (National Earthquake Information Center, Earthquake Data Base System). PITTSBURGH $\left(40.4406^{\circ} \mathrm{N}, 79.9961^{\circ} \mathrm{W}\right)$-People favorably situated felt the earthquake. (Westland and Heinrich, 1940). PITTSBURGH $\left(40.4406^{\circ} \mathrm{N}, 79.9961^{\circ} \mathrm{W}\right)$-Felt. (National Earthquake Information Center, Earthquake Data Base System). ANGOLA $\left(41.6347^{\circ} \mathrm{N}, 84.9994^{\circ} \mathrm{W}\right)$-Felt. (National Earthquake Information Center, Earthquake Data Base System). BERNE $\left(40.6578^{\circ} \mathrm{N}, 84.9519^{\circ} \mathrm{W}\right)$-Felt. (National Earthquake Information Center, Earthquake Data Base System). CRAWFORDSVILLE $\left(40.0411^{\circ} \mathrm{N}, 86.8744^{\circ} \mathrm{W}\right)$-Felt. (National Earthquake Information Center, Earthquake Data Base System). ELKHART $\left(41.6819^{\circ} \mathrm{N}, 85.9767^{\circ} \mathrm{W}\right)$-Felt. (National Earthquake Information Center, Earthquake Data Base System). GARY $\left(41.5933^{\circ} \mathrm{N}, 87.3464^{\circ} \mathrm{W}\right)$-Felt. (National Earthquake Information Center, Earthquake Data Base System). INDIANAPOLIS $\left(39.7683^{\circ} \mathrm{N}, 86.1581^{\circ} \mathrm{W}\right.$ )-Felt. (National Earthquake Information Center, Earthquake Data Base System). KENDALLVILLE $\left(41.4414^{\circ} \mathrm{N}, 85.265^{\circ} \mathrm{W}\right)$-Felt. (National Earthquake Information Center, Earthquake Data Base System). LAFAYETTE $\left(40.4167^{\circ} \mathrm{N}, 86.875^{\circ} \mathrm{W}\right)$-Felt. (National Earthquake Information Center, Earthquake Data Base System). MARION $\left(39.5917^{\circ} \mathrm{N}, 85.755^{\circ} \mathrm{W}\right)$-Felt. (National Earthquake Information Center, Earthquake Data Base System). PORTLAND $\left(40.4344^{\circ} \mathrm{N}, 84.9778^{\circ} \mathrm{W}\right)$-Felt. (National Earthquake Information Center, Earthquake Data Base System). RICHMOND $\left(39.8289^{\circ} \mathrm{N}, 84.8903^{\circ} \mathrm{W}\right)$-Felt. (National Earthquake Information Center, Earthquake Data Base System). SOUTH BEND $\left(41.6833^{\circ} \mathrm{N}, 86.25^{\circ} \mathrm{W}\right)$-Felt. (National Earthquake Information Center, Earthquake Data Base System). TERRE HAUTE $\left(39.4667^{\circ} \mathrm{N}, 87.4139^{\circ} \mathrm{W}\right)$-Felt. (National Earthquake Information Center, Earthquake Data Base System). WARSAW $\left(41.2381^{\circ} \mathrm{N}, 85.8531^{\circ} \mathrm{W}\right.$ ) -Felt. (National Earthquake Information Center, Earthquake Data Base System). COLLEGE HILL $\left(37.7867^{\circ} \mathrm{N}, 84.1233^{\circ} \mathrm{W}\right)$-Felt. (National Earthquake Information Center, Earthquake Data Base System). COVINGTON $\left(39.0836^{\circ} \mathrm{N}, 84.5086^{\circ} \mathrm{W}\right)$-Felt. (National Earthquake Information Center, Earthquake Data Base System). FRANKFORT $\left(38.2008^{\circ} \mathrm{N}, 84.8733^{\circ} \mathrm{W}\right)$-Felt. (National Earthquake Information Center, Earthquake Data Base System). LEXINGTON (38.0492 $\mathrm{N}, 84.5003^{\circ} \mathrm{W}$ )-Felt. (National Earthquake Information Center, Earthquake Data Base System). SHIVELY $\left(38.2000^{\circ} \mathrm{N}, 85.8228^{\circ} \mathrm{W}\right)$-Felt. (National Earthquake Information Center, Earthquake Data Base System). ADRIAN $\left(41.8975^{\circ} \mathrm{N}, 84.0372^{\circ} \mathrm{W}\right)$-Felt. (National Earthquake Information Center, Earthquake Data Base System). ANN ARBOR $\left(42.2833^{\circ} \mathrm{N}, 83.7458^{\circ} \mathrm{W}\right)$-Felt. (National Earthquake Information Center, Earthquake Data Base System). DETROIT $\left(42.3314^{\circ} \mathrm{N}, 83.0458^{\circ} \mathrm{W}\right)$-Felt. (National Earthquake Information Center, Earthquake Data Base System). EAST LANSING $\left(42.7369^{\circ} \mathrm{N}, 84.4839^{\circ} \mathrm{W}\right)$-Felt. (National Earthquake Information Center, Earthquake Data Base System). ESCANABA $\left(45.7453^{\circ} \mathrm{N}, 87.0644^{\circ} \mathrm{W}\right)$-Felt. (National Earthquake Information Center, Earthquake Data Base System). FULTON $\left(47.2989^{\circ} \mathrm{N}, 88.36^{\circ} \mathrm{W}\right)$-Felt. (National Earthquake Information Center, Earthquake Data Base System). GRAND RAPIDS $\left(42.9633^{\circ} \mathrm{N}, 85.6681^{\circ} \mathrm{W}\right)$-Felt. (National Earthquake Information Center, Earthquake Data Base System). HIGHLAND PARK $\left(42.4056^{\circ} \mathrm{N}, 83.0969^{\circ} \mathrm{W}\right)$-Felt. (National Earthquake Information Center, Earthquake Data Base System). IONIA $\left(42.9872^{\circ} \mathrm{N}, 85.0711^{\circ} \mathrm{W}\right)$-Felt. (National Earthquake Information Center, Earthquake Data Base System). KALAMAZOO $\left(42.2917^{\circ} \mathrm{N}, 85.5872^{\circ} \mathrm{W}\right)$-Felt. (National Earthquake Information Center, Earthquake Data Base System). LANSING $\left(42.7325^{\circ} \mathrm{N}, 84.5556^{\circ} \mathrm{W}\right)$-Felt. (National Earthquake Information Center, Earthquake Data Base System). MASON $\left(44.0000^{\circ} \mathrm{N}, 86.28^{\circ} \mathrm{W}\right.$ ) - Felt. (National Earthquake Information Center, Earthquake Data Base System). OLIVET $\left(42.4414^{\circ} \mathrm{N}, 84.9242^{\circ} \mathrm{W}\right)$-Felt. (National Earthquake Information Center, Earthquake Data Base System). PAW PAW $\left(42.2178^{\circ} \mathrm{N}, 85.8911^{\circ} \mathrm{W}\right)$-Felt. (National Earthquake Information Center, Earthquake Data Base System). AKRON $\left(41.0814^{\circ} \mathrm{N}, 81.5192^{\circ} \mathrm{W}\right)$-Felt. (National Earthquake Information Center, Earthquake Data Base System). BELLEFONTAINE $\left(40.3611^{\circ} \mathrm{N}, 83.7597^{\circ} \mathrm{W}\right)$-Felt. (National Earthquake Information Center, Earthquake Data Base System). BUCYRUS $\left(40.8083^{\circ} \mathrm{N}, 82.9756^{\circ} \mathrm{W}\right)$-Felt. (National Earthquake Information Center, Earthquake Data Base System). CALEDONIA $\left(40.6364^{\circ} \mathrm{N}, 82.9692^{\circ} \mathrm{W}\right)$-Felt. (National Earthquake Information Center, Earthquake Data Base System). CHEVIOT $\left(39.1569^{\circ} \mathrm{N}, 84.6133^{\circ} \mathrm{W}\right)$-Felt. (National Earthquake Information Center, Earthquake Data Base System). COLUMBUS $\left(39.9611^{\circ} \mathrm{N}, 82.9989^{\circ} \mathrm{W}\right)$-Felt. (National Earthquake Information Center, Earthquake Data Base System). CORYVILLE $\left(38.5436^{\circ} \mathrm{N}, 82.6647^{\circ} \mathrm{W}\right)$-Felt. (National Earthquake Information Center, Earthquake Data Base System). DELAWARE $\left(40.2986^{\circ} \mathrm{N}, 83.0681^{\circ} \mathrm{W}\right)$-Felt. (National Earthquake Information Center, Earthquake Data Base System). FINDLAY $\left(41.0442^{\circ} \mathrm{N}, 83.65^{\circ} \mathrm{W}\right)$-Felt. (National Earthquake Information Center, Earthquake Data Base System). FOSTORIA $\left(41.1569^{\circ} \mathrm{N}, 83.4169^{\circ} \mathrm{W}\right)$-Felt. (National Earthquake Information Center, Earthquake Data Base System). GALION $\left(40.7336^{\circ} \mathrm{N}, 82.79^{\circ} \mathrm{W}\right)$-Felt. (National Earthquake Information Center, Earthquake Data Base System). HAMILTON $\left(39.3994^{\circ} \mathrm{N}, 84.5614^{\circ} \mathrm{W}\right)$-Felt. (National Earthquake Information Center, Earthquake Data Base System). HILLSBORO $\left(39.2022^{\circ} \mathrm{N}, 83.6117^{\circ} \mathrm{W}\right)$-Felt. (National Earthquake Information Center, Earthquake Data Base System). LIMA $\left(40.7425^{\circ} \mathrm{N}, 84.1053^{\circ} \mathrm{W}\right)$-Felt. (National Earthquake Information Center, Earthquake Data Base System). LOCKINGTON $\left(40.2081^{\circ} \mathrm{N}, 84.2339^{\circ} \mathrm{W}\right)$-Felt. (National Earthquake Information Center, Earthquake Data Base System). MARION $\left(40.5886^{\circ} \mathrm{N}, 83.1286^{\circ} \mathrm{W}\right)$-Felt. (National Earthquake Information Center, Earthquake Data Base System). MARYSVILLE $\left(40.2364^{\circ} \mathrm{N}, 83.3672^{\circ} \mathrm{W}\right)$-Felt. (National Earthquake Information Center, Earthquake Data Base System). Massillion $\left(40.7967^{\circ} \mathrm{N}, 81.5217^{\circ} \mathrm{W}\right)$-Felt. (National Earthquake Information Center, Earthquake Data Base System). MIAMISBURG $\left(39.6428^{\circ} \mathrm{N}, 84.2867^{\circ} \mathrm{W}\right)$-Felt. (National Earthquake Information Center, Earthquake Data Base System). MIDDLETOWN $\left(39.5150^{\circ} \mathrm{N}, 84.3983^{\circ} \mathrm{W}\right)$-Felt. (National Earthquake Information Center, Earthquake Data Base System). 


\section{Appendix 1, Part 36. Damage Reports and Intensity Assignments}

$\mathrm{F} \quad \mathrm{OH} \quad$ MOUNT GILEAD $\left(40.5492^{\circ} \mathrm{N}, 82.8275^{\circ} \mathrm{W}\right)$-Felt. (National Earthquake Information Center, Earthquake Data Base System). F OH MOUNT HEALTHY $\left(39.2336^{\circ} \mathrm{N}, 84.5458^{\circ} \mathrm{W}\right)$-Felt. (National Earthquake Information Center, Earthquake Data Base System).

$\mathrm{F} \quad \mathrm{OH}$

$\mathrm{F} \quad \mathrm{OH}$

$\mathrm{F} \quad \mathrm{OH}$

$\mathrm{F} \quad \mathrm{OH}$

$\mathrm{F} \quad \mathrm{OH}$

$\mathrm{F} \quad \mathrm{OH}$

$\mathrm{F} \quad \mathrm{OH}$

$\mathrm{F} \quad \mathrm{OH}$

$\mathrm{F} \quad \mathrm{OH}$

$\mathrm{F} \mathrm{OH}$

$\mathrm{F} \mathrm{OH}$

$\mathrm{F} \quad \mathrm{OH}$

$\mathrm{F} \mathrm{OH}$

$\mathrm{F} \quad \mathrm{OH}$

$\mathrm{F} \quad \mathrm{OH}$

$\mathrm{F} \quad \mathrm{OH}$

$\mathrm{F} \quad \mathrm{OH}$

$\mathrm{F} \quad \mathrm{OH}$

$\mathrm{F} \quad \mathrm{OH}$

$\mathrm{F}$ ON

F ON

F WI

F WI

F WV
NEW BREMEN $\left(40.4369^{\circ} \mathrm{N}, 84.3797^{\circ} \mathrm{W}\right)$-Felt. (National Earthquake Information Center, Earthquake Data Base System). NEWARK $\left(40.0581^{\circ} \mathrm{N}, 82.4014^{\circ} \mathrm{W}\right)$-Felt. (National Earthquake Information Center, Earthquake Data Base System).

Ostrander $\left(40.2661^{\circ} \mathrm{N}, 83.2128^{\circ} \mathrm{W}\right)$-Felt. (National Earthquake Information Center, Earthquake Data Base System). PAULDING $\left(41.1381^{\circ} \mathrm{N}, 84.5806^{\circ} \mathrm{W}\right)$-Felt. (National Earthquake Information Center, Earthquake Data Base System). PHILO $\left(39.8611^{\circ} \mathrm{N}, 81.9069^{\circ} \mathrm{W}\right)$-Felt. (National Earthquake Information Center, Earthquake Data Base System). PROSPECT $\left(40.4503^{\circ} \mathrm{N}, 83.1886^{\circ} \mathrm{W}\right)$-Felt. (National Earthquake Information Center, Earthquake Data Base System). RIPLEY $\left(38.7456^{\circ} \mathrm{N}, 83.845^{\circ} \mathrm{W}\right)$-Felt. (National Earthquake Information Center, Earthquake Data Base System). SAINT MARYS $\left(40.5422^{\circ} \mathrm{N}, 84.3894^{\circ} \mathrm{W}\right)$-Felt. (National Earthquake Information Center, Earthquake Data Base System). SANDUSKY $\left(41.4489^{\circ} \mathrm{N}, 82.7081^{\circ} \mathrm{W}\right)$-Felt. (National Earthquake Information Center, Earthquake Data Base System). SHELBY $\left(40.8814^{\circ} \mathrm{N}, 82.6619^{\circ} \mathrm{W}\right)$-Felt. (National Earthquake Information Center, Earthquake Data Base System). TIFFIN (41.1144 $\left.\mathrm{N}, 83.1781^{\circ} \mathrm{W}\right)$-Felt. (National Earthquake Information Center, Earthquake Data Base System). TOLEDO $\left(41.6639^{\circ} \mathrm{N}, 83.5553^{\circ} \mathrm{W}\right)$-Felt. (National Earthquake Information Center, Earthquake Data Base System). TROY $\left(40.0394^{\circ} \mathrm{N}, 84.2033^{\circ} \mathrm{W}\right)$-Felt. (National Earthquake Information Center, Earthquake Data Base System). UPPER SANDUSKY $\left(40.8272^{\circ} \mathrm{N}, 83.2814^{\circ} \mathrm{W}\right)$-Felt. (National Earthquake Information Center, Earthquake Data Base System). URBANA $\left(40.1083^{\circ} \mathrm{N}, 83.7525^{\circ} \mathrm{W}\right)$-Felt. (National Earthquake Information Center, Earthquake Data Base System). WARREN $\left(39.4300^{\circ} \mathrm{N}, 84.17^{\circ} \mathrm{W}\right)$-Felt. (National Earthquake Information Center, Earthquake Data Base System). Washington Court House $\left(39.5364^{\circ} \mathrm{N}, 83.4392^{\circ} \mathrm{W}\right)$-Felt. (National Earthquake Information Center, Earthquake Data Base System).

WAUSEON (41.5492 $\left.\mathrm{N}, 84.1417^{\circ} \mathrm{W}\right)$-Felt. (National Earthquake Information Center, Earthquake Data Base System). ZANESVILLE $\left(39.9403^{\circ} \mathrm{N}, 82.0133^{\circ} \mathrm{W}\right)$-Felt. (National Earthquake Information Center, Earthquake Data Base System). LONDON $\left(42.5900^{\circ} \mathrm{N}, 81.14^{\circ} \mathrm{W}\right)$-Felt. (National Earthquake Information Center, Earthquake Data Base System). SAINT THOMAS $\left(42.4700^{\circ} \mathrm{N}, 81.12^{\circ} \mathrm{W}\right)$-Felt. (National Earthquake Information Center, Earthquake Data Base System). MADISON $\left(43.0731^{\circ} \mathrm{N}, 89.4011^{\circ} \mathrm{W}\right)$-Felt. (National Earthquake Information Center, Earthquake Data Base System). MILWAUKEE $\left(43.0389^{\circ} \mathrm{N}, 87.9064^{\circ} \mathrm{W}\right)$-Felt. (National Earthquake Information Center, Earthquake Data Base System). HUNTINGTON $\left(38.4192^{\circ} \mathrm{N}, 82.4453^{\circ} \mathrm{W}\right)$-Felt. (National Earthquake Information Center, Earthquake Data Base System). 


\section{Appendix 1, Part 37. Damage Reports and Intensity Assignments}

\section{\#37 1938 Sept. 17 03:34UTC (Arkansas)}

$\begin{array}{ll}\text { TN } & \text { Bolivar }\left(35.2667^{\circ} \mathrm{N}, 88.9833^{\circ} \mathrm{W}\right) \text { (Moneymaker, 1958). } \\ \text { TN } & \text { Covington }\left(35.5333^{\circ} \mathrm{N}, 89.6667^{\circ} \mathrm{W}\right) \text { (Moneymaker, 1958). } \\ \text { TN } & \text { Dyersburg }\left(36.0333^{\circ} \mathrm{N}, 89.35^{\circ} \mathrm{W}\right)(\text { Moneymaker, 1958). } \\ \text { TN } & \text { Humboldt }\left(35.8333^{\circ} \mathrm{N}, 88.9667^{\circ} \mathrm{W}\right)(\text { Moneymaker, 1958). } \\ \text { TN } & \text { Huntingdon }\left(36.0000^{\circ} \mathrm{N}, 88.45^{\circ} \mathrm{W}\right)(\text { Moneymaker, 1958). } \\ \text { TN } & \text { Jackson }\left(35.6167^{\circ} \mathrm{N}, 88.8333^{\circ} \mathrm{W}\right)(\text { Moneymaker, 1958). } \\ \text { TN } & \text { Memphis }\left(35.1167^{\circ} \mathrm{N}, 90.0833^{\circ} \mathrm{W}\right)(\text { Moneymaker, 1958). } \\ \text { TN } & \text { Paris }\left(36.2833^{\circ} \mathrm{N}, 88.3333^{\circ} \mathrm{W}\right)(\text { Moneymaker, 1958). } \\ \text { TN } & \text { Ripley }\left(35.7500^{\circ} \mathrm{N}, 89.55^{\circ} \mathrm{W}\right)(\text { Moneymaker, 1958). } \\ \text { TN } & \text { Union City }\left(36.4167^{\circ} \mathrm{N}, 89.05^{\circ} \mathrm{W}\right)(\text { Moneymaker, 1958). } \\ \text { AR } & \text { Eureka Springs }\left(36.4426^{\circ} \mathrm{N}, 93.7408^{\circ} \mathrm{W}\right)(\text { Walter, 1939). } \\ \text { AR } & \text { Fayetteville }\left(36.0655^{\circ} \mathrm{N}, 94.1557^{\circ} \mathrm{W}\right)(\text { Walter, 1939). } \\ \text { OK } & \text { Muskogee }\left(35.7536^{\circ} \mathrm{N}, 95.3889^{\circ} \mathrm{W}\right)(\text { Walter, 1939). } \\ \text { OK } & \text { Okmulgee }\left(35.6450^{\circ} \mathrm{N}, 96.0289^{\circ} \mathrm{W}\right)(\text { Walter, 1939). } \\ \text { AR } & \text { Fort Smith }\left(35.3692^{\circ} \mathrm{N}, 94.4147^{\circ} \mathrm{W}\right)(\text { Walter, 1939). } \\ \text { MO } & \text { Saint Louis }\left(38.6590^{\circ} \mathrm{N}, 90.2496^{\circ} \mathrm{W}\right) \text { (Walter, 1939). } \\ \text { OK } & \text { Shawnee }\left(35.3469^{\circ} \mathrm{N}, 96.9262^{\circ} \mathrm{W}\right)(\text { Walter, 1939). } \\ \text { TN } & \text { Wildersville }\left(35.8000^{\circ} \mathrm{N}, 88.3667^{\circ} \mathrm{W}\right) \text { (Moneymaker, 1958). }\end{array}$




\section{Appendix 1, Part 38. Damage Reports and Intensity Assignments}

\section{\#38 1952 April 9 16:29UTC (Oklahoma)}

7 OK

$6 \quad \mathrm{OK}$

$6 \quad \mathrm{OK}$

OK

6 OK

6 OK

$6 \quad \mathrm{OK}$

$6 \quad \mathrm{OK}$

6 OK

6 OK

6

El Reno $\left(35.5502^{\circ} \mathrm{N}, 97.9671^{\circ} \mathrm{W}\right)$-Felt by all and many alarmed to near panic. Brick chimney fell into living room of house; portion of smokestack fell and ripped 2-foot hole in roof at water plant. Many cracks reported in municipal buildings. Plate glass windows shattered in business district; dishes broke; books and canned goods tumbled from shelves; furniture moved around. Damage amounted to several thousand dollars. (Murphy and Cloud, 1954).

Ames $\left(36.2327^{\circ} \mathrm{N}, 98.1872^{\circ} \mathrm{W}\right)$-Proportion of citizens felt rocking motion. Plaster walls cracked. Slight damage. (Murphy and Cloud, 1954).

Anadarko $\left(35.1083^{\circ} \mathrm{N}, 98.2081^{\circ} \mathrm{W}\right)$ - Many felt violent tremors. Museum wall cracked. Small objects disturbed. (Murphy and Cloud, 1954).

Anadarko $\left(35.1083^{\circ} \mathrm{N}, 98.2081^{\circ} \mathrm{W}\right)$ (Murphy and Cloud, 1954).

Atoka $\left(34.3389^{\circ} \mathrm{N}, 96.1714^{\circ} \mathrm{W}\right)$-Populace aware of quake. Near panic at the school as walls cracked and plaster fell. Dishes rattled, windows broke. (Murphy and Cloud, 1954).

Canton $\left(35.9877^{\circ} \mathrm{N}, 98.57^{\circ} \mathrm{W}\right)$-Few people observed small objects moving and buildings swaying. Concrete blockhouse had walls and foundation cracked. (Murphy and Cloud, 1954).

Chickasha $\left(35.0356^{\circ} \mathrm{N}, 97.9493^{\circ} \mathrm{W}\right)$-Everyone heard rumblings that created general alarm. Slight damage to tall buildings. Plaster walls cracked, some plaster fell. (Murphy and Cloud, 1954).

Cleveland $\left(36.2411^{\circ} \mathrm{N}, 96.4562^{\circ} \mathrm{W}\right)$-Many felt abrupt shock. Flagpole noticed swaying. Several plaster walls, ceilings and cellar wall cracked. Some plaster removed. Small objects disturbed, electric lights and chairs swayed, dishes rattled. (Murphy and Cloud, 1954).

Cushing $\left(35.9971^{\circ} \mathrm{N}, 96.7374^{\circ} \mathrm{W}\right)$-Glass door cracked, as well as numerous cases of cracked plaster. Houses and wellconstructed buildings shook as the quake was felt inside and out. Electric iron was thrown from ironing board. Bottles 'jigged' and dishes and windows rattled. (Murphy and Cloud, 1954).

Enid $\left(36.4038^{\circ} \mathrm{N}, 97.8726^{\circ} \mathrm{W}\right)$-Grain elevator cracked - 'the place was really jumping. I thought someone was shaking the conveyor belt. Cellar concrete floor of a brick home had two long cracks with east-west strike.' (Murphy and Cloud, 1954).

Hanna $\left(35.2159^{\circ} \mathrm{N}, 95.8819^{\circ} \mathrm{W}\right)$-School building cracked; largest crack on west wall. Plaster walls cracked. Seventh grade student jumped out of a first-floor window. 'Wall looked as if it was going to fall.' Small objects disturbed appreciably. (Murphy and Cloud, 1954).

Holdenville $\left(35.0753^{\circ} \mathrm{N}, 96.3257^{\circ} \mathrm{W}\right)$-Felt by many inside and out. Walls cracked slightly and some plaster fell. (Murphy and Cloud, 1954).

Kingfisher $\left(35.9139^{\circ} \mathrm{N}, 98.023^{\circ} \mathrm{W}\right)$-Felt by proportion of populace. Buildings seen to tremble; second floor of courthouse cracked slightly. Cracked plaster fell down in many homes. Books and several other small items thrown to floor. Chandeliers, chairs, beds, dishes, and books displaced. (Murphy and Cloud, 1954).

Langston $\left(35.9461^{\circ} \mathrm{N}, 97.2539^{\circ} \mathrm{W}\right)$-Press reported that a radio was knocked off a table. (Murphy and Cloud, 1954).

McAlester $\left(34.9345^{\circ} \mathrm{N}, 95.7643^{\circ} \mathrm{W}\right)$-Felt by many. General alarm but no panic. Many plaster cracks; the cracks were vertical. Chairs with casters rolled across floor. (Murphy and Cloud, 1954).

Minco $\left(35.2878^{\circ} \mathrm{N}, 97.9884^{\circ} \mathrm{W}\right)$-Near panic in school quelled by fast-thinking faculty in ordering the children to proceed orderly from the building. Walls were displaced. Sizable plaster cracks occurred in the school building. Numerous dwellings shaken throughout Grady County as reported by the press. (Murphy and Cloud, 1954).

Oklahoma City $\left(35.4718^{\circ} \mathrm{N}, 97.518^{\circ} \mathrm{W}\right)$-Felt by major proportion of population, many alarmed. Bricks jarred from a wall at city pumping plant. Tile facing of commercial building bulged. Many cracks reported, one 50 feet long at State capitol building. Tank of 114 foot diameter had center columns thrown out of the socket; moved in a westerly direction. Furnishings were displaced. (Murphy and Cloud, 1954).

Ponca City $\left(36.7096^{\circ} \mathrm{N}, 97.0859^{\circ} \mathrm{W}\right.$ )-Majority of populace was alarmed. Brick chimney partially toppled causing minor damage. Brick wall of a building cracked. Pictures and lighting fixtures swayed. (Murphy and Cloud, 1954).

Purcell $\left(34.9890^{\circ} \mathrm{N}, 97.4951^{\circ} \mathrm{W}\right)$-Felt by several. East wall of building cracked, the north wall pushed out 5 inches. Fishbowl ornament overturned. Wall pictures swayed, furniture bounced, small objects moved. (Murphy and Cloud, 1954).

Stillwater $\left(36.1080^{\circ} \mathrm{N}, 97.0764^{\circ} \mathrm{W}\right)$-Many persons witnessed the tremor. General alarm. Plaster walls cracked. Concrete floor cellar of post office cracked slightly. Loose objects rattled, dishes bounced, and iceboxes moved a few inches. (Murphy and Cloud, 1954).

Sulphur $\left(34.4822^{\circ} \mathrm{N}, 96.9759^{\circ} \mathrm{W}\right)$-Felt by many. Stone administration building of Platt National Park had an open crack in one wall and a split beam over the fireplace, and three broken windowpanes. A few small objects disturbed. (Murphy and Cloud, 1954).

Tulsa $\left(36.1539^{\circ} \mathrm{N}, 95.9925^{\circ} \mathrm{W}\right)$-Office workers in the taller buildings were 'terrified.' Walls cracked; one woman was injured due to falling plaster. Instances of cracked plumbing were reported by the press. Food in refrigerators moved noticeably. Desks were noticed to vibrate. Dishes and windows rattled. (Murphy and Cloud, 1954).

Union City $\left(35.3894^{\circ} \mathrm{N}, 97.9358^{\circ} \mathrm{W}\right)$-Ninety percent of populace felt tremors. There was general alarm. Well-constructed brick homes had foundation cracks and many reports of wall plaster cracks. Grocery store reported shelves of both walls were emptied of contents. Some loose objects thrown to floor from shelves and walls. Trees and buildings swayed visibly. (Murphy and Cloud, 1954). 


\section{Appendix 1, Part 38. Damage Reports and Intensity Assignments}

walls were emptied of contents. Some loose objects thrown to floor from shelves and walls. Trees and buildings swayed visibly. (Murphy and Cloud, 1954).

6

OK

KS

KS

5 OK

$5 \quad$ OK

5 OK

5 OK

5 OK

5 OK

5 OK

5 OK

5 OK

5 OK

OK

5 OK

5 OK

5 OK

5 OK

5 OK

5 OK

5 OK

OK

5 OK

5 OK

5 OK

5 OK

5 OK

5 OK

5 OK

5 OK

5 TX

5 TX

4 AR

4 IA

4 KS

$4 \mathrm{KS}$

$4 \mathrm{KS}$

$4 \mathrm{KS}$

KS

$4 \quad \mathrm{KS}$

$4 \mathrm{KS}$

KS

$4 \quad \mathrm{KS}$

$4 \mathrm{KS}$

$4 \mathrm{KS}$

$4 \mathrm{KS}$

$4 \quad \mathrm{MO}$

$\mathrm{MO}$

4 OK

4 OK

4 OK

4 OK

4 OK

4 OK

4 OK

4 OK

Wewoka $\left(35.2181^{\circ} \mathrm{N}, 96.5187^{\circ} \mathrm{W}\right)$-Felt by few persons; general alarm. Press reported bricks tumbled from a chimney. (Murphy and Cloud, 1954). Kansas City $\left(39.1177^{\circ} \mathrm{N}, 94.6307^{\circ} \mathrm{W}\right)$ (Murphy and Cloud, 1954). Medicine Lodge $\left(37.2276^{\circ} \mathrm{N}, 98.699^{\circ} \mathrm{W}\right)$ (Murphy and Cloud, 1954).

Ada $\left(34.7731^{\circ} \mathrm{N}, 96.6687^{\circ} \mathrm{W}\right)$-Felt by majority and frightened many. Dishes knocked off shelves, windows rattled, trees and buildings swayed. (Murphy and Cloud, 1954).

Altus $\left(34.6442^{\circ} \mathrm{N}, 99.325^{\circ} \mathrm{W}\right)$ (Murphy and Cloud, 1954).

Ardmore $\left(34.1749^{\circ} \mathrm{N}, 97.1393^{\circ} \mathrm{W}\right)$ (Murphy and Cloud, 1954).

Bartlesville $\left(36.7465^{\circ} \mathrm{N}, 95.9829^{\circ} \mathrm{W}\right)$ (Murphy and Cloud, 1954).

Beaver $\left(36.7335^{\circ} \mathrm{N}, 100.5724^{\circ} \mathrm{W}\right)$ (Murphy and Cloud, 1954).

Blackwell $\left(36.8228^{\circ} \mathrm{N}, 97.2947^{\circ} \mathrm{W}\right)$ (Murphy and Cloud, 1954).

Bristow $\left(35.7712^{\circ} \mathrm{N}, 96.3174^{\circ} \mathrm{W}\right)$ (Murphy and Cloud, 1954).

Duncan $\left(34.5123^{\circ} \mathrm{N}, 97.9607^{\circ} \mathrm{W}\right)$ (Murphy and Cloud, 1954).

Eufaula $\left(35.3059^{\circ} \mathrm{N}, 95.779^{\circ} \mathrm{W}\right)$ (Murphy and Cloud, 1954).

Frederick $\left(34.4543^{\circ} \mathrm{N}, 98.9907^{\circ} \mathrm{W}\right)$ (Murphy and Cloud, 1954).

Frederick $\left(34.4543^{\circ} \mathrm{N}, 98.9907^{\circ} \mathrm{W}\right)$ (Murphy and Cloud, 1954).

Geary $\left(35.6457^{\circ} \mathrm{N}, 98.4429^{\circ} \mathrm{W}\right.$ ) (Murphy and Cloud, 1954).

Guthrie $\left(35.8546^{\circ} \mathrm{N}, 97.455^{\circ} \mathrm{W}\right)$ (Murphy and Cloud, 1954).

Henryetta $\left(35.4734^{\circ} \mathrm{N}, 95.9695^{\circ} \mathrm{W}\right)$ (Murphy and Cloud, 1954).

Jefferson $\left(36.7206^{\circ} \mathrm{N}, 97.7903^{\circ} \mathrm{W}\right)$ (Murphy and Cloud, 1954).

Marlow $\left(34.6229^{\circ} \mathrm{N}, 97.8614^{\circ} \mathrm{W}\right)$ (Murphy and Cloud, 1954).

McCurtain $\left(35.1315^{\circ} \mathrm{N}, 95.0236^{\circ} \mathrm{W}\right)$ (Murphy and Cloud, 1954).

Medford (36.8558 $\left.\mathrm{N}, 97.6934^{\circ} \mathrm{W}\right)$ (Murphy and Cloud, 1954).

Medford $\left(36.8558^{\circ} \mathrm{N}, 97.6934^{\circ} \mathrm{W}\right)$ (Murphy and Cloud, 1954).

Muskogee $\left(35.7536^{\circ} \mathrm{N}, 95.3889^{\circ} \mathrm{W}\right)$ (Murphy and Cloud, 1954).

Norman $\left(35.2223^{\circ} \mathrm{N}, 97.463^{\circ} \mathrm{W}\right)$ (Murphy and Cloud, 1954).

Pauls Valley $\left(34.7565^{\circ} \mathrm{N}, 97.187^{\circ} \mathrm{W}\right)$ (Murphy and Cloud, 1954).

Pawhuska $\left(36.8173^{\circ} \mathrm{N}, 96.293^{\circ} \mathrm{W}\right)$ (Murphy and Cloud, 1954).

Stigler $\left(35.2971^{\circ} \mathrm{N}, 95.0798^{\circ} \mathrm{W}\right)$ (Murphy and Cloud, 1954).

The Village $\left(35.5608^{\circ} \mathrm{N}, 97.5511^{\circ} \mathrm{W}\right)$ (Murphy and Cloud, 1954).

Tribbey $\left(35.1153^{\circ} \mathrm{N}, 97.0531^{\circ} \mathrm{W}\right)$ (Murphy and Cloud, 1954).

Wetumka (35.2468 $\left.\mathrm{N}, 96.2848^{\circ} \mathrm{W}\right)$ (Murphy and Cloud, 1954).

Lake Pauline $\left(34.2506^{\circ} \mathrm{N}, 99.6714^{\circ} \mathrm{W}\right)$ (Murphy and Cloud, 1954).

Vernon $\left(34.1495^{\circ} \mathrm{N}, 99.2929^{\circ} \mathrm{W}\right)$ (Murphy and Cloud, 1954).

Fort Smith $\left(35.3692^{\circ} \mathrm{N}, 94.4147^{\circ} \mathrm{W}\right)$ (Murphy and Cloud, 1954).

Webster City $\left(42.4676^{\circ} \mathrm{N}, 93.8217^{\circ} \mathrm{W}\right)$ (Murphy and Cloud, 1954).

Concordia $\left(39.4983^{\circ} \mathrm{N}, 97.6976^{\circ} \mathrm{W}\right)$ (Murphy and Cloud, 1954).

Hutchinson $\left(38.0550^{\circ} \mathrm{N}, 97.9148^{\circ} \mathrm{W}\right)$ (Murphy and Cloud, 1954).

lola $\left(37.9477^{\circ} \mathrm{N}, 95.4212^{\circ} \mathrm{W}\right)$ (Murphy and Cloud, 1954).

Junction City $\left(38.9873^{\circ} \mathrm{N}, 96.8314^{\circ} \mathrm{W}\right)$ (Murphy and Cloud, 1954).

Junction City $\left(38.9873^{\circ} \mathrm{N}, 96.8314^{\circ} \mathrm{W}\right)$ (Murphy and Cloud, 1954).

Lawrence $\left(38.9641^{\circ} \mathrm{N}, 95.2536^{\circ} \mathrm{W}\right)$ (Murphy and Cloud, 1954).

Lindsborg $\left(38.6106^{\circ} \mathrm{N}, 97.6744^{\circ} \mathrm{W}\right)$ (Murphy and Cloud, 1954).

Lindsborg $\left(38.6106^{\circ} \mathrm{N}, 97.6744^{\circ} \mathrm{W}\right)$ (Murphy and Cloud, 1954).

McPherson $\left(38.3820^{\circ} \mathrm{N}, 97.6924^{\circ} \mathrm{W}\right)$ (Murphy and Cloud, 1954).

Topeka $\left(39.0555^{\circ} \mathrm{N}, 95.6754^{\circ} \mathrm{W}\right)$ (Murphy and Cloud, 1954).

Wichita $\left(37.6854^{\circ} \mathrm{N}, 97.3357^{\circ} \mathrm{W}\right)$ (Murphy and Cloud, 1954).

Winfield $\left(37.2469^{\circ} \mathrm{N}, 96.965^{\circ} \mathrm{W}\right)$ (Murphy and Cloud, 1954).

Kansas City $\left(39.0333^{\circ} \mathrm{N}, 94.55^{\circ} \mathrm{W}\right)$ (Murphy and Cloud, 1954).

Kansas City $\left(39.0333^{\circ} \mathrm{N}, 94.55^{\circ} \mathrm{W}\right)$ (Murphy and Cloud, 1954).

Antlers $\left(34.2889^{\circ} \mathrm{N}, 95.715^{\circ} \mathrm{W}\right)$ (Murphy and Cloud, 1954).

Apache $\left(34.9195^{\circ} \mathrm{N}, 98.3961^{\circ} \mathrm{W}\right)$ (Murphy and Cloud, 1954).

Bengal $\left(34.8328^{\circ} \mathrm{N}, 95.0617^{\circ} \mathrm{W}\right)$ (Murphy and Cloud, 1954).

Buffalo $\left(36.8008^{\circ} \mathrm{N}, 99.5263^{\circ} \mathrm{W}\right)$ (Murphy and Cloud, 1954).

Cache $\left(34.5650^{\circ} \mathrm{N}, 98.5792^{\circ} \mathrm{W}\right)$ (Murphy and Cloud, 1954).

Calvin $\left(34.8335^{\circ} \mathrm{N}, 96.2921^{\circ} \mathrm{W}\right)$ (Murphy and Cloud, 1954).

Camargo $\left(36.0295^{\circ} \mathrm{N}, 99.2799^{\circ} \mathrm{W}\right)$ (Murphy and Cloud, 1954).

Carnegie $\left(35.0931^{\circ} \mathrm{N}, 98.5541^{\circ} \mathrm{W}\right)$ (Murphy and Cloud, 1954). 


\title{
Appendix 1, Part 38. Damage Reports and Intensity Assignments
}

\author{
OK Chandler $\left(35.6986^{\circ} \mathrm{N}, 96.8616^{\circ} \mathrm{W}\right)$ (Murphy and Cloud, 1954). \\ OK Cherokee $\left(36.7612^{\circ} \mathrm{N}, 98.3694^{\circ} \mathrm{W}\right)$ (Murphy and Cloud, 1954). \\ OK Claremore $\left(36.3184^{\circ} \mathrm{N}, 95.6198^{\circ} \mathrm{W}\right)$ (Murphy and Cloud, 1954). \\ OK Clinton $\left(35.5421^{\circ} \mathrm{N}, 99.0265^{\circ} \mathrm{W}\right)$ (Murphy and Cloud, 1954). \\ OK Cordell $\left(35.2448^{\circ} \mathrm{N}, 98.8515^{\circ} \mathrm{W}\right)$ (Murphy and Cloud, 1954). \\ OK Crescent $\left(35.9732^{\circ} \mathrm{N}, 97.5943^{\circ} \mathrm{W}\right)$ (Murphy and Cloud, 1954). \\ OK Dacoma $\left(36.6538^{\circ} \mathrm{N}, 98.6015^{\circ} \mathrm{W}\right)$ (Murphy and Cloud, 1954). \\ OK Dewey $\left(36.8314^{\circ} \mathrm{N}, 95.9028^{\circ} \mathrm{W}\right)$ (Murphy and Cloud, 1954). \\ OK Durant $\left(34.0036^{\circ} \mathrm{N}, 96.3818^{\circ} \mathrm{W}\right)$ (Murphy and Cloud, 1954). \\ OK Elmore City $\left(34.5976^{\circ} \mathrm{N}, 97.3919^{\circ} \mathrm{W}\right)$ (Murphy and Cloud, 1954). \\ OK Fairview $\left(36.2689^{\circ} \mathrm{N}, 98.4794^{\circ} \mathrm{W}\right)$ (Murphy and Cloud, 1954). \\ OK Fort Supply $\left(36.5417^{\circ} \mathrm{N}, 99.4573^{\circ} \mathrm{W}\right)$ (Murphy and Cloud, 1954). \\ OK Gage $\left(36.3156^{\circ} \mathrm{N}, 99.7698^{\circ} \mathrm{W}\right)$ (Murphy and Cloud, 1954). \\ OK Garber $\left(36.4549^{\circ} \mathrm{N}, 97.5594^{\circ} \mathrm{W}\right)$ (Murphy and Cloud, 1954). \\ OK Goodwell $\left(36.7697^{\circ} \mathrm{N}, 101.8113^{\circ} \mathrm{W}\right)$ (Murphy and Cloud, 1954). \\ OK Guymon $\left(36.7540^{\circ} \mathrm{N}, 101.4594^{\circ} \mathrm{W}\right)$ (Murphy and Cloud, 1954). \\ OK Healdton $\left(34.2306^{\circ} \mathrm{N}, 97.5037^{\circ} \mathrm{W}\right)$ (Murphy and Cloud, 1954). \\ OK Helena $\left(36.5589^{\circ} \mathrm{N}, 98.2884^{\circ} \mathrm{W}\right)$ (Murphy and Cloud, 1954). \\ OK Hobart $\left(35.0163^{\circ} \mathrm{N}, 99.0433^{\circ} \mathrm{W}\right)$ (Murphy and Cloud, 1954). \\ OK Hollis $\left(34.7979^{\circ} \mathrm{N}, 99.9442^{\circ} \mathrm{W}\right)$ (Murphy and Cloud, 1954). \\ OK Hugo $\left(34.0364^{\circ} \mathrm{N}, 95.5219^{\circ} \mathrm{W}\right)$ (Murphy and Cloud, 1954). \\ OK Jet $\left(36.7093^{\circ} \mathrm{N}, 98.1642^{\circ} \mathrm{W}\right)$ (Murphy and Cloud, 1954). \\ OK Konawa $\left(34.9758^{\circ} \mathrm{N}, 96.7006^{\circ} \mathrm{W}\right)$ (Murphy and Cloud, 1954). \\ OK Lawton $\left(34.6085^{\circ} \mathrm{N}, 98.395^{\circ} \mathrm{W}\right)$ (Murphy and Cloud, 1954). \\ OK Lindsay $\left(34.8007^{\circ} \mathrm{N}, 97.5762^{\circ} \mathrm{W}\right)$ (Murphy and Cloud, 1954). \\ OK Madill $\left(34.0678^{\circ} \mathrm{N}, 96.7919^{\circ} \mathrm{W}\right)$ (Murphy and Cloud, 1954). \\ OK Mangum $\left(34.8484^{\circ} \mathrm{N}, 99.5637^{\circ} \mathrm{W}\right)$ (Murphy and Cloud, 1954). \\ OK Mannford $\left(36.0775^{\circ} \mathrm{N}, 96.3822^{\circ} \mathrm{W}\right.$ ) (Murphy and Cloud, 1954). \\ OK Marshall $\left(36.1276^{\circ} \mathrm{N}, 97.5916^{\circ} \mathrm{W}\right)$ (Murphy and Cloud, 1954). \\ OK Meeker $\left(35.5303^{\circ} \mathrm{N}, 96.954^{\circ} \mathrm{W}\right)$ (Murphy and Cloud, 1954). \\ OK Mustang $\left(35.3782^{\circ} \mathrm{N}, 97.7453^{\circ} \mathrm{W}\right)$ (Murphy and Cloud, 1954). \\ OK Newkirk $\left(36.9145^{\circ} \mathrm{N}, 97.0596^{\circ} \mathrm{W}\right)$ (Murphy and Cloud, 1954). \\ OK Okemah $\left(35.4688^{\circ} \mathrm{N}, 96.2927^{\circ} \mathrm{W}\right)$ (Murphy and Cloud, 1954). \\ OK Orlando $\left(36.1325^{\circ} \mathrm{N}, 97.4348^{\circ} \mathrm{W}\right)$ (Murphy and Cloud, 1954). \\ OK Paoli $\left(34.8280^{\circ} \mathrm{N}, 97.2606^{\circ} \mathrm{W}\right)$ (Murphy and Cloud, 1954). \\ OK Pawnee $\left(36.3451^{\circ} \mathrm{N}, 96.8055^{\circ} \mathrm{W}\right.$ ) (Murphy and Cloud, 1954). \\ OK Perry $\left(36.2943^{\circ} \mathrm{N}, 97.2942^{\circ} \mathrm{W}\right)$ (Murphy and Cloud, 1954). \\ OK Piedmont $\left(35.6699^{\circ} \mathrm{N}, 97.7552^{\circ} \mathrm{W}\right.$ ) (Murphy and Cloud, 1954). \\ OK Prague $\left(35.5533^{\circ} \mathrm{N}, 96.7136^{\circ} \mathrm{W}\right)$ (Murphy and Cloud, 1954). \\ OK Ralston $\left(36.5046^{\circ} \mathrm{N}, 96.8513^{\circ} \mathrm{W}\right)$ (Murphy and Cloud, 1954). \\ OK Red Rock $\left(36.4770^{\circ} \mathrm{N}, 97.1693^{\circ} \mathrm{W}\right)$ (Murphy and Cloud, 1954). \\ OK Roff $\left(34.5832^{\circ} \mathrm{N}, 96.8166^{\circ} \mathrm{W}\right)$ (Murphy and Cloud, 1954). \\ OK Roosevelt $\left(34.8436^{\circ} \mathrm{N}, 98.9577^{\circ} \mathrm{W}\right)$ (Murphy and Cloud, 1954). \\ OK Sapulpa $\left(36.0002^{\circ} \mathrm{N}, 96.1128^{\circ} \mathrm{W}\right)$ (Murphy and Cloud, 1954). \\ OK Seiling $\left(36.0765^{\circ} \mathrm{N}, 98.816^{\circ} \mathrm{W}\right)$ (Murphy and Cloud, 1954). \\ OK Shawnee $\left(35.3469^{\circ} \mathrm{N}, 96.9262^{\circ} \mathrm{W}\right)$ (Murphy and Cloud, 1954). \\ OK Skiatook $\left(36.3802^{\circ} \mathrm{N}, 96.0609^{\circ} \mathrm{W}\right)$ (Murphy and Cloud, 1954). \\ OK Snomac $\left(35.0800^{\circ} \mathrm{N}, 96.67^{\circ} \mathrm{W}\right)$ (Murphy and Cloud, 1954). \\ OK Taloga $\left(35.9134^{\circ} \mathrm{N}, 98.9294^{\circ} \mathrm{W}\right)$ (Murphy and Cloud, 1954). \\ OK Tishomingo $\left(34.3534^{\circ} \mathrm{N}, 96.6574^{\circ} \mathrm{W}\right)$ (Murphy and Cloud, 1954). \\ OK Vinita $\left(36.6394^{\circ} \mathrm{N}, 95.1179^{\circ} \mathrm{W}\right)$ (Murphy and Cloud, 1954). \\ OK Vinson $\left(34.8887^{\circ} \mathrm{N}, 99.8153^{\circ} \mathrm{W}\right)$ (Murphy and Cloud, 1954). \\ OK Wagoner $\left(35.9594^{\circ} \mathrm{N}, 95.3692^{\circ} \mathrm{W}\right)$ (Murphy and Cloud, 1954). \\ OK Watonga $\left(35.8556^{\circ} \mathrm{N}, 98.4178^{\circ} \mathrm{W}\right)$ (Murphy and Cloud, 1954). \\ OK Waukomis $\left(36.2657^{\circ} \mathrm{N}, 97.8822^{\circ} \mathrm{W}\right.$ ) (Murphy and Cloud, 1954). \\ OK Waurika $\left(34.2018^{\circ} \mathrm{N}, 97.9555^{\circ} \mathrm{W}\right)$ (Murphy and Cloud, 1954). \\ OK Weatherford $\left(35.5548^{\circ} \mathrm{N}, 98.7404^{\circ} \mathrm{W}\right)$ (Murphy and Cloud, 1954). \\ OK Wirt $\left(34.2308^{\circ} \mathrm{N}, 97.5314^{\circ} \mathrm{W}\right)$ (Murphy and Cloud, 1954). \\ OK Woodward $\left(36.4297^{\circ} \mathrm{N}, 99.3992^{\circ} \mathrm{W}\right)$ (Murphy and Cloud, 1954). \\ OK Yukon $\left(35.4975^{\circ} \mathrm{N}, 97.7329^{\circ} \mathrm{W}\right)$ (Murphy and Cloud, 1954).
}




\section{Appendix 1, Part 38. Damage Reports and Intensity Assignments}

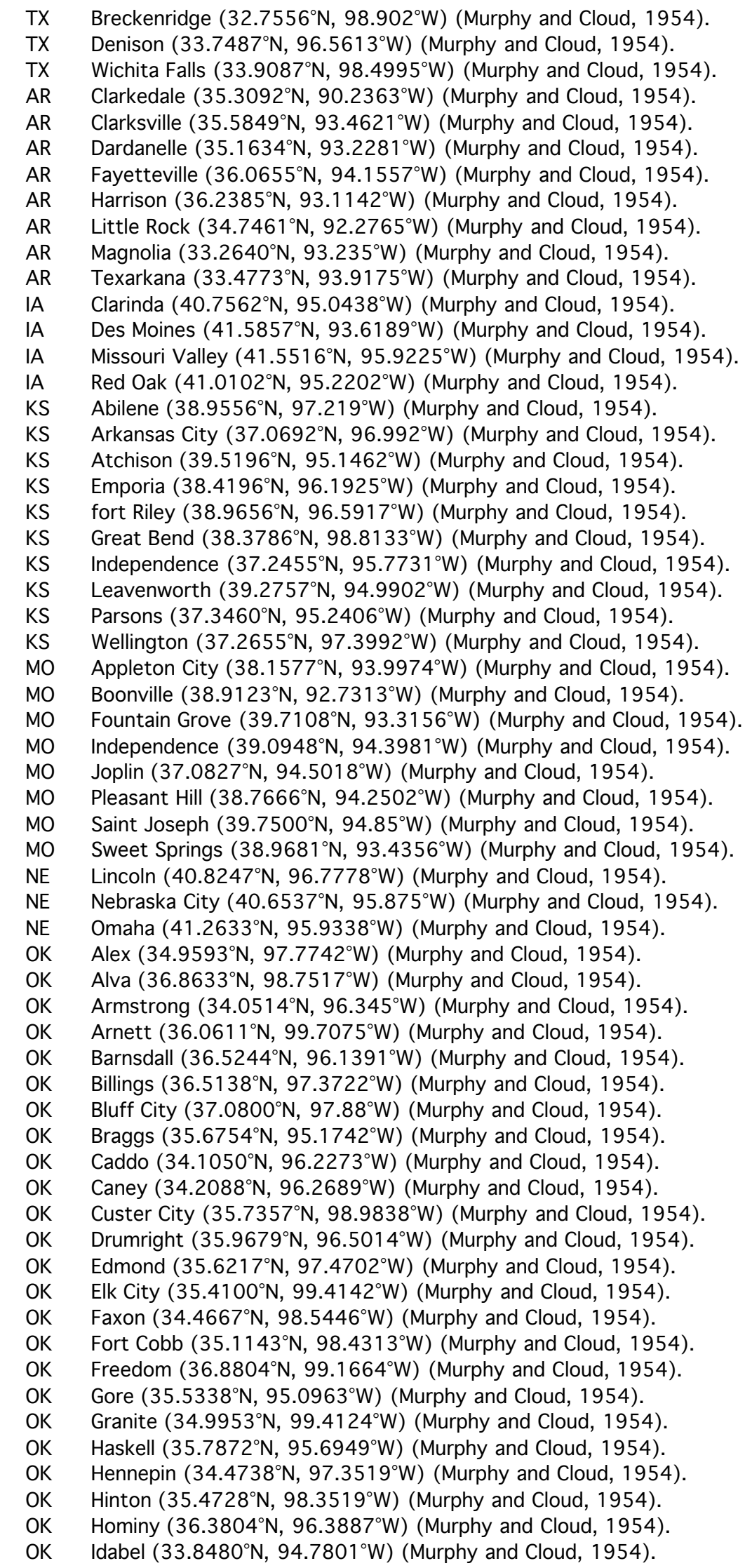




\title{
Appendix 1, Part 38. Damage Reports and Intensity Assignments
}

\author{
OK Kingston $\left(33.9448^{\circ} \mathrm{N}, 96.7087^{\circ} \mathrm{W}\right)$ (Murphy and Cloud, 1954). \\ OK Langley $\left(36.4704^{\circ} \mathrm{N}, 95.0489^{\circ} \mathrm{W}\right)$ (Murphy and Cloud, 1954). \\ OK Lawrence $\left(34.6864^{\circ} \mathrm{N}, 96.7328^{\circ} \mathrm{W}\right)$ (Murphy and Cloud, 1954). \\ OK Maramec $\left(36.2176^{\circ} \mathrm{N}, 96.6767^{\circ} \mathrm{W}\right)$ (Murphy and Cloud, 1954). \\ OK Miami $\left(36.8816^{\circ} \mathrm{N}, 94.8741^{\circ} \mathrm{W}\right)$ (Murphy and Cloud, 1954). \\ OK Mutual $\left(36.2082^{\circ} \mathrm{N}, 99.1062^{\circ} \mathrm{W}\right)$ (Murphy and Cloud, 1954). \\ OK Nowata $\left(36.6737^{\circ} \mathrm{N}, 95.6444^{\circ} \mathrm{W}\right)$ (Murphy and Cloud, 1954). \\ OK Okeene $\left(36.1024^{\circ} \mathrm{N}, 98.3286^{\circ} \mathrm{W}\right)$ (Murphy and Cloud, 1954). \\ OK Okmulgee $\left(35.6450^{\circ} \mathrm{N}, 96.0289^{\circ} \mathrm{W}\right)$ (Murphy and Cloud, 1954). \\ OK Perkins $\left(35.9774^{\circ} \mathrm{N}, 97.095^{\circ} \mathrm{W}\right)$ (Murphy and Cloud, 1954). \\ OK Pickens $\left(34.3975^{\circ} \mathrm{N}, 95.0081^{\circ} \mathrm{W}\right)$ (Murphy and Cloud, 1954). \\ OK Renfrow $\left(36.9256^{\circ} \mathrm{N}, 97.6556^{\circ} \mathrm{W}\right)$ (Murphy and Cloud, 1954). \\ OK Ripley $\left(35.9872^{\circ} \mathrm{N}, 96.8876^{\circ} \mathrm{W}\right)$ (Murphy and Cloud, 1954). \\ OK Rogers $\left(36.9169^{\circ} \mathrm{N}, 95.1975^{\circ} \mathrm{W}\right)$ (Murphy and Cloud, 1954). \\ OK Rush Springs $\left(34.7613^{\circ} \mathrm{N}, 97.888^{\circ} \mathrm{W}\right)$ (Murphy and Cloud, 1954). \\ OK Sayre $\left(35.3290^{\circ} \mathrm{N}, 99.6613^{\circ} \mathrm{W}\right)$ (Murphy and Cloud, 1954). \\ OK Seminole $\left(35.2347^{\circ} \mathrm{N}, 96.6748^{\circ} \mathrm{W}\right)$ (Murphy and Cloud, 1954). \\ OK Shattuck $\left(36.3907^{\circ} \mathrm{N}, 99.9041^{\circ} \mathrm{W}\right)$ (Murphy and Cloud, 1954). \\ OK Snow $\left(34.4428^{\circ} \mathrm{N}, 95.4272^{\circ} \mathrm{W}\right)$ (Murphy and Cloud, 1954). \\ OK Stilwell $\left(35.7924^{\circ} \mathrm{N}, 94.6203^{\circ} \mathrm{W}\right)$ (Murphy and Cloud, 1954). \\ OK Thomas $\left(35.7219^{\circ} \mathrm{N}, 98.7417^{\circ} \mathrm{W}\right)$ (Murphy and Cloud, 1954). \\ OK Tonkawa $\left(36.6694^{\circ} \mathrm{N}, 97.3492^{\circ} \mathrm{W}\right)$ (Murphy and Cloud, 1954). \\ OK Tuttle $\left(35.2688^{\circ} \mathrm{N}, 97.7786^{\circ} \mathrm{W}\right)$ (Murphy and Cloud, 1954). \\ OK Verden $\left(35.0899^{\circ} \mathrm{N}, 98.0507^{\circ} \mathrm{W}\right)$ (Murphy and Cloud, 1954). \\ OK Wakita $\left(36.8673^{\circ} \mathrm{N}, 97.9811^{\circ} \mathrm{W}\right)$ (Murphy and Cloud, 1954). \\ OK Walters $\left(34.3780^{\circ} \mathrm{N}, 98.3761^{\circ} \mathrm{W}\right)$ (Murphy and Cloud, 1954). \\ OK Waynoka $\left(36.5797^{\circ} \mathrm{N}, 98.7994^{\circ} \mathrm{W}\right)$ (Murphy and Cloud, 1954). \\ OK Webbers Falls $\left(35.5002^{\circ} \mathrm{N}, 95.175^{\circ} \mathrm{W}\right)$ (Murphy and Cloud, 1954). \\ OK Yale $\left(36.1081^{\circ} \mathrm{N}, 96.7214^{\circ} \mathrm{W}\right)$ (Murphy and Cloud, 1954). \\ TX Abilene $\left(32.4682^{\circ} \mathrm{N}, 99.7182^{\circ} \mathrm{W}\right)$ (Murphy and Cloud, 1954). \\ TX Amarillo $\left(35.2032^{\circ} \mathrm{N}, 101.8421^{\circ} \mathrm{W}\right)$ (Murphy and Cloud, 1954). \\ TX Austin $\left(30.2712^{\circ} \mathrm{N}, 97.7417^{\circ} \mathrm{W}\right)$ (Murphy and Cloud, 1954). \\ TX Canadian $\left(35.8378^{\circ} \mathrm{N}, 100.2704^{\circ} \mathrm{W}\right)$ (Murphy and Cloud, 1954). \\ TX Crowell $\left(33.9466^{\circ} \mathrm{N}, 99.7633^{\circ} \mathrm{W}\right.$ ) (Murphy and Cloud, 1954). \\ TX Dallas $\left(32.7870^{\circ} \mathrm{N}, 96.7983^{\circ} \mathrm{W}\right)$ (Murphy and Cloud, 1954). \\ TX Denton $\left(33.2295^{\circ} \mathrm{N}, 97.1271^{\circ} \mathrm{W}\right)$ (Murphy and Cloud, 1954). \\ TX Fort Worth $\left(32.7253^{\circ} \mathrm{N}, 97.3206^{\circ} \mathrm{W}\right)$ (Murphy and Cloud, 1954). \\ TX Graham $\left(33.1069^{\circ} \mathrm{N}, 98.5892^{\circ} \mathrm{W}\right)$ (Murphy and Cloud, 1954). \\ TX Jacksboro $\left(33.2183^{\circ} \mathrm{N}, 98.1583^{\circ} \mathrm{W}\right)$ (Murphy and Cloud, 1954). \\ TX Lipscomb $\left(36.2198^{\circ} \mathrm{N}, 100.2802^{\circ} \mathrm{W}\right)$ (Murphy and Cloud, 1954). \\ TX Paris $\left(33.6630^{\circ} \mathrm{N}, 95.5442^{\circ} \mathrm{W}\right)$ (Murphy and Cloud, 1954). \\ TX Sherman $\left(33.6419^{\circ} \mathrm{N}, 96.6092^{\circ} \mathrm{W}\right)$ (Murphy and Cloud, 1954).
}

